
.

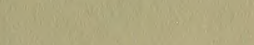






\title{
MALAYAN FERNS
}

AND

\section{FERN ALLIES.}

\author{
SUPPLEMENT 1.
}





\section{MALAYAN FERNS AND FERN ALLLES.}

\section{HANDBOOK}

TO THE DETERMINATION

OF

THE FERNS AND FERN ALLIES

OF

\section{THE MALAYAN ISLANDS}

(INCL. THOSE OF THE MALAY PENINSULA, THE PHILIPPINES AND NEW GUINEA).

BY

CaPt. C. R. W. K. van ALDERWERELT van ROSENBURGH.

\section{SUPPLEMENT 1.}

\section{PUBLISHED BY}

THE DEPARTMENT OF AGRICULTURE, INDUSTRY AND COMMERCE NETHERLANDS INDIA. 



\section{PREFACE.}

It is my intention to take up in this and the succeeding Supplements to my Handbooks on Malayan Ferns and Fern Allies the deseriptions of those genera and species that have been discovered since the Handbooks were finished, and such as are new so far as the Malayan Islands (including the Malay Peninsula, the Philippines and New Guinea) concerned, however well-known in other localities.

I shall take into consideration, as far as possible, the modified conceptions caused by new discoveries, and in cases where I am unable to agree with the new conceptions, I shall at any rate insert the new names as synonyms for the old.

Each supplement will be followed, if necessary, by a sheet for additions and modifications, to affort opportunity to those using the Handbooks quoted above, to make such corrections as may be found advisable.

Where the new discoveries or conceptions require, that species be referred to other genera than those previously given, I shall transcribe the entire diagnoses, unless the number is too large, in which case I shall content myself with simply referring the reader to the names and descriptions where they occur in the Handbooks.

The numbers within brackets, placed before the names of the species, indicate their position in the sequence followed in the keys of the Handbooks, but only approximately for the new or supplementary species (marked $a, b, c$, etc.).

As far as necessary modifications will be given in order to make the keys fit, as much as possible, for the new or accessory species.

ButTenzorg, January 1916.

V. A. V. R. 



\title{
A B B R E VIA TIO NS.
}

\author{
(Additions).
}

Ann. Cons. Gen.

Beitr. Flor. Pap.

Benth.

Brau.

Bull. Btz.

Campb.

Comp. Cat.

Dup.

Fil. Jav.

Flor Hawaii.

Flor, Hongk.

Flor. Jap.

Flor. Vit.

Godd.

Hillebr.

Hochr.

Journ. Str. Br. R. A. Soc. = Straits Branch Royal Asiatic Society, Journal. Krypt. Gew.

Lautb.

Mans. Bail.
$=$ Annuaire du Conservatoire et du Jardin botaniques de Genèvè.

= Beiträge zur Flora von Papuasien, (Lautb., I, 1912), in Engl. Bot. Jahrb., XLIX.

$=\mathrm{G}$. Bentham.

$=\mathrm{G}$. Brause.

$=$ Bulletin du Jardin botanique de Buitenzorg, $2 \theta$ Série.

$=$ D. H. Campbell.

= Comprehensive Catalogue of Queensland Plants (Mans. Bail., 1909-1912).

$=$ L. J. Duperry.

$=$ Filices javanicae (Hassk., 1856), in Verhandelingen der Natuurkundige Vereeniging in Nederlandsch Indië.

$=$ Flora of the Hawaiian Islands. - (Hillebr., 1888).

= Flora Hongkongensis. - (Benth., 1861).

$=$ Flora Japonica. - (Thb., 1784).

= Flora Vitiensis. - (Seem., 1873).

$=\mathrm{W} \cdot \mathrm{A} \cdot$ Goddijn.

$=\mathrm{W}$. Hillebrand.

= B. P. G. Hochreutiner.

$=$ Vier und zwanzigste Klasse des Linnéischen Pflanzensystems oder Kryptogamische Gewächse, I. - (Schk., 1809).

$=$ C. Lauterbach.

= F. Manson Bailey. 
Med. R. H. L.

Nov. Guin. Bot.

Pl. Jungh.

Schk.

Seem.

Teysm.

Voy. Coq.

Wigm. Jr.
$=$ Mededeelingen van 's Rijks Herbarium, Leiden.

= Nova Guinea. Résultats de l'Expédition scientifique néerlandaise à la Nouvelle Guinée. Botanique.

= Plantae Junghuhnianae.

= C. Schkuhr.

= B. Seemann.

= Teysmannia.

$=$ Voyage autour du Monde'etc. . . sur la Corvette de Sa Majesté, La Coquille, Botanique. - (Dup., 1827-1829).

$=$ H. J. Wigman, Jr. 


\section{COMPENDIUM.}

(Additions and modifications

FULCCES (Fiticineae).

CLASS I. PLANITHALLOSAE.

Series I. Anmulatac.

FAMILY I. CYATHEACEAE.

Tribe I. Cyatheae.

GENUS 2. HEMITELIA. Indusium consisting of small or middle-sized, often convex, inferior scale placed at the inner side of the receptacle, at the base.

GENUS 3. ALSOPHILA. Indusium wanting or consisting of a minute inferior scale or a whorl of hairs or fibres encircling the base of the receptacle.

\section{Tribe II. Dicksonieae.}

GENUS 4. DICKSONIA. Indusium cucullate, 2valved, the outer valve consisting of a small lobule of the frond. Ultimate segments equalsided at the base.

GENUS $4 a$. BALANTIUM. Like genus 4 , but the ultimate segments unequal-sided at the base, produced on the upper side. - Ring of the sporangia sometimes vertical and incomplete (as in Polypodiaceae) and the indusium occasionally more or less cup-shaped (as in genus 14).

FAMILY II. PIATONIACEAE.

GENUS 6a. MATONIA. Fronds flabellato-pedate. GENUS $6 b$. PHANEROSORUS. Fronds sympodially branched. 
FAMILY VI. POLYPODIACEAE.

Tribe I. Woodsieae.

GENUS 12. DIACALPE. Sori sessile; indusium globose, bursting down irregularly. Veins free. GENUS 12 $\alpha$. PERANEMA. Like genus 12, but the sori (incl. the indusium) stalked; indusium bursting down into 2 more or less regular halfs.

\section{Tribe III. Davallieae.}

GENUS 27. CYSTOPTERIS. Sori globose or nearly so, dorsal or terminal on the veins; indusium broad, cucullate, fastened under the sorus, attached with a broad base to 3 sides of the receptacle.

GENUS 27a. STENOLEPIA. Like genus 27, but the indusium narrow, not cucullate, attached with a narrow base to 1 side of the receptacle. GENUS 30a. PROTOLINDSAYA. Sori obconical, intramarginal. Fronds pinnate or 2-pinnatifid; leaflets not dimidiate.

GENUS 31b. LEPTOLEPIA. Sori roundish, submarginal, or on marginal, recurved, lobe-like outgrowths; indusium roundish or transversely oblong,-fixed by a single point to the apex of the vein only, for the rest free, the outer edge lacerate-lobate. Fronds divided, not articulated to the rhizome.

Genus 33. Acrophorus. Omit this, it being referred to genus 27.

GENUS 34. DAVALLIA. Sori roundish or longitudinally elongated, submarginal; indusium attached by the base and sides to the vein and parenchyma, the apex free. Fronds divided, naked or somewhat scaly, articulated to the rhizome.

GENUS $34 \alpha$. DAVALLODES. Sori roundish or oblong, at or near the base of the ultimate lobes or teeth; indusium partly as in genus $31 b$, but entire, partly as in genus 32 or 34 . 
Fronds divided, thin, more or less copiously fibrillose-pilose on both sides, articulated to the rhizome.

\section{Tribe VIII. Gymnogrammeae.}

GENUS 62. CONIOGRAMMA. Venation free, pinnate. Fronds naked, or sparingly hairy beneath. GENUS 62a. ANOGRAMMA. Venation free, flabellate-dichotomous. Fronds naked beneath.

GENUS 63. CEROPTERIS. Venation free, pinnate. Fronds white- or yellow-powdery beneath.

GENUS 65. LOXOGRAMMA. Sori parallel, mostly oblique to the costa, rarely parallel or subparallel to it.

GENUS $67 \alpha$. HEMIGRAMMA. Fertile fronds much contracted, with the sori in parallel rows on each side of the costa, with indistinct or without main veins, and the areolae without free veinlets. GENUS 67b. CAMPYLOGRAMMA. Fertile fronds not or slightly contracted, with the sori running in various directions, with distinct main veins, and the areolae with free veinlets.

\section{Tribe IX. Grammitideae.}

GENUS 68. MONOGRAMMA. Sori costal, often protected by $1-2$ lateral outgrowths of leaftissue not belonging to the costal parenchyma. Fronds simple; lateral veins wanting or free. GENUS 69. VITTARIA. Sori immersed in marginal or intramarginal grooves, the inner lip of the grooves not belonging to the costal parenchyma. Fronds simple, rarely forked, not thickened in the fertile region; lateral veins free.

GENUS 69a. SCLEROGLOSSUM. Sori immersed in submarginal grooves, the inner lip of the grooves consisting of the much produced costal parenchyma. Fronds simple, rarely forked, thickened in the fertile region.

GENUS 70a. BRAINEA. Sori superficial, rather continuous along subcostal transverse veinlets 
uniting the bases of the veins, often more or less produced-along the veins in the direction of the margin.

Tribe $X$. Polypodieae.

GENUS 71. POLYPODIUM. Sori round or oblong, several to numerous on each side of the costa. Fronds uniform or dimorphous, simple or divided; barren fronds never oak-leaf-like; surfaces naked, scaly or hairy, the hairs not stellate; veins free or anastomosing regularly, with the areolae provided with included free veinlets running in the direction of the margin. Rhizome scales present.

GENUS $71 \alpha$. PLEOPELTIS, Like genus 71 , but the sori sometimes linear, the veins anastomosing irregularly, and the areolae with the free veinlets mostiy spreading in various directions.

GENUS 71b. LECANOPTERIS. Like genus 71, but the sori placed on marginal outgrowths of the deeply pinnatifid or pinnate fronds, and the venation as in genus $71 \alpha$. Rhizome scales wanting.

GENUS 73. DRYNARIA. Sori round, copious, on non-contracted segments. Fronds dimorphous; barren fronds (cup-leaves) oak-leaf-like, sessile, humus-collecting; fertile fronds pinnatifid or pinnate, stalked, not humus-collecting; veins anastomosing copiously.

GENUS 73a. THAYERIA. Like genus 73 , but the sori restricted to the much contracted higher segments of the fertile fronds. Fronds dimorphous, if not, then both barren and fertile fronds humuscollecting.

GENUS 74. DRYOSTACHYUM. Like genus $71 a$, but the sori round or oblong, restricted to the much contracted higher segments of pinnatifid or pinnate fronds, springing from the veins and the parenchyma. 
GENUS 74a. AGLAOMORPHA. Like genus 74, but the sori springing from the veins only.

GENUS 75a. PALTONIUM. Sori linear, 1 on each side of the costa, parallel to the margin, marginal or submarginal. Fronds simple, rather uniform.

Tribe XI. Acrosticheae.

GENUS 86a. LEPTOCHILUS. Veins anastomosing copiously. Fronds simple or divided, if pinnate, the pinnae not articulate to the rachis; each segment with a single costa. Spores oblong, ovate or 2-lateral.

GENUS 86c. LOMAGRAMMA. Like genus $86 a$, but the veins sometimes free, the fronds always pinnate and the pinnae articulate to the rachis.

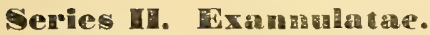

\section{FAMILY IX. MARATTIACEAE.}

GENUS 90. ANGIOPTERIS. Sporangia in 2 opposite close rows, not concrete, $\pm 10-20$ to a sorus. Fronds 2-3-pinnate.

GENUS 90a. MACROGLOSSUM. Like genus 90, but the sporangia more numerous, $\pm 20-60$ 'to a sorus. Fronds simply pinnate.

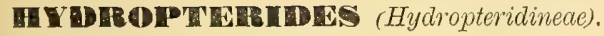



FILICES. 



\title{
F I L I C ES.
}

\author{
(Filicineae).
}

\section{Arrangement of the families. (Modified).}

A. CLASS I. PLANITHALLONAE. Prothallium green, flat or filiform, entire, incised or branched, epigeous or epiphytical, adpressed to the substratum; antheridia and archegonia whether or not immersed in the prothallium. - Engl. \& Prantl, Nat. Pfl.fam., $\mathrm{I}^{4}$, fig. 11 .

a. SERIES I. ANNULATAE. Sporangia very minute, provided with a ring consisting of a row or a group of contiguous, prominent or thickened cells; walls of the sporangia only 1 cell thick; antheridia and archegonia prominent, exceptionally immersed in Ceratopteris. (Eufilicineae).

FAMILY I. Cyatheucene. Ring large, circular, oblique, subvertical, complete ( $\left.{ }^{1}\right)$, the continuity sometimes apparently interrupted by a stomium of less prominent cells, which are, however, distinctly differentiated from the other cells of the sporangium; stomium horizontal. Sori globose or somewhat oblong, consisting of numerous crowded sporangia; indusium, if present, inferior, i. e. attached under the sorus, globose or scale-like, never linear. - Arborescent or subarborescent ferns. - Engl. \& Prantl, 1. c., fig. 82 D; Hk. Bk., Syn. Fil., tab. I, fig. 4-6.

FAMULY II. Bhatoniaceae. Ring large, circular, oblique, subvertical, complete, never interrupted; stomium horizontal. Sori round, consisting of $4-14$ sporangia placed in à whorl; indusium superior, i. e. attached above the sorus, peltate-umbellate. - No arborescent ferns. - Engl. \& Prantl, 1. c., fig. 181, 182 B; Hk. Bk., 1. c., tab. I. fig. 8.

FAMILY III. Gleiehemiaceae. Ring large, horizontal, surrounding the sporangium like an equatorial belt; stomium vertical. Sori dorsal,

(1) Ring exceptionally vertical and incomplete, but only in forms with marginal, cup-shaped or 2-valved indusia.

Ferns and Fern Allies. 
consisting of 2-12 sporangia; receptacle inconspicuous, dot-like; indusium wanting. - Engl. \& Prantl, l. c., fig. 186; Hk. Bk., 1. c., tab. I, fig. 2.

FAMLY IV. Fymemoplayllacese. Ring large, circular, horizontal or very oblique, surrounding the sporangium like an equatorial belt; stomium vertical. Sori terminal or marginal, rarely spicate or paniculate, consisting of several to many sporangia; receptacle distinct, elevated; indusium present. - Engl. \& Prantl, 1. c., fig. 72, 75 D; Hk. Bk., l. c., tab. II, fig. $16-17$.

FAMILY IVa. Eoxsomaceae. Ring small, circular, oblique, subvertical, placed on a dorsal increasing of the sporangium, the cells only partly thickened; stomium vertical. Sori marginal, consisting of several or many sporangia; receptacle distinct, elevated; indusium présent. - Engl. \& Prant, 1. c., fig. 77; Hk. Bk., 1. c., tab. II, fig. 15 not quite correct). - Not in Malaya.

FAMILY V. Sehizmencene. Ring small, operculiform or consisting of a group of thickened cells crowning the sporangium; stomium longitudinal. Sporangia either solitary and terminal on the veins or placed in 2 or 4 rows along the central veins of the fertile segments; indusium wanting or present. - Engl. \& Prantl, 1. c., fig. 191, 192 A-G; Hk. Bk., 1. c., tab. VIII-IX, fig. 64-68.

FAMILY VI. Polypodiaceae. Ring long, vertical, incomplete $\left({ }^{1}\right)$, the extremities sometimes separated by the base or the stalk of the sporangium only; stomium horizontal. Sori definite, various in shape and size, if indefinite, then the sporangia densely crowded over the parenchyma or rarely scattered between the veins; indusium wanting or present. - No arborescent ferns, or, if so, then only in forms with no marginal cup-shaped or 2-valved indusia. Engl. \& Prantl, 1. c., fig. 57, $87 \mathrm{D} \& \mathrm{H}$; Hk. Bk., 1. c., tab. I, fig. $7 d$.

FAMILY VII. Parkerimeeac. Ring long, vertical, incomplete, with the extremities separated by the base of the sporangium only, sometimes wanting (in American material'; stomium transversal. Şori indefinite, consisting of many sporangia scattered irregularly along the few longitudinal veins, protected by the much recurved margin of the frond when young. - Engl. \& Prantl, 1. c., fig. 178-179; Hk. Bk., l. c., tab. III, fig. 32 .

\footnotetext{
(1) Ring exceptionally oblique and complete, but only in forms with marginal, linear indusia.
} 
FAMILY VIII. Dsmundaceae. Ring rudimentary, consisting of a roundish lateral group of thickened cells only; stomium apical. Indusium wanting. - Engl. \& Prantl, 1. c., fig 203; Hk. Bk., l. c., tab. VIII, fig. $62 c, 63 b, d$.

b. SERIES II. Exannulatae. Sporangia rather large, without a ring; walls of the sporangia more than 1 cell thick; antheridia immersed in the prothallium, archegonia immersed or nearly so. (Marattiineae).

FAMILY IX. Wamatraceae. Sori consisting of 6 - 60 sporangia which are either free and placed in 2 close rows or concrete in circular, oblong, linear or 2-valved synangia. - Engl. \& Prantl, l. c., fig. 239; Hk. Bk., l. c., tab. IX, fig. 69-72.

B. CLASS II. TUBERTTHA LCOSAE. Prothallium white, tuberous, hypogeous or immersed in the substratum; antheridia immersed in the prothallium; archegonia immersed or nearly so. (Ophioglossineae).

FAMILY X. Dphioglossnceae. Sporangia large, without a ring, having walls several cells thick, not garthered in sori but placed on stalked, much contracted, non-foliaceous, spiciform or paniculiform fertile segments originating from the stipe, the base, the centre or the margin of the normal-shaped foliaceous barren segment of the frond. - Engl. \& Prantl, l. c., fig. $259 A-B, 260 \mathrm{~F}$; Hk. Bk., tab. IX, fig. 73-75.

Key to the famities (1).

a. Sporangia small, with a wall only 1 layer of cells thick; ring present, complete, incomplete or rudimentary, very rarely wanting. (Leptosporangiatae).

b. Sporangia scattered irregularly along the few longitudinal veins.

VII. Parkeniacene. P. 751.

b.b. Sporangia collected in sori, crowded over the parenchyma or placed in close rows, rarely solitary on the veins or scattered laxly between them.

(') The pages mentioned after the names of the families refer to the Handbook, not to this supplement. 
c. Ring small, lateral or apical, not encircling the sporangium.

d. Ring rudimentary or operculiform, consisting of a compact group or a whorl of thickened cells, apical, if apparently lateral, then the sporangia transversely oblong, i. e. attached at the side. V. Schizaeaceace. P. 109.

d.d. Ring rudimentary or circular, lateral, the sporangia not transversely oblong, attached at the base.

e. Ring rudimentary, consisting of a group of thickened cells only; indusium wanting.

VIII. Dsmundacene. P. 755 .

e.e. Ring circular, the cells only partly thickened; indusium present.

(IVa. Loxsomaceae).

c.c. Ring rather large, more or less completely encircling the sporangium.

1. Ring horizontal or oblique; stomium vertical.

- Fronds with stomata; indusium wanting; receptacle dot-like.

III. Clleicheniacene. P. 55.

- Fronds without stomata; indusium present; receptacle conspicuous, elevated.

IV. Vymenophyllacene. P. 65.

1.1. Ring vertical or oblique; stomium horizontal.

2. Ring vertical, incomplete (rareley oblique and complete, in forms with a non-arborescent stem and marginal linear indusia); indusia wanting or present (never marginal cup-shaped or 2-valved in forms with an arborescent or subarborescent stem).

VI. Polypodiacenc. P. 121.

2.2. Ring oblique, complete (rarely vertical and incomplete, in forms with an arborescent or subarborescent stem and cup-shaped or 2-valved indusia); indusia wanting or present (never marginal linear in forms with a non-arborescent stem).

s. Fronds pedato-flabellate or sympodially branched; indusia superior, peltate-umbellate.

II. Matoniaceae. P. 51.

3.s. Fronds simple or pinnately divided; indusia wanting or inferior, globose, cup-shaped, 2-valved or scale-like.

I. Cynthencene. P. 9. 
a.a. Sporangia rather large, with a wall more than 1 layer of cells thick; ring wanting, very rarely rudimentary. (Eusporangiatae).

- Sporangia collected in sori placed on the under side of normal, foliaceous segments of the fronds.

IX. Marattiacene. P, 761 .

$\odot \odot$ Sporangia placed on much contracted, nön-foliaceous, spiciform or paniculiform segments of the fronds.

X. Aphioglossaceae. P. 771 . 


\section{OYATHEACEAE.}

Key to the tribes and genera. (Modified).

a. Sori not terminal on the veins.

$\S$ 1. CYATHEAE ( $\left.{ }^{1}\right)$.

b. Sori with an indusium.

c. Indusium distinct, globose, quite enclosing the sorus when young, at length bursting down irregularly, evanishing or becoming more or less cup-shaped. No. 1. Cyathea.

c.c. Indủsium distinct or indistinct, not globose.

d. Indusium consisting of a more or less convex, not rarely rudimentary, scale placed at the inner side of the receptacle.

No. 2. Memitelia.

d.d. Indusium consisting of a minute orbicular scale encircling the receptacle.

No. 3. Asophila.

b.b. Sori without an indusium.

No. 3. Alsophila. a.a. Sori terminal on the veins.

$\S 2$. DICKSONIAE.

+ Indusium 2-valved, the outer valve consisting of an unmodified cucullate lobe of the frond, forming with the inner valve a saccate involucre to the sorus.

- Ultimate segments equal-sided at the base.

No, 4. Iicksonia.

- Ultimate segments more or less distinctly unequal-sided at the base, produced on the anterior side. No. $4 a$. IBalantium.

+f Indusium 2-valved, the outer valve like the inner one, distinctly differentiated from the margin of the frond, both forming a saccate involucre to the sorus.

No. 5. Cibotium.

\section{CYATHEA, Smith.}

(1 a) C. rethropoda, Copel., in Philipp. Journ., VI ${ }^{\mathrm{C}}, 134$, tab. XIII.

Stipes $\pm 40 \mathrm{~cm}$. long, smooth, naked, clothed at the base with ferrugineous scales. Fronds simply pinnate, $50-60 \mathrm{~cm}$. long, $20-25 \mathrm{~cm}$. broad.

(1) Perhaps in the whole range of the great family of ferns there is not a group more difficult of accurate determination than are the species of the section Eucyathea of Cyathea (k..). - The same may be said of the whole tribe of Cyatheae. 
Pinnae on stalks $1 \mathrm{~cm}$. long, articulate to the rachis, to $15 \mathrm{~cm}$. long, $21 / 2-3 \mathrm{~cm}$. broad, much acuminated, entire or somewhat crenated, cuneate at the base. Texture papyraceous; surfaces naked. Sori in $1-3$ rows on each side of the costae, small; indusium fugacious.

Borneo.

(2) C. philippinensis, Bk., v. A. v. R., Mal. Ferns, Appendix, 783; - var. nuda, Copel., in Philipp. Journ., IV0, 111.

Var. muda: Rachises beneath soon naked; costao often naked, otherwise sparingly clothed with a few scales towards the base. - Luzon.

\section{(5) C. altermans, $\boldsymbol{P x}$.}

Also in Malacca.

(7a) C. Eeysseri, IRst., in Fed., Rep., XII, 164.

Stipes $\pm 15 \mathrm{~cm}$. long. Fronds $\pm 150 \mathrm{~cm}$. long by $80 \mathrm{~cm}$. broad, acute, 4-pinnate, the rachis roughish. Pinnae ascending, contiguous, shortly petiolulate, elongate-obovate, $50 \mathrm{~cm}$. long, $16 \mathrm{~cm}$. broad above the middle, obtuse. Pinnulae numerous, sessile, horizontal, imbricate, oblong, shortacuminate, the point blunt; largest pinnulae $9 \mathrm{~cm}$. long by $31 / 2-4 \mathrm{~cm}$. broad. Tertiary segments \pm 20 on a side, contiguous, sessile, ascending, $21 / 2 \mathrm{~cm}$. long by $1 / 2 \mathrm{~cm}$. broad, bluntish. Ultimate segments (leaflets) \pm 12 on a side, subcontiguous, sessile, roundish, bullate, $2 \frac{1}{2} \mathrm{~mm}$. each way, revolute and entire at the edge. Texture coriaceous; rachises ferrugineopilose, fibrilloso-tomentose and pale-squamulose, the scales lanceolate, subadpressed; upper surface naked, lower tomentose on the veins; veins subflabellate, simple, the lowest often forked. Sori $1-2$ on a leaflet; indusium at length incised.

\section{New Guinea.}

(8a) C. Iamaensis, Christ, in Philipp. Journ., IIIC, 271.

Stipes rough with minute tubercles. Fronds $65 \mathrm{~cm}$. long, $45 \mathrm{~cm}$. broad. Middle pinnae $30 \mathrm{~cm}$. long, $8 \mathrm{~cm}$. broad, sessile, the lower ones reduced and deflexed. Pinnulae $6 \mathrm{~cm}$. long, $1 \% \mathrm{~cm}$. broad, $\pm 20 \mathrm{on}$ a side, crowded, sessile, cut to a narrow wing, the sinuses acute; segments close, \pm 15 on a side, entire, acute. Texture papyraceous; surfaces naked; upper surface green, lower paler; main rachis glabrescent, reddish-brown; costae beneath bearing red-brown, bullate squamulae; veins \pm 6 on a side, forked 
at the base. Sori costular; indusium breaking down early to an irregular, spread-out base; receptacle large, globose.

Mindanao.

(10) C. suluensis, Bh.

Also in Mindanao.

(11a) C. halconensis, Christ, in Philipp. Journ., IIIC, 270.

Trunk $3 \mathrm{~m}$. high. Stipes short or almost none because of reduced pinnae at the base, chestnut, spiny, scurfy, and scaly with dark, harsh, narrow paleae $1 \mathrm{~cm}$. long. Fronds $1 \mathrm{~m}$. or more long, hardly half as wide. Pinnae $30 \mathrm{~cm}$. long, $13 \mathrm{~cm}$. broad, sessile, acuminate. Pinnulae up to $7 \mathrm{~cm}$. long, to $2 \% \mathrm{~cm}$. broad, sessile or subsessile, cut near the base to the costa, and the segments sessile but usually not adnate; segments $3 \mathrm{~mm}$. broad, obtuse or subacute, serrulate. Texture membranaceous; surfaces naked; upper surface very dark, lower pale and almost glaucous; main rachis shading upward to a rather light reddish-brown, there almost glabrous and the spines reduced to sparse, minute prickles; secondary rachises smooth and almost glabrous, light-brown; costae hairy above, beneath, like the constulae and veins, black and glabrous except for a very few lanceolate scales; veins 7-10 on a side, forked near the base. Sori in the forks; indusium thin, shining-brown, splitting irregularly into large persistent, pieces.

Mindoro.

(11b) C. Mean'msii, Copel., in Philipp. Journ., IVC, 57.

Trunk $5 \mathrm{~cm}$. thick, thinly clothed at the top with black roots. Stipes provided at the base with thin, grey-brown, narrow scales $11 / 2 \mathrm{~cm}$. long. Pinnae up to $60 \mathrm{~cm}$. long, to $25 \mathrm{~cm}$. wide, sessile. Pinnulae sessile, very acuminate, horizontal, up to $3 \mathrm{~cm}$. wide at the base, cut at the base to the costa, elsewhere to a narrow wing; segments falcate, acute, serrate, 3-4 mm. wide, the lowest ones often dilated and pinnatifid. Texture coriaceous; surfaces naked except for occasional squamulae on the costulae beneath; upper surface not very dark, lower pale; main rachis tawny, everywhere glabrous, unarmed; secondary rachises smooth beneath, above clothed, like the costae, with a dark, close pubescence; costae beneath reddish, bearing some fine, furfuraceous scales; veins \pm 13 on a side, forked. Sori costular, crowded, not reaching the apices of the 
segments; indusium splitting into large pieces and only the lower part persistent.

Luzon.

(13b) C. Kingii, Rst., in Fed., Rep., IX, 422; C. fusca, Bk. (t. Copel.).

Fronds 3-pinnatifid. Pinnae $40 \mathrm{~cm}$. more or less long, $25 \mathrm{~cm}$. broad, the rachis shortly dark-strigose above, glabrescent beneath, as are the costae. Pinnulae aiternate, articulate to the rachis, the lower and central ones petiolate, rather spreading, $13 \mathrm{~cm}$. long, $1^{3}{ }_{4} \mathrm{~cm}$. broad near the base, the apex subulate-acuminate, obsoletely serrulate, the edge cut $1 / 2$-way down to the costa in the lower part, the base unequal-sided, broadest, truncate and parallel to the rachis on the upper, narrower, cuneate on the lower side; higher pinnae sessile or adnate, smaller, less incised, highest adnate or confluent, entire or obsoletely crenated. Lobes obscurely crenated, the lower obliquely truncate. Texture herbaceous; costulae pinnate in the lobes; veins $5-6$ on a side, often simple, the lowest posterior springing from the costa. Sori $3-4$ on a side, occupying the lower veins, medial; indusium globose, at length shallowly cup-shaped, the mouth regularly truncate.

New Guinea.

(13c) C. Versteegii, Christ, in Nov. Guin., VIII, Bot., 161; (? C. fusca, Bk.).

Stipes spinose. Lowest pinnae sessile, oblong, up to $50 \mathrm{~cm}$. long and $22 \mathrm{~cm}$. broad, hardly narrowed at the base, the rachis yellowish, short-hairy or furfuraceous. Pinnulae \pm 18 pair below the pinnatifid apex, alternate, approximate, sessile, $2 \mathrm{~cm}$. broad, acuminate, cut down to a winged costa into oblong, crenulate, obtuse or rarely subacute, subfalcate lobes 8-12 mm. -long and $5 \mathrm{~mm}$. broad. Texture papyraceous; colour pale-green; surfaces clothed with minute, ovate, brown scales on the costulae and veins; costulae brown-green; veins \pm 7 on each side, forked. Sori 5-6 on each side, minute; indusium thin, at length plano-patelliform. New Guinea.

\section{(14) C. integra, J. Sm.}

Elmer's No. 13473, from Mindanao, has the pinnulae to $3 \mathrm{~cm}$. broad, the ultimate segments to $6 \mathrm{~mm}$. broad, acute, nearly entire or hardly subserrate-crenate. 
(14a) C. ampla, Copel., in Philipp. Journ., VIc, 361.

Stipes glabrescent, castaneous, verruculose, clothed at the base with broad, ciliate scales; main rachis castaneous, minutely laceratotomentose, the tomentum castaneous, partly persistent, partly deciduous. Pinnae stalked, the central ones the largest, $40 \mathrm{~cm}$. long, nearly $20 \mathrm{~cm}$. broad, acute. Pinnulae stalked, the largest $10 \mathrm{~cm}$. long, $2 \frac{1}{2} \mathrm{~cm}$. broad, pinnatifid, or pinnate at the base, the costa minutely pilose above. Segments $6 \mathrm{~mm}$. broad, obtuse, coarsely toothed towards the apex, the lower not rarely free, adnate, the costulae minutely lacerato-squamulose towards the base beneath. Texture herbaceous; surfaces naked; under surface paler than the upper; veins \pm 7 on each side of the costulae, the lower twice forked. Sori nearly marginal; indusium hyaline, soon cleft down.

Borneo.

\section{(16) C. Zollingeriana, Mett.}

Stipes dark, purple-brown, as are the rachises, aculeolate-asperous, deciduously ferrugineo-furfuraceous. Fronds 3-pinnatifid, sub-3-pinnate, the main rachis muriculato-asperulous, purveyed beneath with prominent, tuberculiform glands near the bases of the pinnae, and (like the secondary rachises) villoso-tomentose above, decidnously furfuraceous beneath, the covering ferrugineous, intermixed with fugacious, brown, narrowly subulate or subfiliform paleae. Pinnae short-stalked, lanceolate-ovate. Pinnulae approximate, sessile, horizontal or spreading, or the lower more or less decurved or deflexed, linear-oblong, shortly and bluntly acuminate, deeply pimnatifid, or the largest pinnate at the very base, the largest about $6-7 \mathrm{~cm}$. long, about $1 \frac{1}{4}-1^{3 / 4} \mathrm{~cm}$. broad at the truncate base; costae puberulotomentose above, deciduously ferrugineo-furfuraceous and squamulose beneath, the scales brown, lanceolate, fugacious. Segments approximate, subhorizontal, subfalcate, linear-oblong, blunt, serrulate-crenate, the lower often free; costulae above naked, beneath squamulose in the lower part. Texture coriaceous; surfaces naked; upper surface dark, lower paler; veins to $10-12$ on a side, mostly forked. Sori costular, on the 1-2 (rarely 3-4) lower veins, the lowest close to the costae; indusium firm, brown, cupuliform, the mouth constricted, \pm repand, afterwards cut down irregularly.

Java.

(16a) C. apoensis, Copel., in Leafl., III, 802.

Stipes short, clothed with greyish-yellowish scales, Fronds large, to 
$2^{1} / 2 \mathrm{~m}$. long, the rachises castaneous, minutely tuberculate, glabrescent, provided with a prominent gland near the bases of each pinna. Pinnae sessile, the largest $40 \mathrm{~cm}$. long, the rachis clothed above with brown hairs intermixed with deciduous, long-filiform scales. Pinnulae sessile, the largest $5 \mathrm{~cm}$. long, cut down to the costa in the lower part. Tertiary segments obtuse, the lower free, $7 \mathrm{~mm}$. long, hardly $2 \mathrm{~mm}$. broad, serrate in the upper part. Texture coriaceous; costae beneath clothed with brown, lanceolate, acuminate scales, especially towards the base, otherwise scaly with minute, ovate or bullate squamulae; veins $6-7$ on a side, mostly forked. Sori costular; indusium soon eup-shaped with an irregular opening, at length often cleft down nearly or quite to the base.

Mindanao.

\section{(17) C. KorthaIsii, Mret.}

Fronds 3-pinnatifid, the main rachis hardly nodulose, yellowish-reddish, shortly ferrugineo-tomentose above, the secondary ones smooth, ferrugineohirsute above, clothed beneath with a few flaccid, scattered scales. Pinnae $30-45 \mathrm{~cm}$. long, subsessile, elongate-oblong. Pinnulae sessile, elongateoblong, $4-8 \mathrm{~cm}$. long, $1 \frac{1}{4}-1^{3} / 4 \mathrm{~cm}$. broad, shortly acuminate with a blunt point, deeply pinnatifid. Lobes elongate-oblong, approximate, subfalcate, subentire, obtuse, narrow, confluent at the base. Texture subchartaceous, firm; surfaces naked; upper surface dark; lower paler; costae ferrugineohirsute above, sparingly bullato-paleaceous beneath, the scales mixed with a few long hairs conf. Copel. ; veins $6-8$ on a side, the lower forked. Sori more or less copious, costular, chiefly in the lower part of the lobes; indusium firmly membranaceous, at first breaking at the top, falling away in fragments, often with a persistent base resembling the indusium of Hemitelia.

Sumatra, Java, Celebes, Mindanao.

\section{(18) C. erenulata, $\boldsymbol{m}$.}

Stipes not spiny but not rarely minutely muriculato-asperulous, deciduously scaly. Fronds 3-pinnatifid or sub-3-tripinnate, the main and secondary rachises above ferrugineo-tomentose, beneath deciduously paleferrugineo-furfuraceous, soon naked, smooth or hardly asperulous. Pinnae subsessile or short-stalked, elongate-oblong, to $50 \mathrm{~cm}$. long, to $20 \mathrm{~cm}$. broad, acuminate. Pinnulae lanceolate-oblong, 5-10 $\mathrm{cm}$. long, to $2 \mathrm{~cm}$. broad, acuminate, deeply pinnatifid below the crenate or crenulate apex. Segments 
approximate, elongate-oblong, subfalcate, to $3 \mathrm{~cm}$. broad, subobtuse, the edge somewhat revolute, subentire or crenulate. Texture more or less coriaceous; surface naked; upper surface dark-green, lower paler; costae hirsute above, furfuraceous or scaly beneath, costulae slightly so, the covering more or less deciduous; veins 9-12 on a side, mostly forked. Sori costular, occupying the 1-4-6 lower veins; indusium membranaceous, breaking very irregularly by a single slit, with a mostly persistent, roundish, lobed or erose, flattish base encircling the base of the receptacle.

Forma typica: Pinnulae $1 \frac{1}{2} \mathrm{~cm}$. broad; segments $21 / 2 \mathrm{~mm}$. broad, subentire or crenulate, often entire at the apex; tomentum of costae and costulae beneath not intermixed with larger scales. - Java.

Forma latior: Like the type but the pinnulae and segments respectively $2 \mathrm{~cm}$. and $3 \mathrm{~mm}$. broad. - Java.

Forma subspinulosa: Like the preceding, but the rachises more or less asperulo-muriculate, and the stipe shortly and sharply aculeolate at the base. - Sumatra.

Forma squamulosa: Like the type but the segments more distinctly crenulate, and the tomentum intermixed with proportionally long, lanceolatesubulate, brown scales. - Java.

Forma asperula: Like the preceding but the rachises more or less strongly asperulo-muriculate. - Java.

(18b) C. Foersteri, Rst., in Fed., Rep., X, 321.

Fronds 3-pinnatifid. Pinnae elongate-oblong, $40 \mathrm{~cm}$. or more long, $18 \mathrm{~cm}$. broad, acuminate. Pinnulae alternate, subsessile, suberecto-patent, linear-lanceolate, nearly $10 \mathrm{~cm}$. long, 1//2 broad, acuminate, cut down nearly to the costa. Laciniae linear, subfalcate, $8 \mathrm{~mm}$. long, hardly more than $2 \mathrm{~mm}$. broad, subacute, distinctly serrate-crenate in the lower part. Texture chartaceous; upper surface olive-green, lower paler; rachises of the pinnae purple-brown, ferrugineo-villose above, clothed beneath with dense, small, orbicular, ovate or linear, membranaceous, pale-brown or pellucid, setose squamules intermixed with a few lanceolate, setoso-ciliate larger ones; costae strigoso-villose above, beneath scaly like the rachises; costulae and veins distinct, subpellucid, hairy on both sides; veins 8-10 on a side, forked, the higher simple. Sori subcostular, $2-3$ on a side; indusium firm, red-brown.

New Guinea, 


\section{(19) C. orientalis, Moore.}

Stipes thickened, spinulose and farinoso-tomentose at the base, densely, but deciduously, scaly, minutely muriculato-asperous, fulvo-pulverulent, at length glabrescent, beneath ferrugineo-castaneous; main rachis like the upper part of the stipe, at least in the lower part, otherwise smooth or nearly so, grooved above, hardly puberulous in the groove; secondary rachises punctulate in the lower part, ferrugineo-velutinous above; costae velutinous above, minutely chaffy beneath.

(19a) C. caudata, Copel.

Omit this species, it being referred to Hemitelia.

\section{(196) C. Clnnistit, Copet.}

Elmer's No, 10601 differs from Copeland's original diagnosis in having the pubescence of the rachises above intermixed with scattered, darkcoloured, filiform scales, and the costulae beneath copiously bullatosquamulose; No. 11459 is a plant with reduced foliage.

(19c?) C. pruinosa, Rst., in Fed., Rep., XII, 163.

Fronds 3-pinnatifid, the rachises ochraceo-tomentose above, naked beneath, livid-brown or nearly glaucous. Pinnae $50 \mathrm{~cm}$. long by $15 \mathrm{~cm}$. broad, short-stalked. Pinnulae remote, $71 / 2 \mathrm{~cm}$. long by $1 \frac{3}{4} \mathrm{~cm}$. broad, acuminate, deeply pinnatifid, sessile, slightly decurrent-adnate. Segments subfalcate, nearly $2 \frac{1}{2} \mathrm{~mm}$. broad, the edge recurved, crenulate. Texture subcoriaceous; surfaces naked; upper surface olivaceous, lower paler; costa somewhat tomentose above, scaly beneath, the scales narrowly linear, white, deciduous; costulae naked above, scaly beneath, the scales oval, ferrugineous, subciliate; veins 9-10 on a side, forked. Sori costular, on the 2-3 lower veins; indusium large, membranaceous, persistent, the mouth truncate. - Rachis unarmed?

\section{New Guinea.}

(20a) C. stipulata, Copel., in Philipp. Journ., VIC, 362.

Stipes slightly spiny with numerous lanceolate, brown scales at the base; main rachis unarmed, dirty-brown, glabrescent beneath, clothed above with minute, adpressed tomentum. Pinnae spreading, short-stalked, $40 \mathrm{~cm}$. long, $12 \mathrm{~cm}$. broad, acute, the rachis castaneous, quadrangular, sparingly furfuraceous beneath. Pinnulae $20-25$ on a side, horizontal, 
cordate at the base, $1 \frac{1}{2} \mathrm{~cm}$. broad, narrowed gradually towards the apex, cut down nearly to the costa, short-stalked, the petiole tomentose, the costa castaneo-pilose above, scaly beneath with scattered, castaneous, often lacerate squamules. Lobes oblong, $4 \mathrm{~mm}$. broad, obtuse, crenulate. Texture subcoriaceous; surfaces naked; veins \pm 6 on a side. Sori medial; indusium castaneous, rather persistent.

Borneo.

(21b) C. geluensis, Ist., in Fed., Rep., V, 371; - var. tomentosa, Rst., 1. c., XII, 525.

Trunk $2 \mathrm{~m}$. high. Stipes unknown. Fronds 3-pinnatifid. Pinnae alternate, subsessile, erecto-patent, $30 \mathrm{~cm}$. or more long, $8 \mathrm{~cm}$. broad, linear-lanceolate, acuminate, the upper part pinnatifid, the apex linearly narrowed, serrate. Pinnulae $4 \mathrm{~cm}$. or more long, $1 \% \mathrm{~cm}$. broad, elongate-oval, subacute or the largest ones shortly acuminate, deeply pinnatifid, the apex slightly serrate. Lobes linear, suboblique, subfalcate, crenate-serrate. Texture chartaceo-herbaceous; surfaces naked; upper surface olive-coloured, lower paler, subglaucous; rachises slender, livid, strigoso-villose above, clothed beneath with small, unequally stellato-dilacerate or hair-like, subflaceid or rarely rigid, broad paleae; costae slightly strigose above, clothed beneath with minute, white, bullate paleolae; costulae pinnate with \pm 6 veins on each side; 3-4 lower veins forked, the others simple. Sori near the costulae, below the forking of the forked veins, the simple veins destitute of sori; indusium large, hypocrateriform, membranaceous, with the margin cut down into 5 nearly regular, broadly deltoid lobes. - Resembles in habit C. philippinensis $B k$.

Var. Iomentosa: Rachis ochraceo-tomentose with adpressed hairs; secondary rachises more laxly tomentose, the hairs intermixed with narrowly lanceolate, acuminate, yellowish-white scales; costalae scaly, the lower scales straight, the higher bullate.

New Guinea.

(21c) C. Teoblnsonii, Copel., in Philipp. Journ., VIC 145.

Trunk 2-4 m. high, $4 \mathrm{~cm}$. thick. Stipes $40 \mathrm{~cm}$. long, clothed at the base with linear, brown, entire scales, the upper part dark-coloured, minutely squamulose and hispid. Fronds $1 \mathrm{~m}$. long, $70 \mathrm{~cm}$. broad, abruptly acute, 3-pinnate, especially the partial rachises clothed with crowded scales, the scales partly linear and brown, partly minute. Pinnae on stalks 
2-3 cm. long, the largest to $40 \mathrm{~cm}$. long, $16 \mathrm{~cm}$. broad, the lower sometimes smaller. Pinnulae short-stalked, horizontal, $1^{1}{ }_{2} \mathrm{~cm}$. broad. Segments narrowly elliptical, obtuse, entire, the lower free, the lowest very short-stalked. Texture rigidly papyraceous; upper surface blackish, naked, lower bluish, setose on the veins; veins \pm 6 pair. Sori medial; indusium globose, cleft.

\section{Luzon.}

(21d) C. patellifera, v. A. v. R., in Bull. Btz., 1914, XVI, 4.

Stipes $50 \mathrm{~cm}$. long, aculeate with short, sharp, conical warts, scaly towards the base, tomentose towards the frond, the scales linear-subulate, brown, subentire. Fronds 3-pinnatifid, sub-3-pinnate, abruptly acuminate. Pinnae oblanceolate, the largest sessile, $35-40 \mathrm{~cm}$. long, 8-10 cm. broad at or above the middle, more or less narrowed at the base, acuminate, the lower abbreviated, on stalks $3 \frac{1}{2} \mathrm{~cm}$. long. Pinnulae close, linearoblong, to $6 \mathrm{~cm}$. long, $1 \frac{1}{2} \mathrm{~cm}$. broad, acute, sessile or subsessile, spreading or suberecto-patent, the lower horizontal or deflexed. Segments nearly close, to $1 \mathrm{~cm}$. long, $3 \mathrm{~mm}$. broad, the central and higher linear-oblong; blunt, crenated, connected at the base, the lower free, adnate, the lowest subobovate-oblong, coarsely toothed (lobate-dentate), broadly cuneate at the base. Texture coriaceous; upper surface dark, lower paler; main rachis densely tomentose, muricato-asperous, the tomentum pale-brown, persistent above, deciduous beneath, intermixed with a few nearly filiform, deciduous scales; secondary rachises tomentose; costae hairy above, shortly pubescent and bullato-squamulose beneath, as are the costulae, at least in the lower part; veins blackish or dark-brown, very minutely and sparingly appressopilose beneath, 5 - 6 on a side, forked, the highest simple. Sori occupying the lower veins, subcostular; indusium breaking away, the base persistent, castaneous, shallowly cup-shaped.

\section{Sumaira.}

(21e?) C. albidosquamata, rst., in Fed, Rep., XII, 525; (? Hemitelia).

Fronds sub-3-pinnate, elongate-oblong, acuminate; rachises above brownhirsute in the groove, pale-tomentose beneath, the tomentum intermixed with scales, the scales partly whitish, spreading, linear-lanceolate, hairpointed, subentire or sparingly ciliated, partly hair-like. Pinnae remote, subsessile, linear-lanceolate, to $35 \mathrm{~cm}$. or more long, $8 \mathrm{~cm}$. broad below 
the middle. Pinnulae somewhat remote, sessile, the largest $4 \mathrm{~cm}$. long by $1 \% \mathrm{~cm}$. broad, deeply pinnatifid, pinnate at the base; lower pinnulae hardly abbreviated. Segments subremote, linear, somowhat oblique, $6 \mathrm{~mm}$. long by $2 \mathrm{~mm}$. broad, bluntish, slightly crenulate and revolute at the edge. Texture chartaceous; surfaces short-hairy; upper surface dark-green, lower paler; costulae beneath squamulose with whitish, long-acuminate, bullate scales; veins \pm 6 on a side, forked. Sori on the $4-5$ lower veins, subcostular, confluent; indusium at length hemitelioid. - Main rachis unarmed?

\section{(22) C. javaniea, Bi.}

Stipes minutely aculeate at the base, deciduously scaly and farinosotomentose, otherwise punctulato-asperulous; rachises smooth or asperulous, tomentose, the tomentum intermixed with deciduous, linear, subfiliform scales; pinnulae with the lower segments not rarely remote and free or nearly so; costae naked or slightly hairy above, more or less deciduously scaly and hairy beneath, the lower scales narrowly lanceolate-subulate, the higher rather bullate or subbullate, the hairs long, crisped, ferrugineous like the seales; sori subcostular or the lower divaricating; indusium at length rather shallowly saucer-shaped, entire or incised into 2-4 rounded segments.

\section{(23) C. sumatrana, Br.}

Stipes shortly aculeate at the base, otherwise muricate, furfuraceous and scaly; scales dense, deciduous, linear-subulate, brown, glossy, partly minutely eroso-denticulate, deciduously ciliolate with short, remote, castaneous hairs, the lower the longest, the higher smaller; lower scales of the main rachis similar to the higher ones of the stipe, the following growing gradually smaller and less dense.

Forma subabrupta: Pinnulae more gradually acuminate.

Forma obtusata: Pinnulae blunt to very shortly acuminate.

(23a) See No. 22.

(23b) C. subutiformis, v. A. v. F., in Bull. Btz., 1913, XI, 6.

Stipes $35-40 \mathrm{~cm}$. or more long, deciduously tomentose and scaly, as are the rachises, the scales very dense, more or less spreading, linearsubulate, partly straight, partly crisped, dark-brown or blackish, leaving 
the rachises rough when they fall. Pinnae close, horizontal, to $50 \mathrm{~cm}$. long or longer, subabruptly acuminate. Pinnulae numerous, close, the central ones the largest, horizontal, $7-8^{\prime} \mathrm{cm}$. long and $2 \mathrm{~cm}$. broad, acuminate, cut down nearly to the costa, pinnate at the base, the higher rather ascending, the lower more or less abbreviated and deflexed. Segments linear, straight or subfalcate, subhorizontal or more oblique, $3 \mathrm{~mm}$. broad, blunt, crenate or crenate-dentate, the lower free, adnate, somewhat narrowed near the base, the lowest more distinctly toothed, rather rounded at the base. Texture rigidly coriaceous; surfaces naked; costulae sparingly subbullate-squamulose beneath; veins $8-10$ on a side, the higher simple, the following and the lower forked, the central twice forked or sparingly pinnate. Sori occupying the lower veins, costular; indusium thin, breaking away irregularly.

\section{Sumatra.}

123c) C. borneensis, Copel., in Philipp. Journ., VIC, 135.

Stipes fuscous, spiny, clothed at the base with narrow, rigid, blackbrown scales. Central pinnae sessile, nearly $60 \mathrm{~cm}$. long, acuminate. Pinnulae subsessile, $10 \mathrm{~cm}$. long, $2 \mathrm{~cm}$. broad, the larger ones acuminate, the edge cut down to a narrow wing to the costa. Segments subfalcate, 3-4 mm. broad, obtuse, entire. Texture coriaceous; rachises minutely tomentose above, the tomentum intermixed with scattered, deciduous, linear scales, the main rachis asperous, the secondary ones pustulous; costae velutinous above, very sparingly brown-scaly beneath; costulae naked above, sometimes scaly beneath; veins 8-10 on a side, often forked. Sori costular; indusium patelliform.

Borneo.

(23d?) C. rigens, Rst., in Fed., Rep., XII, 163.

Fronds 3-pinnatifid, the rachises brown, above densely castaneotomentose, beneath appresso-squamulose. Pinnae sessile, close, $30 \mathrm{~cm}$. or more long, $8 \mathrm{~cm}$. broad, bluntly acuminate. Pinnulae sessile, close, spreading, $4 \mathrm{~cm}$. long by $1 \frac{1}{2} \mathrm{~cm}$. broad, deeply pinnatifid. Segments oblong, subfalcate, $4^{1} / 2 \mathrm{~mm}$. long by $2-2^{1}{ }_{2} \mathrm{~mm}$. broad, subacute, crenate. Texture subcoriaceous; surfaces naked; upper surface olivaceous, lower paler; costae somewhat dark. tomentose above, clothed beneath with crowded, acuminate, membranaceous, pale or subferrugineous, subentire or slightly ciliated, plane-lanceolate and subbullate scales; costulae naked above, white-woolly beneath; veins 6 - 8 .

Ferns and Fern Aluites. 
on a side, often forked. Sori costular, on the $2-3$ lower veins; indusium large, firm, persistent, truncate at the mouth. - Rachis unarmed?

New Guinea.

(24a) C. semex, v. A. v. R., in Bull. Btz., 1914, XVI, 4.

Stipes densely deciduously sealy, at length muriculato-asperous; scales nearly white, long, narrowly linear-subulate, filiform at the point, like all the other scales finely ciliolate-denticulate at the edge, the teeth or ciliae red-brown. Fronds 3-pinnatifid, sub-3-pinnate, abruptly acuminate; rachises tomentose above with adpressed, brown or grey-brown hairs, beneath deciduously scaly and hirsute, at length asperulous, the scales partly minute, ferrugineous, partly similar to those of the stipe but smaller, the hairs long, firm, whitish or brownish, articulated. Pinnae stalked; central pinnae spreading, falcate, $40 \mathrm{~cm}$. long, $15 \mathrm{~cm}$. broad at or near the base, abruptly acuminate; lowest pinnae reduced, rather horizontal, broadest at the middle. Pinnulae numerous, close, subsessile, linear, straight or falcate, $1 \frac{1}{4} \mathrm{~cm}$. broad at the base, deeply pinnatifid, acutely acuminate. Segments close, oblong, $3 \mathrm{~mm}$. broad, subfalcate, blunt to slightly acuminate, the edge recurved when dry, crenate; lowest segments free. Texture subcoriaceous to rigidly coriaceous; both surfaces long-hairy on the veins; costae hairy above, scaly and hirsute beneath; costulae long-hairy above, hairy and squamulose beneath, the scales bullate; veins $7-8$ on a side, simple or forked. Sori few, medial on the lower veins; indusium scariose, at length cup-shaped or irregularly lobed.

Sumatra.

(26a) C. fuga $x$, v. A. v. IR., in Bull. Btz., 1912, VII, 8; C.contaminans, Copel., Phillipp. Journ., VIC 69 (not IV, 60 ).

Fronds large. Primary and secondary rachises pale-fuscous, aculeate and asperous with large and small, sharp, dark-tipped, scattered prickles, deciduously dark-tomentose above. Pinnae $70 \mathrm{~cm}$. long, pinnate, on stalks to $10 \mathrm{~cm}$. long, the apex shortly acuminate, pinnatipartite. Pinnulae lancelate-oblong, abruptly caudate-acuminate, the central ones $15 \mathrm{~cm}$. long, $2 \% \mathrm{~cm}$. broad at the base, sessile, the lowest nearly as long, $3 \mathrm{~cm}$. broad near the base, stalked, cut down nearly to the costa, pinnate at the base, the acumen subulate, acute, entire, slightly lobed at the base. Segments linear, falcate, horizontally spreading or nearly so, the largest $2 \mathrm{~cm}$. long, 3-4 mm. broad, blunt, entire, narrowly recurved at the 
edge; lower segments free, adnate, those of the lowest pinnulae deflexed, shorter than the next higher, adnate or truncate at the base. Texture coriaceous; upper surface naked, dark, lower paler, minutely and deciduously furfuraceous and short-hairy on the veins; veins $15-20$ on a side, mostly forked. Sori numerous, submedial, nearer the costulae than the margin, not occupying the higher veins; indusium globose, thin, consisting of copious soon evanishing interlaced hairs quite enclosing the sorus when young, the base persistent, at length deeply fimbriate.

\section{New Guinea.}

(26b) C. novo-guineensis, Rrau., in Engl. Bot. Jahrb., IL, 12, fig. $1 B$.

Stipes short, $4 \mathrm{~cm}$. long, muricate, tomentose and copiously scaly, as are the rachises, the scales linear-lanceolate, lacerate, yellowish-grey in the lower part, fuscous towards the long-acuminate apex. Fronds probably lanceolate, narrowed at the base, 3-pinnatifid. Pinnae alternate, subpetiolulate, the central ones the largest, to $20 \mathrm{~cm}$. long and $7 \mathrm{~cm}$. broad, horizontal, abruptly narrowed at the bluntish apex, slightly narrowed at the base; lower pinnae growing gradually smaller, the lowest remote; $1 \frac{1}{2} \mathrm{~cm}$. long and $3 / 4 \mathrm{~cm}$. broad. Pinnulae sessile, remote, alternate, sublinear, bluntish, deeply pinnatifid, the largest to $4 \mathrm{~cm}$. long and $1 \mathrm{~cm}$. broad; lobes spreading, $1 / 2-{ }^{3}{ }_{4} \mathrm{~cm}$. long and to $1 / 4 \mathrm{~cm}$. broad, bluntish, subcrenulate, slightly dilated at the base. Texture chartaceous; surfaces naked; upper surface dark, lower paler; costae and costulae brown-hairy above, palesquamulose benaeth, the scales bullate, acuminate; veins \pm 6 on a side, simple or forked. Sori numerous, the lower medial on the veins, the higher nearer the costulae than the edge; indusium thin when young, umbilicate, pale-red.

\section{Nero Guinea.}

(27a) C. Foxwartliyi, Copel., in Philipp. Journ., IV ${ }^{\mathrm{C}}, 46$.

Trunk to $2 \mathrm{~m}$. high. Stipe and lower end of the main rachis beset on the under side with close, short, sharp spines, and finely scurfy, on the upper side with very narrow, dark paleae, and bearing scar-like, linearoblong aërophores along the 2 ridges. Fronds $150 \mathrm{~cm}$. long, bearing reduced pinnae almost down to the trunk. Middle pinnae $45 \mathrm{~cm}$. long, sessile, abruptly narrowed to a pinnatifid apex. Pinnulae $10 \mathrm{~cm}$. long, $1 \frac{\mathrm{cm}}{\mathrm{c}}$. broad, narrowed gradually from the base to the caudate apex, cut almost 
to the costa; segments $3 \mathrm{~mm}$. wide, linear-oblong, obtuse, the margin everywhere minutely but sharply serrulate. Texture subcoriaceous; surfaces naked; upper surface dark-green, lower pale; upper part of the main rachis and secondary rachises light-brown, beneath almost glabrous and bearing sparse, minute tubercles, above dark-velvety; costae hairy above, beneath dark-purple and bearing a few small scales; veins 11 on a side, forked. Sori costular, small; indusium dark-stramineous, at first complete, then with a small irregular mouth, finally all breaking away.

\section{Luzon.}

\section{(28) C. Spinulosa, Wall.}

Stipes strongly prickly, purpureous or blackish, deciduously puberulous and scaly; main rachis aculeolate at the base, muricate at the middle, often smooth towards the apex; lower fertile segments not invariably close.

Var. muriculate: Stipe and main rachis less prickly, the former muriculato-spinulose at the base, muriculate in the upper part, the latter at best muriculato-asperous; ultimate segments more or less obsoletely crenate-serrulate.

(28a) C. cinerea, Copel., in Leafl., V, 1681.

Stipes aculeate with black or blackish, acute spines $8 \mathrm{~mm}$. long. Fronds $2 \mathrm{~m}$. or more long, the rachis fulvous, spinose, minutely furfuraceous or at length glabrescent, provided with glands near the bases of the pinnae. Pinnae $40-50 \mathrm{~cm}$. long, short-stalked, abruptly acuminate, the rachis aculeolate, furfuraceous with very minute, deciduous, cinereous scales intermixed with a few scattered, longer, narrow-linear paleae. Pinnulae subsessile, lanceolate, acuminate, the edge cut down nearly to the costa; barren pinnulae to $10 \mathrm{~cm}$. long, $1^{3 / 4} \mathrm{~cm}$. broad, fertile ones a little smaller; costae above sparingly velutinous, clothed beneath with minute scales intermixed with a few scattered lanceolate-ovate paleae. Lobes $1 \mathrm{~cm}$. long, $1 / 4 \mathrm{~cm}$. broad, subfalcate, acute, serrate in the upper part; costulae sparingly scaly. Texture chartaceous; veins 12 on a side, often forked. Sori costular, large, contiguous; indusium large, deep-brown, breaking down into large persistent fragments. - A duplicate of Elmer's No. 13860, occurring in the Buitenzorg Herbarium, has the furfur not cinereous but pale-yellow-brown.

Mindanao. 
(29b C. mitrata, Copel., in Philipp. Journ., IV C, 42.

Pinnae $40 \mathrm{~cm}$. long, $15 \mathrm{~cm}$. wide, sessile. Pinnulae $7 \mathrm{~cm}$. long, $1 \frac{1}{2} \mathrm{~cm}$. wide, acuminate, cut almost throughout into distinct segments. Segments linear-oblong, obtuse, the lower ones stalked and deeply lobed, the upper crenate. Texture coriaceous; surfaces naked; upper surface black, lower brownish-green; margins deflexed; main rachis brown, almost glabrous, minutely scabrous, bearing scar-like aërophores at the bases of the pinnae and along the angles of the rachis; secondary rachises sparsely clothed beneath with a scurf of minute scales and a very few lanceolate ones $2 \mathrm{~mm}$. long; tertiary rachises hairy above, bearing 2 kinds of scales beneath; veins forked. Sori costular; indusium very large and globose, then split like a mitre, or to the base, and very persistent, covering the nether surface.

\section{Mindanao.}

\section{(30) C. dinops, Hisst.}

Stipes deciduously scaly at the base, otherwise punctulate, and tomentose like the rachis; costae striguloso-puberulous above, densely ferrugineo-paleaceous beneath, the scales linear; costulae naked above; scaly beneath.

\section{(31a) C. Loheri, Christ.}

Omit the variety tonglonensis. See Hemitelia tonglonensis v. A. v. R.

(31b) C. callosa, Christ; Alsophita extensa, J. Sm., in Hk. Journ. of Bot., III, 419 .

(31c) C. fructuosa, Copel., in Philipp. Journ., IV, 34.

Trunk 3-5 m. high, $10 \mathrm{~cm}$. thick. Fronds almost sessile, 3-pinnate, $200 \mathrm{~cm}$. long, 60-90 cm. broad, the main rachis setoso-paleaceous above, purplish, scabrous and furfuraceous below. Pinnae 15-20 on each side, the lowest reduced, the rachis purple-brown, beneath asperous and clothed with minute, purplish squamules and rufo-stramineous scales. Pinnulae $8 \mathrm{~cm}$. long, $2-2 \frac{1}{2} \mathrm{~cm}$. broad, sessile, acuminate and serrate at the apex, the rachis velutinous above, rufo-paleaceous beneath. Tertiary segments distinct, mostly separate, obtuse, $1 \frac{1}{4} \mathrm{~cm}$. long, $2-21 / 2 \mathrm{~mm}$. broad, adnate or the lowest truncate at the base, dimorphous, the barren ones entire or nearly so, the fertile ones deeply crenate, the costules naked above, squamulose 
at the base beneath. Texture subcoriaceous; surfaces naked; under surface paler than the upper; veins $9-11$ on a side, $2-3$ higher simple, others forked, with the anterior veinlet sometimes forked again. Sori crowded, whether or not wanting in the upper part of the segments; indusium ferrugineous, breaking down into large segments.

Negros.

(31d) C. sibuyanemsis, Copel., in Leafl., IV, 1150.

Stipes $60 \mathrm{~cm}$. long, brown-scaly at the base. Fronds to $180 \mathrm{~cm}$. long, the rachises short-hairy and densely scaly with minute, lacerate squamules intermixed with linear, ciliate, caducous paleae, both leaving the rachises roughish by their persistent bases. Pinnae petiolate, the central ones the largest, to $35 \mathrm{~cm}$. long and $18 \mathrm{~cm}$. broad, abruptly acuminate. Lower pinnulae short-stalked. Tertiary segments blunt or rounded at the apex, the lower cordate at the base, $12 \mathrm{~mm}$. long and half as broad, petiolulate, cut down nearly to the costa into suborbicular lobes, the following and those of the higher pinnae somewhat longer, less deeply incised or subentire. Texture coriaceous; surfaces naked; costae squamulose, or setulose in the upper part; veins once or twice forked. Sori submedial; indusium globose, persistent.

Sibuyan Island.

(31e?) C. mierophylloides, Rst., in Ferl., Rep., XII, 164.

Fronds 3-pinnate. Pinnae approximate, ascending, petiolate or the higher sessile, $22 \mathrm{~cm}$. long by $6-7 \mathrm{~cm}$. broad. Pinnulae \pm 20 on a side, subsessile, to $3 \frac{1}{2} \mathrm{~cm}$. long by nearly $1 \mathrm{~cm}$. broad, bluntish, the lowest a little abbreviated. Ultimate segments (leaflets, \pm 9 on a side, remote, oblong or subcuneate, $4 \mathrm{~mm}$. long by $2 \mathrm{~mm}$. broad, obtuse, repandocrenate, contracted and adnate at the base. Texture herbaceous; primary and secondary rachises ochraceo-strigose above, scaly beneath, the scales partly minute, adpressed, hair-like, partly longer, lanceolate, pale-ferrugineous, subentire or sparingly ciliate; tertiary rachises scaly, the scales lanceolate, acuminate, whitish; veins $5 \pm$ on a side, the higher simple, the lower forked. Sori costular; indusium membranaceous, persistent, the mouth truncate. - Rachis unarmed?

New Guinea.

(32) C. arachnoidea, $\boldsymbol{H k}$.

Teysmann's No. 5201 (Ternate) and Scheffer's plant (Java) have the 
under surface cobwebby, the veins indistinct, the lowest tertiary segments lobed towards the rather cordate and slightly petiolulate base with the lowest lobes free and the edges much recurved.

(33) C. celebica, v. A. v. R.

Omit this name, it should be C. Teysmannii Copel.

(33) C. Teysmannii, Copel., in Philipp. Journ., IV C, 51 ; C. celebica, v. A. v. R. (not Bl.).

Differs from C. arachnoidea $H k$, in having the under surface not cobwebby, the veins distinct, and the edges hardly recurved.

\section{(34) C. tripinnata. Copel.}

Rachises with the tomentum intermixed with small scales different in size and shape; costae scaly beneath, the scales intermixed with scattered, crisped, deciduous hairs; scales of rachises, costae and costulae whitish, partly lanceolate, partly linear, with the edges beset with oblique, sharp, dark, minute, spine-like ciliae. Tertiary segments cordate or truncate at the base, crenate in the lower part, serrate towards the apex; veins 8-10 on a side, forked, the higher simple. Texture firm.

Also in Mindanao and Negros.

(35) C. suriculifera, Copel., in Philipp. Journ., VIC 364.

Main rachis castaneous, finely furfuraceous, minutely and sparingly prickly like the secondary rachises which are densely and minutely castaneotomentose . Pinnae $50 \mathrm{~cm}$. long, $12 \mathrm{~cm}$. broad, nearly sessile. Pinnulae subsessile, horizontal, pinnate, $14 \mathrm{~mm}$. broad, abruptly acute, the acumen entire. Tertiary segments short-stalked, $2 \mathrm{~mm}$. broad, obtuse, entire, the central ones unequal-sided and truncate at the base, the lower provided with a suborbicular auricle on each side at the base. Upper surface green and naked, lower paler and sparingly paleaceous; veins $7-8$ on a side, the lower forked. Sori costal, close, bright-brown, occupying the central veins; indusium membranaceous.

New Guinea.

Species of an uncertain systematical place.

(36) C. hypocrateriformis, v. A. v. R., in Bull. Btz., 1912, VII, 9; ? C. integra, J. Sm., forma, Copel., in Leafl., V, 1680.

Pinnae short-stalked, abruptly acuminate at the apex, the rachis 
somewhat compressed, bisulcate down the face, clothed with dark, subadpressed hairs between the grooves, the lower side asperous with very minute, acute warts. Pinnulae linear-lanceolate, short-stalked, articulate to the rachis, the largest $12-15 \mathrm{~cm}$. long, $2 \mathrm{~cm}$. broad, truncate at the base, acuminate at the deeply serrate apex, the edge cut $\pm{ }^{2} / 3$-way down to the costa. Segments falcate-oblong, $71 / 2 \mathrm{~mm}$. broad, blunt, more or less crenate to deeply and sharply serrate towards the often spinulosoapiculate apex. Texture coriaceous; costae hairy above; costae and costulae provided beneath with moderately long, dark, acute, scattered, firm hairs; veins 5-7 on a side, naked, forked or the higher simple, arcuate-ascending. Sori remote from the costulae, at the forkings of the veins, $3-7$ on $a$. side, not occupying the higher veins, the lower divaricating; indusium globose, the base persistent, at length saucer-shaped, the mouth irregular or irregularly incised.

Polillo Island.

\section{HEMITELIA, R. Krown.}

\section{§ 2. AMPHICOSMIA.}

1. Costae (tertiary rachises) beneath hairy and scaly.

$\triangle$ Costulae beneath rather densely hairy and scaly, at least in the lower half.

(4) H. sumatrana.

$\triangle \triangle$ Costulae beneath not densely hairy and scaly.

- Pinnulae pinnatifid.

$\nabla \quad$ Pinnulae to $2 \mathrm{~cm}$. broad. $\quad(4 a)$ H. caudipinnula.

$\nabla \nabla$ Largest pinnulae more than $2 \mathrm{~cm}$. broad.

(4b) H. barisanica.

OO Pinnulae pinnate, at least at the base.

$\nabla \quad$ Pinnulae to $1 \frac{1}{2} \mathrm{~cm}$. broad.

(4c) H. confluens.

$\nabla \nabla$ Largest pinnulae more than $1 \frac{1}{2} \mathrm{~cm}$. broad.

(4d) H. salticola.

1.1. Costae (tertiary rachises) beneath naked, hairy or scaly.

2. Main rachis distinctly muricate or aculeate, at least towards the base.

- Indusium indistinct, represented by a minute scale hidden under the sorus. 
$\times$ Secondary rachises distinctly muricale or aculeate.

(7) H. latipinnula.

$\times \times$ Secondary rachises smooth, or roughish with fine prickles.

Roughish.

Smooth.

(6) H. latebrosa.

(6a) H. caudata.

00 Indusium distinct, rather large.

$\times$ Tertiary segments obtuse.

8) H. manilensis.

$\times \times$ Tertiary segments not obtuse.

9) H. heterochlamydea.

2.2. Main rachis smooth, or rough with minute warts or pustules

3. Tertiary segments acute or acuminate.

$\times$ Veins to \pm 9 on a side.

(2) H. capensis.

$\times \times$ Veins \pm 10 or more on a side.

Pinnulae abruptly acuminate.

(2a H. bicolor.

$\square \square$ Pinnulae not abruptly acuminate.

(2b) H. merapiensis.

3.3. Tertiary segments blunt or bluntish.

4. Under surface glaucous.

(5) H. glaucophylla.

4.4. Under surface not glaucous.

5. Main rachis more or less scaly, or (though not rarely sparingly) scaly and tomentose, hairy or furfuraceous.

+ Stipes smooth or asperous

(.) Stipes often with reduced pinnne at the base.

$\hat{v}$ Texture membranaceous or herbaceous.

(1) H. crenulata.

\ Texture coriaceous or chartaceous.

(1a) H. tonglonensis.

$\odot \odot$ Stipes without reduced pinnae at the base.

(1b) H. warihon.

++ Stipes muricate or aculeate.

(1c) H. singalanensis.

5.5. Main rachis naked, hairy, tomentose or furfuraceous, not scaly.

6. Stipes without aërophores

*. Sori costular or subcostular.

8. Veins to 10 on a side

(3) H. Junghuhniana.

8.8. Veins 10 or more on a side.

(3a) H. alsophiliformis, 
7.8. Sori not costular.

6.6. Stipes with aërophores. (3b) H. horridipes.

(3c) H. hemichlamidea.

(1) H. crenulata, Mett., Rac., Flor. Btz., I, 38; Alsophila crenulata, Mett., Hk. Bk., Syn. Fil., 44, Cyathea Raciborskii, Copel., Philipp. Journ., IV , 45; - var. subsimplicivenia, v. A. v. R., Bull. Btz., 1912, VII, 15.

Trunk up to $3 \mathrm{~m}$. high, $5 \mathrm{~cm}$. thick. Stipes smooth or asperulous like the main rachis with few very minute, scattered, elevated points different in length, often bearing some much reduced pinnae at the base. Fronds oblong, $140-150 \mathrm{~cm}$. long. Pinnae short-stalked, lanceolate, to $45 \mathrm{~cm}$. long. Pinnulae approximate, rather sessile or short-stalked, 6-10 cm. long, oblong, obtuse, the apex narrowed, subentire or crenulate, the margin cut down nearly or quite to the costa. Ultimate segments (lobes or leaflets) close, oblong or elongate-oblong, obtuse, subfalcate, $71 / 2 \mathrm{~mm}$. long, entire or crenulate. Texture membranaceous or herbaceous, flaccid or firm; surfaces naked; upper surface bright-green, lower paler; rachises stramineous or subfuscous, hirsute above, beneath clothed with deciduous tomentum, the covering intermixed with few subulate, fuscous scales, at length often naked; costae hairy above, costae and costulae beneath provided with more or less scattered, minute, bullate, acuminate, pale or brownish scales; veins $6-9$ on a side, the lower and central forked, the higher simple. Sori costular, 1-6 on a side, occupying the lower veins; indusium small.

Forma typica. - Sumatra, Java, Philippines.

Var. subsimplicivenia: Stipe and rachis more copiously asperous with minute warts; veine simple, or the 1--4 lower occasionally regularly or irregularly forked. - Java.

(1a) II. tonglonensis, v. A. ø. R., Bull. Btz., 1912, VII, 14; Cyathea Loheri, Christ, var. tonglonensis, Christ, Philipp. Journ., IIC, 180; C. fuliginosa, Copel., Philipp. Journ., IV , 43, p. p.

Stipes pale-brown, deciduously pale-furfuraceous, beneath verrucose or aculeate with small sharp prickles, above scaly with brown, linearsubulate scales, bearing much reduced pinnae at the base; main rachis like the stipe but the under side rather verrucose, the seales of the upper side intermixed with crowded brown hairs; rachises of pinnae like 
the main rachis, and provided with minute, bullate scales, not furfuraceous. Pinnulae $4-10 \mathrm{~cm}$. long, $1-2 \mathrm{~cm}$. broad at the base, acuminate, cut down nearly or quite to the costa, pinnate at the base. Segments falcate, obtuse or obtusely apiculate, entire or crenate, to $2 \frac{1}{2} \mathrm{~mm}$. broad, the lower varying from adnate to shortly petiolulate and rounded at the base. Texture coriaceous; costae (tertiary rachises) hairy above, scaly beneath, the lower scales lanceolate-subulate, the others shorter, rather lanceolate, bullate at the base; costulae (at least the lower) bullatosquamulose especially in the lower part; veins 8-10 on a side in the largest segments, naked, mostly once or twice forked; Sori subcostular, crowded, not occupying the higher veins; indusium distinct but not very large, dark-brown.

Luzon.

(1b)? H. warihoin, v. A. v. R.; Cyathea Warihon, Copel., Leafl., $\mathrm{V}, 1680$.

Stipes clothed with pale-castaneous seales. Fronds $90-150 \mathrm{~cm}$. long, narrowed towards the base; main rachis smooth, castaneous, glabrescent beneath, clothed above with red-brown-purple hairs intermixed with long, subfiliform paleae. Pinnae subsessile, to $35 \mathrm{~cm}$. long and $12 \mathrm{~cm}$. broad, acuminate, the rachis red-brown-hairy above, clothed beneath with minute bullate scales intermixed with a few scattered, deciduous, linear ones; lower pinnae very small, $1_{i_{4}}$ long. Pinnulae often sessile, lanceolate, pinnate in the lower part, acute, the costa red-brown-hairy above, bullatesquamulose beneath. Segments $8 \mathrm{~mm}$. long, $2-2 \% \mathrm{~m} . \mathrm{m}$. broad, the lower free, adnate, straight or subfalcate, obtuse, entire or crenulate to obscurely serrulate, with the central ribs clothed beneath with small, bullate-ovate scales especially in the lower part; veins $8 \pm$ on a side, the lower once or twice forked. Texture papyraceous; surfaces naked; under surface paler than the upper. Sori costular, often subtended by a minute scale (rudimentary indusium).

Mindanao.

(1c) H. singalanensis, v. A. v. R., Bull. Btz., 1914, XVI, 15.

Stipes verrucose, deciduously pale-ferrugineo-furfuraceous and scaly, the scales pale-brown, linear-subulate, finely long-acuminate, suberose at the edge; main and secondary rachises rather smooth, densely hairy, the hairs of the upper side erect, adpressed, straight, red-brown, of the 
under side crisped, pale-brown, intermixed with rather numerous small, subbullate, lanceolate, acuminate and a few large, linear-subulate, ferrugineous scales, the two kinds of hairs separated by long, subfiliform-subulate, crisped, brown scales. Pinnulae $4 \frac{1}{2}-5_{12}^{1} \mathrm{~cm}$. long, $1-1 \frac{1}{2} \mathrm{~cm}$. broad at the base, shortly acuminate, cut down nearly or quite the costa, pinnate at the base. Segments subfalcate, obtuse or very minutely apiculate, crenate, $2 \frac{1}{2} \mathrm{~mm}$. broad, the lower free, adnate (always ?). Texture coriaceous; costae (tertiary rachises) hairy above, scaly beneath, the lower scales rather dense, linear-subulate, passing gradually into the very small, bullate higher ones; costulae (at least the lower) bullatesquamulose in the lower part; veins 8-10 on a side, mostly once forked. Sori subcostular, occupying the lower veins, hidden among the scales; indusium small, dark-brown.

Sumatra.

2) H. capensis, R. Rr., Hk. Bk., Syn. Fil., 29; Bau \& Hk., Gen. Fil., tab. XII A; Cyathea capensis, Sm., Christ, Farnkr. d. Erde, 322 , fig. 1023; Amphicosmia riparia, Gardn., Lond. Journ. of Bot., I, tab. XII; Polypodium capense, L. $f$., (oldest name).

Trunk 3-4 m. high. Stipes unarmed, scaly at the base, and often bearing multifid anomalous pinnae $5-10 \mathrm{~cm}$. long and compoundly pinnately divided with a rigid rachis and linear-filiform segments. Fronds large, 2-3-pinnate. Pinnae petiolate, ovate-oblong. Pinnulae subsessile, elongate-oblong, 5-71/2 cm. long, $1 \frac{1}{2}-2 \mathrm{~cm}$. broad, deeply pinnatifid or again pinnate, the apex long-acuminate, serrate. Tertiary segments (lobes or leaflets, linear-oblong, acute, sharply and strongly serrated. Texture submembranaceous; main rachis smooth, clothed with deciduous, bullate scales; surfaces naked; costae and costulae beneath clothed with deciduous, acuminate, bullate scales; veins $6-9$ on a side, simple or very rarely forked, 1 to each serrature. Sori frequently solitary at the base of the ultimate segments, rarely $3-4$; receptacle large, prominent; indusium small, brown, fimbriate.

Java (?); South Africa, Brazt.

2a) rI. bicolor, v. A. v. R.; Cyathea bicolor, Copel., in Leafl., III, 804 ; C. Chr., Ind. Fil., Suppl.

Stipes very short, clothed with brown scales, spinulose below. Fronds $1^{3} / 4-23 / 4 \mathrm{~m}$. long, the rachises soon glabrescent, minutely verrucose 
beneath. Pinnae subsessile, the lowest much reduced, deflexed, the largest $50 \mathrm{~cm}$. long, $20 \mathrm{~cm}$. broad, the apex abruptly acuminate, the rachis minutely asperulous beneath, black-purpureous-velutinous above. Pinnulae subsessile, $10 \mathrm{~cm}$. long, $2 \mathrm{~cm}$. broad, acuminate, pinnate, the rachis pilose above, clothed beneath with lanceolate and ovate, entire, rufous scales intermixed with smaller ones of the same colour. Tertiary segments more or less falcate, acute, subentire to serrate, the lower often free, adnate or subpetiolate, $10-12 \mathrm{~mm}$. long, the others connected. Texture coriaceous; surfaces naked or nearly so; veins 10-12 on a side, forked. Sori costular, brown; indusium brown.

Mindanao.

(2b) I. meraplensis, v. A. v. R., in Bull. Btz., 1914, XIV, 16.

Stipes muricate to aculeate in the upper part, gradually spinose towards the somewhat scaly base, probably deciduously furfuraceous; rachises probably deciduously furfuraceous, hardly asperulous, rusty. tomentose above. Pinnae to $50 \mathrm{~cm}$. or more long, acuminate, apparently articulate at the base. Pinnulae linear-lanceolate, the largest $12 \frac{1}{2} \mathrm{~cm}$. long, $2 \frac{1}{2} \mathrm{~cm}$. broad near the base, long-acuminate, cut down nearly to the costa, pinnate at the base, the higher somewhat remote, ascending, the lower rather close, horizontal or subdeflexed, somewhat reduced. Segments linear-falcate, $3 \mathrm{~mm}$. broad, acute or subacute, separated by broad sinuses, crenate or toothed and somewhat recurved ad the edge, the lower free, rather smaller, adnate to truncate at the base, not rarely horizontal and nearly straight. Texture coriaceous; surfaces naked; upper surface dark, lower yellow-brown when dry; costae tertiary rachises) brown-hairy above; costulae sparingly subbullate-squamulose beneath; veins $10-12$ on a side, the higher forked, the central and lower twice forked or sparingly pinnate. Sori costular or subcostular, suboviform; receptacle columnar; indusium minute, rudimentary.

Sumatra.

(3) F. Junghuhniana, Mett., Rac., Flor. Btz., I, 38., Alsophila Junghuhniana, Kze, in Bot. Zeit., 1848, 284; Cyathea Junghuhniana, Copel., in Philipp. Journ., IVC, 58; - var. dissoluta, Rac., 1. c.

Stipes aculeate at the base only, otherwise smooth or minutely nodulose, as are the rachises. Fronds 3-pinnatifid; rachise stramineous or brownish, deciduously tomentose, hirsute above. Pinnae lanceolate-oblong, to $60 \mathrm{~cm}$. 
long, subsessile, acuminate. Pinnulae sessile or subsessile, elongate-oblong, $6-10 \mathrm{~cm}$. long, $1 \frac{1}{2}-21 / 2 \mathrm{~cm}$. broad, the apex acuminate, crenate or serrulate. Ultimate segments free or slightly connected at the base, approximate, linear-oblong, subfalcate, 2-5 mm. broad, obtuse, crenate, serrulate, toothed or lobed. Texture membranaceous to chartaceous; surfaces naked; upper surface bright-green, lower paler; costae and costulae provided beneath with deciduous, remote, small, bullate or somewhat flattened, acuminate-ovate, adpressed, pale-brown scales; veins 6-10 on a side, 2-3-furcate or sparingly pinnate, only the higher simple Sori costular, subremote; indusium small, scale-like. - The specimens occurring in the Buitenzorg Herbarium have higher scales of the costae and those of the costulae rather bullate-ovate.

Var. dissoluta: Ultimate segments less approximate, to $5 \mathrm{~mm}$. apart.

Java, Sumatra.

(3a) H1. alsophiliformis, v. A. v. R., Bull. Btz., 1914, XVI, 15.

Trunk to $5 \mathrm{~m}$. or more high. Stipes about $40-50 \mathrm{~cm}$. long, deciduously grey-brown-furfuraceous, muricate in the upper part, aculeate and deciduously scaly towards the base; scales long, lanceolate-subulate, fuscous, glossy, partly minutely eroso-denticulate. Fronds 3-pinnatifid, sub-3-pinnate, abruptly acuminate, the main rachis muriculate in the lower part, otherwise smooth or asperulous, when young probably ochraceofurfuraceous beneath, as are the secondary rachises and costae. Pinnae lanceolate-elongate, the higher sessile, ascending, the others shortly petiolulate, horizontal, the lower proportionally long-stalked, reduced; largest pinnae about $50-60 \mathrm{~cm}$. long, $20-25 \mathrm{~cm}$. broad at the middle, acuminate, somewhat narrowed at the hase, the rachis and costae subcastaneo-tomentose above. Pinnulae numerous, coriaceous, naked, dark above, paler beneath, sessile or subsessile, approximate, linear-lanceolate, the higher subspreading, the others horizontal or nearly so, the lower somewhat abbreviated, not rarely somewhat deflexed; largest pinnulae about $10-12 \mathrm{~cm}$. long, $1 \frac{1}{2}-2 \mathrm{~cm}$. broad at or above the base, subabruptly acuminate and toothed at the apex, otherwise deeply pinnatifid; costae and costulae sparingly scaly beneath. Ultimate segments linear-oblong, more or less approximate, more or less falcate, bluntish or subacute, more or less recurved and crenate-denticulate at the pellucid-lined edge; largest segments $10-12 \mathrm{~mm}$. long by $3-4 \mathrm{~mm}$. broad; lower segments 
often abbreviated, lowest or 2-3 lower mostly free; veins to $10-12$ on a side, fuscous beneath, pellucid, the higher simple, the others forked or sometimes 3-furcate. Sori subcostal, mostly on the $6-7$ lower veins; indusium very minute, eroso-denticulate or -fimbriate.

\section{Sumatra.}

(3b) H. horridipes, ש. A. ซ. r., in Bull. Btz., 1914, XVI, 16.

Stipes $35 \mathrm{~cm}$. or more long, deciduously ferrugineo-furfuraceous, glabrescent, one side aculeate with narrowly conical, sharp spines, the other side asperous or muricate; rachises asperulous or muriculate, ferrugineo-araneous above, deciduously furfuraceous, glabrescent. Pinnae stalked, lanceolate, to $60 \mathrm{~cm}$. or more long, $18 \mathrm{~cm}$. broad, acuminate, slightly narrowed at the base. Pinnulae numerous, subsessile, approximate, linear-lanceolate, the largest horizontal, $9 \mathrm{~cm}$. long, $1_{12}^{1 / 2} \mathrm{~cm}$. broad at the base, acuminate, cut down nearly to the costa, the costa ferrugineotomentose above, scaly beneath, the scales pale-brown, lanceolate-ovate, acuminate. Lobes spreading, subcontiguous, linear-oblong, rather straight or slightly falcate, $3 \mathrm{~mm}$. broad, blunt or bluntish, crenate; costules beneath bullato-squamulose in the lower part; veins 10-12 on a side, once (or rarely twice) forked, the higher simple. Texture firm-herbaceous; surfaces naked. Sori medial on the lower or lowest veins; indusium very minute, rudimentary.

\section{Sumatra.}

(3c) II. hemichlamydea, v. A. v. R.; Cyathea hemichlamydea, Copel., in Philipp. Journ., VIC, 361; C. Chr., Ind. Fil., Suppl.

Stipes black, $30 \mathrm{~cm}$. long, provided with a few small spines, purveyed above with linear, black-brown scales and 2 rows of glands; rachis beneath black, tuberculate, glabrescent. Pinnae $45 \mathrm{~cm}$. long, $18 \mathrm{~cm}$. broad, sessile, acuminate, the rachis beneath minutely tuberculate and sparingly deciduously minutely pilose, above sparingly hairy and scaly; lowest pinnae reduced. Pinnulae $9 \mathrm{~cm}$. long, subsessile, acuminate, unequal-sided at the base, cut down nearly to the costa, the costa pilose above, scaly beneath; lowest pinnulae reduced. Lobes approximate, 3-4 $\mathrm{mm}$. broad, rounded and serrulate at the apex; costulae naked above, slightly scaly beneath. Texture herbaceous; surfaces naked; veins \pm 7 on each side of the costulae, the lower forked. Sori costular, the lower more remote; indusium distinct.

Borneo. 


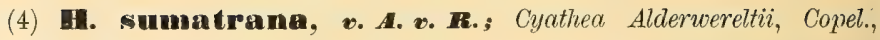
in. Philipp. Journ., IV, 50.

Fronds 3-pinnatifid, sub-3-pinnate; main and secondary rachises fuscous, asperous to muricate with numerous short, blunt or sharp, dark-tipped warts, densely dark-tomentose above, deciduously ferrugineo-furfuraceous beneath, the pubescence intermixed with many more or less scattered, deciduous, linear-subulate, spreading scales, the main rachis finally roughish beneath by the persistent bases of the covering. Pinnae $\pm 55 \mathrm{~cm}$. long, stalked. Pinnulae short-stalked, linear-lanceolate, $8-12 \mathrm{~cm}$. long; $\pm 2 \mathrm{~cm}$. broad, shortly acuminate, deeply pinnatifid below the lobed apex, pinnate at the base. Ultimate segments linear-oblong, $\pm 21 / 2 \mathrm{~mm}$. broad, subacute, subascending, rather falcate and crenate-dentate, the lower ones free, horizontal. Texture chartaceous, fragile when dry; colour dark above, paler beneath; surfaces naked; costae (tertiary rachises) pilosotomentose above; costae and costulae densely clothed beneath with pale or brown, lanceolate or ovate scales and long, crisped, woolly, ferrugineous hairs; veins $\pm 6-12$ on a side, once or twice forked, the higher only simple. Sori $1-4$ on a side, ocupying the lower veins, subcostular, densely mixed with, and nearly hidden under, the costular clothing, subtended by a very minute, brown scale on the inner side.

Sumatra.

(4a) U. caudipinumla, v. A. v. R., in Bull. Btz., 1912, VII, 16.

Fronds 3-pinnatifid; main and secondary rachises fuscous, smooth or somewhat roughish with very minute warts, naked above, deciduously ferrugineo-tomentose beneath. Pinnae probably above $35-40 \mathrm{~cm}$. long, sessile or subsessile, or the lower stalked. Pinnulae rather sessile, linearlanceolate, $\pm 8 \mathrm{~cm}$. long, $\pm 1 \frac{1}{2}-1 \frac{3}{4} \mathrm{~mm}$. broad at the base, rather suddenly subcaudate-acuminate, deeply pinnatifid, the acumen entire or subcrenate. Ultimate segments linear-oblong, $\pm 2 \frac{1}{2} \mathrm{~mm}$. broad, blunt, subfalcate, entire or subcrenate, the lower not free, spreading. Texture chartaceous, fragile when dry; colour beneath paler than above; surfaces naked; costae naked above, distinctly but not densely clothed beneath with pale or brown flat scales and ferrugineous hairs; costulae naked above, hardly scaly beneath; veins $6-9$ on a side, the lower and central forked, the higher simple. Sori subcostular, 4-8 on a side, not occupying the higher veins, subtended by a small, but well-developed, semiorbicular indusium.

Sumatra. 
(4b) H. barisanica, v. A. v. R., in Bull. Bt\%., 1915, XX, 17.

Trunk slender, about $3 \mathrm{~m}$. high. Stipes $30 \mathrm{~cm}$. more or less long, fuscous, minutely aculeate, and deciduously furfuraceous and scaly, the scales narrowly subulate, fuscous, somewhat crisped, ciliate with scattered, deciduous, short, erected, acute, dark-brown hairs. Fronds to ahout $3 \mathrm{~m}$. long and $1 / 2$ as broad, 3-pinnatifid, the main rachis muriculate or aculeolate and scaly at least towards the base, otherwise smooth or roughish, and deciduously ferrugineo-tomentose and squamulose. Pinnae short-stalked, the lower very remote, deflexed and reduced, the largest to $75 \mathrm{~cm}$. long, about $20 \mathrm{~cm}$. broad at the middle, the rachis at length often naked above, beneath ferrugineo-tomentose and deciduously squamulose, as are the costae. Pinnulae subsessile, numerous, somewhat remote, horizontal or nearly so, often subfalcate (upeurved or decurved), the largest lanceolateelongate, acuminate, the acumen crenulate to toothed, the edge deeply incised, the base truncate or subtruncate, $2 \frac{1}{2}-2{ }_{14}^{3 / 4} \mathrm{~cm}$. broad. Ultimate segments linear-oblong, blunt or bluntish, much spreading, approximate or somewhat remote, to $1 \frac{1}{2} \mathrm{~cm}$. long by $4 \mathrm{~mm}$. broad, entire or crenulate, the lowest subdistinct and a little more remote; costulae naked above, beneath sparingly provided with lanceolate, subbullate, acuminate, brown scales, slightly hairy towards the base; veins to about 10 on a side, intermixed with numerous spurious veinlets when seen towards the light, forked, the higher simple, the lower not rarely 3-furcate. Texture firmpapyraceous; surfaces naked. Sori remote, occupying the $4-6$ lower veins, the higher costular, the lower somewhat divaricating; indusium distinct, persistent.

Sumatra.

(4c) H. confluens, v. A. v. R., in Bull. Btz., 1914, XVI, 14.

Stipes $\pm 55 \mathrm{~cm}$. long, more or less deciduously villoso-tomentose, sparingly muriculate in the upper part, acutely spinulose and scaly in the lower part, the scales dirty-brown, linear-subulate, partly entire, partly erose. Fronds $\pm 70 \mathrm{~cm}$. broad, sub-3-pinnate, the rachises more or less deciduously villoso-tomentose, the hairs crisped, ferrugineous, intermixed with scattered scales similar to those of the stipe but smaller. Pinnae spreading, $\pm 10 \mathrm{~cm}$. broad above the base, sessile, close, rather abruptly acuminate; lower pinnae rather remote, shorter, stalked. Pinnulae horizontal or spreading, linear, $\pm 1-\mathrm{cm}$. broad, bluntish, deeply pinnatifid, pinnate at the base, the lower shorter. Segments linear-oblong, approximate,

Ferns and Fern Aluies. 
spreading, $\pm 2{ }_{2}^{\prime}-3 \mathrm{~mm}$. broad, blunt, crenate-dentate and recurved at the edge, the lower free, the lowest horizontal, shorter, subpetiolulate. Texture coriaceous; surfaces naked; costae and costulae hairy above, the former copiously scaly and sparingly crisped-pilose beneath; veins $\pm 6-8$ on a side, naked, or very sparingly and minutely hairy above, forked, the lowest and higher simple. Sori costular, close, at length confluent; indusium conspicuous, persistent.

Sumatra.

(4d) H. salticola, v. A. v. R., in Bull. Btz., 1915, XX, 18.

Trunk to $1 \frac{1}{2} \mathrm{~m}$. or more high. Stipes dark-brown, deciduously furfuraceous and copiously spinoso-aculeate. Fronds 3-pinnatifid, sub-3pinnate; main and secondary rachises brown or pale-brown when dry, muriculate or aculeolate with short, acute warts, dark-tomentose above, deciduously ferrugineo-furfuraceous beneath, the covering when young intermixed with linear-lanceolate or subfiliform brown scales. Pinnae short-stalked, lanceolate, acuminate, the largest horizontal, about $50 \mathrm{~cm}$. long, $20 \mathrm{~cm}$. broad at the middle, somewhat narrowed at the base. Pinnulae numerous, close or approximate, very shortly petiolulate, the higher ascending, the central spreading, the lower horizontal or somewhat deflexed; largest pinnulae to about $10 \mathrm{~cm}$. long by $2 \mathrm{~cm}$. broad, deeply pinnatifid, gradually acuminate and crenate-dentate at the apex, the costa villoso-tomentose above, squamulose beneath, the scales pale-ferrugineous, acuminate, partly lanceolate and moderately large, partly bullate and very minute, intermixed with proportionally few crisped, pale-ferrugineous hairs; lowest pinnulae abbreviated, somewhat narrowed at the base. Ultimate segments spreading, close, linear-oblong, to $1_{14}^{1 /} \mathrm{cm}$. long, $4 \mathrm{~mm}$. broad, blunt, crenate-dentate; lowest segments free, often abbreviated, somewhat narrowed at the base; sinuses between the lobes piloso-fimbriate in the tip (angle); costulae glabrous or subglabrous above, minutely bullato-squamulose beneath; veins to $8-10$ on a side, the higher simple or forked, the others mostly 3-furcate or sparingly pinnate. Texture subcoriaceous; surfaces naked. Sori subcostular, on the lowest (1 or more lower ?) veins; indusium minute, brown.

Sumatra.

(5) 11. glaucophylla, v. A. v. R., in Bull. Btz., 1912, VII, 16. Fronds 3-pinnatifid. Pinnae subsessile, ascending or subspreading, 
$\pm 60-70 \mathrm{~cm}$. long. Pinnulae sessile, linear-lanceolate, to $\pm 10 \mathrm{~cm}$. long, $2 \mathrm{~cm}$. broad at or near the base, subfalcate, ascending or spreading, or the lower horizontal or somewhat deflexed, the apex moderately long. acuminate, toothed or serrate-crenate, the edge cut down nearly to the costa. Tertiary segments linear-oblong, spreading, subfalcate, $\pm 2^{\prime}{ }_{i 2} \mathrm{~mm}$. broad, generally blunt, more or less crenate and revolute, the higher rather approximate, the lower more remote, the lowest sometimes nearly free. Texture firm but not rigid; rachises pale-brown, naked (glabrescent ?) beneath, clothed above with more or less deciduous pale-brown hairs, smooth, or the main one provided with a few minute warts; upper surface naked, lower glaucous, naked or sparingly and very minutely appressofibrillose on the veins; costae hairy above, sparingly scaly beneath, the hairs pale, the scales flat, pale, deciduous, partly suborbicular, partly ovate-lanceolate; costulae naked above, provided beneath with few pale, acuminate, bullate scales; veins $\pm 9-12$ on a side, once or occasionally twice forked, the higher only simple. Sori $2-4$ on a side, costular, occupying the lower veins but the lowest veins often destitute of sori; indusium very small but not positively rudimentary, semiorbicular.

Java.

(6) H. Iatebrosa, Mett., Rac., Flor. Bt\%., I, 39; Alsophila latebrosa, Wall. (not Hk.), Bk., Syn. Fil., 43; Bedd., Ferns S. I., tab. LVIII; C. Chr., Ind. Fil.; Cyathea latehrosa, Copel., in Philipp. Journ., IVc, 52 ; - var. major, Christ, in Philipp. Journ., IIC, 183.

Stipes dark-brown or purple, very spiny towords the base, muricate upwards, scurfy, and bearing at the base a few linear, harsh, brown scales, soon naked. Fronds large, the main rachis maroon, muricate at least towards the base, hirsute above, scurfy with deciduous and very minute squamules. Pinnae $\pm 30-60 \mathrm{~cm}$. long or longer, sessile or nearly so, the lowest ones somewhat reduced and deflexed; rachises from palebrown to maroon, naked or minutely scaly, rough with sparse, fine, sharp prickles. Pinnulae sessile, $\pm 9-10 \mathrm{~cm}$. long, $\pm 1 \frac{1}{2}-2 \mathrm{~cm}$. broad, crenate or serrate and acuminate at the apex, the edge cut to a narrow wing throughout; lobes subacute or obtuse, subfalcate, serrulate or subentire, $\pm 2 \mathrm{~mm}$. broad, the lower not rarely free, adnate or not so. Texture membranaceous to subcoriaceous, upper surface bright-green, naked, lower paler, naked or slightly hairy; costae hairy above, beneath naked, or scaly with more or less approximate, ovate-acuminate or bullate scales, as are 
the costulae; veins $\pm 6-12$ on a side, forked, or the higher only simple. Sori inframedial, somewhot remote from the costulae, on the $1-7$ lower veins, distinct or finally confluent, subtended by a minute scale on the inner side.

\section{Forma typica. - Br. India across Malaya to Formosa.}

Var. majon": Main rachis fulvo-stramineous, naked or furfuraceous; pinnulae caudate, cut down to a slender, black costa; lobes oblong, \pm $2 \frac{1}{2} \mathrm{~mm}$. broad, obtuse, crenulate; costae scaly with roundish, peltate, yellow, umbilicate squamules; veins 2-3-furcate. - Mindanao.

(6a) F. Caudata, Mett., in Fil. Lechl., II, 30; Alsophila candata, J. Sm., Hk. Bk., Syn. Fil., 42; Hk., Spec. Fil., I, tab. XX B; Cyathea caudata, Copel., in Philipp. Journ., IVC, 58; C. Chr., Ind. Fil., Suppl.

Stipes very short because of reduced pinnuae coming down almost to the trunk, almost black, minutely scurfy and bearing harsh, acicular, dark scales, such as extend some $30 \mathrm{~cm}$. up the upper surface of the rachis, densely spiny. Fronds $\pm 1{ }_{12}^{1 /} \mathrm{m}$. long, the rachis spiny only near the base, very minutely and sparsely roughened above, brown, bearing a deciduous scurf beneath. Middle pinnae $\pm 35 \mathrm{~cm}$. long, subsessile, abruptly acuminate, the rachis scaly, the scales furfuraceous, more persistent. Pinnulae 7-11 cm. long, $\pm 2 \mathrm{~cm}$. broad, sessile, acuminate or cordate, cut at the base to the costa, elsewhere deeply pinnatifid; segments serrulate and subfalcate at the apex, obtuse, $\pm 3 \mathrm{~mm}$. broad, the lowest ones free, sessile, not adnate. Texture coriaceous; upper surface naked, very dark, lower paler; costae dark-hairy above, beneath purplish and minutely and deciduously scaly; costulae naked above, scaly beneath; veins up to 13 on a side, mostly forked. Sori costular, small; indusium usually represented by a minute scale.

Luzon.

(7) E. Iatipinnula, v. A. v. R.; Cyathea latipinnula, Copel., in Leafl., IV, 1149; C. Chr., Ind. Fil., Suppl.

Stipes $\pm 60 \mathrm{~cm}$. long, spinose, brown-scaly at the base. Fronds $\pm 180 \mathrm{~cm}$. long, the main rachis spinulose, dark-hairy above, clothed like the secondary rachises with dirty-brown, rather deciduous scales various in shape, the longest of which are linear-subfiliform. Pinnae $\pm 45 \mathrm{~cm}$. long, $\pm 20 \mathrm{~cm}$. broad, truncate-acuminate, the rachis aculeolate. Pinnulae petiolulate, 2-4 cm. broad, acuminate, pinnate in the lower part; 
segments bluntish, $\pm 5 \mathrm{~mm}$. broad, the lower free, pinnatifid, the central adnate, contiguous. Texture coriaceous; surfaces naked; costae squamulose in the lower part with minute, pale, bullate scales intermixed with some scattered, deciduous, crisped hairs; veins $\pm 10-12$ on a side, mostly forked; veinlets of lower veins often forked again. Sori costal; indusium rudimentary.

Sibuyan Istand.

(8) ․‥ manilensis, Pr., in Abh. Böhm. Ges., V, 351.

Pinnae oblong, to $30 \mathrm{~cm}$. or more long. Pinnulae subsessile, linear, $\pm 7 \%$ cm. long, $\pm 2 \%$ cm. broad, deeply pinnatifid towards the apex, pinnate at the base, the apex abruptly acuminate, the acumen $\pm 1{ }_{4}^{3} \mathrm{~cm}$. long; segments linear, slightly falcate, obtuse, serrulate, the lower ones free, rounded at the base, sessile. Texture thinly coriaceous; rachis muricate below; surfaces naked; under surface very pale, glaucescent; veins deeply forked, the lower ones sterile, twice forked. Sori rather costular; indusium small, adpressed to the lamina, at length deeply and irregularly incised.

Luzon.

(9) II. heterochlamydea, v. A. v. R.; Cyathea heterochlamydea, Copel., in Philipn. Journ., IVC, 42; C. Chr., Ind. Fil., Suppl.

Trunk $3-5 \mathrm{~m}$. high, $5-7 \frac{1}{2} \mathrm{~cm}$. thick. Fronds sessile, $\pm 1 \frac{1}{2} \mathrm{~m}$. long. Largest pinnae $30-35 \mathrm{~cm}$. long, abruptly narrowed below the acuminate apex. Pinnulae subsessile, central largest, to $\pm 10 \mathrm{~cm}$. long, $\pm 1 \frac{1}{2} \mathrm{~cm}$. wide at the base, acuminate; segments acute, subfalcate, serrulate towards the apex, $2-3 \mathrm{~mm}$. wide, separated by sharp sinuses, the lowest segments free and contracted at the base, and a few succeeding ones free but adnate. Texture coriaceous; surfaces naked; upper surface dark-green, lower paler; main rachis clear-brown, almost glabrous, aculeate with small, sharp prickles; secondary rachises chestnut, mottled, asperulous, clothed with minute, bullate scales and lanceolate, chestnut ones $21 / 2 \mathrm{~mm}$. long, with dilated bases, both kinds deciduous; tertiary rachises (costae) hairy above and bearing sparse, broadly lanceolate scales $1 \frac{1}{2} \mathrm{~mm}$. long beneath; veins up to \pm 9 on a side, the lower ones forked, black beneath, pale above. Sori costular, on the lower $1 / 2-2 / 3$ part of the segments; indusium consisting of a single large scale enclosing on the costular side half or more of the sorus.

Negros, Mindanao. 


\section{ALSOPHILA, R. Brovn.}

(*1) A. woudlarkensis, v. A. v. R.; Cyathea woodlarkensis, Copel., in Philipp. Journ., IX, 1.

Stipes pale-brown, minutely pale-puberulous with the pubescence intermixed with nearly black, firm, hairs or setae, as is the rachis. Fronds 2-pinnatifid. Pinnae numerous, linear-lanceolate, to $\pm 40 \mathrm{~cm}$. long by 3-4 cm. broad, deeply pinnatifid. Lobes very numerous, subfalcate, to $\pm 2 \mathrm{~cm}$. long by $3 \mathrm{~mm}$. broad, obtuse, entire. Texture thinly coriaceous; surfaces naked; costae and costulae more or less pilose; veins to $30 \mathrm{on}$. a side. Sori medial.

New Guinea.

(1a) A. obliqua, C. Chr., Ind. Fil., Suppl.; Cyathea obliqua, Copel, in Leafl., IV, 1150.

Stipes $\pm 60 \mathrm{~cm}$. long, spinose and scaly at the base, the scales pale; rachises purple-brown, glossy, above sulcate, pubescent especially in the groove. Pinnae stalked, $30-35 \mathrm{~cm}$. long, acuminate. Pinnulae stalked, $5-7 \mathrm{~cm}$. long, hardly $1 \mathrm{~cm}$. broad, much acuminated, coarsely serrate, the base obliquely cuneate, subtruncate on the upper side, more narrowly cuneate on the lower side; costae and veins naked or sparingly pilose, the former minutely paleaceous in the lower part. Sori medial.

Sibuyan Island.

(1b) A. subdubia, v. A. v. R., in Bull. Btz., 1915, XX, 3.

Trunk to $1 \% \mathrm{~m}$. or more high. Stipes $35 \mathrm{~cm}$. more or less long, fuscous, densely scaly like the rachises, muriculato-asperous, the scales partly deciduous, lanceolate-subulate, glossy, fusco-ferrugineous, finely erosofimbriate, those of the stipe and main rachis intermixed with deciduous, ochraceous furfur or tomentum, those of the secondary rachises growing gradually smaller. Pinnae horizontal or nearly so, stalked, broadly lanceolate, to about $50 \mathrm{~cm}$. long and $/ / 2$ as broad, acuminate, the rachis brown-hairy above. Pinnulae to about 15 on each side below the terminal one; terminal pinnulae long-triangular, serrate at the acuminate apex, gradually deeply pinnatifid towards the base; lateral pinnulae more or less approximate, horizontal or nearly so, the higher more or less adnate, somewhat ascending and passing subabruptly into the basal lobes of the terminal one, the following shortly petiolulate, the lower more or 
less deflexed and abbreviated; largest pinnulae linear-lanceolate, about $12^{\prime}{ }_{2} \mathrm{~cm}$. Iong by $21_{2} \mathrm{~cm}$. broad, gradually acuminate, the acumen obliquely serrate-dentate, the edge cut about $1 / 2$-way down to the costa, the base truncate or subcordate-truncate, not rarely slightly narrowed, the costa brown-hairy above, sparingly and deciduously subulato-squamulose beneath, the costulae and veins naked. Lobes or lobules somewhat oblique, rather close, blunt to truncate, the largest 5-6 mm. each way, crenatedentate at the apex. Texture firm-herbaceous; surfaces naked; upper surface dark, lower paler; costulae pinnate in the lobes; veins to \pm 6 on a side, simple, arcuate-ascending. Sori moderately large, inframedial on the $1-3$ lower veins.

\section{Sumatra.}

(2) A. glabra, wk. ; Cyathea glabra, Copel., in Philipp. Journ., IVc, 3 o. This species has the rachises not rarely tomentose, and the fronds redidish-brown when dry. It differs principally from A. squamulata $H k$. by the often, though not invariably, conspicuously $V$-shaped rows of sori (especially in the typical form) and the polished, reddis-black stipe and main rachis, and in having the pinnulae cut rarely more than ${ }^{1}{ }_{2}$-way down to the costa into mostly crenate or serrate lobes with $4--5$ veins on a side.

(2a) A. Mewittii, v. A. v. R. . Cyathea Heroittii, Copel., in Philipp. Journ., IVC, 134, tab. XIV; C. Chr., Ind. Fil., Suppl.

Stipes naked, black-purple, $\pm 50 \mathrm{~cm}$. long, nearly unarmed, the base spiny, and squamose with brown, entire scales, the spines consisting of reduced pinnae. Pinnae stalked, $\pm 35 \mathrm{~cm}$. long. Pinnulae stalked, dimorphous; barren pinnulae to $\pm 6 \mathrm{~cm}$. long, $\pm 1 \frac{1 / 2}{1} \mathrm{~cm}$. broad, acute, truncate at the base, the higher entire or erenated, the central lobed, the lower deeply incised, the lobes falcate-rotundate, crenate; fertile pinnulae to $\pm 4 \mathrm{~cm}$. long, to $6 \mathrm{~mm}$. broad, lobed, the lobes triangular. Texture subcoriaceous; surfaces naked. Sori numerous, costular or the lower divaricating.

Borneo.

(3) A. Ridleyi, Bk.; Cyathea Ridleyi, Copel, in Philipp. Journ., IV, 36 .

(4) A. Burbidgei, Bk.; Cyathea Burbidgei, Copel., in Philipp. Journ., IVC, 55. 
(5) A. squamulata, His.; Cyathea squamulata, Copel., in Philipp. Journ., IV, 37.

This species has the stipe and rachises often scaly with pale or brown, brown-ciliolate paleae. It has the sori not rarely more or less divaricating as in A. glabra $H k$. but differs principally in having the stipe and main rachis brown or yellow-brown, and the pinnulae cut commonly at least $1 / 2$-way down to the costa into mostly entire lobes with generally $6-7$ veins on a side.

(6) A. Daragarethne, schroet.; Cyathed Margarethae, Copel., in Philipp. Journ., IV 38.

(7) A. ramispina, Hk.; Cyathea ramispina, Copel., in Philipp. Journ., IV ${ }^{\mathrm{C}}, 36$.

(7a) A. polensis, v. A. v. R.; Cyathea poiensis, Copel., in Philipp. Journ., VIC, 362 ; C. Chr., Ind. Fil., Suppl.

Stipes $\pm 18 \mathrm{~cm}$. long, eastaneous, the base provided with lanceolate, entire, ferrugineous scales and a few subacanthoid outgrowths $2-3 \mathrm{~cm}$. long; rachises densely strigose. Fronds hardly $100 \mathrm{~cm}$. long, $40 \mathrm{~cm}$. broad, narrowed at both ends. Pinnae to $\pm 23 \mathrm{~cm}$. long, $6 \mathrm{~cm}$. broad, stalked, acuminate, the lowest deflexed. Pinnulae to $3 \mathrm{~cm}$. long, $9 \mathrm{~mm}$. broad, short-stalked, rounded at the apex, truncate-cuneate at the base, cut $\pm 1 / 2$-way down to the costa; lower pinnulae reduced; costae hairy towards the base above, hairy and scaly beneath, the scales bullate. Lobes subfalcate, $\pm 2 \frac{1}{2} \mathrm{~mm}$. broad, obtuse, entire; costulae sparingly bullato-squamulose beneath. Texture subcoriaceous; surfaces naked; under surface paler than the upper; veins $3-4$ on each side of the costulae, simple. Sori small, medial; indusium, if present, spurious or depressed. Borneo.

(7b) A. heteromorpง

Stipes $40 \mathrm{~cm}$. more or less long, purple-brown, deciduously chaffy, provided like the rachis with 2 rows of longitudinal, remote, oblong, depressed glands, glabrescent, the base scaly, and provided with several reduced pinnae, the scales brown, linear-subulate, with the margin paler, eroso-fimbriate, the reduced pinnae horizontal or spreading, rèlatively longstalked, to $6 \mathrm{~cm}$. long, pinnate at the base with distant, stalked, oblong, 
blunt, crenated pinnulae to $1 \mathrm{~cm}$. long, cuneate at the base. Fronds 3-pinnatifid, the rachises dark-brown or publish, deciduously chaffy, glabrescent, dark-tomentose above. Pinnae short-stalked, lanceolate, to $\pm 50 \mathrm{~cm}$. long, to $\pm 20 \mathrm{~cm}$. broad, somewhat narrowed at the base. Pinnulae horizontal, short-stalked, dimorphous; barren pinnulae lanceolate, the largest $\pm 11_{12}-2 \mathrm{~cm}$. broad, acuminate, cut $\pm 1 / 2-1 / 3$-way down to the costa, the base somewhat narrowed, truncate-cordate, the lobes spreading; blunt, crenated, the lowest horizontal, rounded at the lower base; fertile pinnulae contracted, linear-lanceolate, $3 / 4-1 \frac{1}{4} \mathrm{~cm}$. broad, with the lowest lobes nearly free, round or short-oblong. Texture coriaceous; surfaces naked; costae and costulae dark, above naked or hairy, beneath sparingly minutely scaly; veins simple, $\pm 4-8$ on a side, those of the fertile lobes the less numerous. Sori costular, the capsules probably intermixed with hair-like paraphyses.

\section{Sumatra.}

(8) A. obseura, Scort.; Cyathea obscurt, Copel., in Philipp. Journ., IV, 37.

Stipes muriculato-asperulous, upward deciduously furfuraceous, downward densely scaly, the scales somewhat crisped, rather deciduous, pale, often brown-margined, copiously serrulate-ciliolate with short, suberect, acute, dark-brown hairs; rachises smooth, above dark-tomentose, beneath probably sparingly pale-long-hairy when young; lobes nearly straight, blunt or obliquely subtruncate; veins prominent on both sides; sori at length confluent so as to form broad brown bands on each side of, and rather close to, the costae.

(8a) A. subobseura, v. A. ש. R., in Bull. Btz., 1915, XX, '1, tab. I.

Trunk to $6 \mathrm{~m}$. or more high. Stipes muricato-asperous, densely scaly, the scales long, subulate-lanceolate, scariose, very pale-stramineous, finely acuminate, often brown-margined, copiously serrulate-ciliolate with suberect, short, acute, dark-brown hairs. Fronds 3-pinnatifid, to about 80 $\mathrm{cm}$. broad; rachises copiously punctulato-asperulous, above dark-villosetomentose, beneath when young probably furfuraceous with very minute fimbriate-stellate brown scales, the sides deciduously scaly with scales similar to those of the stipe but smaller. Pinnae spreading, the largest lanceolate, to $45 \mathrm{~cm}$. long, $10-15 \mathrm{~cm}$. broad, somewhat narrowed at the 
base, the apex pinnatifid, acuminate. Pinnulae linear, horizontal or spreading, about $1 \mathrm{~cm}$. broad, the apex acuminate, crenate-dentate, the edge cut about $1 / 2$-way down to the costa into subfalcate, blunt or obliquely subtruncate, entire lobes about $3 \mathrm{~mm}$. broad. Texture coriaceous; surfaces naked; costae hairy ahove; costae and costulae sparingly fimbriatosquamulose beneath; veins to $\pm 4-5$ on a side, mostly simple, not or hardly prominent. Sori on the $1-3$ lower veins, inframedial, at length confluent so as to form a broad brown band on each side of, and close to, the costae; capsules intermixed with long, pale, hyaline hairs.

\section{Sumatra.}

(8b) A. sarawakemsis, c. Chr., Ind. Fil., Suppl.; Cyathea Brooksii, Copel., in Philipp. Journ., VIC, 135, tab. XVI.

Trunk $\pm 1 \mathrm{~m}$. high. Stipes $\pm 45 \mathrm{~cm}$. long, purple-black like the lower part of the main rachis, clothed especially towards the base with densely crowded, narrowly lanceolate, firm, stramineous, minutely blackciliated scales. Fronds ovate, $\pm 75 \mathrm{~cm}$. long, hardly $60 \mathrm{~cm}$. broad, the main rachis scaly in the lower part, pale in the upper part which is velutinous above and glabrescent beneath. Pinnae subsessile, the central the largest, $\pm 30 \mathrm{~cm}$. long, $\pm 10 \mathrm{~cm}$. broad, acuminate, with the rachis narrowly winged. Pinnulae subsessile, approximate, oblong or somewhat elongated, $\pm 1 \frac{1}{2} \mathrm{~cm}$. broad, obtuse, truncate at the base, the edge cut at best to $1 / 2$-way down to the costa. Lobes approximate, falcate, broadly oblong, entire. Texture papyraceous; surfaces naked; costae sparingly pilose above, nearly naked beneath; costulae clothed beneath with deciduous, minute, whitish, bullate scales; veins $4-6$ on a side, often simple. Sori medial; sporangia intermixed with hair-like paraphyses which are not much longer than the sporangia.

\section{Borneo.}

(8c, A. paraphysa1a, v. A. v. R.; Cyathea paraphysata, Copel., in Philipp. Journ., VIC, 135, tab. XV; C. Chr., Ind. Fil., Suppl.

Stipes $\pm 40 \mathrm{~cm}$. long, naked, nearly unarmed, fuscous, scaly at the base, the scales entire. Central pinnae the largest, $\pm 40 \mathrm{~cm}$. long, short-stalked, acuminate. Pinnulae sessile, $6-7 \mathrm{~cm}$. long, $\pm 1_{12}^{\prime \prime} \mathrm{cm}$. broad, obtuse, the margin eut more than $1 / 2$-way down to the costa, the lobes falcate, $\pm 3 \mathrm{~mm}$. broad, entire, obtuse. Texture coriaceous; surfaces naked; rachises minutely velutinous above, as are the costae, the secondary 
ones minutely puberulous beneath, the costae minutely scaly towards the base beneath; costulae minutely bullato-squamulose beneath; veins simple, $\pm 4-5$ on a side. Sori medial; sporangia intermixed with capilliform paraphyses which are much longer than the sporangia.

Borneo.

(9) A. commutata, Mett.; Cyathea recommutata, Copel., in Philipp. Journ., IV ${ }^{\mathrm{C}}, 36$.

Also in Borneo.

(10) A. Irichodesma, Scort.s Cyathea trichodesma, Copel., in Philipp. Journ., IV ${ }^{\mathrm{C}}, 55$.

(11a) A. Calocuma, Christ; Cyathea calocoma, Copel., in Philipp. Journ., IV, 53.

(11b) A. Naumanni, Kuhn, Forschr. Gaz., IV, Farne, 13.

Stipe shortly tuberculate, as is the rachis, ferrugineous, densely clothed at the base beneath with long, white, elongate-lanceolate scales, naked above. Fronds 2-pinnato-pinnatipartite; secondary rachises tuberculatemuricate, clothed above with pale-grey hairs. Pinnae short-stalked, elongatelanceolate, up to $45 \mathrm{~cm}$. long, $16-18 \mathrm{~cm}$. broad. Pinnulae sessile, subapproximate, spreading-divaricating, linear-oblong, falcate, obtuse, somewhat crenulate at the apex. Texture subchartaceous; upper surface dark, lower bright-green, provided with scattered, palmate scales and filiform hairs; veins slender, subprominent, forked at the base. Sori subcostular, at the forkings of the veins, contiguous, $\pm 5-8$ on each side; capsules intermixed with long, articulated hairs. - The specimen gathered by Dr. Versteeg (Dutch New Guinea) has the secondary rachises distinctly hairy above, very sparingly punctulato-tuberculate, rather smonth, the pinnulae abruptly acuminate at the apex, for the rest deeply pinnatifid into numerous approximate, linear-oblong, blunt lobes $\pm 1 \mathrm{~cm}$. long and 4 $\mathrm{mm}$. broad, with the edges crenate, the crenations 2-crenate, the costulae bullato-squamulose beneath, pinnate in the lobes with $\pm 10-11$ veins on each side, the higher veins simple, the central and lower forked or 2-furcate.

New Guinea; New Pommern. 
(12) A. dimorpha, Christ; Cyathea dimorpha, Copel., in Philipp. Journ., IVC, 34.

(13) A. Kingi, Clarke; Cyathea Kingi, Copel, in Philipp. Journ., IV, 56 .

(13a) A. sulh dinnorpha, v. A. v. R.; Cyathea subdimorpha, Copel., in Philipp. Journ., VIIIC, 140, tab. II.

Pinnae $45 \mathrm{~cm}$. more or less long and $\pm 16 \mathrm{~cm}$. broad, acuminate, the rachis black-purple, glossy, smooth, velutinous above, glabrescent beneath Pinnulae dimorphous. Barren pinnulae to $9 \% \mathrm{~cm}$. long and $2 \mathrm{~cm}$. broad, petiolulate, acuminate, pinnate towards the truncate base, pinnatifid in the upper part, the costa (tertiary rachis) rather densely scaly; 2-6 lowest segments free, the lowest not adnate, $3-4 \mathrm{~mm}$. broad, serrulate, scaly, the veins forked. Fertile pinnulae to $7 \mathrm{~cm}$. long and $1 \frac{1}{2} \mathrm{~cm}$. broad, more distinctly pinnate; segments short-stalked, coriaceous. Sori subcostular, confluent. - I don't know whether this species is well-classified here because of incomplete description taken from a single pinna only. Java.

(13b) A. heterophylln, v. . v. R., in Bull. Btz., 1914, XVI, 2. Stipes purple-brown, glossy, deciduously scaly, at length verruculosoasperulous, provided like the rachis with 2 rows of longitudinal, elliptical, pale-brown, depressed glands; scales partly minute, yellowisch-brown, fimbriate, partly long, linear-subulate, yellow-brown, erose, with a redbrown costa. Rachises tomentose above, glabrescent beneath, the tomentum consisting of red-brown hairs and minute, fimbriate-ciliate scales intermixed with filiform or narrow-linear ones. Costae tomentose-villose above, copiously scaly beneath, the lower scales subulate, subentire, grey-brown, the others red-brown, smaller, lanceolate, fimbriate-ciliate; costulae rather naked above, fimbriate-squamulose beneath in the lower $2 / 3$. Barren segments with the veins forked, the lower crenate-dentate; fertile segments with the veins simple, the lower lohate-dentate. Otherwise like A. subdimorpha $v$. A. $v \quad R .-$ A. Kingi Clarke as far as visible in a specimen received from Dr. King, gathered in Perak; differs from this in having the pinnulae deeply pinnatifid, at best pinnate at the very base, the segments entire or slightly crenated, the scales less distinctly heteromorphous, lanceolate, fimbriate-ciliate.

New Guinea. 
(13c) A. Sehlechteri, Brau., in Engl. Bot. Jahrb., IL, 15, fig. 1 D.

Fronds to $2 \mathrm{~m}$. long, 3-pinnatifid. Pinnae to $50 \mathrm{~cm}$. long, to $15 \mathrm{~cm}$. broad or broader, remote, long-acuminate. Pinnulae sessile, remote, lanceolate, the largest $\pm 8 \mathrm{~cm}$. long, $\mathbf{1}_{\mathbf{3}} \mathbf{4} \mathrm{cm}$. broad, deeply pinnatifid, or pinnate at the truncate base, the apex long-acuminate and rather crenate, the base not or slightly narrowed; lower pinnae horizontal, higher more ascending. Segments dimorphous; barren segments approximate, subfalcate, to $1_{12}^{1 /} \mathrm{cm}$. long and $1 / 2 \mathrm{~cm}$. broad, entire in the lower part, serrate or 2-serrate towards the bluntish apex, the central spreading, the lower horizontal or deflexed; fertile segments contracted, more distant. Texture coriaceous; surfaces naked; upper surface dark-green, lower paler; rachises fuscous, glossy, above hairy, beneath short-hairy and brown-scaly, glabrescent; veins simple or forked. Sori numerous, medial.

New Guinea.

(14) A. Wallacei, Mett.; Cyathes, Wallacei, Copel., in Philipp. Journ., IVC, 48.

(15) A. modesta, Rki.; Cyuther modesta, Copel, in Philipp Journ., IV, 48.

(16) A. caudata, J. Sm.

Omit this species, it being referred to Hemitelia.

(16a) A. dimorphotricha, v. A. v. R.; Cyathea dimorphotricha, Copel., in Leafl., V, 1681.

Stipes $\pm .30 \mathrm{~cm}$ long, below brown and densely clothed with red hairs or scales. Fronds $\pm 2 \mathrm{~m}$. long, the rachis fulvous, smooth or roughish, grooved, soon naked except in the pale-hairy furrow above. Pinnae shortstalked, $\pm 40-45 \mathrm{~cm}$. long, rather suddenly acuminate, the rachis villose above with-long, crowded, adpressed, pale-yellow-brown or pale-ochraceous hairs, glabrescent beneath. Pinnulae horizontal, subsessile, to $\pm 9 \mathrm{~cm}$. long, $\pm 1 \frac{1}{2} \mathrm{~cm}$. broad, acuminate, deeply pinnatifid, the costa laxly clothed beneath with long, pale hairs and caudate, fimbriate scales. Lower segments rounded at the apex, bluntly serrulate, connected at the base by a hyaline wing; costulae beneath pilose and sparingly scaly with ovate, bullate, long-cuspidate or fimbriate-caudate (hair-pointed. scales; veins \pm 10 on a side, the higher simple, the others forked or sometimes twice 
forked. Texture papyraceous; upper surface deep-green, lower more or less palish. Sori costular.

Mindanao.

(17) A. sangirensis, Christ; Cyathed sangirensis, Copel., in Philipp. Journ., IVC, 37.

\section{(18) A. lepidocladia, Christ.}

Under surface provided with scattered, long, crisped, whitish hairs on the veins, and the costae moderately closely hairy; main rachis purplish when destitute of its covering, densely villose with long, grey, interlaced, woolly hairs besides the scales.

(18a) A. atropurpurea, C. Chr., Ind. Fil., Suppl.; Cyathea atropurpurea, Copel., in Philipp. Journ., IV ${ }^{\mathrm{C}}$, 36, tab. XVIII.

Trunk $\pm 2 \mathrm{~m}$. high, $4 \mathrm{~cm}$. in diameter. Stipe and rachis purple, unarmed, the base of the stipe clothed with long, rigid, adpressed paleae with pale margins, and bearing some very reduced pinnae almost without lamina, but not spine-like; rachises bearing above purple hairs intermixed with filiform paleae and beneath very sparse squamulae. Fronds \pm 150 $\mathrm{cm}$. long, $\pm 60 \mathrm{~cm}$. wide. Pinnulae $\pm 7 \mathrm{~cm}$. long, caudate, at the base cut to the rachis; lower segments contracted at the base, often subpetiolulate, margins serrate. Surfaces naked, purplish-green; costae hairy above, scaly. beneath, the costulae slightly so; veins simple, \pm 5 on a side. Sori costular

Luzon, Mindoro, Mindanao.

(19) A. latebrosa, Wall.

Omit this species, it being referred to Hemitelia.

(20a) A. Alpina, v. A. v. R., in Bull. Btz., 1915, XX, 4.

Stipes when dry pale-fuscous, aculeate with acutely conical warts, deciduously furfuraceous and scaly, the tomentum ochraceous, the scales long, subulate-lanceolate, fuscous, more or less eroso-denticulate in the lower part. Fronds 3-pinnatifid, sub-3-pinnate, the rachis asperulous and deciduously fusco-squamose, the upper side ferrugineo-tomentose, the lower side deciduously ochraceo-furfuraceous. Pinnae subhorizontal, sessile, the rachis castaneo-tomentose above, pale-furfuraceous beneath. Pinnulae 
rather sessile, close, linear, acuminate, the higher oblique, the lower horizontal or deflexed, the largest $9-11 \mathrm{~cm}$. long, $1^{\prime}{ }_{2}-2^{\prime}{ }_{2} \mathrm{~cm}$. broad at the truncate base, deeply pinnatifid, nearly pinnate, the costa castaneotomentose above, deciduously pale-furfuraceo-squamose beneath. Ultimate segments linear or linear-oblong, straight or falcate, approximate, the lower horizontal and not rarely free, the largest to $1^{\prime}{ }_{2} \mathrm{~cm}$. long by 3 mm. broad, blunt or bluntish, crenate, somewhat recurved at the edge, the costula naked above, deciduously pale-furfuraceo-squamulose beneath; veins to \pm 10 on a side, forked, sometimes 3-furcate, the higher simple. Texture coriaceous; upper surface naked, lower provided with deciduous gland-like, adpressed, short hairs on the veins. Sori costular, occupying the 1-4 lower veins; receptacle encircled by a moderately large, orbicular, erose, brownish scale.

\section{Sumalra.}

(20b) A. indrapurae, v. A. v. $\boldsymbol{~}$., in Bull. Btz., 1915, XX, 2.

Trunk to $2 \mathrm{~m}$. or more high. Stipes to $45 \mathrm{~cm}$. or more long, fuscous when dry, aculeate with short, acute, conical warts, deciduously scaly, the scales long, subulate-lanceolate, fuscous, ciliate with deciduous, erected, short, acute, dark-brown hairs. Fronds 3-pinnatifid, the main rachis muricato-asperulous or subaculeate and deciduously scaly in the lower part, 'otherwise, like the secondary rachises, smooth or roughish, above deciduously ferrugineo-villoso-tomentose, beneath when young very minutely ochraceo-lanuginose. Pinnae subsessile, imbricating, subhorizontal, the largest about 55-60 cm. long. Pinnulae numerous, approximate, subsessile, deciduous apparently articulated at the base), lanceolate-linear, shortly and somewhat abruptly acuminate, the higher oblique, the lower horizontal, the largest about $9 \mathrm{~cm}$. long by $2 \mathrm{~cm}$. broad, deeply pinnatifid, hardly narrowed at the subtruncate base; costae ferrugineo-villose above, when young very minutely ochraceo-lanuginose and sparingly lanceolatosquamulose beneath. Ultimate segments linear-oblong, approximate or somewhat remote, much spreading or nearly horizontal, straight or somewhat falcate, blunt, entire or crenulate, the largest $1 \mathrm{~cm}$. long by $2^{1}{ }_{2}-3 \mathrm{~mm}$. broad, somewhat dilated at the base, the lower sometimes subdistinct; costulae naked above, sparingly and minutely subbullatosquamulose beneath; veins to 8-10 on a side, forked, the higher simple. Texture firm-herbaceous; surfaces naked. Sori costular, occupying the lower veins, to 6 on a side; receptacle encircled by a moderately large, 
regularly and more or less shallowly saucer-shaped, sometimes more deeply cup-shaped, scale.

Sumatra.

(20c) A. punctulata, v. A. v. R., in Bull. Btz., 1915, XX, 5.

Stipes fuscous when dry, aculeate with short, acutely conical warts, deciduously squamuloso-furfuraceous, scaly towards the base, the tomentum rufo-fuscous, the scales long, subulate-lanceolate, rufo-fuscous, very minutely eroso-denticulate. Fronds 3-pinnatifid, sub-3-pinnate, the main rachis muricato-asperous, above grooved and villoso-tomentose in the groove, beneath densely punctulate and, when young, probably furfuraceous. Pinnae stalked, subhorizontal, $65-70 \mathrm{~cm}$. more or less long, acuminate, the rachis subcastaneo-villoso-tomentose above, copiously punctulate and deciduously subferrugineo-furfuraceous beneath. Pinnulae numerous, approximate, linear-lanceolate, acuminate, the higher oblique, the lower horizontal or deflexed; medial or inframedial pinnulae largest, short-stalked, 13-14 $\mathrm{cm}$. more or less long, $2 \frac{1}{2}--2 \frac{1}{2} \mathrm{~cm}$. broad below the middle, acuminate, deeply pinnatifid, nearly pinnate, slightly narrowed at the more or less truncate base, the costa villoso-tomentose above, deciduously furfuraceous and squamulose beneath. Ultimate segments linear, more or less falcate, the largest to $13 / 4 \mathrm{~cm}$. long, about $3 \mathrm{~mm}$. broad, bluntish or subacute, the edge recurved, dentate-crenate; higher segments rather approximate, lower more remote and often free and more or less abbreviated; costulae naked above, squamulose beneath, the scales partly bullate, partly lanceolate; veins to $12-15$ on a side, forked, the higher simple, the lower not rarely 3-furcate. Texture coriaceous; surfaces naked; upper surface dark-olivaceous when dry, lower paler. Sori inframedial on the veins, contiguous, to $8-10$ on a side, the receptacle encircled by a very minute, brown, erose scale.

\section{Sumatra.}

(20d) A. brevifuliolaia, v. A. v. R., in Bull. Btz., 1915, XX, 3.

Trunk slender, to $5 \mathrm{~m}$. or more high. Stipes about $35 \mathrm{~cm}$. long, muricato-asperous in the upper part, sealy, and aculeolate with short, acute, conical warts towards the base; scales deciduous, narrowly subulate, fuscous, more or less eroso-denticulate, and remotely ciliated with short, erect, red-brown hairs. Fronds 3-pinnatifid, acuminate, the main rachis 'muriculato-asperulous towards the base, and, like the secondary ones, 
purveyed above with partly grey partly red-brown tomentum, when young beneath probably ochraceo-furfuraceous. Pinnae subsessile or very shortly petiolulate, the higher oblique, the following horizontal or nearly so, approximate, the lower reduced, not rarely somewhat deflexed, remote; largest pinnae linear-sublanceolate, $30 \mathrm{~cm}$. more or less long, about $8 \mathrm{~cm}$. broad at the middle. Pinnulae approximate, the higher sessile, oblique, the lower subsessile, horizontal or subdeflexed, abbreviated; largest pinnulae linear-oblong, $4-5 \mathrm{~cm}$. long, $1-1 \frac{1}{2} \mathrm{~cm}$. broad, straight or subfalcate, blunt to bluntly short-acuminate, truncate and slightly narrowed at the base. Ultimate segments approximate, linear-oblong, nearly horizontal, to $3 / 4 \mathrm{~cm}$. long and $2-2 \% \mathrm{~mm}$. broad, blunt, crenulate towards the apex. Texture papyraceous, when fresh pale-yellow-green; surfaces naked; costae hirsute above, like the costulae sparingly squamulose beneath, the scales pale, sublanceolate, bullate; veins to 8-9 on a side, the higher simple, the others mostly forked. Sori costular, occupying the $1-2$ 'or more ?) lower veins; receptacle encircled by a moderately large, mostly regularly orbicular, flat or shallowly saucer-shaped, membranaceous scale.

Sumatra.

(21) A. fuliginosa, Christ; Cyather fuliginosa, Copel., in Philipp. Journ., IV ${ }^{\mathrm{c}}, 43$, p. p.

(22) A. Iepifera, J. Sm.; Cyathea lepifera, C,pel., in Philipp. Journ., IV, 40.

This fern has been collected only by Cuming, and has been reduced to A. tomentosa $H k$. from which it is very distinct. (Copel.).

(23) A. batjanemsis, Christ; Cyathea batjanensis, Copel., in Philipp. Journ., IVC, 45.

(24) A. melanopus, Hassk.; Cyathea melanopus, Copel., in Philipp. Journ., IVC, 48.

Stipes aculeate and deciduously fusco-puberulous and densely, but deciduously, scaly at the base, for the rest roughish and somewhat sealy like the rachis; secondary rachises rufo-tomentose above; costae tomentose above, and, like the costulae, naked or somewhat squamulose beneath, the scales ovate, acuminate; sori covering $1 / 2-3 / 4$ of the lobes.

Ferns and Fern Allites. 
(24a) A. Fenicis, C. Chr., Ind. Fil., Suppl.; Cyathea Fenicis, Copel., in Philipp. Journ., IV, 61.

Trunk said to be but $1 \mathrm{~m}$. high. Stipes $\pm 60 \mathrm{~cm}$. long, dark-brown, prickly with short, sharp spines, bearing 2 small, simply pinnate pinnae just above the base, and clothed at the base with a few narrow, brown scales $1_{1 / 2}^{1} \mathrm{~cm}$. long, otherwise glabrous, as are the slightly roughish rachises. Largest pinnae $35-40 \mathrm{~cm}$. long, $\pm 20 \mathrm{~cm}$. broad, abruptly narrowed to a pinnatifid apex. Pinnulae $\pm 10 \mathrm{~cm}$. long, hardly $2 \mathrm{~cm}$. broad, sessile, cut at the base to the costa, elsewhere to a wing; segments $\pm 4 \mathrm{~mm}$. broad; obtuse, obscurely serrulate. Texture rather membranaceous; upper surface dark-green, lower olive-coloured; costae hairy above, mostly glabrous beneath; costulae bearing a few small scales beneath; veins forked. Sori costular.

Batanes Islands.

(24b) A. Jeucocarpan, C. Chr., Ind. Fil., Suppl.; Cyathea leucocarpa, Copel., in Philipp. Journ., VIC, 362.

Stipes more than $30 \mathrm{~cm}$. long, castaneous, deciduously ferrugineotomentose, verruculose, the base spiny and provided with black-brown subulate scales; rachises rufous, nearly smooth, minutely scaly beneath, at length glabrescent. Pinnae subsessile, $\pm 45 \mathrm{~cm}$. long, $13 \mathrm{~cm}$. broad, acuminate. Pinnulae short-stalked, $\pm 7 \frac{1}{2} \mathrm{~cm}$. long, $1 \frac{1 / 2}{2} \mathrm{~cm}$. broad, acuminate, truncate at the base, cut down nearly to the costa, the costa brown-hairy above, clothed beneath with entire, acuminate, scattered scales. Lobes $\pm 3 \frac{1}{2} \mathrm{~mm}$. broad, rounded at the apex, obscurely serrulate. Texture membranaceous; surfaces naked; costulae sparingly bullato-squamulose beneath; veins \pm 8 on a side, often forked. Sori subcostular, immersed; capsules at length white, when young intermixed with brown paraphyses.

Borneo.

(25) A. ormatso, Scott.; Cyathea ornata, Copel., in Philipp. Journ, IV, 59 .

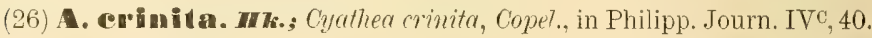

(26a) A. Elmeri. Copel., in Leafl., II, 419; Cyathea Elmeri, Copel, in Philipp. Journ., IVC, 54.

Trunk 5-10 m. high, 10-15 cm. thick. Stipes short, densely cover- 
ed with dark-brown, minutely ciliate-serrate, setiform scales $2 \frac{1}{2}-3 \mathrm{~cm}$. long and $1 / 2 \mathrm{~mm}$. wide. Fronds (incl. the stipe) $2-3 \mathrm{~m}$. long. Pinnae \pm $60 \mathrm{~cm}$. long, $\pm 25 \mathrm{~cm}$. broad, subsessile, acuminate. Pinnulae $\pm 13 \mathrm{~cm}$. long, $\pm 2^{1}{ }_{2} \mathrm{~cm}$. wide, acuminate, sessile, close, pinnate near the base; segments subfalcate, obtuse, $\pm 3 \frac{1}{2} \mathrm{~mm}$. wide, serrulate, separated by narrow sinuses, the lowest not adnate. Texture herbaceo-coriaceous; both surfaces green, naked; main rachis stramineous beneath, beset with small, sharp spines with black, mammiform bases, scurfy with minute, rather deciduous squamules; secondary rachises tawny beneath, finely prickly and deciduously squamulose; costae bearing pale hairs above, and beneath 2 kinds of stramineous scales: minute (? bullate) ones which are ciliate or subentire, and larger, lanceolate ones which are strongly lacerate into brown setae; costules beneath bearing pale, bullate squamules and hairs; veins 10 12 on a side, mostly forked below the middle. Sori in the forks of the veins.

Negros, Mindanao.

(26b) A. Iongipiana, C. Chr., Ind. Fil., Suppl.; Cyathea longipinna, Copel., in Philipp. Journ., VI', 363.

Stipes spinose, castaneous, clothed towards the base with glossy, castaneous, caducous, linear-subulate scales; main rachis giabrescent, spinulose, the upper part castaneous and tuberculate, as are the secondary rachises. Pinnae $\pm 45 \mathrm{~cm}$. long; $9-11 \mathrm{~cm}$. broad, horizontal, sessile, acute, the rachis velutinous above, naked beneath, with the base thickened and pilose, provided with a pale spot on the upper side; lowest pinnae stalked, reduced, deflexed, narrowed at both ends. Pinnulae numerous, sessile, horizontal, often straight, cut down hardly to the costa, 9-11 $\mathrm{mm}$. broad at the base, narrowed gradually towards the serrate apex; costae above velutinous towards the base, beneath densely clothed with ovate, stramineous or castaneous scales. Lobes approximate, subfalcate, $\pm 2 \mathrm{~mm}$. broad, obtuse. Texture herbaceous; surfaces naked; under surfaces paler than the upper; costulae paleaceous at the base beneath; lower veins forked, higher simple. Sori costular, occupying the forked veins, contiguous, confluent.

\section{Borneo.}

126c) A. Hieronymi, Brau., in Engl. Bot. Jahrb., IL, 14.

Trunk $\pm 2-3 \mathrm{~m}$. high. Stipes $\pm 10 \mathrm{~cm}$. long, muricate, sparingly clothed with linear-lanceolate, lacerate-ciliate or -denticulate, fuscous scales. 
Fronds lanceolate, probably $1 \frac{1}{4}-1 \frac{1}{2} \mathrm{~m}$. long by $1 / 2 \mathrm{~m}$. broad, 3-pinnatifid, abruptly acuminate, rather narrowed at the base. Pinnae $\pm 8-9$ on a side, horizontal or spreading, remote, alternate, lanceolate, the central ones the largest, $\pm 26 \mathrm{~cm}$. long, abruptly acuminate, the higher sessile, the lower $\pm 10 \mathrm{~cm}$. long, petiolate. Pinnulae petiolulate, pinnatifid, triangular-lanceolate, the largest $\pm 7 \mathrm{~cm}$. long and $1 \frac{1}{\mathrm{~s}} \mathrm{~cm}$. broad. Segments approximate, linear-falcate, $\pm 1 \mathrm{~cm}$. long and $1 / 3 \mathrm{~cm}$. broad, serrate, obtusate. Texture chartaceous; surfaces naked; upper surface dark-green, lower paler; rachis muricate, fusco-pilose; costae fusco-pilose above, beneath when young clothed with short, fuscous hairs and ferrugineous, ovate, long-acuminate, ciliate scales; as are the costulae which are naked above; veins forked. Sori \pm 10 on a side, near the costulae, the lower somewhat divaricating.

New Guinea.

(26a) A. wengiensis, Mram., in Engl. Bot. Jahrb., IL, 13, fig. 1 C.

Fronds 3-pinnatifid. Pinnae sessile, lanceolate, $39 \mathrm{~cm}$. more or less long, $12 \frac{1}{2} \mathrm{~cm}$. broad, slightly narrowed at the base. Pinnulae remote, triangular-lanceolate, the central ones the largest, $\pm 61_{2} \mathrm{~cm}$. long, $13 / 4$ $\mathrm{cm}$. broad at the base, slightly acuminate, deeply pinnatifid; lobes subfalcate from a slightly dilated base, $\pm 8 \mathrm{~mm}$. long and $31 / 2 \mathrm{~mm}$. broad, entire or subcrenulate in the lower part, serrate towards the bluntish apex. Texture chartaceous; surfaces naked; rachises muricate, above densely brown-hairy, when young beneath short-hairy and brown-scaly, glabrescent; costae densely hairy above, sparingly hairy and bullatosquamulose beneath; costulae naked above, sometimes sparingly hairy and bullato-squamulose beneath; veins \pm 12 on a side, simple or forked. Sori mostly occupying the upper part of the lobes, 5-7 on a side, the lower medial, the higher nearer the costula than the edge; sporangia intermixed with setiform paraphyses.

New Guinea.

(27) A. glauca, J. Sm.; A. contminans, Wall., var. robusta, Hassk., Obs. Fil. Jav., 32; - var. squamulata, densa, microloba (microlobus), setulosa, Hassk., 1. c., 36-38; - var. squamulosa; — var. celebica, Christ, in Ann. Btz., XV, 79; — var. longepaleata, Christ, l. c., XIX, 42.

Capsules intermixed with articulated paraphyses as long as the capsules; receptacle encircled by a minute, flat, entire or incised scale 
or a whorl of fibres. - The type and the varieties are passing into each other by intermediates which are difficult of determination.

Forma typica: Main rachis naked; pinnae and pinnulae proportionally long and narrow; costae fulvo-tomentose above, naked or sparingly bullatosquamulose beneath; ultimate segments rather numerous; costulae and veins beneath squamulose with scattered, caducous, small, bullate, laciniatefimbriate scales; veins forked, the lower often 3-furcate, the higher simple; sori occupying the lower $1 / 4-2 / 3$ of the lobes.

Var. squamulata: Costae and costulae squamulose on both sides (?) but more copiously on the lower side, the scales flattish, ovatelanceolate, acuminate, ciliate-lacerate, adpressed, small, whitish, especially the lower of the pinnulae intermixed with longer, linear ones; ultimate segments relatively short and broad.

Var. densa : Costae above fulvo-puberulous, substrigose, beneath naked or sparingly squamulose with very narrow, whitish, minute scales; costulae naked, or sparingly squamulose with minute, caducous, ovate, subbullate scales; veins mostly forked; sori occupying nearly the whole under surface of the lobes except the apex, at length confluent.

Var. microloba: Intermediate between the preceding and the following; costulae bullato-squamulose between the sori, otherwise setulose.

Var. setulosa: Costae hirsuto-tomentose above; costulae provided beneath with scattered, moderately long, pale, spreading, acicular setae especially in the barren region; veins and sori as in the type.

Var. squamulosa: Like the preceding but the setae intermixed with caducous, pale, rather flat, ciliate-fimbriate squamules between the sori; ultimate segments relatively long and narrow; veins naked, or sparingly setulose with bristles shorter and finer than those of the costulae; sori as in var. densa in the longer forms.

Var. celebica: Pinnae and pinnulae relatively short and broad; ultimate segments not numerous, $2-3 \mathrm{~mm}$. apart.

Var. Iongepaleata: Main rachis scaly with long, linear-subulate brown scales.

.27a) Clementis, Copel.; Cyathea Clementis, Copel., in Philipp. Journ., IVC, 59.

(28) A. Christi, v. A. v. R.

Omit this name, it should be A. subcomosa C. Chr. 
(28) A. subcomosa, C. Chr., Ind. Fil., Suppl.; A. comosa, Christ (not Wall.); A. Christii, v. A. v. R. (not Sod.).

(29) A. truncata, Brack.; Cyathea truncata, Copel, in Philipp. Journ., IVC, 39.

(32) A. Comentosa, Hli.; Cyathea tomentosa, Zoll. \& Mor, Copel., in Philipp. Journ., IV ${ }^{\mathrm{C}}, 40$.

(33) A. extensa, spr.; Polypodium lumulatum, Forst., Schk., Krypt. Gew., I, tab. 23.

Stipes dark, deciduously farinoso-pulverulent; main rachis muriculate in the lower part, deciduously pulverulent, subvelutinous above; secondary rachises pulverulent, strigoso-tomentose above; costae striguloso-puberulous above, squamulose beneath, the scales pale, bullate, acute or subulate; costulae naked above, bullato-squamulose beneath.

(33a) A. Curranii, C. Chr., Ind. Fil., Suppl.; Cyathea Curranii, Copel, in Philipp. Journ., IV ${ }^{\mathrm{C}}, 52$.

Trunk $\pm 3 \mathrm{~m}$. high, $\pm 20 \mathrm{~cm}$. thick. Stipes $\pm 35 \mathrm{~cm}$. long, maroon, tuberculate, bearing thin, soft, tawny scales which are up to $61_{2} \mathrm{~cm}$. long, entire unless at the tip, long-angustate, $\pm 4 \mathrm{~mm}$. wide at the base which is cordate, or rounded and peltate. Fronds $\pm 100 \mathrm{~cm}$. long, half as wide. Lowest pinnae long-stalked, reduced and deflexed; median ones $\pm 35 \mathrm{~cm}$. long, $\pm 17 \mathrm{~cm}$. wide, short-stalked. Pinnulae sessile, $\pm 9 \mathrm{~cm}$. long, $\pm 1 \mathrm{~cm}$. broad, long-angustate, pinnate; lowest segments deflexed over the rachis and not adnate, the others adnate, crowded, narrowly oblong, obtuse, entire or nearly so, bullate. Texture coriaceous; surfaces naked; upper surface brownish-green, lower apparently glaucous; main rachis bearing sparse, small, deciduous, lanceolate paleae, rough with small but numerous usually very blunt tubercles, brown, dorsal side hairy; secondary rachises similar but less tuberculate, and dark-maroon in colour; costulae beneath occasionally with a scale; veins \pm 10 on a side, minutely hairy beneath; simple or forked near the costulae. . Sori subcostular, soon covering the whole under surface.

Luzon.

(34) Iurida, Bk.; Cyathea lurida, Copel., Philipp. Journ., IVC, 45. Stipe and rachis unarmed but roughish, purplish, densely tomentose, 
and scaly with thin, ciliate, subulate paleae, beneath bearing sparse, crisped, lanceolate scales, brown with light margins. Pinnae $\pm 30 \mathrm{~cm}$. long, short-stalked. Pinnulae $\pm 5 \mathrm{~cm}$. long, $\pm 1 \mathrm{~cm}$. wide, cut almost or quite to the costa into numerous linear-oblong, subentire segments. Texture coriaceous; costae hairy above, beset beneath with dentate, ovate-lanceolate, imbricate, dull-ferrugineous scales, which become shorter and more bullate toward the apices and on the costulae; veins $5-6$ on a side, simple or the lowest forked. Sori subcostular, cinnamon-red.

Java, Celebes.

(34a) A. melanorachis, Copel., Cyathea melanorachis, Copel., in Philipp. Journ., IVC, 38.

(35) A. mindanaensis, Christ; Cyathea mindanaensis, Copel., in Philipp. Journ., IV , 34.

(37) ? A. Satthewii, Christ, in Journ. of Linn. Soc., Bot., XXXIX, 213.

Unarmed. Trunk to $65 \mathrm{~cm}$. high. Stipes $\pm 20 \mathrm{~cm}$. long, sulcate, clothed with grey, lanceolate, acuminate, scariose, rigid, entire, keeled, imbricate seales which are subadpressed or spreading at the apex. Fronds broadly ovate, $\pm 45 \mathrm{~cm}$. long, $30 \mathrm{~cm}$. broad, acuminate, moderately narrowed at the base. Pinnae spreading, approximate, broadly ovate; central pinnae $\pm 18 \mathrm{~cm}$. long, $9 \mathrm{~cm}$. broad, acuminate, nearly sessile; lower pinnae deflexed. Pinnulae approximate, sessile, broadly lanceolate, \pm $4 \mathrm{~cm}$. long, $13 \mathrm{~mm}$. broad, acute, somewhat narrowed at the base, cut down to the costa. Secondary pinnulae separated by a narrowly ovate sinus, adnate, ligulate, obtuse, entire or obscurely crenulate, the lower ones smaller, distant, free, ovate at the base. Texture thin, herbaceous; colour black-green, opaque; rachises fulvous, clothed with fine, subferrugineous hairs and fuscous, subulate, scariose scales; costae strigose above, squamose beneath 'with roundish, umbilicate, bullate scales; veins oblique, distant, inconspicuous, \pm 6 on each side, the lowest forked. Sori unknown.

Luzon.

(38) A. Diformis, Tist., in Fedd., Rep., IX, 423; Cyathea biformis, Copel., in Philipp. Journ., VIC 364 ; C. botryocarpa, Copel., MS.

Fronds 3-pinnate, the rachises purple-black, nearly glossy, clothed 
above with brownish tomentum and scattered, subulate or lanceolate scales. Pinnulae dimorphous. Barren pinnulae simple, lanceolate, petiolate, $\pm 8 \mathrm{~cm}$. long, $\pm 1 \frac{3}{4} \mathrm{~cm}$. broad, acute, broadly but not deeply serratedentate, rotundate-cuneate at the base. Texture coriaceous; costae and veins beneath provided with minute, scattered, deciduous, bullate, lanceolate or subulate seales; main veins pinnate with $\pm 2-3$ erected veins on a side. Fertile pinnulae pinnate, the rachis marginate (narrowly winged) on both sides; leaflets spreading or horizontal, linear-oblong; to $\pm 5 \mathrm{~mm}$. long, $1-1^{1}{ }_{2} \mathrm{~mm}$. broad, 3-4 mm. apart, the apex blunt or truncate, the sides parallel or nearly so, the costal parenchyma canaliculate above, the edges subrevolute, irregularly repand, the base abruptly broadly cuneate or truncate, nearly sessile. Sori $\pm 5-6$ on a side, occupying the whole under surface of the leaflets.

New Guinea.

(39) A. inciso-serrata, $\boldsymbol{C}$. Chr., Ind. Fil., Suppl.; Cyathea incisoserrata, Copel., in Philipp. Journ., VIC, 361.

Main rachis bright-brown, minutely and sparingly punctulate, beneath naked or glabrescent, above minutely velutinous. Pinnae $\pm 50 \mathrm{~cm}$. long, $15 \mathrm{~cm}$. broad, subsessile, acuminate, the rachis smooth, provided beneath with few narrow, minute, scattered scales. Pinnulae short-stalked, \pm 8 $\mathrm{cm}$. long, to $2 \frac{1}{12} \mathrm{~cm}$. broad, acuminate, cut down nearly to the costa which is hairy above, provided beneath with fusco-ferrugineous, lanceolate or bullate scales; lower pinnulae somewhat reduced. Lobes $\pm 4 \mathrm{~mm}$. broad, obtuse, inciso-serrate; costulae naked above, clothed beneath with caducous, bullate squamules; lowest basiscopic lobes reduced, entire. Texture herbaceous; surfaces naked; veins twice forked. Sori medial, provided with numerous hairs somewhat longer than the sporangia.

Borneo.

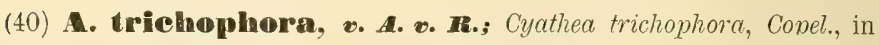
Philipp. Journ., VIC, 363; (? Hemitelia).

Stipes $\pm 50 \mathrm{~cm}$. long, asperulous, deciduously hairy, elothed at or near the base with stramineous, needle-like and lanceolate scales. Fronds $\pm 120 \mathrm{~cm}$. long, 50-60 $\mathrm{cm}$. broad, narrowed at both ends. Pinnae pinnate, $30-35 \mathrm{~cm}$. long, $\pm 10 \mathrm{~cm}$. broad, subsessile, the rachises whitehairy; lowest pinnae deflexed, hardly pinnate, $\pm 10 \mathrm{~cm}$. long. Pinnulae sessile, $\pm 5 \mathrm{~cm}$. long, $1 \mathrm{~cm}$. broad, obtuse, the margin cut more than 
$1 / 2$-way down to the costa, the base truncate-cuneate, the costa beneath sparingly hairy and scaly. Lobes $3-4 \mathrm{~mm}$. long, $2-3 \mathrm{~mm}$. broad, truncate, denticulate, approximate. Texture herbaceous; coulour pale; surfaces naked; veins $4-5$ on a side, often simple. Sori medial; indusium wanting or rudimentary; capsules intermixed with paraphyses.

Luzon.

(41) A. apiculata, Rst., in Fed., Rep., XIII, 213.

Fronds 3-pinnatifid. Pinnae petiolate, elongate-oblong, $\pm 40 \mathrm{~cm}$. long by $14 \mathrm{~cm}$. broad, acuminate, hardly narrowed at the base. Pinnulae subsessile, linear, deeply pinnatifid, the apex abruptly narrowed into a crenulate acumen $\pm 12 \mathrm{~mm}$. long by $3 \mathrm{~mm}$. broad. Lobes crowded, linear-subfalcate, $\pm 7 \mathrm{~mm}$. long by $31 / 2 \mathrm{~mm}$. broad, obtuse, entire. Texture rigidly chartaceous; rachises pale-brown, smooth, tomentose above, as are the costae and costulae; costae (costulae?) provided beneath with scattered, flat, lanceolate-ovate, slightly erose scales; veins \pm 8 on a side, often forked. Sori \pm 6 on a side, subcostular; spurious indusium present, narrowly ring-shaped, encircling the receptacle. - Stipes unarmed?

\section{Sumatra.}

(42) A. seabriseta, v. A. v. I.; Cyathea scabriseta, Copel., in Philipp. Journ., IX ${ }^{\mathrm{C}}, 2$.

Fronds deeply 3-pinnatifid, the main rachis fulvous, scaly with minute, white, deciduous paleae fimbriate at the base, provided at the base with firm, whitish, caducous hairs, the hairs red at the base, ciliolate with very minute black-red and whitish teeth. Pinnae short-stalked; \pm 60 $\mathrm{cm}$. long, $18 \mathrm{~cm}$. broad, abruptly acuminate, the rachis dark-dirty-coloured, above fusco-velutineous, beneath minutely furfuraceous and sparingly hispid, glabrescent. Pinnulae horizontal, approximate, the lower shortstalked, $\pm 2 \mathrm{~cm}$. broad, deeply pinnatifid, abruptly caudate-acuminate, the acumen. serrate. Lobes often subfalcate, $\pm 2^{1}{ }_{2} \mathrm{~mm}$. broad, obtuse, minutely serrate or twice serrate. Texture subcoriaceous; upper surface black-green, lower paler; costae appresso-pilose above, clothed beneath with whitish, often divided, rarely entire lanceolate scales; costulae provided beneath with pale bullate scales and a few scattered, flattened, dirty-coloured, often divided paleae; veins to 12 on a side, often naked, mostly forked. Sori medial; capsules intermixed with brown hairs. - Stipes unarmed? New Guinea. 


\section{DICKSONIA, l'Hémitier.}

(1) QD. HIumei, Moore, Copel., in Philipp. Journ., IV ${ }^{\mathrm{C}}$, tab. XX. Also in Negros, Mindoro, Mindanao, Sumatra.

(2) D. Copelandi, Christ.

Omit this species, it being referred to Balantium.

(3) D. sorbifolla, Sm., Hk. Bk., Syn. Fil., 52; Hk., Spec. Fil., I, tab. XXV A; D. papuana, Muell., Copel., in Philipp. Journ., VIC, 69; Cystodium sorbifolium, J. Sm., Bau. \& Hk., Gen. Fil., tab. XCVI; Saccoloma sorbifolium, Christ, Farnkr. d. Erde, 309; C. Chr., Ind. Fil.; - var. dentata.

Stipes tufted, $50 \mathrm{~cm}$. or much more long, the base densely clothed with long, silky or woolly, yeilowish hairs. Fronds large, 2-pinnate, 60 $\mathrm{cm}$. or much more long, ovate-lanceolate. Largest pinnae $25-35 \mathrm{~cm}$. long, $\pm 8 \mathrm{~cm}$. broad, stalked, the lowest sometimes smaller than the next in order. Pinnulae numerous, the highest sessile with a broad base, the lowest the largest, $\pm 7-10 \mathrm{~mm}$. broad, short-stalked, the base truncate or cordate, whether or not auricled on the upper side, the edge serrate towards the apex. Texture coriaceous; rachises and under side of the costae and veins more or less hairy; veins simple or forked. Fertile pinnulae bluntly toothed, bearing the sori on the teeth. Sori numerous, 1 to each tooth; indusium 2-valved, the upper valve cucullate, formed by the tooth (lobe), the lower smaller, rather flat.

Var. dentata: Lower pinnulae deeply toothed.

Malaya.

(4) D. Seblechteri, Erar., in Engl. Bot. Jahrb., IL, 11; - var. glabrescens, Rst., in Fed., Rep., XII, 165.

Fronds 3-pinnatifid. Pinnae lanceolate, spreading, $45 \mathrm{~cm}$. more or less long, $\pm 14 \mathrm{~cm}$. broad. Pinnulae numerous, subspreading, rather remote, the largest $\pm 7 \frac{1}{2} \mathrm{~cm}$. long and $1^{3 / 4} \mathrm{~cm}$. broad, bluntish at the serrate apex, the higher gradually more oblique, the lowest somewhat reduced, horizontal. Segments oblong, $\pm 1 \mathrm{~cm}$. long and $1 / 2 \mathrm{~cm}$. broad, deeply incised, connected by a narrow wing at the base; lobules to 4 on a side, subquadrangular, the apex obtuse, 2-dentate or deltoid. Texture coriaceous; surfaces naked; rachises tomentose with ferrugineous, fibrillike scales, grooved above, rounded beneath, the secondary ones whitish- 
hairy above; costulae above sparingly whitish-hairy, beneath rather densely clothed with reddish, articulated hairs; veins naked or nearly so. Sori marginal, globose; indusium with the upper valve entire, the lower crenated.

Var. glabrescens: Rachises nearly naked; lobules looser.

New Guinea.

\section{4a. BALANTIUM, Kaulfuss.}

Like Dicksonia, but the indusium occasionally more or less cup-shaped (as in Dennstaedtia) and the annulus of the sporangia sometimes vertical and incomplete (as in the Polypodiaceae).

Caudex more or less arborescent, but usually not rising much above the ground. Fronds decompound, with the ultimate segments unequalsided at the base, the anterior side the most developed. - Diels, in Engl. \& Prantl, Nat. Pfl.fam., I ${ }^{4}$, fig. 78 A. (')

Malaya, Polynesia, Trop. America, Azores.

1. Sori in the sinuses of the teeth.

(1) B. javanicum.

1.1. Sori on the teeth.

2. Fronds under $50 \mathrm{~cm}$. long.

2. B. pilosum.

2.2. Fronds more than $50 \mathrm{~cm}$. long.

(3) B. Copelandi.

1) B. javanieum, Copel., in Philipp. Journ., IVC, 62; Dennstaedtia javanica, Christ, in Bull. Herb. Boiss., 2e Série, IV, 617; Dicksonia javanica, Bl., Rac., Flor. Btz., I, 120.

Caudex arborescent but not high, rather slender. Stipe and rachis densely covered with short, adpressed hairs. Fronds lanceolate-oblong, up to $1 \frac{1}{2} \mathrm{~m}$. long, to $60 \mathrm{~cm}$. broad. Pinnae and pinnulae ovate-oblong,

(1) This genus, as treated by Copeland, is very nearly related to both Dicksonia and Dennstaedtia. - See Copeland's information in Philipp. Journ., IIIC, 301. 
acuminate, the latter short-stalked, $2-3 \mathrm{~cm}$. broad at the base. Tertiary segments sessile with a cuneate base, the lowest anterior ones the largest; $1 \frac{1}{2}-2 \mathrm{~cm}$. long, to $5 \mathrm{~mm}$. broad, the apex blunt, toothed, the edge cut down nearly or quite to the costa into oblong, blunt, toothed segments $1-2$ mm. wide, the lowest anterior segment the longest. Texture herbaceous; upper surface more or less glabrous, lower densely hairy, as are the secondary and tertiary rachises. Sori small, in the sinuses, submarginal; indusium more or less cup-shaped; annulus vertical, incomplete.

Java.

(2) H. pilosum, Copel., in Journ. Str. Br. R. A. Soc., LXII, 71.

Stipes $20 \mathrm{~cm}$. or more long, dark-purple-brown and asperulous. Fronds subdeltoid, $\pm 30 \mathrm{~cm}$. long by $15 \mathrm{~cm}$. broad, 4-pinnatifid, the rachises densely hairy, the hairs rufo-castaneous. Pinnulae stalked, deltoid, $\pm 3 \mathrm{~cm}$. long, with the lowest segments $\pm 8 \mathrm{~mm}$. long, $5 \mathrm{~mm}$. broad, oblique, deeply pinnatifid. Texture coriaceous; upper surface glossy and sparingly hairy, lower densely hairy. Sori terminal on the smaller teeth; indusium equally 2-valved; capsules intermixed with copious paraphyses.

Borneo.

(3) IB. Copelandi, Christ, Copel, in Philipp. Journ., IVC, 62, tab. XIX; Dicksonia Copelandi, Christ, in Philipp. Journ., IIC, 183; Dennstaedtia Elmeri, Christ, MS.

Caudex up to $60 \mathrm{~cm}$. high. Stipes up to $11 / 2 \mathrm{~m}$. long, rufo-stramineous when young, rather glossy, hairy when young, the base densely clothed with fine, reddish-brown, moderately long hairs. Fronds $3-4$ pinnate, varying from $50-300 \mathrm{~cm}$. long. Pinnae up to $100 \mathrm{~cm}$. long, deltoid, acuminate, petiolate, produced on the upper side at the base. Pinnulae close, the lower and central ones deltoid, the lowest stalked, acuminate. Ultimate segments small, oblong, acute, the lowest free in the largest fronds, rather unequal-sided, serrate, the teeth acute, mucronate. Texture firm; upper surface naked, rather glossy, lower hairy on the veins; colour ochraceous-green; veins forked or pinnate in the ultimate segments, rather obscure. Sori numerous, on rounded teeth, surpassed by the mucrones, 1 to each tooth, occupying especially the anterior side; indusium irregularly -2-valved.

Philippines, Borneo. 


\section{5. СІВОТІUМ, Kanlfuss.}

C. barometz, J. Sm.

Omit this name, it should be C. baranetz J. Sm.

1) C. baranetr, J. Sm.; - var. sumatranum; C. sumatranum, Christ, C. Chr., Ind. Fil., Suppl.; — var. Cumingii; C. Cumingii, Kze, Copel., Philipp. Journ., IV , tab. XXI; C. Chr., 1. c.; - var. semihastatum, v. A.v. R., in Bull. Btz., 1911, I, 3; C. Cumingii, Kze, var. semihastatum, v. A. v. R., MS., in Herb. Bog.

Dar. Cumingii: A specimen received from Luzon (leg. Ramos) has the pinnulae with the lower segments $\pm 2-21 / 2 \mathrm{~mm}$. broad, free, adnate, or subpetiolate and then truncate or subcordate at the base.

Var. semihastatam: Like the preceding, but the tertiary segments $\pm 3-4 \mathrm{~mm}$. broad, crenate-serrate, the lower more or less prominently hastato-auriculate on the lower side at the base, the sori distant from the costa, even from the tips of the sinuses, perfectly parallel to the costulae not the costae). - Luzon. 


\section{MATTUIIAEAE.}

Key to the genera.

* Fronds pedate-flabellate.

No. $6 a$. Vlatonia.

* Fronds sympodially branched.

No. 6b. Phanerosorus.

\section{Ga. MATONIA, R. Hrown.}

Fronds erect, stout, forked; primary branches giving off several pinnatifid pinnulae on the upper (inner) side only, the lower side unbranched; veins free except that the sori are borne where a number of veinlets converge.

Malayan.

+ Ultimate segments erecto-patent, falcate, acute.

(1) M. pectinata. t+ Ultimate segments spreading, straight, retuse or obtuse.

(2) M. Foxworthyi.

(1) M. pectinata, F. Er., Christ, Farnkr. d. Erde, 335, fig. 1064; Diels, in Engl. \& Prantl, Nat. Pfl.fam. I ${ }^{4}$, fig. 180 A \& 182: Bedd., Ferns Br. I., II, tab. CLXXXVI; Bau. \& Hk., Gen. Fil., tab. XLIII.

Stipes stout, erect, to $\pm 2 \mathrm{~m}$. long. Fronds fan-shaped. Pinnulae linear, the terminal ones mostly the shortest, the basal ones the longest, to $\pm 45 \mathrm{~cm}$. long, cut down nearly to the costa into numerous linear or linear-oblong, erecto-patent, falcate or subfalcate, acute lobes to \pm 2 $\mathrm{cm}$. long and $5 \mathrm{~mm}$. broad, dilated at the base. Texture very rigid, fragile when dry; costules distinct; veins simple or forked. Sori solitary at the base of the lobes or placed in 1 row on each side of the costules, 
consisting of $\pm 4-8$ mostly $5-7$ ) capsules; indusium curved back under the capsules.

Malacca, Lingga Islands; Borneo, Amboyna.

(2) II. Foxworthyi, Copel., in Philipp. Journ., IIIC, 343, tab. II; IVC, 27, tab. XVI.

Like the preceding, but the lobes straight, spreading, obtuse or retuse, up to $3 \frac{1}{2} \mathrm{~cm}$. long, often bearing more than 1 sorus on each side.

Borneo, Amboyna.

\section{6b. PHANEIROSORUS, Copeland.}

Fronds pendulous, sympodially branched (as in Lygodium). each dwarfbranch bearing a pair of simple or once or twice forked pinnae; veins free or forming costal areolae; sori usually just outside these areolae.

Malayan.

(1) Ph. sarmentosus, Copel., in Philipp. Journ. IIIC, 344, tab. III; IVc, 28, tab. XVII; Matonia sarmentosa, Bk., in Journ. of Linn. Soc., XXIV, 256; Ann. of Bot., V, 191, tab. XIV; Diels, in Engl. \& Prantl, Nat. Pfl. fam., I ${ }^{4}$, fig. $180 B$ \& 183.

Stipe and rachis slender, pendulous. Fronds up to $100 \mathrm{~cm}$. long. Ultimate segments linear, 5-15 cm. long, 3-4 cm. or more broad, entire or somewhat sinuated, blunt. Texture coriaceous; colour ash-green; surfaces naked; costae distinct; veins simple or forked. Sori in 1 row on each side, sometimes copious, on short anterior veinlets, \pm medial between the costa and margin, consisting of $\pm 8-14$ capsules ; indusium but slightly curved under the capsules.

Borneo. 


\section{II. GLEIOHENIAOEAE.}

\section{GLEICHENIA, Smith.}

\section{\$2. EUGLEICHENIA.}

(1) G. circinata, $S w$.

Omit this name, it shouid be G. microphylla $R$. Br.

(1) F. microphyllu, R. Ir., Hk., Spec. Fil., I, 3; G. circinata, auctt. plur. (not Sw.); - var. semivestita; G. semivestita, Lab., Hk., l. c., tab. II $A$.

Forma typica: Pinnae (ultimate branchlets) with the rachis (costa) naked or nearly so, soon glabrescent; leaflets flattened, with the edges slightly recurved.

Var. semivestite: Pinnae (ultimate branchlets) with the rachis (costa) provided beneath with dark or fusco-ferrugineous, deeply fimbriate (substellate) scales; leaflets slightly convex.

Malaya; Australia, Tasmania, New Caledonia, New Zealand.

(2a) G. dicarpa, $R$. Br.

Omit this species as being not Malayan.

\section{\& 3. MERTENSIA.}

(3a) A. opposita, v. A. v. A., in Bull. Btz., 1913, XI, 13.

Fronds forked; fork-branches slightly flexuose, $\pm 50 \mathrm{~cm}$. long, pinnate, forked at the apex. Pinnulae (including the apical fork-branches; secondary branches) only leafy, opposite or nearly so, linear-lanceolate, $\pm 20-25$ $\mathrm{cm}$. long, 2-5 cm. broad, narrowed towards the apex, deeply pinnatifid, 
straight or arcuate-ascending, the higher ascending, the lower rather horizontal, the lowest exterior deflexed, provided with a more or less rudimentary axillary bud, the others alternately so (i. $\theta$. each pair of pinnulae is provided with an alternately placed axillary bud). Lobes close, horizontal; linear, $\pm 4 \mathrm{~mm}$. broad, emarginate at the apex, entire, the higher growing gradually shorter, the $1-3$ lower more or less reduced, not rarely subsemiorbicular. Texture coriaceous; under surface glaucous, more or less deciduously ferrugineo-flocculent on the costae and costulae; veins forked, with the anterior veinlets forked again.

\section{Sumatra.}

(3b) C. Elmeri, Copel., in Leafl., III, 799.

Rachis wide-scadent, stout. Pinnae sessile, nearly $1 \mathrm{~m}$. apart, $\pm 1 \frac{1}{2}$ m. long, decurved, the rachis nearly naked, castaneous, glossy. Pinnulae $25 \mathrm{~cm}$. more or less long, short-stalked, foliaceous, acuminate, the lowest stipule-like. Lobes remote, linear, straight or curved, entire or rarely crenate, connected by a narrow wing, the lower somewhat reduced. Texture coriaceous; under surface more or less cobwebby with pale, deeply fimbriate scales resembling copiously branched hairs. Sori occupying nearly the whole under surface of the lobes, consisting of $4-7$ sporangia.

Mindanao.

(3c) C. conversa, *. A. v. R., in Bull. Btz., 1915, XX, 17.

Stipes stout. Fronds forked, the axillary buds flanked by pinnatifid stipules and provided with long, linear-subulate, brown or pale-brown scales with black or black-brown ciliated edges. Primary branches to 150 $\mathrm{cm}$. or more long, pinnate. Pinnulae more or less horizontal, remote, alternate, shortly petiolulate, to $25 \mathrm{~cm}$. long by $\pm 3-4 \mathrm{~cm}$. broad at the base, acuminate, deeply pinnatifid. Lobes more or less horizontal, approximate, up to $3-4 \mathrm{~mm}$. broad, entire or nearly so, rounded at the apex. Texture coriaceous; rachises, costae and costulae soon naked, when young the rachises scaly like the axillary buds but the scales smaller, intermixed with black or black-brown tomentum, the costae and costulae provided sparingly beneath with brown or black-brown, deeply fimbriate squamules. Sori consisting of $\pm 3-4$ capsules.

Java.

(4a) C. glauca, mk., Spec. Fil., I, tab. III B; G. longissima, Bl.; G. japonica, Spr., Copel., in Philipp. Journ, IV ${ }^{\mathrm{C}}, 26$.

Ferns and Fern Allies. 
Axillary buds with a tuft of foliaceous stipules (bracts) and clothed densely with lanceolate-subulate, black or black-brown scales with brown or pale-brown ciliated edges; pinnulae more or less horizontal, sessile or nearly so, deeply pinnatifid; lobes more or less horizontal, approximate, typically long and narrow, flattened, obtuse, the lowest not reduced, sometimes more or less deeply incised, the edges not or narrowly recurved, entire, or crenulate to serrulate towards the apex, without or with a slightly elevated line at the base; texture herbaceous to subcoriaceous; rachises, costae, costulae and veins naked or somewhat beset with tawny, wool-like scales or hairs especially beneath.

( $\left.4 a^{*}\right)$ G. sordida, Copel., in Leafl., III, 798.

Rachises and the lower part of the costae densely clothed with small, dirty-eastaneous scales. Pinnulae stalked, hardly $20 \mathrm{~cm}$. long, $3 \mathrm{~cm}$. broad, acute, with the lobes approximate, entire, the lower whether or not reduced. Texture coriaceous; surfaces naked; under surface palish but not glaucous; veins forked. - Near G. glauca $H k$.

Mindanao.

(4b) G. gigantea, Wall.

Omit this species here. See No. $5 a$.

(4c) C. Laevissima, Christ, Copel., in Philipp. Journ., IVC, 25, tab. XIV.

Stipes stout, up to $60 \mathrm{~cm}$. long, scaly and verrucose at the base, otherwise smooth. Fronds forked, the axillary bud with stramineous, scarious scales. Branches ascending, 40-60 cm. long, pinnate. Pinnulae alternate, erecto-patent, short-stalked, up to $17 \mathrm{~cm}$. or more long, acuminate; segments (lobes or leaflets) erecto-patent, up to $\pm 1^{3 / 4} \mathrm{~cm}$. long, $1 \frac{1}{2}-2 \mathrm{~mm}$. broad, entire, bullate, subacute, the lowest not reduced. Texture coriaceous; rachises naked, stramineous or brown; surfaces naked; under surface not glaucous. Sori of $3-5$ capsules, almost covering the under surface of the segments.

Luzon; China.

(5) G. arachnoidea, Mett.

Omit this name, it should be G. volubilis Jungh. 
(5) C. volubilis, Jungh., Reis. Jav., 452; G. bullata, Moore, Ind. 374 ; C. Chr., Ind. Fil., Suppl.; G. arachnoidea, Mett.

Like $G$. glauca $H k$. but the segments more rigidly coriaceous, bullate by the strongly recurved edges, clothed beneath like the rachises and costae with more or less persistent, dense, ferrugineous, woolly tomentum intermixed with deciduous, brown to black-brown squamules with pale ciliated margins.

(5a) C. gigantea, Wall., Hk., Spec. Fil., I, tab. III $A$; G. glauca, Hk., var., C. Chr., Ind. Fil.

Near G. glauca $H k$. but the segments typically, though not invariably, short and broad, with an elevated base so as to form an interrupted raised line on each side of the costae, on the upper side; rachises, costae and costulae densely scaly at least below, the scales lanceolate, partly entire, partly erose, partly ciliate, pale-brown or pale-ochraceous, intermixed with woolly tomentum of the same colour.

(7) C. Inearis, Clarke; G. dichotoma, Hk., Rac., Flor. Btz., I, 13; Bedd. Ferns S. I., tab. LXXIV; G. Hermanni, R. Br., Bl., Enum., 248 (incl. var. tenera, Bl., 1. c., 249); Mertensia dichotoma, Willd., Schk., Krypt. Gew., I, tab. 148; Polypodium lineare, Burm. (oldest name); - var. malayana, Christ, in Ann. Btz., XV, 77; - var. tetraphylla, Rst., in Fed., Rep., XII, 213; - var. alternans, Mett., in Ann. Mus. Bot. L. B., I, 51, tab. III; - var. irregularis, v. A. v. R., ; - var. inaequalis, Rst., 1. c., 212; - var. normalis, Bl., l. c., 249; - var. rigida, Bl., 1. c., 249; G. rigida, J. Sm., in Journ. of Bot., III, 420; G. crassifolia, Copel., in Philipp. Journ., IVc, 25; C. Chr., Ind. Fil., Suppl.; M. crassitolia, Pr., Epim., 23, tab. XIII; - var. venosa \& var. pubigera, Bl., 1. c., 249; - var. emarginata, Christ, l. c. ; 一 var. ferruginea, Rac., 1. c.; G. ferruginea, Bl., 1. c., 249.

Fronds commonly large and about 3-4 times forked, each forking bearing a pair of deflexed, unbranched, stipule-like accessory branches at the base, on the outer side; geminate terminal branches mostly without accessory branches; ultimate (accessory and terminal geminate) branches foliaceous, generally long-elliptical or linear-lanceolate, commonly deeply pinnatipartite with often very numerous more or less horizontally spreading segments on each side. - Exceedingly variable, with forms united by intermediates which often are very difficult of determination. 
1. Fronds membranaceous to subcoriaceous, not rigid.

* Under surface not glaucous or pruinose, and if so, then greenish or bluish.

Forma typica: Ultimate segments subcoriaceous, under $4 \mathrm{~cm}$. long, entire, or emarginate at the apex; under surface naked or provided with deciduous, more or less crisped hairs on the costulae and veins.

Forma tenera: Ultimate segments membranaceous.

Var. malayana: Very large, with the branches much elongated; ultimate segments $4 \mathrm{~cm}$. or more long.

* Under surface glaucous or pruinose, purplish.

Var. tetraphylla: Accessory and geminate branches nearly equal, relatively short and broad, to $12 \mathrm{~cm}$. long by $7 \mathrm{~cm}$. broad.

1.1. Fronds chartaceous or coriaceous, not rarely rigid.

2. Fronds very irregularly dichotomous.

Var. altermans: Branches with the internodations geniculate or flexuose and bearing at or near the nodes alternate, simply pinnatifid branches and opposite or subopposite to these a branch provided with an axillary bud and not rarely elongated and grown out again to an irregularly dichotomous branch; costae not acutely 2-marginate above; ultimate segments chartaceous or subchartaceous, beneath glaucous or pruinose, and deciduously ferrugineo-pilose on the costulae.

Var. irregularis: Like var. alternans but the ultimate segments beneath not glaucous, copiously, though deciduously, provided with crisped, ferrugineous hairs on the costulae and veins.

Var. imaequalis: Like var. alternans but with one of each pair of fork-branches often oppressed and the accessory branches wanting or rudimentary; costae acutely 2-marginate above; ultimate segments beneath densely ferrugineo-tomentose.

2.2. Fronds regularly dichotomous.

3. Uttimate segments distinctly glaucous or pruinose beneath.

Var. normalis: Fronds chartaceous, beneath naked or sparingly tomentose.

3.3. Ultimate segments not distinctly glaucous or pruinose beneath.

4. Veins beneath not sulcate (impressed) neither dark-coloured; under surface soon naked.

Var. rigiala: Fronds rather small, up to $40 \mathrm{~cm}$. each way, once to thrice forked; ultimate segments oblong or linear-oblong, obtuse, subbullate, very hard and rigid; veins indistinct or somewhat prominent beneath. 
4.4. Veins beneath sulcate (impressed) or often dark-coloured, or the under surface not soon naked.

5. Under surface naked.

Var. vemosa: Near var. rigida but the ultimate segments proportionally longer, linear, fragile when dry, reddish in aspect, the veins beneath impressed or often dark-coloured.

5.5. Under surface more or less persistently scaly, hairy or tomentose at least on the costulae.

Var. pubigera: Like var. venosa but larger, the ultimate segments often less rigid, not reddish, deciduously ferrugineo-tomentose on the costulae beneath.

Var. emarginata: Ultimate segments very rigid, copiously ferrugineo-villose beneath.

Var. ferruginea: Ultimate segments coriaceous, not rigid, densely ferrugineo-tomentose beneath.

(7a) G. Iaevissima, Christ.

Omit this species here. See No. $4 c$.

(8) C. Iaevigata, Hk.; - var, bracteata, Rst., in Fed., Rep., V, $370 ; G$. bracteata, Bl., in Herb. Hook.

Axillary buds sometimes with some small, congested, green bracts.

Var. bracteata: Axillary buds distinctly pectinato-bracteate.

(9) C. deennica, Kuhn.

Fronds up to $2 \mathrm{~m}$. high, several times dichotomous at an acute angle; axes deeply pinnatifid, the lowest whether or not nudate. Ultimate branches $10 \mathrm{~cm}$. or more long. Lobes close, standing at a subacute angle, to $2 \frac{1}{2} \mathrm{~mm}$. broad, those toward the apex of the ultimate branches abruptly reduced. Texture subcoriaceous; under surface glaucous; rachises clothed with ferrugineous, fimbriate squamules.

Celebes (?); Polynesia.

(12) C. hirta, Bt; G. amboinensis, v. A. v. R.; G. dolosa, Copel.; Dicranopteris dolosa, Copel., in Perk., Fragm. Philipp., 193, tab. IV C.

(12a) G. ornamentalis, Rst., in Nov. Guin., VIII, Bot., 715.

Fronds dichotomous, the stipe and primary branches black-brown, scaly, the scales ferrugineous, partly moderately large, lanceolate, fimbriate- 
ciliate, rather deciduous, partly minute, flocculoso-tomentose (wool-like), rather persistent. Primary branches $3-4 \times$ forked; lowest internodations 2-3 cm. long, secondary ones brown, the following foliaceous, cut down nearly to the costa, the terminal ones linear-lanceolate, $\pm 20-25$ cm. long, 2-2 $\frac{1}{2} \mathrm{~cm}$. broad, acuminate. Ultimate segments nearly horizontal, $\pm 1 \frac{1}{2}-2 \mathrm{~mm}$. broad, bluntish, crenate-dentate at or towards the apex, dilated and confluent at the base. Texture thinly chartaceous; costae scaly beneath, the scales similar to those of the lower branches but more persistent, the largest spreading, in 2 opposite rows; under surface deciduously flocculent on the costulae and veins, at length often naked; veins forked. Sori medial; sporangia 3-4.

New Guinea.

(13) C. hispida, Mett.

Also in Luzon.

(14) C. vestita, $\boldsymbol{B l}$.

The scales of the rachises often placed in 2 opposite spreading rows, those of the costulae often soon caducous.

(16) G. amboinensis, $v . A . v . R$.

Omit this species, it being an abnormal form of $G$. hirta $B l$.

(17) G. dolosa, Copel. (not C. Chr.)

Omit this species, it being an abnormal form of $\mathrm{G}$. hirta $\mathrm{Bl}$.

Species of an uncertain systematical place.

(18) C. bolanica, Rst., in Fed., Rep., XII, 162.

Fronds pinnate in the upper part, the rachis and costae provided beneath with scattered, ovate or lanceolate, shortly acuminate, ciliolate scales. Pinnae opposite, 4 times forked, on stalks $\pm 2 \mathrm{~cm}$. long, the internodations $\pm 1 \frac{1}{2} \mathrm{~cm}$. long, the lowest nudate, the others deeply pinnatifid, the ultimate branches linear, $\pm 12 \mathrm{~cm}$. long by $7 \mathrm{~mm}$. broad, narrowed gradually towards the apex. Lobes deltoid, $\pm 3 \mathrm{~mm}$, each way. Texture coriaceous; upper surface naked, lower sparingly scaly on the veins; veins \pm 4 on a side, forked. Sori consisting of $3-5$ capsules. New Guinea. 


\section{HYMENOPHYLLAOEAE.}

\section{HYMENOPMYLLUM, Smith.}

\section{§ 1. EUHYMENOPHYLLUM.}

(1) H. discosum, Christ.

Omit this, it is a form of $\mathrm{H}$. paniculiflorum $\mathrm{Pr}$.

(1a) FH. angulosum, Christ, in Philipp. Journ., IIIC, 269.

Rhizome filiform, creeping, caespitose, black, naked like the whole plant. Stipes straight, slender, ebeneous, unwinged, $1 / 2-3 \mathrm{~cm}$. long. Barren fronds subflabellate, $\pm 3 \mathrm{~cm}$. each way, 3-pinnatifid at the base, the upper part 2-pinnatifid, the main rachis black, narrowly winged in the upper part; pinnae 3-4 on each side, cuneate-flabellate, the lowest 6-partite, the higher 3-partite; ultimate laciniae $\pm 4 \mathrm{~mm}$. long, $\pm 1 \frac{1}{2}$ mm. broad, linear, obtuse. Fertile fronds ovate-oblong, narrowed at the base, $\pm 7 \frac{1}{2} \mathrm{~cm}$. long, $\pm 3 \mathrm{~cm}$. broad, sub-3-pinnatifid; pinnae in \pm 7 pairs, soriferous towards the apex. Texture thin; colour pale-browngreen; veins black. Sori terminal on the laciniae, roundly ovate; valves of the indusium crenate-denticulate.

Mindoro.

(3) H. eximium, Kae.

Also in Luzon, Mindoro, Negros.

(3a) H. penangianum, Matt. Christ, in Journ. of Linn. Soc., Bot., XXXIX, 214.

Rhizome filiform, creeping; short-tomentose. Stipes scattered but subcaespitose, black, filiform, rigidly pubescent, $\pm 2 \mathrm{~cm}$. long. Fronds ovate-oblong, narrowed at the base, up to $7 \mathrm{~cm}$. long, $2 \mathrm{~cm}$. broad, the rachis winged in the upper half. Pinnae alternate, erecto-patent, $6-8$ on each side, the lower distant, the largest to $2 \mathrm{~cm}$. long, $9 \mathrm{~mm}$. broad, 
oblong, cut down to a winged rachis. Pinnulae \pm 3 on each side, the lower 2-3-fid. Ultimate segments obtuse, 2-3 $\mathrm{mm}$. long, $\mathbf{3} / \mathbf{4}-1 \mathrm{~mm}$. broad, entire. Texture thin, hyaline; colour olive-green; veins conspicuous, black. Sori on the anterior side of the pinnae, often axillary, rarely terminal on the higher lobes; indusium dark-olivaceous; valves distinct, semiovate, subentire; receptacle stout, exserted.

Penang.

( $3 b$ ?) H. semifissum, Copel., in Philipp. Journ., $X^{\mathrm{C}}, 145$.

Rhizome very slender, wide-creeping, minutely and sparingly pilose. Stipes remote, filiform, $1-3 \mathrm{~cm}$. long, very minutely and sparingly pilose, as is the rachis. Fronds ovate, $6-8 \mathrm{~cm}$. long, 2-3-pinnatifid, the rachis narrowly winged in the upper part. Pinnae oblong, the larger 2-pinnatifid, with a few entire laciniae to $6 \mathrm{~mm}$. long and $3 / \mathrm{mm}$. broad, with the apex blunt or rarely emarginate. Colour fuscous; surfaces naked; veins black. Sori terminal on the first anterior or the next following laciniae; indusium divided about 1/2-way down, the valves subacute, entire; receptacle long, black.

Borneo.

(6) H. australe, Willd.; $H$. crispum, Nees \& Bl., Nova Acta, XI, tab. XIV, fig. 1 A, a-e; - var. atrovirens;? H. javanicum, Spr., var. complanata, Rst., in Bull. Btz., 1911, II, 22.

(7) H. demissum, Sw.

This species is construed as including 2 forms: H. demissum $S w$. and H. productum Kze.

(7a) I. demissum, Sw.; Schk., Krypt. Gew., I, tab. 135 c; ? H. productum, Kz., var. integriloba, Rst., in Bull. Btz., 1911, II, 22.

Indusium roundish or broadly ovate, entire.

Borneo (?); New Zealand, Polynesia.

(7b) I. productum, Kae; V. D. B., Hym. Jav., tab. XLV; H. demissum, Sw., var., C. Chr., Ind. Fil.

Indusium elongate-ovate, the outer edge denticulate.

Malaya.

(10) H. paniculiflorum, Pr.; $H$. discosum, Christ, in Bull. Herb. Boiss., XI, 140. 
(11a) H. pilosum, v. A. v. R., in Bull. Btz., 1914, XVI, 57; var. nirmalanum, v. A. v. R., 1915, XX, 19.

Rhizome wide-creeping, filiform, sparingly long-hairy, glabrescent, the hairs ferrugineous. Stipes scattered, $1-2 \mathrm{~cm}$. long, copiously hairy on the dorsal side, as are the rachis, costae, costulae and central veins of the ultimate lancinulae, winged, the hairs partly crowded, partly scattered, erect or spreading, long, ferrugineous, curved or flexuose, the wing narrowly linear-cuneate. Fronds lanceolate-oblong, $\pm 3-8 \mathrm{~cm}$. long, \pm $2-2 \%$ cm. broad, 2-pinnatifid, the rachis winged. Pinnae ascending, close, $\pm 8-10$ on a side, the central the largest, to $1 \frac{1}{2} \mathrm{~cm}$. long, pinnatifid into $2-5$ ascending, close, simple or rarely 2 -fid segments on a side; wings and lacinulae flat, the latter oblong or linear, $1-4 \mathrm{~mm}$. long by $\pm 1 \mathrm{~mm}$. broad, rounded at the apex. Texture membranaceous; surfaces naked; colour brown when dry; ultimate veins not reaching the apex of the lacinulae. Sori solitary and axillary on the higher pinnae; indusium oblong, 2-valved about $1 / 2$-way down, hairy on the lower side at the base; valves rounded or subacute, entire or somewhat crenulate; receptacle somewhat exserted.

Forma typica. - Sumatra.

Var. nirmalanum: Fronds relatively shorter and broader, 士 $21 / 2-31 / 2 \mathrm{em}$. long, $\pm 1 \frac{1}{2}-21 / 2 \mathrm{~cm}$. broad, oblong or ovate; pinnae less numerous. - Java.

(12a) See No. 13.

\section{(13) H. salakense, Rac.}

Edges of wings and segments not rarely distinctly crisped; indusia entire to repando-crenulate.

Also in Borneo.

(13a) H. Mallierii, Rst., in Bull. Btz., 1911, II, 23.

Rhizome rather firm, woody, creeping, glabrescent. Stipes distant, to $5 \mathrm{~cm}$. long, distinctly winged nearly quite to the base. Fronds lanceolateoblong, $\pm 12 \mathrm{~cm}$. long, $3 \mathrm{~cm}$. broad, long-acuminate. Largest pinnae ovate-lanceolate, suberect, to $3 \mathrm{~cm}$. long, $1 \frac{1}{2} \mathrm{~cm}$. broad, incurved at the apex. Lower pinnulae spreading or somewhat decurved, flabellately 2-pinnatifid. Ultimate segments linear, rounded and emarginate at the apex. Surfaces naked; colour dark-olivaceous; rachises subflexuose, broadly 
winged, naked; veins rather stout, not reaching the apices of the segments. Sori on abbreviated segments; indusium subcylindrical, conical at the base, broadly winged, 2-valved ${ }^{1}{ }_{3}$-way down, the valves triangular-ovate, acute; receptacle exserted, incurved.

(14) H. Blumeanum, Spr.

This species is construed as including two distinct forms: H. Blumeanum $S p r$, and H. pycnocarpum $V . D . B$.

(14a) H. Blumeanum, spr.g C. Chr., Ind. Fil.; - var. novoguineensis, Rst., in Fed., Rep., V, 371.

Sori on non-abbreviated lacinulae.

Var. novoguineensis: Fronds 3-4-pinnatifid, to $70 \mathrm{~cm}$. or more long by $\pm 6-10 \mathrm{~cm}$. broad; pinnae often conspicuously elongated, to more than $30 \mathrm{~cm}$. long, segments deeply emarginate at the apex; indusium more acute. - New Guinea.

(14b) 11. pyenocarpum, . D. $\boldsymbol{\text { H.; }}$ C. Chr., Ind. Fil., Suppl.; H. subdemissum, Christ, in Bull. Herb. Boiss., VI, 140.

Sori on abbreviated lacinulae.

(14c) See No 7.

(15) H. Treubii, Rac.; - var. novoguineensis, Rst., in Fed., Rep., XII, 526.

Forma typica. - Also in Amboina.

Var. novoguineensis: Fronds $6-7 \mathrm{~cm}$. long, more copiously . laciniated, the laciniae shorter. - New Guinea.

(17) H. formosum, Brack.; $H$. dilatatum, Sw.; Schk., Krypt. Gew., I, tab. 135.

17a) H. Emmlerianum. Rst., in Fed., Rep., X, 323.

Rhizome creeping, filiform, sparingly pilose. Stipes to $7 \mathrm{~cm}$. long, firm, livid, straight or subflexuose, winged throughout, naked. Fronds ovate, 3-pinnate, to $\pm 20 \mathrm{~cm}$. long, $6-7 \mathrm{~cm}$. broad, long-acuminate; rachises winged, the wings crisped. Pinnae sessile, erecto-patent, oval, imbricate, to $5 \mathrm{~cm}$. long, $1 / 1 / 2-2 \mathrm{~cm}$. broad, obtuse to acuminate; upper 
base truncate, lower cuneate. Pinnulae crowded, rhomboid-oblong, cut down into simple or 2 -fid, cuneate segments, the ultimate lobes obtuse or somewhat emarginate at the apex. Texture elastic; rachises and surfaces naked; colour yellowish-green; veins 1 in each ultimate lobe, fuscous. Sori confined to the upper part of the frond, placed on much abbreviated lobes; indusium 2-valved quite to the base; valwes round or somewhat dilated, entire or slightly wavy, nearly $1 \frac{1}{2} \mathrm{~mm}$. broad.

New Guinea.

\section{(18) H. Dumghunii, $\boldsymbol{V} . \boldsymbol{D} . \boldsymbol{B}$.}

Forma typica: Wings of the principal rachises flat.

Forma crispato-alata: Wings of the principal rachises crisped.

Also in Luzon, Mindanao, Negros.

(18a) See No. 14.

(18b) U. pantotactum, v. A. v. R., in Bull. Btz., 1912, VII, 20.

Like H. Blumeanum Spr but the fronds larger, $\pm 15-20 \mathrm{~cm}$. long, $\pm 5-20 \mathrm{~cm}$. broad, the narrowest form lanceolate, mostly broadest at the middle, the broadest form deltoid, broadest at the base, the pinnae erecto-patent to horizontal; sori occupying the higher regions of all the pinnae in the fully developed plants, the indusia deeply 2-valved, the valves oblong, ovate or obovate, narrowed, rounded or truncate and generally irregularly crenate or emarginate at the apex; receptacle linear, not exserted.

Java.

(18c) II. Iongifolium, v. A. v. $\boldsymbol{R}$., in Bull. Btz., 1914, XVI, 17.

Rhizome creeping, slender, wiry, sparingly long-hairy. Stipes scattered, $\pm 3-4 \mathrm{~cm}$. long, naked, winged at least in the upper half. Fronds broadly linear, $\pm 40-50 \mathrm{~cm}$. long, $\pm 8-9 \mathrm{~cm}$. broad, narrowed at the base, the rachis broadly winged. Pinnae numerous, close, spreading, arcuate-ascending, triangular-lanceolate, the largest to $\pm 5 \mathrm{~cm}$. long, to $\pm 2 \% \mathrm{~cm}$. broad at the obliquely truncate-cuneate base, the rachis broadly winged. Segments to \pm 7 on a side below the somewhat elongated terminal one, the higher simple or forked, the lowest anterior the largest, triangular-oblong, to $1 \frac{1}{2} \mathrm{~cm}$. long, to $1 \mathrm{~cm}$. broad, the base 1-2-pinnatifid on the posterior side, 2-4-pinnatifid on the anterior side. 
Ultimate segments $\pm 13 / 4-2 \mathrm{~mm}$. broad, blunt, emarginate at the apex. Texture thin; surfaces naked; a single central vein in each ultimate segment, not reaching the apex. Sori terminal on the ultimate segments which are narrowed a little below the sorus; indusium 2-valved; valves round or suboblong, to $2 \mathrm{~mm}$. broad when ripe, entire or nearly so; receptacle short, included.

Celebes.

(19) Wollingeri, Kze.

Forma minor, Rst., in Bull. Btz., 1911, II, 22 : Fronds smaller, not elongated at the apex. - Borneo.

$(20 \alpha)$ 1. Ia minatum, Copel., in Philipp. Journ., VIC, 70.

Rhizome creeping, clothed with purpureous pubescence. Stipes \pm $4-5 \mathrm{~cm}$. long, upwards pubescent. Fronds lanceolate, $\pm 15 \mathrm{~cm}$. long, $2 \frac{1}{2}-3 \frac{1}{2} \mathrm{~cm}$. broad, the rachis narrowly $2-4$-winged. Pinnae lanceolate, acute, the lower short-stalked, eut down nearly to the costa; segments oblanceolate or obovate, slightly incised and serrulated at the apex. Texture thinly coriaceous; colour rufous; central ribs broadly crested, the crests undulated. Sori placed near the rachis; indusium crested at the base, the mouth 2 -fid, the valves denticulated.

New Guinea.

(21a) See No $23 b$.

(23a) I. batuense, Rst., in Bull. Btz., 1911, II, 22.

Rhizome slender, hairy, creeping. Stipes $\pm 1-1 / 2 \mathrm{~cm}$. long, slender, terete, brown-hairy, very narrowly winged towards the frond. Fronds linear or lanceolate-oblong, olive-green, $\pm 6 \mathrm{~cm}$. long and $2 \mathrm{~cm}$. broad, the main rachis very narrowly winged towards the base, more broadly so towards the apex. Pinnae suberect, linear-oblong, subcontiguous, pinnatifid, the higher simple or forked, the largest nearly $2 \mathrm{~cm}$. long, $\pm 7 \mathrm{~mm}$. broad. Segments linear, subparallel, to $5 \mathrm{~mm}$. long, $\pm 1 \mathrm{~mm}$. broad, entire, retuse at the apex, simple, or the lower forked. Rachis and costae fusco-pilose beneath; veins evanishing towards the apex. Sori terminal on the lower segments; indusium elongate-oblong, conical, and naked or rarely appendiculate or indistinctly crested at the base, narrowly marginate in the lower half, 2 -valved about $1 / 2$-way down, the valves 
elongate-triangular, entire or minutely crenulate at the apex; receptacle at length exserted, firm.

Baíu.

(23b) H. taliabense, v. A. v. R., in Bull., Btz., 1914, XVI, 18.

Rhizome slender, creeping, hairy, soon naked. Stipes $\pm 1-11 \frac{1}{2} \mathrm{~cm}$. long; slender, terete, pale-brown-hairy, winged towards the frond. Fronds linear-oblong or lanceolate-oblong, to $\pm 7 \mathrm{~cm}$. long and $3 \mathrm{~cm}$. broad in the fully developed plant, the main rachis winged. Pinnae erecto-patent, oblong or linear-oblong, rather contiguous, pinnatifid, the higher simple or forked, the largest to $\pm 1_{1}^{1} \mathrm{~cm}$. long and $1 \mathrm{~cm}$. broad. Segments contiguous, forked or the higher simple; ultimate segments linear, ${ }^{1} !_{2}-{ }_{1}^{3}$ is cm. long, 1-1 1/2 mm. broad, entire, rounded at the apex. Rachis, costae and veins hairy, the hairs pale-brown, rather long, crisped, those of the main rachis rather crowded, of the veins often scattered; veins distinct. Sori axillary; indusium elongate, 2-valved 1/2-way down, obconical and narrowly winged in the lower half, hairy on the lower side at the base, the hairs similar to those of the main rachis, the valves oblong, subacute or rounded, entire; receptacle exserted.

Taliabo.

\section{§ 2. LEPTOCIONIUM.}

\section{(25) H. subflabellatum, Ces.}

Also in Luzon.

(26) H. edulentum, v. A. v. R. (not C. Chr.).

Omit this name, it should be $\mathrm{H}$. edentulum $C$. Chr.

(26) F. edentulum, C. Chr., Ind. Fil.; Leptocionium edentulum, V. D. B., in Ned. Kruidk. Arch., $\mathrm{V}^{3}, 148 ;$ L. edulentum, v. A. v. R. (not $V . D . B$.$) .$

(26a) пI. Foersteri, rst., in Fed., Rep., XI, 165.

Rhizome creeping, filiofrm, clothed with ferrugineous hairs. Stipes 2-3 cm. apart, 1-2 cm. long, hirsute, narrowly margined upward. Fronds linear, $\pm 15 \mathrm{~cm}$. long by $1 \frac{1}{2} \mathrm{~cm}$. or more broad, shortly acuminate, 
the rachis flexuose, margined, like the costae and costulae densely ferrugineo-hirsute. Pinnae numerous, ascending, petiolulate, trapezoidoblong, 上 $15 \mathrm{~mm}$. long by $6-7 \mathrm{~mm}$. broad, obtuse, deeply incised into linear or cuneate, simple or 1-2-partite segments, the lower segments decurrent upon the petiole; lobules to $2-3 \mathrm{~mm}$. long by nearly $1 \mathrm{~mm}$. broad, toothed, acuminate from the base. Texture membranaceous; colour yellowish when dry; surfaces long-hairy, the hairs ferrugineous. Sori solitary in the axils of the pinnae; indusium obconical, 2valved to $1 / 3 \ldots 1 / 2$-way down, densely hirsute, the valves rounded, long-ciliate.

New Guinea.

(27a) H. Elberti, Rst., in Med. R. H. L., 1912, 14, 31.

Rhizome creeping, filiform, sparingly hairy. Stipes filiform, $\pm 21 / 2-3$ cm. long, brown, sparingly hairy. Fronds elongate-oblong, $\pm 5-6 \mathrm{~cm}$. long, $1 \frac{1}{2}-2 \% \mathrm{~cm}$. broad, 2-pinnatifid, obtuse, somewhat narrowed at the base, the rachis very narrowly winged, provided with short, scattered, yellowish hairs, as are the costae and costulae. Pinnae trapezoid-oblong, deeply pinnatifid. Segments linear, simple or the lowest 2-fid, obtuse, acutely toothed. Texture membranaceous; colnur brown when dry. Sori terminal on slightly narrowed segments, in the uppermost part of the frond; indusium obconical at the base, 2-valved, the valves subtriangular, obtuse, entire; receptacle exserted.

Lombok.

(28) W. Lobloii, Moore; - var. minor, Rst., in Bull. Btz., 1911, II, 24.

Var. minor: Fronds $1-1 \frac{1}{2} \mathrm{~cm}$. long, with the laciniae very narrow. - Borneo.

(30) ㅍ. holoehilmu, C. Chr.; - var. subgenuinum, v. A. v. R., in Bull. Btz., 1915, XX, 19; - var. affine; Didymoglossum affine, V. D. B., in Pl. Jungh., 561; H. Boschii, Rst., in Bull. Btz., 1911, II, 24; - var. euryglossum, Rst., 1. c.

Forma typica: Ultimate segments $\pm 1-2 \mathrm{~mm}$. broad; valves of the indusium triangular or oblong, entire or slightly repand, acute or rounded at the apex; receptacle short-filiform, included. - Malaya.

Vur. subgenuimum: Valves of the indusium triangular, entire, 
8. HYMENOPHYLLUM. \$ 2. LEPTOCIONIUM.

crenulate or subserrulate, acute at the point; receptacle long-filiform, exserted. - Java.

Var. afine: Valves of the indusium broad, rounded, toothed; receptacle long-filiform, exserted. - Java.

Var. euryglossum: Valves of the indusium broad, entire; receptacle long-filiform, exserted. - Borneo, Sumatra.

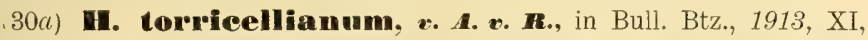
14, H. polyanthos, Christ (not Sw.), in Schum. \& Laut., Flor. deut. Sch.geb., Suppl., 35.

Rhizome slender, subfiliform, clothed with more or less deciduous, adpressed, pale-ferrugineous hairs. Stipes scattered, slender, $3-6 \mathrm{~cm}$. long, narrowly marginate or winged, more or less deciduously hairy with long, ferrugineous hairs, as are the rachises beneath. Fronds linearlanceolate or triangular-ovate, $\pm 71 / 2-15 \mathrm{~cm}$. long, $\pm 5-7{ }_{2} \mathrm{~cm}$. broad, acuminate, 3-4-pinnate at a base, the rachises winged, the wings entire. Pinnae 10-20 pair, approximate, erecto-patent, or the lower spreading or horizontal, the higher short, tooth-like and simple or sparingly divided, the lower to $\pm 4 \frac{1}{2} \mathrm{~cm}$. long, to $1 \frac{1}{2} \mathrm{~cm}$. broad, copiously pinnate; pinnulae cut down into few to several simple or 2-3-fid, blunt, acutely serrate segments $\pm 1 / 2-3 / 4 \mathrm{~mm}$. broad. Sori moderately large, solitary and axillary on the higher pinnae; indusium cuneate-oblong, 2-valved $1 / 2$-way down, the base obconical, sparingly and longitudinally crested on the outer side, the valves oblong, rounded, entire or nearly so; receptacle long-filiform, exserted.

New Guinea.

(30b) See No. 35.

(30c?) H. rubellum, Rst., in Nov. Guin., VIII, Bot., 716.

Rhizome slender, wiry, sparingly hairy, the hairs pale-ferrugineous, subadpressed. Stipes scattered, slender, wiry, black-brown, $\pm 4-6 \mathrm{~cm}$. long, naked. Fronds deltoid, $\pm 10-12 \mathrm{~cm}$. long, $8-10 \mathrm{~cm}$. broad, 3-4-pinnate at the base, long-acuminate, the rachises more or less narrowly winged, sparingly ferrugineo-pilose, the wings entire. Pinnae \pm 15 pair, approximate, alternate, the highest simple, shortly and narrowly linear, the lowest compound, lanceolate-ovate or lanceolate, to $5 \mathrm{~cm}$. long and $2 \mathrm{~cm}$. broad. Lower pinnulae largest. Ultimate segments 
$\pm 2-3 \mathrm{~mm}$. long, nearly $1 / 2 \mathrm{~mm}$. broad, blunt, remotely acútely serrulate, or entire towards the base. Sori solitary and axillary on the higher pinnae; indusium somewhat ventricose, obconical at the base, narrowly marginate, 2 -valved $1 / 3$-way down, the valves triangular.

New Guinea.

(30d) vr. brevidens, v. A. v. r., in Bull. Btz., 1912, VII, 20.

Rhizome wide-creeping, wiry, clothed with long, crowded, deciduous, ferrugineous hairs. Stipes scattered, wiry, $\pm 7-10 \mathrm{~cm}$. long, deciduously long-hairy, 2-marginate towards the frond, the hairs ferrugineous. Fronds 4 -5-pinnate towards the base, ovate, $\pm 12 \mathrm{~cm}$. long, $9 \mathrm{~cm}$. broad, the rachises winged, and beneath hairy like the stipe, the wings entire. Pinnulae ovate or ovate-lanceolate, imbricate. Ultimate segments copious, to $2 \frac{1}{2} \mathrm{~mm}$. long; $\pm 1 / 2 \mathrm{~mm}$. broad, blunt at the apex, the edges hardly crisped, remotely and shortly serrulate. Texture firm-membranaceous; surfaces naked; a central vein in each ultimate segment. Sori on short lobes, occupying the anterior side of the pinnulae, near the base, at best 1 to a pinnule; indusium oblong, the lower half narrowly obconical, 2 marginate, longitudinally crested at the base, the upper half 2-valved, the lobes subtriangular-oblong, entire or obsoletely repand; receptacle included, columnar-filiform.

New Guinea.

(30e) H. geluense, Rst., in Fed., Rep., V, 372; - var. apiciflorum \& var. minor, Rst., 1. c., XII, 526.

Rhizome wide-creeping, hardly branched, rufous, $1 \mathrm{~mm}$. thick, densely clothed with rufous hairs. Stipes distant, $\pm 5-15 \mathrm{~cm}$. apart, rigid, terete, black-brown, elothed with brownish, interlaced hairs 2-3 mm. long. Fronds $20-30 \mathrm{~cm}$. long, either linear and $\pm 2-3 \mathrm{~cm}$. broad, or lanceolate and $\pm 8 \mathrm{~cm}$. broad at the base; narrowest fronds pinnate, with the pinnae alternate, numerous, erecto-patent, incurved at the apex, narrowly decurrent, rhomboidal-oblong, unequal-sided at the base, truncate or elongate-acuminate at the apex, $1 \frac{1}{2}-3 \mathrm{~cm}$. long, $\pm 1 \mathrm{~cm}$. broad, 2-3-pinnatifid, with the ultimate lobes narrowly linear, close, rather clustered and subparallel, with the edges flattened, acutely serrate, and the apex entire, narrowed; broadest fronds pinnate, with the lower pinnae to $10 \mathrm{~cm}$. long, 3-4 cm. broad, resembling the narrowest fronds, the other pinnae growing gradually smaller. Texture rigidly membran- 
aceous; colour brownish; rachis black-brown, elastic, hairy like the stipe, narrowly margined, the wing olive-brown, flat, entire, or toothed towards the apex; costae and veins stout, black-brown, brown-hairy, provided on both sides with binate, membranaceous, conspicuously serrate crests. Sori $1-4$ to a pinnula, axillary, placed on abbreviated anterior branchlets; indusium large, broadly tubular, 2-valved $\pm 1 / 2$-way down, narrowly marginate, crested, the valves rounded, entire or minutely denticulate; receptacle thick-setiform, exserted. - Resembles partly H. Zollingerianum Kze partly H. fuscum $V . D . B$.

Var. apiciflorum: Costal crests indistinct; lobes obscurely denticulate, sometimes subentire; sori occupying the narrowed apical part of the fronds only; indusium with the valves entire.

Var. minar: Stipes $\pm 3 \mathrm{~cm}$.long; fronds $\pm 4 \mathrm{~cm}$. long, \pm 3 cm. broad; costal crests indistinct or wanting; indusium conspicuously crested.

\section{New Guinea.}

(30f) See No 41.

(30g) Th. Subrotundenan, v. A. v. R., in Bull. Btz., 1915, XX, 19.

Rhizome filiform, naked or sparingly ferrugineo-pilose, as are the stipes and rachises. Stipes filiform, $\pm{ }^{3} / 4-3 \mathrm{~cm}$. long. Fronds oblong, $\pm 3-4 \mathrm{~cm}$. long, $\pm 1 \frac{1}{2}-2 \frac{1}{2} \mathrm{~cm}$. broad, 3-4-pinnatifid, the rachis narrowly winged in the upper half. Pinnae $\pm 8-10$ on a side, subhorizontal, close or approximate, often deeply pinnatifid on the upper side only, with the higher segments generally simple, the central and lower once or twice forked; higher pinnae long-decurrent and often connected, lower hardly decurrent, free. Ultimate segments $\pm 1_{1} / 2 \mathrm{~mm}$. broad, blunt, remotely serrate-dentate, each with a single central vein. Texture herbaceous; surfaces naked. Sori in the axils of the higher pinnae, exserted, 2-valved 1/2-way down, the base acute, provided with none to several short or elongated, irregularly placed, slightly elevated longitudinal ridges, the valves semiorbicular or nearly square, $\pm 1 \mathrm{~mm}$. broad, sharply toothed; receptacle hardly exserted.

\section{Sumatra.}

\section{(31) W. blandum, Rac.}

Sori subterminal on much abbreviated segments, on the anterior Ferns and Fern Aluies. 
side; indusium with the base acutely obconical and not rarely provided with a few hardly elevated, longitudinal crest-like ridges.

Also in Sumatra, Mindanao, Negros.

(31a) 댈. ovatum, Copet., in Philipp. Journ., VIC, 70.

Rhizome filiform, glabrescent. Stipes $\pm 1 \mathrm{~cm}$. long. Fronds ovate, $\pm 4 \mathrm{~cm}$. long and $3 \mathrm{~cm}$. broad, obtuse, the rachis blackish, winged towards the apex. Pinnae \pm 9 on a side, approximate to imbricate, sessile, rounded at the apex, the edge cut down nearly to the costa, the segments $1 \leftarrow 2$-lobed (1-2 times lobed?), approximate, the ultimate lobes $\pm 3 / 4 \mathrm{~mm}$. broad, obtuse, not crisped, sparingly serrated at the edge. Texture coriaceous; surfaces naked; colour brown. Indusium 2-valved more than $1 / 2$-way down, the valves broadly ovate, toothed in the upper part.

New Guinea.

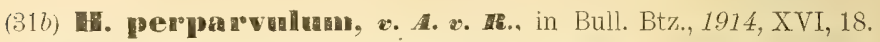

Rhizome filiform, brown-hairy, rather glabrescent. Stipes seattered, filiform, to $5 \mathrm{~mm}$. or sometimes to $1 \mathrm{~cm}$. long, naked or sparingly hairy, as are the rachis, costae and costulae. Fronds ovate or oblong, ${ }^{3} / 4-1_{4}{ }_{2}$ $\mathrm{cm}$. long, 3-7 mm. broad, the rachis winged in the upper part. Pinnae close, $3-5$ on a side, spreading to erecto-patent, the smallest simple or forked, the largest forked or sparingly pinnatifid on the anterior side, the segments simple or forked; lobules $\pm 1 \mathrm{~mm}$. broad, irregularly spinuloso-denticulate. Texture thin; surfaces naked; a central vein in each ultimate segment. Sori few, axillary, on the higher pinnae; indusium 2-valved 1/2-way down, the base obconical, the valves when young rather narrowly oblong, when adult rather semiorbicular, with the edge spinuloso-denticulate.

Sumatra.

(34) 대. multifidun, Sw.; - var. novoguineense, Rst., in Fed., Rep., XII, 166.

Var. movoguineense: Differs from the type in having the stipes stouter, punctato-rugulose, margined nearly quite to the base. New Guinea.

(35) HA⿱

Indusium obconical at the base, the valves subtriangular, bluntish at the apex (conf. Hooker's plate). 
- Plants received from the Phitippines, determined as H. serrulatum, have the main rachis more or less narrowly winged throughout, the rachises and veins hirsute with pale-ferrugineous hairs, the pinnae lanceolate. to ovate, the higher with a single axillary sorus, the indusia distinctly crested and deciduously hairy at the base, with the valves partly subtriangular partly rounded.

\section{H. Heeinwarditi, $\boldsymbol{W}, \boldsymbol{D} . \boldsymbol{B}$.}

Also in Borneo, Newo Guinea.

(37a M. Copelandiannm, v. A. v. R., in Bull. Btz., 1912, VII, 19; H. australe, Copel. (not .Willd.' in Leafl, III, 800.

Rhizome creeping, branched, naked. Stipes $\pm 4-6 \mathrm{~cm}$. long; winged, nudate at the base, the wing very conspicuously crisped. Fronds \pm 6-10 cm. long, $4-5 \mathrm{~cm}$. broad, firm-membranaceous, ovate-oblong, narrowed at the apex, 3-pinnatifid or sub-4-pinnatifid, fertile in the upper half, the wing of the main rachis very conspicuously crisped. Pinnae several, subcontiguous, partly erecto-patent partly spreading, cut down to a very conspicuously crisped wing into several similarly crisped pinnulae. Pinnulae pinnatifid, with the segments simple or forked. Ultimate segments narrow, $\pm{ }_{2} \mathrm{~mm}$. broad. Margins of the lobes and wings sparingly but positively, though shortly, toothed. Sori terminal on the lobes; indusium $1-1 \frac{1}{2} \mathrm{~mm}$. broad, deeply 2-valved; valves suborbicular, entire or minutely and irregularly repando-denticulate; receptacle stipitate-capitate (when ripe'. - H. Reinwardtii $V . \quad$. $B$. differs from this in having the margins less conspicuously crisped, more copiously denticulate and the receptacle thick, elongate-clavate.

Mindanao.

(38a) I. bismarckianum, Christ, in Schum. \& Laut., Flor. deut. Sch.geb., Suppl., 34; ? H. thuidium, Harr., C. Chr., Ind Fil., Suppl.). Rhizome wide-creeping, naked. Stipes scattered, to $\pm 10 \mathrm{~cm}$. or more long, naked, upper half winged, as are the rachises, the wings crisped, irregularly serrate-dentate. Fronds roundish-ovate, more than 10 cm. long when fully developed, 4-pinnate in the lower part. Ultimate segments $\pm 3 / 4-1 \mathrm{~mm}$. broad, more or less crisped, serrate. Texture thin; surfaces naked. Sori terminal on the ultimate. segments, small, 
roundish, somewhat broader than the segments when ripe; indusium entire, naked.

New Guinea.

(40) H. Neesii, Hk.

This species is construed as including 2 distinct forms: H. Neesii $H k$. and H. acanthoides Rst.

(40a) 11. Neesii, Hk.; H. tunbridgense, Bedd. (not Sm.), Ferns S. I., tab. CCLXV; H. denticulatum, Sw., var., C. Chr. Ind. Fil. V. D. B., Hymen. Jav., tab. XXX.

Teeth of laciniae and prickles of indusia short-triangular.

(40b) II. Incanthoides, Trst., in Bull. Btz., 1911, II, 25; H. aculeatum, Rac., var., C. Chr., Ind. Fil. - V. D. B., Hymen. Jav., tab. XXXII. Teeth of laciniae and prickles of indusia long-subulate.

(40c; See No. $30 f$.

(41) N. denticulatum, Sw.; - var. complanatum, Rst., in Bull. Btz., 1911, II, 25.

Colour when dry dirty-brown or brown-green, the edges of the wings and segments not rarely bounded by a band consisting of 1 or more rows of dark-walled cells; indusium provided on the outer side with fow to several short (punctiform) to longitudinally linear, often basal, scattered ridges terminating at the apex into a short and tooth-like or more elongated and filiform appendage.

Va 1. complamatum: Stipes often winged to the base; fronds often narrowed and elongated; ultimate lobes more distant, $1 / 3-1 / 2$ narrower, flattened, rarely crisped here and there. - Borneo.

(42) U. acaleatum, Rac.

Two forms:

Forma typica: Lips (valves) of the indusium subsemiorbicular.

Forma ucutivalvula: Lips (valves) of the indusium sharply triangular.

(43) H. bismarckianum, Christ.

Omit this species here. See No. $38 \alpha$. 
(43a) H. macrossrun, v. A. v. R., in Bull. Btz., 1914, XVI, 18.

Rhizome wide-creeping, filiform, deciduously long-hairy, the hairs ferrugineous. Stipes scattered, filiform, $\pm 1-4 \mathrm{~cm}$. long, deciduously hairy, winged in the upper half. Fronds oblong, $\pm 2-8 \mathrm{~cm}$. long, $1-2 \frac{1}{2}$ $\mathrm{cm}$. broad, 3-4-pinnate, the rachises winged. Pinnae erecto-patent, crowded, rather imbricated, to $2 \mathrm{~cm}$. long and $1 \mathrm{~cm}$. broad. Ultimate segments linear, $\pm 3 / 4-1 \mathrm{~mm}$. broad, and, like the wings, curved (crisped) and toothed at the edge, the teeth varying from short to long-subulate. Texture firm-membranaceous; surfaces naked; a single central vein in each ultimate segment. Sori large, $\pm 3-4 \mathrm{~mm}$. long, axillary, on the lowest anterior pinnulae in the smaller specimens, more copious in the larger ones; indusium divided nearly $1 / 2$-way down, the base obconical, provided with long-fimbriated appendages; valves semiorbicular, entire; receptacle exserted.

Sumatra.

\section{TRIOHUMANES, Linné.}

\section{§ 2. EUTRICHOMANES.}

(5a) T. mintorense, Christ, in Philipp. Journ., III , 270.

Rhizome slender, branched, intricate, clothed with minute, brown squamulae. Fronds close, numerous, densely caespitose, sessile, $\pm 1 \frac{1}{2}$ $\mathrm{cm}$. long, 2-3 mm. broad, either simple and narrowly lanceolate, obtuse, narrowed gradually at the base, or lobed at the sides and apex, the lobes $1-4$, roundly ovate, $\pm 1 \frac{1}{2} \mathrm{~mm}$. long, obtuse; margin bounded by a fine spurious vein. Texture thick, not diaphanous; colour opaque, brown-green; surfaces naked except at the base of the frond and purveyed there with brown setulae; costae distinct, black; veins oblique, black, 6-8 on each side, reaching the margin. Sori terminal, immersed, dilated, subreniform; receptacle sometimes long-exserted.

Mindoro.

(6a) 'T'. crespedomearam, Copet., in Philipp. Journ., VII, 53. Rhizome creeping, filiform. Stipes short or nearly wanting, hairy. Fronds, $1-1 / 2 \mathrm{~cm}$. long, oblanceolate, entire or sparingly lobed, narrowed at the base. Texture thin; surfaces hairy towards the base; costa 
pinnate; veins oblique; spurious veinlets rather distinct, connected at the apex by a rather distinct submarginal vein. Sori solitary and terminal on the fronds; indusium sunk in the frond, cylindrical, the mouth 2-lipped.

Luzon.

(9a) Thasense, Christ, in Philipp. Journ., IIIC, 270.

Rhizome filiform, intricate, provided with black bristles. Stipes approximate, capillary, black, $\pm 2 \mathrm{~cm}$. long. Fronds caespitose, linearlanceolate from a broad base, 3-4 cm. long, with 4-5 approximate pinnae on each side at the base. Pinnae cuneate-flabellate, $3-4 \mathrm{~cm}$. each way, deeply 2-pinnatisect, with the ultimate lobes hardly $1 \mathrm{~mm}$. broad, obtuse, with a single black costa in each; central part of the frond contracted, spicate, the rachis filiform, narrowly winged, with 10-12 alternate, stalked sori; indusium campanulate, narrowly marginate, the mouth dilated; receptacle exserted.

Mindoro.

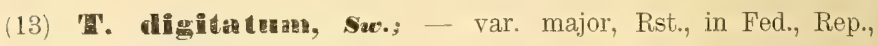
XII, 166.

War. major: Fronds \pm twice as large, $4-5 \mathrm{~cm}$. each way; lowest pinnae 4 times forked; lacinae $2 \mathrm{~mm}$. or more broad. - New Guines.

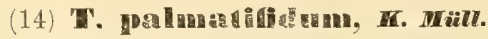

Also in Borneo.

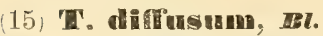

Also in Amboina.

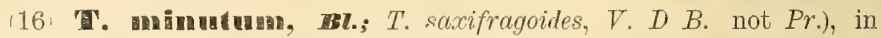
Ned. Kr Arch., IV, 353; Godd., in Med. R. H. L., 1913, 1\%, 20, fig. 10. Also in Negros, Amboina.

(20) T. parkelusm, Br.; V. D. B., Hymen. Jav., tab. VII-IX.

A form gathered in New Guinea differs from the type in having the lower part of the main rachis not winged, at best narrowly 2-marginate, and distinguished from the figures given by van den Bosch and Beddome 
in having the stipes longer, to $\pm 10 \mathrm{~cm}$. long and the pinnae more distant, and a form collected on Mount Apo (Mindanao) is similar to the latter except that the space between the margin and central rib is nearly enfirely filled up with dark-coloured cells, the pale interstice therefore reduced to a few pale patches only.

Forma typica (V. D. B., tab. VIII): Hairs of the fronds long, spreading, jointed; stripes of dark cells broad.

Var. albatan ( $T$. album, Bl., Enum., 226; V. D. B., tab. VII): Hairs of the fronds moderately short, erect, not jointed; stripes of dark cells broad.

Var. Gammii (V. D. B., tab. IX): Fronds naked or very sparingly long-hairy; stripes of dark cells narrow.

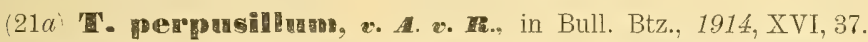

Caespitose. Fronds scattered, oblong, to $1 \mathrm{~cm}$. long, on stipes to $1 / 2 \mathrm{~cm}$. long, deeply pinnatifid, cuneate or decurrent at the base. Segments erecto-patent, linear, $1-4$ on each side below the terminal one, to $5 \mathrm{~mm}$. long, $\pm{ }_{4}$ broad, rather abruptly acute, bounded by an apparently marginal, pale, continuous spurious vein. Texture thin; surfaces naked; a pale central rib in each segment. Sori few, terminal on the higher segments; indusium funnel-shaped, winged, the base acute, the mouth dilated, spreading; receptacle exserted.

New Guinea.

\section{(22) 'W. Damulile, Forst.}

Malayan.

(23) 'T'. Hำด laxa, Rst., in Fed., Rep., V, 370.

Forma subbipunctata: Fronds lanceolate-ovate; valves of the indusium triangular, rather acute.

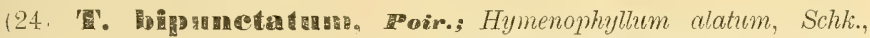
Krypt. Gew., I, tab. 135b; - var. venulosa, Rst., in Hedwi., LVI, 350.

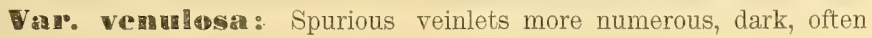
reticulate. - New Guined.

\section{(26 T'. capbillzatum, Tasch.}

Also in Luzon. 
(27a) T. Hieronymi, Brau., in Lautb., Beitr. Flor. Pap., I, 6, fig. $1 A-a$.

Rhizome wide-creeping, filiform, sparingly hairy, at length glabrescent, the hairs reddish-brown. Stipes scattered, filiform, $\pm 1-1 \frac{1}{4} \mathrm{~cm}$. long, hairy like the rhizome, when young somewhat winged. Fronds deltoid to oval, to $5 \mathrm{~cm}$. long and $3 \mathrm{~cm}$. broad, bluntish, sub-3-pinnatifid. Pinnae $7-10$ on a side, the largest $\pm 1 \frac{1}{12} \mathrm{~cm}$. long and $3 / 4 \mathrm{~cm}$. broad, the higher rather spreading, the lower rather horizontal. Pinnulae $4-8$ on a side, simple or pinnatifid. Ultimate segments linear, $\pm 5 \mathrm{~mm}$. long and $1 / 2 \mathrm{~mm}$. broad, bluntish, slightly toothed. Texture pellucid; colour brown (when dry?; rachises narrowly winged, beneath hairy like the stipe; veins stout, blackish. Sori numerous, occupying the lower part of the pinnae; indusium infundibuliform, dilated and subserrate at the mouth (after Brause's figure 2-valved, with the valves deltoid).

New Guinea.

(30a) 'T. grande, Copel., in Philipp. Journ, VIc, 70.

Rhizome erect. Stipes crowded, $\pm 20 \mathrm{~cm}$. long, winged. Fronds $\pm 20-35 \mathrm{~cm}$. long or longer, $\pm 10-15 \mathrm{~cm}$. broad, 4-pinnatifid, the rachis winged. Ultimate segments $\pm 1 / 2 \mathrm{~mm}$. broad, flat, obtuse. Surfaces sparingly puberulous. Sori paratactous; indusium funnel-shaped, 2 marginate, the mouth dilated and sometimes revolute.

Newo Guinea.

(30b) 'T. Selnultzei, Brau., in Lautb., Beitr. Flor. Pap., I, 8.

Rhizome creeping, wiry, the scales dense, ferrugineous, elongatetriangular, toothed. Stipes $\pm 1 / 2-1 \mathrm{~cm}$. apart, slender, $\pm 3{ }^{1 / 4} \mathrm{~cm}$. long, winged throughout, clothed with reddish hairs. Fronds oblong, $\pm 81 / 2$ $\mathrm{cm}$. long, $31 / 4 \mathrm{~cm}$. broad, bluntish, hardly narrowed at the base. Pinnae \pm 12-jugate, petiolate, alternate, the lower horizontal, the higher erectopatent, the central the largest, $\pm 13 / 4 \mathrm{~cm}$. long. Pinnulae to 4-jugate, alternate, the lower $\pm 1 \mathrm{~cm}$. long, $3 / 4 \mathrm{~cm}$. broad. Segments very narrow, obtuse, simple or forked. Texture membranaceous, pellucid; surfaces naked; rachises winged, deciduously hairy, at length naked. Sori small, rather copious, stalked, axillary; indusium cupuliform, the mouth not dilated; receptacle short.

New Guinea.

(30c) See Nos. 39a, $39 b$. 
$(30 d)$ See No. 49.

(30e) '1: palchanarimum, Copel., in Philipp. Journ., IX ${ }^{\mathrm{C}}, 227$.

Rhizome wide-creeping, densely and shortly black-hairy, the axils of the normal fronds provided with finely dissected reduced fronds with setiform segments. Stipes $\pm 10-20 \mathrm{~cm}$. long, castaneous, glabrescent, the upper part very narrowly winged, as is the rachis. Fronds oblong, more than 30 (probably to 60 ) $\mathrm{cm}$. long, 4-5-pinnatifld, acuminate, the rachis deciduously puberulous, and the costae provided with few scattered long hairs. Ultimate segments hardly $1 / 2 \mathrm{~mm}$. broad, often retuse at the apex. Indusium narrowly cylindrical-turbinate, the mouth slightly dilated and 2-valved; receptacle exserted.

Sumatra.

(33a) See Nos. 39a, 39b.

(34a) T. melanotrichum, schl., Adumbrat., 56.

Rhizome creeping, scaly. Stipes compressed, scaly towards the base, winged towards the lamina. Fronds pinnate, the rachis winged; lower pinnae pinnatifid, higher 2-3-fid; segments linear, obtuse, retuse. Surfaces naked. - According to Kunze a small form of T. pyxidiferum $L$.

Trop. and South A/rica, Trop. Asia(?).

(34b) T. Fothertif, v. A. v. R., in Bull. Btz., 1911, I, 13.

Rhizome creeping, tomentose. Stipes distant, $5-20 \mathrm{~mm}$. long, slender, winged above. Fronds ovate in general outline, to $5 \mathrm{~cm}$. long, to $2 \mathrm{~cm}$. broad, 2-pinnatifid; main rachis narrowly winged. Ultimate segments linear, simple or forked. Texture membranaceous; surfaces naked, or the veins provided with distant, indistinct, minute, fibril-like scales; a central vein in each segment, not reaching the apex of the segment. Sori solitary on the upper side of the primary segments, at the base, or on both sides of them; indusium slightly winged, the mouth hardly dilated, conspicuously 2-valved, the valves triangular, erect or somewhat spreading. - Resembling in aspect. T. humile Forst. but differring from it by the absence of the marginal spurious vein and the presence of numerous irregularly scattered, erecto-patent spurious veinlets between the margin and the central veins.

Java. 
(35a) 'T'. Dillobartara, v. A. v. R., in Bull. Btz., 1915, XX, 24.

Rhizome creeping, densely black-hairy. Stipes $\pm 3-4 \mathrm{~cm}$. long, narrowly winged in the upper half. Fronds deltoid-ovate, $\pm 5-6 \mathrm{~cm}$. long by 3-4 $\mathrm{cm}$. broad; main rachis narrowly winged. Pinnae subhorizontal, oblong, cut down to a winged rachis; lowest pinnulae again deeply pinnatifid with linear, simple or forked segments to $6 \mathrm{~mm}$ long and $\pm{ }^{3}:-1 \mathrm{~mm}$. broad, blunt and rounded or emarginate at the apex, provided with many oblique or sublongitudinal, flexuose or nearly straight spurious veinlets between the margin and the simple costa. Texture membranaceous; edges slightly but distinctly crisped; surfaces naked. Sori terminal on abbreviated segments, the indusium narrowly winged, acute at the base, 2-valved 1/2-way down; valves bluntish or rounded.

Java.

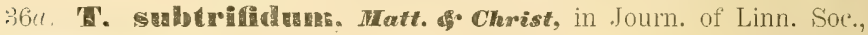
Bot, XXXIX, 214.

Rhizome creeping, black, capillary, short-tomentose. Stipes scattered but subcaespitose, $\pm 1 / 2 \mathrm{~cm}$. long, capillary, black, naked, as is the whole plant. Fronds triangular, $\pm 2 \mathrm{~cm}$. long, broadest at the base, cut down to a broad wing to the rachis into 6 pinnae. Highest pinnae shortest, 2-3-fid at the apex, lower opposite, to $1^{\prime}{ }_{2} \mathrm{~cm}$. long, and 5 $\mathrm{mm}$. broad at the base, deeply incised with 5 lobes on each side, which are partly incised again. Ultimate segments obtuse, rarely acute, \pm 2 $\mathrm{mm}$. long, $1 \mathrm{~mm}$. broad. Texture thin; colour pale-green; a single central vein in each lobe, reaching the apex. Sori axillary, on the anterior side of the pinnae, \pm 3 on a side; indusium oblong-campanulate, the base immersed, the mouth somewhat dilated; receptacle not exserted.

Luzou.

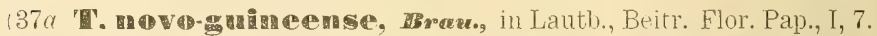

Rhizome creeping, filiform, hairy. Stipes close, very slender, to $3 \frac{1}{2}$ cm. long, naked, very narrowly winged, proliferous. Fronds sublanceolate, $\pm 3 \% \mathrm{~cm}$. long, $13 / 4 \mathrm{~cm}$. broad, shortly forked at the apex, hardly narrowed at the base, the rachis very narrowly winged. Pinnae erectopatent, petiolate, \pm 6-jugate, alternate, the central the largest, $\pm 11 / 4$ cm. long, pinnate. Pinnulae deeply pinnatifid with a single segment on each side, $\pm 3 / 4 \mathrm{~cm}$. long by nearly $1 \mathrm{~cm}$. broad Segments cuneate, flat, bluntish and crenulate at the apex. Texture membranaceous; sur- 
faces naked; veins rather stout. Sori few, occupying the upper part of the rachis, mostly 2 on a side; indusium cupuliform, dilated at the mouth; receptacle short.

New Guinea.

(39a) T. anæxinum, BI.; V. D. B., Hym. Jav., tab. XVII.

Rhizome creeping; stipes scattered; under surface naked; indusium somewhat dilated at the mouth.

(39b: T. millefoliom, Pr.; V. D. B., Hym Jav., tab. XX; T. maximum, Bl., var., C. Chr., Ind. Fil.; — var. anceps; T. anceps, Hk., var. $\beta$, Hk., Spec. Fil, I, 135, tab. XL C, fig. 2-3;-var. grandiflorum; T. maximum, Bl., var. grandiflora, Rst., in Fed., Rep., V, 371.

Rhizome erect; stipes aggregate; indusium somewhat dilated at the mouth; under surface naked.

a ar. anceps: Under surface more or less copiously and deciduously fibrilloso-glandulose; indusium conspicuously dilated at the mouth.

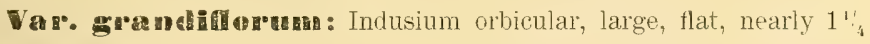
$\mathrm{mm}$. each way.

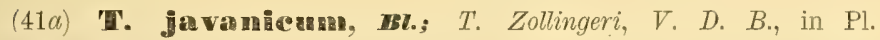
Jungh., 552.

Pinnae serrate-dentate, the teeth on the anterior side rather blunt, those on the pasterior side blunt, acute, or subsetiform but not conspicuously elongated; indusium with the mouth truncate, erect, slightly contracted or hardly dilated; receptacle exserted.

Forma typica V. D. B., Hymen. Jav., tab. XXII): Pinnae with the cell walls opaque, darker than the lumina ('); sori with the receptacle much elongated, somewhat thickened at the tip $\left({ }^{2}\right)$.

Forma Zollingeri (V. D. B., 1. c., tab XXIII; T. javanicum, Bl., var., C. Chr., Ind. Fil.): Pinnae with the cell walls diaphanous, paler than the lumina ${ }^{1}{ }_{1}$; sori with the receptacle about twice as long as the indusium, not thickened at the tip $\left({ }^{2}\right)$.

( $\left.{ }^{1}\right)$ When examined in a saturate chloral-hydrate solution.

${ }^{2}$ ) Often broken in dried material. 
(41b) T. rhomboideum, J. Sm., in Journ. of Bot., III, 417; V. D. B., Hymen. Jav., tab XXIV; T. javanicum, Bl., var., C. Chr., Ind. Fil.

Like T. javanicum Bl. but at least the lower teeth on the posterior side of the pinnae very long-setiform; indusium with the mouth distinctly dilated and more or less spreading:

(41c, 'T. desinervium, Copel., in Philipp. Journ., VIC, 71.

Stipes firm, $\pm 10 \mathrm{~cm}$. long. Fronds $\pm 18 \mathrm{~cm}$. long, hardly $4 \mathrm{~cm}$. broad, narrowed gradually towards the apex. Pinnae close, imbricated, the lower not remote, oblique, rounded at the apex, ciliated. Veins stout, oblique, close, forked, the lower sometimes twice forked. Sori occupying the upper part of the frond, acroscopical, \pm 8 on a pinna; indusium funnel-shaped, somewhat compressed, the mouth truncate, whether or not dilated; receptacle exserted.

New Guinea.

(41d) 'T, singaporianum, v. A. v. R., in Bull. Btz., 1915, XX, 25; T. javanicum, Hk. \& Grev., Ic. Fil., tab. CCXL; T. javanicum, Bl., var., C. Chr., Ind. Fil.; Cephalomanes singaporianum, V. D. B., in Ned. Kr. Arch., IV, 351; Godd., in Med. R. H. L., 1913, 18, 15, fig. 6.

Rhizome short, ascending. Stipes clustered, $\pm 6-8 \mathrm{~cm}$. long, provided with reddish-brown hairs. Fronds oblong; $\pm 8-12 \mathrm{~cm}$. long, $3 \frac{1}{2}-4 \frac{1}{2} \mathrm{~cm}$. broad, pinnate, narrowed at the apex, the rachis very narrowly margined. Pinnae spreading, or horizontal from an oblique base, rather coutiguous, very shortly petiolulate, either oblong and narrowed gradually towards the rounded apex, or linear-oblong and incised towards the base especially on the upper side and less so on the lower side, the edge obtusely denticulate, the base very narrowly decurrent; lobules subtriangular, narrowed towards the apex. Texture rigid; surfaces naked; veins stout, crowded, once or twice forked. Sori small, acroscopical, in the sinuses of the segments, at length recurved; indusium immersed $\pm 1 / 2$-way down, short, urceolate, inflated, the mouth more or less contracted; receptacle long-exserted.

Singapore; Mergui.

(41e) T. bomeense, v. A. v. R., in Bull. Btz., 1915, XX, 25.

Near T. singaporianum $v$. A. v. R. but the fronds somewhat larger, 
to $\pm 20 \mathrm{~cm}$. long by $5 \mathrm{~cm}$. broad, the pinnae more numerous, contiguous or slightly imbricate, somewhat incised towards the base, on the upper side, the lobules subquadrangular, with the apex truncate or rounded, the indusia not immersed but not rarely narrowly winged towards the base.

Borneo.

(41f) T. Hosenstockii, v. A. v. R., in Bull. Btz., 1912, VII, 27 ; T. Christii, Rst., in Bull. Btz., 1911, II, 27, (not Copel., in Philipp. Journ., I, Suppl., 251).

Rhizome erect, woody, the apex rufo-pilose, as are the stipes and rachises. Stipes densely tufted, firm, terete Fronds linear-lanceolate, to $18 \mathrm{~cm}$. long and $5 \mathrm{~cm}$. broad, pinnate. Pinnae numerous, alternate, short-stalked or subsessile, the lower spreading, the others more or less ascending, the higher gradually reduced, the lowest the largest, horizontal or decurved, trapezoid-oblong, $\pm 3 \mathrm{~cm}$. long, $7 \mathrm{~mm}$. broad, lobed, obliquely cuneate at the base; lobes oval, toothed. Colour dark-olivaceous; costae pilose beneath; veins pinnate or forked, the highest simple. Sori $1-6$ to a lobe, placed on the edge or in the sinuses; indusium cylindrical, exserted, narrowly 2-marginate, the mouth slightly crenulate; receptacle exserted.

Borneo.

(42a) T. sumatrenum, v. A. v. R.

Also in Borneo.

(42b) 'G'. acrosorum, Copel., in Philipp. Journ., VIC, 72; var. alatum, v. A. v. R., in Bull. Btz., 1913, XI, 23.

Stipes crowded, $\pm 1-2 \mathrm{~cm}$. long. Fronds $\pm 6-10 \mathrm{~cm}$. long, $1 \frac{1}{2}-2 \frac{1}{4} \mathrm{~cm}$. broad, the rachis hairy, glabrescent. Pinnae $10-12 \frac{1}{2} \mathrm{~mm}$. long, rounded at the apex, toothed and sometimes divided, cuneate at the base, the higher fertile, contracted, without lamina. Veins moderately lax. Sori $1-3$ to a fertile pinna; indusium more or less dilated below the mouth; receptacle exserted.

Var. alatum: Central pinnae obliquely cuneate at the base, lower roundish, truncate at the base; sori $3-5$ to fertile pinna, the indusium narrowly obconical, narrowly winged, the receptacle fragile.

New Guinea. 


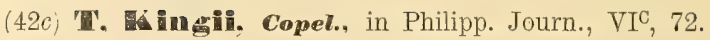

Differs from the preceding in having the rachis narrowly winged, naked, the pinnae lacerate, the indusium obconical, hardly dilated at the mouth.

New Guinea.

(42d) E'. Foersteroi, Hest., in Fed., Rep., XIII, 213.

Near T. javanicum Bl. and T. asplenioides Pr. but the sori occupying especially the apices of the central and lower pinnae, those of the higher pinnae more or less decurrent from the apex along the anterior side of the pinnae; indusium narrowly 2-marginate, the mouth provided with \pm 20-25 papilliform teeth 2-3 times as long as broad.

Sumatra.

(44a) 'T. pappillatuan, K. Mül., in Bot. Zeit,, 1854, 751; T. rigidum, Sw., var., C. Chr., Ind. Fil.

Caespitose. Rhizome black-brown, naked. Stipes aggregate, erect, slender, short. Pinnae alternate, forked; segments lanceolate, long, narrow, acute. Texture weak; colour dirty-fuscous; surfaces minutely papillose; rachis not winged. Indusium cylindrical, ancipital, fuscous, the mouth rather open and subcrenate; receptacle exserted, long, subglobose at the apex.

Phitippines, Borneo.

(44b; 'Thoenerianum, Rst., in Nov. Guin., VIII, Bot., 717.

Rhizome short, the extremity clothed with crowded, brown hairs. Stipes subtufted, wiry, terete, dirty-brown, $\pm 6-9 \mathrm{~cm}$. long, naked or sparingly hairy. Fronds subdeltoid-ovate, $\pm 10-12 \mathrm{~cm}$. long, 4-pinnate or 5-pinnatifid, the rachises narrowly winged or marginate towards the apex. Pinnae subopposite, $\pm 10-15$ on a side, ascending, the highest simple or forked, subfiliform, the lower lanceolate-ovate, decompound, to $7 \mathrm{~cm}$. long and $3 \mathrm{~cm}$. broad, imbricate. Ultimate segments narrowly linear, subfiliform, $\pm 1-3 \mathrm{~mm}$. long, $\pm 1 / 5 \mathrm{~mm}$. broad. Texture firm; surfaces naked. Sori terminal or lateral on the pinnae and pinnulae, on somewhat abbreviated segments; indusium narrowly clavato-obconical, the mouth subtruncate, somewhat contracted, hardly 2-valved, the valves very minutely and rather indistinctly denticulate; receptacle long-filiform, exserted, deciduous.

New Guinea. 
45 ( ) T. paniculaduna, v. A. v. $\mathbb{R}$., in Bull. Btz., 1914, XVI, 38.

Rhizome creeping, tomentose. Stipes scattered, $\pm 1-2 \frac{1}{2} \mathrm{~cm}$. long, nakéd, wiry. Fronds ovate-oblong, $\pm 5-71 / 2 \mathrm{~cm}$. long, $21_{2}-4 \mathrm{~cm}$. broad near the base, 3-pinnatifid, the main rachis not winged, sulcate above, rounded beneath. Pinnae horizontal or spreading, shortly petiolulate, to $2 \mathrm{~cm}$. long, to $1 \mathrm{~cm}$. broad at the truncate base, cut down to a winged rachis into deeply pinnatifid pinnulae. Ultimate segments $1-3$ on a side, to $2 \mathrm{~mm}$. long and $3 / 4 \mathrm{~mm}$. broad, rounded or bluntish at the apex; the lowest sometimes forked; edges often more or less distinctly crispatoundulate, provided with an intramarginal spurious vein. Texture thin, membranaceous; surfaces naked; rachises, costae, costulae and veins deciduously glanduloso-fibrillose beneath; a central vein carried in each ultimate segment. Sori numerous in the adult plants, partly terminal on the pinnae and higher pinnulae, partly solitary at the base of the lower pinnulae on the anterior side, partly forming a compound panicle in the upper part of the frond; indusium infundibuliform, rather obconical, winged, the mouth dilated, spreading, 2-lobed. - Lower pinnae resembling single fronds of. T. humile Forst.

Java.

\section{6) T. aphlebionides, Christ.}

Pinnae not invariably distant, occasionally the main rachis more broadly margined, the ultimate segments a little broader, and the abnormal fronds to 5-ninnate, less finely dissected.

Also in Amboina, Taliabo, Batu.

(46a) 'T. microlirion, Copel., in Philipp. Journ., $\mathrm{X}^{\mathrm{c}}, 146$.

Rhizome wide-creeping, filiform, densely clothed with short, black hairs. Stipes slender, 5-15 mm. long, terete, naked except at the base. Fronds ovate, 4-6 cm. (?) long, the rachis not winged. Lower pinnae short-stalked, the stalk not winged; central pinnae the largest, oblong, obtuse, cut down to a narrowly winged rachis, the segments divided into 2-5 linear or linar-oblong lacinulae about $1 / 2 \mathrm{~mm}$. broad, the margin not or slightly crisped, provided with an interrupted, submarginal spurious vein. Sori terminal, scattered or paniculate; indusium narrowly obconical, 2-marginate, the mouth broad, conspicuous, spreading or revolute; receptacle included.

Borneo. 


\section{(47a) T. Clnristil, Copel.}

A duplicate of Elmer's No. 14020, from Mindanao, occurring in the Buitenzorg Herbarium, is distinguished by the following characters: Rhizome subatro-tomentose. Stipes scattered, to $2 \mathrm{~cm}$. or more long, provided with short or fibril-like, pale-brown, scattered hairs, as are the rachises, costae and costulae beneath. Fronds deltoid-ovate, 3-pinnatifid, acute. Ultimate segments $1 / 2-3 / 4 . \mathrm{mm}$. broad, blunt, entire or emarginate at the point, slightly crisped, provided with an intramarginal, flexuose, slightly interrupted spurious vein. Texture thin; main rachis at best winged in the upper part except in the younger plants; a single central vein carried only into each ultimate segment. Sori paniculate in the upper part of the fronds of adult plants; indusium distinctly winged, the mouth dilated, at length spreading, sub-2-lobate; receptacle whether or not exserted.

Also in Mindanao.

(47b) 'T. Iatipinmuan, Copel., in Philipp. Journ., VIC , 71.

Rhizome creeping, stout, densely clothed. with purple-black, needlelike hairs. Stipes $\pm 10-20 \mathrm{~cm}$. long, and, like the rachises, brown or purple-black and deciduously fibrilloso-pilose. Fronds deltoid, $\pm 15 \mathrm{~cm}$. long and $10 \mathrm{~cm}$. broad, 4-pin̂natifid. Pinnae and pinnulae lanceolatedeltoid, the lower anterior pinnulae the largest; pinnulae cut down to the rachis, with the lowest anterior segment the largest, elongate-oblong, cuneate at the base. Ultimate segments suberect, linear, $\pm 1 / 2-2 \mathrm{~mm}$. long, the longest very narrow, $\pm 1 / 4-1 / 8 \mathrm{~mm}$. broad, simple, acute, the broadest \pm 2 -4-dentate at the apex. Texture coriaceous; surfaces naked, or very minutely paleaceo-fibrillose on the veins. Sori often on the higher pinnulae, on the inner side near the base; indusium cuneateclavate, narrowly winged at the base, truncate, the receptacle somewhat exserted when ripe.

Nero Guinea.

(47c) h' recedens, Rst., in Med. R. H. L., 1912, $1,2$.

Rhizome creeping; clothed with dense, black-brown tomentum. Stipes slender, terete, $1 \frac{1}{2}-2 \mathrm{~cm}$. long, when young (provided like the whole plant) with caducous, hair-like, cellular corpuscles, at length naked. Fronds lanceolate-ovate, to $\pm 5 \mathrm{~cm}$. long and $3 \mathrm{~cm}$. broad, 3-pinnatifid at the base, the main rachis slender, winged in the upper part by the decurrent 
higher pinnae. Pinnae lanceolate, subcontiguous, the lower short-stalked, horizontal, 2-pinnatifid, the following sessile, more or less oblique, less compound, the edges provided with a continuous intramarginal spurious vein accompanied by a few longitudinal short intermedial ones. Ultimate segments narrowly linear, simple or rarely forked, emarginate at the apex, separated by narrow sinuses, when dry ruguloso-undulate. Texture membranaceous, hyaline; colour brown-green (when dry; veins fuscous. Sori axillary in the highest portion of the frond; indusium broadly marginate, obconical at the base, the mouth dilated, entire, reflexed at the edge; receptacle hardly exserted.

Borneo.

(49) T. cupressoides, Desv.; -.. var. minor, Rst., in Bull., Btz., 1911, II, 28.

Main rachis whether or not narrowly winged, and the sori sometimes more or less conspicuously deflexed; indusium long-tubular, gradually narrowed towards the base; receptacle much exserted.

Var. minor: Indusium distinctly margined. - Borneo.

(49a) T. setnceum, $\boldsymbol{V}$. D. $\boldsymbol{B}$.

Malaya.

(50c) Sehlechteri, Brau., in Lautb., Beitr. Flor. Pap., I, 10. Rhizome short, erect, densely clothed with long, brown hairs. Stipes tufted, $\pm 31 / 2-10 \mathrm{~cm}$. long, terete, wiry, erect, densely clothed with long, spreading, red-brown hairs. Fronds $30-40 \mathrm{~cm}$. more or less long, 2-4 cm. broad, linear-lanceolate, narrowed towards both ends, acuminate, copiously 4-6-pinnate; rachis hairy, marginate towards the apex. Longest pinnae $\pm 2-4 \mathrm{~cm}$. long, $3 / 4-13 / 4 \mathrm{~cm}$. broad, suberect or erecto-patent, lanceolate-oblong. Pinnulae several, the lower cut down into flattened, deeply 1-2-3-pinnatifid segments, the ultimate ones to $6 \mathrm{~mm}$. long, 1/3 mm. broad. Texture thin but firm; surfaces naked; a single central rib in each ultimate segment. Sori solitary at the base of the pinnae or pinnulae, on the anterior side: indusium small, obconical-clavate, the mouth truncate, slightly narrowed; receptacle filiform, long-exserted.

New Guinea.

FERns ANd Fern ALLies. 


\section{SOHIZAFACEAF.}

\section{O. LYGODIUM, Swarta.}

\section{\& 1. EULYGODIUM.}

a. Barren pinnae forked, palmate, digitate or dichotomous.

1. Spikes in rows along the undivided margin of the fertile segments. 2. Hairs of the gemmiform apex of the rachis and primary petioles brown or yellow.

3. Divisions of fertile pinnae auriculate, at least on one side at the base.

(1) L. semihastatum.

3.s. Divisions of fertile pinnae not auriculate at the base.

4. Divisions subtruncate at the base.

(2) L. Teysmannii.

4.4. Divisions cuneate at the base.

5. Barren pinnae palmatifid, or dichotomous with palmatifid segments.

(3) L. circinatum.

5.5. Barren pinnae not palmatifid.

(3a) L. borneense.

2.2. Hairs of the gemmiform apex of the rachis and primary petioles blackish.

(4) L. digitatum.

1.1. Spikes in groups either on the incised margin of the segments or on variously divided fertile segments.

- Spores not reticulate-crested.

+ Fertile pinnae not paniculiform.

(5) L. trifurcatum.

++ Fertile pinnae paniculiform.

(5a) L. dimorphum.

* Spores reticulate-crested.

(5b) L. Moszkowskii.

a.a. Barren pinnae pinnate, the pinnulae variously divided.

b., b.b., etc. 
(1) L. semihastatum, Desw., Hk. Bk., Syn. Fil., 437; L. flexuosum, Sw., C. Chr., Ind. Fil., p.p.; Hydroglossum auriculatum, Willd. Spec., V, 84; Ugena semihastata., Cav., Icon. Descr. Pl., VI, 74, tab. 594, fig. 1.

Primary petioles short or obsolete, secondary to about $2 \% \mathrm{~cm}$. long. Fertile pinnae petiolulate, geminate. Pinnulae shortly petiolulate, simple or forked, or geminate again. Final segments lanceolate or ligulate, to about $20 \mathrm{~cm}$. long and $2 \frac{1}{2} \mathrm{~cm}$. broad, serrulate-crenulate, cordateauriculate on the outer side (or on both sides) at the base, the auricles rounded or more commonly conspicuously arcuate-decurvate. Spikes in close rows along the edge, to about $3 / 4 \mathrm{~cm}$. long; spores verruculose. The sterile pinnae are deseribed as palmate or 2-partito-palmate. - See my information under L. dimorphum Copel.

Philippine and Marianne Isles.

\section{(2) L. Teysmannii, v. A. v. $\boldsymbol{R}$.}

Pinnae irregularly forked (as described), geminate or sparingly (sub-)pinnate with 1 pinnula on each side below the terminal one; pinnulae once or twice forked, the lateral ones alternate, the lowest (posterior) \pm horizontal; ultimate segments free or connected, truncatecuneate or subcordate on the outer side (the free ones cuneate on the inner side) at the base.

(3) L. circinatum, Sw.; Ugena dichotoma \& macrostachya, Cav., Icon. Descr. Pl., VI, 74-75, tab. 594, fig. 2-3.

Adult plants with the ultimate fertile segments not rarely free and incised at the base, with the lower spikes arranged in groups of $2-6$ on the lobules, as in L. trifurcatum Bk., but the spores not coarsely verrucose.

Var. monstruosum: Omit this, it is an abnormal form of the type only. (Forma monstruosa).

(3a) L. borneense, v. A. v. R., in Bull. Btz., 1915, XX, 29.

Primary petioles short or obsolete, secondary ones $1 / 2-1 \frac{1}{2} \mathrm{~cm}$. long, margined, provided with deciduous, short hairs. Pinnae geminate. Leaflets simple, uniform, or the fertile ones somewhat contracted, longelliptical, acuminate, serrulate-crenulate, cuneate at the base, petiolulate, 
the stalk margined, deciduously short-hairy: Spikes in continuous rows along the edge; spores minutely verruculose.

Forma typica: Leaflets $15-20 \mathrm{~cm}$. long by $1 \frac{1}{2}-2 \frac{1}{2} \mathrm{~cm}$. broad. Forma samarindae: Leaflets $25-35 \mathrm{~cm}$. long by $3 \frac{1}{2}-5 \mathrm{~cm}$. broad. Borneo.

\section{(5) L. trifurcatum, Bh.}

See also No. 3.

(5a) L. dimorphum, Copel., in Philipp. Journ., VI ${ }^{\mathrm{C}}, 67 ; L$. novo-guineense; Rst., in Fed., Rep., IX, 427.

Primary petioles very short or obsolete, secondary ones about $1-2$ $\mathrm{cm}$. long. Barren pinnae forked, the pinnulae stalked, simple or (mostly the posterior ones) forked again, the stalks narrowly marginate, deciduously hairy. Ultimate segments free or connected, sessile or shortstalked, linear-lanceolate, $8-20 \mathrm{~cm}$. long, 1-2 cm. broad, acuminate, minutely serrulate, truncate or cordate or more commonly cordateauriculate on the outer side at the base, the auricles rounded or generally conspicuously arcuate-decurvate. Texture firm; costae and veins naked, or provided beneath with scattered, deciduous hairs. Fertile pinnae forked or pinnate, the branching between compoundly pinnate and dichotomous; all the divisions much contracted, without lamina or nearly so, the pinnae therefore paniculiform. Spikes short, to $3 \mathrm{~mm}$. long; spores tubereulate (after Rst. smooth or obscurely reticulate). - A duplicate of Copland King's No. 134, occurring in the Buitenzorg Herbarium, has the spores verruculose. A plant from Skroe (coll. Prof. Dr. M. Treub) bears on the very same rachis: $a$, sterile and fertile pinnae like those of Copland King's No. 134; $b$, fertile pinnae like those of L. Semihastatum Desv. but sparingly spiciferous only; $c$, fertile pinnae more or less resembling those of $\mathrm{L}$. trifurcatum $B k$. as intermediates between those mentioned under $a$ and $b$. - It may be possible, that L. dimorphum is a very compound form of L. semihastatum and that Treub's plant unites both extremes as well as the intermediates, but I don't know whether the true Philippine L. semihastatum ever reaches the compound development of the Papuan L. dimorphum.

New Guinea, Amboina.

(5b?) H. Ulosgkowskii, Erau., Lautb., Beitr. Flor. Pap., I, 57. 
Primary petioles $\pm 1 \mathrm{~mm}$. long, $8 \mathrm{~mm}$. broad, foliaceous, secondary ones nearly wanting. Pinnae digitate, 3-4-foliolate, auriculate at the base. Segments linear, to $\pm 35 \mathrm{~cm}$. long; barren segments $\pm 2 \%-2 \% \mathrm{~mm}$. broad, hairy on both sides, deeply pinnatifid into numerous approximate lobes $\pm 1 \mathrm{~mm}$. long and $3 / 4 \mathrm{~mm}$. broad; fertile segments $\pm 6 \mathrm{~mm}$. broad, deeply pinnatifid into numerous approximate lobes $\pm 3 \mathrm{~mm}$. long and $1 \mathrm{~mm}$. broad, terminating in slightly crenated fertile lobules. Spores provided with reticulated, wing-like crests. - The systematical place of this species is uncertain because of incomplete description.

New Guinea.

(7a) 1. Kingii, Copel., in Philipp. Journ., VI 68.

Near L. scandens Sw. - Rachises minutely pubescent. Primary petioles none or obsolete; secondary ones conspicuously thickened at the apex. Leaflets lanceolate, $4-6 \mathrm{~cm}$. long, articulated and broadly cuneate or truncate at the base. Spores tuberculate.

New Guinea.

(10a) See No. 2.

\section{(11) L. japonicum, Sw.}

Two distinct forms united by intermediates:

Forma typica (Bedd., Ferns S. I., tab. LXIV; Christ, Farnkr. d. Erde, fig. 1122): Pinnae moderately narrow; terminal pinnulae rather short, oblong, blunt, broadly crenate or coarsely toothed, the crenations and teeth entire or more generally crenate to serrulate; central pinnulae hastate to palmatifid, de segments rather short, oblong, blunt, similar to the terminal pinnulae but smaller, the terminal segment somewhat larger; lower pinnulae similar to the central ones but pinnate at the base with the lower leaflets similar to the central pinnulae but smaller.

Forma elongata (v. A. v. R., in Bull. Btz., 1911, I, 10, tab. III): Like the type but the terminal pinnulae much elongated, narrowly linear or linear-lanceolate, as are the terminal segments of the central and lower pinnulae, the pinnae therefore much broader; lateral segments of the pinnulae not rarely subulate, and the teeth of the segments of pinnae and pinnulae sometimes so. 


\section{§ 2. HYDROGLOSSUM.}

(13) L. Mermilli, Copel., in Philipp. Journ., II ${ }^{\mathrm{C}}, 146$, tab. IV; IV, 20 , tab. XII.

Rachis hairy or glabrescent. Primary petioles obsolete. Pinnae up to $35 \mathrm{~cm}$. long, pinnate. Pinnulae $2-3$ on a side, the lower long-stalked, forked or rarely dichotomously palmate, decurrent-truncate; terminal pinnulae once or rarely twice forked; segments up to $15 \mathrm{~cm}$. long and $\pm 1^{3 / 4} \mathrm{~cm}$. broad, obscurely serrate. Texture membranaceous; surfaces naked. Spikes $\pm 5 \mathrm{~mm}$. long, not close, on the tips of rather prominent teeth.

Mindoro.

(14) I. Versteegii, christ, in Nov. Guin., VIII, Bot., 161.

Fronds wide-scandent, the rachis smooth, dirty-brown. Pinnae 2-3foliolate, short-stalked. Leaflets short-stalked, dimorphous, the barren ones lanceolate, $10-15 \mathrm{~cm}$. long, $\pm 2-2 \frac{1}{2} \mathrm{~cm}$. broad, entire, narrowed gradually towards an acute barren or a narrow-caudiform fertile apex, the lower part narrowed gradually into the petiole, provided with 1 or more very minute, free auricles at the very base, the fertile ones narrowly linear, 1-5 mm. broad. Texture thin-chartaceous, parehment-like, rather transparent; rachis and surfaces naked, the petioles short-hairy; costae prominent on both sides, dirty-brown; veins reticulate, very conspicuous, forming \pm 6 rows of oblique areolae between the costa and margin in the barren pinnulae. Fertile spikes numerous, elose, short, hairy at least when young.

New Guinea. 


\section{PULYPODIACEAE.}

Keys to the tribes and genera.

(Additions and modifications).

\section{§1. WOODSIEAE.}

1. Indusium globose or sausage-shaped, bursting down irregularly.

2. Indusium globose; veins free.

3. Sori (incl. the indusium) sessile. No. 12. Diacalpe.

3.3. Sori (incl. the indusium) stalked. No. 12a. Peramema.

2.2. Indusium sausage-shaped, or the veins anastomosing.

No. 13. Diplaniopsis.

1.1. Indusium cup-shaped, open at the top.

* Caudex arborescent.

(No. 4a. Balantium).

- Rhizome mostly creeping, not arborescent.

No. 14. Dennstaedtia.

\section{§ 3. DAVALLIEAE.}

1. Sori round, solitary on the veins, dorsal or terminal; indusium fastened under the sorus, the point of insertion covered by the sporangia.

- Indusium broad, hood-shaped when young, attached by a broad base to 3 sides (the inner and lateral sides) of the receptacle.

No. 27. Cystopteris.

- Indusium narrow, not hood-shaped, attached by a narrowed base to 1 side (the inner side) of the receptacle.

No. $27 \alpha$. Stenolepia.

1.1. Sori round, oblong or linear, solitary on the veins, or uniting the apices of 2 or more veins or veinlets; indusium fastened at the 
inner side of the sorus, the point (or line) of insertion not covered by the sporangia, at least when young.

2. Indusium attached by a single point to the receptacle, otherwise free.

+ Indusium inciso-lacerate.

No. 31b. Leptolepia.

++ Indusium not inciso-lacerate.

No. $34 a$. Davalledes.

2.2. Indusium attached by a broad base to the receptacle or to the receptacle and the parenchyma.

3. Fronds divided; leaflets dimidiate, i. e. with the half on the lower side of the midrib cut away. No. 29. Hindsaya.

3.s. Fronds simple or divided, if divided, the leaflets not dimidiate, i. $\theta$. distinctly developed on both sides of the midrib.

4. Stipes articulate to the rhizome.

- Fronds membranaceous or herbaceous, surfaces hairy or fibrillose.

No, $34 \alpha$. Davallodes.

$\bigcirc \bigcirc$ Fronds chartaceous or coriaceous, or the surfaces naked or scaly.

$=$ Indusium fastened by the base only, the sides and outer edge free. No. 32. Humata.

$==$ Indusium fastend by the base and sides, the outer edge only free. No. 34. Davallia.

4.4. Stipes not articulate to the rhizome.

5. Ultimate fertile segments cuneate or linear-cuneate, bearing the sori on the truncate apex.

No. 28. Dutontosoria.

s.s. Ultimate fertile segments otherwise.

6. Sori uniting the tips of 2 or more veins or veinlets.

○ Fronds pinnate; pinnae provided above with minute, deciduous, cretaceous, submarginal scales.

(No. 17. Nephrolepis, \& Lindsayopsis:.

Do Fronds simple, if divided, without cretaceous scales.

No. 30. Shizoloma.

$\therefore$. Sori solitary on the veins, sometimes confluent in pairs.

*. Sori terminal on very short and inconspicuous 
VI. POLYPODIACEAE. § 3. DAVALIIEAE.

lateral veinlets or springing from the side of a vein or veinlet.

(No. 55. Asplenium, \& Loxoscaphe).

\%. Sori always terminal on rather long veins or veinlets.

8. Sori placed on cucullate marginal outgrowths forming with the indusium a saccate involucre to the sorus.

(No. 4. Dicksonia).

8.8. Sori and indusia otherwise.

ə. Indusium narrowly cuneate, deeper than broad, fastened at the sides.

\$ Fronds small, simply pinnate, at best 2-pinnate at the base. No. $30 a$. Protolindsaya.

\$. Fronds large, decompound.

No. 31a. Saccoloma.

9.9. Indusium broadly cuneate, broader than deep, semicupuliform or fastened by a broad base and then free at the sides.

\$ Ultimate segments rhomboidal or linear-triangular, unequalsided at the base.

No, 35. Mierolepia.

\$\$ Ultimate segments linear or oblong, not or hardly unequalsided at the base.

No. 36. Tapeinidium.

\section{§ 8. GYMNOGRAMMEAE.}

a. Veins quite free, in Malayan material.

b. At least the fertile fronds coated beneath with white or yellow powder.

No. 63. Ceropteris.

b.b. Fronds not powdery beneath.

c. Venation dichotomo-flabellate. No. $62 \alpha$. Anogramma. 
c.c. Venation not dichotomo-flabellate.

d. Fronds or leaflets entire or toothed; lateral veins simple or forked.

No. 62. Coniogramma.

d.d. Fronds or leaflets lobed or pinnatifid; main veins pinnate.

(No. 60a. Phegopteris).

$\boldsymbol{a}, \boldsymbol{e}$. Veins anastomosing variously.

l. Costa wanting at least in the upper part.

No. 64. Antrophyum.

1.1. Costa distinct quite to the apex.

2. Veins anastomosing near the costa only.

- Lateral veins simple or forked; sori confluent at the base.

(No. 70 . Brainea).

* Main veins pinnate; sori free, or confluent at the apex. + Lower veins of contiguous groups uniting as in Nephrodium; costal areolae rather deltoid or subdeltoid.

(No. 60a. Phegopteris).

+ Lower veins of contiguous groups uniting as in Pleocnemia; costal areolae trapezoidal or nearly so.

(No. 60b. Dictyopteris).

2.2. Veins anastomosing otherwise, often copiously and irregularly.

3. Main veins distinct at least in the barren fronds.

- Sori running in parallel lines.

No. $67 a$. Henigramma. +† Sori running in various directions.

\section{No. $67 b$. Campylogramma.}

3.3. Main veins wanting or indistinct.

1. Sori copiously reticulate throughout.

No. 67. Femionitis.

4.4. Sori parallel, free, or uniting near the apex only.

5. Areolae hidden, with free veinlets.

No. 65. Lexogramma.

5.5. Areolae distinct, or without free veinlets.

No. 66. Symgramma.

\section{§ 9. GRAMMITIDEAE.}

1. Lateral veins wanting or free, at least in the barren fronds. (Vittarieae). 
2. Lateral veins wanting, or the sori covering the costa at full maturity.

No. 68. Dilomogramma.

2.2. Lateral veins present; sori always more or less remote from the costa.

3. Fertile fronds proportionally very thick; paraphyses wanting.

No. $69 a$. Seleroglossum.

3.3. Fertile fronds mostly thin; paraphyses present.

No. 69. Vittaria.

1.1. Lateral veins present, anastomosing variously. (Taenitidede).

i. Lateral veins anastomosing near the costa only.

No. $70 a$. Brainea.

a.a. Lateral veins anastomosing more copiously.

b. Costa wanting at least in the upper part; areolae longitudinally elongated.

(No. 64. Antrophyum).

b.b. Costa distinct quite to the apex, areolae not longitudinally elongated, at least in the barren fronds.
c. Rhizome scaly.
No. 65. Loxogramma).
c.c. Rhizome hairy or fibrillose.
No. 70. Tuenitis.

\section{§ 10. POLYPODIEAE.}

a. Sori round, if elongated, then not more than about $3 \times$ as long as broad.

b. At least the under surface covered with scattered or more or less crowded, stellately branched hairs. No. 72. Cyelophorus.

b.b. Fronds naked or scaly, if hairy, then the hairs not stellately branched.

c. Fronds incised or divided; sori restricted to the much contracted higher segments.

d. Fronds solitary on short, specialized, lateral branchlets of the rhizome. No. $73 \alpha$. Thayeria.

d.d. Fronds not solitary on specialized branchlets of the rhizome.

e. Sporangia springing from the veins and the parenchyma. No. 74. Dryostachyum.

e.e. Sporangia springing from the veins only, not from the parenchyma.

No. $74 a$. Aslaomorpha. 
c.c. Fronds simple or divided; sori not restricted to much contracted higher segments.

1. Fronds dimorphous, barren sessile, humus-collecting, fertile stalked.

No. 73. Drynaria.

1.1. Fronds uniform, if dimorphous, then not as in 1.

2. Veins free or anastomosing regularly; areolae with the free included veinlets directed towards the margin.

No. 71. Polypodium.

2.2. Veins anastomosing irregularly; areolae with the free included veinlets mostly spreading in various directions, rarely wanting or directed towards the costa or the margin.

3. Sori not on marginal outgrowths of the fronds.

No $71 a$. Pleopeltis.

3.3. Sori on specialized marginal outgrowths of the fronds.

No $71 b$. Lecanopteris.

a.e. Sori elongated, more than $3 \times$ as long as broad, continuous or interrupted.

- Sori oblique to the costa and margin, several on each side of the costa.

No. $71 \alpha$. Pleopeltis.

๑) Sori parallel to the costa or margin, 1 on each side of the costa.

- Fronds dimorphous.

+ Fronds simple.

No. 75. Drymoglossum,

+* Fronds, at least the barren ones, not simple,

No. 76. Christopteris.

- Fronds not dimorphous, at best somewhat contracted in the fertile region.

No. 75 . Paltonium.

\section{§ 11. ACROSTICHEAE.}

1., 1.1. Etc.

2., 3., 3.3., 4. Etc.

1.4. Ete.

5. Leaflets not articulate to the rachis.

No. 80. Polybotrya.

5.5. Leaflets articulate to the rachis.

No. $86 c$. Lomagramma. 
VI. POLYPODIACEAE. \$11. ACROSTICHEAE.

2.2., 2.2.2. Etc.

$\boldsymbol{\alpha}, \boldsymbol{\alpha} . \boldsymbol{\alpha}$. Etc.

a.e.⿲丿丨. Etc.

$\$$ Etc.

SS Etc.

- Paraphyses present, linear, thickened at the apex; spores globoso-tetrahedral.

No. $86 b$. Platylaenia.

* Paraphyses wanting, if present, then not as in * or the spores oblong, ovate or 2-lateral.

- + Fronds simple, if divided, the leaflets not articulate to the rachis.

No. $86 a$. Leptochilus.

$\div \div$ Fronds divided, the leaflets articulate to the rachis.

No. $86 c$. Lomagramma.

12a. PERANMMA, Don.

Sori globose, dorsal on a vein or veinlet, stalked. Indusium inferior, rather globose, at first entire and enclosing the whole sorus (except the stalk', al length bursting into 2 more or less irregular valves. Capsules stalked. Otherwise like Diacalpe. - Hk. Bk., Syn. Fil., tab. I, fig. 12 (Sphaeropteris); Diels, in Engl. \& Prantl, Nat. Pfl.fam., $I^{4}$, fig. $87 E-H$.

Br. India, Philippines.

(1) P. Inzonica, Copel., in Philipp. Journ., IV, 111.

Stipes $\pm 30 \mathrm{~cm}$. long, scaly, the scales brown, the largest ones lanceolate-ovate, very apiculate. Fronds up to $60 \mathrm{~cm}$. long, narrowly deltoid, 4-pinnatifid. Pinnulae stalked, lanceolate-oblong, obtuse, to $7 \mathrm{~cm}$. long. Tertiary segments obtuse, oblong, the largest short-stalked, $\pm 1 \%$ $\mathrm{cm}$. long, pinnatifid nearly to the costa. Texture coriaceous; rachises scaly; surfaces pubescent. Sori often oblate; indusium glaucous, irregularly incised; spores tuberculate.

Luzon. 


\section{DEIVNSTA A DTI A, Bernhardi.}

(2a) D. canalieulata, v. A. v. R., in Bull. Btz., 1914, XVI, 6.

Fronds $\pm 150 \mathrm{~cm}$. long by $90 \mathrm{~cm}$. broad, 3-pinnatifid, the rachises pale-brown, naked beneath, grooved above, copiously hirsute in the grooves, the hairs pale-brown or rufous, often fibril-like. Pinnae lanceolate, subsessile, articulate at the base, the lower opposite, the largest $\pm 45 \mathrm{~cm}$. long, to $15 \mathrm{~cm}$. broad. Pinnulae horizontal, sessile, lanceolate, acuminate, broadly cuneate and articulate at the base, the edge cut $\pm 3 / 4$-way down to the costa; largest pinnulae $\pm 11 / 2 \mathrm{~cm}$. broad; lowest pinnulae much abbreviated, the lowest anterior nearly stipule-like. Lobes ascending, oblong, broadly rounded or rotundatetruncate at the apex, to $4 \mathrm{~mm}$. broad, separated by narrow, often acute sinuses, subentire or sparingly crenated. Texture coriaceous; surfaces naked; costae 2-marginate-canaliculate above; costulae flexuose, often thickened at the base; veins simple or forked. Sori solitary on the anterior side of the lobes, near the base; indusium cup-shaped.

Java.

(3) W. erythrorachis, Diels.

Probably identical with D. ampla Bedd.

(4) D. nmpla, Bedd.

Plants gathered in New Guinea by Versteeg and von Römer, determined by Christ and Rosenstock as D. ampla Bedd., have the rachises partly purple-brown partly pale-brown, partly deciduously pubescent partly naked but shortly pubescent in the groove and at the place of insertion of the pinnae and pinnulae, the pinnae and pinnulae articulate at the base, the lower pinnulae reduced, the leaflets lobed, connected by ad very narrow wing, the largest leaflets $\pm 1 \mathrm{~cm}$. long and $1 / 2$ as broad. They differ from D. articulata Copel. in having the pinnae long-acuminate, broadly cuneate at the base, and the ultimate leaflets much smaller.

(4a) D. articulatu, Copel., in Leafl., II, 396.

Rhizome creeping, stout, black-brown. Stipes distant, $1-1 \frac{1}{2} \mathrm{~m}$. long, sparingly black-aculeate towards the base, distinctly canaliculate above; rachises castaneous, very glossy, sulcate, pubescent in the grooves, provided with bunches of hairs at the points of insertion 
of the pinnae and pinnulae, otherwise naked. Fronds $100 \mathrm{~cm}$. or more long, deltoid, 3-pinnate. Pinnae opposite, triangular-lanceolate, articulate. Pinnulae horizontal, subsessile, articulate, the lower opposite, the largest $\pm 10 \mathrm{~cm}$. or more long, $\pm 2^{1}{ }_{2} \mathrm{~cm}$. broad, rather short-acuminate, truncate at the base, the lowest somewhat reduced. Tertiary segments mostly distinct, connected by a very narrow wing, the largest to $\pm 2 \mathrm{~cm}$. long, $\pm 8 \mathrm{~mm}$. broad, oblong, obtuse, obliquely cuneate at the base, with a few shallow lobes, the lowest anterior lobe the largest, subauriculiform. Texture papyraceous; surfaces naked; colour dark; veins $4-5$-jugate, the lower forked. Sori in the sinuses of the lobes.

Negros.

(5) D. Smithii, Moore; - var. novoguineensis, Rst., in Fed., Rep., X, 323 .

A fragment of a plant received from Luzon, determined as D. Smithii Moore (leg. Elmer No. 11513), has the frond decidedly 4-pinnate, with the pinnae more than $75 \mathrm{~cm}$. long, $\pm 27 \frac{1}{2} \mathrm{~cm}$. broad at the base, the lowest anterior pinnula much the largest, $\pm 17 \frac{1}{2} \mathrm{~cm}$. long, $\pm 4 \mathrm{~cm}$. broad, the lowest anterior leaflet the largest, $\pm 2{ }^{3} / 4 \mathrm{~cm}$. long, cut down to the rachis into several rhomboidal, more or less deeply incised segments \pm $6 \mathrm{~mm}$. long and $2 \mathrm{~mm}$. broad at the base, with the lowest anterior lobe the largest, the under surface copiously provided with long, crisped, articulated hairs, as are the rachises, the upper surface less copiously so, here and there naked. - I believe Hooker's original diagnosis has been founded on an incomplete specimen of the species.

Var. novoguineensis: Fronds 4-pinnate; stipe and main rachis often spinose; secondary rachises roughish beneath. - New Guinea.

(6a) D. dennstaedtioides, Copel.

Omit this species, it being referred to Microlepia.

(6c) D. Hosenstockii, v. A. v. R., in Bull. Btz., 1912, VII, 11 ; D. articulata, Rst. (not Copel.), in Fed., Rep., X, 322.

Fronds larg, 4-pinnatifid; main rachis livid-green, shortly tomentose, spinose at the base, canaliculate on the upper side. Pinnae articulatepetiolate, elongate-oblong, to $70 \mathrm{~cm}$. long and $30 \mathrm{~cm}$. broad, acuminate, the rachis like the main one but not spinose. Pinnulae subsessile, elongate-oval or lanceolate, $\pm 15 \mathrm{~cm}$. long, $3 \mathrm{~cm}$. broad, the apex 
acuminate, linear, serrate, the rachis partly ferrugineo-tomentose, articulate at the base. Leaflets short-stalked, articulate at the base, trapezoidoblong, to $1 \frac{1}{2} \mathrm{~cm}$. long, $1 \mathrm{~cm}$. broad and produced on the upper side at the base, subobtuse, the lower and central deeply pinnatifid, the higher lobed on the upper side, subcrenate on the lower side, the highest simple, the stalks narrowly winged. Lobes oblong, obtuse, the lower produced and crenate on the upper side, entire on the lower side. Texture rigidly chartaceous or subcoriaceous; surfaces naked; colour grey-green; lower veins pinnate, higher simple or forked. Sori in the sinuses of the crenations.

New Guinea.

(6d) See No. $13 a$.

(6e) D. paraphysata, v. A. v. F., in Bull. Btz., 1914, XVI, 7.

Rhizome creeping, densely long-hairy, the hairs articulated, red-brown or castaneous. Stipes scattered, $\pm 70 \mathrm{~cm}$. long, stramineous, brown at the base, deciduously hairy, at length punctulato-asperulous. Fronds triangular-lanceolate, $\pm 70 \mathrm{~cm}$. long, $\pm 55 \mathrm{~cm}$. broad at the base, 4 pinnatifid or 4-pinnate, acuminate, the rachises deciduously long-hairy, the hairs partly whitish partly red-brown, often inflated at the base. Pinnae triangular-lanceolate, the lowest stalked, spreading or horizontal, $\pm 27 \frac{1}{2}$ $\mathrm{cm}$. long, $\pm 15 \mathrm{~cm}$. broad above the base, acuminate; central pinnae a little longer, arcuate-ascending. Tertiary segments oblong, to $1-2 \mathrm{~cm}$. long, connected by a narrow wing, the lowest anterior mostly the largest, deeply pinnatifid, or pinnated at the base. Ultimate segments cuneateoblanceolate or cuneate-obovate, oblique, to $5 \mathrm{~mm}$. long and $2 \frac{1}{2} \mathrm{~mm}$. broad, the lowest anterior the largest, sparingly and bluntly crenatedentate or coarsely toothed. Texture herbaceous; under surface longhairy on the costae and costulae, subverruculose between the veins. Sori solitary on the anterior edge of the ultimate segments, at the centre; indusium 2-valved, the valves semiglobose; capsules when young intermixed with red-brown, hair-like, crisped paraphyses.

Java.

(7) D. samoensis, Moore.

Philippines across New Guinea to Polynesia. 
(76) D. Hooveri, Christ.

A plant gathered by Elmer (No. 11430) has all the dimensions nearly half as long as described by Christ, and the fertile quaternary segments partly crenate or lobato-crenate partly entire but then with a single soriferous tooth on the anterior side, the lower anterior segments the largest, with $1-2$ sori on the anterior side, crenate on the upper and inner side, with the lowest anterior tooth often lobe-like and crenated again, with a single sorus borne on the anterior side.

(7c) See No. 5.

(7d) D. terminalis, v. A v. R., in Bull. Btz., 1914, XVI, 6, tab. IV.

Rhizome creeping, densely fibrillose with red-brown, spreading, articulated hairs. Stipes scattered, $50 \mathrm{~cm}$. more or less long, glossy, reddish-brown when dry, deciduously fibrillose, at length rough. Fronds ovate, acuminate, $\pm 30-35 \mathrm{~cm}$. long, nearly as broad, 4-5-pinnatifid, the rachises soon naked, with a few persistent fibrils on the grooved upper side. Pinnae stalked, close; higher pinnae lanceolate, acute, with the lower anterior pinnulae spreading, produced, the lowest posterior suberecto-patent, the rachis narrowly winged lowest pinnae longest, $\pm 17^{1 / 2}-20 \mathrm{~cm}$. long, $7 \frac{1}{2}-10 \mathrm{~cm}$. broad at the base, the lowest posterior pinnulae the longest. Pinnulae petiolulate, lanceolateoblong, to $9 \mathrm{~cm}$. long and $3 \mathrm{~cm}$. broad, in shape similar to the higher pinnae. Tertiary segments oblong, the largest to $2 \mathrm{~cm}$. Iong and $3 / 4 \mathrm{~cm}$. broad, bluntish, cut down nearly to the costa into $\pm 3-4$ pair of oblique, decurrent, simple or 2-3-fid leaflets; simple leaflets linearoblong; to $\pm 5 \mathrm{~mm}$. long, $1 \mathrm{~mm}$. broad, bluntish or subacute; incised leaflets subobovate-cuneate, to $7 \frac{1}{2} \mathrm{~mm}$. long. Texture subcoriaceous; surfaces naked; a central vein in each ultimate segment, not reaching the apex. Sori terminal on the ultimate segments; indusium cupuliform.

Sumatra.

(7e) D. multifiala, v. A. v. Re., in Bull. Btz., 1915, XX, 10.

Stipe and rachises provided with deciduous, fibril-like, articulated, pale hairs, as are the costae, costulae and veins beneath. Fronds \pm 80 $\mathrm{cm}$. broad at the base, copiously sub-5-pinnate. Largest pinnulae triangular-oblong, to $\pm 20 \mathrm{~cm}$. long, to $\pm 7 \frac{1}{2} \mathrm{~cm}$, broad at the base.

Ferns and Fern Alties. 
Quaternary segments linear-oblong, to $1 \frac{1}{2} \mathrm{~cm}$. long by $1 / 2 \mathrm{~cm}$. broad, deeply pinnatifid, subpinnate at the base, the apex 1-3-dentate. Texture coriaceous; upper surface naked; rachises canaliculate above. Sori numerous; higher sori terminal on short, blunt lobules $\pm 2 \mathrm{~mm}$. long and $1 \mathrm{~mm}$. broad; lower sori often surpassed by a lateral, subacute, simple or 2 -fid horn to $2 \mathrm{~mm}$. long; indusium 2-valved, the valves hemispherical.

Java.

(8) D. javanica, Christ.

Omit this species, it being referred to Balantium.

(8a) D. acuminata, Rst., in Hedwi., LVI, 350.

Rhizome erect, the apex clothed with reddish-brown, lanceolate scales. Stipes $45 \mathrm{~cm}$. more or less long, stramineous, fuscous at the base, provided with scattered, deciduous, ferrugineous, lanceolate scales when young. Fronds ovate-lanceolate, to about $60 \mathrm{~cm}$. long by $35 \mathrm{~cm}$. broad, 4-pinnatifid, acuminate; rachises and costae stramineous, provided beneath with a few deciduous, lanceolate squamules. Pinnae to about 40 on a side, suberecto-patent, short-stalked, lanceolate; largest pinnae about 20 $\mathrm{cm}$. long, $6 \mathrm{~cm}$. broad below the middle, produced on the anterior side, acuminate, obliquely truncate-cuneate at the base; lower pinnae somewhat smaller. Pinnulae similar in shape, the lowest anterior the largest, about $6 \mathrm{~cm}$. long by $2 \mathrm{~cm}$. broad. Tertiary segments sessile, the higher elongate-oblong; decurrent, confluent, toothed, the lower lanceolate, narrowly cuneate at the base, deeply pinnatipartite with incurved, linearoblong lobes narrowed at the apex Texture subcoriaceo-chartaceous; surfaces naked; veins mostly simple, the lower forked or subpinnate. Sori terminal on the teeth, recurved.

New Guinea.

(10) D. cumenta, Moore; - var. obtusa, Copel., in Philipp. Journ., VIIC, 63.

Forma typica: Pinnulae acute or acuminate. - Philippines, Batjan.

Var. olotusis: Pinnulae obtuse. - Borneo.

(12) W. Haccida, Bernh.; Dicksonia flaccida, Sw.

Glabrous or subglabrous in Malayan and more or less copiously hairy in 
Papuan and Polynesian material. Secondary and tertiary divisions spreading or more or less oblique. - Two forms united by intermediates:

Forma typica (Hassk., Fil. Jav., 57): Fronds 4-pinnatifid; pinnulae up to $\pm 8-10 \mathrm{~cm}$. long, to $\pm 21 / 2 \mathrm{~cm}$. broad, the base truncate; tertiary divisions to $\pm 11 / 4 \mathrm{~cm}$. long, to $4 \mathrm{~mm}$. broad, pinnatifid $1 / 2-3 / 4-$ way down to the costa, the apex toothed, the base obliquely cuneate-truncate, broadest on the upper side, the lobes oblong, close, crenate or toothed, at best $3 \mathrm{~mm}$. long.

Forma decomposita (v. A. v. R., in Bull. Btz., 1912, VII, 11; Schk., Krypt. Gew., I, tab. 129): Fronds 4-pinnate or nearly so; pinnulae \pm $10-20 \mathrm{~cm}$. long, up to $5 \mathrm{~cm}$. broad; tertiary divisions obliquely cuneatesubtruncate at the base, up to $\pm 2 \frac{1}{2} \mathrm{~cm}$. long, to $1 \mathrm{~cm}$. broad, cut down to a narrowly winged costa into small, more or less distant, obliquely cuneate-oblong leaflets; leaflets cuneately narrowed at the base, oblique, the lowest anterior one the largest, up to $5 \mathrm{~mm}$. long, to $3 \mathrm{~mm}$. broad, with the edge crenate, toothed or pinnatifid.

Sumatra, Java, New Guinea; Polynesia.

(12a) D. concinma, Rst., in Hedwi., LVI, 349.

Fronds large, $4 \mathrm{~m}$. or more long, $1 \mathrm{~m}$. broad, 4-pinnate. Pinnae to $1 \mathrm{~m}$. long, $30 \mathrm{~cm}$. or more broad, elongate-ovate-lanceolate, acuminate, the acumen shortly linear, serrate. Pinnulae about 50-jugate; higher pinnulae sessile, following short-stalked, horizontal, linear-lanceolate, longacuminate, obliquely truncate-cuneate at the base; central pinnulae largest, $15 \mathrm{~cm}$. long by $3 \mathrm{~cm}$. broad. Tertiary segments trapezoid-oblong, to $1 \frac{1}{2} \mathrm{~cm}$. long by $7 \mathrm{~mm}$. broad, pinnatifid in the upper part, pinnate in the lower part. Ultimate segments oblique, elongate-obovate, 4-5 on a side, narrowed at the subcuneate base, obtuse, entire or erenulate, the lower produced, sparingly lobed. Texture subeoriaceous; colour pale-green; costae densely setulose, veins less so. Sori 1 to each lobule, near the costula, below the sinus.

New Guinea.

(13a)

D. Elmeri, Copel.

Elmer's No. 8027 has the main rachis distinctly, though minutely, pubescent above. 


\section{OLEANDIRA, Cavanilles.}

\section{(3) D. colubrina, Copel.}

Also in New Guinea, Celebes.

(3a) D. oblanceolada, Copel., in Philipp. Joum., VIIC, 64.

Stipes short, articulated at the apex. Fronds oblanceolate, \pm 18 $\mathrm{cm}$. long and $3 \frac{1}{2} \mathrm{~cm}$. broad, abruptly and finely caudate at the apex, narrowed gradually towards the truncate base. Texture coriaceous; surfaces naked. Sori close to the costa.

Borneo.

(4a) 1. coriacest, Copel., Journ. Str. Br. R. A. Soc., LXIII, 72. Stipes to $1 \frac{1}{2} \mathrm{~cm}$. or a little more long, articulated near the base, densely and minutely squamulose. Fronds linear-lanceolate, $20-25 \mathrm{~cm}$. long, $1^{3 / 4} \mathrm{~cm}$. or more broad, very narrowly caudate. Texture coriaceous; colour reddish; upper surface glabrescent, lower minutely white-hairy; costa squamulose beneath, the scales linear, castaneous; veins prominent. Sori nearer the margin than the costa.

\section{Borneo.}

(5a) D. geniculata, v. A. v. Re, in Bull. Btz., 1914, XVI, 23; 1915, XX, tab. IV.

Rhizome wide-creeping, woody, remotely branched, scaly; branches opposite or nearly so, short, or elongated and similarly branched again, regularly flexuose, with the internodations arched, the arches open above, the nodes knee-shaped; scales adpressed, long-acuminate-lanceolate, when young pale-brown, ciliate, the ciliae cobwebby, when adult dark-brown or glaucous-brown, subentire. Stipes $3 / 4-2 \mathrm{~cm}$. long; articulate at the base, placed in pairs on the apices of the rhizome-branches and the knee-tips. Fronds linear-lanceolate, $\pm 20-50 \mathrm{~cm}$. long, $2-4 \frac{1}{2} \mathrm{~cm}$. broad at te middle, entire, narrowed gradually to the acuminate apex and the subcuneate, rotundate, rotundate-truncate or rotundate-cordate base. Texture papyraceo-coriaceous; surfaces deciduously pilose, glabrescent; costa beneath deciduously hairy and sparingly scaly, glabrescent. Sori in an irregular line on each side, near the costa; indusium partly transversely oblong partly reniform, ciliolate when young:

Java. 
(7) D. Cuningit, J. Sm.

Var. Sibbaldiî. - Also in New Guinea.

\section{(9) W. Whitmeei, Bk.}

Also in New Guinea.

\section{ARTHROPTERIS, J. Smith.}

(1) A. obliterata, J. Sm.; - var. inciso-crenata, Rst., in Fed., Rep., X, 339.

Forma typica: Fronds $2 \frac{1}{2}-8 \mathrm{~cm}$. broad. - Paleotropical.

Forma dilatatissima: Fronds $8-12 \mathrm{~cm}$. broad. - Java.

Var. imcisa-crenata: Texture thin; veins distinct; edges deeply inciso-crenate. - New Guinea.

(3) A. caudata, Rst., in Fed., Rep., VIII, 163.

Rhizome wide-scandent, scaly. Stipes scattered, $\pm 3 \mathrm{~cm}$. long; compressed, sulcate in front, the lower part clothed with subdeltoid or ovate-lanceolate, peltate, fimbriate scales. Fronds ovate-elongate, narrowed towards both ends, $\pm 40 \mathrm{~cm}$. long, $3 \frac{1}{2}-5 \mathrm{~cm}$. broad below the middle, pinnate, acuminate, the acumen linear-lanceolate, entire, or lobed in the lower part. Pinnae to 30 or more on each side, sessile, horizontally spreading, subcontiguous, the lower more distant, deflexed, the largest $\pm 1 \mathrm{~cm}$. broad, entire, linear-oblong, obtuse; upper base truncate, obtusely auricled, lower nairrowly cuneate. Texture thin to subcoriaceous; surfaces naked, black-green; rachis rufous, glabrescent, short-hairy at the points of insertion of the pinnae; costae hardly prominent, immersed above, as are the veins, the lower part short-hairy; veins forked, the lowest anterior veins pinnate. Sori remote, somewhat distant from the margin.

New Guinea.

(4) A. Kingii, Copel., in Philipp. Journ., VIC 80.

Rhizome ereeping, slender, black, deciduously scaly. Stipes remote, 3-5 cm. long, black, jointed $\pm 2 \mathrm{~cm}$. above the base. Fronds $12-20$ $\mathrm{cm}$. long, 4-4 $\frac{1}{2} \mathrm{~cm}$. broad, acuminate, hardly narrowed at the base, 
the rachis puberulous with very short, grey hairs. Pinnae horizontal, sessile, subacute, auriculated on the upper side at the base, blackish when dry. Indusium more or less persistent.

New Guinea.

(5) A. oblanceoluta, v. A. v. Th., in Bull. Btz., 1915, XX, 6.

Rhizome scandent, wiry, sparingly scaly. Stipes seattered, very short, sparingly sealy. Barren fronds oblanceolate-oblong, $\pm 12_{12}^{1}-15$. $\mathrm{cm}$. long, $\pm 2 \frac{1}{2}-4 \mathrm{~cm}$. broad at or above the middle, pinnate, the sides subparallel in the broadest portion, the apex short-acuminate. Pinnae $\pm 15-20$ on a side; terminal pinna rather small, rhomboidal, subacute, the base cuneate or decurrent, often obliquely hastate-auriculate; lateral pinnae rhomboidal-oblong; horizontal or nearly so, the largest \pm $2 \mathrm{~cm}$. long by $\pm 7^{1 / 2} \mathrm{~mm}$. broad, the apex broadly rounded, the edges entire or subentire, subparallel, sparingly and deciduously ciliolate, the upper base cuneate-truncate, subparallel to the rachis, bluntly auriculate, the lower base more narrowly cuneate; lower pinnae growing gradually shorter, deflexed. Texture papyraceous; surfaces naked; rachis sulcate above, deciduously pubescent beneath, the hairs ochraceous or rufous; veins oblique, forked, the lowest anterior pinnate. Fertile fronds...... Obi Island.

\section{NEPHIROLEPIS, sekot.}

\section{\& 1. LINDSAYOPSIS.}

(1) N. dicksonioides, Christ.

Also in New Guinea.

(1a) N. Tosenstockii, Brau., in Lautb., Beitr. Flor. Pap., I, 25.

Stipes $\pm 15 \mathrm{~cm}$. or more long, grooved down the face and provided with caducous, ferrugineous scales, soon glabrescent, as is the rachis. Fronds linear-lanceolate, $\pm 11 / 2 \mathrm{~m}$. long and $17 \mathrm{~cm}$. broad, narrowed at both ends. Pinnae sessile, dimorphous, close; barren pinnae linear-falcate, to $81 / 2 \mathrm{~cm}$. long and $1 \frac{3}{4} \mathrm{~cm}$. broad, long-acuminate, slightly crenate, oblique at the upper base, rounded or cordate at the lower base, the 
lower reduced, roundish-ovate; fertile pinnae to $12 \mathrm{~cm}$. long, under $1 \mathrm{~cm}$. broad, deeply pinnatifid but only slightly incised at the base, the lobes $\pm 1 / 4 \mathrm{~mm}$. broad, dilated at the apex when fertile. Texture chartaceous; surfaces bright-green, naked; costae naked; veins approximate, once or twice forked. Sori terminal on the lobes, similar to those of $\mathrm{N}$. dicksonioides Christ.

New Guinea.

(37) Q. Sehlechteri, Brau., in Lautb,, Beitr. Flor, Pap., I, 24.

Rhizome short, erect. Stipes tufted, $\pm 11 \mathrm{~cm}$. long, grooved down the face, the base densely clothed with linear, entire, long-acuminate scales. Fronds linear-lanceolate, to $50 \mathrm{~cm}$. long, $6-7 \mathrm{~cm}$. broad, hardly narrowed at the base, the rachis piloso-squamulose. Pinnae short-stalked, linear-lanceolate, rather truncate at te base, falcate, the largest $3-4 \mathrm{~cm}$. long, 5-7 mm. broad, the fertile ones the longest and narrowest; barren pinnae entire, but crenate or serrate towards the apex, fertile ones crenate. Texture chartaceous; surfaces fibrilloso-squamulose when young, at length naked; veins forked, not reaching the margin, the fertile ones with the posterior fork-branch sterile and much abbreviated. Sori numerous in the higher pinnae, less so in the lower; indusium cup-shaped.

Nero Guinea.

\section{\& 2. EUNEPHROLEPIS.}

(8) v. hirsurula, Fr.; Aspidinm hirsutulum, Sw., Schk., Krypt. Gew., I, tab. 33.

Differs from N. tomentosa $v$. A. v. R. by the absence of the fibrillose tomentum on the rachis; pinnae clothed beneath with fimbriate or ciliate, lanceolate scales.

(8a) N. tomentosa, v. A. v. R., in Bull. Btz., 1911, I, 11; $1913, \mathrm{XI}, 17$.

Near N. hirsutula $\mathrm{Pr}$. but the fronds narrower, to $\pm 5 \mathrm{~cm}$. broad, the rachis deciduously floccoso-squamulose, and tomentose with crowded, squarrose or crisped, articulated, reddish-brown, persistent fibrils, the pinnae (both barren and fertile) blunt or bluntly rounded at the apex, $\pm 1 / 2 \mathrm{~cm}$. broad, with the costa tomentose (like the rachis) on the upper 
side towards the base, and the under side deciduously scaly and shorthairy, at length glabrescent. Sori submarginal.

Java.

(8b?) N. niphoboloides, v. A. v. R., in Bull. Btz., 1913, XI, 18.

Like N. hirsutula Pr, but the fronds narrower and both rachis and pinnae clothed with woolly tomentum consisting of long, crowded, interlaced, curved or flexuose, deciduous hairs placed in groups of 3-6 and springing from a minute, stellate-peltate, scale-like centre. Sori ... Karimon Java Islands.

(8c) N. pilosula, v. A. v. R., in Bull. Btz., 1913, XI, 18.

Rhizome short, the scales dark-brown, pale-margined and sparingly ciliolate-dentate, subulate. Fronds lanceolate, $60-90 \mathrm{~cm}$. more or less long, $\pm 10-20 \mathrm{~cm}$. broad, acuminate, te rachis when young densely scaly and pilose, as is the stipe, at length glabrescent, the scales palebrown, more or less adpressed and slightly crisped, linear-subulate, finely acuminate, the hairs spreading, copious, reddish-brown. Pinnae numerous remote, horizontal or nearly so, often prominently (bluntly to acutely) auriculate at the truncate upper base, not or less so at the truncate. rotundate to abruptly cuneate lower base, the edge shallowly and rather broadly crenated, the central pinnae the longest, linear, $\pm 11_{2}-2 \mathrm{~cm}$. broad, the lower more or less reduced, and rounded at the apex, the higher growing gradually shorter, acute to acuminate and more prominently serrate-crenate at the apex; fertile pinnae often conspicuously crenate-dentate. Texture membranaceous to coriaceous; costae and surfaces copiously (not densely) pilose; the hairs of the upper surface deciduous, those of the under surface more persistent, those of the costae intermixed with deciduous, long, fine, subfiliform scales. Sori distant from the margin; indusium orbicular-reniform, with a closed sinus.

Borneo.

(8d) See No. 12.

(10) N. cordifolia, Pr.; - var. calcarea, Christ, in Nov. Guin., VIII, Bot., 158.

Var. calcarea : Pinnae less hlunt, rather acute, subfalcate; sori submarginal; indusium round, the basal lobes close or overlapping. - New Guinea. 
(10a) N. Clementis, Christ, in Philipp. Joum., IIIC, 272.

Rhizome unknown. Stipes $4-9 \mathrm{~cm}$. long, terete, stramineous, chaffy with ochraceous, peltate-ovate seales, as is the rachis. Fronds 25-40 cm. long, $\pm 4 \mathrm{~cm}$ broad, elongate-cordate. Pinnae numerous, close, sessile, ovate-hastate at the base; lower pinnae barren, obtuse, \pm $2 \mathrm{~cm}$. ıong, hardly $1 \mathrm{~cm}$. broad, the very lower ones roundish; fertile pinnae acute, $\pm 2 \frac{1}{2} \mathrm{~cm}$. long, $\pm 1 / 2$ broad. Texture subcoriaceous; surfaces smooth; colour ochraceous-green, opaque; costae slender; veins numerous, close, oblique, many provided with a terminal, calcareous, dot-like scale on the upper surface. Sori rather marginal; indusium peltato-reniform. Between N. cordifolia $P r$. and N. radicans $K u h n$, with a semi-indefinite growth of the leaf.

\section{Mindanao.}

\section{(11) N. radicans, Kuhn.}

Scales of rhizome branches lanceolate, entire or hardly ciliolate, castaneous with a ferrugineous margin or ferrugineous with a more or less broad, castaneous, central patch, adpressed; both barren and fertile pinnae bluntly rounded at the apex, or te fertile ones more acute and not rarely more or less falcate, resembling those of N. exaltata Schott. but smaller, and the sori somewhat immersed.

(11a?) N. ir.idescens, v. A. v. R., in Bull. Btz., 1915, XX, 21.

Stipes aggregate, $\pm 5-12 \frac{1}{2} \mathrm{~cm}$. long and, like the rachis, darkolivaceous (often nearly black) and provided with deciduous, dark (often nearly black), iridescent, lanceolate, acute or acuminate, irregularly fimbriate-ciliate scales. Fronds linear, more than $40 \mathrm{~cm}$. long in the fully developed plant, $\pm 3-3 \frac{1}{2} \mathrm{~cm}$. broad, narrowed towards both ends. Pinnae horizontal; barren pinnae oblong, the largest approximate, to $13 / 4$ $\mathrm{cm}$. long by $\pm 5 \mathrm{~mm}$. broad, blunt or rounded at the apex, broadly and shallowly crenate to serrate-crenate, the base truncate or rather obliquely subtruncate, rather distinctly auriculate on the upper side, less so on the lower side; lower pinnae gradually more remote and auricle-like. Texture coriaceous; surfaces naked; costae somewhat dark-scaly towards the base beneath; veins oblique, forked. Fertile pinnae....

Kei Islands.

\section{(12) M. Wnrbata, Copel.}

Specimens received from Negros Island differ from Copeland's diagnosis 
in having the rachis copiously deciduously scaly with dark-brown, nearly blackish, rather entire scales, the barren pinnae partly subentire partly coarsely serrate, provided beneath with copious fine, nearly hair-like, deciduous scales.

(14) N. biserrata, schott.; - var. laurifolia; N. laurifolia, Christ, Copel., in Leafl., II, 394.

(15) N. persicifolia, Christ, in Nov. Guin., VIII, Bot,, 159.

Rhizome firm, creeping, clothed with scattered, brown, lanceolate, lacerate scales. Stipes rather thick, yellowish, to $50 \mathrm{~cm}$. long, copiously scaly and setose. Fronds lanceolate-oblong, $\pm 80 \mathrm{~cm}$. long, narrowed towards both ends. Pinnae \pm 25 on each side, lanceolate, the largest $19-20 \mathrm{~cm}$. long, $\pm 2-31 / 2 \mathrm{~cm}$. broad, rather sessile, the base broadly cuneate or subtruncate, the margin crenate-serrate, the apex acuminate. Texture papyraceous to chartaceous, thin, rather diaphanous; colour bright-green; rachis setose; veins fine, forked, clavate at the apex. Sori numerous, submedial between the costa and margin, nearer the latter; indusium small, rather orbicular, hidden among the capsules at maturity.

New Guinea.

\section{CYCLOPELTIS, J. Smith.}

\section{(1) C. semicordanta, J. Sm.}

Forma typica: Fronds lanceolate-oblong; lower pinnae remote, somewhat abbreviated.

(1a) C. Iatupana, v. A. v. $\boldsymbol{\text { R. }}$, in Bull. Btz., 1914, XVI, 5.

Stipes to $10 \mathrm{~cm}$. or more long, pubescent and scaly, as is the rachis, the hairs very short, nearly gland-like, the scales proportionally long and narrow, ferrugineous, the lower scales rather dense, filiformsubulate, the higher more scatterred, crisped, hair-like. Fronds lanceolate, $\pm 30-35 \mathrm{~cm}$. long, $12-15 \mathrm{~cm}$. broad at or below the middle, pinnate. Pinnae remote, articulate, $10-15$ on a side below the terminal one; central or inframedial pinnae largest, spreading or horizontal, lanceolate, often falcate, $\pm 6-7{ }_{2} \mathrm{~cm}$. long, $\pm 11_{1_{4}}-11_{2} \mathrm{~cm}$. broad, bluntly acuminate, repando-undulate, the upper base rotundate-subtruncate, the 
lower base truncate-cordate or auriculate-cordate, the auricle not incurved; lower pinnae a little shorter, rather straight, nearly equally cordatetruncate to rotundate on both sides at the base; lowest pinnae more or less deflexed; higher pinnae growing gradually smaller, ascending, rotundate-cuneate at the upper base, the highest smaller than the terminal one. Texture subcoriaceous; surfaces naked; costae beneath sparingly deciduously long-hairy in the lower part; veins spreading, pinnate with 1-3 branchlets on a side; veinlets alternate, erect, parallel to the veins, the lower not reaching the margin. Sori in 2 rows on each side of the costae, the inner row occupying the lowest anterior, the outer row the lowest posterior veinlets; indusium peltate, persistent.

Celebes.

\section{(2) C. Preslinana, Berk.}

Forma typica: Fronds lanceolate; lower pinnae gradually much reduced.

(3) C. novoguineensis, Rst., in Fed., Rep., X, 329; ? C. Presliana, Berk., var. biauriculata.

Rhizome thick, erect, woody, clothed with ferrugineous, narrowly linear, hair-pointed scales. Stipes tufted, $\pm 10 \mathrm{~cm}$. long, 3-sulcate above, convex beneath, pale-brown, densely scaly, upwards glabrescent. Fronds lanceolate-oblong, $80 \mathrm{~cm}$. more or less long; $\pm 20 \mathrm{~cm}$. broad, narrowed gradually towards both ends. Pinnae horizontal, numerous, subapproximate, alternate, the central the longest, subfalcate-linear, \pm $1 / 2-1 \mathrm{~cm}$. broad, narrowed gradually to the acuminate apex, entire or subundulate, minutely appresso-ciliolate, 2-auriculate at the base, the anterior auricle suberect, spur-shaped, adpressed to the under side of the rachis, the posterior circinate, adpressed to the upper side of the rachis; lower pinnae obtuse, deflexed. Texture chartaceo-membranaceous; surfaces naked; rachis shortly tomentose and sparingly scaly, soon naked; costae hardly prominent, provided beneath with scattered, deciduous scales; veins 3-4-furcate. Sori in 1 row on each side, submedial between the costa and margin, terminal or subterminal on abbreviated anterior veinlets, sometimes accompanied by accessory ones placed little beyond the others.

Forma typica: Basal pinnae simple.

Forma subbipinnata: Basal pinnae elongated, pinnate again.

New Guinea. 
(4) C. minabilis, Copel., in Philipp. Journ., IIIC, 346, tab. IV.

Stipes more than $35 \mathrm{~cm}$. long, thick, scaly like the lower part of the rachis, the scales setiform, up to $10 \mathrm{~mm}$. long, often adpressed. Fronds $\pm 60 \mathrm{~cm}$. long, pinnate. Pinnae sessile, $\pm 16 \mathrm{~cm}$. long, $\pm 2 \mathrm{~cm}$. broad, caudate-acuminate, entire or irregularly and coarsely toothed, conspicuously hastate, the basal prongs long, caudate-acuminate, the upper one \pm 3 , the lower $\pm 6 \mathrm{~cm}$. long. Texture coriaceous: surfaces naked; colour olivaceous; rachis short-hairy in the upper part; costae hairy beneath, soon glabrescent; veins pinnate. Sori small, in 4 subregular rows.

Borneo.

\section{POLYSTIOHUM, Roth.}

(2) diaphamum, Moore; - var. Moussetii, v. A. V. R., in Buil. Btz., 1913, XI, 21.

Forma typica: Stipes up' to $\pm 15 \mathrm{~cm}$. long, the scales ferrugineous or pale-ochraceous. Fronds to $\pm 25 \mathrm{~cm}$. long and to half as broad. Pinnae pinnate in the fully developed fronds, pinnatifid towards the apex. Pinnulae obovate or rhomboidal-ovate, $1 / 2-1 \mathrm{~cm}$. long, $1 / 4-3 / 4 \mathrm{~cm}$. broad, toothed or lobed and toothed, the largest mostly distinctly auriculate at the upper base, the teeth irregular, the largest often subulate. Rachises scaly; scales of the main rachis similar to those of the stipe, partly lanceolate and ciliate partly hair-like or stellate with long branches or irregularly fimbriate, as are the hairs of the surfaces and costae. Indusium thin, peltate, fimbriate.

Var. Moussetii: Stipes and fronds somewhat larger, a little firmer, the pinnae more copiously pinnate, with the lower pinnulae whether or not pinnatifid to pinnate, the lobes less toothed, often entire or obscurely crenate.

Java.

(3) T, aculeatum, Schott; Aspidium aculeatum, Sw., Schk., Krypt. Gew., I, tab. 39; — var. microphyllum; A: microphyllum, Bl., Enum., 163; - var. mueronipinnulum, v. A. v. R., in Bull. Btz., 1914, XVI, 60; - var. sordidum, Copel., in Leafl., II, 392.

Teeth, lobes and auricles aristate or spinulose. 
Forma typica: Under surface naked or sparingly fibrillose, the fibrils mostly undivided.

Forma stellata: Under surface provided with copious long-stellate hairs or deeply stellate-fimbriate scales with generally unequal branches.

Var. micropbyllum: Near var. vulcanicum. Pinnulae rather small, mucronate-denticulate, auriculate, the auricle rounded. apiculatedenticulate. Sori not solitary. - Java.

Var. macronipinnulues: : Near var. mucronifolium. Rachises densely thin-scaly; scales pale-ferrugineous; pinnulae longer, pinnate, the lowest anterior segment much the largest, spreading; under surface more copiously paleaceo-pilose. - Java.

Var. Sordidum: Near var. moluccense. Scales dirty-coloured, hardly rufous. - Negros.

(4) P. obtusuran, J. Sm.; - var. densum; ? P. aculeatum, Schott, var. eurylobum, Rst., in Fed., Rep., VIII, 164.

Forma typica: Pinnulae rhomboidal, toothed towards the blunt or mucronate apex, the teeth obscure, or blunt to spinulose, the upper side coarsely crenated or shallowly lobed in the lower part, subauriculate at the base, the crenations, lobes and auricle blunt, truncate or rounded, not toothed, the lower side rather entire. - Luzon.

Var, densum ( $\mathrm{v} . \mathrm{A} . \mathrm{v} . \mathrm{R}$, in Bull. Btz., 1913, XI, tab. VI): Like the type but, the fronds larger, $\pm 40-80 \mathrm{~cm}$. long or even much longer, the pinnae numerous, longer, to $25 \mathrm{~cm}$. long, crowded, the lower not always the largest, to $4 \mathrm{~cm}$. broad, copiously pinnate, the pinnulae crowded, more sharply toothed towards the apex and on the lower side, the lower sometimes more deeply lobed or even deebly pinnatifid on the upper side, and with the auricle not rarely free or nearly so and sometimes minutely apiculate. - Specimens received from and determined by Mousset as P. tenggerense \& P. mucronifolium Rst. resemble this in all respects except that they are in all dimensions larger than in Zippelius' original plant. - Java.

(4a) P. rengarense, Rst., in Fed., Rep., VIII, 164; ? P. obtusum, J. Sin., var. densum.

Large. Stipes stout, stramineous, densely scaly; scales of 2 kinds, the smaller ones subadpressed, ferrugineous, narrowly lanceolate, densely ciliate, the larger ones less numerous, spreading, slightly ciliate, black in 
the centre. Fronds elongate, $200 \mathrm{~cm}$. or more long, $\pm 40 \mathrm{~cm}$. broad, shortly acuminate, the point acute. Pinnae linear-lanceolate, narrowly long-acuminate. Pinnulae trapezoidal-oblong, obtuse, slightly auricled at the base on the upper side, inciso-dentate or lobed, the anterior basal ones somewhat larger, deeply incised, the teeth or lobes broad, hardly aristate. Rachises densely scaly. Sori subcostal.

Java.

(4b) P. Keysserianum, Rst., in Fed., Rep., X, 331.

Stipes stramineous-brown, densely scaly, as are the rachises; scales ferrugineous, membranaceous, flaccid, lanceolate lacerate-ciliate in the lower part, sparingly fimbriate or toothed towards the hair-pointed apex, often very narrow or hair-like. Fronds deltoid-ovate, 3-pinnatifid, or nearly 3-pinnate at the base, $\pm 50 \mathrm{~cm}$. long, $25 \mathrm{~cm}$. broad, shortly acuminate. Pinnae \pm 20 on a side, the lower subopposite, spreading, the higher suberect, alternate, the largest linear-lanceolate, $\pm 18 \mathrm{~cm}$. long, $4 \mathrm{~cm}$. broad, acuminate, pinnatifid in the upper part, pinnate towards the base, somewhat produced on the upper side. Pinnulae short-stalked, suberect, trapezoid-oblong, the lowest anterior the largest, $\pm 4 \mathrm{~cm}$. long and $1 \frac{1}{\mathrm{~s}} \mathrm{~cm}$. broad, pinnatifid towards the serrate apex, deeply pinnatifid or subpinnate at the base, the base decurrent, auricled on the upper side, the petiole winged. Lobes obtuse, erenulate or subentire. Texture subcoriaceous; surfaces naked; upper surface olivegreen, lower paler; colour brownish when dry; costae and costulae densely scaly beneath; veins simple, forked or pinnate. Sori subcostular; indusium unknown (deciduous?).

New Guinea.

(4c) See under No. 5 .

(4d) Wolaneum, Mst., in Fed., Rep., XII, 170; - var. ovalis, Rst., 1. e. 171.

Stipes erect, $15 \mathrm{~cm}$. or more long, densely scaly like the rachises and costae, the scales ferrugineous, partly narrowly linear from a dilated base, fibrillose, partly lanceolate, long-fibrilloso-ciliate. Fronds elongateoblong, $\pm 50 \mathrm{~cm}$. long by $22 \mathrm{~cm}$. broad, acuminate, 2-pinnate. Pinnae numerous, approximate, short-stalked, erecto-patent, linear-lanceolate, acuminate; central pinnae largest, $\pm 8 \mathrm{~cm}$. long by $2 \mathrm{~cm}$. broad; lower 
pinnae somewhat shorter. Pinnulae short-stalked, spreading or suberect, subapproximate, trapezoid-oblong, the edge obtusely toothed, the upper base auriculate, truncate, the lower base cuneate. Texture rigidly chartaceous or coriaceous; veins subimmersed, the higher simple, the others $2-3 \times$ forked, the lowest anterior pinnate in the auricle; upper surface naked, lower sparingly fibrillose. Sori nearer the costae than the margin.

Vor. ovalis: Fronds broadly oval; pinnae and pinnulae close; pinnulae hardly auricled; teeth more acute.

New Guinea.

(4e) alpioum, Rst., in Fed., Rep., XII, 171.

Rhizome erect, the scales ferrugineous, lanceolate, long-acuminate, denticulate. Stipes $10-20 \mathrm{~cm}$. long, castaneous at the base, stramineous upward, clothed like the rachis with scales similar to those of the rhizome but shorter, fibrillose. Fronds $\pm 10-20 \mathrm{~cm}$. long, $4-6 \mathrm{~cm}$. broad, 2-pinnate, obtuse. Pinnae $10-15$ on a side, suberecto-patent, subapproximate, short-stalked, deltoid-oblong, obtuse; lowest pinnae largest, $2-4 \mathrm{~cm}$. long by $1 \frac{1}{2}-2 \mathrm{~cm}$. broad. Pinnulae petiolate, subcontiguous, ovate or obovate from a cuneate base, subentire or crenate, rarely acutely toothed, the teeth sometimes aristate; lowest pinnulae auricled, the auricle often free. Texture subcoriaceous; surfaces sparingly fibrillose; rachises fibrilloso-paleaceous; veins immersed, subflabellate or pinnate. Sori medial; indusium minute, caducous.

New Guinea.

(5a) R. Bamlerianune, Iest., in Fed., Rep., X, 330; - var. ferrugineo-paleaceum, Rst., 1. c., 331.

Stipes red-brown, to $\pm 30 \mathrm{~cm}$. long, clothed with crowded, deciduous, linear-lanceolate, long-acuminate, denticulate, blackish scales, the teeth simple or 2-fid. Fronds elongate-ovate, 3-pinnate, $\pm 45 \mathrm{~cm}$. long and $10 \mathrm{~cm}$. broad, shortly acuminate. Pinnae numerous, contiguous, erectopatent, straight or flexuose, short-stalked, linear-lanceolate, gradually acuminate, serrate towards the apex, the central ones $\pm 12 \mathrm{~cm}$. long and $2 \mathrm{~cm}$. broad, the lowest $\pm 9 \mathrm{~cm}$. long. Pinnulae suberect, shortstalked, trapezoid-oblong; subacute, obliquely and broadly cuneate at the base, the central ones to $1 \frac{1 / 2}{1 / 2} \mathrm{~cm}$. long, $1 / 2 \mathrm{~cm}$. broad, pinnatifid, pinnate and subauriculate at the base, the lowest elongated, the higher smaller, 
sessile. Tertiary segments oblique-oblong, acute, aristate, repando-crenate or sparingly aristate-dentate. Texture subcoriaceo-chartaceous; rachises and surfaces scaly; veins simple, forked or pinnate. Sori medial; indusium orbicular, peltate, coriaceous.

Var. ferrugineo-paleaceun : Scales ferrugineous; pinnulae entire, hardly auriculate.

Newo Guinea.

(6a) Tr. trumcatulusat, v. A. v. Th., in Bull., Btz., 1914, XVI, 60, tab. VIII.

Rhizome short, the scales brown, narrowly subulate, subentire. Stipes $\pm 15 \mathrm{~cm}$. long, densely scaly like the rachis; scales partly long, subulate, spreading, reddish-brown, entire, partly minute, subadpressed, irregularly fimbriate, ferrugineous. Fronds lanceolate, $45 \mathrm{~cm}$. more or less long, \pm $15-20 \mathrm{~cm}$. broad at the middle, acuminate. Pinnae somewhat remote, spreading or horizontal, to $\pm 10 \mathrm{~cm}$. long and $1 \%$ cm. broad, acute, the lower gradually abbreviated, deflexed, more remote. Pinnulae linearoblong, approximate, nearly horizontal, the largest $\pm 3 / 4-1 \mathrm{~cm}$. long by $\pm 3-4 \mathrm{~mm}$. broad, connected at the base by a very narrow wing, subentire or indistinctly crenulate or hardly toothed, the apex rounded or truncate, the base broadly adnate; lowest pinnulae rather narrowly adnate at the base. Texture subcoriaceous; surfaces sparingly fibrillose or hairy on the costulae and veins; costae (secondary rachises) fibrillosopilose above, scaly beneath; costulae flexuose; veins simple or forked. Sori medial; indusium reniform, persistent, at length deflexed and crisped. - An alpine species.

Java.

(90) F. Iastredides, Inst., in Fed., Rep., IX, 425.

Fronds 2-pinnatifid, probably 2-pinnate at the base, the apex acuminate, deeply pinnatifid, the main rachis livid-brown, rather naked beneath and deciduously fibrillose above, as are the costae. Pinnae ascending; central pinnae alternate, shortly petiolate, linear-lanceolate, $\pm 11 \mathrm{~cm}$. long, \pm $2 \% \mathrm{~cm}$. broad, broadly cuneate and unequal-sided at the base, the upper base the broadest, the edge cut down nearly to the costa; lower pinnae probably pinnate. Secondary segments ascending, linear, subfalcate, \pm $11 / 4 \mathrm{~cm}$. long and $4 \mathrm{~mm}$. broad, approximate, acute, somewhat narrowed near and slightly dilated at the base, the lowest anterior the largest, 
the edge subrevolute; shortly and sharply serrate but more distinctly so towards the apex. Texture coriaceous; surfaces naked; upper surface blackish when dry, lower paler; veins $\pm 5-6$ on a side, deeply forked: Sori $4-5$ on a side, medial; indusium round, peltate; coriaceous; blackish, rather persistent, slightly erose at the edge.

New Guinea.

(10) P. aristatum, Pr.; Aspidium aristutum, Sio., Schk., Krypt. Gew., I, tab. 49.

\section{DIDYMOOHIA ENA, Deswax.}

D. Iunulata, Desv.; - var. oceanica; D. truncatula, J. Sm., var. ozeanica, Rst., in Fed., Rep., V, 374.

Var. ceeanica: Pinnulae smaller, at best $9 \mathrm{~mm}$. long and 4 $\mathrm{mm}$. broad, truncate at the apex; sori more numerous, $6-9$ on the largest pinnulae. - New Guinea.

\section{PI,EOCNEMIA, Prest.}

(1) T. heterophylla, v. A. v. R.; Dryopteris huterophylla, 0. Ktze, Rev. Gen. Pl., II, 813; C. Chr., Ind. Fil., Suppl.

(4) Leuneann, Pr.; P. Cumingiana, $P_{r}$, Copel., in Leafl., II, 392; - var. echinocarpa, Rst., in Fed., Rep., X, 337; - var. lobato-crenata, Rst., 1. c. 338; ? Dryopteris chrysotricha, C. Chr., Ind. Fil. (Nephrodium chrysotrichum, Bk., in Ann of Bot., V, 328).

Var. hemiteliiformis: Omit this variety, it being referred to Dictyopteris hemiteliiformis $v, A . v, R$.

Var. echinocarpa: Texture thinner; under surface clothed with scattered, adpressed, white or yellow hairs. - New Guinea.

Var. Iobato-erenata: Like the preceding but the hairs more crowded, and the lobes elongated, coarsely toothed; costal arches not rarely wanting. - New Guinea.

Ferns and Fern Aluies. 
(5) P, gigantea. Pr.; Tectaria gigantea, Copel., in Philipp. journ., VIIC, 141.

\section{6) P. membranifolia, Bedd.}

Veins commonly quite free in the forms with the most contracted fertile fronds, forming loops near the costae in the barren.

(6a) P. fibrillifera, v. A. v. R., in Bull., Btz., 1914, XVI, 28; Aspidium fibrilliferum, v. A. v. R., MS. in Herb. Bog.

Rhizome densely scaly, the scales linear-subulate, fuscous, sparingly piloso-denticulate. Stipes to $25 \mathrm{~cm}$. or more long, deciduously fibrillose like the rachis, deciduously scaly at the base. Fronds elongate-ovate, to $40-50 \mathrm{~cm}$. or more long, $\pm^{{ }^{\prime}}{ }_{2}$ as broad, acuminate, pinnate, pinnatifid at the apex. Pinnae opposite or nearly so, $\pm 6-8$ on a side, falcate, arcuate-ascending, the higher lobed, the lower deeply pinnatifid, $\pm 4-4 \frac{1}{2}$ $\mathrm{cm}$. broad at the truncate base, the lowest stalked, broader, with at least the lowest posterior segment free, elongate, falcate, deeply lobed. Lobes close or nearly so, oblique, oblong or linear-oblong, the smallest blunt, entire to serrate, the largest acute or subacute, lobed, often separated by a small tooth in the sinus. Texture herbaceous; surfaces more or less sparingly fibrillose on the costae, costulae and veins; veins forming 1-2 rows of areolae on each side of the costae and costulae, without free veinlets, the higher and those near the margins free. Sori in 1 row, medial between the costulae and margin, compital, or partly terminal and medial on free veins; indusium minute, deciduous.

Sumatra.

(7) Trimeni. Bedd.; Aspittum. Trimeni, Diels, in Engl. \& Prantl, Nat. Pfl.fam., I ${ }^{4}, 185$; C. Chr., Ind. Fil., Suppl.

Malaya; Ceylon, South India.

(ia) L. malnyensis, v. A. v. R.; ? P. Trimeni, Bedd.; Tectaria malayensis, Copel., in Philipp. Journ., II ${ }^{\mathrm{C}}$, 416; Aspidium malayense, Christ, in Philipp. Journ., II ${ }^{\mathrm{C}}$, 187; C. Chr., Ind. Fil., Suppl.

Stipes brown, more or less densely scaly, the basal scales long, lanceolate-subulate, black-brown, rigid, the others similar to those of the main rachis, black, setiform; main rachis brown or yellow. Pinnulae 
narrowly lanceolate, lohed or pinnatifid, the lobes orate-lanceolate, acute, coarsely toothed. Surfaces nearly naked; veins blackish. Indusia peltate. - A duplicate of Elmer's No. 11742, from Mount Apo, has the main rachis sparingly scaly, roughish, the pinnulae about $15-20 \mathrm{~cm}$. long, $2-5 \mathrm{~cm}$. broad, the higher pinnulae connected, sinuate-lobate, the lower pinnatifid, the lobes blunt, entire to lobate-dentate, the veins forming 1-2 rows of areolae on each side of the costae and costulae (except in the higher pinnae and lobes, where they are anastomosing less copiously), for the rest free towards the margin, the sori in 1 row (or more commonly 2 irregular rows) on each side of the costulae, or scattered in the larger lobes, the indusia reniform.

Philippines, Malacca: Br. India.

(7b) W. Eingii, v. A. v. R.; Tectaria Kingii, Copel, in Philipp. Journ., IX ${ }^{\mathrm{C}}, 4$.

Stipes $\pm 4 \mathrm{~cm}$. long, castaneous, provided at the base with a few scattered, narrowly linear scales. Fronds deltoid, $\pm 30-35 \mathrm{~cm}$. each way, 3-pinnate at the base. Lowest pinnae deltoid. Upper surface naked, lower nearly so; veins slightly tomentose. Sori small, numerous, often submarginal.

New Guinea.

(8) P. Levexa, v. A. v. R.; - var. novoguineensis; P. membranacea, Bedd., var, novoguineensis, Rst., in Fed., Rep., X, 338.

Oar. and (a) castaneous, shortly tomentose above; pinnae broader and shorter; veins forming 1-3 costal areolae; otherwise like var. minor. - New Guinea.

\section{DLYOFTELIS, Adunson.}

\section{§ 1. LASTREA.}

(2a) D. uranetensis, Copel., in Leafl., V, 1682.

Rhizome short-creeping. Stipes close, $3-10 \mathrm{~cm}$. long, densely clothed with curved, pale hairs, as is the rachis. Fronds linear-lanceolate, 8-15 cm. long, acuminate, pinnnate towards the base, otherwise pinnatifld. 
Segments $3 \mathrm{~mm}$. broad, oblong, rounded at the apex, revolute at the margin; lower pinnae often remote and reduced, petiolulate, central sessile, lobato-dentate; higher adnate. Texture papyraceous; surfaces minutely hairy; under surface glandular; lower veins at best anastomosing in the larger pinnae only. Sori medial; indusium hirsute.

\section{Mindanao.}

(3a) D. conversa, v. A. v. R., in Bull., Btz., 1915, XX, 13.

Rhizome short, clothed with lanceolate-subulate, entire, fuscous or ferrugineous scales. Stipes slender, $\pm 2-6 \mathrm{~cm}$. long, ferrugineo-tomentose, as is the rachis, the tomentum intermixed with numerous proportionally long, narrowly subulate, entire, subcurved or subflexuose scales. Fronds elongate-ovate, $\pm 7 \frac{1}{2}-10 \mathrm{~cm}$. long, $\pm 3-5 \mathrm{~cm}$. broad, pinnate. Terminal pinna entire, crenate or toothed towards the apex, deeply pinnatifid at the base with toothed or lobed, decurrent-confluent segments; lateral pinnae toothed in the upper part, deeply pinnatifid towards the base; higher and central pinnae adnate and more or less decurrent at the base, the largest lanceolate, to $\pm 3 \mathrm{~cm}$. long and $1 \mathrm{~cm}$. broad, the lobes entire, acute or bluntish; lowest pinnae short-stalked, broadly deltoid, to $\pm 2 \frac{1}{2} \mathrm{~cm}$. long, with the posterior lobes elongated, the lowest posterior lobe the largest, deeply lobate-dentate. Texture membranaceoherbaceous; surfaces sparingly appresso-pilose; rachis and costae provided with scattered, narrowly subulate scales; costulae pinnate in the lohes; veins simple, or forked in the teeth. Sori medial on the veins, small; indusium very deeply fimbriate, consisting nearly of fibres only.

Sumatra.

(4a) D. Iura, Copel., in Leafl., III, 805.

Rhizome short, erect. Stipes tufted, rigid, black-purpureous, clothed towards the base with black-purpureous, falcate, acuminate, broadly lanceolate scales, otherwise naked. Fronds lanceolate, to $\pm 25 \mathrm{~cm}$. long, 4-8 cm. broad, acuminate, narrowed towards the base, sub-2-pinnate, the rachis sparingly paleaceous, densely pubescent above. Lower pinnae deflexed, abbreviate, shortly petiolate, the following sessile, lanceolate, acute, minutely ciliated, cut $1 / 2$-way down to the costa, deeply pinnatifid nearly to the costa in the lower part, with the lowest acroscopical segment sometimes free; segments rounded, entire. Texture rigid; surfaces naked; costae pubescent above; main veins pinnate; veins 
simple. Sori costal; indusium persistent, usually reniform, but some smaller ones athyrioid.

\section{Mindanao.}

(6a) D. badia, v. A. v. $\boldsymbol{R}$. , in Bull. Btz., 1914, XVI, 9.

Rhizome short, scaly, the scales dense, linear-subulate, castaneous, glossy. Stipes aggregate, $\pm 15-35 \mathrm{~cm}$. long, purple-brown, and glossy, as in the rachis, deciduously hairy and scaly in the lower part, at length naked, the hairs moderately long, ferrugineous, articulated. Fronds lanceolate, $\pm 30-35 \mathrm{~cm}$. long, $8-10 \mathrm{~cm}$. broad, 2-pinnatifid, acuminate, the rachis hairy above; the hairs dense, uncinate, red-brown. Pinnae numerous, approximate or somewhat remote; central pinnae largest, spreading, subfalcate, petiolulate, to $5 \mathrm{~cm}$. long, $\pm 1 \frac{1}{2} \mathrm{~cm}$. broad at the subtruncate or subcordate base, the edge cut $\pm 2 / 3-4 / 5$-way down to the costa in the lower part, coarsely crenate at the acuminate apex; lower pinnae horizontal, lowest deflexed, abbreviated. Lobes oblong or linear-oblong, the largest 3-4 $\mathrm{mm}$. broad, close, straight or subfalcate, blunt or bluntish, subentire. Texture firm, chartaceous; surfaces naked; costae more or less hairy above; main veins pinnate; veins $4-5$ on each side in the largest lobes. Sori medial or lower on the veins; indusium naked, dirty-brown, often persistent.

Sumatra.

\section{(7) D. crassifolia, o. Ktze.}

Var. Niotleyana: Also in Negros.

(7a) D. persquamifer'a, v. A. v. K., in Bull. Btz., 1914, XVI, 10.

Stipes $35-40 \mathrm{~cm}$. or more long, densely scaly, as is the rachis, the scales squarrose, lanceolate-subulate from a broad base, entire, acuminate, pale-fuscous, of the stipe persistent, of the rachis rather deciduous, the lower the largest, with a thickened base leaving the stipe rough when they fall, intermixed with much smaller ones, the higher growing gradually smaller, intermixed with numerous pale, crisped hairs, the hairs of the upper side rather persistent, those of the lower side rather deciduous. Fronds lanceolate, $\pm 50-55 \mathrm{~cm}$. long, $20-25 \mathrm{~cm}$. broad, acuminate, slightly narrowed at the base. Pinnae \pm 20 pair below te pinnatifid apex, linear-subulate, sessile, horizontal or nearly so, remote, te largest $\pm 10-12 \frac{1}{2} \mathrm{~cm}$. long, $1 \frac{1}{2}-2{ }_{12} \mathrm{~cm}$. broad at the base, acuminate, the 
edge cut ${ }_{3}{ }_{3}$-way down to the costa, the base truncate; lowest pinnae a little abbreviated, deflexed. Lobes numerous, horizontal, linear, somewhat falcate, $\pm 3-4 \mathrm{~mm}$. broad at the base, entire, or subcrenate towards the bluntish apex; lowest lobes mostly a little larger than the next following. Texture firm, rather chartaceous; surfaces naked; edges sparingly eiliated; costae above grooved and hirsute, beneath terete, deciduously hairy, glabrescent; costulae naked; veins naked; $\pm 10 \div 17$ on a side, simple, arcuate-ascending, the lowest often meeting at the apex, but rarely joining. Sori numerous, nearer the costulae than the edge; at length confluent; indusium small, short-hairy, deciduous.

Celebes.

(7b). Lauterbachii, Brav., in Lautb., Beitr. Flor. Pap., I, 18.

Stipes $22 \mathrm{~cm}$. or more long, grooved on the face, fuscous, hairy and sparingly scaly, as are the rachises, the scales long-triangular from a cordate-peltate base, acuminate, subentire. Fronds long-deltoid, \pm .43 $\mathrm{cm}$. long, to $14 \mathrm{~cm}$. broad. Pinnae \pm 24 on a side below the pinnatifid apex, sessile, long-deltoid, somewhat remote, horizontal, the lower deflexed, the lowest the longest, $\pm .71 / 2 \mathrm{~cm}$. long, to $1^{3}{ }_{4} \mathrm{~cm}$ broad, deeply pinnatifid. Segments linear, \pm .18 on a side, shortly acuminate, crenulate, spreading, the lowest a little produced, horizontal, the largest to $\pm{ }_{{ }_{1}} \mathrm{~cm}$. long and $1 / \mathrm{cm}$. broad. Texture papyraceous; upper surface more or less copiously long-hairy on the costae, costulae and veins; under surface hairy on the costae, nearly naked on the costulae and veins; veins to \pm 8 on a side, simple. Sori numerous, to 6 on a side, medial; indusium large, subrotund, hairy and ciliated, persistent.

New Guinea.

(8a) D. wuriensis, Copel., in Philipp. Journ., VIC, 73; D. basisora, Copel., 1. c.

Stipes fuscous, grooved, pubescent in the groove. Fronds more than $60 \mathrm{~cm}$. long, $\pm 35 \mathrm{~cm}$. broad, the rachis pubescent, provided with deciduous, tuberculiform glands near the bases of the pinnae, on the under side. Lower pinnae remote, deflexed; central pinnae largest, \pm $22 \mathrm{~cm}$. long, $2 \%-4 \mathrm{~cm}$. broad, shortly petiolulate, acuminate, very deeply pinnatifid. Lobes straight or falcate, the lowest somewhat reduced, the largest $\pm 1 \frac{1}{2}-2{ }^{1}{ }_{2} \mathrm{~cm}$. long, $31_{2}{ }_{2}-4^{1}{ }_{2} \mathrm{~mm}$. broad, entire, acute. Texture coriaceous; under surface sparingly puberulous on and between the veins; 
veins to \pm 23 on a side, free, simple. Sori costal; indusium naked, dark rather persistent. - See my information in Bull. Btz., 1912, VII, 13.

Nero Guinea.

(8b D. fulcatipinnula, Copel., in Philipp. Journ., VIC, 74.

Stipes pale-brown, $\pm 30 \mathrm{~cm}$. long, glabrescent. Fronds $25-30 \mathrm{~cm}$. long, $\pm 20-30 \mathrm{~cm}$. broad, pinnate, the main rachis pubescent, provided with more or less tuberculiform glands near the bases of the pinnae, on the under side. Pinnae opposite, \pm 7 - 12-jugate, linear-lanceolate, 8-12 $\mathrm{cm}$. long, $1-11_{j_{2}} \mathrm{~cm}$. broad at the middle, much acuminated, narrowed at the base, eut down nearly to the costa, the terminal one similar to the lateral ones but not rarely broader, the lowest as large as the following or somewhat shorter, the acumen narrow, entire or obtusely repando-crenate. Lobes linear, falcate, the largest $\pm 8-12 \mathrm{~mm}$. long, hardly acute, rather subobtuse, entire, more or less recurved and ciliated at the edge. Texture coriaceous; upper surface pubescent on the costae only, lower sparingly so on the costae, costulae and veins; veins \pm 10-12 on a side, simple. Sori numerous, nearer the costulae than the margin; indusium brown, hairy, persistent.

\section{New Guinea.}

(9a) See No. 17.

(9b) D. horizontalis, v. A. v. R., in Bull. Btz., 1913, XI, 10; Athyrium horizontale, Rst., in Nov. Guin., VIII, Bot., 722.

Stipe and rachis dirty-brown, densely clothed with whitish, spreading hairs intermixed with a few scattered, deciduous, acute-ovate scales. Fronds lanceolate-oblong, $\pm 40^{\circ} \mathrm{cm}$. long and $12 \mathrm{~cm}$. broad, shortly acuminate. Pinnae rather sessile, \pm 20 on a side, remote, horizontal or nearly so, linear, acuminate, blunt at the point, deeply pinnatifid, truncate at the base, the central ones the largest, $\pm 6 \mathrm{~cm}$. long, $\pm 11 / 2 \mathrm{~cm}$. broad, horizontal, the lower somewhat shorter, deflexed. Lobes linearoblong, to $7 \mathrm{~mm}$. long and $3 \mathrm{~mm}$. broad, separated by narrow sinuses, blunt, crenate, horizontal or nearly so. Texture rigid; upper surface deciduously pubescent with short, adpressed, curved hairs; under surface nearly naked; costae hairy on both sides; costulae pinnate in the lobes; veins oblique, \pm 6 on a side, simple. Sori medial; indusium persistent, fimbriate-ciliate, naked or sparingly hairy.

New Guinea. 
(10) D. pectimata, v. A. . H.; - var. Webbiana;? D. orientalis, C. Chr., var. fejeensis, Rst., in Fed, Rep., V, 370.

(12a) D. paleata, Copel., in Philipp. Journ., IX ${ }^{\mathrm{C}}, 228$.

Near D. Hallieri C. Chr. - Rachis clothed with large, lanceolate scales; pinnae conspicuously ciliated, the barren ones $\pm 30 \mathrm{~cm}$. long, $\pm 4 \mathrm{~cm}$. broad, the fertile narrower; apices of the veins sometimes confluent in the sinuses; indusia persistent, hairy.

Sumatra.

(17) D. calcara ta, o. Ftze; $D$. Marthae, v. A v. R., in Bull. Btz., 1911, I, 7; - var. ciliata; Lastrea calcarata, Moore, var. ciliata, Bedd., Handb. Ind. Ferns, 235; L. falciloba, Hk., Bedd., Ferns S. I., tab. CV.

Texture varying from herbaceous to subcoriaceous.

Var. cilla tan: Stipes rounded; pinnae about $10 \mathrm{~cm}$. long, nearly $21 / 2 \mathrm{~cm}$. broad, caudate at the apex; lowest segments deflexed; no auricles on the stipe; indusium hairy or glabrous. - Malacca; Br. India.

(17a) D. propria, v. A. v. R., in Bull. Btz., 1914, XVI, 10.

Stipes tufted, $\pm 7 \%$-10 $\mathrm{cm}$. long, deciduously hairy and at length apparently copiously glanduloso-punctulate, as is the rachis, the lower part scaly, the hairs spreading, fine, relatively long, the scales spreading, lanceolate, brown, slightly crisped, entire, with the cells rather thickwalled. Fronds lanceolate, $\pm 10-15 \mathrm{~cm}$. long, $\pm 6 \mathrm{~cm}$. broad, acuminate. Pinnae \pm 10 on each side below the terminal one; terminal pinna triangular-elongate, subcrenate towards the blunt apex, gradually deeply pinnatifid into linear, blunt, horizontal, entire, crenated or repando-lobate lobes towards the subtruncate base; lateral pinnae horizontal, remote; higher pinnae adnate, not rarely connected with the terminal one, lobed below the moderately long, linear-oblong, entire or subentire, blunt apex; central pinnae similar but gradually deeply incised towards the subtruncate base, the base $\pm{ }^{3}-1 \mathrm{~cm}$. broad, the segments linear-oblong, entire or repando-crenate, $\pm 1 \frac{1}{2}-2 \mathrm{~mm}$. broad; lowest pinnae the largest, \pm 4 $\mathrm{cm}$. long, $1-1_{14}^{\prime \prime} \mathrm{cm}$. broad at the middle, deflexed, subpetiolulate, with the lower posterior segments gradually abbreviated, the lowest anterior segment free, oblong, blunt, lobed, narrowed at the base. Texture firmherbaceous; surfaces deciduously hairy, the costae at length more or less punctulate; costulae pinnate in the lobes; veins simple, to 6 on each 
side in the largest segments. Sori rather medial; indusia deciduously short-hairy, horse-shoe-shaped or reniform, or even (apparently?) peltate, the higher sometimes very small and hamate or short-oblong. -- By its indusia apparently an Athyrium, in other respects a Dryopteris.

Celebes.

\section{(18) D. viscosa, o. Ftre.}

Costae, costulae and veins pubescent on both sides with rather firm, pale-grey hairs; only the under surface provided with yellow, globose glands.

(18a) D. subviscosa, *. A. F., in Bull. Btz., 1915, XX, 14; Nephrodium viscosum, Bk., p. p., in Journ. of Bot., XVIII, 212.

Stipes tufted, $\pm 20 \mathrm{~cm}$. long, castaneous, finely villose with very short, curved, adpressed, ferrugieous or pale-brown hairs and provided with brown, lanceolate-subulate scales. Fronds lanceolate-oblong, 士 25-30 cm. long, $\pm 10-12 \mathrm{~cm}$. broad, acuminate. Pinnae \pm 22 on a side, the higher ascending, the central horizontal, the lower deflexed; lower and central pinnae largest, sessile, lanceolate, $\pm 5-6 \mathrm{~cm}$. long, $\pm 1-1 \%$ cm. broad, acuminate, cut down nearly to the costa into linear-oblong, obtuse, subrepando-crenate, ciliate segments separated by bluntish sinuses. Texture firm-herbaceous; rachis and costae densely hairy above; costulae and veins slightly so, glabrescent, the hairs spreading, ferrugineous or pale-brown; both surfaces and especially the costae beneath copiously purveyed with yellow, subglobose glands; veins \pm 6 on a side, simple. Sori medial; indusium persistent, brown, finely glandular.

Sumatra.

(19) D. gracilescens, o. Ktze.; Athyrium benguetense, Christ, Copel., in Philipp. Journ., IIIC, 300; - var. calva; D. calva, Copel., in Leafl., III, 808; C. Chr., Ind. Fil., Suppl.

Var. calva: Sori nearer the costulae than the margin. - Mindanao.

(19a) D. paucisora, Copel., in Philipp. Journ., VI 136.

Stipes aggregate, $3-6 \mathrm{~cm}$. long, clothed like the rachis with narrow, crinite, brown, horizontal scales intermixed with very minute others. Fronds lanceolate-ovate, $\pm 12 \mathrm{~cm}$. long and $3-4 \mathrm{~cm}$. broad. Pinnae subsessile, oblong, rounded at the apex, cut down nearly to the costa into 
oblong, abtuse lobes; lowest pinnae somewhat shorter, deflexed, with the lowest segmets free. Texture herbaceous; veins simple, sparingly setose above, minutely piloso-glandular beneath. Sori medial on the lowest anterior veins, small; indusium small, ciliated. — See Copeland's information, 1. c.

Borneo.

121a) Iogravensis, Rst., in Fed., Rep., X, 332.

Rhizome short-creeping. Stipes to $80 \mathrm{~cm}$. long, rufous, clothed towards the base with crowded, lanceolate, acuminate, crisped scales. Fronds oblong, $\pm 1 \mathrm{~m}$. long, $60 \mathrm{~cm}$. broad, 2-pinnatifid. Pinnae numerous, suberecto-patent, subapproximate, the inframedial ones the largest, elongate-lanceolate, to $45 \mathrm{long}, 3 / 2 \mathrm{~cm}$. broad, narrowed gradually towards the acuminate apex, deeply pinnatifid, with the sinuses \pm half as broad as the lobes; lower and central pinnae short-stalked, lower hardly abbreviated, narrowed at the base, higher sessile; terminal pinna deeply pinnatifid at the base, serrate towards the apex. 'Lobes numerous, suberecto-patent, linear-oblong, subfalcate, to $1 \mathrm{~cm}$. long, $4 \mathrm{~mm}$. broad, entire, the sinuses acute. Texture membranaceous; upper surface naked, lower glandular with yellow, cylindrical, scattered glands; rachis, costae and costulae glandular beneath; veins \pm 15 pair, simple, the lowest more or less meeting in the sinuses. Sori medial; indusium small, lacerate, glandular.

Nero Guinea.

(21b) D. divergens, Rst., in Fed., Rep., XIII, 218.

Stipes pale-brown, clothed like the rachis and costae with short, whitish hairs and lanceolate, brown, fimbriate, scattered scales. Fronds subdimorphous. Barren fronds $\pm 70 \mathrm{~cm}$. long by $40 \mathrm{~cm}$. broad, 2-pinnatifid, acuminate. Pinnae \pm 16 on each side below the pinnatifid apex, stalked, the higher sessile; lower pinnae largest, lanceolate-oblong, \pm 22 $\mathrm{cm}$. long by $5 \mathrm{~cm}$. broad, the base narrowly rounded, the margin deeply incised, the apex long-acuminate, subentire. Lobes contiguous, $\pm 17 \mathrm{~mm}$. long by $8 \mathrm{~mm}$. broad, subfalcate, obtuse, the edge sparingly white-ciliate, subentire, reflexed. Texture chartaceo-herbaceous; surfaces naked; costae and costulae above strigose, beneath very minutely hairy; veins prominent, to \pm 15 on each side; simple, the lowest meeting very near the sinus. Fertile fronds with the pinnae half as long and broad, the lobes more 
remote. Sori numerous, subcostular; indusium firm, brown, persistent, white-sètose.

\section{Sumaitra.}

(21c) D. superficialis, v. A. v. R., in Bull. Btz., 1915, XX, 12. .

Stipes more than $55 \mathrm{~cm}$. long, like the rachis pale-fuscous and probably very minutely puberulous when young. Fronds ovate-lanceolate, $\pm 135 \mathrm{~cm}$. long, acuminate, 2-pinnatifid. Pinnae numerous, remote, linear-lanceolate, gradually long-acuminate; higher pinnae erecto-patent, sessile or adnate; inframedial pinnae -largest, subsessile, horizontal or spreading, $\pm 25-30 \mathrm{~cm}$. long, $\pm 2 \mathrm{~cm}$. broad, deeply pinnatifid narrowed at the base; lowest pinnae conspicuously petiolate, reduced but not auricle-like. Lobes spreading, linear-oblong, subfalcate, $\pm 2-3$ mm. broad, somewhat dilated at the base, blunt, entire, when dry revolute at the edge. Texture herbaceous, upper surface naked, lower very minutely puberulous, glabrescent; veins $\pm 20-25$ on a side in the longest lobes, simple, upcurved. Sori numerous, medial or inframedial, superficial; indusium rudimentary, hardly detectable even in the youngest sori.

Obi Island.

\section{D. inmersa, O. Ktze.}

Stipes aggregate, stout, pale-brown, densely scaly towards the base, sparingly so towards the frond, for the rest densely, deciduously pilose with whitish, acute hairs, as is the rachis, at length smooth or very finely asperulous and provided with very minute, scattered warts (persistent bases of fallen scales). Pinnae numerous, rather spreading, close or approximate, linear, subulate-acuminate, deeply pinnatifid or nearly pinnate, the lower narrowed towards the base. Segments very numerous, sessile or subsessile, linear or linear-oblong, horizontal or nearly so, obtuse or subacute, approximate, or somewhat remote with the sinuses nearly as broad as the lobes, the edges parallel, entire or subrepando-crenulate, the lowest posterior lobes of the lower pinnae often gradually much abbreviated, deflexed and appressed on the main rachis. Texture thin; veins simple, straight or the lower arcuate, $\pm 12-20$ on each side. Sori numerous, prominent above, supramedial on the veins, occupying nearly all the veins except the highest, the lower somewhat divaricating.

Java. 
(22a) D. bipinnata, Copel., in Philipp. Journ., IX ${ }^{\mathrm{C}}, 2$.

Stipes $30 \mathrm{~cm}$. long, slender but firm, brown, black at the base, the upper part very minutely pubescent, as is the rachis. Fronds $\pm 30 \mathrm{~cm}$, long, $\pm 17 \mathrm{~cm}$. broad, abruptly long-acuminate, 2-pinnatifld, sub-2-pinnate . at the base. Pinnae horizontal, straight or subfalcate, sessile, the lower short-stalked, not reduced, the rachis minutely pale-setulose. Segments numerous, $\pm 20-30$ on a side, oblique, acute, crenulate at the apex, $\pm 7 \mathrm{~mm}$. long by $2 \mathrm{~mm}$. broad, the lower free, short, shortly petiolulate. Texture papyraceous; veins to 10 on a side, simple, sparingly setose beneath. Sori numerous, subimmersed, submarginal; indusium densely short-hairy, persistent.

New Guinea.

(2ta*) D. Selhultzei, Brau., in Lautb., Beitr. Flor. Pap., I, 19.

Fronds lanceolate, to $85 \mathrm{~cm}$. long and $35 \mathrm{~cm}$. broad, acuminate, hardly narrowed at the base. Pinnae sessile, to 20 on each side below the pinnatifid apex, ascending, lanceolate, to $25 \mathrm{~cm}$. long and $4, \mathrm{~cm}$. broad, deeply pinnatifid, the apex repand, caudate-acuminate; higher pinnae approximate, lower remote, a little abbreviated. Lobes subspreading, linear, to $21 / 4 \mathrm{~cm}$. long and $3 \frac{1}{2} \mathrm{~mm}$. broad, approximate, separated by rounded sinuses, subobtuse, entire or crenulate. Texture membranaceous; surfaces naked; rachises, costae and costulae hairy; veins simple, to 17 on a side. Sori numerous, to 16 on a side, marginal; indusium nearly round, rather large, hairy, fugacious.

New Guinea.

(25a: D. besukiensis, v. A. $\boldsymbol{v}, \boldsymbol{R}$. , in Bull. Btz., 1911, I, 7.

Stipes $\pm 30-35 \mathrm{~cm}$. long, pale-brown, glabrous at least in the fully deve'oped fronds, the base clothed with moderately long, brown, subulate, entire scales. Fronds ovate-lanceolate, to $40 \mathrm{~cm}$. or more long, $\pm 25-30$ $\mathrm{cm}$. broad, 2-pinnatifid. Pinnae spreading or horizontal, linear-lanceolate, $\pm 1^{1 / 2}-1^{3}{ }_{4} \mathrm{~cm}$. broad, sessile, cut down nearly to the costa into numerous spreading or subhorizontal lobes, the apex acuminate; central pinnae largest, truncate at the base; lower pinnae somewhat deflexed, slightly abbreviated, narrowed towards the base. Lobes entire, oblong or linear-oblong, blunt, the edges parallel, slightly recurved, finely ciliated. Texture herbaceous or submembranaceous; rachis naked at least in the fully developed fronds; upper surface hairy on the costae and veins but 
more densely on the former; under surface very densely but very minutely pilose or glandulose on and between the veins, more or less distinctly hairy on the costulae, apparently glaucous by the minute clothing, the stipe and rachis more or less so; costulae pinnate in the lobes; veins simple, $\pm 9-14$ on a side. Sori small, terminal on the veins or nearly so; indusium round, i. e. reniform with the basal lobes close or overlapping. -. Two distinct forms:

Forma confertiloba: Fertile lobes close or subcontiguous, not or hardly dilated at the base.

Forma laxiloba: Fertile lobes separated by sinuses often nearly as broad as the lobes, dilated at the base.

Java.

(25b) D. Keysserianu, Rst., in Fed., Rep., X, 333.

Rhizome creeping. Stipes $\pm 50 \mathrm{~cm}$. long, sparingly clothed at the base with ferrugineous, lanceolate scales. Fronds ovate-lanceolate, 2-pinnatifid, $\pm 1 \mathrm{~m}$. long and $40 \mathrm{~cm}$. broad, long-acuminate. Pinnae numerous, alternate, erecto-patent, contiguous, subsessile, cut down nearly to the costa, caudate-acuminate; largest pinnae linear-lanceolate, \pm 25 $\mathrm{cm}$. long, $6 \mathrm{~cm}$. broad, sligthly narrowed at the base; lowest pinnae somewhat shorter, ovate-lanceolate; terminal pinna subulate-lanceolate, deeply lobed at the base, serrate at the middle, subentire at the apex. Lobes linear, straight or subfalcate, obtuse, entire or crenate, separated by rounded sinuses as broad as the lobes; lower lobes somewhat abbreviated. Texture thin-herbaceous to subcoriaceous; rachis and costae pale-stramineous, shortly puberulous; surfaces naked except on the veins beneath; upper surface dark, glossy, lower paler, opaque; veins $\pm 15-20$ pair, suberect, simple or rarely forked. Sori large, submarginal; indusium thin, short-hairy, persistent.

New Guinea.

(25c) See No. 68.

(26) D. exigua, o. Ftze.

Omit the synonym Lastrea exigua J. Sm. which is D. confusa Copel.

(26a?) D. Confusa, Copel., in Philipp. Journ., VIC, 146; Lastrea exignia, J. Sm., in Journ. of Bot., III, 412. 
Rhizome creeping. Stipes close, $\pm 20 \mathrm{~cm}$. long, minutely puberulous. Fronds $\pm 20-30 \mathrm{~cm}$. long, 4-5 cm. broad. Pinnae sessile, obtuse or rounded at the apex, subauriculate and truncate at the base, the edge cut $\pm 1 / 3-1 / 2$-way down to the costa. Costae and veins very sparingly puberulous. Sori costal (costular?); indusium minute, fugacious.

Luzon.

(26b) D. dichrotricha, Copel., in Philipp. Journ., VIIC, 54.

Rhizome erect, the scales narrow, castaneous. Stipes $\pm 30 \mathrm{~cm}$. long, shortly hirsute. Fronds $\pm 35 \mathrm{~cm}$. long (exclud. the reduced pinnae), 12-15 cm. broad, acuminate. Pinnae rather numerous, \pm 20 or more on a side, sessile, $\pm 1-1 \% \mathrm{~cm}$. broad, acuminate, cut $3 /$-way down to the costa; lower pinnae reduced to mere auricles. Surfaces white-setulose, setose on the costae and veins; veins simple, $6-9$ on a side. Sori medial on the veins; indusium persistent, setulose.

Mindanao, New Guinea.

(27b) D. subattenuata, $\boldsymbol{R s t}$, in Fed., Rep., X, 332.

Rhizome short-creeping, woody, clothed with linear-lanceolate, ferrugineous, hairy scales. Stipes stramineous, sulcate and slichtly hirsute above, terete and nearly naked beneath, as is the rachis. Fronds elongate-oblong, $\pm 1-1 \frac{1}{2} \mathrm{~m}$. long, $50 \mathrm{~cm}$. broad, shortly narrowed at both ends, 2-pinnatifid. Pinnae numerous, erecto-patent, approximate, sessile, the largest linear-lanceolate, $\pm 35 \mathrm{~cm}$, long, $2^{1} \cdot 2 \mathrm{~cm}$. broad, very deeply pinnatifid, acuminate and serrate at the apex; lower pinnae abbreviated, 1-2 lowest reduced, auricle-like; terminal pinna triangular, pinnatifid at the base, serrate at the apex. Lobes very numerous, horizontal, linear, the largest to $\pm 12 \% \mathrm{~mm}$. long, $2^{1}{ }_{2} \mathrm{~mm}$. broad, subobtuse, entire and slightly hairy at the edge, dilated at the base, the sinuses as broad as the lobes, rounded; lower lobes of lower pinnae often abbreviated, of the lower side sometimes somewhat produced. Texture thinly herbaceous; colour bright-green; upper surface glandular, lower more densely so, the glands yellow, sessile; costae grooved and hirsute above, glandular beneath; costulae prominent on both sides, slightly hairy; veins \pm 20 pair, simple, sparingly hairy, the lowest meeting in the sinuses. Sori subcostular, approximate, confluent; indusium membranaceous, glandular at the edge.

New Guinea. 


\section{(28) D. Luerssenii, C. Chr.}

A specimen received from Luzon differs from the type in having the stipe stramineous, the under surface hairy, and the sori partly sub marginal partly medial.

(28a) D. novoguineensis, Brau., in Lautb., Beitı. Flor. Pap., I, 21 .

Rhizome erect, clothed with subulate-deltoid, acuminate, subentire, fuscous scales. Stipes tufted, $\pm 12 \mathrm{~cm}$. long, subquadrangular, grooved, clothed like the rachis and costae with grey tomentum intermixed with whitish bristles and linear, acuminate, entire, ferrugineous scales. Fronds lanceolate, $\pm 80 \mathrm{~cm}$. long and $20 \mathrm{~cm}$. broad, pinnate, the apex pinnatifid. Pinnae alternate, sessile, approximate, linear-lanceolate; central pinnae largest, $\pm 91 / 2 \mathrm{~cm}$. long by $1 \frac{1}{2} \mathrm{~cm}$. broad, horizontal, cut down nearly to the costa, the apex caudate, repand; \pm 4 lowest pinnae abruptly reduced, next higher deflexed. Lobes numerous, approximate, spreading, linear-falcate, $\pm 3 / 4 \mathrm{~cm}$ long by $21 / 4 \mathrm{~mm}$. broad, obtuse, entire or slightly crenated; lowest lobes a little produced. Texture chartaceous; upper surface white-puberulous, lower naked; veins to \pm 10 on a side, simple, upcurved. Sori numerous, to 8 on each side of the costulae, medial or supramedial; indusium large, nearly round, subsetose.

New Guinea.

(29) D. Beddomei, o. Ktse.; D. Smithii, v. A. v. R., in Bull., Dép. Agr. I. N., 1908, XVIII, 15; Phegopteris Smithii, v. A. v. R., 1. c.; — var. nadiwononis, V A. v. R., in Bull. Btz., 1912, VII, 13.

Specimens received from Mindanao (leg. Elmer, have the fronds narrower, the pinnae shorter and narrower, deeply pinnatifid, the lobes partly acute partly blunt, entire or crenate, sparingly setulose beneath, the veins less numerous.

Var. nadiwonomis: Pinnae pinnatifid; lnwer lobes of the larger pinnae nearly free, separated by more or less broad sinuses with truncate angles, and the edge bluntly toothed or lobate-dentate; costae and costulae setulose beneath, veins less so; veins \pm 6 , the lower forked; sori intramarginal. Rhizome unknown. - Java.

(29a) D. mixto, rst., in Fed., Rep., XII, 172.

Rhizome short-creeping or ascending, the scales ferrugineous, 
lanceolate, entire. Stipes subtufted, $\pm 6 \mathrm{~cm}$. long, shortly tomentose; as is the rachis, the tomentum intermixed with longer, whitish, subulate hairs and ferrugineous scales. Fronds elongate-oblong, $\pm 12 \mathrm{~cm}$. long by $4 \mathrm{~cm}$. broad, deeply 2-pinnatifid, acuminate. Pinnae \pm 16 on a side below the pinnatifid apex, spreading, approximate, sessile, linear-ligulate, obtuse; central pinnae largest, $\pm 2 \% \mathrm{~cm}$. long by $3 / 4 \mathrm{~cm}$. broad; lower pinnae often deflexed; 2-3 lowest reduced to mere auricles. Lobes oblong; suboblique, to $3 \mathrm{~mm}$. long by $1^{1_{2}}-2 \mathrm{~mm}$. broad, acute. Texture thin-herbaceous; upper surface strigose with short, whitish, adpressed hairs; costae and veins provided with longer, whitish, spreading hairs; veins \pm 5 on a side, simple. Sori numerous, nearer the margin than the costulae; indusium brown, sparingly hairy, deciduous.

New Guinea.

\section{(30) D. adinata, v. A. v. R.}

The specimens gathered by Raciborski have the fronds above partly sparingly fibrilloso-paleaceous partly naked (glabrescent), the lobes here and there bluntish. -- See Copeland's information in Philipp. Journ, VIIIC, 140.

(31a) D. subsagenioides, v. A. v. R., in Bull. Btz., 1913, XI, 9.

Near D. sagenioides 0 . Ktze but: Rhizome short-creeping; stipes not tufted, grey when dry; pinnae more numerous, often $11-15$ on a side, 1-4 cm. broad, coriaceous, when dry often blackish above, grey beneath, the edge cut ${ }^{1 / 2}-{ }_{3}^{2}$-way down to the costa, the lobes serrate-crenate towards the apex, and the tips of the sinuses provided with a single produced tooth, the lowest pinnae with the $1-3$ lower posterior lobes elongated and lobed.

Borneo.

(31b) D. thelypteris, A. Gray, C. Chr., Ind. Fil.; Nephrodium Thetypteris, Stremp. (not Desv.), Hk. Bk., Syn. Fil., 271; Lastrea Thelypteris, Bory, Bedd., Handb. Ind. Ferns, 241; Ferns Br.I., I, tab. XLIV; Aspidium thelypteris, Sw., Christ, Farnkr. d. Erde, 253; Acrostichum Thelypteris, L., (oldest name).

Rhizome slender, wide-creeping. Stipes up to about $30 \mathrm{~cm}$. long, slender, stramineous. Fronds lanceolate-triangular, $30-60 \mathrm{~cm}$. long, $10-15 \mathrm{~cm}$. broad, truncate at the base. Pinnae spreading, the lower 
the longest or equalling the following, $\pm 1 \% \mathrm{~cm}$. broad, cut down very nearly to the costa into entire, spreading, linear-oblong lobes, those of the barren fronds the broadest. Texture herbaceous; rachis and both surfaces naked; costulae pinnate; veins forked or the higher simple. Sori small, not confluent, in rows nearer the recurved edge than the costulae; indusium small, caducous, glanduloso-pilose.

Malacca; South and North India, Central China, Temp. Asia, Europe, Temp. and Trop. Africa, America, New Zealand.

(31c) D. tamatana, C. Chr., Ind. Fil., Suppl.; D. Kingii, Copel., in Philipp. Journ., VIC, 73.

Near D. syrmatica 0 . Ktze. - Stipes fuscous, $\pm 30 . \mathrm{cm}$. long, clothed towards the base with long, linear scales, the upper part nearly naked like the rachis. Fronds $\pm 30 \mathrm{~cm}$. long, $15 \mathrm{~cm}$. broad. Lower pinnae hardly reduced; largest pinnae $\pm 10 \mathrm{~cm}$. long, $2-2 \frac{1}{2} \mathrm{~cm}$. broad, subsessile, acuminate, cut down nearly to the costa. Lobes $\pm 1_{i_{2}}^{1_{2}} \mathrm{~cm}$. long, $\pm 1 / 2 \mathrm{~cm}$. broad, falcate, acute, separated by acute sinuses. Texture coriaceous; surfaces nearly naked; veins $5-6$ on a side, forked. Sori medial; indusium .....

New Guinea.

(32a) D. aureo-viridis, Rst., in Fed., Rep., XIII, 216.

Rhizome erect, provided with linear-lanceolate, brown, hair-pointed, minutely denticulate scales. Stipes tufted, $25-30 \mathrm{~cm}$. long, sparingly scaly at the base. Fronds triangular-lanceolate, $\pm 25-60 \mathrm{~cm}$. long by 15-30 cm. broad, acuminate, 2-pinnatifid. Pinnae to \pm 16 on a side below the pinnatifid apex, straight or subfalcate, sessile, spreading; lower pinnae largest, to $16 \mathrm{~cm}$. long by $3 \mathrm{~cm}$. broad, slightly contracted at the base, with the segments horizontal, linear, bluntish, entire or subcrenulate; lowest pinnae with the lowest posterior segment somewhat elongated, to $1 \frac{1}{2} \mathrm{~cm}$. long by $3-4 \mathrm{~mm}$. broad and distinctly serrate-crenate. Texture herbaceous; colour yellow-green or yellow (when dry?); axes short-hirsute above, beneath sparingly short-hairy, as are the veins; veins to 9 on a side, once or twice forked. Sori medial, occupying the lowest anterior veinlets; indusium often evanishing, reniform, glandulose-fimbriate.

Sumatra.

(34) D. filix mas, Schott.

Var. parallelogramma: Also in Luzon, Java.

Ferns and Fern Alities. 
(36) D. erythrosora, o. Ktae.; Nephrodium enythrosorum, Hk.; Spec. Fil., IV, 120, tab. CCLIII.

The specimens of this species, which I have seen in Japan, were distinguished by the following characters.

Rhizome short, scaly. Stipes tufted, $15-35 \mathrm{~cm}$. long, more or less densely scaly with long, lanceolate and linear-subulate scales especially in the lower half, the scales more or less deciduous in age. Fronds $30-60 \mathrm{~cm}$. long, $20-30 \mathrm{~cm}$. broad, ovate-lanceolate, acuminate. Pinnae lanceolate, more or less truncate at the base, acuminate, rather bluntish at the point, the lowest often a little smaller than the next higher ones, broadest on the lower side, sometimes deflexed, the largest more or less snreading, to $15 \mathrm{~cm}$. long, $5-7 \mathrm{~cm}$. broad, cut down quite to the rachis into oblong, sessile or adnate, more or less oblique, blunt or bluntish pinnulae. Pinnulae 5-12 $\mathrm{mm}$. broad, with the edges slightly, spinulosely or more or less coarsely toothed; lowest pinnulae the broadest, rather spreading, truncate at the base and not rarely subpetiolulate; the largest teeth often lobe-like, more or less close, blunt and often slightly or spinulosely toothed again. Texture firm-herbaceous, rather subcoriaceous; surfaces naked, or the under surface slightly provided with a few inconspicuous, pale hairs on the veins; rachises slightly scaly or more or less furfuraceous with small, crisped scales. Sori in rows of $4-9$ on a pinnula, often slightly immersed, nearer the midrib than the margin; indusium bright-red when young, with a distinct, pale or decoloured margin. - The young fronds have the stipe and rachis densely scaly with bright-brown or dark-brown scales.

(36a) D. media, v. A. v. Fe., in Bull. Btz., 1918, XI, 9.

Stipes $\pm 30 \mathrm{~cm}$. long, finely deciduously pubescent, scaly towards the base; scales brown, linear-subulate, entire, the base persistent, verruciform. Fronds lanceolate, $\pm 70 \mathrm{~cm}$. long and $20-25 \mathrm{~cm}$. broad, acuminate. Pinnae numerous, close, spreading, short-stalked, lanceolate, the central ones $\pm 10-12 \frac{1}{2} \mathrm{~cm}$. long, $\pm 3 \mathrm{~cm}$. broad at or near the base, cut down nearly to the costa, acuminate, the lower a little shorter. Lobes numerous, approximate, spreading, linear, blunt, the largest to \pm $2 \mathrm{~cm}$. long, $\pm 4 \mathrm{~mm}$. broad, bluntly toothed (hardly lobed), the lowest somewhat smaller, more or less deflexed or decurved, often more deeply incised, rather pinnatifid at the base. Texture herbaceous; rachis finely pubescent; surfaces naked; costae, costulae hairy above, finely pubescent 
beneath; veins $\pm 8-10$ on a side, forked in the teeth or lobes, the longest not rarely twice forked or sparingly pinnate, the higher or shortest simple. Sori medial or the higher subcostular; indusium minute.

Sumatra.

(36b) D. olivacen, Rst, in Hedwi., LVI, 352.

Rhizome creeping, the scales brown, lanceolate. Stipes to $50 \mathrm{~cm}$. or more long, olive-brown, scaly towards the base. Fronds elongate-oblong from a cuneate base, about $75 \mathrm{~cm}$. long, $30 \mathrm{~cm}$. broad below the middle, acute, 2-pinnatifid. Pinnae subhorizontal, to about 20 on each side below the pinnatifid apex, linear, acuminate, cut to about $4 / 5$-way down to the costa, the apex coarsely serrate; higher pinnae sessile, adnate or decurrent-confluent, following short-stalked; largest pinnae to $18 \mathrm{~cm}$. long by $4 \mathrm{~cm}$. broad; lowest pinnae somewhat abbreviated, produced on the lower side. Lobes linear, subhorizontal, subfalcate, acute, coarsely serrate, decurrent, the sinuses acute or rounded. Texture membranaceous; surfaces naked, olive-green; veins forked, with the anterior veinlet often proliferous. Sori small, medial, $7-8$ on a side; indusium naked.

New Guinea.

D. Bamaleriana, Rst., in Fed., Rep., X, 334.

Stipes castaneous, glossy. Fronds ovate-oblong, to $70 \mathrm{~cm}$. long, 40 cm. broad, acuminate, 3-pinnatifid. Pinnae \pm 18 on a side below the pinnatifid apex, remote, often horizontal, alternate, petiolate, linearlanceolate, the largest $\pm 20 \mathrm{~cm}$. long, $5 \mathrm{~cm}$. broad, shortly acuminate, somewhat narrowed at the base, the lower shorter, deflexed, the higher áscending. Pinnulae short-stalked, spreading, subapproximate, subfalcate, deltoid-oblong, acute, inciso-lobate, truncate and auricled at the upper base, shortly cuneate at the lower base, the central and higher ones contracted at the base, adnate or decurrent. Lobes linear or oblong, obtuse, crenate. Texture subcoriaceous; surfaces nearly naked; rachises sulcate and shortly tomentose above, the secondary ones narrowly winged; veins immersed, pinnate in the lower lobes, forked or simple in the higher lobes. Sori subcostular; sporangia intermixed with long-stalked utriculiform paraphyses; indusium coriaceous, naked.

New Guinea.

(39) D. edulenta, v. A. v. R. (not O. Ktze).

Omit this name, it should be D. edentula 0 . Ktze. 
(39) D. edentula, o. Ftze, C. Chr., Ind. Fil.; Aspidium edentulum, Kze, in Bot. Zeit., 1846, 474; A. edulentum, v. A.v.R. (not Kze); Nephrodium edentulum, Bk., Hk. Bk., Syn. Fil., 279; N. edulentum, v. A.v. R. (not Bk.).

(40a) D. alpina, Rst., in Fed., Rep., XII, 173.

Rhizome erect, the scales ferrugineous, narrowly lanceolate. Stipes $\pm 8 \mathrm{~mm}$. (8 cm.?) long, castaneous, subflexuose, firm, scaly at the base, the upper part hairy and scabrous, as is the rachis, the hairs ferrugineous, articulated. Fronds lanceolate-oblong, $\pm 13 \mathrm{~cm}$. long by $6 \mathrm{~cm}$. broad, 3-pinnatifid, acuminate, truncate at the base. Pinnae \pm 15 on a side below the serrate apex, the lower opposite, subhorizontal, short-stalked, lanceolate from a truncate base, bluntish; central pinnae largest, \pm 3 $\mathrm{cm}$. long by $1 \mathrm{~cm}$. or more broad at the base. Pinnulae \pm 10 on a side below the inciso-serrate apex, ascending or suberect, subsessile, elongate-oblong, obtuse, deeply lobed; $3-5$ lower pinnulae subremote, contracted at the base, following decurrent on the lower side at the base; lowest pinnulae largest, to $7 \mathrm{~mm}$. long by $2-3 \mathrm{~mm}$. broad. Lobes entire or obscurely crenated. Texture rigidly coriaceous; surfaces sparingly paleaceo-fibrillose; veins simple or forked, immersed. Sori submedial on the lower part of the lobes; indusium minute, eiliate and sparingly yellow-glandular.

New Guinea.

(40b) D. athyniocarpa, Copel., in Philipp. Jouxn., IIIC, 344.

Rhizome short, erect. Stipes 士 $20 \mathrm{~cm}$. long, purplish-black, sparingly scaly above, more densely so towards the base with narrowly lanceolate, castaneous scales. Fronds $\pm 20 \mathrm{~cm}$. long, $7 \mathrm{~cm}$. broad, acuminate. Pinnae often sessile, spreading, $\pm 1 \% \mathrm{~cm}$. broad, obtuse, pinnatifid nearly to the costa, the lower ones the longest, deflexed, with the segments lobed nearly $1 / 2$-way down to the costula. Segments \pm 10 on a side, linear-oblong, obtuse, the highest entire, the lowest incisoserrate, minutely ciliate. Texture membranaceous; surfaces glandulose; upper surface pilose on the veins; costae villose above, naked beneath; rachis castaneous in the lower part beneath, otherwise green, villose on the upper and nearly naked on the lower side; veins simple. Sori polymorphous, partly nephrodioid, more generally athyrioid, rarely asplenioid; indusium hardly coriaceous, glandulose.

Borneo. 
(40b) See under No. 29.

$\left(41 a^{*}\right)$ D. Mavovirens, Rst., in Fed., Rep., X, 334.

Rhizome erect; scales lanceolate, ferrugineous, short-hairy at the apex. Stipes stramineous, $\pm 60 \mathrm{~cm}$. long, sparingly scaly at the base, furfuraceous and sulcate on the upper side. Fronds lanceolate-oblong, $\pm 75 \mathrm{~cm}$ long, $25 \mathrm{~cm}$. broad. Pinnae \pm 20 pair below the terminal one, suberecto-patent, sessile, linear-lanceolate, acuminate, cut down nearly to the costa; central pinnae largest, $\pm 30 \mathrm{~cm}$. long, $3-31 / 2 \mathrm{~cm}$. broad; lower pinnae somewhat shorter, subopposite, $\pm 6 \mathrm{~cm}$. apart; higher pinnae approximate, alternate; terminal pinna pinnatifid at the base, entire towards the apex. Lobes numerous, spreading, subapproximate, separated by acute sinuses, linear-oblong, crenato- or inciso-lobate, the apex subentire, obtuse; lobules rounded, sparingly ciliolate. Texture herbaceous; colour yellow-green; surfaces naked; rachis stramineous; costae hirsute above; costulae sparingly hairy; veins \pm 12 on a side, the lower pinnate in the lobules, the higher forked or simple. Sori $4-5$ on the lower lobules, $2-3$ on the central ones, medial (?); indusium membranaceous, whitish, fimbriate and glandular at the edge.

New Guinea.

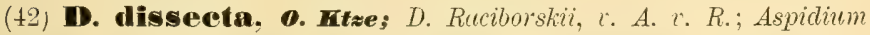
sagenioides, Rac. inot Mett.); (not Nephrodium conjugatum, T. \& B).

Rhizome erect. Stipes to $30 \mathrm{~cm}$. long or even much longer, sparingly deciduously subulate-squamulose, often fibrilloso-pilose like the rachis. Fronds deltoid to ovate, $30-150 \mathrm{~cm}$. long, $15-90 \mathrm{~cm}$. broad, pinnate. Pinnae few to numerous; higher pinnae linear, lobed or pinnatifid to $\pm{ }^{2}$ is-waw down to the costa, adnate and decurrent, or connected by short intermedial lobules (i. e. the tops of the sinuses between the higher primary segments are provided with a lobe-like tooth!; central pinnae linear-lanceolate, pinnatifid form 1/3-way down to nearly to the costa with deltoid-oblong or linear-oblong, blunt or acute lobes; at least the lowest pinnae often stalked, and pinnate at least on the lower side at the base, otherwise pinnatifid, with at least the lowest posterior pinnula elongated and pinnatifid or 2-pinnatifid again. Lobes to 2-4 $\mathrm{cm}$. long, $1 / 2-1 \frac{1}{2} \mathrm{~cm}$. broad, the largest crenulate, toothed or not deeply lobed. Texture herbaceous; surfaces often, though not invariably, fibrilloso-pilose; costulae and main veins forked or pinnate in the ultimate 
lobes, sometimes uniting so as to form here or there a:single costal or costular areola; a simple, forked on pinnate vein often proceeds from the costa or costula in the direction of the sinus between two segments. Sori terminal on the veins, nearer the margin than de central ribs; indusium reniform, naked. - Fertile portions of the fronds not rarely more or less contracted. - Very variable; resembles Pleocnemia membranifolia Bedd. in the smaller forms.

$\mathrm{Br}$. India across Malaya to Tropical Austratia and Polynesia, Madagascar.

(426) D. herbacea, v. a. v. F., in Bull. Btz., 1915, XX, 13.

Rhizome erect, the extremity clothed with crowded, ovate-lanceolate, acuminate, entire, pale-ochraceous-brown scales. Stipes fasciculate, \pm $30 \mathrm{~cm}$. long, provided towards the base with linear-subulate crisped scales. Fronds ovate, $\pm 45 \mathrm{~cm}$. long, $\pm 30-35 \mathrm{~cm}$. broad, deeply 3-pinnatifid, acuminate, the rachis somewhat flexuose, when young probably provided with filiform scales, at length naked. Largest pinnae subhorizontal, shortly petiolulate, lanceolate-triangular, $\pm 8-9 \mathrm{~cm}$. broad near the base; the rachis sparingly fibrillose-squamulose, narrowly winged. Pinnulae somewhat remote, horizontal, the lower adnate with a much contracted base, the higher broadly adnate, the lowest much reduced, the following the largest, ovate-lanceolate, broadest above the base, the central triangular-lanceolate, broadest at the truncate base; largest pinnulaə to $\pm 4 \frac{1}{2} \mathrm{~cm}$. long, to $\pm 1 \frac{1}{2} \mathrm{~cm}$. broad deeply pinnatifid. Lobes oblong, elose, nearly horizontal, the largest. $\pm 7{ }_{2} \mathrm{~mm}$. long, $\pm 3 \frac{1}{2} \mathrm{~mm}$. broad, broadly rounded at the apex, obliquely bluntly crenate-denticulate; higher teeth subtriangular, lower broad, retuso-truncate. Texture thin; surfaces sparingly minutely fibrilloso-squamulose on the costae, costulae and veins; veins forked, to 5 on a side. Sori small, medial; indusium rudimentary or soon evanishing.

Java.

(43a), See No. $56 a$.

(45) D. Raciborskii, v. A. v. R.

Omit this, it is a form of D. dissecta O. Ktze.

(46) D. recedens, o. Ktae. 
Largest pinnulae with the segments deeply lobed or pinnatifid; lobes acute, entire or slightly toothed.

(47) ? D. borneemsis, o. Ktze; Davallia borneensis, J. Sm., C. Chr., Ind. Fil., Suppl.

See Rosenstock's information in Fed., Rep., X, 324.

(49a) See No 42.

(496) See No. 44.

(50) vilis, o. Kt:e.

Scales of stipe and rachises intermixed with long, fine, pale, deciduous hairs.

(51) D. internedia, o. Ktze.

The specimens occurring in the Buitenzorg Herbarium have the rachises tomentose at least on the upper side.

(52) D. sarawakensis, v. A. v. R. (not Copel.).

Copeland thinks this to be probably indentieal with D. intermedia

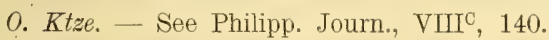

\section{(53) D. pulvinulifera, o. Ktze.}

Posterior pinnulae of lowest pimnae not rarely elongated with the lower segments often free and deeply lobed or pinnatifid again; sori whether or not terminal or short veinlets. - An incomplete plant occurring in the Buitenzorg Herbarium, gathered in Java (Mt. Gedeh, Matthew No. 556), seems to be a large form of this species (forma major).

(53a) D. squamulifera, v. A. v. R., in Bull. Btz., 1914, XVI, 9.

Rhizome short, erect, densely scaly, the scales long, narrowly subulate, ferrugineous, entire, filiform at the apex. Stipes aggregate, $\pm 60 \mathrm{~cm}$. long, scaly, the lower scales similar to those of the rhizome, the following growing gradually smaller, the higher similar to those of the rachis. Fronds lanceolate, $\pm 45-75 \mathrm{~cm}$. long, $\pm 1 / 3$ as broad, the rachises tomentose above, scaly, the scales fine, nearly hair-like, fuscous, deflexed, dilated at the base. Pinnae numerous, suberecto-patent or 
spreading, the lowest the largest, obliquely deltoid, produced on the lower side, to $17: 2 \mathrm{~cm}$. long, $\pm 6-9 \mathrm{~cm}$. broad at the base, acuminate. Pinnulae many, the higher adnate, decurrent, more or less connected, oblique, the lower free, short-stalked, the lowest posterior the largest, to $7 \mathrm{~cm}$. long, $+1 \frac{1}{4}-2 \mathrm{~cm}$. broad, deeply pinnatifid, acuminate Tertiary segments oblong or linear-oblong, to $1 \% \mathrm{~cm}$. long, $4-5 \mathrm{~mm}$. broad, blunt, entire or crenate, or the lowest posterior lobate-dentate. Texture firm-herbaceous; surfaces naked; costae pubescent above, slightly scaly beneath; veins simple or forked or sometimes twice forked. Sori small, medial on simple veins or veinlets, or at the forking of the forked veins; indusium breaking irregularly.

Sumatra.

(56) D. purpurascens, Christ (not $v . A . v . R$.), in Philipp. Journ., II', 213.

A form gathered in Java by Païtan ( $M t$. Salak) differs from the typical form in having all the dimensions much larger. Fronds up to $160 \mathrm{~cm}$. long and $110 \mathrm{~cm}$. broad; pinnulae up to $15 \mathrm{~cm}$. long and 5 em. broad.

\section{(56a) D. balabacensis, Christ.}

A specimen received from Sibuyan differs from Christ's orginal diagnosis in having the dimensions somewhat smaller, the stipe glabrescent, the fronds 3-pinnate at the base only, the tertiary segments subentire except the largest which are moderately deeply lobed.

(57a) D. glabrior, Copel., in Philipp. Journ., Vc, 283.

Near D. crenata 0 . Ktze but the fronds larger, slenderer, much looser, more naked, and the sori smaller.

Borneo.

(58) D. rhodolepis, C. Chr.

Omit this species here. See No. 62e.

(58a) D. dubia, Copel.

Also in Negros.

(58b) D. decomposita, o. Ktwe, C. Chr., Ind. Fil.; Nephrodium decompositum, R. Br., Hk. Bk., Syn. Fil., 281. 
Rhizome wide-creeping, black, sparingly scaly or naked. Stipes $30-45$ cm. long, scaly only at the base, firm, villose. Fronds deltoid or ovatelanceolate, $\pm 30-60 \mathrm{~cm}$. long, $30 \mathrm{~cm}$. or more broad. Lower pinnae much the largest, deltoid, $10-20 \mathrm{~cm}$. long, $5-10 \mathrm{~cm}$. broad. Pinnulae lanceolate, more or less deeply pinnatifid. Tertiary segments unequalsided, ovate-rhomboidal, deeply pinnatifid with toothed lobes. Texture variable; rachis more or less villose; under surface more or less villose on the veins. Sori rather large, medial. - Variable.

New Guinea; Australia, Tasmania, Norfolk Island, New Zealand.

(58c) See No. 46.

(59) D. setigera, o. Ktze; - var. Backeri, v. A v. R., in Bull. Btz., 1913, XI, 10, 11; D. Backeri, v. A. v. R., in Bull. Dép. Agr. I. N., 1908, XVIII, 8; - var. pallida, v. A. v. R., l. c.

Rhizome erect or suberect; stipes and rachises provided with flattened or subterete, deciduously eiliated or setulose, linear-subulate or néedlelike, squarrose, subsetiform scales leaving the stipe and rachises rough by their persistent hases when they fall; indusium small or rudimentary. - D. multiseta Bk.) C. Chr. is perhaps a large form of this only.

Var. Hackeri (includ. var. aspera: Like the type but the rhizome creeping.

Var. pallida: Like the type but the stipe and rachises not setigerous, smooth, only pubescent along the upper side.

\section{9a) D. mesodom, Copel., in Philipp. Journ., VII ${ }^{\mathrm{C}}, 54$.}

Stipes provided at the base with linear, castaneous scales, sparingly spinulose above. Fronds $\pm 35-40 \mathrm{~cm}$. each way, the rachises castaneous above, velutinous ahove, as are the costae. Lowest pinnae largest, triangular, much acuminated; lower pinnulae stalked, acuminate; lower tertiary segments short-stalked, cordate, acute, provided at the base with a single pair of adnate, obtuse, coarsely toothed ultimate segments; all the division pinnatifid in the upper part, with the lobes connected by a decurrent wing which is often provided with a single tooth; penultimate segments coarsely. and acutely toothed, oblanceolate. Sori remote from the margin, small; indusium persistent. - Near D. dissecta O. Ktze but more compound.

Mindanao. 
(59b) See No. 42.

(59c) D. subspar'sa, v. A. v. R., in Bull. Btz., 1915, XX, 14.

Rhizome short: Stipes aggregate, $30-35 \mathrm{~cm}$. long, dirty-yellow-brown when dry, copiously pubescent, as are the rachises, sparingly scaly towards the base, the hairs short, articulated, dirty-rufous, those of the stipe more or less deciduous, of the rachises persistent, the-scales ovatelanceolate, fuscous, fimbriate-ciliate. Fronds lanceolate or broadly ovate, 20-30 cm. or more long, $10-30 \mathrm{~cm}$. broad, acuminate, 3-pinnate at the base. Terminal pinna lobed or lobate-dentate towards the apex, gradually deeply pinnatifid towards the base, with the segments similar or nearly similar to the higher pinnae; lateral pinnae ascending; higher pinnae linear-oblong, about $5 \mathrm{~mm}$. broad, lobed or labate-dentate, toothed at the apex, decurrent, connected with the terminal one; lowest pinnae largest, triangular, $12 \frac{1}{2}-25 \mathrm{~cm}$. long, $7 \frac{1}{2}-20 \mathrm{~cm}$ broad, petiolate, the apex similar to the apex of the frond, the base 2-pinnate. Pinnulae ascending, 7 - 14 on a side, the lowest posterior of the lowest pinnae the largest, petiolulate, with the apex similar to the apex of the frond, the base pinnate, and the segments oblique, decurrent, the higher confluent, the lower the largest, subpetiolulate, connected by a very narrow wing, to $21 / 2 \mathrm{~cm}$. long and $5 \mathrm{~mm}$. broad, bluntish, coarsely toothed towards the apex, lobed towards the obliquely cuneate base which is broadest on the upper side. Ultimate segments (lobules or teeth) entire or sparingly crenate to dentate, bluntish. Texture rather coriaceous; surfaces naked; costae and costulae pubescent above; costae, costulae and veins sparingly fibrilloso-pilose beneath; veins very oblique, the higher simple, the central forked, the lower sparingly pinnate in the lobules. Sori remote, medial on the veins or at the base of anterior veinlets; indusium evanishing.

Java.

\section{(59d) ID. Escritorii, v. A. v. $\boldsymbol{K}$.}

Stipes $30 \mathrm{~cm}$. more or less long, red-brown when dry, naked in the lower part, above slightly tomentose in the upper part. Fronds subdeltoid, about 25-30 cm. each way, acuminate, 3-pinnate at the base, the rachises and costae dark-rufo-tomentose above with short, crowded, articulated hairs. Terminal pinna serrate towards the apex, deeply pinnatifid towards the base with the segments subsimilar to the higher pinnde; lateral pinnae ascending; higher pinnae linear-lanceolate, lobed 
$1 / 3-2 / 3-w a y$ down to the costa, serrate at the acuminate apex; decurrent; connected with the terminal one; lowest pinnae largest, triangular, to $20 \mathrm{~cm}$. long, to $15 \mathrm{~cm}$. broad at the base, petiolate, the apex similar to the apex of the frond, the base 2-pinnate. Pinnulae ascending, to $4-5$ on a side, the lowest posterior of the lowest pinnae the largest, petiolulate, $5 \mathrm{~cm}$. broad at the middle, with the apex similar to the apex of the frond, the base pinnate, and the segments oblique, decurrent, the lowest free, smaller than the central, $2-2 \frac{1}{2} \mathrm{~cm}$. long, $3 / 4-1 \mathrm{~cm}$. broad, blunt, coarsely crenate to lobed, obliquely rotundate-truncate at the base. Ultimate segments (lobes or teeth) entire to serrate, blunt to subacute. Texture rigidly coriaceous; surfaces naked; upper surface darkbrown or reddish-fuscous when dry, under one somewhat paler; costulae above naked, or somewhat tomentose towards the base; veins oblique, mostly 2-3-furcate or the lower pinnate; a simple, forked or pinnate vein proceeds from the casta or costula in the direction of the sinus between two segments, often accompanied by a second one. Sori remote, medial, terminal on short, anterior veinlets, immersed, prominent on the upper surface; indusium coriaceous, black-brown, persistent.

Luzon.

\section{(61) D. multiseta, C: Chr.}

This is probably a larger form of $\mathrm{D}$. setigera 0 . Ktze only.

(61a) D. Backeri, v. A. v. R.

Omit this, it being a variety of D. setigera $O$. Ktze.

(62) D. subarborea. C. Chr.o - var. attenuata, quadripinnata, decomposita, biformis, Rst., in Fed., Rep., XU, 731-174.

Var. attenuata : Fronds 3-pinnate; pinnulae distinctly stalked, lanceolate, acuminate, pinnate below the serrate apex, the segments narrowed, 2-3 mm. broad, te basal ones produced. - New. Guinea.

Var. quadripinmata: Fronds 4-pinnate; leaflets obliquely ovate, hardly longer than broad, sparingly crenated, the upper side subinciso-dentate; costae and costulae scaly at the base, the scales lanceolate, ferrugineous; sori 2-4 on a leaflet. - New Guinea.

Var. decomposita: . Fronds 4-pinnate; leaflets subpinnate at the base, smaller than in the preceding. - New Guined.

$\therefore$ Var. biformis: Fronds 3 pinnate; rachises and costae scaly, the 
scales lanceolate or ovate-lanceolate, pale-ferrugineous, fibrilloso-acuminate; leaflets dimorphous; fertile leaflets much contracted, to $1 \mathrm{~cm}$. long, 1 $\mathrm{mm}$. broad, remote, the lowest of the largest leaflets pinnatifid; sori subcostular. -- New Guinea.

(62a) See No. 53.

(62b) Spe No. 58.

(62c) See No. 59.

(62a) D. tabacicoma, v. v. R., in Bull. Btz., 1914, XVI, 11.

Stipes $\pm 80 \mathrm{~cm}$. long, deciduously fibrilloso-furfuraceous and scaly, glabrescent, as are the rachises, the scales dark-brown, the lower long, very narrowly linear-subulate, slightly crispato-undulate, resembling fine tobacco, the following passing gradually into those of the rachises which are finer, hair-like, caducous. Fronds 4-pinnatifid at the base. Lowest pinnae triangular-oblong, $\pm 45 \mathrm{~cm}$. long, $\pm 30 \mathrm{~cm}$. broad at the base, acuminate, on stalks $\pm 5 \mathrm{~cm}$. long. Pinnulae similar in shape, the lowest $\pm 12-18 \mathrm{~cm}$. long, those of the posterior side the longest, on stalks $\pm 1-1 \frac{1}{2} \mathrm{~cm}$. lons. Tertiary segments elongate-triangular, the largest $3-6 \mathrm{~cm}$. long, $1 \frac{1}{2}-3 \mathrm{~cm}$. broad at the base, on stalks $\pm 1-3 \mathrm{~mm}$. long, the apex acute, toothed, the base truncate, deeply pinnatifid; ultimate lobes spreading, linear-oblong, to $1^{1 / 2} \mathrm{~cm}$. long and $5 \mathrm{~mm}$. broad, decurrent, blunt, entire to coarsely crenated. Texture coriaceous; surfaces naked; costae and costulae more or less canaliculate above, beneath deciduously crispato-pilose; veins $\pm 5-6$ on a side in the largest lobes, mostly forked. Sori rather medial; indusium firm, deciduous.

Sumatra.

(62e) D. rhodelepis, C. Chr., Ind., Fil.; D. subarborea, C. Chr., var. glabrior, V. A. V. R., in Bull. Btz., 1914, XVI, 57; Aspidium intermedium, Christ (not Bl.), Farnkr. d. Erde, 263; Lastrea Blumei, Moore, Bedd., Ferns S. I., tab. CCIL; Nephrodium Bhumei, Hk., Spee. Fil., IV, 135 , p. p.; N. intermedium, Bk., Hk. Bk., Syn. Fil., 283; N. rhodolepis, Clarke, Trans. Linn. Soc., Bot., 2nd Series, I, tab. LXXII.

Stipes $\pm 30-60 \mathrm{~cm}$. long, deciduously shaggy with long, linear or subulate, brownish or brown-grey scales, as are te rachises, clothed 
towards the base with long, filiform, bright-brown scales. Fronds large, deeply 4-pinnatifid. Pinnae $\pm 25-35 \mathrm{~cm}$. long, $\pm 10-15 \mathrm{~cm}$. broad. Segments entire or subentire, rarely toothed or incised again, $\pm 2-3$ mm. broad. Texture herbaceous; rachises and costae tomentose above with reddish-brown fibrils, whether or not sparingly so beneath; upper surface more or less sparingly fibrilloso-pilose, often nearly naked; costae more or less scaly beneath, the costulae occasionally so; veins simple or forked, naked or minutely appresso-pilose beneath. Sori medial or inframedial on the veins; indusium thin, fugacious.

Trop. Asia, China, Japan.

\section{§ 2. NEPHRODIUM.}

(63) D. Bakeri, Copel.; - var. acrostichoides; D. diversiloba, Christ, var. acrostichoides; Christ, in Philipp. Journ., IIC, 200; D. canescens, C. Chr., var., C. Chr., Ind. Fil.; Nephrodium acrostichoides, J. Sm., in Journ. of Bot., III, 411; Aspidium canescens, Christ, forma acrostichoides, Christ, in Ann. Btz., XV, 130-131; - var. incana; D. canescens, C. Chr., var. incana, Rst., in Fed., Rep., XII, 530.

Var. nerostichoides: Barren fronds $2 \frac{1}{2}-5 \mathrm{~cm}$. broad; pinnae close, the lower rather horizontal, the central linear-oblong, to $2 \frac{1}{2} \mathrm{~cm}$. long and $1 \mathrm{~cm}$. broad, obtuse, subentire, truncate or cordate at the base; reins $2-3$ on a side, the $1-2$ lower anastomosing. Fertile fronds on stipes to $11 \mathrm{~cm}$. long; pinnae remote, smaller, contracted. Sori crowded, in $1-2$ rows on each side of the costae; indusium distinct.

Var. incana: Lower pinnae of fertile fronds dilated or hastate at the base, nearly nakerl. - New Guinea.

(63a) D. sessilipinna, Copel., in Philipp. Journ., VIC, 145.

Rhizome ereeping, woody. Stipes close, 5-15 cm. long, minutely pubescent, provided with scattered, suddenly much reduced (rudimentary) pinnae. Fronds $\pm 12-20 \mathrm{~cm}$. long, 4-5 cm. broad, pinnate, the upper half pinnatifid, gradually long-acuminate. Pinnae sessile, the lowest deflexed, the higher approximate, $\pm 8 \mathrm{~mm}$. broad, rounded at the apex, cut $1 / 3-1 / 2$-way down to the costa, truncate at the base. Lobes truncate, 
whether or not serrulated, minutely ciliated. Texture subcoriaceous; upper surface naked, lower setose on the costae and veins; veins \pm 4 on a side, the lowest anastomosing. Sori medial; indusium very minute; rudimentary.

Mindanao, Negros.

(63b) See No. $2 a$.

(63c) D. mirabilis, Copel., in Philipp. Journ., VIC, 137, tab. XIX.

Rhizome ascending. Stipes aggregate, $\pm 40-45 \mathrm{~cm}$. long, puberulous, those of the fertille fronds the longest. Fronds with a large terminal pinna to $7 \frac{1}{2} \mathrm{~cm}$. broad, truncate at the base and below this a single much smaller sessile one on each side, the barren ones entire or nearly so, the fertile crenate. Texture herbaceous; surfaces sparingly pubescent, minutely pustulose, costae densely so. Sori numerous; indusium white-hairy.

Borneo.

(68d) D. uniaurealata, Copel., in Philipp. Journ., IX, 3.

Rhizome woody, clothed at the extremity with small, black-brown, lanceolate scales. Stipes aggregate, $\pm 20 \mathrm{~cm}$. long, fuscous, black at the base, more or less hairy, provided (always?) with a single auriculiform pinna. Fronds paucipinhate. Terminal pinna largest, to $20 \mathrm{~cm}$. long and $4 \mathrm{~cm}$. broad, acuminate, often crenate, cordate or truncate at the base; lateral pinnae often 1-jugate, $4-8 \mathrm{~cm}$. long by $2-3 \mathrm{~cm}$. broad, obtuse or acute, truncate at the base. Texture subcoriaceous; surfaces smooth, naked; veins \pm 8 on each side of the main ones, minutely hairy beneath. Sori numerous, the higher remote, round, the lower approximate, sometimes meniscioid; indusium hairy.

Newo Guinea.

(64) D. lineata, C. Chr.

Omit this species here. See No. $81 \mathrm{c}$.

(64a) D. Iistans, O. Ktze, C. Chr.. Ind. Fil.; Nephrodium distans, Hk., Hk. Bk., Syn. Fil., 288.

Rhizome wide-creeping. Stipes $30 \mathrm{~cm}$. or more long, firm, erect, brownish, slightly villose. Fronds $45-60 \mathrm{~cm}$. long, $20-25 \mathrm{~cm}$. broad. 
Pinnae horizontal, petiolate, lanceolate-oblong, $7 \frac{1}{2}-10 \mathrm{~cm}$. long, $2 \mathrm{~cm}$. broad, sinuate-crenate or very slightly lobed, the lower ones rather smaller than the others but not reduced to mere auricles. Texture papyraceo-herbaceous; rachis and midribs beneath villose and veins slightly so; veins $5-6$ on a side. Sori rather large, very dark-brown. Java (t. Christ); Madagascar, Comores.

\section{(68) D. extensa, o. Kt:e.}

Veins free or the lowest pair commonly anastomosing or meeting in the sinus.

D. axida, o. Ktze; - var. ebeneorhachis, Copel., in Leafl. II, 390.

Forma typica: Stipe and rachis green or brown.

Var. ebeneorhachis: Stipe and rachis ebeneous. - Negros.

(73a?) D. conferta, Brau, in Lautb., Beitr. Flor. Pap., I, 22, fig. $1 F-f$.

Rhizome creeping, the scales fuscous, subulate-deltoid, acuminate, ciliate. Stipes $\pm 1-2 \mathrm{~cm}$. apart, to $5 \mathrm{~cm}$. long, grooved above, hairy and scaly, the scales similar to those of the rhizome. Fronds lanceolate, to $45 \mathrm{~cm}$. long by $12 \mathrm{~cm}$. broad, pinnate, the apex suddenly narrowed into an elongate-triangular, pinnatifid terminal pinna. Pinnae alternate, close, sessile, linear-oblong; central pinnae largest, horizontal, $\pm 6 \mathrm{~cm}$. long by $1 \frac{1}{2} \mathrm{~cm}$. broad, shortly acuminate, crenated, truncate-rotundate at the base; higher pinnae gradually ascending and abbreviated, lower gradually deflexed and abbreviated, $\pm 3-4$ lowest suddenly reduced to mere auricles. Texture coriaceous; rachis hairy and scaly; upper surface puberulous; costae and main veins hairy on both sides; veins $\pm 4-7$ on each side of the main veins, the 3 lowest anastomosing: Sori numerous, occupying the $3-4$ lower veins, nearly medial; indusium reniform, setose.

New Guinea.

\section{(78) D. Limsuta, o. Krze.}

A duplicate of a plant gathered by Elmer in Mindanao (No. 11657), received as D. adenophora $C$. Chr., differs from the type in having the frond smaller, the pinnae more deeply lobed, the veins less copiously anastomosing, copiously setulose on both sides. 
(80a) D. Iridescens, v. A. v. R., in Bull. Btz., 1913, XI, 11.

Rhizome short, erect or ascending, the scales brown, lanceolate, somewhat fine-hairy. Stipes approximate, $\pm 20-25 \mathrm{~cm}$. long, densely pubescent above, glabrescent towards the base. Fronds ovate-oblong or triangular-oblong, $\pm 15-20 \mathrm{~cm}$. long, 10-12 cm. broad, abruptly acuminate. Pinnae approximate, \pm 6 on a side below the terminal one, the terminal and lower ones coarsely crenate or lobate-crenate, entire at the acuminate apex, the higher subentire; terminal pinna subulatelanceolate, long-acuminate, somewhat larger than the lower ones; lateral pinnae lanceolate-oblong, the central or lower the largest, $\pm 5-6 \mathrm{~cm}$. long, $1 \frac{1}{2}-2 \mathrm{~cm}$. broad; lowest pinnae horizontal or somewhat deflexed, shortly petiolulate, with the upper base rotundate or auriculate-truncate, the lower base cuneate; central pinnae subfalcate, with the upper base auriculate, truncate, the lower base more rotundate or rotundate-truncate; higher pinnae sessile or adnate, free or connected with the terminal one, suberecto-patent, abbreviated. Texture coriaceo-herbaceous; rachis pubescent; upper surface copiously clothed with adpressed hairs, when dry provided with pale-iridescent streaks between the main veins; under surface verruculose, covered with numerous yellow, globose glands, hairy on the veins; veins $4-6$ on a side, the $2-3$ lower anastomoring. Sori $2-3$ on a side, the higher medial on the veins, the lower terminal and often confluent; indusium small, densely villose.

Sumatra.

81) D. glandulosa, O. Ktze.

Omit this name, it should be $\mathrm{D}$. malayensis $O$. Chr.

(81) D. malayensis, C. Chr., Ind. Fil., Suppl.; D. glandulosa, O. Ktze (not Desv.)

(81a) D. compacta, Copel., in Philipp. Journ., VIC, 137, tab. X VIII.

Rhizome ascending. Stipes aggregate, naked, scaly at the base. Fronds lanceolate, to $\pm 30 \mathrm{~cm}$. long and $10 \mathrm{~cm}$. broad, the fertile ones somewhat smaller than the barren, acuminate, simply pinnate. Pinnae elongate-lanceolate, acute or acuminate, the central ones horizontal, coarsely serrate towards the apex, subcordate on the lower side at the base, acutely auricled on the upper side, the auricle imbricate over the 
rachis; lower pinnae somewhat shorter, deflexed, narrowed at the base. Texture papyraceous; surfaces naked: rachis velutinous above, naked beneath; 2 lower veins anastomosing. Sori small; indusium persistent, pilose.

\section{Borneo.}

181b) D. verruculosa, v. A. v. R., in Bull. Btz., 1913, XI, 12. Rhizome moderately short-creeping, black-brown, the scales brown, deciduous. Stipes subapproximate, $\pm 10-30 \mathrm{~cm}$. long, slender, hairy, more or less glabrescent towards the base, those of the fertile fronds the longest. Fronds $\pm 10-20 \mathrm{~cm}$. long, with a terminal pinna \pm 8-15 $\mathrm{cm}$. long by $2-3 \frac{1}{2} \mathrm{~cm}$. broad and $1-2$ similar but smaller lateral ones on each side. Pinnae lanceolate, acuminate, entire or broadly and shallowly crenate, rounded or cuneate at the base, the lateral ones sessile, erecto-patent, alternate, with the costa provided with a hardly elevated gland at the base beneath, the fertile ones smaller than the barren. Texture herbaceous; rachis and costae hairy; surfaces minutely but copiously verruculose; under surface very minutely deciduously hairy; areolae in $\pm 6-9$ rows between the costa and margin. Sori minute, in 2 rows between the main veins, round, rarely confluent; indusium caducous, probably minute or rudimentary. - Resembles in aspect Phegopteris triphylla Mett.

Java.

\section{1c) D. lineata, C. Chr.}

For the description, see my handbook p. 209.

(83) D. urophylla, C. Chr.; - var. novoguineensis, Rst., in Fed., Rep., X, 336.

Var. novoguineensis: Pinnae subentire or slightly repand, gradually short-acuminate; under surface provided with gland-like, hamiform hairs; main rachis provided with a callous gland at the place of insertion of the pinnae. - New Guinea.

(83a) D. nquatiloides, Copel., in Philipp. Journ., VIIC, 59.

Rhizome short-creeping. Stipes $\pm 10-25 \mathrm{~cm}$. long, those of the fertile fronds the longest, stramineous, minutely pubescent in the upper part. Fronds $15-25 \mathrm{~cm}$. long, $12-17 \mathrm{~cm}$. broad. Pinnae \pm 6 on a Ferns and Fern Aluies. 
side below the terminal one, all alike, to $9 \mathrm{~cm}$. long and $1 \mathrm{~cm}$. broad, entire or crenulate, mostly narrowed towards both ends, the point blunt, the higher often subauriculate. Texture papyraceo-coriaceous; rachis and costae pubescent; surfaces naked; veinlets $2-3$ on a side. Sori small, medial, sometimes confluent; indusium minute, rudimentary.

Borneo.

(83b) D. pancijuga, v. A. v. R., in Bull. Btz., 1915, XX, 17, tab. II; Phegopteris paucijuga, v. A. v. R., l. c.

Rhizome short-creeping, the scales brown, somewhat crisped, subulate, entire, filiform-acuminate. Stipes slender, $12 \%_{2}-25 \mathrm{~cm}$. long, very sparingly scaly towards the base, at length naked. Fronds subdeltoidovate, $\pm 9-25 \mathrm{~cm}$. each way, the rachis naked. Pinnae $2-3$ on each side below the terminal one, very sparingly deciduously ciliolated; terminal pinna elongate (ovate or lanceolate), 5-15 cm. long, $2-4 \mathrm{~cm}$. broad at the subtruncate-rotundate or subtruncate-cuneate base, acuminate, the edge irregularly serrulate to toothed in the upper part, moderately irregularly and shortly lobed in the lower part; lateral pinnae more or less falcate, the higher subsessile, lanceolate-oblong, acuminate, irregularly serrulate to twice serrate, or somewhat lobed and serrate, broadly cuneate or rotundate-truncate at the base, smaller than the terminal one; lowest pinnae largest, short-stalked, nearly horizontal, $\pm 5-12 \% / 2 \mathrm{~cm}$. long, $\pm 2-4 \mathrm{~cm}$. broad below the middle, acuminate, serrulate towards the apex, the upper side shortly lobed towards the subtruncate-rotundate base, the lower side lobed at the middle, entire at the cuneate or rotundate-cuneate base. Lobes, lobules and teeth partly entire partly irregularly serrulate. Texture herbaceous; surfaces naked; veins to 6 on each side of the main veins, subparallel to these, the higher free. Sori in 2 rows between the main veins, distant, near the main veins, apparently irregularly scattered; indusium deciduous, reniform (roundish or elongated) the basal lobes not rarely very unequal in length, the margin deeply fimbriate-ciliate.

Java.

84a) D. Iandikatensis, v. A. v. R., in Bull. Btz., 1913, XI, 11.

Rhizome short-creeping. Stipes approximate, $\pm 35-40 \mathrm{~cm}$. long, densely finely pubescent, as is the rachis, at length more or less glabrescent, provided with many distant, auricle-like, suddenly reduced 
pinnae. Fronds (exclud, the auricles) $\pm 25-35 \mathrm{~cm}$. long. Pinnae \pm $1-3$ on a side below the terminal one, lanceolate-oblong; terminal pinna the larger, $\pm 15-20 \mathrm{~cm}$. long and $6-9 \mathrm{~cm}$. broad, of the barren fronds the largest, subabruptly caudate-acuminate, rotundate-cuneate at the base, subentire or coarsely crenate; lateral pinnae somewhat smaller, distant, sessile. Texture coriaceous; upper surface copiously appresso-pilose; under surface densely finely pubescent on the veins, less so and glandular between the veins, the glands minute, round, yellow; veins $\pm 15-20$ on a side, nearly all anastomosing; areolae often subrectangular. Sori terminal on the veins, at length confluent; indusium ciliate, rudimentary or very small.

\section{Sumatra.}

: 85a) W. TEoemeriana, Rst., in Nov. Guin., VIII, Bot., 723.

Rhizome 'erect, the apex clothed with ferrugineous, lanceolate, acuminate scales. Stipes tufted, $\pm 3 \mathrm{~cm}$. long, slender, hirsute, as is the rachis. Fronds oblanceolate-oblong, $\pm 8-10 \mathrm{~cm}$. long, $21_{2}-4^{1 \prime} \mathrm{cm}$. broad, shortly acuminate, moderately gradually narrowed towards the base. Pinnae spreading or more ascending, subapproximate; central pinnae the largest, sessile, linear-oblong, $\pm 1 \frac{1}{2}-2^{1}{ }_{2} \mathrm{~cm}$. long, $4-6 \mathrm{~mm}$. broad, blunt and subentire at the apex, broadly crenate-lobate at the middle, cuneate at the base, the upper base produced, auricled; lower pinnae more or less stalked and gradually reduced; higher pinnae abbreviated, adnate, free or connected with the terminal one; terminal pinna linearoblong, rather similar to the central ones, undivided, or pinnatifid at the base. Texture subcoriaceous; surfaces soon glabrescent or somewhat hairy on the costae and veins; main veins slender, oblique; veins \pm 2 -3 on a side, the lowest anastomosing. Sori in $1-2$ rows on each side of the costa; medial on the veins or approaching the main veins; indusium naked, persistent.

New Guinea.

(87) D. megaphylla, C. Chr.

This species is construed as including 2 distinct forms: D. megaphylla C. Chr. and D. pseudomegaphylla $v, A . v, R$.

(87a) D. megaphylla, C. Chr.; - var. abbreviata, Rst., in Fed., Rep., XII, 529.

Pinnae numerous, inserted on subcallous increasings of the rachis, 
lobed from $1 / 4$ to $1 / 3$-way down to the costa, the lobes oblique, subfalcate, blunt, more or less hairy on or near the edge; rachis and costae villose at least on the upper side; surfaces naked or more or less provided with scattered, minute, yellow glands between the veins; veins 6-10 on a side, slightly puberulous on the under side or on both sides, the $3-6$ lower anastomosing; sori with the capsules somewhat setose, and the indusium mostly naked.

Forma typica. - Malaya; North India, Ceylon, Comores, South Africa.

Var. abbreviata: Pinuae 7 -8.jugate, $7-10 \mathrm{~cm}$. long by $2-2 \frac{1}{2}$ $\mathrm{cm}$. broad, more densely villose on the anterior side. - New Guinea.

(87b) D. pseudomegaphylla, v. A. v. R.; D. megaphylloides, v. A. v. R., in Bull. Btz., 1915, XX, 16.

Like the preceding, but the rachis without subcallous increasings, densely hirsute, as are the costae; costulae and veins copiously hirsute beneath with moderately long, acute hairs; sori with the capsules and the indusium copiously setose.

Sumatra.

(88) D. arbuscula, o. Ftze.

Rhizome erect, woody, often forming a small trunk to $\pm 10 \mathrm{~cm}$. high. Stipes tufted. Fronds $\pm 10-20 \mathrm{~cm}$. broad. Pinnae about $1 \mathrm{~cm}$. broad, bluntly short-acuminate; $\pm 6-10$ lower pinnae gradually reduced to mere, blunt, deltoid auricles.

Forma minor: Small, to $20 \mathrm{~cm}$. long and $7 \frac{1}{2} \mathrm{~cm}$. broad, and the reduced pinnae less numerous; veins $3-4$ on a side. - New Guinea (Schlechter No. 14403).

(89) D. amboinensis. O. Ktze; C. Chr., Ind. Fil., Suppl.

Rhizome, short-creeping or erect, not trunk-like. Stipes approximate or fasciculate. Fronds $\pm 15-25 \mathrm{~cm}$. broad. Pinnae $1-2 \% \mathrm{~cm}$. broad, entire, crenate or lobed, acutely long-acuminate; $\pm 1-6$ lower pinnae reduced, often hastate and acuminate. - Often confounded in herbaria with D. arbuscula 0 . Ktze.

(90) D. multilineata, o. Ktze.

A plant gathered in New Guinea (leg. Versteeg; det. Christ) has the 
fronds smaller, $35-80 \mathrm{~cm}$. long, $12-30 \mathrm{~cm}$. broad, with the pinnae $1^{\prime}{ }_{2}-2 \mathrm{~cm}$. broad, the edges broadly crenate, the base cuneate-truncate, slightly auricled on the upper side, the veins $\pm 4-7$.on a side, the 4-6 lower veins anastomosing; sori medial but the lower not rarely confluent, elongated and produced along the intermedial vein, the indusium deciduous. - The form with confluent lower sori at length hardly distinguishable from Phegopteris $\$$ Meniscium when the indusia are fallen away.

Also in Sumatra and Java, Nero Guinea.

94) D. ferox, o. Ktze; - var. calvescens; D. penangiana, C. Chr., var. calvescens, Copel., in Phillipp. Journ., VC, 283.

Under surface naked, or more or less copiously pilose on the costae, costulae and veins.

Var. calvescens. - Also in Borneo, Negros.

(96a) D. hamifera, v. A. v. R., in Bull. Btz., 1914, XVI, 12.

Rhizome ascending, forming a short trunk. Stipes $\pm 45 \mathrm{~cm}$. long, densely short-hairy and 3-sulcate, as is the rachis, provided with many remote, opposite, reduced, auricle-like pinnae nearly to the base, the hairs pale. Fronds elongate-lanceolate, $\pm 70 \mathrm{~cm}$. long excluding the reduced pinnae, $\pm 20 \mathrm{~cm}$. broad near the base, narrowed gradually towards the acuminate apex. Pinnae horizontal, numerous, sessile, provided with a long-elevate, hamate gland at the base beneath, the largest linear, \pm $1-1 \frac{1}{2} \mathrm{~cm}$. broad, cut ${ }^{2}$-way down to the costa below the crenated acuminated apex, truncate at the base, the lower nearly suddenly reduced. Lobes nearly horizontal, subfalcate-oblong, blunt or bluntish, crenated, \pm $2^{1}{ }_{2} \mathrm{~mm}$. broad, somewhat remote. Texture coriaceous; costae and costulae rather long-hairy, the hairs pale; veins sparingly long-hairy above; upper surface short-hairy on and between the veins, naked beneath; veins $\pm 7-8$ on a side, simple, the lowest anastomosing. Sori medial on the veins; indusium persistent, coriaceous, short-hairy.

Sumatra.

(97) D. piloso-squamsta, o. A. ש. R.; - var. obtusata, v. A. v. R., in Bull. Btz., 1914, XVI, 12.

Barren fronds larger than the fertile ones, to $\pm 65 \mathrm{~cm}$. long and 40 $\mathrm{cm}$. broad, with the pinnae broader, to $3 \%, \mathrm{~cm}$. broad, suddenly long- 
caudate-acuminate at the apex, the veins more numerous, to 15 on each . side of the costulae (main veins), the lobes more falcate, bluntish.

Forma typica. - New Guinea.

Var. olotustata: Fertile fronds with the central pinnae the largest, naked or more or less sparingly hisped, provided beneath with numerous very minute globose yellow glands; lobes more obtuse, broader; indusium minutely glandular. Barren fronds not seen. - Sumatra.

(97a) See No. 99a.

(97b) D. suprastrigosa, Rst., in Fed., Rep., X, 335; - var. mollis, Rst., l. c., 336.

Rhizome erect, clothed at the apex with ferrugineous, ovate-lanceolate scales. Stipes tufted, to $20 \mathrm{~cm}$. long, brown, subquadrangular, grooved, shortly pubescent. Fronds lanceolate-oblong, nearly $20 \mathrm{~cm}$. long, $7-8$ $\mathrm{cm}$. broad, shortly acuminate, pinnate. Pinnae \pm 20 on a side, sessile, spreading, alternate; 'largest pinnae linear-oblong; to $4 \mathrm{~cm}$. long, $8 \mathrm{~mm}$. broad, shortly -acuminate, cut more than $1 / 2$-way down to the costa; terminal pinna lobed at the base, entire towards the apex; higher pinnae truncate at the base, following narrowed at the base, $4-6$ lower pairs reduced gradually to mere auricles. Lobes oblong, subfalcate. Texture subcoriaceous; colour grey-green; upper surface strigose with adpressed, pale-grey hairs, lower hirsute and glandular; rachis and costae strigose above, pubescent below, as are the veins; veins $4-6$ on a side, simple, the lowest pair anastomosing or meeting in the sinus. Sori medial, or the lower subcostal; indusium persistent, coriaceous, hairy and glandular.

Var. mollis: Stipes longer; fronds to $45 \mathrm{~cm}$. long, $20 \mathrm{~cm}$. broad; texture herbaceous.

New Guinea.

(98) D. sagittifolia, $\boldsymbol{D}$. Ktze.

Also in New Guinea.

\section{(99a) D. basilaris, C. Chr.}

A specimen received from Luzon differs from Christ's diagnosis in having the stipe and frond much smaller, the stipe glabrescent; the rachis densely tomentose with short, pale hairs, the pinnae shorter and narrower, obliquely and abruptly broad-cuneate or rounded at the base, 
both surfaces provided with numerous scattered; minute, yellow glands, the costae copiously short-hairy, the veins slightly so, the $1-2$ lower veins anastomosing, the indusium brown, slightly puberulous.

(102) D. parasitica, O. Ktze.

Omit this name, it should be D. mollis Hieron.

(102) D. mollis, Hieron., in Hedwi., XLVI, 348; C. Chr., in Ark. för Bot., IX'1, 28; Ind. Fil., Suppl.; D. parasitica, C. Chr. (not O. Ktze), Ind. Fil., 282; Nephrodium molle, R. Br. (not Desv. Rac., Flor. Btz., I, 188; Bedd., Ferns S. I., tab. LXXXIV; N. parasiticum, Bk., Copel., Polypod. Philipp., 32; Aspidium parasiticum, Sw. (not Mett.), Christ, Farnkr. d. Erde, 243; A. nymphale, Schk., Krypt. Gew., I, tab. 34; Poly. podium molle, Jacq. (oldest name), C. Chr., in Ark. för Bot., l. c., 27, fig. 5.

Lower pinnae mostly shorter than the next higher.

(106) D. didymosora, C. Chr., Ind. Fil.; Nephrodium Didymosorum, Pav., Bedd., Ferns Br. I., II, tab. CC; N. tectum, Bedd., Handb. Ind. Ferns, Suppl., 79; D. parasitica, O. Ktze, C. Chr., in Ark. för Bot., IX ${ }^{11}$, 28; Ind. Fil., Suppl.; Polypodium parasiticum, L., C. Chr., 1. c., 27, fig. 4 .

Lower pinnae not at all abbreviated.

Also in Northern India, Southern China, Amboina.

(109) D. perakensis, C. Chr.; -- var. sumatrensis, v. A v. R., in Bull Btz., 1913, XI, 13.

Var. sumatrensis: Fronds smaller, to $\pm 30 \mathrm{~cm}$. long. Pinnae firm-herbaceous, less deeply lobed, the lower moderately gradually reduced, the lowest, very minute; upper surface short-hairy on and between the veins; under surface long-hairy and short-hairy on the costae, long-hairy on the costulae, veins and margins, deciduously short-hairy between the veins. Sori medial; indusia minute; capsules short-hairy. - Sumatra.

(109a See No. 88 .

(109b) See under No. $97 \alpha$.

(109c) D. perpilifera, v. A. v. R., in Bull. Btz., 1913, XI, 12.

Rhizome erect. Whole plant (i. e. stipe, rachis, surfaces, costae, 
costulae veins, parenchyma and indusia) copiously hairy with short or long, whitish hairs, and glandular with minute, subglobose, yellow glands which are provided with a minute, blackish depression at the tip. Stipes tufted, $\pm 5-15 \mathrm{~cm}$. long, glabrescent towards the base, furnished with distant, auricle-like, reduced pinnae passing gradually into the normal ones. Fronds lanceolate-oblong, $\pm 20-40 \mathrm{~cm}$. long (exclud. the auricles), acuminate, narrowed gradually to the base. Pinnae numerous, nearly close, more or less spreading, linear-lanceolate, the central ones the largest, $\pm 4-8 \mathrm{~cm}$. long, acuminate and subentire at the apex, cut \pm $1 / 2$-way down to the costa, $\pm 1-1^{1}{ }_{4} \mathrm{~cm}$. broad, truncate-cuneate at the base. Lobes numerous, subspreading, subfalcate, subacute, $\pm 2 \mathrm{~mm}$. broad, the lowest not rarely a little longer than the others. Texture firm-herbaceous; costulae pinnate in the lobes; veins simple, $4-5$ on a side, the 1-2 lowest anastomosing. Sori small, medial; indusium deciduous.

New Guinea.

(109d) See No. $99 b$ (handb., p. 820).

(110a) D. angustipes, Copel., in Philipp. Journ., VIIC, 60.

Rhizome short, the scales brown. Stipes $1-2 \mathrm{~cm}$. long, firm, scaly. Fronds $\pm 80 \mathrm{~cm}$. long, $20 \mathrm{~cm}$. broad, the rachis stramineous, grooved, glabrescent except in the groove. Central pinnae horizontal, approximate, sessile, $1 \frac{1}{4}-1 \frac{1}{3} \mathrm{~cm}$. broad, acuminate, the base auricled on the upper side, the edge cut $\pm 1 / 2$-way down to the cesta into subfalcate lobes $2-21 / 2 \mathrm{~mm}$. broad; lower pinnae moderately suddenly reduced to many pinnatifid auricles. Texture membranaceous; upper surface sparingly white-hairy; lower minutely appresso-pilose on the costae, costulae and veins, otherwise minutely glandular; costae glabrescent; veins \pm 7 on a side, the 1-2 lower anastomosing. Sori small, medial; indusium persistent, naked or hairy, glandular in the centre.

Borneo.

\section{(111a) D. Todnyensis, Christ.}

Specimens received from the Philippine Islands differ from Christ's diagnosis in having the fronds larger, the pinnae to $\pm 25 \mathrm{~cm}$. long and $2^{3} / 4 \mathrm{~cm}$. broad. truncate at the base, the lobes oblong, not or hardly falcate, blunt, to $4 \mathrm{~mm}$. broad, the upper surface quite naked except on 
the costae, the under surface deciduously and minutely puberulous, the veins to 10 on a side, the $1-3$ lower veins anastomosing, the sori not minute.

(111c) D. batacorum, Rst., in Fed., Rep., XIII, 217; - var. Winkleri, Rst, 1. c., 218.

Rhizome erèct. Stipes tufted, 5-10 $\mathrm{cm}$. long, sparingly hairy above, clothed with lanceolate, ferrugineous, flaccid scales. Fronds $\pm 40-55$ cm. long, pinnate, the upper part ovate, $\pm 7 \mathrm{~cm}$. broad, acuminate. Pinnae $\pm 20-30$ or more on each side below the pinnatifid apex, approximate, the 10-20 lower suddenly reduced to mere auricles to 8 $\mathrm{mm}$. long; largest pinnae sessile, subhorizontal, linear, to $31 / 2 \mathrm{~cm}$. long by $1 \mathrm{~cm}$. broad (or a little broader) towards the apex, obtuse or subacute, lobed, truncate at the base. Lobes somewhat oblique, $\pm 2 \mathrm{~mm}$. long by $2 \frac{1}{2} \mathrm{~mm}$. broad, truncate. Texture papyraceo-herbaceous; surfaces slightly verruculose; under surface provided with minute yellow glands; rachis grooved above, short-hairy in the groove, the hairs. whitish, intermixed with longer ones, for the rest provided with short, adpressed hairs and linear-lanceolate, deciduous scales; costae hirsute above, shorthairy beneath, as are the costulae, provided with a black-brown, conical gland on the lower side at the base; veins simple, $3-4$ on a side, the lowest only anastomosing. Sori nearer the costulae than the margin; indusium firm, black-brown, naked, persistent.

Var. Winkleri: Like the type, but the pinnae more remote, without basal glands, the under surface not glandular, short-hairy, the 2 lowest veins anastomosing.

Sumatra.

(112) D. truncata, o. Ktze.

Under surface smooth, verruculose or finely glandular.

(112a) D. Erooksii, Coped, in Philipp. Journ., IIIC, 345.

Rhizome probably creeping, clothed with black scales. Stipes \pm 40 $\mathrm{cm}$. long, green, sulcate, naked, the base scaly like the rhizome. Fronds $\pm 80 \mathrm{~cm}$. long, $\pm 15 \mathrm{~cm}$. broad. Pinnae \pm 30 pair, subremote, the largest ones $\pm 10 \mathrm{~cm}$, long, $\pm 1 \mathrm{~cm}$. broad, sessile, falcate. truncate and auricled at the base, shallowly lobed, acuminate, the lowest ones reduced, minute, $6 \mathrm{~cm}$. apart. Lobes $1-2 \mathrm{~mm}$. deep, $3-4 \mathrm{~mm}$. broad, 
often truncate: Texture herbaceous; surfaces naked; veins \pm 4-jugate, the lowest anastomosing, the others free, simple. Sori medial, round, subimmersed, distinct above; indusium fugacious or wanting. - The true place of this species is uncertain because of incomplete description. Borneo.

(112b) D. porphyricola, Copel., in Philipp. Joủn., VIJ, 60.

Rhizome erect. Stipes $\pm 10 \mathrm{~cm}$. long, sparingly ferrugineo-paleaceous. Fronds $\pm 80 \mathrm{~cm}$. long, $27 \mathrm{~cm}$. broad. Lowest pinnae suddenly reduced to auriculate auricles; next following pinnae not reduced, deflexed, \pm $14 \mathrm{~cm}$. long and $2 \%, \mathrm{~cm}$. broad, the base truncate, the edge cut $1 / \mathrm{s}_{12}$ way down to the costa into falcate lobes $3 \frac{\mathrm{mm}}{2}$ broad. Texture membranaceo-papyraceous; upper surface clothed with adpressed silky hairs, lower minutely pilose and densely glandular; veins \pm 7 on each side of the main veins, the $2-3$ lower anastomosing. Sori small, medial; indusium persistent, glandular and shortly pilose.

Borneo.

(112c) See Nos. $87 a, 87 b, 99 a$ (handb., p. 820), 109e, 111 .

(112d) D. angusta, Copel., in Philipp. Journ., IX ${ }^{\mathrm{C}}, 3$.

Rhizome short, erect. Stipes stout, aggregate, $\pm 30 \mathrm{~cm}$. long, provided with auriculiform, reduced pinnae, sparingly scaly at the base, the upper part densely white-hairy, as is the rachis. Fronds lanceolate, $\pm 65 \mathrm{~cm}$. long, $\pm 15 \mathrm{~cm}$. broad below the middle, narrowed towards both ends, 2-pinnatifid. Pinnae numerous, sessile; the largest horizontal, $\pm 7_{i 2}^{1} \mathrm{~cm}$. long, $\pm 1 \mathrm{~cm}$. broad above the dilated base, the edge cut $\pm 1_{2}$.way down to the costa, the apex narrowed, entire, acute; lower pinnae somewhat deflexed, higher ascending. Lobes contiguous, oblique, $\pm 2 \mathrm{~mm}$. broad. Texture herbaceous; surfaces minutely pilose; veins \pm 6 on a side, the $2-3$ lower anastomosing. Sori numerous, medial; indusium minute, minutely pilose and glandular.

New Guinea.

(113a) D. hispidifolia, ש. A. v. R., in Bull. Btz., 1915, XX, 15; Nephrodium hispidulum, Christ (not Bk.), in Ann. Btz., XX, 107.

Rhizome erect, short, the extremity clothed with brown, lanceolate, hair-covered scales. Stipes tufted, $7 \frac{1}{2}-15 \mathrm{~cm}$. long, deciduously hairy, 
the hairs red-brown or pale-ochraceous, often decurved. Fronds lanceolate, 15-45 cm. long. $5-10 \mathrm{~cm}$. broad, acuminate; rachis and costae densely short-hispido-pubescent above, deciduously long-hispido-setose beneath, the hairs pale. Pinnae deciduously hispido-ciliate; terminal pinna triangularlanceolate, broadest at the deeply pinnatifid and broadly cuneate base, entire or crenate at the long-caudate-acuminate apex; lateral pinnae remote, much ascending or the lower more spreading, 10-20 on a side; higher pinnae linear-oblong, adnate, entire or subentire; central pinnae largest, linear-lanceolate, $3-6 \mathrm{~cm}$. long $4-6 \mathrm{~mm}$. broad at the middle, entire at the long-acute point, cut ${ }^{\prime}{ }_{2}$-way down to the costa towards the subabruptly cuneate base; inframedial pinnae more or less gradually abbreviated and often somewhat more deeply incised; lower pinnae suddenly rudimentary. Lobes obliquely subtriangular, blunt or bluntish, entire or subentire. Texture firm-herbaceous; surfaces naked or the under one provided with scattered, minute, yellow, subglobose glands; veins $3-5$ on a side, the lowest uniting at or a little below the sinus. Sori medial or supramedial on the veins; indusium firm, naked, persistent, dark-brown when dry.

Borneo.

(116a) D. aquatilis, Copel., in Philipp. Journ., VIC, 75; D. caudiculata, Rst., in Fed., Rep., IX., 426.

Stipes $\pm 15-20 \mathrm{~cm}$. long, fuscous or brown, sealy and black at the báse, narrowly grooved down the face, clothed with minute, adpressed bristles. Fronds lanceolate, $\pm 35-45 \mathrm{~cm}$. long, $\pm 10-15 \mathrm{~cm}$. broad, pinnate, the rachis tomentose with minute, adpressed bristles, as are the costae. Pinnae $\pm 15-25$ on each side below the terminal one; lateral pinnae alternate, the central ones the largest, linear-lanceolate, $\pm 6-8$ cm. long, $\pm 7-9 \mathrm{~mm}$. broad, ascending, remote, short-stalked, caudateacuminate, serrate-crenate, unequal-sided at the base, the upper base rather broadly cuneate, parallel to the rachis and often slightly auriculate, the lower narrowly cuneate, the caudiform apex rather entire; lower pinnae gradually more or less reduced; terminal pinna lobed towards the base. Texture firm-herbaceous or membranaceous; surfaces naked but the edges and veins beneath sparingly ciliated; veins $2-3$ on each side of the main veins, the 2 lower anastomosing. Sori in 2-3 rows on each side of the costa, the lowest often contiguous or confluent (as in 
Meniscium), the highest often medial on the veins; indusium roundishreniform, naked, the sinus often close. - Rhizome .... .

New Guinea.

(116b) D. Spenceri, Christ, in Philipp. Journ., IIC , 206; Nephrudium Spenceri, Copel., MS.; Phegopteris Spenceri, v. A. v. $R$.

Rhizome elongate. Stipes $20-30 \mathrm{~cm}$. long, rufo-stramineous, clothed with short and long, grey hairs, as is the rachis. Fronds $50 \mathrm{~cm}$. or more long, $\pm 12-15 \mathrm{~cm}$. broad, oblong, acuminate, pinnate, with a large, lobed terminal pinna to $\pm 12 \mathrm{~cm}$. long and $3 \%$ cm. broad. Lateral pinnae sessile, oblong, falcate, to $\pm 10 \mathrm{~cm}$. long and $y \mathrm{~cm}$. broad, shortly acuminate, broadly and shallowly lobed, the base truncate on the upper side, semicordate and overlapping the rachis on the lower side; lobes \pm $5 \mathrm{~mm}$. broad; lower pinnae rather suddenly reduced to triangular auricles (4-10 on a side. Texture herbaceous; upper surface minutely hairy, lower hairy especially on the costae, costulae and veins, the hairs more or less resembling those of the stipe; veins \pm 6 on a side, the $3-4$ lower anastomosing, those of the terminal pinna more numerous. Sori $4-10$ on each side of the main veins (costulae), medial, often somewhat oblong; indusium partly persistent partly deciduous, short-hairy. - The description is taken from a duplicate of Elmer's No. 11723.

Mindanoo.

(116c) D. megaphylloides, Rst., in Fed., Rep., XII, 174.

Stipes $25 \mathrm{~cm}$. or more long, villose, clothed below with narrowly lanceolate, sparingly ciliated scales. Fronds elongate-ovate, $\pm 40 \mathrm{~cm}$. long by $25 \mathrm{~cm}$. or more broad, pinnate. Pinnae 10 or more on each side below the terminal one, subsessile, suberecto-patent, elongate, the apex short-acuminate, subentire, the edge cut $1 / 4-1 / 3$-way down to the costa; central pinnae $13 \mathrm{~cm}$. or more long, $\pm 21 / 2 \mathrm{~cm}$. broad; $2-4$ lower reduced; 1-2 lowest auricle-like. Lobes straight or subfalcate, $3-4 \mathrm{~mm}$. long by $\pm 4 \mathrm{~mm}$. broad at the base, bluntish. Texture herbaceous; or subcoriaceous; rachis and costae partly hairy partly strigose; upper surface densely strigose with short, white hairs; under surface glandular and sparingly pilose; veins hirsute with long, white hairs on both sides, 10 or more on a side, $\pm 3-4$ lower anastomosing. Sori subterminal on the veins; capsules short-hairy; indusium provided with a long, white hair. - Rhizome .... .

New Guinea. 
(117a) D. diehrotricha, Copel., in Philipp. Journ., VIC 74.

Stipes $\pm 40 \mathrm{~cm}$. long, brown, sparingly hairy. Fronds $\pm 60 \mathrm{~cm}$. or more long, $30-35 \mathrm{~cm}$. broad, the rachis densely pubescent. Pinnae \pm 20 on a side below the long, pinnatifid terminal one, the $2-3$ lower pair reduced, the lowest auricle-like, the largest short-stalked, nearly horizontal, $\pm 2 \mathrm{~cm}$. broad, acuminate, truncate at the base, cut $\pm 1 / 2$ way down to the costa into rounded, subfalcate, entire lobes. Surfaces pilose and glandular; 2--3 lower veins anastomosing. Sori medial; indusium persistent, pilose, glandular at the edge; spores reticulate. Rhizome ....

New Guinea, Mindanao.

(119a) D. paraphysata, Copel., in Philipp. Journ., VIC, 74.

Fronds $\pm 75 \mathrm{~cm}$. long and $30 \mathrm{~cm}$. broad. Pinnae straight, the largest short-staiked, $\pm 18 \mathrm{~cm}$. long, $2 \mathrm{~cm}$. broad at the base, narrowed gradually towards the acuminate apex, cut $\pm{ }^{1 / 2}$-way down to the costa into truncate lobes; terminal pinna similar to the lateral ones; 1 or more lowest pinnae suddenly reduced to mere auricles. Texture coriaceous; surfaces sparingly setose, costae densely so; veins simple, \pm 7 on a side, mostly the 2 lowest anastomosing. Sori nearer the costulae than the edge; indusium inconspicuous; sporangia intermixed with numerous glanduloso-capitate paraphyses. - Differs fom D. truncata 0 . Ktze by the very minute indusium, the presence of paraphyses, and the spores are tuberculate or spinulose. - Rhizome .... .

New Guinea.

\section{§ 3. CYCLOSORUS.}

(120) D. IBumei, v. A. v. $\boldsymbol{R}$.

Phitippines, Celebes, Nëro Guinea to Fïi.

120a) D. Hewittii, Copel., in Philipp. Journ., IIIC, 344.

Rhizome short-creeping, clothed with lanceolate, brown scales. Stipes slender, straight, $\pm 10-20 \mathrm{~cm}$. long, those of the fertile fronds the longest, grooved, hairy in the furrow, otherwise naked. Barren fronds $\pm 12 \mathrm{~cm}$. long, $\pm 5 \mathrm{~cm}$. broad, acute. Pinnae approximate, straight, 7-8 mm. broad, obtuse, coarsely inciso-serrate towards the apex, 
subentire towards the truncate, auriculate base, the lowest ones deflexed, parallel. Texture herbaceous; rachis like the stipe; surfaces naked except on the costae; costae nearly naked beneath; veins 2 on each side of the main veins, the highest often free. Fertile fronds $\pm 15 \mathrm{~cm}$. long, $\pm 4 \mathrm{~cm}$. broad, acuminate; pinnae more acutely auriculate, euspidate-acuminate, serrate above the middle, hardly $5 \mathrm{~mm}$. broad. Sori near the main veins, close; indusium bristly, cucullate, diaphanous, often peltate or with a closed sinus.

Borneo.

(120b) D. peltata, v. A. v. R., in Bull. Btz., 1914, XVI, 12.

Rhizome ascending, brown-scaly. Stipes aggregate, $\pm 17_{1 / 2}^{1}-22^{1 / 2}$ $\mathrm{cm}$. long, pubescent like the rachis, the hairs spreading, recurved, of the under side more or less deciduous. Fronds lanceolate, $\pm 20-25 \mathrm{~cm}$. long, $\pm 6-9 \mathrm{~cm}$. broad at or near the base, acuminate. Pinnae \pm 10-12 on a side; terminal pinna triangular, acuminate, crenate at the apex, deeply lobed or pinnatifid at the base; lateral pinnae more or less remote, horizontal or nearly so, more or less falcate, $\pm 1-1 \frac{1}{2} \mathrm{~cm}$. broad, the higher rather adnate, the lower subpetiolate, the apex acuminate in the barren pinnae, bluntish in the fertile ones, the edges parallel or subparallel, serrate-crenate in the barren pinnae, coarsely dentate-crenate in the fertile ones, the base truncate, distinctly auricled on the upper side and sometimes also on the lower side, the auricles often crenate or serrate; lower pinnae whether or not the largest, more or less deflexed. Texture herbaceous; surfaces naked; under surface verruculose; costae hairy above; veins 3 on a side, the 2 lower anastomosing. Sori small, medial on the veins; indusium reniform with a closed sinus or more commonly round and peltate.

Sumatra.

(120c) D. discophora, Rst., in Fed., Rep., XII, 172.

Stipes $\pm 25 \mathrm{~cm}$. long, dark-stramineous, clothed like the rachis with ferrugineous, lanceolate, minutely denticulate scales. Fronds elongateoblong, 2-pinnatifid. Pinnae \pm 10 on a side below the pinnatifid apex, suberect, alternate, remote, long-stalked, obliquely lanceolate or linearlanceolate, long-acuminate, unequal-sided at the base, the upper base truncate, the lower cuneate; lowest pinnae largest, $\pm 12 \mathrm{~cm}$. long by $4 \mathrm{~cm}$. broad. Pinnulae \pm 8 on a side below the serrate apex, suberect, remote, alternate, linear-oblong, acute, obtúsely crenate or repand, cuneate at the 
base; lower pinnulae petiolulate; lowest posterior pinnulae of lowest pinnae. produced, to $3 \frac{1}{2} \mathrm{~cm}$. long by $1 \mathrm{~cm}$. broad, deeply lobed; lobes entire or crenulate. Texture subcoriaceous; upper surface naked, lower provided with a fow scattered, minute, adpressed scales; costae naked above, sparingly scaly beneath; costulae and veins immersed; veins often forked. Sori subterminal on the anterior veinlets, large; indusium large, round, black, pale-brown-margined, evanishing.

New Guinea.

25. ASPIDIUM, Swart:

\section{$\S 1$. TECTARIA.}

(1) A. singaporianum, Waut.; Tectaria singaporiana, Copel., in Philipp. Journ., IXC, 229.

(2) A. Iricuspe, Tedd.

Also in Borneo.

(6a*) See No. 19.

(8) A. ternatense, $\boldsymbol{v}$. A. $\boldsymbol{v}$. I.

Fronds varying from 25 to $45 \mathrm{~cm}$. long; pinnae $3-8$ on a side, herbaceo-membranaceous to subcoriaceous; barren pinnae somewhat longer than and to twice as broad as the fertile ones, with the main veins more distinct, the veins anastomosing irregularly and the free veinlets spreading in various directions.

Also in New Guinea.

(8a) A. papuanum. v. A. v. R., in Bull. Btz., 1912, VII, 3; Tectaria papuana, Copel., in Philipp. Journ., VIC, 76.

Stipes to $\pm 45 \mathrm{~cm}$. long, black or purple-black, glossy, at length naked. Fronds oblong or deltoid, $\pm 25-40 \mathrm{~cm}$. long, $\pm 20-30 \mathrm{~cm}$. broad, pinnate. Pinnae 2 on each side below the terminal one, close or remote; lowest pinnae ascending, stalked, deltoid, trifurcate at the base, $\pm 15-20 \mathrm{~cm}$. long, the basal lobes rather spreading, elongate and 
acuminate, or the anterior one short and blunt, the central lobed, elongate, subfalcate, blunt or acuminate, $\pm 4-5 \mathrm{~cm}$. broad at the base, sinuated in the lower half; highest pinnae lanceolate, subfalcate, acuminate, \pm as long as the lowest, sinuated, adnate, free or connected with the terminal one; terminal pinna 3-partite or deeply and narrowly lobed at the base, with the central or terminal segment lanceolate, lobed or sinuated towards the base. Texture coriaceous; rachis dark, more or less deciduously and minutely puberulous, as are the costae at least towards the base; upper surface naked, lower very minutely puberulous especially on the veins; main veins reaching the margin; areolae numerous; free veinlets few. Sori terminal on free veinlets, mostly placed in 2 rows between the main veins; indusium partly round, partly reniform, with the sinus often close.

New Guinea.

(9) A. Beccarianum, Bk.; Tectaria Cesatiana, Copel., in Philipp. Journ., VIc 76 , p. p.

(9a) A. HamLerianum. Hst., in Fed., Rep., X, 338.

Rhizome erect, woody; scales dense, castaneous, glossy, strajght, linear-lanceolate, acuminate, entire. Stipes tufted, to $30 \mathrm{~cm}$. long, fuscous, glossy, scaly, at length naked. Fronds deltoid-ovate, to $20 \mathrm{~cm}$. long, 15 $\mathrm{cm}$. broad, 2-pinnatifid, shortly acuminate, cordate at the base. Pinnae 2 on each side below the terminal one; lowest pinnae stalked, unequalsided, ovate, $\pm 12 \mathrm{~cm}$. long, $7 \% / 2 \mathrm{~cm}$. broad, produced on the lower side, shortly acuminate, deeply pinnatifid, with the lowest basiscopical lobe to $6 \frac{1}{2} \mathrm{~cm}$. long, $2^{1 / 2} \mathrm{~cm}$. broad, lobed; highest pinnae linear-oblong, \pm 10 $\mathrm{cm}$. long, $2 \frac{1}{2} \mathrm{~cm}$. broad, shortly acuminate, lobed, with the lobes linear, subfalcate, subacute; terminal pinna triangular, elongate, broadly cuneate at the base, deeply pinnatifid, with the lobes falcate, acuminate, the lowest lobes inciso-lobate. Texture coriaceous; edges shortly ciliate; rachises fuscous, glossy, shortly pilose, as are the veins; areolae elongatohexagonal, with free veinlets. Sori in 1 row on each side near the costulae, terminal on free veinlets; indusium persistent.

Newo Guinea.

(10) A. repandum, Willd., Hk. Bk., Syn. Fil., 258; A pachyphyllum, Kze, in Bot. Zeit.. 1848, 259; Diels, in Engl. \& Prantl., Nat. Pl.fam., $\mathrm{I}^{\dagger}$, fig. $97 \mathrm{~A}-\mathrm{C} ; \mathrm{A}$. siifolium, Mett., var. pachyphyllum, Christ, in Ann. 
Btz., XV, 138; A. platyphyllum, Pr., Epim., 65; A. persoriferum, Gopel., Polypod. Philipp., 36; Sagenia repanda, Moore, Ind., 102; S. pachyphylla, Moore, Rac., Flor. Btz., I, 195; Nephrodium pachyphyllum, Bk., Hk. Bk., 1. c., 299 ; Tectaria crenata, Cav., Copel., in Philipp. Journ., $\Pi^{\mathrm{C}}, 414$.

Caudex erect, to $10 \mathrm{~cm}$. high, the scales ovate, dark-brown. Stipes $30-75 \mathrm{~cm}$. long, naked, scaly towards the base. Fronds $60-100 \mathrm{~cm}$. long in the fully developed plants, to $1 / 2$ as broad, with an oblong. lanceolate, entire to bluntly sinuated terminal pinna $10-30 \mathrm{~cm}$. long, $2-5 \mathrm{~cm}$. broad, often deeply pinnatifid in the lower part; below this 2-8 erecto-patent, entire to sinuated, acuminated, lanceolate or lanceolateoblong lateral pinnae on each side; lowest pinnae petiolulate, often lobed, forked or pinnatifid on the lower side, narrowed at the base, following often simple, higher more or less adnate to the rachis; fertile pinnae often more or less contracted. Texture herbaceous to subcoriaceous; surfaces naked; main veins straight, slightly flexuose or upcurved, distinct nearly to the edge; areolae of barren pinnae irregular, copious, with many free veinlets. Sori rather large, in 2 rows between the main veins, on short, excurrent free veinlets. - Two ultimate forms united by intermediates.

Forma typica: Areolae of fertile pinnae irregular, with many free veinlets spreading in various directions; indusium round, peltate.

Forma pachyphylla: Areolae of fertile pinnae subquadrangular, each with a single excurrent free veinlet bearing the sorus; indusium reniform, not rarely somewhat elongated.

Malaya to Polynesia.

\section{§ 2. SAGENIA}

(14) A. ternatum, Diels.

Simple fronds entire or sinuate; divided fronds not rarely 5-foliate in the adult plant, on stout stipes to $60 \mathrm{~cm}$. long.

Also in Malacca.

A. Irifolium, v. *. R., in Bull. Btz., 1912, VII, 4; var. compitale, v. A. v. R., 1915, XX, 6.

Rhizome short, erect or ascending, the scales subulate-lanceolate, dark-brown. Stipes subtufted, $20-40 \mathrm{~cm}$. long, purplish, somewhat deciduously scaly towards the base, puberulous like the central ribs of

FERNS AND FERN Allies. 
the segments, the hairs dense, minute, deciduous or persistent. Fronds $20-30 \mathrm{~cm}$. long, ternate, cordate at the base; central segment lanceolate, $18-25 \mathrm{~cm}$. long, $6-9 \mathrm{~cm}$. broad, blunt to acuminate, entire or irregularly repand, narrowed at the base, free or connected with the lateral segments; lateral segments ascending, oblong, falcate, much smaller than the central one, acuminate, the upper base cuneate, the lower broadly rounded or cordate, entire to broadly lobate-auriculate. Texture membranaceous to firm-herbaceous; surfaces naked; main veins arcuateascending, veins dark-brown; areolae with free veinlets. Sori scattered, numerous, small, terminal on free veinlets; indusium minute, fugacious.

Forma typica. - Luzon.

Var. compitale: Sori mostly compital on anastomosing veins, sometimes confluent or elongated. -- Obi Island.

(15b) A. termifolium, v. A. v. R., in Bull. Btz., 1913, XI, 3.

Near A. trifolium $v . A, v . R$. but the fronds with the leaflets less different in size, the veins not dark-brown, the fertile fronds more or less contracted, the sori compital, the indusia deeply fimbriate. - The reniform shape of the indusium very indistinct.

Malacca.

(17) Aolymorphum, Wall.

A plant found in Java by Dr. Koorders, very probably a from of this species, has the lowest pinnae pinnate at the base.

(19) A. Tobbii, Hk.; Tectaria Lobbii, Copel., in Philipp. Journ. $\mathrm{X}^{\mathrm{C}}, 146$.

Rhizome short, erect. Stipes tufted, $\pm 10-30 \mathrm{~cm}$. long, substramineous or pale-greyish-brown when dry. Fronds $10-30 \mathrm{~cm}$. long, pinnate. Pinnae $1-3$ on each side below the terminal one; terminal pinna linearlanceolate, $7 \frac{1}{2}-15 \mathrm{~cm}$. long, $1-2 \mathrm{~cm}$. broad, entire, tapering gradually from the middle to each end; lateral pinnae erecto-patent, the higher similar to the terminal one, sessile or sometimes connected with the terminal one, the lowest stalked, simple or forked in the younger or smaller specimens, 3-partite, ternate or pinnate with 1--2 pinnulae on each side in the adult or larger specimens; pinnulae similar to the terminal pinna. Texture more or less coriaceous; surfaces naked; rachis and costae pubescent above; main veins very oblique; areolae with or without few 
free veinlets. Sori scattered irregularly, mostly compital; indusium persistent, round or reniform.

Borneo.

(20) A. semibipinnatum, Wall.

Fronds to $\pm 80 \mathrm{~cm}$. long; higher pinnae mostly adnate, not rarely connected with the terminal one, simple or sometimes forked at the base; lower pinnae stalked, pinnate with $1-2$ pinnulae on each side below the terminal one; ultimate segments similar in shape to the terminal pinna but often smaller or narrower.

(24a) A. subconfluens, Bedd., Handb. Ind. Ferns, 214; Ferns Br. I., Suppl., tab. CCCLXIV.

Stipes tufted, $30-60 \mathrm{~cm}$. long, furnished with dark-coloured, linearsubulate scales. Fronds about $30 \mathrm{~cm}$. each way, triangular in outline, 3-partite. Lateral pinnae opposite or subopposite, short-stalked, unequalsided, with the anterior segments small, falcate, subentire, the posterior ones much produced, lanceolate, acuminate, the 2-3 lower ones cut about $1 / 3$ down into falcate lobes; central (terminal pinna deeply pinnatifid, with the lowest segments $71 / 2-15 \mathrm{~cm}$. long, cut $1 / 4$ of the way down to the costula. Texture moderately firm; surface naked above, pubescent on the veins beneath; areolae with a few free veinlets. Sori scattered, small, generally compital; indusium variable, reniform, curved, horseshoeshaped or nearly peltate, persistent. - The proper place of this species is uncertain because of incomplete description.

Mindanao; Khasya.

(26) A. heterodon, Copel.

Omit this, it being identical with A. decurrens $P r$.

(27) A. decurrens, Pr.; A. heterodon, Copel.; A. Copelandii, C. Chr.

(28a) A. Weberi, c. Chr., Ind. Fil., Suppl.; Tectaria Weberi, Copel., in Philipp. Journ., VIIC, 54.

Rhizome suberect, the apex densely clothed with narrow, black-brown scales. Stipes ..... ? Fronds $\pm 20-25 \mathrm{~cm}$. long, $15-20 \mathrm{~cm}$. broad, shortly decurrent, the margin cut down to a costal wing $2-5 \mathrm{~mm}$. 
broad*). Lobes generally 5 on a side, rather remote, broadly lanceolate, obtuse, sinuate, narrowed towards the base. Texture herbaceous; surfaces naked; main veins remote, reaching nearly the margin, minutely glanduloso-pilose. Sori in 1 row on each side of the main veins, solitary in the primary areolae; indusium persistent, roundish-reniform.

Mindanao.

(30a) A. 留awakamii, v. A. v. R., in Bull. Btz., 1912, VII, 4. Stipes $\pm 20 \mathrm{~cm}$. long, pale-brown, densely and finely but deciduously short-hairy, as is the rachis, sulcate down the face, somewhat scaly towards the base, the scales linear to subulate, entire, brown. Fronds $\pm 20 \mathrm{~cm}$. each way, 3-foliate. Terminal (central) pinna moderately long-stalked, deeply 3-fid, the lowest lobes oblique, much elongated, lanceolate-falcate, $\pm 10 \mathrm{~cm}$. long, subcaudate-acuminate, irregularly repand, the central lobe broader than the lateral ones, lobed with short, rounded lobes; lateral pinnae sessile or nearly so, forked on the lower side at the base, obliquely rotundate-subcordate at the base, the segments similar to the lowest lobes of the terminal pinna, the posterior lobe the shortest. Texture firm; surfaces naked; costae and costulae finely hairy above, the hairs more or less dense; areolae with numerous included free veinlets. Sori numerous, remote, placed in 2 rather irregular rows between the main veins, terminal on short free veinlets, somewhat prominent on the upper surface, each encircled by a hyaline patch of the parenchyma; indusium reniform, coriaceous, persistent.

Celebes.

(30b) A. adlenophorum, v. A. v. R.; Tectaria adenophora, Copel, in Leafl., IV, 1151.

Rhizome short-creeping; densely clothed with black, glossy, needlelike scales. Stipes slender, $10-20 \mathrm{~cm}$. long, fibrillose, scaly at the base. Fronds deltoid, $\pm 10-15 \mathrm{~cm}$. long, acuminate, pinnate. Pinnae often 2-jugate, the lower deltoid, forked or deeply pinnatifid, and produced on the lower side; terminal pinna relatively larger; deeply pinnatifid; segments oblong to lanceolate, the largest acuminated, lobed, the smallest entire or crenated, the edges often ciliated. Texture herbaceous; both

*) Copeland says: "Stipite 20 ad $25 \mathrm{~cm}$. alta, $15-20 \mathrm{~cm}$. lata, . . . . . etc." which is, of coarse, a typographical error. 
surfaces fibrillose. Sori compital, scattered or 2-soriate; indusium small, reniform, glandular, ciliated, soon hidden among the sporangia.

Sibuyan Island.

(30c?) A. de Castroi, v. A. v. R., in Bull. Btz., 1912, VII, 3.

Rhizome short-creeping, thick, woody, densely clothed with long, subulate, hair-pointed, black-brown, glossy scales. Stipes approximate, $\pm 30-55 \mathrm{~cm}$. long, fuscous, very minutely hairy, at length naked, angular and grooved when dry, scaly towards the base. Fronds $\pm 30-45$ $\mathrm{cm}$. long, pinnate, the rachis deciduously and very minutely puberulous. Pinnae \pm 4 on each side below the terminal one, opposite, remote; terminal pinna simple and lanceolate, or trifid at the base with lanceolate segments; higher pinnae ascending, sometimes suberect, simple, lanceolate, subfalcate, $\pm 10 \mathrm{~cm}$. long, $\pm 3-31 / 2 \mathrm{~cm}$. broad, sessile or short-stalked, acuminate, cuneate or more or less rotundate-cuneate at the base; $1-2$ lower pinnae stalked, to $\pm 20 \mathrm{~cm}$. long, forked at the base on the lower side with 1-2 lateral segments, rounded, truncate or cordate at the base, the terminal segment $\pm 5-6 \mathrm{~cm}$. broad, similar to the higher pinnae, the lateral segments similar but smaller, free or connected, sessile or stalked; stalks very minutely puberulous, as are the costae and main veins above; edges entire or irregularly repand to sinuate. Texture herbaceous; surfaces naked; main veins slender, reaching nearly the margin, upcurved; areolae irregular, numerous, with many included free veinlets. Sori in 2 rows between the main veins, sometimes accompanied by a few scattered ones, compital; indusium minute, soon evanishing, probably reniform.

Timor.

(30d) A. amplifolium, v. A. v. R., in Bull. Btz., 1913, XI, 2.

Stipes long, hrown when dry, glossy, finely fibrilloso-pilose. Fronds ovate, $\pm 60-65 \mathrm{~cm}$. long, nearly as broad, acuminate, pinnate. Terminal pinna ovate, acuminate, deeply pinnatifid at the base, with the lowest segments falcate, acuminate, bluntly lobed; lateral pinnae \pm 4 on a side, falcate, acuminate, the lowest the largest, on stalks to $\pm 3 \mathrm{~cm}$. long, deeply pinnatifid, pinnate at the base, the lowest posterior segments the largest, falcate-lanceolate, $\pm 20 \mathrm{~cm}$. long by $7 \frac{1}{2} \mathrm{~cm}$. broad, entire at the acuminate apex, pinnatifid, the lobes triangular-falcate, to $\pm 4 \mathrm{~cm}$. long 
and $2 \frac{1}{2} \mathrm{~cm}$. broad, blunt or acute. Texture herbaceous; rachis, costae and costulae more or less densely pubescent above, sparingly fibrillosopilose or glabrescent beneath; surfaces naked; areolae with copious free veinlets. Sori relatively large, compital, in 1 row on each side of the costulae or in 2 short rows between the main veins; indusium naked, persistent.

Malacca.

(32) A. coadunatum, Christ.

Omit this name, it should be A. Christii C. Chr.

32) A. Chrristii, C. Chr., Ind. Fil., Suppl.; A. coadunatum, Christ (not Wall.).

(32a) A. prominems, v. A. v. R., in Bull. Btz., 1914, XVI, 56.

Stipes naked (glabrescent?) in the upper part, sparingly scaly (finally asperulous or aculeolate) towards the base. Fronds $\pm 30-35 \mathrm{~cm}$. long, to $30 \mathrm{~cm}$. broad at the base, the rachises ferrugineo-tomentose (shortly fibrillose) above, not roughish. Pinnae \pm 3 on a side below the terminal one; terminal pinna ovate, caudate-acuminate, deeply pinnatifid towards the base, with the largest segments ascending, falcate, $\pm 7-10 \mathrm{~cm}$. long, acuminate, lobed; lateral pinnae falcate, the highest short-stalked, nearly sessile, deeply lobed, the lowest conspicuously stalked, obliquely triangular, $\pm 15-171 / 2 \mathrm{~cm}$. long, $\pm 10 \mathrm{~cm}$. broad at the base, broadest on the lower side, long-acuminate, the upper side deeply lobed with broadly repand lobes, the lower side deeply pinnatifid, pinnate at the very base, the lower segments much elongated, acuminate, the lowest deeply lobed or pinnatifid with linear-oblong, subfalcate, blunt, entire or subrepand lobes; ultimate lobes entire in the smaller forms, repand in the larger, with the edges distinctly ciliolate. Sori immersed, distinctly though not much prominent on the upper surface, mostly terminal on excurrent free veinlets, placed in 1 row on each side of the costulae, sometimes accompanied by a few scattered others.

Sumatra.

(34) A. grande, J. Sm.

Also in New Guinea.

(36a) See No. $32 a$. 
(37a) See No. $8 a$.

(38) A. persoriferum, Copel.

Omit this, it being referred to $\mathrm{A}$. repandum Willd.

(38a) A. pleiosorum, v. A. v. H.; A. persoriferum, Copel., forma latipinna \& forma paucipinna, v. A. v. R., Mal. Ferns, 251 and Bull. Btz, 1912, VII, 5.

Rhizome short. Stipes aggregate, about $40-60 \mathrm{~cm}$. long, stramineous or pale-brown, provided in the lower part with scattered, subulate-lanceolate, sparingly eroso-denticulate or subentire, fuscous scales, the rest naked, as is the rachis. Fronds about $25-50 \mathrm{~cm}$. long, pinnate, the barren fronds the largest. Barren fronds with the pinnae simple, much acuminated, entire to subrepand or subsinuate; terminal pinna lanceolate-oblong, 25-30 cm. long, 10-12 cm. broad, cuneate at the base; lateral pinnae $1-6$ on a side, ascending, opposite, lanceolate, straight or subfalcate, $20-30 \mathrm{~cm}$. long by $3-10 \mathrm{~cm}$. broad, the highest adnate and suddenly decurrent at the base, free or connected with the terminal one, the lowest the largest, shortly petiolate. Texture coriaceous; surfaces naked; main veins oblique, straight or more commonly upcurved, connected by nearly straight transversal veins so as to form numerous subquadrangular primary areolae; secondary areolae irregular, with free included veinlets. Fertile fronds with the pinnae about $1 /{ }_{2}-3 / 4$ as large as in the barren fronds, with the areolae nearly square with solitary excurrent free veinlets Sori large, numerous, in 2 rows between the main veins, terminal on the free veinlets, suboblong; indusium persistent.

Borneo, New Guinea.

(39a) A. Mülleri, C. Chr., Ind. Fil.; A. confluens, Mett., Kuhn, in Linn., XXXVI, 125; (? A. latifolium, J. Sm., var. coriacea, Rst., V. A. v. R., in Bull. Btz., 1912, VII, 3); Nephrodium confluens, Muell., Hk. Bk., Syn. Fil., 504; (? Tectaria Cesatiana, Copel., in Philipp. Journ., VIC, 76, p. p.)

Stipes naked, castaneous. Fronds deltoid, $\pm 30-45 \mathrm{~cm}$. each way, 3-pinnatifid. Lower pinnae largest, deltoid, unequal-sided, with large lanceolate pinnulae, the lowest deeply lobed. Texture moderately firm; surfaces bright-green, densely pubescent on the ribs; rachises castaneous, pubescent; areolae fine, with copious included free veinlets. Sori large, uniserial near the main veins; indusium minute, fugacious. - A duplicate 
of Rev. Copland King's No. 161, from New Guinea, which is probably a form of this species, has the frond smaller, less broad than long, with the lowest pinnae deeply pinnatifid at the base and the lowest posterior lobe deeply lobed, the surfaces naked except on the costae and rostulae which are rather densely pubescent above, the indusium roundish-reniform with the basal lobes often close or overlapping.

New Guinea (?); Queensland.

(40) A. pachyphyllum, Ktze.

Omit this, it being referred to A. repandum Willd.

\section{OYSTOPTERIS, Bernhardi.}

Sori subglobose, dorsal or terminal on a vein or veinlet, or at the forking of a vein. Indusium membranaceous, round and cucullate, convex, covering the sorus, at length more or less reflexed or fugacious, fastened by a broad base under the sorus, i. e. the indusium is attached to the receptacle on 3 sides of it, opening towards the apex or the margin of the segment.

(1) C. tristis, Mett.

Omit this, it being referred to Stenolepia.

(3) C. stipellata, v. A. v. R., in Bull. Btz., 1911, I, 4; C.nodosa, Mett., Ann. Mus. Bot. L. B., I, 142. Aspidium nodosum, Bl., Enum., 171; Acrophorus nodosus, Pr.. Christ, Farnkr. d. Erde; 285; Bedd., Ferns Br. I., I, tab. XCIII; A. stipellatus, Moore, C. Chr., Ind. Fil.; Leucostegia nodosa, Bedd., Ferns Br. I., Suppl., 4; Davallia nodosa, Hri., Rac., Flor. Btz. I, 130 ; D. stipellata, Wall. (oldest name); — var. alpina, Christ, in Ann. Btz., XV, 89; - var. montana, Rst., in Fed., Rep., XI, 166.

Rhizome erect, short, densely clothed with entire, lanceolate, brown scales. Stipes glossy, 30-100 cm. long, scaly below, purple-brown to yellow-brown. Fronds ovate to deltoid, $\pm 25-120 \mathrm{~cm}$. long, $15-80 \mathrm{~cm}$. broad, 3-4 pinnate. Pinnae subopposite, sessile or short-stalked, not rarely upcurved, the rachis ferrugineo-tomentose at the base on the upper side; lower pinnae $\pm 15-25 \mathrm{~cm}$ broad, with the pinnulae on the 
lower side often the largest. Pinnulae lanceolate-triangular, the rachis tomentose at the base on the upper side. Ultimate leaflets cut down nearly or quite to the costa into blunt, entire, toothed or lobed segments to $3 \mathrm{~mm}$. long, to $1 \frac{1}{2} \mathrm{~mm}$. broad, narrowed at the base. Texture thinly or more firmly herbaceous; surfaces sparingly hairy on the veins; main rachis somewhat nodose at the place of insertion of the pinnae and provided there with ferrugineous tomentum on the upper side; secondary and tertiary rachises provided with a minute seale at the base beneath. Sori small, numerous, solitary and submarginal or medial on the ultimate teeth or lobes. - A specimen gathered in Java by Païdan has the indusium intermediate between this and Stenolepia.

Forma typica: Stipe and rachis smooth, or rough by the persistent bases of fallen scales. - Malaya to North India.

Var. alpima: Fronds small, to $\pm 15 \mathrm{~cm}$. long; stipes scaly. New Guinea, Celebes.

Var. montana: Rachises scabrous, densely clothed with glandlike hairs or squamules; ultimate segments very minute, the lower acutely toothed; veins glandular beneath, the glands yellow, cylindrical. - New Guinea.

\section{2\% $a$. S'TENOLEPIA, v. A. v. R.}

Sori subglobose, dorsal on a vein or veinlet or at the forking of a vein. Indusium small, narrow, not hood-shaped, fastened by a gradually narrowed base under the sorus i. e. the indusium is attached to the receptacle on 1 side, at length reflexed or deciduous; receptacle elevated.

Rhizome erect. Stipes not articulate to the rhizome. Fronds decompound; veins free, simple or forked.

(1) St. Iristis, v. A. v. r., in Bull. Dép. Agr. I. N., 1909, XXVII, 46, tab. VII; C. Chr., Ind. Fil., Suppl.; Alsophila tristis, Bl., Hk. Bk., Syn. Fil., 44; Cystopteris tristis, Mett., Ann. Mus. Bot. L. B., I, 241; Davallia tristis, Rac., Flor. Btz., I, 131; Aspidium triste, Bl. (oldest name).

Rhizome erect, short, densely clothed with entire, lanceolate, brown scales. Stipes $50-90 \mathrm{~cm}$. long, $\pm 7 \mathrm{~mm}$. thick at the scaly, tuberculatoasperous base, brown, upward deciduously fibrillose and punctulatoasperulous, as are the rachises Fronds ovate-lanceolate to deltoid, 
acuminate, $\pm 45-90 \mathrm{~cm}$. long, $\pm 40-60 \mathrm{~cm}$. broad, 3-pinnate. Pinnae. ovate to lanceolate, acuminate, short-stalked, the largest ones to $10 \mathrm{~cm}$. broad. Pinnulae lanceolate, short-stalked. Ultimate segments sessile, narrowed at the base, 5-12' ${ }_{2} \mathrm{~mm}$. long, to $\pm 4 \mathrm{~mm}$. broad, oblong, obtuse, incised to \pm half-way down to the costa, more or less decurrent. Texture subcoriaceous; costae fibrillose; veins simple or forked. Sori 1 in each lobule; receptacle elevated; indusium small, narrowly ligulate, at length reflexed, deciduous, apparently very caducous in dried young material.

Java.

\section{ODONTOSORIA, Presl.}

\section{§ 1. EU-0DONTOSORIA.}

(1) D. Chinensis, J. Sm.; Davallia terruginea, Cav. (not Willd.), Nees \& Bl., Nova Acta, XI, tab. XII, fig. 4 A, b; D. venusta, Schk., Krypt. Gew., I, tab. 128.

(4) O. lindsayae, $v . A . v . R$.

Omit this name, it should be 0 . decipiens Christ.

(4) Aceipiens, Christ, in Nov. Guin., VIH, Bot., 158; C. Chr., Ind. Fil., Suppl.; O. lindsayae, v. A. v. R.; Davallia decipiens, Ces., Fel. Becc. Polin., $3 \& 7$;

\section{LI I DSA Y A, Dryander.}

\section{\$1. ODONTOLOMA.}

\section{(1) H. repens, Bedd.}

Fronds not rarely dimorphous and then the lower fronds or those of the younger plants (aquatic leaves) quite different from the higher ones or those of the adult plants (evolute leaves), very thin in texture, varying from simply pinnate to deeply bipinnatipartite with very narrow, linear secondary segments. According to Christ the species L. delicatula, hymenophylloides and capillacea are founded on the water-leaves of this 
species and of L. pectinata $B l$. (Christ, Geogr. der Farne, 70). - Var. intermedia (Christ, in Ann. Cons. Gen., XV-XVI, 197) has the fronds intermediate between the type and the water-leaves, i. e. simply pinnate in the upper part, 2-pinnatipartite towards the base.

Omit the variety hemiptera, it being only a form of the species.

(1a) L. Iunulata, v. v. re., in Bull. Btz., 1913, XI, 15.

Rhizome ereeping, scaly, wiry. Stipes short, brown at the base. Fronds linear, $\pm 15-20 \mathrm{~cm}$. long, $\pm 1 \frac{1}{2}-2 \mathrm{~cm}$. broad, pinnate, narrowed abruptly at the apex but gradually towards the base. Leaflets horizontal, approximate, sublunulate-oblong, to $1 \mathrm{~cm}$. long and $1 / 2 \mathrm{~cm}$. broad, the apex broadly rounded, the upper and lower edge subparallel, decurved, the base truncate, parallel to the rachis, the upper edge entire or repando-crenate; lower leaflets gradually reduced, lowest auricle-like. Texture thin, herbaceous or membranaceous; rachis and both surfaces naked; veins not reaching the margin. Sori terminal on the veins, often confluent in pairs.

Batu Island.

(1b) L. sessillis, Copel., in Philipp. Journ., VIC, 82.

Rhizome creeping, scaly. Stipes very short, at best $2 \mathrm{~mm}$. long. Fronds unbranched, $\pm 20 \mathrm{~cm}$. long or somewhat longer, $\pm 4-4 \frac{1}{2} \mathrm{~cm}$. broad, abruptly acuminate. Leaflets numerous, the lower reduced, the central recurved or somewhat deflexed, cuneate at the base, inciso-crenate on the upper (outer) side. Sori terminal on the lobes, small; indusium minute, fugacious.

New Guinea.

\section{(4) L. delientula, Christ.}

See the information under L. repens Bedd.

(4a) L. Foersteri, Rst., in Fed.,. Rep., XII, 527.

Rhizome wide-creeping, flexuose, the scales lanceolate, yellowish. Stipes seriate, $\pm 2-3 \mathrm{~cm}$. apart, $\pm{ }_{12} \mathrm{~cm}$ long. Fronds linear-lanceolate, to $25 \mathrm{~cm}$. long by $2 \mathrm{~cm}$. broad, acuminate, hardly narrowed at the base. Pinnae numerous, sessile, spreading, the central the largest, to $10 \mathrm{~mm}$. long by 3-4 mm. broad, trapezoid-lanceolate, obtuse, the lower side straight or slightly recurved, the upper side lobed; lower pinnae recurved. 
Texture thin; surfaces naked. Sori 1 or rarely 2 on a pinna, subterminal; indusium reniform, the edge not reaching the margin of the pinna.

New Guinea.

\section{(5a) L. andiantoiles, Fuhn.}

Elmer states that the fronds sometimes fork.

(6c) L. glandulifera, v. A. v. R., in Bull. Btz., 1911, I, 9.

Rhizome scandent, woody, olivaceous, clothed with copious but not crowded ferrugineous, lanceolate, entire seales. Stipes distant, short \pm $1 \mathrm{~cm}$. long, and, like the main rachis, angular and stramineous. Fronds unbranched, $\pm 15-35 \mathrm{em}$. long, $1 \frac{1}{2}-3 \mathrm{~cm}$. broad, narrowed gradually towards the apex and slightly so towards the base. Leaflets numerous, rather remote, spreading or erecto-patent, the lower often deflexed, the largest to $1 \% \mathrm{~cm}$. long, $\pm 5 \mathrm{~mm}$. broad at the base, the lower edge straight or decurved, the upper cut $\pm 1 / 2$-way down into \pm 5 lobes; lobes oblong, the highest the longest and narrowest, entire or emarginate, the central mostly emarginate or 2-fid, erecto-patent, the lowest. the broadest and shortest, with the inner side \pm parallel to rachis, the upper side 2-fid, with the segments emarginate or 2-fid again; ultimate segments bluntly rounded. Texture firm but not thick; main rachis and upper surface naked; under surface provided with copious scattered, minute, adpressed, fibril-like glands. Sori on the ultimate segments, mostly solitary, if double, then not rarely confluent, terminal; indusium rounded at the base.

Java.

\section{(7) L. IIerrilli, Copel.}

Also in New Guinea.

(8) L. hymenophylloides, $\boldsymbol{B L}$.

See the information under L. repens Bedd.

(8a) L. Irichophylla, Copel., in Philipp. Journ., VIC, 83.

Rhizome erect. Stipes aggregate, slender, $\pm 2 \mathrm{~cm}$. long Fronds unbranched, $\pm 5-8 \mathrm{~cm}$. long, $\pm 1 \mathrm{~cm}$. broad, narrowed at both ends, the rachis grooved. Leaflets stalked, naked, dimidiate, cut down on the upper side to a narrowly winged costa into a few divaricating, entire 
segments $\pm 1 / 5 \mathrm{~mm}$. broad and abruptly dilated at the apex. Sori terminal on the segments, as broad as the dilated apices.

New Guinea.

(9) L. ca pillacea, Christ; L. pectinata, Bl., var., C. Chr. Ind. Fil., Suppl.

(9a) L. Toemeriana, Rst., in Nov. Guin., VIII, Bot., 719.

Rhizome wide-creeping, slender, fuscous, provided with a few scattered, yellowish, linear-lanceolate scales. Stipes scattered, $\pm 5-10 \mathrm{~cm}$. long, naked and stramineous, as is the rachis, fuscous at the base. Fronds lanceolate, $\pm 10-17 \mathrm{~cm}$. long, $\pm 2-4 \mathrm{~cm}$. broad at the middle, acuminate, the base truncate, whether or not somewhat narrowed. Pinnae spreading or horizontal, straight or recurved, subremote to imbricate, the largest $\pm 1-2 \mathrm{~cm}$. long, $\pm 1 / 2$ as broad at the base, the upper side eut down to a narrowly winged costa into 2-4 remote segments below the terminal one. Highest segments simple, suberect, lowest forked, subspreading; ultimate segments linear-euneate, $\pm 1 / 2 \mathrm{~mm}$. broad, the barren ones blunt or bluntish, entire, the fertile ones rotundate-clavate-dilatate and more or less copiously denticulate at the apex. Texture thin; surfaces naked; a central vein in each ultimate segment, not reaching the apex. Sori terminal on the veins, oceupying the central portion of the dilated apex of the fertile segments; indusium roundish-subreniform.

New Guinea.

(9b) I. Sehlechteri, Brau., in Lautb., Beitr. Flor. Pap.. I, 28, fig. $1 I-i$.

Rhizome short. Stipes tufted, filiform, $\pm 1 / 2-1 \mathrm{~cm}$. long, narrowly winged, hairy when young. Fronds lanceolate, to $3 \frac{1 / 2}{1 / 2}$. long and 1 $\mathrm{cm}$. broad, narrowed towards both ends; rachis filiform. Leaflets alternate, \pm 11 on a side, the central ones the largest, $\pm 6 \mathrm{~mm}$. long, cut down on the upper side to a filiform rachis into $1-3$ narrowly linear, simple or forked segments. Segments cuneate-clavate at the end, the apex truncate, retuse so as to form 2 distinct acute teeth. Surfaces naked, pale-green. Sori solitary and terminal on the dilated tips of the segments, between the teeth; indusium cup-shaped.

New Guinea. 
(11a) L. Versteegii, v. A. v. R.; Odontosoria Verstepgii, Christ, in Nov. Guin., VIII, Bot., 157; C. Chr., Ind. Fil., Suppl.

Rhizome wide-creeping, scaly, the scales brown, triangular-subulate, more or less deciduous. Fronds distant, partly branched partly unbranched. -- Branched fronds long-stalked, with the stipes naked, dark-brown, $10-20 \mathrm{~cm}$. long; lamina deltoid to oblong, up to $\pm 30 \mathrm{~cm}$. long; branches up to \pm 10 on each side, erecto-patent, distant, pinnate, the lower ones $\pm 4 \mathrm{~cm}$. apart, $\pm .10-20 \mathrm{~cm}$. long, $\pm 2-3 \mathrm{~cm}$. broad, sessile, broadest at or near the base, narrowed towards the apex. Leaflets numerous, close, up to \pm 30 on each side, cut down on the upper side to a filiform, decurved rachis into very slender, filiform segments, the largest leaflets $\pm 5 \mathrm{~mm}$. broad; higher segments forked, lower twice forked. Texture firm but not thick; surfaces and rachises naked. Unbranched fronds sessile, similar to the branches of the branched fronds, rather broadest at the middle. Sori roundish, small, subterminal on the dilated apices of the ultimate segments, 1 to each segment.

New Guinea.

\section{§ 2. EULINDSAYA.}

(12a) 耳. bullata, ש. c. R., in Bull. Btz., 1914, XVI, 20.

Rhizome short-creeping, clothed with brown, flbrilliform scales. Stipes somewhat remote, $3-5 \mathrm{~cm}$. long, deciduous fibrillose at the base, grooved above, and naked, as is the rechis. Fronds linear, $\pm 5-10 \mathrm{~cm}$. long, $1--11 \% \mathrm{~cm}$. broad, simply pinnate, narrowed gradually towards the apex, rather truncate and whether or not slightly narrowed at the base. Leaflets spreading, petiolulate, the largest $4-8 \mathrm{~mm}$. long, $3-5 \mathrm{~mm}$. broad at base, the apex blunt, the lower edge entire, upcurved towards the apex, the upper edge distinctly but not deeply incised into $3-5$ lobes, the inner edge rather parallel to the rachis. Lobes entire or emarginate, rounded when barren, truncate, somewhat retuse and often irregularly denticulate at the apex when fertile, the lowest lobe of the lowest leaflets sometimes free and cuneate at the base. Texture firm; surfaces naked; veins simple or once forked, hidden beneath, distinct above. Sori solitary on the veins or uniting the fork-branches of forked veins, immersed so as to form submarginal, bullate protuberances on the upper surface; indusium firm, often irregularly denticulate, bullate.

Java. 


\section{(13) L. concinma, J. Sm.}

Lower pinnae (leaflets) not reduced.

(13a) L. brevipes, Copel., in Philipp. Journ., VIC, 83; L. Lobbiana, Hk., var. sessilifolia, Rst., MS. in Herb. Bog.

Differs from the preceding in having the fronds sessile or on stalks to $\pm 4 \%$ cm. long, the pinnae (leaflets) not rarely more deeply lobed and the lower pinnae gradually reduced to mere auricles; fronds $20-45$ $\mathrm{cm}$. long, $\pm 1--1 \frac{1}{2} \mathrm{~cm}$. broad; the largest leaflets $6-7 \frac{1}{2} \mathrm{~mm}$. long; $31 / 2-4 \mathrm{~mm}$. broad.

New Guinea, Amboina.

(15) L. montana, Copel.

Omit this, it being referred to Schizoloma heterophyllum J. Sm.

(15a) See No. $18 a$.

(18a) L. cultrata, Swo.; — var. minor, Hk., Spec. Fil.; I, 204; var. varia, Copel.

Fronds membranaceous or firm, 10-50 cm. long, $\pm 2-t \mathrm{~cm}$. broad.

var. minor: Fronds under $10 \mathrm{~cm}$. long, under $1 \frac{1}{2} \mathrm{~cm}$. broad.

$\left(18 a^{*}\right)$ L. propria, v. A. v. $\boldsymbol{\pi}$. , in Bull. Btz., 1914, XVI, 20.

Rhizome short-creeping, brown-fibrillose. Stipes approximate, $5-12 \%$ $\mathrm{cm}$. long, fibrillose at the base, finally naked, obtusely quadrangular. Fronds linear, simply pinnate, $20-30 \mathrm{~cm}$. long, $2-2 \frac{1}{2} \mathrm{~cm}$. broad, acuminate to subcaudate, and coarsely obliquely lobate-dentate at the apex, truncate at the base. Leaflets numerous, close, horizontal or nearly so, the lower remote, a little smaller than the central ones and sometimes slightly deflexo-falcate, the largest $1-11 / 4 \mathrm{~cm}$. long, $1 / 2-3 / 4$ cm. broad, the apex blunt, rounded or obliquely truncate, the upper edge lobate-crenate with $\pm 3-4$ lobules, the lobules when fertile truncate (straight or somewhat retuse), when sterile crenate-dentate with 2-4 bluntish teeth, the inner edge parallel to the rachis, the lower edge straight or somewhat sigmoideo-curvate. Texture thin; rachis angular, naked; surfaces naked; veins slender, not reaching the margin. Sori 1-3 (mostly 2) to a leaflet, occupying the higher lobules, the longest 
terminal on the leaflets, linear, rarely interrupted, the others shorter, transversely oblong or linear-oblong.

Java.

(19) D. pectimata, \#t. - var. brevipinnula, Rst., in Hedwi., LVI, 351.

Fronds not rarely dimorphous. See the information under L. repens Bedd. - Var. varia may perhaps be a form with water leaves.

Forma truncatiloba (forma dimorpha, Rst., in Fed., Rep., XIII, 213): Large; fronds up to $70 \mathrm{~cm}$. long by $6 \mathrm{~cm}$. broad, with the central leaflets dilated and truncate at the apex. - Sumatra.

Var. brevipinnula: Leaflets shorter, to $1 \mathrm{~cm}$. long, the lower of the simply pinnate fronds often incised into linear lobes; sori about 5-6 to leaflet. -- New Guinea.

(21) L. orbiculata, Mett.; - var. odontosorioides, Copel., in Philipp. Journ., VIC, 138; - var. sumatrana, Rst., in Fed., Rep., XIII, 214.

Var. odontosorioides: Fronds lanceolate; pinnulae cuneate, more or less deeply incised, the lobes $\pm 1 \frac{1}{2} \mathrm{~mm}$. broad; veins 2 in a lobe; sori subterminal on the lobes. - Borneo.

Var. sumatrana: Fronds lanceolate, the leaflets cut $1 / 2$-way down or more, with the lobes 2-fid, and the lobules often 2-lobed again. - Sumatra

(23a) L. monoearpa, Rst., C. Chr., Ind. Fil., Suppl.; L. monosora, Rst., in Nov. Guin., VIII, Bot., 720.

Stipes firm, to $20 \mathrm{~cm}$. long, roughish towards the base, like the rachises terete, grooved down the face, naked, black-purple. Fronds 2-pinnate. Branches $\pm 2-3$ on each side below the terminal one, linearlanceolate, $\pm 10-20 \mathrm{~cm}$. long, $1 \frac{1}{2}-2 \mathrm{~cm}$. broad, narrowed gradually towards the apex, less so towards the base, the lateral ones ascending. Leaflets numerous, somewhat remote, shortly petiolulate, oblique, rhomboidal-oblong, the margin pellucido-cartilaginous, the central ones \pm 8-10 $\mathrm{mm}$. long, $1 / 2$ as broad, the lower edge decurved at the base, upcurved at the apex, the upper edge sparingly broadly crenate-serrate, the base cuneate, the apex broadly acute and often shortly apiculate or 2-dentate when barren, obliquely truncate when fertile; veins simple or 
forked, or the lower twice forked. Texture coriaceous; surfaces naked. Sori linear-oblong, solitary and terminal on the fertile leaflets.

New Guinea.

(23b) L. regularis, Rst., in Med. R. H. L., 1912, 14, 31.

Stipes \pm half a long as the fronds, compressed, angular, livid-brown, the base asperulous and provided with scattered, ferrugineous scales. Fronds $45 \mathrm{~cm}$. more or less long, $\pm 15 \mathrm{~cm}$. broad, 2-pinnate with \pm 5-6 linear-lanceolate branches on each side below the terminal one. Branches $\pm 15-25 \mathrm{~cm}$. long, to $2 \mathrm{~cm}$. broad, acuminate, hardly narrowed at the base, the terminal one the longest, the lateral ones subsessile, the higher and lower the shortest. Leaflets numerous, alternate, short-stalked, much ascending, the higher and lower subcuneate, the central trapezoidoblong, to $\pm 1 \mathrm{~cm}$. long and $1 / 2 \mathrm{~cm}$. broad, obtuse, the upper and outer edge slightly crenated, the base truncate, often overlapping the rachis. Texture membranaceous; surfaces naked; veins fine, 4-5, the highest simple, the lowest twice forked. Sori solitary on the vein tips or uniting the apices of 2 veinlets; indusium membranaceous.

\section{Lombok Island.}

(23c) W. mapaea, v. A. v. R., in Bull. Btz., 1915, XX, 19, tab. III.

Rhizome short-creeping, deciduously fibrillose. Stipes somewhat remote, $20-25 \mathrm{~cm}$. long, quadrangular, naked, stramineous when dry. Fronds 2-pinnate with $1-2$ branches on a side below the terminal one. Branches elongate-lanceolate, $10-15 \mathrm{~cm}$. long, $1 \frac{1}{2}-2 \mathrm{~cm}$. broad at the middle, acuminate, slightly narrowed at the base; terminal branch longest, short-stalked; lateral brabches shorter, subsessile. Leaflets numerous, sessile, close or approximate, horizontal or nearly so, linear-oblong or the lower anterior ones obliquely conico-flabellate, bounded by a marginal vein; largest leaflets $7^{1} / 2-10 \mathrm{~mm}$. long by $3-4 \mathrm{~mm}$. broad at the middle, slightly dilated at the base, the apex rounded or rotundate-truncate, the sides subparallel, the base cuneate, the upper and outer edge subentire or obliquely, irregularly and broadly (not deeply) subundulatecrenate or duplicate-crenate. Texture firm-herbaceous; surfaces naked; veins fine, mostly once or twice forded. Sori linear, in a more or less sparingly interrupted line along the upper and outer edge; indusium narrow.

\section{Lingga.}

Ferns and Fern Allies. 
(25) I. rigida, J. Sm.

Forma typica: Leaflets shallowly lobed, the lobes entire, rounded or rotundate-truncate, retuse or rotundate-emarginate or -crenate; veins and edges thick-cartilagineous, very prominent; sori on 1-2 terminal lobes, oblong or linear-oblong.

Forma acutata: Like the type but the lobes or crenations subacute. Also in Sumatra.

(25a) 1. Kingii, Copel., in Philipp. Journ., VIC, 83.

Rhizome creeping, moderately thick. Stipes approximate, 25-30 $\mathrm{cm}$. long, brown, naked like the whole plant but the lower part scaly and at length asperous. Fronds $\pm 45-70 \mathrm{~cm}$. long, $\pm 25-30 \mathrm{~cm}$. broad, branched, the rachis square, grooved. Branches $\pm 10-15$ on a side, lower reduced, central to $18 \mathrm{~cm}$. long, $1 \frac{1}{2} \mathrm{~cm}$. broad, subsessile, acuminate. Leaflets $30-40$ on a side, short-stalked, dimidiate, $\pm 8 \mathrm{~mm}$. long, 3-4 $\mathrm{mm}$. broad, inciso-crenate on the upper side. Sori solitary on the lobes, intramarginal, mostly uniting the apices of 2 veins or veinlets; indusium short an broad, pale-brown.

New Guinea.

(25b) L. monosoran, Copel., in Leafl., II, 398.

Stipes up to $20 \mathrm{~cm}$. or more long, sparsely scaly at the base. Fronds up to $50 \mathrm{~cm}$. long, 2-pinnate, with $3-5$ pairs of subopposite or alternate, rather strict, acuminate lateral branches overtopped by the terminal one Leaflets $\pm 7 \mathrm{~mm}$. long, $\pm 4 \mathrm{~mm}$. broad, entire below, lobate-crenate on the upper side, the lobules rounded or rotundate-truncate to retuse. Texture herbaceo-papyraceous; veins not prominent, free except that 2 or more coalesce in the base of the sori. Sori solitary at the outer point or on the upper side near the outer point of the leaflets; indusium thin. - Differs from L. rigida J. Sm. by its fine, hardly prominent veins. Negros.

(25c) J. diplosora, v. A. v. R., in Bull. Btz., 1914, XVI, 21.

Rhizome wiry, wide-creeping, sparingly deciduously scaly, the scales sessile, brown, lanceolate-subulate, entire, subadpressed, making the rhizome rough by their persistent bases. Stipes scattered, $\pm 71 / 2-15 \mathrm{~cm}$. long, glossy and naked like the rachis, deciduously scaly and asperous at the base. Fronds $\pm 221 / 2-25 \mathrm{~cm}$. long or longer, 2-pinnate, with a linear, 
acuminate, straight, curved or subflexuose terminal branch $\pm 12^{1 / 2}-17^{1 / 2}$ $\mathrm{cm}$. long by $1 \frac{1}{2}-2 \mathrm{~cm}$. broad at or near the base and $3-5$ erecto-patent, similar but mostly shorter ones on each side. Leaflets oblique or subspreading, approximate, oblong, the largest $7 \frac{1}{2}-10 \mathrm{~mm}$. long, 3-4 mm. broad, the apex blunt, the lower edge straight or nearly so, the upper edge lobed, the base cuneate; lobes $\pm 3-5$ (mostly 5), the barren ones small and rounded, the fertile ones larger (longer and broader) and truncate (often dilated) at the apex. Texture thin; surfaces naked; rachises when dry quadrangular and grooved at least on the upper side, veins mostly forked, sometimes sparingly anastomosing. Sori terminal on the fertile lobes, $1-3$ (mostly 2) to a leaflet, solitary on the veins or commonly uniting the apices of $2-3$ veins or veinlets, if solitary, then terminal on the leaflets, if 2, then 1 terminal and the other occupying one of the central lobes, if 3 , then occupying the terminal and next following lobes; indusium rather thin, subcrenulate.

\section{Sumatra.}

(25d) L. triplosora, v. A. v. R., in Bull. Btz., 1914, XVI, 21.

Near L. diplosora $v, A$. v. $R$. but the leaflets not rarely larger, bounded by a more or less pellucid marginal strand, the lower edge upcurved, the sori occupying the $1-3$ higher lobes, the fertile lobes often broader than the barren ones but not longer, the indusium firmer and rather entire.

Sumatra.

(25e) I. multisora, v. A. v. R., in Bull. Btz., 1914, XVI, 21.

Stipes stramineous, nạked, quadrangular, $17 \%,-25 \mathrm{~cm}$. long. Fronds $\pm 15-20 \mathrm{~cm}$. long, $\pm 12 \frac{1}{2}-17 \frac{1}{2} \mathrm{~cm}$. broad, 2-pinnate, with $2-3$ branches on each side below the terminal one; rachis naked, quadrangular. Branches short-stalked, linear, acuminate, $3 / 4-11 / 2 \mathrm{~cm}$. broad; terminal branch $\pm 12 \frac{1}{2}-17 \frac{1}{2} \mathrm{~cm}$. long; lateral branches mostly shorter, the highest much ascending, the lowest less so. Leaflets close, erecto. patent, the central the largest, $\pm 6-12 \mathrm{~mm}$. long, $\pm 1 / 2$ as broad, the base cuneate, the lower edge entire, upcurved, the upper edge cut \pm $1 / 2$-way down, the base cuneate. Lobes suberect, shortly linear, $1 / 2-1$ mm. broad, simple or 2-fid, slightly dilated towards the base, separated by rather acute sinuses, the barren ones bluntish at the anex, the fertile truncate. Texture firm-herbaceous; surfaces naked; veins simple or mostly 
forked in the lobes. Sori terminal on the lobes, solitary on the veins or more generally uniting the apices of the branches of forked veins.

Celebes.

(27) H. natumae, Bit.

Not in Lingga. - See No. 23c.

(27a) L. microstegin, Copel., in Philipp. Journ., VIC, 83.

Rhizome creeping, slender. Stipes $\pm 11 / 2 \mathrm{~cm}$. apart, to $\pm 12 \mathrm{~cm}$. long. Fronds branched, $\pm 30 \mathrm{~cm}$. long, 20-25 cm. broad. Branches 2-3 on a side, $\pm 15-18 \mathrm{~cm}$. long, $2 \frac{1}{2} \mathrm{~cm}$. broad, acute. Leaflets \pm 30 on a side, short-stalked, cuneate at the base; lower edge entire, often decurved, outer edge rounded, crenulate. Sori intramarginal, small, occupying the apices of $1-2$ veins or veinlets; indusium short and broad, pale.

New Guinea.

\section{§ 3. SYNAPHLEBIUM.}

(30) L. azurea, Christ; - var. mambae, v. A. v. R., in Bull. Btz, 1912, VII, 21; 1913, XI, 16.

Var. mambae: Stipe and rachis stramineous, sometimes redpunctulate or partly reddish; leaflets longer than in the type, the largest $\pm 1-1^{1 / 2} \mathrm{~cm}$. Iong and $6-7 \mathrm{~mm}$. broad, bronce-green above, paler beneath. - New Guinea.

(30a) L. Hewittii, Copel., in Philipp. Journ., IIIC, 346, tab V.

Rhizome creeping, slender, woody, clothed with minute, castaneous scales. Stipes seriate, $25-30 \mathrm{~cm}$. long, stiff, castaneous, glossy, the upper part 2-marginate, as is the rachis, the margins pale. Fronds $\pm 15 \mathrm{~cm}$. long, 8-15 cm. broad, 2-pinnate, with 2-3 branches on each side below the terminal one; branches very gradually acuminate, the lateral ones erecto-patent, the terminal one the longest. Leaflets numerous, dimidiate, the central ones the largest, $\pm 7 \mathrm{~mm}$. long, $\pm 2 \frac{1}{2} \mathrm{~mm}$. broad, the base cuneate, the upper edge slightly incised, the outer edge often truncate, the lower edge straight or slightly decurved; upper and lower leaflets cuneate. Texture thinly coriaceous; veins moderately conspicuous. Sori 
often 1 to each leaflet, apical, rarely accompanied by other smaller ones which are subterminal on the lobes.

Borneo.

(30b) L. nitida, Copel., in Philipp. Journ., VIC, 138, tab. XXI.

Rhizome creeping, minutely scaly. Stipes rather approximate, \pm 30 cm. long, brown, quadrangular and deeply grooved, as is the rachis. Fronds $\pm 15 \mathrm{~cm}$. long and $23 \mathrm{~cm}$. broad, 2-pinnate, with 2 pairs of opposite, sessile, acuminate branches below the terminal one. Leaflets numerous, sessile, $\pm 1 \frac{1}{4} \mathrm{~cm}$. long and $1 / 2 \mathrm{~cm}$. broad, entire or the upper edge slightly and broadly incised, the outer edge rounded, and bounded by a single intramarginal, narrow sorus. Texture papyraceous, subdiaphanous; surfaces naked; upper surface glossy. - There is usually but one sorus, rarely another small one in a lobe.

Borneo.

(30c) I. papuana, Copel., in Philipp. Journ., VII, 68.

Fronds pinnate. Pinnae simple and to $3 \mathrm{~cm}$. long, or 3 -partite with the pinnulae to $2 \mathrm{~cm}$. long. Leaflets (pinnae or pinnulae) short-stalked, obtuse rather than rounded at the apex, entire or the largest slightly incised, broadest and abruptly truncate at the base. Sori long, almost always without a break.

New Guinea.

(31a) L. decomposita, Willd.; L. obtusa, Hk., Spec. Fil., I, 224. Forma minor (var. minor, Rst., MS. in Herb. Bog.): Leaflets smaller, the largest $\pm 5 \mathrm{~mm}$. long. - New Guinea.

(33a) I. Selnultzei, Braw., in Lautb., Beitr. Flor. Pap., I, 29.

Rhizome creeping, nearly naked. Stipes $\pm 2-3 \mathrm{~cm}$. apart, 9-14 cm. long, subquadrangular, stramineous, naked. Fronds long-lanceolate, to $\pm 16 \mathrm{~cm}$. long, $\pm 3 \frac{1}{2}-4 \mathrm{~cm}$. broad, simply pinnate. Leaflets to \pm 25 on a side, short-stalked, provided with a continuous, intramarginal spurious vein, the higher ascending, the central and lower horizontal; largest leaflets to $2 \mathrm{~cm}$. long, $\pm 6 \mathrm{~mm}$. broad at the base, the inner edge parallel to the rachis, the upper and outer edge incised into \pm 7 truncate, 1-2-dentate lobes. Texture membranaceous, pellucid; surfaces naked, veins anastomosing. Sori linear; indusium chartaceous.

New Guinea. 
(34) L. Samainorum, Christ.

Also in Borneo.

\section{SOHIZOLOMA, Gaudichaud.}

\section{$\S 1$. ISOLOMA.}

(3b) S. fulligineum, Copel.

Probably identical with S. induratum Bk. - See Copel., in Philipp. Journ. $\mathrm{X}^{\mathrm{c}}, 148$.

(3c) S. sehizolomae, v. A. v, T.; Nephrolepis schizolomae, v. A. v. R., in Bull. Btz., 1912, VII, 22.

Rhizome wide-creeping, black-brown, clothed with short, fibril-like, black-purple seales. Stipes scattered, wiry, $\pm 20-25 \mathrm{~cm}$. long, nearly terete, glossy, naked, purple-black, as is the rachis. Fronds linear, \pm $15-30 \mathrm{~cm}$. long, $1 \frac{1}{2}-2 \frac{1}{2} \mathrm{~cm}$. broad, narrowed towards the apex. Pinnae subsessile, articulated to the rachis, oblong, the largest $3 / 4-1 \frac{1}{2} \mathrm{~cm}$. long, $1 / 2-3 / 4 \mathrm{~cm}$. broad, the apex rounded, the margin entire, unequal-sided at the base, the upper base truncate, rather acutely auriculate, the lower base cuneate in the higher, rounded in the lower pinnae; central pinnae horizontal or more or less deflexed, lower sharply deflexed, not reduced. Texture coriaceous; surfaces olivaceous, naked, veins thickened at the apex, not reaching the margin. Sori and indusia continuous or interrupted.

New Guinea.

(6a) S. Srontii, v. A. v. $\boldsymbol{R .}$, in Bull. Btz., 1914, XVI, 36.

Stipes stout, $65 \mathrm{~cm}$. more or less long, naked, pale-brown or stramineous, as is the rachis. Fronds $165 \mathrm{~cm}$. more or less long, pinnate. Pinnae petiolate, erecto-patent, subulate from an abruptly oblique-cuneate base, the apex acuminate, coarsely serrate-dentate, the edge entire, the base mostly acutely hastato-auriculate on the upper side; central pinnae mostly the largest, $20-30 \mathrm{~cm}$. long, $\pm 3 \mathrm{~cm}$. broad (exclud. the auricle). Texture more or less coriaceous; surfaces naked. Sori long, not reaching the apex of pinnae; indusium subcoriaceous.

Borneo. 


\section{§ 2. EUSCHIZOLOMA.}

(12)

S. heterophyllum, J. Sm.; Lindsaya montona, Copel., Polypod. Philipp., 62; - var. speluncae, Copel., in Philipp. Journ., $\mathrm{V}^{\mathrm{C}}, 284$.

Var. Speluneae: Stipes $4-10 \mathrm{~cm}$. long, green, dark-brown at the base; fronds $\pm 5 \mathrm{~cm}$. long; largest pinnae $\pm 31 / 3 \mathrm{~cm}$. long, $11 / \mathrm{cm}$ broad, obtuse, nearly equilateral, the edge rather entire, the base cuneate. texture membranaceous; sori continuous. - Borneo.

\section{0a. PRETTOLINDSAYA, Copeland.}

Sori submarginal, solitary and terminal on the veins, not confluent. Indusium obconical, attached by the sides, the outer edge free.

Rhizome creeping, with a single, central, solid vascular bundle. Stipes not articulate to the rhizome. Fronds divided, the leaflets equilateral, not dimidiate; veins free.

(1) Pr. Brooksii, Copel., in Philipp. Journ., Vc, 283.

Rhizome scaly, the scales reddish-brown. Stipes ascending, $3-5 \mathrm{~cm}$. long, castaneous below, often greenish upwards, as is the rachis. Fronds $5-7 \mathrm{~cm}$. long, $\pm 1 \mathrm{~cm}$. broad, simply pinnate. Pinnae alternate, 10-12 on each side, the lowest the largest, short-stalked, cuneate, $\pm 7 \mathrm{~mm}$. long, $3 \mathrm{~mm}$. broad, cut down into \pm 3 oblong, obtuse segments; central pinnae entire or inciso-crenate at the apex, higher adnate, oblanceolate, obtuse. Surfaces naked; veins 1 to each ultimate segment.

Borneo.

\section{1a. SACOOLOMA, Kaulfess.}

\section{§ 1. CYSTODIUM.}

Omit this section, it being indentical with Dicksonia.

(1) S. sorbifolium, Christ.

Omit this species, it being referred to Dicksonia. 


\section{HUMA'TA, Cavanilles.}

\section{$\S 1$. EUHUMATA.}

(2a) H. microsora, Copel., in Philipp. Journ., VIIC, 55, tab. IV.

Rhizome wiry, wide-creeping, the scales castaneous, needle-pointed. Stipes scattered, $\pm 4-7 \mathrm{~cm}$. long, sparingly scaly. Fronds subulate, to $18 \mathrm{~cm}$. long, narrowed gradually from a truncate base $\pm 1 \frac{1}{2}-13 / 4 \mathrm{~cm}$. broad, the edge entire or crenated towards the apex, lobed at the middle, cut down nearly to the costa in the lower part; lobes rounded or truncate, the largest $\pm 1 \mathrm{~cm}$. broad. Texture rigidly coriaceous; surfaces naked; veins distinct, forked. Sori small, to 12 to a lobe.

Mindanao.

(3a) II. Brooksii, Copel., in Philipp. Journ., VIIC, 64.

Rhizome wiry, calcareous, densely scaly. Stipes $\pm 7-10 \mathrm{~cm}$. long, slender, provided with a few scattered, caducous scales. Fronds uniform, 10-12 cm. long, 4-5 cm. broad, 2-pinnatifid, the rachis thick. Pinnae lanceolate, acute, the lower short-stalked, often shorter and sometimes a little narrower than the next following. Lobes oblong, entire, the higher reduced to obtuse teeth. Texture coriaceous; surfaces naked. Sori placed in the sinuses of the teeth; indusium broad.

Börneo.

(4) Ir. sessilifolia, Mett.

Singapore, Java, Celebes, New Guinea to Fiji.

(5) H. parvula, Mett.; Lencostegia parvula, J. Sm., in Journ. Str. Br. R. A. Soc., 1908, 5o, 16.

(5a) ․ㅐ. minuseula, v. A. v. I.; $H$. repens, Diels, var. minuscula, Christ, in Philipp. Journ., IIIC 272.

Stipes short, $2-3 \mathrm{~cm}$. long, slender. Fronds very small, $\pm 2 \frac{1}{2} \mathrm{~cm}$. long, $\pm 2 \mathrm{~cm}$. broad, shortly and broadly lobed. - Resembling H. parvula Mett. but the fronds not finely divided.

Luzon.

(6) H. pinnatifida, Bedd.

Also in Sumatra. 
(8) I. repens, Diels; Davallia pedate, Sm., var. minor, Nees \& Bl., Nova Acta, XI, 122, tab. XIII, fig. $1 A, a-b$.

Forma nana: Stipes to $1-4^{1 / 2} \mathrm{~cm}$. long; fronds to $3 \frac{1}{2}-4^{1 / 2} \mathrm{~cm}$, broad; lobes subentire to crenulate.

\section{(8a) E. Cromwelliana, Rst., in Ferl., Pep., X, 32t.}

Rhizome wide-creeping, bluish, densely clothed with ferrugineous, lanceolate or ovate, membranaceous, flaccid, fimbriate, crispato-apiculate, subadpressed scales. Stipes remote, flexuose, to $15 \mathrm{~cm}$. long, black-brown, somewhat glossy, deciduously scaly, soon naked. Fronds ovate-lanceolate, to $\pm 18 \mathrm{~cm}$. long, $6 \mathrm{~cm}$. broad, shortly acuminate, 3-pinnatifid. Pinnae \pm 18 pair below the pinnatifid apex, subopposite, short-stalked, ascending, contiguous, lanceolate, the lower $\pm 5 \mathrm{~cm}$. long, $2 \mathrm{~cm}$. broad, pinnatifid, serrate at the apex, pinnate in the lower part. Pinnulae parallel, the lower elongate-oval, to $2 \mathrm{~cm}$. long, $3 / 4 \mathrm{~cm}$. broad, subobtuse, very deeply pinnatifid, narrowed at the base, the edges subentire to serrate. Texture coriaceous; surfaces pale-green, glabrescent or provided with scattered, adpressed, fimbriate scales; rachises sparingly scaly, soon naked; veins hidden, simple or forked. Sori in 2 rows on the lobes, often $4-6$ on a side, submedial or subcostular.

New Guinea.

(9a) F. crassifrons, v. A. v. R., in Bull. Btz., 1912, VII, 18; H. pusilla, Christ (not J. Sm.), in Schum. \& Laut., Flor. deut. Sch.geb., Suppl., 40, p. p.

Rhizome wide-creeping, clothed with stifly adpressed, lanceolate, brown. scales. Stipes scattered, $1 / 2-1 \frac{1}{2} \mathrm{~cm}$. long, narrowly winged, naked. Fronds dimorphous. Barren fronds subcordate or subdeltoid in outline, $\pm 1-2 \mathrm{~cm}$. each way, 2-pinnatifid, the rachis narrowly winged like the stipe, the wings thickened at the edge and therefore 2-sulcate on the upper surface, i. e. the stipe and prominent rachis are separated from the thickened edges of the wings by rather deep grooves. Pinnae close, subimbricate; higher pinnae erecto-patent, simple, emarginate or bifid, very small, tooth-like, blunt; central pinnae oblong, $\pm 5 \mathrm{~mm}$. broad, deeply and closely pectinato-pinnatifid; lowest pinnae horizontal, with the lower pinnulae on the lower side elongated and pinnatifid. Lobes oblong; blunt, the largest $1 \frac{1}{2} \mathrm{~mm}$. long and $1 \mathrm{~mm}$. broad, or broader but then truncate, emarginate or bifid. Texture very thick and rigid; surfaces 
naked; veins 1 to each ultimate segment, subprominent beneath, as are the costae and costulae. Fertile fronds similar but the segments contracted, the lowest pinnae pinnatifid, the ultimate lobes either much abbreviated, as broad as long, with the apex dilated, obliquely truncate and retuse, or somewhat elongated and obtusely repando-dentate. Sori occupying the ultimate lobes or their teeth, the former often with a narrow space which projects like a very short, blunt, tooth-like horn beyond the sori; indusium much broader than deep.

H. pusilla $J$. Sm. differs from this in having all the dimensions larger, and the fronds laxly divided.

New Guinea.

(9b) ㄴ. subtilis, v. A. ש. R., in Bull. Btz., 1912, VII, 18; H. perpusilla, v. A. v. R., l. c., 17.

Rhizome slender, wide-creeping, clothed with adpressed, subulatelanceolate, peltate scales. Stipes scattered, filiform, naked. Fronds small; barren fronds cuneate-obovate, ovate or semiorbicular, deeply pinnatifid or nearly pinnate, the base cuneate or truncate. Segments $2-4$ on a side below the terminal one, erecto-patent in the proportionally narrowest, subflabellate in the proportionally broadest forms, the lowest segments therefore varying from very oblique to horizontal; largest segments sparingly pinnatifid in the smallest, 2-pinnatifid in the largest forms. Lobules short-oblong, linear-oblong or cuneate-oblong, the apex acute or irregularly 2-8-dentate, the teeth shortly deltoid, acute or bluntish. Texture coriaceous, more or less fragile when dry, surfaces naked; venation pinnate or subflabellate; veinlets prominent, 1 to each tooth. Fertile fronds with the segments much contracted, nearly petioliform. Sori solitary on the dilated apices of the fertile lobules, at the base of $1-2$ proportionally long, horn-shaped teeth. - H. perpusilla, which is a youth form of this only, has the fertile fronds with the segments hardly contracted, nearly similar to those of the barren fronds.

Forma typica: Stipes $1--2 \mathrm{~cm}$. long; fronds about $1 \mathrm{~cm}$. long by $3 / 4-1 / 2 \mathrm{~cm}$. broad; divisions moderately crowded.

Forma major: Stipes to $4 \mathrm{~cm}$. long, those of the fertile fronds the longest; fronds to $2 \frac{1}{2} \mathrm{~cm}$. long and to $2 \mathrm{~cm}$. broad; divisions rather laxly spreading.

New Guinea, Amboina, Taliabo. 
(9c) H. Selhlechteri, Brau., in Lautb., Beitr. Flor. Pap., I, 26, fig. 1 G; v. A. v. R., in Bull. Btz., 1914, XVI, 17.

Rhizome wide-creeping, slender, the scales dense, ferrugineous, peltate. lanceolate, entire, acuminate. Stipes alternate, $1^{1}{ }_{2}-2{ }_{2} \mathrm{~cm}$. apart, ${ }_{14}-1 \frac{1}{2} \mathrm{~cm}$. long, those of the fertile fronds the longest. Barren fronds cordate, $\pm 11_{14}^{3 /} \mathrm{cm}$. long and $1 \frac{1}{4} \mathrm{~cm}$. broad, 2-3-pinnatipartite. Pinnae \pm 3 on a side below the cuneate, dentate apex, connected by a very narrow wing, close, alternate; higher pinnae cuneate, dentate; lowest pinnae largest, lobed; lobes 2-dentate, the lowest posterior produced, deflexed, inciso-dentate. Texture chartaceous; colour fuscous when dry; surfaces naked; veins very prominent beneath. Fertile fronds deltoid, pellucid, $\pm 1 \frac{1}{4}$ each way, with the pinnae more deeply incised into narrow-linear lobes. Sori numerous, with 2 teeth beyond, the outer teeth claw-shaped.

New Guinea.

(12) M. alpina, Moore; - var. edentula, Rst., Fed., Rep., X, 324.

Var. edentula: Barren lobes subentire, fertile ones with the extrorse (?) teeth often wanting. - New Guinea.

(12a) I. Alimorpha, Copel., in Philipp. Journ., VII', 68.

Rhizome wiry, clothed with lanceolate-castaneous scales. Stipes \pm 5-7 cm. long, slender, naked, those of the fertile fronds the longest. Barren fronds $\pm 5 \mathrm{~cm}$. long, $4 \mathrm{~cm}$. broad, the rachis scaly; pinnae to 2 em. long, the lowest $\pm 1 \mathrm{~cm}$. broad, obtuse, subentire, truncate and narrowly adnate at the base. Texture rigidly coriaceous; surfaces naked. Fertile fronds $\pm 13 \mathrm{~cm}$ long, $8 \mathrm{~cm}$. broad, much acuminated; lower pinnae $4-41 / 2 \mathrm{~cm}$. long, to $1 \frac{1 / 2}{\mathrm{~cm}}$. broad, stalked, incised; segments remote, the lowest free, $2-3 \mathrm{~mm}$. broad, toothed; teeth triangular, $2-4$ on a side. Sori on the teeth; indusium transversely oblong, with a black centre.

New Guinea.

(12b) IT. puberula, Copel., in Philipp. Journ., VII, 64.

Rhizome wide-creeping, wiry, calcareous, the scales castaneous. Stipes $\pm 7-10 \mathrm{~cm}$. long, sparingly deciduousiy scaly. Barren fronds $\pm 7 \mathrm{~cm}$. long and $5 \mathrm{~cm}$. broad, 2-pinnatifid, the lobes oblong, entire. Texture coriaceous; surfaces short-hairy and often ciliated. Fertile fronds somewhat 
longer, on the longest stipes, 2-pinnatifid, the lobes not acutely crenate. serrate. Sori submarginal in the sinuses; indusium broad,

Borneo.

(14) ㅍ. vestita, Moore.

Pinnae more or less oblique, the lowest 2-pinnatifid to 2-pinnate.

(14a) H. introrsa, Christ, in Nov. Guin., VIII, Bot,, 160.

Rhizome wide-creeping, black-brown, clothed with narrow, lanceolate, brown scales. Stipes distant, $\pm 4-10 \mathrm{~cm}$. long, slender, rigid, terete, castaneous, naked or provided with a few scattered, brown, lanceolate scales. Fronds triangular, $\pm 71 / 2-17 \frac{1}{2} \mathrm{~cm}$. long, the fertile ones larger than the barren, 3-pinnatifid at the base, acuminate, the main rachis sulcate, more or less marginate. Barren pinnae close, \pm 8-16 pair, spreading, opposite, the central produced at the upper base, the lowest stalked, deltoid-oblong, nearly equal on both sides at the base, $\pm 2-4$ $\mathrm{cm}$. broad, blunt. Pinnulae \pm 7-14 pair, the lower oblong, blunt, approximate, $\pm 1 / 2-1 \mathrm{~cm}$. broad, cut down to a winged costa into close, obtuse, entire or crenate segments. Fertile pinnae contracted, more remote; pinnulae not close, rather copiously serrate or serrato-pinnatifid, the teeth falcate, acute. Texture coriaceous; colour brown-green; rachises and costae provided with a few scattered, brown, crisped scales; veins hidden. Sori numerous, intramarginal; indusium transversely oblong or roundish. - Near H. vestita Moore but in aspect distinct from it.

New Guinea.

(14b) H. obtusata, v. A. v. R.. in Bull., Btz. 1911, I, 8.

Rhizome wide-creeping, the scales brown, acute, lacerato-ciliate when young, lanceolate, peltate near the base. Stipes scattered, $21 / 2-71 / 2$ cm. long, deciduously scaly. Fronds ovate, $\pm 5-8 \mathrm{~mm}$. long, $3-6 \mathrm{~cm}$. broad, the barren ones 3-pinnate at the base. Pinnae erecto-patent, pinnate, the lowest the largest, with the lowest posterior pinnulae pinnate; segments oblong, erecto-patent, the largest to $\pm 5 \mathrm{~mm}$. long and $2 \mathrm{~mm}$. broad, toothed, the teeth relatively long and narrow, rather lobe-like, blunt. Fertile fronds with the segments narrower, toothed; the teeth relatively distant, short and broad, very blunt, rather rounded or truncate, the largest bluntly toothed again. Texture very thick and rigidly coriaceous; under surface scaly, the scales very caducous in the barren but more 
persistent in the fertile fronds, similar to those of the rhizome but shorter and paler. Sori occupying the whole under surface of the teeth, $1-2$ on a tooth; indusium transversely oblong, proportionally very short and broad.

Luzon.

(14c) 11. tenuis, Copel., in Philipp. Journ., VIIC, 67.

Rhizome wiry, densely clothed with brown scales. Stipes scaly, 3-7 cm. long, those of the fertile fronds the longest. Barren fronds deltoid, $\pm 5-8 \mathrm{~cm}$. long, 3-pinnatifid; pinnulae oblong. Texture coriaceous; rachises scaly; surfaces naked. Fertile fronds deltoid, $10-13 \mathrm{~cm}$. long, 4-pinnatifid, acuminate, the lowest tertiary segments linear-oblong, narrowly pinnatifid. Sori near the base of the ultimate segments.

New Guinea.

\section{§ 2. LEUCOSTEGIA.}

\section{(15) H. falcinella, copel.}

A specimen received from the Isle of Leyte has the rhizome scales round, peltate, adpressed, with the apex suddenly narrowed into a very long, spreading, mostly blackish, deciduously ciliated, hair-like point; barren fronds with the ultimate segments blunt, entire to inciso-dentate, the teeth not sharp, not falcate.

\section{(18) H. immer'sa, Mett.}

Forma typica. - Also in Borneo (?).

Var. amplissima: A form gathered in Mindanao (Elmer No. 11548) has the fronds 4-5-pinnate, with the ultimate segments toothed on the upper and the outer edge, the sori very large, and the indusia rather straight at the base. - Celebes to Luzon.

(20) II. hymenophylloides, Copel.; L. affinis, J. Sm., in Journ. Str. Br. R. A. Soc., 1908, 5o, 16.

\section{ACROPHORUS, Prest.}

Omit this genus, it being referred to Cystopteris. 


\section{DAVALIIA, Smith.}

\section{§ 1. SCYPHULARIA.}

(*1) D. Simplicifolia, C. Chr., Ind. Fil., Suppl.; Scyphularia simplicifolia, Copel., in Philipp. Journ., VIIC, 64.

Fronds simple, $15-25 \mathrm{~cm}$. long, $3 \frac{1}{2}-4 \frac{1}{2} \mathrm{~cm}$. broad, the barren ones entire, the fertile obscurely crenulate.

Borneo.

(2) D. pentaplnylla, $\boldsymbol{B} \boldsymbol{x}$; - var. incisa, Rst, in Hedwi., LVI, 351.

Var. incisa: Pinnae thinner, more deeply inciso-crenate, often deeply lobed towards the base; veins distinct; indusia not adnate and slightly dilate-rotundate at the apex. - New Guinea.

\section{§ 2. COLPOSORIA}

(3) D. hirsuta, v. A. v. R.

Omit this, as being referred to Davallodes.

(6a) D. sumatarana, Copel., in Philipp. Journ., IXC 230 ; D. decurrens, Bk. (not Hk.), in Journ. of Bot., XVIII, 210.

Rhizome creeping, densely scaly. Stipes $+50-60 \mathrm{~cm}$. long, castaneous. Fronds to $80 \mathrm{~cm}$. or more long, to $60 \mathrm{~cm}$. broad, hardly 3-pinnate. Pinnae stalked, the lowest lanceolate-deltoid, to $\pm 35 \mathrm{~cm}$ long, $\pm 15 \mathrm{~cm}$. broad, acuminate, the rachis winged in the upper part. Pinnulae stalked, the lowest $\pm 8 \mathrm{~cm}$. long, $\pm 31 / 2 \mathrm{~cm}$. broad, aeuminate, pinnatifid. Segments linear-oblong, obtuse, serrate or crenate, the lowest connected by a very narrow wing only, deeply lobed, subpinnatifid, the lowest anterior lobule the largest. Texture coriaceous; surfaces naked; veins simple; no spurious veinlets. Sori numerous, minute, intramarginal; indusium \pm 1 $\mathrm{mm}$. each way but commonly broader than deep, the upper edge not reaching the margin of the frond.

Sumatra.

(9) D. Ienticulain, Mett.; D. bidentata, Schk., Krypt. Gew., I. tab. 127. 
Forma minor: Fronds smaller, deltoid, $\pm 15-25 \mathrm{~cm}$. long, mostly as broad, much acuminated, as are the pinnae. Indusia usually somewhat elongated, the apex partly truncate partly rounded.

\section{(11) ID. decurrems, Hk.}

Indusium as long as broad or somewhat longer than broad. Resembles D. divaricata Bl. in the shape and position of the sori, but the fronds less divided. The Sumatran plant determined by Baker is D. sumatrana Copel. - See No. $6 a$.

\section{D. elata, spr.}

A specimen gathered in Amboina differs from Hooker's plate in having the adnate basal portion of the indusium subsemiorbicular, the free apical portion triangular with rather straight edges, and the spurious veins less numerous and less distinct.

(12a) D. papuana, Copel., in Philipp. Journ., VIC, 81.

Stipes $\pm 30 \mathrm{~cm}$. long, clothed at the base with narrow, ferrugineous scales. Fronds deltoid, $\pm 45 \mathrm{~cm}$. long, nearly 4-pinnate. Lower pinnae deltoid, $\pm 30 \mathrm{~cm}$. long, acuminate, with the rachis narrowly winged towards the apex. Pinnulae ovate, obtuse, with the largest segments incised again, the ultimate lobes or teeth more or less cornuted. Texture coriaceous; rachis and surfaces naked; spurious veinlets present. Sori intramarginal; indusium as broad as long or narrower, the apex often rounded, sometimes obtusely and broadly cuspidate.

New Guinea.

(14a) See No. 11.

\section{(15) D. bullata, Wall.}

Rhizomes scales pale, narrowly subulate, recurved, ciliate, narrowed suddenly from a suborbicular, adpressed, peltate base, the ciliae at length; decidous soriferous lobules (teeth) short and broad, broadly sessile or cuneately narrowed at the base; indusium relatively short and broad, semicupuliform, $\pm 1 \frac{1}{2}-2 \times$ as long as broad, with usually a horn on the outside, the apex whether or not reaching the margin of the lobule.

(15a) See No. 24. 
(16) D. fructuosa, Christ.

Rhizome scales filiform (from a suddenly dilated base?); lowest pinnae equal-sided at the base (i. $\Theta$. with the lowest posterior pinnula not produced); upper surface rather blackish (dark-grey?) when dry; indusium short- or long-semicylindrical.

\section{(17) D. Irichomanoides, $\boldsymbol{H I}$.}

Rhizome scales brown or ferrugineous, linear-subulate, spreading, probably more or less deciduously ciliolate, narrowed more or less gradually from an oblong, peltate, adpressed base; soriferous lobules dilated from a cuneate or linear base into a clavate-oval, truncate and emarginate, often 1-2-dentate or corniculate apex; indusium $\pm 11 / 4-2 \times$ as long as broad, urceolate, constricted at or below the apex, the apex whether or not reaching the margin of the lobule. - I think this to be hardly different from D. dissecta J. Sm.

\section{(18) 耳. Wagneriana, Copel.}

Elmer's No. 14138 is distinguished by the following characters: Rhizome scales glossy, deciduously araneoso-ciliate; fronds triangularoblong, acuminate, copiously and deeply 2-pinnatifid; pinnae more or less opposite, horizontal or nearly so, triangular-lanceolate, straight or subfalcate, acutely acuminate, to $2 \frac{1}{2} \mathrm{~cm}$. broad at the truncate or subtruncate base, the lower shortly petiolulate; segments somewhat oblique, acute or subacute, serrate, the barren elliptical-oblong, close, the fertile narrowed, linear, straight or subfalcate, not close.

Also in Negros.

(19a) See No. 11.

(20) D. Sulida, Sm.; Schk., Krypt. Gew., I, tab. 126.

Forma tomentella (Rst., in Fed., Rep., XIII, 213): Fronds slightly tomentose everywhere, the tomentum ferrugineous, consisting of simple fibrilliform hairs and long-ciliate-lacerate paleolae; upper surface at length glabrescent. - Sumatra.

\section{(21) D. embolostegia, Copet.}

Also in Negros. 


\section{(24) D. dissecta, J. Sm.}

Rhizome scales ferrugineous, subulate, more or less ciliolate-denticulate, recurved or crisped, narrowed more or less gradually from a roundish or oblong, adpressed, peltate base; soriforous lobules (teeth) rather suddenly dilated from a narrow, often linear base into a clavate-cuneate apex; indusium semicylindrical, relatively long and narrow, \pm twice as long as broad when ripe but shorter when young, the apex truncate or truncaterotundate, at length reaching the margin of the lobule.

Also in New Guinea.

(24a) See No. 17.

(24b) D. Koordersii, v. A. v. R., in Bull. Btz., 1911, I, 5.

Rhizome wide-creeping, densely scaly, the scales long, linear-subulate, ciliolate, rounded and peltate at the base, ascending and pale-brown when young, at length dark and more irregularly spreading. Stipes distant, naked, $\pm 10-20 \mathrm{~cm}$. long. Fronds ovate-deltoid, finely dissected, $4-5$ pinnatifid in the lower part, $\pm 15-30 \mathrm{~cm}$. each way, acute or acuminate. Pinnae more or less oblique, the lowest the largest, triangular, \pm 8-16 $\mathrm{cm}$. long, $\pm 5-10 \mathrm{~cm}$. broad at the base, acuminate, the lowest posterior pinnula the largest. Ultimate segments erecto-patent, small, the lowest anterior the largest, to $\pm 3-6 \mathrm{~mm}$. long, $\pm 1-2 \mathrm{~mm}$. broad, the narrowest linear, bluntish or acute, entire or toothed at the apex with 2-3 teeth, the broadest oblong, cuneate at the base, with $4-8$ bluntish or acute teeth in the upper half. Texture thinly coriaceous; rachises and surfaces naked; upper surface brown when dry; main rachis marginate in the upper part, secondary rachises narrowly winged; veins 1 to each tooth; no spurious veinlets. Sori on the dilated apices of the ultimate segments, narrowly winged by the edge of the segments, with 1 or mostly 2 sometimes very long teeth or horns beyond them; indusium semicylindrical or urceolate, $\pm 2-3 \times$ as long as broad, often narrowed at or near the apex, the apex rather truncate, at some distance $\left({ }_{3}-1 / 2\right.$ $\mathrm{mm}$.) from the margin of the segment. - Near D. dissecta J. Sm.

Java.

(24c) See No. 15.

(24d) See No. 16.

Ferns and Fern Allies. 
(24e) D. Warbata, v. A. v. R., in Bull: Btz., 1913, XI, 7.

Near D. dissecta $J$. Sm. but the rhizome scales black or black-brown, flexuose, filiform-subulate, densely barbate-ciliate, narrowed suddenly from a suborbicular, adpressed, peltate base, the ciliae pale-ochraceous; fronds relatively small; fertile lobules sublanceolate-clavate from a cuneate or linear base; indusium semicylindrical, $\pm 2 \frac{1}{2}-3 \times$ as long as broad, generally with $1-2$ often elongated teeth projecting beyond, the apex to $1 \mathrm{~mm}$. distant from the margin of the lobule, truncate or somewhat rounded. - Differs from D. bullata Wall. by its much longer sori.

Java, Sumatra, Mindanao (?).

(24f) D. Pullei, Rst., in Nov. Guin., VIII, Bot., 719.

Rhizome creeping, woody, pruinose, clothed with lax, ferrugineous, lanceolate, acuminate scales. Stipes remote, $3-5 \mathrm{~cm}$. long, sulcate above, provided with scattered, short, spreading, brown hairs, as are the rachises and both surfaces. Barren fronds triangular or ovate, $\pm 8-10 \mathrm{~cm}$. long, $5-6 \mathrm{~cm}$. broad at or near the base, acuminate. Pinnae subapproximate, the lowest opposite, obliquely triangular, $\pm 1 \frac{1}{2} \mathrm{~cm}$. broad, horizontal or spreading, acute or acuminate, produced on the lower side at the base. Pinnulae close, the lowest cut down to the rachis into close, erecto-patent, cuneate-oblong, deeply inciso-dentate segments to $3 \mathrm{~mm}$. long; ultimate lobes (teeth) triangular, close, spinuloso-acuminate, connected at the base. Texture rigidly coriaceous. Fertile fronds similar but the ultimate segments not close, oblong in the upper half, narrowly linear (substipitiform) in the lower half. Sori occupying the dilated region of the ultimate segments; indusium nearly semicylindrical, \pm twice as long as broad, the apex rounded or subtriangular, reaching the margin of the segment, with 2 very sharp and long, subuliform horns beyond, which are different in length.

New Guinea.

\section{4a. DAVALLODES, Copeland.}

Sori roundish or oblong, solitary at or near the base of the ultimate teeth or lobes, terminal on the veins or veinlets; indusium partly as in Humata or Davallia partly as in Leptolepia.

Rhizome creeping, scaly, the scales with a very small, suborbicular 
base and very long, subulate, hair-like or setiform apex many times longer than the basal portion. Stipes articulated to the rhizome. Fronds divided, herbaceous, more or less copiously hairy on both sides, as is the main rachis; veins free; soriferous veinlets sometimes very short and then the sori apparently medial on the anterior side of the veins.

Malaya.

1. Indusium attached by the base and sides (as in Humata or Davallia).

2. Indusium mostly broader than long, attached as in Humata. (i. e. by the base only).

(3) D. gymnocarpum.

2.2. Indusium mostly longer than broad, attached as in Davallia (i. e. by the base and sides).

3. Indusium relatively short and broad, semicupuliform.

(1) D. hirsutum.

3.3. Indusium relatively long and narrow, semicylindrical.

(2) D. grammatosorum.

1.1. Indusium attached by a single basal point (as in Leptolepia).

2. Main rachis winged.

2'.2'. Main rachis not winged.
(4) D. Kingii.

(5) D. viscidulum.

(1) D. Lirsutum, Copel, in Philipp. Journ., IIIC, 33; Davallia hirsuta, v. A. v. R., in Bull. Dép. Agr. I. N., 1909, XXVII, 35; I). ciliata, Hk., Hk. Bk., Syn. Fil., 98; Microlepia ciliata, Copel., Polypod. Philipp., 55; M. hirsuta, Pr., C. Chr., Ind. Fil.; Leucostegia hirsuta, J. Sm., (oldest name).

Rhizome firm, woody, creeping, the scales with the base small, peltate, round or oblong, the apex abruptly narrowed into a very long, subulate, setiform or hair-like, spreading or erecto-patent acumen $\pm 1-1 \frac{1}{2} \mathrm{~cm}$. long. Stipes scattered, 5-10 cm. long, firm, erect, pubescent, as is the main rachis. Fronds lanceolate, $\pm 20-60 \mathrm{~cm}$. long, $\pm 71 / 2-25 \mathrm{~cm}$. broad, 2-3-pinnatifid. Pinnae spreading, lanceolate, the lower moderately reduced, the central ones the longest, $1 \frac{1}{2}-4 \mathrm{~cm}$. broad, deeply pinnatifid with more or less crowded, oblong or linear-oblong, entire, toothed, lobed or pinnatifid, blunt or acute segments. Texture herbaceous, rather flaccid; under surface and occasionally also the upper surface more or less copiously hairy or fibrillose especially on the costae and veins. Sori 
2-12 to a lobe, solitary at the base of the ultimate teeth or lobes, near the centre, small; indusium semicupuliform, relatively short and broad, nearly semipatelliform, attached by the base and sides (as in Davallia), naked, ciliate or hairy, the outer edge truncate or rounded.

Philippines, Celebes, Borneo.

(2) D. grammatosorum, Copel., in Philipp. Journ., IIIC, 34; Microlepia grammatosora, C. Chr., Ind. Fil., Suppl.

Differs from D. hirsutum Copel. in having the lower pinnae hardly reduced, not much shorter than the following, and the indusia relatively long and narrow, nearly semicylindrical.

San Ramon, Mindanao.

(3) D. gymmocarpum, Copel., in Philipp. Journ., IIIC, 34: Microlepia gymnocarpa, C. Chr., Ind. Fil., Suppl.

Differs from D. hirsutum Copel. in having the lower pinnae gradually much reduced, and the indusia very short, mostly broader than long, attached by the base only, free at the sides (as in Humata). - See Copeland's information in Leafl., V, 1683.

Negros, Camiguin.

(4) D. Kingii, Copel., in Philipp. Journ. VIC, 147; Humata Kingii, Diels, in Engl. \& Prantl, Nat. Pfl.Fam., I, 210, fig. 112 H; Davallia Kingii, Bk., Hk., Icon. Pl., XVII, tab. 1622; C. Chr., Ind. Fil.

Rhizome firm, woody, creeping, the scales with the base small, round, peltate, membranaceous, the apex abruptly narrowed into a very long, spreading, subulate, hair-like or setiform acumen. Stipes scattered, straight, firm, naked, $\pm 15 \mathrm{~cm}$. long. Fronds lanceolate-oblong, $\pm 30-45 \mathrm{~cm}$. long, 20-25 cm. broad, 3-pinnatifid, the main rachis pubescent and narrowly winged. Pinnae lanceolate, rather spreading, the central and lowest the largest, $\pm 3-4 \mathrm{~cm}$. broad. Pinnulae oblong, adnate, decurrent, deeply pinnatifid into close, oblong, bluntish or acute lobes. Texture thin; surfaces sparingly hairy; veins free. Sori solitary at the base of the ultimate lobes; indusium triangular or oblong, attached at the truncate or cordate base by a single central point to the vein only and not to the parenchyma (as in Leptolepia).

Java. 
(5) D. viseidulum, v. A. v. $\boldsymbol{R}$., in Bull. Btz., 1911, I, 6; Humata viscidula, v. A. v. R., Mal. Ferns, 294; Davallia viscidula, Mett., Rac., Flor. Btz., I, 131; C. Chr., Ind. Fil.; - var. novoguineense, Rst., in Fed., Rep., XII, 526.

Differs from D. Kingii Copel. in having both stipe and main rachis clothed with more or less persistent pubescence, the frond 3-4-pinnatifid, the main rachis not winged, the lower pinnae somewhat shorter than the following, the pinnulae free and decurrent, or confluent at the base, cut down to a winged rachis into toothed or pinnatifid tertiary segments. - Rhizome scales with the basal portion reniform with conspicuously overlapping lobes, and pale-margined like the filiform apex.

Forma typica. - Sumatra, Java, Borneo.

Var. novoguineemse: Rhizome scales ciliate; indusia broader than long. - New Guinea.

\section{MICROLEPIA, PresI.}

(2) DI. marginalis. Bedd.; - var. calvescens, Bedd., Handb. Ind. Ferns, 64; Dovallia calvescens, Hk. (not Wall.), Spec. Fil., I, tab. XLVIII B; D. urophylla, Bedd., Ferns Br. I, tab. CIII.

Var. calvescens: Pinnae nearly naked beneath except on the strigose midrib. - Java; Kumaon, Khasia.

(2a) D. Hookeriana, Pr., Bedd., Handb. Ind. Ferns, 62; Ferns Br. I., I, tab. CI; Davallia Hookeriana, Wall., Hk. Bk., Syn. Fil., 97 ; Hk., Spec. Fil., I, tab. XLVII $B$.

Rhizome creeping, both it and the stipes pubescent-fibrillose, at length glabrescent. Stipes to $30 \mathrm{~cm}$. or more long. Fronds lanceolate, $\pm 30-45 \mathrm{~cm}$. long, $\pm 15-20 \mathrm{~cm}$. broad, long-acuminate, pinnate, the rachis hirsuto-fibrillose. Pinnae many, lanceolate-subulate, gradually acuminate, duplicate-crenate; terminal pinna mostly hastate or deeply pinnatifid at the base; lateral pinnae horizontal or nearly so, approximate or the higher more close and the lower more remote; lower pinnae shortly petiolulate, truncate and hastate or semihastate at the base, broadest at the upper base, the auricles parallel to the rachis, deltoid or oblong to linear-oblong; acute or rounded at the apex; higher pinnae 
rather sessile, passing gradually into the lobes of the terminal pinna, oblique at the base, the upper base truncate, auricled, the lower cuneate; largest pinnae to $\pm 10 \mathrm{~cm}$. long, $\pm 1 \frac{1}{4} \mathrm{~cm}$. broad at the base (excl. the auricles). Texture herbaceous or submembranaceous; surfaces naked; costae prominent, hirsuto-fibrillose above, less so beneath; veins once or twice forked, sparingly hirsuto-setose beneath. Sori small, close or approximate, forming a continued submarginal line; indusium semicupuliform, \pm as broad as deep, the free edge somewhat rounded.

Java; South China, North India.

(3a) M. Aennstaedtioides, Copel., in Phillip. Journ., I, Suppl., 148, tab. IV; Dennstaedtia dennstaedtioides, Copel., 1. c., II $\mathrm{II}^{\mathrm{C}}, 126$; -- var. arthrotricha, Copel., l. c., III' 34 .

Rhizome creeping, naked or nearly so. Stipes $13-20 \mathrm{~cm}$. long or longer, brown, naked. Fronds deltoid in outline, $40-60 \mathrm{~cm}$. long or longer, \pm half as broad, 4-pinnatifid. Pinnae lanceolate, oblique, acute to caudate, toothed at the apex, the rachis marginate or narrowly winged. Pinnulae lanceolate-oblong, obtuse, or acuminate with the point obtuse, the base obliquely cuneate-truncate, cut down to a winged rachis into entire or lobed, oblong, blunt, decurrent tertiary segments; lobes oblong or obovate, blunt, entire or toothed. Texture herbaceous; rachises and surfaces naked. Sori small, intramarginal, at the base of the ultimate lobes or teeth, on the anterior side; indusium naked, or slightly hairy at the very base.

Var. nrthrotriche: Stipe and rachis hairy with articulated hairs, at length not rarely naked and roughish by the persistent bases of the hairs; surfaces more or less shortly pubescent.

Luzon, Mindanao.

(4a?) M. Hancei, Prant1, in Arb. Bot. Gart. Bresl., I, 35; Davallia polypodioides, Benth. (not Don), Flor. Hongk., 461.

Rhizome creeping. Fronds 60-90 cm. long, 3-4-pinnate. Pinnae distant, the 1-2 lowest pair smaller than the following which are often $15-20 \mathrm{~cm}$. long, gradually diminishing to the apex. Segments lanceolate, oblong or obovate, the larger ones deeply lobed with obovate, obtuse lobes. Texture flaccid; surfaces more or less pubescent. Sori solitary under each sinus of the lobed segments or near the margin on the entire ones; indusium short and broad.

Borneo; Hongkong, Khasia. 
(5a) 1. Trooksii, Copel., in Phillipp. Joum., IX ${ }^{\mathrm{C}}, 230$.

Like M. trichosticha $J$. Sm. but the lowest pinnae $\pm 30 \mathrm{~cm}$. long, \pm $13 \mathrm{~cm}$. broad, acuminate; pinnulae stalked, deltoid-lanceolate, acutely acuminate; segments roundish-oblong, rounded at the apex, entire, the lowest anterior the largest and more or less incised; surfaces sparingly puberulous.

\section{Sumatra.}

(6b) M. Tidleyi, Copel., in Philipp. Journ.,.XIC, 39.

Fronds large, 2-pinnate, the rachis very minutely pubescent. Pinnae short-stalked, $\pm 70 \mathrm{~cm}$. long, nearly $20 \mathrm{~cm}$. broad. Pinnulae subsessile, oblique at the base, the apex acuminate, straight or subfalcate, the edge inciso-crenate. Lobes to $8 \mathrm{~mm}$. broad, truncate, entire or crenulate. Texture membranaceous; surfaces naked; costae slightly puberulous in the lower part; veins indistinet. Sori solitary below the incisions, more numerous in the large, anterior, lowest lobe; indusium subcyathiform, slightly puberulous.

Malacca.

(10) M. strigosa, $\boldsymbol{P r}$.

This species, as construed on p. 312 of my handbook, includes 2 forms:

Forma typica: Pinnulae subentire, crenate or broadly toothed (nearly lobed), the teeth entire; sori mostly near the sinuses.

Forma bidentata: Pinnulae broadly toothed or somewhat lober, the teeth or lobes toothed; sori often in the sinuses.

\section{(11) M. Kurzii, Bedd.}

Pinnulae deeply lobed or pinnatifid at least on the upper side at the base into triangular or rounded, bluntly crenate or serrate lobes; surfaces at length not rarely subglabrous; texture thinly coriaceous, nearly herbaceous.

(12) M. proxima, v. A. v. R. (not Pr.).

Omit this name, it should be M. puberula $v . A . v . R$. - M. proxima Pr. is quite another plant nearly allied to M. hirta $\operatorname{Pr}$. - See No. 15.

(12) M. puberula, v. A. v. $\boldsymbol{H}$. , in Bull. Btz., 1913, XI, 17; M. 
proxima, v. A.v. R. (not Pr.); Davallia proxima, Rac. (not Bl.), Flor. Btz., I, 134 .

(15) M. proxima, Pr., Epim., 95; Davallia proxima, Bl., Enum., 238.

Fronds 3-pinnate, the rachises finely tomentose, at length punctulatoasperulous. Pinnae lanceolate, alternate, rather remote, copiously pinnate, acuminate. Pinnulae lanceolate, $\pm 4-10 \mathrm{~cm}$. long, $1 \frac{1}{2}-3 \frac{1}{2} \mathrm{~cm}$. broad and obliquely broadly cuneate or subtruncate at the base, acuminate. Segments oblique, oblong, blunt, the higher confluent, entire, the highest tooth-like, the lower free, sessile, cuneate, decurrent at the base, the lowest anterior the largest, subrhomboidal, to $2 \frac{1}{2} \mathrm{~cm}$. long, lobed, the lobules subentire, blunt or abruptly subacute. Texture coriaceous; upper surface naked, lower short-hairy on the costae, sparingly hairy on the costulae and veins. Sori minute, submarginal, near the ultimate sinuses; indusium semicupuliform, hairy at the base.

Malaya.

(16) M1. pseudo-hirta, Rst., in Fed., Rep., IX, 425.

Stipes nearly $50 \mathrm{~cm}$. long, compressed, subangular, slightly grooved, clothed with minute, adpressed, deciduous hairs, provided towards the base with numerous scattered, small, verruciform warts. Fronds elongateoblong, $\pm 60 \mathrm{~cm}$. long, $\pm 35 \mathrm{~cm}$. broad at the base, shortly acuminate, 3-pinnate. Pinnae numerous, alternate, ascending, the lowest the largest, stalked, lanceolate, subfalcate, $\pm 20 \mathrm{~cm}$. long, $8-9 \mathrm{~cm}$. broad at the base, broadest on the anterior side, narrowed gradually towards the long-acuminate apex. Pinnulae lanceolate, the lowest anterior the largest, $\pm 4 \frac{1}{2} \mathrm{~cm}$. long, $\pm 1 \frac{1}{2} \mathrm{~cm}$. broad, acuminate, broadest on the anterior side. Leaflets oblong or rhomboidal-oblong, the lowest anterior the largest, petiolulate, to $1 \mathrm{~cm}$. long, $\pm 1 / 2 \mathrm{~cm}$. broad, obtuse, rather obliquely cuneate at the base, obtusely erenato-lobate, the largest deeply. pinnatifid at the base, the others growing gradually smaller, repando-crenate or entire. Texture firm, chartaceous; rachises subadpressed-hairy beneath, less so above, the secondary and tertiary ones narrowly winged, rather marginate; upper surface nearly naked, lower pilose with short or glanduliform scattered hairs especially on the costae, costulae and veins; veins prominent beneath. Sori intramarginal, near the ultimate sinuses; indusium broadly semicupuliform, truncate at the apex, slightly hairy at the rounded base.

New Guinea. 
(17) M. Lodnyensis, Christ, in Philipp. Journ., III', 272.

Large. Stipes tufted, succulent, $100-150 \mathrm{~cm}$. long. Fronds up \pm $150 \mathrm{~cm}$. long, ovate, 4-pinnatifid, sub-4-pinnate, the rachis thick, rufostramineous, lucent, furfuraceo-pilose. Pinnae \pm 25 on each side, the largest ones stalked, oblong, acuminate, moderately narrowed at the base, up to $70 \mathrm{~cm}$. long, $\pm 23-27 \mathrm{~cm}$. broad, the lower ones distant, the others more close, alternate, short-stalked, triangular-oblong, produced at the base on the upper side, the rachises ochraceous, pilose. Pinnulae \pm 14-jugate, subsessile, neither adnate nor decurrent, the lowest ones short-stalked, the lowest anterior ones more or less deeply pinnatifid, cut down to the costa at the base, lobed towards the apex, close, lanceolate-oblong, more or less acute. Ultimate lobes ovate-oblong, obtuse. subentire, 3-4 $\mathrm{mm}$. long, the lowest anterior ones often free, larger and incised. Texture thinly chartaceous; upper surface dark-green, rather glossy, with a few scattered, whitish hairs, under surface opaque, pilose; costae like the rachises; veins distinct, beneath prominent and clothed with long hairs, forked (subpinnate) in the lobes. Sori immersed, minute, sparse, intramarginal at the base of the lobes, rather submedial, surrounded by long hairs; indusium fugacious, roundish, grey. - Fronds with the general habit of M. speluncae Moore.

Mindanao.

(18) M. hispidula, v. A. v. R., (not M. villosa, Pr.); M. hirta, Pr., C. Chr., Ind. Fil, var. villosa, in Herb. Bog.; Dennstaedtia villosa, Copel., in Leafl., III, 824; Davallia villosa, Don. (not Wall.), Prod. Flor. Nep., 10.

Fronds 4-pinnate, the main rachis finely villose, glabrescent. Pinnae elongate-lanceolate, $60 \mathrm{~cm}$. or more or less long. Pinnulae lanceolate, the central ones the largest, to $\pm 10 \mathrm{~cm}$. long, $3 \mathrm{~cm}$. broad at the base, acuminate. Tertiary segments lanceolate, the lower anterior the largest, to $2 \mathrm{~cm}$. long, acute, pinnate at least at the base. Ultimate leaflets oblong, the lowest posterior cuneate-oblong, blunt, erecto-patent, the lowest anterior the largest, nearly horizontal, to $6 \mathrm{~mm}$. long and $3 \mathrm{~mm}$. broad, blunt, cuneate at the base, lobed with $1-3$ rounded lobes on a side. Texture coriaceous; upper surface naked or sparingly setulose on the veins; under surface copiously piloso-hispid on the costae, costulae and veins. Sori near the ultimate sinuses; indusium half-cup-shaped, broad, hairy at the base. - The description in taken from a fragment of Elmer's No. 10472 from Mindanao. - A specimen from Mt. Himalaya, occurring in the 
Buitenzorg Herbarium, which may be the true Davallia villosa Don. (received as M. hirta $\mathrm{Pr}$.), differs from this especially by its aspect and more acute ultimate lobules.

Philippines, Java to $\mathrm{Br}$. India.

(19) DI. melamorachis, Rst., in Fed.. Rep., XII, 526.

Stipes firm, like the rachis black-purple, opaque, densely asperulostrigose. Fronds ovate-oblong, to $50 \mathrm{~cm}$. or more long, $\pm 35 \mathrm{~cm}$. broad below the middle, sub-4-pinnate, the lateral rachises dark beneath, paler above, short-hairy. Pinnae ascending, contiguous, stalked, \pm 10 on a side, nearly linear, the largest $\pm 20 \mathrm{~cm}$. long by $7 \mathrm{~cm}$. broad. Pinnulae rhomboidal-lanceolate, shortly acuminate, the lowest anterior $\pm 6 \mathrm{~cm}$. long by $2^{1}{ }_{2} \mathrm{~cm}$. broad, the others somewhat shorter. Leaflets rhomboidal-oblong, obtuse, deeply incised or inciso-dentate, the largest cut down to the costa, with the segments obovate-cuneate, to $5 \mathrm{~mm}$. long by $3 \frac{1}{2} \mathrm{~mm}$. broad, obtusely toothed on the anterior side. Texture thinly chartaceous; upper surface sparingly appresso-setose on the veins, lower hirsute on the costulae and veins; veins \pm 3 on a side, prominent beneath. Sori solitary on the segments, placed below the sinuses; indusium sparingly hairy.

New Guinea.

36. TAPEINIDIUM, Christensen.

(2a) T. margimale, Copel., in Philipp. Journ., VIc, 82.

Stipes $\pm 50 \mathrm{~cm}$. long, black and square in the upper part, as is the rachis. Fronds $\pm 60 \mathrm{~cm}$. long. Largest pinnae $\pm 25 \mathrm{~cm}$. long and 1 $\mathrm{cm}$. broad, serrate, the teeth truncate. Texture herbaceous. Sori marginal, much broader than deep.

New Guinea.

\section{(3) T. grmeile, v. A. $\boldsymbol{v}$. $\boldsymbol{R}$.}

Forma decomposita: Schlechter's No. 13718, determined by Christ as Wibelia pinnata Fée (not Bernh.) var. gracilis in Schum. \& Laut, Flor. deut. Schgeb., Suppl., 40, is a rather small, 3-pinnate form with narrowed branches; ultimate lobes linear, $\pm 1 \mathrm{~mm}$. broad, the apex obtuse or rather obliquely truncate or irregularly 2-3-dentate, the edge sparingly 
toothed; sori partly terminal on the lobes partly at the base of the teeth. - Papua (New Mecklenburg).

\section{(4) 'T. amboinense, $c$. Chr.}

Differs from T. gracile $v . A$. $v$. $R$. forma decomposita in having the leaflets lanceolate, more copiously lohate-dentate, with the soriferous teeth or lobules obliquely triangular.

\section{3\%. ADIANTUUM, Linné.}

\section{§1. EU-ADIANTUM.}

(5a) A. scabripes, Copel., in Philipp. Journ., VIIc, 55, tab. V.

Rhizome densely clothed with short, black-purple setae. Stipes blackbrown, naked, glossy, as are the rachises, scaly and finally roughish towards the base. Fronds deltoid, $\pm 15-20 \mathrm{~cm}$. each way, pinnate with $\pm 1-3$ branches on ech side below the terminal one, the lower branches whether or not forked at the base. Leaflets numerous, dimidiate, oblong, $\pm 1-\mathbf{1}_{1 / 4} \mathrm{~cm}$. long, rounded at the apex, the upper and outer edge cartilagineo-denticulatae; terminal leaflets subulate-lanceolate. Texture coriaceous; surfaces glossy; under surface slightly copper-coloured when seen by oblique light. Sori commonly solitary on the leaflets, transversely oblong, sometimes interrupted; sporangia springing from the veins and parenchyma; indusium broad, coriaceous.

Mindanao.

(5b) A. Kingii, Copel., in Philipp. Journ., IX ${ }^{\mathrm{C}}, 5$.

Stipes aggregate, purple-black, glossy, to $10 \mathrm{~cm}$. long, densely hairy, the hairs purple-black. Fronds 2-pinnate, with a terminal branch to \pm $10 \mathrm{~cm}$. long and a few lateral branches. Leaflets petiolulate, slightly lobed, minutely toothed, to $10 \mathrm{~mm}$. long by $7 \mathrm{~mm}$. broad, trapezoidal or the smaller obovate or suborbicular. Texture coriaceous; surfaces naked; veins flabellate. Sori few, $1-3 \mathrm{~mm}$. broad; indusium firm.

New Guinea.

(6a) A. sermatifolium, v. A. v. R., in Bull. Btz., 1912, VII, 1. Near A. diaphanum $B$ l. but the leaflets relatively long and narrow, 
often subacute, the rachis pilose, both surfaces hairy, the hairs very pale, more or less deciduous, the sori obreniform, nearly round, very small, the margins sharply serrate or slightly lobed (broadly crenate), the lobules sharply and irregularly serrate, the indusia pilose.

Borneo.

(8) A. cauda tum, L., Schk., Krypt. Gew., I, tab. 117.

$\left(10 a^{*}\right)$ A. Edgewonthii, Hk., Spec. Fil., II, 14, tab. LXXXI $B$.

Stipes elongated, slender, and as well as the rachis ebeneous, glabrous. Fronds linear-oblong, elongated, $\pm 15-30 \mathrm{~cm}$. long, narrowed and often rooting at the apex and there bare of pinnae. Pinnae nearly sessile, alternate, dimidiate-oblong, rounded to subacute at the apex, the upper base truncate and parallel to the rachis; upper edge obscurely lobed, rather more so in the barren pinnae, the lobes rounded when barren, truncate when fertile. Texture membranaceous; surfaces naked; veins not prominent, not compact. Sori 1 on each lobe; indusia transversely oblong, rather semiorbicular, sometimes confluent. - Near A. rhizophorum Sw.

Timor, Luzon; China, Br. India.

(11) A. Irapeziforme, c.; A. rhomboideum, Schk., Krypt. Gew., I, tab. 122.

(15c) A. pulcherrimum, Copel., in Philipp. Journ. VIC, 138, tab. XXII.

Stipes aggregate, black-brown, glossy, clothed at the base with narrow, brown scales. Fronds 3-pinnate, $\pm 25 \mathrm{~cm}$. long; the rachises velutinous above; branches $2-3$ on a side below the terminal one, the lower 2-pinnate towards the base. Leaflets dimidiate, to $\pm 1 / 4 \mathrm{~cm}$. long and $3 / 4 \mathrm{~cm}$. broad, the upper edge lobed, the outer edge rounded or truncate and toothed. Texture coriaceous; upper surface black-green, lower bluish; veins sulcate above. Sori terminal on the lobes, obreniform; capsules springing from the veins and parenchyma.

Borneo.

(15d) A. Doctersii, v. A. v. R., in Bull. Btz., 1913, XI, 1, tab. I.

Rhizome short, the scales linear-subulate, dense, brown. Stipes approximate, $\pm 25-35 \mathrm{~cm}$. long, glossy, dark-purple-brown, the base 
scaly, at length asperulous. Fronds $\pm 12 \%-20 \mathrm{~cm}$. each way, with a terminal branch $7 \frac{1}{2}-15 \mathrm{~cm}$. long and $2 \frac{1}{2}-3 \mathrm{~cm}$. broad and 1 or more lateral branches. Lateral branches shorter, the lowest the largest, forked or branched again at the base. Leaflets dimidiate, close, subrhomboidal or the lowest subflabellate, the largest $\pm 1-1 \frac{1}{2} \mathrm{~cm}$. long and $1 / 2$ as broad or a little broader, the base broadly cuneate or rotundatecuneate, the upper edge slightly lobed, denticulate, the apex blunt or rounded, denticulate. Texture coriaceo-chartaceous; rachises dark-purplebrown, hirsuto-tomentose above; surfaces naked; veins terminating in the ultimate serratures. Sori transversely oblong or shortly linear, placed in broad shallow hollows along the upper and sometimes also on the outer edge; sporangia springing from the veins only.

Java.

(15e?) A. Christii, Rst., in Fed., Rep., XII, 166.

Stipes firm, $15-20 \mathrm{~cm}$. or more long, naked and purple-black like the rachis, asperulous at the base. Fronds ovate or ovate-oblong, $\pm 40 \mathrm{~cm}$. or more long by $24 \mathrm{~cm}$. broad, acuminate, 3-pinnate at the base. Pinnae \pm 6 on a side, petiolate, ascending; lower pinnae linearovate, shortly acuminate, 2-pinnate. Leaflets horizontal or spreading, dimidiate, subrhomboidal, straight or slightly recurved, somewhat narrowed towards the apex, $\pm 16 \mathrm{~mm}$. long by $4 \mathrm{~mm}$. broad, the upper and outer edge slightly lobed. Texture chartaceous; under surface subglaucous; rachises rough-hairy above, the hairs fulvous. Sori reniform, $1-2$ on the upper and outer edge of the leaflets; indusium reniform, coriaceous, blackpurple, pale-margined; sporangia from the veins only. - Rhizome . . . . .

New Guinea.

(16a) A. hollandiae, v. A. v. R., in Bull. Btz., 1912, VII, 1.

Rhizome short-creeping, clothed with black-purple, setiform scales. Stipes aggregate, $\pm 30-40 \mathrm{~cm}$. long, black-purplish, glossy, the lower part deciduously subulato-paleaceous, at length scabrous. Fronds ovate, $\pm 20-25 \mathrm{~cm}$. each way, branched, the rachises naked, purplish-black; branches linear, $\pm 2-3$ below the terminal one, rather erecto-patent, \pm $12 \frac{1}{2}-17 \frac{1}{2} \mathrm{~cm}$. long, $\pm 1 \frac{1}{2}-2 \mathrm{~cm}$. broad, narrowed towards the apex, the lowest forked on the lower side at the base with a single rather short branchlet. Leaflets dimorphous, dimidiate, short-stalked, rather close, oblique, the largest $\pm 3 / 4-1 \mathrm{~cm}$. long, 5-6 mm. broad; barren leaflets 
oblong, cuneate at the base, rounded at the apex, with the upper and outer edge pellucid-margined; fertile leaflets trapeziform (the higher cuneate), obliquely truncate at the apex. Texture coriaceous; surfaces naked; upper surface glossy, lower more or less opaque and glaucous; veinlets terminating in the sinuses between the ultimate serratures. Sori transversely oblong, sublinear, 1-3 (commonly 2) on a leaflet, occupying the upper and outer edge; sporangia springing from the veinlets only; indusium brown, coriaceous, finely rugulose when dry.

Nero Guinea.

(18a) A. Farlleyense, Moore, in Gard. Chron., 1866, 730.

Fronds large or middle-sized, triangular, pinnately compound. Leaflets broadly cuneate-flabellate or tending toward quadrate-dimidiate in shape, the largest $\pm 2-3 \mathrm{~cm}$. long: $24 \mathrm{~cm}$. broad, articulate to the nodose apex of the petioles, the outer (or upper and outer) edge irregularly and often deeply flabellately incised with oblong, emarginate or incised lobes, the hase broadly cuneate with entire, often decurved sides; ultimate lobes rounded or subtruncate at the apex. - Probably a garden variety of A. tenerum Sw.

Cultivated.

\section{(19b) A. opacum, Copel.,}

A duplicate of this, received from Manila (Merrill No. 9618), has the stipe and rachises provided with a few scattered, moderately long hairs only, the leaflets varying from cuneate-flabellate to subdimidiate, with the veins terminating in the serratures.

(20) A. aethiopicum, $\boldsymbol{L}$.

Also in Malacca.

(21) A. Suborbiculare, v. A. v. R.

Leaflets bounded by a conspicuous, pellucid, marginal line.

(21a) See No. $19 b$.

(22a) cupreum, Copel., in Leafl., IV, 1152.

Near A. opacum Copel. - Stipes $5-15 \mathrm{~cm}$. long. Fronds $8-15 \mathrm{~cm}$. long, 6-15 cm. broad. Leaflets roundish, deciduous, bordered by a 
narrow hyaline line. Texture coriaceous; upper surface finely coppercoloured when seen by oblique light; veins terminating in the sinuses between the ultimate serratures. Sori large, $1-2$ on a leaflet, transversely oblong; sporangia confined to the veinlets.

Sibuyan Island.

(24) A. tinctum, Moore.

This species is construed as including two forms: A. tinctum Moore and A. decorum Moore.

(24a) A. tinctum, Moore; A. Wagneri, Mett. (not $H k$. Bk.), Kuhn, in Linn., XXXVI, 77.

Fronds 2-pinnate; leaflets shallowly lobed on the outer edge.

(24b) A. Iecorum, Moore; A. Wagneri, Hk. Bk. (not Mett.), Syn. Fil., 473.

Fronds 3-4-pinnate; leaflets distinctly lobed on the outer edge.

(25) A. cuneatum, L. א. F.; - var. variegatum, in Hort. Bog.

Var. variegatum: Leaflets ornated with flabellate-spreauling white stripes irregular in length.

(26a) A. Fergusonii, Moore, Nich., Dict. d'Hort., I, 55.

Stipes long, purplish-black, naked, glossy, as are the rachises. Fronds middle-sized, triangular to ovate, 2-4-pinnate at the base, simply pinnate at the apex, the terminal leaflet often deeply incised, with the segments lobed again, as are the terminal leaflets of the branches und branchlets. Pinnulae mostly with $1-5$ leaflets on each side below the terminal one, the lowest of which are not rarely deeply pinnatifid or even pinnate again. Leaflets different in shape, sessile or stalked, mostly large, ovate, rounded or obtuse, truncate to cuneate at the base, with the stalks adherent to the rachises; terminal leaflets of fronds branches and branchlets the largest, the segments (penultimate lobes) not rarely conspicuously imbricating. Texture thin but firm; veins terminating in the ultimate crenations or serratures. Sori transversely oblong, terminal on the ultimate lobes, slightly curved, placed in slightly rounded, shallow hollows, the sporangia originating from the veins only. - Perhaps a garden variety of another species.

Much cullivated. 
(27) A. hispidulum, Sw.; A. mubescens, Schk., Krypt. Gew., I, tab. 116.

\section{(28) A. stendehlamys, Bk.}

Also in Malacca.

\section{HYPOLEPIS, Hernhardi.}

Indusium not rarely consisting of an unmodified lobe-like outgrowth of the margin of the frond.

\section{\& 1. ASPIDOTIS.}

(*1) HI. tenerifrons, Christ, in Philipp. Journ., IIIC, 274.

Rhizome oblique, subereeping. Stipes tufted, thickened towards the base, angular, sulcate, stramineous, $\pm 25 \mathrm{~cm}$. long, clothed with lanceolate, acuminate, flaccid, pale-brown scales intermixed with subulate smaller ones. Fronds deltoid-ovate, acuminate, hardly narrowed at the base, \pm $40 \mathrm{~cm}$. long, $\pm 30 \mathrm{~cm}$. broad, 3-pinnate. Pinnae \pm 25 on each side, sessile, opposite, lower ones distant, $\pm 9 \mathrm{~cm}$. apart, highest ones close, lower and medial ovate-lanceolate, hardly narrowed at the base, caudateacuminate, $\pm 6 \mathrm{~cm}$. broad. Pinnulae spreading, up to 20 on each side, approximate, ovate-lanceolate, acute, $\pm 1 \mathrm{~cm}$. broad, cut down to the costa. Tertiary segments ligulate-lanceolate, up to \pm 10 on each side, the lowest free, obtuse, $\pm 2 \%$ mm. broad, inciso-dentate with 3-4 ovate, acute teeth on each side. Texture herbaceous, flaccid, diaphanous; colour pale-green; main rachis pale-yellow, scaly; surfaces, secondary rachises and costae partly puberulous. Sori numerous, 1 on each ultimate segment, submarginal on the anterior side; indusium marginal, round, yellow-brown. - See Copeland's information in Leafl, IIt, 807.

Mindoro, Mindanao.

\section{§ 2. EUHYPOLEPIS.}

1. Fronds smail or middle-sized, at best 3-pinnate.

(1) H. alpina. 
1.1. Fronds rather large, at least 4-pinnatifid.

2. Indusium indistinct, tooth-like, or the sori protected by the recuived margin of the ultimate lobules.

(2) H. punctata.

2.2. Indusium distinct, not tooth-like.

3. No rampant species.

4. Indusium single.

5. Ultimate segments toothed or shallowly pinnatifid (deeply lobate-dentate).

(3) H. tenuifolia,

5.5. Ultimate segments entire or crenate.

(4) H. Bamleriana.

4.4. Indusium double.

(5) H. bivalvis.

3.3. Rampant species.

(6) H. papuana.

(2) II. pranciata, Mett. (not Bedd.), in Kuhn, Fil. Afric., 120; Phegopteris punctata, Mett., v. A. v. R., Mal. Ferns. 495, includ. synonyms; - var. rugulosa; H. rugulosa, J. Sm.; Ph. rugulosa, Mett.

Fronds more or less copiously fibrilloso-pilose on the rachises, costae, costulae and veins, $50-350 \mathrm{~cm}$. long and about half as broad.

Forma typica: Sori few, in or near the axils of the lower lobules of the segments, when young protected by a very minute, recurved, axillary, tooth-like indusium only.

Var. rugulosa : Sori generally 1 to each ultimate lobule, so copious that they frequently cover the whole under surface or the segments, when young protected by the recurved lobule and often also by an axillary tooth.

(4) Hanleriana, Rst., in Fed., Rep., X, 325.

Fronds large, 5-pinnatifid. Pinnae petiolulate, lanceolate, $\pm 50 \mathrm{~cm}$. long, $35 \mathrm{~cm}$. broad, shortly acuminate, produced on the lower side. Secondary and tertiary segments horizontally spreading, petiolate, lanceolate, acuminate, nearly equal-sided. Leaflets sessile, rather narrowly adnate at the base, linear, obtuse, deeply pinnatifid with $\pm 4-6$ oblique, ovate, acute, subentire or subcrenulate lobes on a side. Texture thinly herbaceous; surfaces sparingly hairy; colour olive-green; rachises orangebrown, glossy, hirsute above, naked or sparingly hairy beneath, the

FERNS AND FERN Aluies, 
ultimate ones green above, orange beneath, pilose, narrowly marginate; veins immersed, subpeliucid, pinnate or forked, naked above, pilose beneath. Sori solitary at the base of the lobes, on the anterior side.

New Guinea.

(5)? T. Divalvis, v. A. v. R., in Bull. Btz., 1914, XVI, 19, tab. V.

Rhizome wide-creeping, densely fibrillose like the stipes and rachises; fibrils spreading, red-brown, articulated, partly long, partly short, more or less deciduous, with a persistent base. Stipes scattered, $\pm 25-30$ cm. more or less long, brown to purplish, as are the rachises. Fronds 4 -5-pinnatifid, the main rachis flexuose. Pinnae alternate, short-stalked, triangular- or ovate-lanceolate, $\pm 15-45 \mathrm{~cm}$. long, $5-15 \mathrm{~cm}$. broad at or near the base. Pinnulae short-stalked, opposite or alternate, horizontal, $1-2^{1} / 2 \mathrm{~cm}$. broad at or near the base, acuminate. Tertiary segments subsessile, triangular-oblong, horizontal, close, $\pm 3-9 \mathrm{~mm}$. broad at the base, blunt. Leaflets sessile, oblong, horizontal, nearly close, blunt, entire to lobate-dentate, the largest $\pm 4^{1} \frac{1}{2} \mathrm{~mm}$. long, $1-2 \mathrm{~mm}$. broad, obliquely cuneate and subdecurrent at the base, conneted by a very narrow wing Texture thick-coriaceous, fragile when dry; surfaces fibrillose; veins indistinct. Sori 1-2 to a leaflet, on the anterior side or on both anterior and posterior sides, terminal on the veinlets or (apparently ?) occupying the space between the 2 vein-tips of forked veins; indusium when young rotundate or transversely oblong, apparently 2-valved (compresso-cupuliform ?), the outer valve (half) coriaceous at the base, membranaceous towards the edge, the inner membranaceous. - The generic place of this species is uncertain because of too young material; it may also be a Dennstaedtia or a Paesia.

Sumatra.

(6) H. Dapraana, Bail., in Queensl. Agt. Journ., XXIIt, 158.

Rampant, to $4 \mathrm{~m}$. high, probably 4 -pinnate, the rachises more or less glossy-brown, and for the most part bearing prickles and short gland-like hairs. Ultimate pinnae $5-7 \frac{1}{2} \mathrm{~cm}$. long, bearing oblong pinnulae about $2 \frac{1}{2} \mathrm{~cm}$. long, short-stalked or sessile, deeply lobed. Lobes bluntly ovate. Sori just above the sinuses; indusium very membranous.

New Guinea. 


\section{CHEILANTHEF, Swart:}

\section{§ 3. EUCHEILANTHES.}

(6) Ch. Lenuifolia, Sw.; Schk., Krypt. Gew., I, tab. 125.

Rhizome short-ereeping, scaly. Stipes approximate, $\pm 5-20 \mathrm{~cm}$. long, wiry, straight or flexuose, dark-brown, or purplish-black, polished, naked or more or less sparingly and deciduously fibrillose, fibrillosopaleaceous towards the base. Fronds deltoid to lanceolate, $\pm 5-20 \mathrm{~cm}$. long, 4-10 cm. broad, 3-pinnatifid or 3-pinnate. Pinnae in several or numerous spreading or erecto-patent pairs, the lower the largest, opposite, the following opposite or alternate, the largest 2-10 cm. long, deltoid. Lowest posterior pinnulae largest, to $2 \frac{1}{2} \mathrm{~cm}$. long, eut down nearly or quite to the rachis into very small, oblong, entire, crenate, sinuate or pinnatifid segments to $\pm 4 \mathrm{~mm}$. long and $2 \mathrm{~mm}$. broad, the free segments often short-stalked and cuneate at the base, blunt at the apex. Texture thinly coriaceous, firm; rachises like the stipe; surfaces naked or more or less sparingly and deciduously fibrillose. Sori roundish or subcontinuous; indusium narrow, brownish, transversely oblong, more or less crenated or toothed. - Ch. hirta Sw. differs from this in having the whole plant densely hairy, commonly larger, with the lower pinnae very distant and gradually much reduced.

Trop. Asia, Australia, Polynesia, Tasmania, Nero Zealand.

\section{PLAGIOGXIRA, Mettenius.}

(3a?) Minuta, Copel., in Philipp. Journ., XC, 148.

Rhizome erect, short. Stipes $1-3 \mathrm{~cm}$. long, those of the fertile fronds the longest. Barren fronds $6 \mathrm{~cm}$. more or less long, $10-12 \mathrm{~mm}$. broad, the rachis quadrangular and minutely paleaceous below, as is the stipe. Pinnae numerous, sessile, to $6 \mathrm{~mm}$. long by $1 \frac{1}{2}-2 \mathrm{~mm}$. broad, obtuse, crenate, narrowed at the base. Texture coriaceous; surfaces naked; veins simple, $3-4$ on a side. Fertile fronds paucipinnate, the pinnae stalked, cordate, $2-3 \mathrm{~mm}$. long by $1 /{ }_{12}-2 \mathrm{~mm}$. broad, with the margin broadly retroflexed.

Borneo. 
( $3 b$ ?) P. egenolfioides, Copel., in Journ. Str. Br. R. A. Soc., LXIII, 72; Lomaria egenolfioides, Bk.; in Kew Bull., 1894, 7; Blechnum egenolfioides, C. Chr., Ind. Fil.

Rhizome erect. Stipes densely tufted, $3 \frac{1 / 2}{2}-13 \mathrm{~cm}$. long, those of the fertile fronds the longest. Barren fronds $12-15 \mathrm{~cm}$. long, $3-4 \mathrm{~cm}$. broad at the middle, the stipe slender, brown. Pinnae linear, obtuse, crenate, auricled on both sides at the base; lower pinnae deflexed, gradually reduced. Texture subcoriaceous; surfaces naked; veins distant, erectopatent, immersed, obscure, simple, the lower forked. Fertile fronds $2-21 / 2$ cm. broad, with the pinnae narrower, more distant.

Borneo.

(4a) P. nana, Copel., in Philipp. Journ., IV ${ }^{\mathrm{C}}, 114$.

Stipes of barren fronds $3-5 \mathrm{~cm}$. long; basal tubercles present, few. Barren fronds $\pm 10-13 \mathrm{~cm}$. long, $\pm 5-6 \mathrm{~cm}$. broad. Pinnae approximate or the lower ones somewhat distant, sessile, nearly all free, $\pm 6 \mathrm{~mm}$. broad, obtuse, minutely serrulate. Texture rigidly coriaceous; under surface glaucous. Fertile fronds $\pm 10 \mathrm{~cm}$. long, on stipes $\pm 15 \mathrm{~cm}$. long; pinnae $2 \frac{1}{2}-3 \frac{1}{2} \mathrm{~cm}$. long, linear, falcate. - Specimens growing in brush are probably larger.

Luzon.

(5) T. Dycnophylla, Mett.; - var. integra, Copel., in Philipp. Journ., $\mathrm{VC}^{\mathrm{C}}, 285$.

Var. Integra: Pinnae narrower, the edges entire, at best serrulate towards the apex.

Borneo.

(7) Toberculata, Copel.; - var. gracilis, Copel., Leafl., II, 405. Forma typica. - Also in Mindanao.

Var' graciles: Liko the type but much smaller and finer. - Negros.

(8) sumatrama, Rst., in Fed., Rep., XIII, 214.

Stipes tufted, $20-40 \mathrm{~cm}$. long, those of the fertile fronds the longer, brown, glossy, deeply grooved, the base provided with $2-4$ tubercles. Barren fronds ovate-oblong, to $50 \mathrm{~cm}$. or more long, $\pm 18 \mathrm{~cm}$. broad, pinnate, shortly acuminate. Pinnae ascending, lanceolate, \pm 25 on a side, provided beneath with a gland at the base; central pinnae largest, 
$\pm 10 \mathrm{~cm}$. long by $1 \frac{1}{2} \mathrm{~cm}$. broad, sessile with a cuneate base, subcrenulate, crenulate-serrate towards the apex; lower pinnae $\pm 5 \mathrm{~cm}$. long, sessile or short-stalked; higher pinnae adnate with a decurrent base ${ }^{\prime}$ highest confluent and connected with the terminal one. Texture subcoriaceous; surfaces naked; veins spreading, simple or forked. Fertile fronds as broad. or broader, with the pinnae contracted, to $15 \mathrm{~cm}$. long by 3-4 mm. broad.

Sumatra.

42u. DORYOPTERIS, J. Smith.

\section{§ 2. EUDORYOPTERIS.}

(2) D. Iudens, I. Sm.

Also in Java.

(3) D. papuana. Copel., in Philipp. Journ., VIC, 86; D. ludens, J. Sm., var. pluriloba, Rst., MS. in Herb. Bog.

Stipes $\pm 30-40 \mathrm{~cm}$. long, naked, glossy, blackish. Barren fronds rather ovate, $\pm 15-30 \mathrm{~cm}$. long, $10-20 \mathrm{~cm}$. broad, deeply pinnatifid, cordate at the base, the costal wing $\pm 11 / 2 \mathrm{~cm}$. broad (from edge to edge). Lobes $\pm 4-5$ on each side below the acuminate apex, erectopatent, separated by rather narrow sinuses, the lowest the largest, the next higher simple, lanceolate-oblong, nearly straight, somewhat falcate, $\pm 1 \frac{1}{2} \mathrm{~cm}$. broad at or near the base, narrowed gradually to the acuminate apex, the higher similar but smaller, rather blunt; lowest lobes $\pm 10-15 \mathrm{~cm}$. long, more or less distinctly falcate, deeply pinnatifid on the lower side with \pm 3 lobes the lowest of which are the longest, and lobed again with \pm .2 blunt lobes on the lower side towards the base; edges crisped. Texture coriaceous; costa and costulae of the basal primary lobes blackish beneath at least towards the base; veins reticulate; areolae numerous, small, subhexagonal, oblique, without free veinlets. Fertile fronds similar but the lobes narrower, more falcate, all acute, separated by sinuses as broad as the lobes or broader, the costal wing $\pm 1 \mathrm{~cm}$. broad. Sori narrow, occupying the whole margin except the apices of the lobes. New Guinea. 
(3) H. integrifolian, Copel., in Philipp. Journ, VIIC, 63; ? H. incisa, J, Sm., var. integrifolia, Bedd., Handb. Ind. Ferns, Suppl., 25.

Pinnae petiolate; pinnulae sessile or the lower subpetiolate, long, linear, acuminate, subcordate at the base, the basal pair wanting or auricle-like and orbicular. Sori not reaching the apices of the segments.

Borneo.

(4) H. stipulacea, Copel., in Philipp. Journ., IIIC, 347., H. incisa, J. Sm., C. Chr., Ind. Fil., p. p.; Pteris stipulacea, Hk., Spec. Fil., II, 233.

Stipes, rachises and costae beneath rich-castaneous, very glossy. Fronds ample, 2-pinnate. Pinnae $\pm 45 \mathrm{~cm}$. long, opposite, the petioles swollen at the base and furnished there with a pair of orbicular, foliaceous, adpressed auricles or stipules. Pinnulae $\pm 15 \mathrm{~cm}$. long, remote, petiolate, gradually acuminate, quite entire, obliquely cuneate at the base, the terminal and lowest ones subhastate. Texture chartaceous; surfaces pale, opaque and subglabrous beneath; costae prominent beneath; veins copiously and nearly uniformly anastomosing, forming oblong, hexagonal, obliquely spreading areolae, those next the costae rather the largest. Indusium continuous, narrow, firm, almost the texture of the frond. A form found by Mr. Herwitt has the pinnulae almost sessile and sometimes extravagantly hastate.

Borneo.

\section{4ธต. P'TERIS, Limné.}

\section{\$ 1. EUPTERIS.}

(1) reducia, Bk.; v. A. v. R., in Bull. Btz., 1914, XVI, 36.

Lowest segments sometimes more remote from the others, elongated and pinnatifid again, as in Pt. salakensis $v . A . v$. R., but with the lowest secondary segments close to the main rachis, not decurrent upon the petiole

(2) Pt. rangiferingt,

Also in Borneo. 
(3) t. orientalis, v. A. v. R.; -- viar. glabra, V. A. v. R., in Bull. Btz., 1912, VII, 26.

Var. slabran: Pinnae glabrous, at least the lower conspicuously cordate at the base.

(4a) Pt. Iongifolia, T.; Schk., Krypt. Gew., I, tab. 88.

(5a) Pt. taenitis. Copel. in Philipp. Journ., VIIC, 53, tab. III.

Stipes densely tufted, $3-10 \mathrm{~cm}$. long, yellow-brown, clothed towards the base with fulvous, crinite scales, grooved above like the rachis, the groove often puberulous. Fronds $25-35 \mathrm{~cm}$. long. Pinnae $1-3$ on each side below the terminal one, linear, $\pm 20--30 \mathrm{~cm}$. long, $\pm 1 / 2 \mathrm{~cm}$. broad, entire, narrowed gradually towards both ends, decurrent and often connected by a very narrow wing. Texture coriaceous; surfaces soon glabrescent. Indusium moderately broad. - See Copeland's information under Pt. opaca J. Sm. in Leafl., V, 1684.

\section{Mindanao.}

(9) Pt. pellucida, Pr.; - var. variegata, v. A. V. R., in Bull. Btz., 1913, XI, 22.

Stipes sometimes purple-black; rachis and costae smooth; pinnae equally green above. - Pt. venulosa Bl. is the form which has the axes red-polished, the sterile pinnae not wavy, coarsely crenate-serrate at the apex, most of the pinnae decurrent-connected, with the veins less conspicuous.

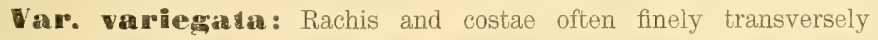
rugulose or verruculose towards the base; pinnae provided with broad pale bands running down the centre, the lateral ones 2-jugate in the fully developed plants, the higher not or but slightly decurrent. Intermediate between the type-and Pt. stenophylla Wall. - Java.

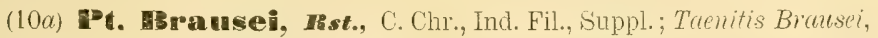
Rst., in Nov. Guin., VIII, Bot., 730.

Fronds $100 \mathrm{~cm}$. more or less long, $\pm 25 \mathrm{~cm}$. broad, pinnate. Pinnae numerous, the terminal one linear, $\pm 15 \mathrm{~cm}$. long, narrowed gradually at both ends, the lateral ones numerous, erecto-patent, the highest simple, broadly adnate at the base, the next following similar to the terminal one but shorter, sessile, the following simple, or forked at the base, the lower short-stalked, forked at the base, with the segments simple or forked 
again; segments or simple pinnae to $25 \mathrm{~cm}$. long, $1 / 2-3 / 4 \mathrm{~cm}$. broad, with the edges pale-cartilagineous, subentire, or slightly serrate-crenate towards the apex. Texture chartaceous; rachis purple-brown, glossy, grooved above, glabrescent; under surface deciduously short-hairy, at length naked; veins subhorizontal, approximate, simple or forked, fine, pellucid. Sori Jong, not reaching the apex of the segments; indusium subscariose, entire; capsules intermixed with stalked, red-brown, clavate paraphyses.

New Guinea.

(11) Pt. ereriea, L.; Schk., Krypt. Gew., I, tab. 90; - var. Wimsettii; Pt. Wimsettii, hort.

Var. Wimsettii: Pinnae partly very irregularly lobed and not rarely irregularly dichotomous at the apex; lobes spinuloso-serrate, the lateral ones horizontally spreading.

(11b) Pt. deltoidea, Copel., in Philipp. Journ., VIC, 85; Pt. glabella, Rst., in Fed., Rep., IX, 423.

Fronds $\pm 30-35 \mathrm{~cm}$. long, pinnate. Pinnae erecto-patent, simple or forked, or the lowest stalked and irregularly 3-partite or once or twice forked again, with the leaflets free, sessile or stalked, or connected at the base; highest pinnae often adnate and connected with the terminal one. Ultimate leaflets similar to the simple pinnae, linear, $\pm 5-20 \mathrm{~cm}$. long, $\pm 4-7^{\mathbf{1}} j_{2} \mathrm{~mm}$. broad, narrowed gradually towards both ends, acutely serrate when barren, broadly repand or subundulate in the fertile portions. Texture firm; surfaces naked; main rachis rather stramineous or pale-brown like the stipe; costae prominent beneath; veins numerous, nearly horizontal. Sori long, narrow.

New Guinea.

(14) Ft. serrulata, C. f.; Schk., Krypt. Gew., I, tab. 91.

(16) IPt. semippinnata, E.; Pt. flubelluta, Schk., Krypt. Gew., I, tab. 93.

(20) Pt. Dallhousine, Hk.

Also in Malacca.

(21 $\alpha$ ) Pt. gracillima, Rst., in Fed. Rej., IX, 424; ? Pt, Beccariana, C. Chr. (t. Copel.). 
Rhizome short, erect. Stipes tufted, slender, $\pm 6-10 \mathrm{~cm}$. long, black-brown, glossy, naked. Fronds subdeltoid, $\pm 10-15 \mathrm{~cm}$. long, the rachis like the stipe. Pinnae opposite, 3 on each side below the terminal one; terminal pinna lanceolate, $\pm 7-10 \mathrm{~cm}$. long, $\pm 1 \frac{1}{2}-2 \mathrm{~cm}$. broad at the base, caudate-acuminate and entire or subcrenate in the upper part, cut down nearly to the costa into several erecto-patent, blunt or acute, remote lobes $\pm 2-3 \mathrm{~mm}$. broad, decurrent at the base; highest pinnae erecto-patent, linear, flexuose or upcurved, adnate, $3-6 \mathrm{~cm}$. long; to \pm $3 \mathrm{~mm}$. broąd, entire or more or less pinnatifid; lowest pinnae largest, \pm $8 \mathrm{~cm}$. long, erecto-patent, often upcurved, sessile or short-stalked, caudateacuminate and entire to irregularly lobed in the upper part, deeply and irregularly pinnatifid in the lower part, the lobes varying from $1-10 \mathrm{~mm}$. long, to $\pm 3 \mathrm{~mm}$. broad, the lowest posterior lobe elongated, to $5 \mathrm{~cm}$. long, not rarely free but adnate. Texture firm; surfaces naked; veins not very distinct, often forked. Sori lateral on the longer lobes, terminal on the reduced ones, not occupying the sinuses and the apices of the former.

Nero Guinea.

(21b) Pt. mixta, Christ, in Schum. \& Laut., Flor., deut. Sch.geb.' Suppl., 45; Pt. quadriaurita, Retz, var. Lauterbachii, Christ, p. p.; Pt. heterogenea, v. A. v. R., in Bull. Btz., 1912, VII, 25, tab. II.

Near Pt. gracillima Rst. but the stipes and fronds longer, the fronds to $25 \mathrm{~cm}$. long, the pinnae larger, 4-5-jugate, the lowest pinnae often forked at the base with similarly pinnatifid, mostly short-stalked forkbranches, the lobes broadly but not deeply crenated, straight, longer, and the caudiform terminal lobes often very conspicuously elongated.

New Guinea.

(22c) Pt. saltakensis, v. A. v. R., in Bull. Btz., 1912, VII, 26.

Near Pt. pluricaudata Copel. but the stipes, costae and costulae deciduously and minutely fibrillose; fronds ovate, larger, to $35 \mathrm{~cm}$. long, to $20 \mathrm{~cm}$. broad; pinnae 1 on each side below the terminal one, very deeply pinnatifid, $6-10 \mathrm{~cm}$. broad, the central (terminal) one the broadest, the lateral ones not forked at the base, short-stalked, arcuate-ascending; segments nearly horizontal, $5-8 \mathrm{~mm}$. broad, connected by a narrow wing, the lowest anterior one suddenly and slightly decurrent upon the petiole, the fertile ones entire at the obtuse barren apex; upper surface sparingly and very minutely fibrillose; texture papyraceous; veins distinct, naked; sori 
reaching nearly the apex. - Barren fronds not seen. - Perhaps a local derivative of Pt. quadriaurita Retz.

Java.

(22d) See No. 1.

(23a) Pt. Brooksii, Copel., in Philipp. Journ., IX 231.

Stipes to $\pm 60 \mathrm{~cm}$. long, stramineous, deciduously minutely furfuraceous, provided towards the base with a few horizontal castaneous scales. Fronds $\pm 40 \mathrm{~cm}$. long, $\pm 25 \mathrm{~cm}$. broad, pinnate, the rachis very minutely asperulous, stramineous. Pinnae stalked, to $16 \mathrm{~cm}$. long, \pm 4 $\mathrm{cm}$. broad, deeply pinnatifid, the apex caudate, the stalk winged; lowest pinnae forked on the lower side with similarly pinnatifid fork branches. Lobes pectinate, approximate, $\pm 2 \% \mathrm{~mm}$. broad, obtuse, entire Texture herbaceous; surfaces naked; costae setose; veins forked. Sori reaching nearly the apex of the lobes.

Sumatra.

(27) 1. Iurcans, Bh.

Also in Sumatra.

(28) Pt. decussata, J. Sm.

Also in Nero Guinea.

(31a) Pt. Keysseri, Rst., in Fed., Rep., XII, 167.

Fronds 3-partite, the branches to $45 \mathrm{~cm}$. or more long, $\pm 24 \mathrm{~cm}$. broad, 3-pinnatifid. Pinnulae horizontal, contiguous, linear-oblong, acuminate. the acumen serrate. Ultimate segments subhorizontal, approximate, linear, $\pm 1^{3 / 4} \mathrm{~cm}$. long by $1 / 2 \mathrm{~cm}$. broad, acute, serrate in the barren region, upper base somewhat contracted, lower base dilated and decurrent; lower segments nearly free, contracted on both sides at the base. Texture herbaceous; colour dark-green; surfaces naked; veins \pm 10 on a side, forked or the lower often twice forked, the higher simple. Sori not reaching base and apex of the segments.

New Guinea.

(32) Pt. radicsens, Christ; - var. javanisa, v. A. v. R, in Bull. Btz., 1912, VII, 27. 
Forma typica: Fronds 3-5-partite, the pinnae not proliferous and the veins not indistinct at least in some specimens.

Var. javanica: Like the type hut the stipes stramineous on the upper (inner) side, pale-fuscous on the lower (outer) side, darker and scaly towards the base. Pinnulae more numerous and longer, with the veins conspicuous, simple or forked. Sori not seen. - Branches not proliferous, sulcate and tomentose above. - Java, Mindanao.

(34) Pt. mixta, Christ.

Omit this species here, see No. $21 b$.

(35a) Tt. tremula, R. \#»., Hk. Bk., Syn. Fil., 161; Hk., Spee, Fil., II, 175, tab. CXX B; - var. cheilanthoides, Rst., in Med. R. H. L., $1912,12,32$.

Stipes $30 \mathrm{~cm}$. or more long; strong, erect, naked, polished, brightchestnut-brown. Fronds $60-120 \mathrm{~cm}$. or more long, $15-60 \mathrm{~cm}$. broad, 3-4-pinnate, the terminal pinna with a few closely placed, linear, entire lobes which are obliquely decurrent at the base, the largest hardly more than $2^{1 / 2} \mathrm{~cm}$. long, $2_{2}^{1 / 2} \mathrm{~mm}$. broad (5 mm. broad in Hooker's plate), obtuse serrate-crenate in the sterile portions; lower pinnae compound, sometimes $30 \mathrm{~cm}$. long, with the lower pinnulae narrowed gradually from a broad base, the ultimate lobes similar to those of the terminal pinna. Texture herbaceous; rachis and both surfaces naked; veins sunk, about $3 \mathrm{~mm}$. apart at the base, usually once forked. Sori copious, sometimes filling up the whole under surface of the segments except the costules.

Forma typica: Sori not interrupted. - Austratia, Tasmania, New Zealand, Norfolk Island.

Gar. cheilanthoides: Sori interrupted, cheilanthoid. - Lom. bok Island.

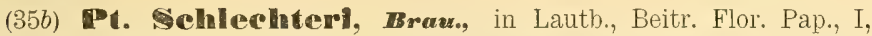
33, fig. $2 \cdot B-b$.

Stipes to $46 \mathrm{~cm}$. or more long, above stramineous and grooved, beneath brown, glabrescent, when young pale-brown-scaly. Fronds 3pinnate at the base, $\pm 48 \mathrm{~cm}$. long, $38 \mathrm{~cm}$. broad. Pinnae opposite, spreading, stalked, to $30 \mathrm{~cm}$. long, $17 \mathrm{~cm}$. broad at the base. Pinnulae stalked, to $15 \mathrm{~cm}$. long, $9 \mathrm{~cm}$. broad. Tertiary segments spreading, to 15 on a side, sessile, linear-subulate, the largest $\pm 10 \mathrm{~cm}$. long, $1 \frac{3}{4} \mathrm{~cm}$. 
broad at the truncate-cuneate base, deeply pinnatifid, the apex long acuminate, repand. Lobes approximate or subcontiguus, separated by acute or subacute sinuses, to 20 on a side, linear, the largest to $1 \mathrm{~cm}$. long by $1 / \mathrm{cm}$. broad, rounded at the apex, entire or subcrenate, somewhat narrowed in the fertile region. Texture chartaceous, subpellucid; upper surface naked, lower white-puberulous; rachises above stramineous, hairy, beneath brown, glabrescent; costae and costulae above hairy and provided with remote, weak, spine-like projections, beneath glabrescent, when young hairy; veins forked, to 7 on a side. Sori short, placed above the middle of the lobes, 1 on each side.

New Guinea.

\section{§ 2. CAMPTERIA.}

(38) Pt. Wallichiana, Agardh.

Ultimate lobes sometimes provided with a single basal costular areola besides the costal ones.

Also in New Guinea.

\section{§ 3. LITOBROCHIA.}

(40a) Fr. Wan'burogii, Christ; Pt. finisteritae, Rst., in Feel., Rep., $\mathrm{V}, 37,376$.

(40b) Pt. finisterrae, Rst.

Omit this species, it being referred to the preceding.

\section{PAESIA, st. Hilaire.}

(3) Iuzonica, Christ, in Phillpp. Journ., IIIC, 275.

Differs from P. rugulosa Kuhn in having the fronds much smaller, with the main rachis fulvous-stramineous, very flexuose, clothed with flexuose, white hairs, asperulous, the pinnae distant, elongate, flexuose, up to $18 \mathrm{~cm}$. long, caudate, the ultimate pinnulae. $\pm 5 \mathrm{~mm}$. long, when 
barren narrowly cuneate and deeply incised with linear-lanceolate lohes, when fertile mucronate. - A specimen received from Luzon (Bur. of Sci. No. 16313) differs from this in having the hairs of the rachis reddish, very deciduous, the barren leaflets oblong, cuneate at the base, deeply toothed, the fertile ones slightly so or subentire.

Luzon.

(4) P. Elmeri, Copel., in Leafl., III, 826.

Stipes brown, and fibrillose like the rachises and costulae beneath but the latter less densely so or almost naked. Fronds large, 4-pinnate. Pinnae to $50 \mathrm{~cm}$. long, nearly sessile. Largest pinnulae $\pm 12 \mathrm{~cm}$. long. Tertiary segments to $\pm 18 \mathrm{~mm}$. long. Ultimate segments oblong, obtuse, the lower free, $\pm 3 \mathrm{~mm}$. long; entire or incised, with the lobes entire or 2-fid at the apex, the following adnate, the higher confluent, bearing the sori mostly on the upper side only. Texture firm.

Mindanao.

(5) P. scaberula, Kuhn, C. Chr.. Ind. Fil.; Pteris scuberula, Rich., Hk. Bk., Syn. Fil., 163; Hk., Spec. Fil., II, tab. XCIII $A$.

Rhizome wide-ereeping, clothed with spreading hairs. Stipes wiry, $\pm 15-30 \mathrm{~cm}$. long, strong, flexuse, reddish-brown, scabrous. Fronds lanceolate or ovate, $\pm 30-45 \mathrm{~cm}$. long, $15-25 \mathrm{~cm}$. broad, 3-4-pinnatifid, the main rachis flexuose, rough. Lower pinnae $\pm 10--20 \mathrm{~cm}$. long, cut down to the rachis into numerous lanceolate pinnulae on each side; ultimate segments oblong, toothed, $\pm 5-7 \frac{1}{2} \mathrm{~mm}$. long and $2 \frac{1}{2}--3 \mathrm{~mm}$. broad. Texture subcoriaceous; surfaces more or less resinoso-glandulose or subpubescent. Sori copious, on entire ultimate segments, when mature occupying nearly the whole segment except the midrib.

New Guinea; New Zealand.

\section{PTERI DIUM, Gleditsch.}

P1. aquilinum, Kuhn; Pteris aquilina, L., Schk., Krypt. Gew.4 1, tab. 95; - var. esculentum; Pteris esculenta, Forst., Schk., 1. c., tab. 97. 


\section{LOMLARTA, Willdenow.}

(1a) W. Keysseri, v. A. v. R.; Blechnum Keysseri, Rst., in Fed,, Rep., XII, 527.

Stipes provided in the upper part with 10 or more pair remote, auricle-like, reduced pinnae $\pm 2-3 \mathrm{~mm}$. long by $15 \mathrm{~mm}$. broad. Barren fronds lanceolate-oblong, to $35 \mathrm{~cm}$. or more long by $\pm 14 \mathrm{~cm}$. broad, narrowed towards both ends, deeply pinnatifid. Lobes \pm 20 on a side, subhorizontal, nearly linear from a dilated base, the central the largest, $\pm 7 \mathrm{~cm}$. long by $1_{1 / 4} \mathrm{~mm}$. broad, straight, or upcurved towards the short-acuminate apex, the edge entire, revolute; sinuses acute, the lower more rounded. Texture coriaceous; surfaces naked; costa above pale, flat, slightly grooved, beneath black-purple, subterete. Fertile fronds smaller, with the lobes contracted, remote, connected by a very narrow wing.

New Guinea.

(1b) See also Blechnum egregium Copel.

(3) L. egenolfioides, $B k$.

Omit this species, it being referred to Plagiogyria.

(5a) E. Hanileriana. . A. v. R.; Blechum Bamlerianum, Rst.. in Fed., Rep., X, 325; C. Chr., Ind. Fil., Suppl.

Rhizome erect, thick, woody, densely scaly at the apex; scales lanceolate, shortly acuminate, rigidly coriaceous, blackish, brown-margined, sparingly fibrilloso-ciliate. Stipes tufted, to $30 \mathrm{~cm}$. long, angular, lividbrown, fuscous and scaly at the base. Barren fronds lanceolate-ovate, \pm $50 \mathrm{~cm}$. long, $20 \mathrm{~cm}$. broad, acuminate, pinnate in the lower part, pinnatifid in the upper part, entire or subentire at the lanceolate apex. Segments linear-lanceolate, acute or acuminate, cartilagineous and minutely spinososerrate at the edge, the central ones $\pm 10 \mathrm{~cm}$. long, $1 \frac{1}{2} \mathrm{~cm}$. broad; lower segments contracted at the base, lowest $\pm 5 \mathrm{~cm}$. long, often deflexed, remote, central adnate, higher connected and slightly dilated at the base, approximate. Texture chartaceo-coriaceous; surfaces naked; rachis subquadrangular, ochraceous, provided with scattered, deciduous scales; veins immersed, simple or forked. Fertile fronds often broader, with the segments and sori long-decurrent.

New Guinea. 
(8) I. Fraseri, A. Cunn.; v. A. v. R., in Bull. Btz., 1914, XVI, 22.

Barren fronds $\pm 20-45 \mathrm{~cm}$. long, $10-25 \mathrm{~cm}$. broad; secondary segments entire to toothed; fertile fronds smaller than the barren ones.

Also in Sumatra.

\section{BLEOHNUM, Linné.}

\section{\& 1. EUBLECHNUM.}

(1) W. Treubii, v. A. v. R.; Bull. Dép. Agr. I. N., 1909, XXVII, tab. V.

(4) EB. Finlaysonianum, wall.

Also in Java.

(5) IB. Islumei, Moore.

A plant gathered on Mount Patoedja (C. A. Backer No. 12664), probably specimen of this species, has the pinnae rigidly coriaceous, sessile, the lower normal ones horizontal or deflexed, subcordate-truncate at the base, the central narrowly adnate and subauriculate at the dilated base, the higher oblique or arcuate-ascending, broadly adnate to and broadly decurrent upon the rachis. Stipes provided with remote, aurieuliform, reduced pinnae.

(6) 9?. orientale, $\boldsymbol{L}$. ; Schk, Krypt. Gew., I, tab. 109; - var. paleaceum, $\nabla$. A. v. R., in Bull. Btz., 1915, XX, 9.

Forma typica: Pinnae quite entire.

Forma subsemihastata: Some of the pinnae semihastate with a spreading or deflexed, subulate, posterior, basal auricle to $\pm 71_{2} \mathrm{~cm}$. long.

Var. paleaceum: Stipe and rachis densely scaly, the scales long, linear-subfiliform, ferrugineous, slightly crisped, sparingly and minutely denticulate, intermixed with adpressed, woolly, pale-ochraceous, crisped hairs. - Borneo.

(7) IB. Serrulutum, Rich.; Schk., Krypt. Gew., I, tab. 108. 


\section{(8) IB. egregium, Copel.}

Specimens received from the Phitippines differ from Copeland's original description in having the fronds much smaller, not at all pinnate, with the lower pinnae not reduced to mere auricles, and the fertile pinnae suddenly contracted at the base, positively Lomarioid.

\section{SADLERTA, Haulfuss.}

(1) S. eyatheoides, ruf.

Also in Malacca.

\section{DOODIA, R. Brown.}

\section{(1) D. dives, Kae.}

Central segments of barren fronds confluent or connected at the base, generally contiguous or hardly dilated at the base, the $1-3$ lower segments whether or not reduced, occasionally free, adnate, sessile, cordate, truncate, broadly cuneate, auriculate or hastate at the base; segments of fertile fronds similar to those of barren fronds but generally distant and suddenly much dilated on both sides at the base.

Timor, Sumbawa, Java; Ceylon.

\section{(2) media, R. Br.}

Like D. dives $K z e$ but the central segments of barren fronds often free, those of the fertile fronds always free, not adnate with a dilated base, similar to the occasionally free lower segments of D. dives $K z$, the lower segments growing gradually smaller.

Malayan (?); Australian.

\section{WOODWARDIA, Smith.}

\section{$\S 1$. EUWOODWARDIA.}

W. Madicams, sm.; Schk., Krypt. Gew., I, tab. 112. 


\section{DIPLAZIU்M, Swart:}

\section{§ 1. EUDIPLAZIUM.}

(1) D. Serratum, Moore.; Athyrium subservatum, Milde., Copel.; in Philipp. Journ., VIIIC, 142.

Also in Borneo.

(1c) D. Innceum, Pr., Bedd., Handb. Ind. Ferns, 174; Ferns S. I., tab. CCXXVII; Asplenium lanceum, Thb., Hk. Bk., Syn. Fil., 229; Mett., Farng., VI, Aspl., 161; Athyrium lanceum, Milde, Copel., in Philipp. Journ., VII, 55.

Rhizome creeping, clothed with dark, nearly blackish scales. Stipes remote, 5-15 cm. long, more or less paleaceous with deciduous, blackish scales. Fronds linear-lanceolate, $\pm 10-25 \mathrm{~cm}$. long, $1 \frac{1}{4}-3 \mathrm{~cm}$. broad, narrowed gradually towards both ends, acuminate at the apex but the point often bluntish, cuneate or rounded at the base, revolute and entire or repand at the edge. Texture thin-papyraceous to thick-coriaceous; surfaces naked; costa rather prominent beneath; veins spreading, sparingly pinnate er dichotomous. Sori linear, not reaching margin and costa, often double, occupying mostly the lowest anterior veinlets; indusium firm, persistent.

Luzon; Formosa, Japan, China, Br. India, Ceylon.

(2a) D. Menrinli, Copel.; Athyrium Merrilli, Copel., in Philipp. Journ., III, 300 .

(2b) atb. zeylamicum, Moore; Athyrium zeylanicum, Mitde, Copel., in Philipp. Journ., III'; 300.

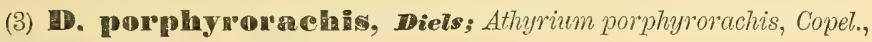
in Philipp. Journ., IIIC, 300.

Stipe and rachis (costa) purple-black; fronds acuminate, the acumen serrate; lowest segments not auricle-like; sori fuscous.

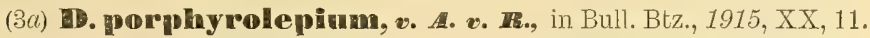

Stipes short, like the rachis (costa) pale-brown and provided with numerous purple-black, subulate scales. Fronds lanceolate, $\pm 25 \mathrm{~cm}$. long, $\pm 23 / 4-3 \mathrm{~cm}$. broad, pinnatifid $\pm 3 / 4$-way down to the costa,

Ferns and Fern Alimes. 
narrowed gradually to both ends, the apex caudate-acuminate, entire. Segments oblong, horizontal, straight or subfalcate, subentire, rounded at the apex; central segments largest, $\pm 6 \mathrm{~mm}$. broad; $1-4$ lower segments free, the lowest semiorbicular, auricle-like, subdeflexed. Texture coriaceous; costulae and veins beneath sparingly scaly; veins to \pm 6 on a side, mostly simple. Sori bright-brown, when young ochraceous.

Celebes.

(4) D. chlorophyllum, Bedd.

Omit this name, it should be D. Pullingeri J. Sm.

(4) D. Pullingeri, Æ. Sma, Ferns Br. \& For., II, 315; D. chlorophyllum, Bedd., Handb. Ind. Ferns, Suppl., 39; Asplenium chlorophyllum, Bk., in Journ. of Bot., XXIII, 104; Athyrium chlorophyllum, Copel., in Philipp. Journ., IIIC, 279; Aspl. Pullingeri. Bk., (oldest name).

Penang (?); Hongkong, China, Formosa.

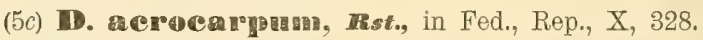

Stipes $8 \mathrm{~cm}$. or more long, blackish like the rachis, densely clothed with linear-lanceolate, crisped, minutely spinoso-denticulate, dark-brown scales. Fronds lanceolate-ovate, $\pm 45 \mathrm{~cm}$. long, $12 \mathrm{~cm}$. broad, pinnate, shortly acuminate. Pinnae rather numerous (25 or more on each side), alternate, subapproximate, horizontal, sessile, linear, truncate and auricled on both sides at the base, acute or shortly acuminate, entire and subrevolute at the edge; central pinnae largest, $\pm 6 \mathrm{~cm}$. long, $11 / 2 \mathrm{~cm}$. broad; lower pinnae deflexed, more or less abruptly abbreviated, 1-2 lowest ones auricle-like; terminal pinna linear, lobed at the base, serrate towards the apex. Texture herbaceous; colour dark-green; surfaces scaly; rachis densely scaly, as are the costae beneath; veins repeatedly forked or subpinnate. Sori occupying the upper postion of the pinnae, long, reaching both costa and margin; indusium narrow, coriaceous, brown.

New Guinea.

(7) D. Silvaticumin, Sav.; Schk., Krypt. Gew., I, tab. 85 b; D. bulbiferum, Brack., Expl. Exp., XVI, 141, tab. XVII, fig. 1; D. Brack. enridgei, Diels, in Schum. \& Laut., Flor. deut. Sch.geb., 124; D. petiolare, Pr., Epim., 86; Asplenium Brackenridgei, Bk., Hk. Bk., Syn. Fil., 234; Athyrium pinnatum, Copel., in Philipp. Journ., III , 297, p. p.; - var. 
latipinnatum, v. A. v. R., - var. novoguineense, Rst., in Hedwi., LVI, 351.

Main rachis often finely (deciduously?) puberulous above; pinnae crenate, toothed or slightly lobed, acute to acuminate, the lowest not rarely oblique at the base and cut to $1 / 5$-way down to the costa into blunt, entire, erenated or slightly toothed lobes; texture varying from thin-herbaceous to firm-papyraceous; veins about $3-5$ on a side; sori about $3-5$ on each side of the main veins or costulae.

Var. Iatipinnatum: Lateral pinnae proportionally short and broad, to $12 \frac{1}{2} \mathrm{~cm}$. long by $4 \mathrm{~cm}$. broad, the apex acuminate, serrate, the margin broadly serrate-crenate, crenate-lobate, somewhat lobed towards the base, the lobules subentire or repando-crenulate. - Sumatra.

Var. novoguineerse: Fronds with a terminal pinna to 20 $\mathrm{cm}$. long by $5 \mathrm{~cm}$. broad, serrate towards the apex, crenate-lobate towards the base; lateral pinnae to $25 \mathrm{~cm}$. long by $b / / 2 \mathrm{~cm}$. broad, coarsely long. serrate, rarely truncate-serrate. - New Guinea.

(7a) D. elatums, Fée., Mém., V, 214; D. silvaticum, Swo, var., C. Chr., Ind. Fil.; Asplenium elatum, Mett., Farng., VI, Aspl., 180; Athyrium elatum, Copel., in Philipp. Journ., VIIC, 63.

Rhizome erect, clothed with black-brown scales. Stipes $\pm 20 \mathrm{~cm}$. long, dirty-brown, sparingly squamose with rigid, blackish, lanceolate, hair-pointed scales. Fronds broadly lanceolate-oblong, $\pm 45 \mathrm{~cm}$. long, acuminate, copiously pinnate. Pinnae lax, spreading, linear, $\pm 17^{1 / 2} \mathrm{~cm}$. long and $2 \mathrm{~cm}$. broad, stalked, narrowed gradually towards the long, caudate-acuminate apex, shallowly broadly crenate-lobate, serrate towards the apex, the base more or less obliquely truncate or rotundate-truncate, the upper base more descendent upon the petiole, the lobules crenulate; lower pinnae more remote and somewhat shorter. Texture firm-herbaceous; main veins ascending, pinnate; veins $\pm 2-3$ on a side. Sori $1-2$ on each side of the main veins, occupying the lower $1 / 2$ of the veins, at least the lowest anterior generally double; indusium membranaceous.

Borneo; Ceylon.

(7b?) D. propinquam, v. A. v. H.; Athyrium propinquum, Copel., in Leafl., V, 1683.

Near D. silvaticum Sw. - Fronds $\pm 40 \mathrm{~cm}$. long, long-caudate, 
bulbiferous below the apex; pinnae stalked, subfalcate, $\pm 9 \mathrm{~cm}$. long, \pm $1 / 4 \mathrm{~cm}$. broad, acute, serrate.

Mindanao.

(11b) D. Talbacinum, Copel.; Athyrium tobacinum, Copel., in Philipp. Journ., IIIC, 299.

Upper surface dark-green, lower yellowish-green.

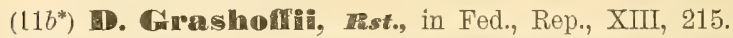

Rhizome woody, the scales ferrugineous, narrowly lanceolate, firm fusco-denticulate, simple, or forked with 2 recurved branches. Stipes tufted, $\pm 20 \mathrm{~cm}$. long, brown, scaly at the base, clothed like the rachis and costae with short, gland-like hairs. Fronds ovate, to $32 \mathrm{~cm}$. or more long by $25 \mathrm{~cm}$. broad, pinnate. Pinnae \pm 2 on each side below the terminal one, short-stalked, ovate or oblong, $\pm 17 \mathrm{~cm}$. long by $7-8$ cm. broad, acuminate, entire or subrepand, rounded at the base; lateral pinnae subhorizontal, the lower not rarely a little larger than the higher. Texture chartaceous, copiously pellucid-dotted; colour olive-green; surfaces naked; veins placed in groups of 6 . Sori mostly short and single, the lower anterior, however, long and double; indusium pale, membranaceous.

Sumatra.

(12) D. confertum, C.Chr.; Athyrium confertum, Copel., in Philipp. Journ., VIC, 62.

Also in Borneo.

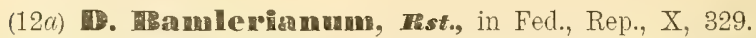

Rhizome short-creeping, the scales scattered, small, lanceolate, minutely spinoso-denticulate. Stipes close, $\pm 15-20 . \mathrm{cm}$. long, clothed with scattered, lacerate, spinoso-fimbriate, spinoso-stellate or serrato-lanceolate scales, as is the rachis. Fronds to $\pm 20 \mathrm{~cm}$. long, to $7 \mathrm{~cm}$. broad, ovateoblong, acuminate, pinnate. Pinnae simple in the smaller fronds, pinnatifid in the larger, to \pm 12 on a side, altermate, subapproximate, erecto-patent, the lower short-stalked, the higher sessile; largest pinnae $\pm 3 \frac{1}{2} \mathrm{~cm}$. long, hardly $1 \mathrm{~cm}$. broad, straight or subfalcate, linear-lanceolate, subacute, the edge cut more than 1/2-way down to the costa, the base truncate, shortly auricled on the upper side; lower pinnae hardly shorter than the following; terminal pinna lobed at the base, serrate towards the apex. Lobes linear, rounded, toothed on the upper side. Texture chartaceous; 
surfaces naked; upper surface olive-green, lower paler; costae scaly beneath; veins pinnate, the higher forked or simple. Sori long, linear, reaching the margin; indusium thin, broad, entire.

New Guinea.

(13) D. pallidum, Moore; Athyrium pallidum, Milde, Copel., in Philipp. Journ., IIIC, 298.

(15) D. Dantamense, $\boldsymbol{B t}$.; Athyrium fraxinifolium, Milde, Copel., in Philipp. Journ., IIIC, 299, p. p.

Var. elternifoliuna: A form gathered by C. A. Backer has the pinnae much longer, $15-20 \mathrm{~cm}$. long.

(17) D. palauanense, Copel.; Athyrium palauanense, Copel., in Philipp. Journ., IIIC, 299; - var. apoense, Copel., in Leafl., III, 817.

Var. apoemse: Pinnae often stalked, serrulate, truncate at the base, sometimes pinnate; rachis proliferous.

(19) D. cultratum, Pr.; Athyrium cultratum, Milde, Copel., in Philipp. Journ,, III 298.

(20) D. crespato-serratum, Hoore; Athyrium crenato-serratum, Milde, Copel., in Philipp. Journ., IIIC, 298.

\section{(22) D. Lobbianum, Moore.}

A specimen from Java, occurring in the Buitenzorg Herbarium, is distinguished by the following characters. Stipes $40-60 \mathrm{~cm}$. or more long, sparingly scaly towards the base, the scales deciduous, linear-subulate, dark-brown, shortly toothed, the teeth horizontal, black-castaneous, simple or more commonly hamato-2-fid. Fronds to $50 \mathrm{~cm}$. or more long. Pinnae remote, the terminal one simple or pinnatifid, the higher the smallest, sessile, obliquely rotundate or rotundate-cuneate at the base, the lower short-stalked, gradually long-acuminate, with the upper base rounded or rotundate-cuneate, the lower base a little shorter, rotundate-cordate or truncate-cordate. Rachis and costae fibrilloso-tomentose above. Sori long, reaching nearly the midrib but not the margin, accompanied by a few scattered shorter ones. 
(23) D. japonicun, Bedd.; Athyrium japonicum, Copel., in Philipp. Journ., III , 290, p. p.

Stipe and rachis not rarely more or less copiously fibrillose; pinnae hairy, fibrillose or quite naked.

(25a) W. Willinusi, Copel.; Athyrium Williamsi, Copel., in Philipp. Journ., III, 297.

Also in Luzon.

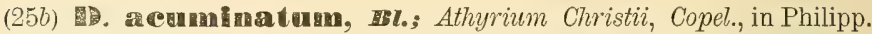
Journ., VIIC, 62.

(26) D. petiolare, $\mathrm{Pr}$.

Omit this, it being referred to D. silvaticum Sw.

(27a) D. Copel., in Philipp., Journ., IIC ${ }^{\mathrm{C}}$ 290, p. p.

(27b) Dodili, Copel; D. sorzogonense, Pr., p. p.; C. Chr., Ind. Fil., Suppl.; Athyrium sorsogonense, Copel., in Philipp. Journ., IIIO, 296, p. p.

Allied to D. sorzogonense $\mathrm{Pr}$. by intermediates.

(27c) See No. 23.

(27d) See No. 28a.

(27e) D. protensum, Ist., in Fed., Rep., XII, 169.

Stipes firm, grey-green, blackish towards the base, scaly, as are the rachis costae and costulae, the scales scattered, partly minute, stellate, black, partly longer, lanceolate, obtuse, whitish, black-ciliate. Fronds oblong-ovate, $\pm 25 \mathrm{~cm}$. Iong by $15 \mathrm{~cm}$. broad, shortly acuminate, 2 . pinnatifid. Pinnae \pm 10 on a side, ascending, subapproximate, subsessile, subfalcate, cut down nearly to the costa at the truncate or subcordate base, less deeply incised upward, toothed towards the shortly acuminate apex; largest pinnae $\pm 9 \mathrm{~cm}$. long by $2 \mathrm{~cm}$. broad; lowest pinnae somewhat shorter. Lobes oblong, the largest $\pm 12 \mathrm{~mm}$. long by $7 \mathrm{~mm}$. broad, denticulate towards the rounded apex, entire towards the base; 
lower pinnulae sometimes nearly free, contracted at the base, the lower posterior of the lowest pinnae often somewhat reduced. Texture herbaceous; upper surface olivaceous, naked, lower paler, minutely scaly; veins simple, sometimes forked. Sori long, often double; indusium narrow. New Guinea.

(28a) D. Petersenit, Christ.; Athyrium Petersenii, Copel., in Philipp. Journ., VIIIC, 141.

Hairs or scales of rachis and surfaces fibrilliform.

(29a) D. Sol'zogonens i", Pr.; Athyrium sorsogonense, Copel., in Philipp. Journ., IIIC, 296, p. p.; - var. poense, Copel., VII ${ }^{\mathrm{C}}, 61$; — var. mamberamense, v. A. v. R., in Bull. Btz., 1915, XX, 11.

Forma typica. - Br. India to Papua.

Forma angustior: Largest pinnae hardly $10 \mathrm{~cm}$. long and $1 \frac{3}{4} \mathrm{~cm}$. broad, deeply pinnatifid, the lobes crenate; lower pinnae somewhat reduced, deflexed, short-stalked. - Luzon (Ramos).

Var. poense: A large and lax form, with the pinnae remote, the lowest pinnae to $25 \mathrm{~cm}$. long, $2 \frac{1}{2}-31 / 2 \mathrm{~cm}$. broad, the rachis soon glabrescent. - Borneo.

War. Haandoramense: Higher pinnae adnate, coarsely serrate; central pinnae largest, obliquely truncate or subtruncate at the base, lobed; lower pinnae shorter, obliquely rounded or cuneate at the base, lobed to $1 / 2$-way down to the costa; lobes serrate or serrulate. New Guinea.

(29b) D. Inrachysoroides, Copel.s Athyrium brachysoroides, Copel., in Philipp. Journ., III', 296.

(31a) D. brachy podum, Copel.s Athyrium grammitoides, Mitde, Copel., in Philipp., Journ., IIIC, 290, p. p.

(31b) D. Bolsteri, Copel.; Athyrium Bolsteri, Copel., in Philipp. Journ., III, 296.

(31c) See No. 40.

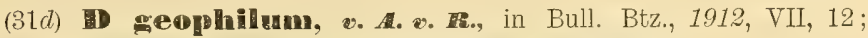
Athyrium geophilum, Copel., in Philipp. Journ., IIIC, 296.

Rhizome 1-2 mm. thick. Stipes 2-10 cm. long, dark-grey, slender, 
clothed towards the base with small, pale- or dirty-fuscous, scatterred, deciduous scales. Fronds 5-12 cm. or more long, $\pm 2-4 \mathrm{~cm}$. broad, 2-pinnate in the lower part. Pinnae $\pm 5-8$ or more on a side, stalked, the simple ones oblong, cuneate and more or less auricled at the base, obliquely toothed, the teeth often hooked; lower and central pinnae pinnate at the base. Pinnulae few, $1-2$ on a side, cuneate, provided with 1-4 teoth, the lowest acroscopical ones generally the largest. Texture herbaceous; surfaces naked; upper surface somewhat darker than the lower; rachis nearly naked or sparingly scaly; veins 1 to each tooth. Sori linear, 1-5 mm. long, simple or double.

Mindanao, Negros.

(34) D. bulbiferum, Brack.

Omit this, it being referred to D. silvaticum Sw.

(34a) D. matangense, c. chr., Ind. Fil., Suppl.; Athyrium carnosum, Copel., in Philipp. Journ., VII', 61.

Fronds $\pm 45 \mathrm{~cm}$. long and nearly $30 \mathrm{~cm}$. broad, pinnate, the rachis grooved, naked or soon glabrescent except in the groove. Pinnae \pm 10 on a side, horizontal, $\pm 3 \frac{1 / 2}{2} \mathrm{~cm}$. broad, subsessile or the higher adnate, falcate-acuminate, broadly cuneate at the base, the margin cut ${ }^{1 / 3}{ }_{\mathbf{3}}-\mathbf{1} / \mathbf{2}$. way down to the costa into rounded lobes $\pm 9 \mathrm{~mm}$. broad. Texture carnoso-subcoriaceous; surfaces naked; veins simple, \pm 9 on a side. Sori linear, to $10 \mathrm{~mm}$. long; indusium narrow, soon hidden under the sporangia.

Borneo.

(35a) 置, Whitforrdi, Copel.; Athyrium Whitfordi, Copel., in Philipp. Journ., ШIC, 296.

(35c) D. polyearpan, C. Chr., Ind. Fil., Suppl.; Athyrium polycarpum, Copel., in Philipp. Journ., VIIC, 61.

Stipes probably $\pm 60 \mathrm{~cm}$. long, provided with a few small, brown, ovate scales. Fronds $\pm 75 \mathrm{~cm}$. long, $45 \mathrm{~cm}$. broad, pinnate, bulbiferous below the pinnatifid apex, the rachis grooved, naked except in the groove, brown, sparingly sharply spinose towards the base. Pinnae stalked, subacuminate, obliquely truncate at the base, the lowest not reduced, \pm $25 \mathrm{~cm}$. long, and $4 \frac{1}{2} \mathrm{~cm}$. broad, subpinnate in the lower part; lobes \pm $2 \mathrm{~cm}$. long and $1 \mathrm{~cm}$. or more broad, rounded or truncate, obseurely, serrulate, 
the lower remote. Texture coriaceous; surfaces naked; upper surface provided with white marginal dots; veins \pm 11 on a side, simple or forked. Sori numerous, occupying all the veins; indusium linear, black.

Borneo.

(35dl) D. spinifenum, v. A. v. R.; D. muricatum, C. Chr., Ind Fil., Suppl.; Athyrium muricatum, Copel., in Philipp. Journ., VIIC, 61.

Stipes $\pm 30 \mathrm{~cm}$. long, spinose, clothed towards the base with lanceolate-ovate, incurved, dirty-brown scales. Fronds pinnate, pinnatifid towards the apex. Lower pinnae $20-25 \mathrm{~cm}$. long, $\pm 5 \mathrm{~cm}$. broad, stalked, acuminate, hardly pinnate at the base, pinnatifid towards the apex; higher pinnae sessile to adnate, lobed. Segments oblong, $\pm 1 \mathrm{~cm}$. broad, obtuse or subacute, often serrate towards the apex, the lowest reduced. Texture coriaceous; surfaces naked; veins \pm 12 on a side, forked. Sori short, subterminal on the veins; indusium black, soon evanishing.

Borneo.

(36a) D. Eyatheifolium, Pr.; Attyrium cyatheifolizm, Milde, Copel., in Philipp. Journ., III ${ }^{\mathrm{C}}$, 293, p. p.

Also in Borneo.

(36h) D. Iavadense, Copel.; Athyriun davaoense, Copiel., in Philipp. Journ., III ${ }^{\mathrm{C}}, 295$.

$\left(37 a^{*}\right)$ D. Hewittii, C. Chr., Ind. Fil., Suppl.; Athyrium Heroittii, Copel., in Phillpp. Journ., VIIC, 62.

Fronds $\pm 75 \mathrm{~cm}$. long and $30 \mathrm{~cm}$. or more broad, the rachis castaneous, grooved, naked except in the groove. Pinnae short-stalked, the higher pinnatifid, the lower pinnate, the lowest opposite, $\pm 23 \mathrm{~cm}$. long, $5 \mathrm{~cm}$. broad, acuminate. Pinnulae straight, horizontal, subsessile, truncate and often hastate at the base, $\pm 1 \mathrm{~cm}$. broad above the base, the higher entire, the lower cut $\pm 1 / 3$-way down to costa into lobes $\pm 2 \mathrm{~mm}$. broad. Texture papyraceous; surfaces naked; veins forked, oblique. Sori linear, 2-4 mm. long; indusium bright-green.

Borneo.

(37b) D. dolichosorium, Copel.; Athyrium dolichosorum, Copel., in Philipp. Journ., IIIC, 294, p. p. 
A plant received from Luzon, which may be a form of this species, has the pinnulae eut to ${ }_{3}^{2}$-way down to the costa, with the lobes varying from rounded to subacute, and the lowest posterior lobe often abbreviated.

Throughout the Phitippines.

$\left(37 b^{*}\right)$ D. sarawakenge, c. Chr., Ind. Fil., Suppl.; Athyrium sarawakense, Copel., in Philipp. Journ., VIIC, 62.

Stipes sparingly spinulose, naked. Fronds probably $\pm 75 \mathrm{~cm}$. long, $\pm 45 \mathrm{~cm}$. broad, the rachis bright-castaneous, grooved, naked except in the groove and axils. Pinnae short-stalked, $\pm 25 \mathrm{~cm}$. long, caudate and sharply serrate at the apex, pinnate in the lower part. Pinnulae few, sessile, to $5 \mathrm{~cm}$. long, $1 \mathrm{~cm}$. broad, acute, serrate, truncate and subhastate at the base. Texture subcoriaceous; surfaces naked; veins forked, oblique. Sori linear, close to the central ribs; indusium bright-brown.

Borneo.

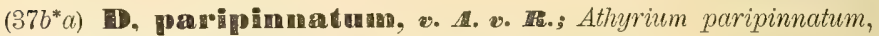
Copel., in Philipp. Journ., X', 147.

Stipes about $45 \mathrm{~cm}$. long, muricate. Fronds $1 \mathrm{~m}$. more or less long, pinnate below the short, pinnatifid apex. Pinnae opposite; lowest pinnae stalked, $25 \mathrm{~cm}$. long, broadest at the middle, pinnate, with the pinnulae subsessile, to $6 \mathrm{~cm}$. long, acuminate, inciso-serrate, $15 \mathrm{~mm}$. broad at the subhastate base; central pinnae larger; following pinnae with the pinnulae adnate or confluent, elliptical, $2-3 \mathrm{~cm}$. long, rounded at the apex, serrulate; higher pinnae deeply pinnatifid; highest pinnae $15 \mathrm{~mm}$. long by $4 \mathrm{~mm}$. broad, hardly serrulate. Texture subcoriaceous; surfaces naked; under surface pale; rachises castaneous, naked. Sori narrow, simple, whether or not reaching the margin.

Borneo.

(38a) D. melanolepis, v. *. R., in Bull. Btz., 1913, XI, 8.

Stipes $\pm 50-60 \mathrm{~cm}$. long, greyish or dirty-brown, bisulcate above, scaly like the rachises and deciduously subfurfuraceo-tomentose; scales subulate, spreading, crisped, deciduously ciliolate-denticulate, black or black-brown, partly deciduous partly persistent, the lower the largest and more crowded. Fronds probably large and triangular-lanceolate, acuminate. Pinnae ascending or spreading; higher pinnae sessile or sulssessile, subulatelanceolate, to $\pm .4 \mathrm{~cm}$. broad, acuminate, truncate at the base, deeply 
pinnatifid into spreading, linear-oblong, blunt, entire or crenated lobes; lower pinnae probably largest, petiolulate, lanceolate, $\pm 35 \mathrm{~cm}$. long by $8 \mathrm{~cm}$. broad, acuminate, pinnate, deeply pinnatifid towards the apex. Pinnulae spreading or horizontal, remote, adnate, the central linear, $\pm 4-4 \frac{1}{2} \mathrm{~cm}$. long and $7 \frac{1}{2} \mathrm{~mm}$. broad, acuminate, toothed or deeply lobed, the lower abbreviated, blunt; ultimate lobes or teeth oblique, to $4 \mathrm{~mm}$. long and $2 \mathrm{~mm}$. broad, acute or blunt, entire or serrulate. Texture coriaceous; surfaces naked; secondary rachises narrowly margined; veins forked to sparingly pinnate in the lobes or teeth; veinlets at best 3 on a side. Sori numerous, mostly in 2 rows on each side of the costa, the inner the longest, linear-oblong, often double, to $2 \mathrm{~mm}$. long, the outer the shorter, often simple; indusium pale-brown, thin, persistent.

Sumatra.

D. vestitum, Pr.; Athyrium vestitum, Milde, Copel., in Philipp. Journ., $\amalg^{\mathrm{C}}, 295$.

(39a) 面. Vanvuureni, v. A. v. Te, in Bull. Btz., 1914, XVI, 7.

Stipes sparingly, decidvously scaly. Fronds lanceolate, $\pm 65 \mathrm{~cm}$. long, pinnate, the apex pinnatifid, caudate-acuminate, the acumen partly lobed and serrate, partly twice serrate partly repand; main rachis flexuose, more or less chaffy beneath, as are the costae and costulae. Pinnae petiolate, \pm 10 on a side; lower pinnae rather deflexed, at best pinnate at the base; central pinnae largest, more or less falcate, to $20 \mathrm{~cm}$. long and $9 \mathrm{~cm}$. broad at the base, acuminate, pinnate in the lower half, pinnatifid in the upper half. Tertiary segments varying from adnate to shortly petiolulate, horizontal or spreading, lanceolate-oblong from a broad base, the lowest the largest, $\pm 4-4^{1 / 2} \mathrm{~cm}$. long, $\pm 1 \mathrm{~cm}$. broad, acute, serrate towards the apex, serrate-lobate in the lower part, the base subtruncate, often 1-2-auriculate. Texture subcoriaceous; surfaces naked or the under surface sparingly, minutely, deciduously fibillose on the veins; veins of the larger segments pinnate, of the smaller forked. Sori copious, often double, occupying the lower half of the veins.

Celebes.

(396) D. mìcrophyllum, Desv., Prod., 281, tab. VII, fig. 1.

Whole plant up to $\pm 90 \mathrm{~cm}$. high. Pinnae lanceolate, 10-12 cm. long, pinnate. Pinnulae linear-lanceolate, $1 \frac{1}{4}-1 \frac{1}{2} \mathrm{~cm}$. long, $\pm 71 / 2 \mathrm{~mm}$. 
broad, the apex acute, the base cuneate, slightly rounded, subauriculate on both sides, the erge inciso-crenate; laciniae short, acute, incurved. Rachis hairy. Sori subconfluent, 2-fid; indusium thin.

Malaya; Br. India.

(39c) D. atropurpanceunt, Fest., in Fed., Rep., XII, 528.

Bhizome short-creeping, the scales ochraceous, lanceolate, short-acuminate, black-ciliate. Stipes approximate, $\pm 25 \mathrm{~cm}$. long, densely tomentose with black-purple, fascicled, short setae, as are the rachises, the tomentum, intermixed with a few scattered, deciduous scales. Fronds ovate or oblong, to $\pm 30 \mathrm{~cm}$. long, $25 \mathrm{~cm}$. broad below the middle, 2-pinnate. Pinnae to \pm 10 on a side, ascending, subcontiguous, short-stalked, slightly upcurved, the largest to $15 \mathrm{~cm}$. or more long by $3 \mathrm{~cm}$. broad, acuminate, pinnae pinnatifid below the serrate or subentire apex, pinnate in the lower part; lowest pinnae with the lower pinnulae short-stalked, linear, $\pm 17 \mathrm{~mm}$. long by $9 \mathrm{~mm}$. broad, obtuse, crenate-serrate, truncate and sub-2-auriculate at the base, following to $2 \% \mathrm{~cm}$. long, sessile with a contracted base, higher adnate, free or connected. Texture papyraceous; surfaces naked; costae setuloso-tomentose beneath; veins 8-9 on a side, simple or forked, ascending. Sori long, reaching nearly the costa and margin, the lower often double; indusium ciliate, fasciculate-setulose.

New Guinea.

(40) D. deltoideum, Pr.; Christ, in Philipp..Journ., IIIC, 273; Athyrium deltoideum, Milde, Copel., in Philipp. Journ., III , 296.

Specimens of this species found in Luzon (by Ramos) and Mindoro (by Warburg) have the rhizome oblique, short-creeping, the stipes longer, to $40 \mathrm{~cm}$. long, solitary or subfasciculate, the fronds smaller, with the upper part suddenly narrowed and pinnatifid, the lowest pinnae shortstalked, $\pm 4 \mathrm{~cm}$. broad, deeply pinnatifid, narrowed and cut down to the costa at the base, the secondary segments lanceolate-ligulate, $1-2 \mathrm{~cm}$. long, obtuse, subentire or crenate, with $7-8$ forked veins on each side of the costula, the sori often double, occupying the anterior veinlets (fork branches), reaching from the costula to the margin, $2-3 \mathrm{~mm}$. long.

(40a) See No. 45a. 
(40b) D. scotinuan, Rst., in Fed., Rep., XII, 169; -. var. platy. lobum \& microlobum, Rst., 1. c., 170.

Stipes firm, $20 \mathrm{~cm}$. or more long, like the rachises and costae blackbrown and naked. Fronds ovate or deltoid-lanceolate, sub-3-pinnate, \pm $36 \mathrm{~cm}$. long by $26 \mathrm{~cm}$. broad, acuminate. Pinnae \pm 12 on a side below the pinnatifid apex, horizontal on the lower deflexed, petiolate, lanceolateoblong, the central the largest, $\pm 16 \mathrm{~cm}$. long by $6 \mathrm{~cm}$. broad, acuminate. Pinnulae \pm 12 on a side below the serrate-dentate apex, ascending, petiolate, lanceolate-oblong; the lowest the largest, $\pm 3 \frac{1}{2} \mathrm{~cm}$. long by 1 $\mathrm{cm}$. broad, bluntish, very deeply pinnatifid. Lobes \pm 8 on a side below the serrate apex, upeurved at the apex, recurved and serrate or dentate at the edge, the higher and medial decurrent, the lower connected by a very narrow wing, contracted at the base, often free, adnate. Texture subcoriaceous; surfaces naked; colour blackish when dry; veins 3-4 on a side, simple. Sori linear, occupying the 1-2 lower veins, rarely double; indusium firm.

Var. platylobume: Fronds much narrower at the base; pinnulae shorter, obtuse; lobes less numerous, broader; texture herbaceous.

Var. micrololouma: Lobes smaller, more oblique, often not contracted at the base, entire or crenulate.

New Guinea.

(41a) D. Meyenianum, Pr.; Athyrium Meyenianum, Milde, Copel., in Philipp. Journ., IIIC, 295.

Forms recently gathered by different collectors have the pinnulae cut down nearly to the costa, the texture very thin, the sori sparse, the veins pinnate in the lobes, the lowest veinlets simple or forked, sterile, or occasionally fertile and the lowest sori then usually double, the under surface often minutely scaly on the costae.

(416) D. atratum, Christ.; Athyrium atratum, Copel., in Philipp. Journ., III', 293.

A plant gathered by Ramos is reddish in cast, and further lightened in colour by the copious more or less confluent sori.

(41c) D. nitens, Rist., in Fed., Rep., V, 373.

Fronds elongate-lanceolate in outline, 3-pinnatifid. Terminal pinna lobed, pinnatifid at the broad base, the apex shortly acuminate, serrate; 
lateral pinnae alternate, short-stalked, erecto-patent, lanceolate, acuminate, whether or not slightly dilated at the base, the central ones the largest, $\pm 25 \mathrm{~cm}$. or more long, pinnate, the higher ones pinnatifid with broadly linear lobes which are blunt at the acutely serrate and obliquely apiculate apex, the highest ones the smallest, sessile, simple, acutely crenato-serrate, passing gradually into the lowest lobes of the terminal pinna. Pinnulae short-stalked, subcontiguous or somewhat remote, the lowest ones subopposite, the others alternate, lanceolate, acuminate to $4 \frac{1}{2} \mathrm{~cm}$. long or the lowest anterior ones somewhat larger, $\pm 1 \frac{1}{2} \mathrm{~cm}$. broad at the slightly dilated base, with the upper base parallel to the rachis and the lower nearly rounded, the lower part cut more than $1 / 2$-way down to the costa, the apex often subfalcate, acutely serrate; lower and central lobes linear, subcontiguous, horizontally truncate at the apex which is provided with a few acute teeth, the edges entire or slightly repand. Texture rigidly chartaceous; both surfaces naked, glossy; upper surface olive-green, lower paler; rachises stramineous or yellowish, sulcate above, subterete beneath, provided with a few scattered, hair-like scales; costulae pinnate in the lobes with 4-5 simple veins on each side. Sori elongate, parallel, the lowest anterior ones double; indusium membranaceous, entire.

Nero Guinea.

(42b) D. stomanense, *. *. Re., in Bull. Btz., 1913, XI, 9; Athyrium sibuyanense, Copel., in Leafl., IV, 1152; C. Chr., Ind. Fil., Suppl.

Stipes $50-100 \mathrm{~cm}$. long, the base black and prickly and clothed with caduous, brown scales, the upper part stramineous-green, smooth, naked, as is the rachis. Fronds deltoid, $\pm 1 \mathrm{~m}$. long, 2-3-pinnate. Lower pinnae opposite, horizontal, stalked, to $40 \mathrm{~cm}$. long and $15 \mathrm{~cm}$. broad. Pinnulae petiolulate, $3-4 \mathrm{~cm}$ : broad, acuminate, pinnatifid, or pinnate in the lower part; segments linear-oblong, the lower when free adnate or sessile and slightly auricled, rounded, bluntish or mucronulate at the apex, slightly serrate. Texture coriaceous; surfaces naked; veins $7-9$ on a side. Sori occupying the lower half of the veins; indusium narrow, brown.

Sibuyan Island.

(42c) D. amplifrons, v. v. R., in Bull. Btz., 1913, XI, 8.

Near D. sibuyanense $v$. A. $v$. $R$. but the pinnae larger, to $60 \mathrm{~cm}$. or more long and $25 \mathrm{~cm}$. or more broad, the pinnulae with the lower 
segments adnate or free but not auricled, serrate, acutely falcate-lobato, the lobes to $\pm 2 \mathrm{~mm}$. deep and broad, entire or crenulate to serrulate; veins of the higher segments mostly forked, of the lower segments pinnate in the ultimate lobes; veinlets generally 2-jugate, simple or sometimes forked; rachises, costae, veins beneath deciduously (not densely) fibrillose. Tertiary segments remote, connected by a very narrow costal wing, the interstices to as broad as the segments themselves; sori occupying the lower half of the lowest anterior veinlets, often double.

Java.

(42d) D. chrysocarpum, *. A. v. H., in Bull. Btz., 1914, XVI, 8.

Stipes $\pm 65 \mathrm{~cm}$. long, stramineous, naked, moderately glossy, as are the rachises. Fronds of fully developed plants at least $65 \mathrm{~cm}$. long. Pinnae erecto-patent, the lowest $\pm 45 \mathrm{~cm}$. long. Pinnulae numerous, short-stalked; triangular-lanceolate, the largest $\pm 7 \frac{1}{2} \mathrm{~cm}$. long, $\pm 3 \mathrm{~cm}$. broad at the base, acuminate, deeply pinnatifid in the upper part, subpinnate at the base, the acumen serrate, the stalk narrowly winged. Segments rather close, the higher oblong, blunt, serrate, broad and subdecurrent at the base, the lower rhomboidal-oblong, nearly free, $\pm 1-2$ $\mathrm{cm}$. long and half as broad, serrate at the rounded apex, more or less deeply lobed towards the broadly and obliquely cuneate-truncate, decurrent, narrowly adnate base; ultimate lobes serrate-dentate. Texture thin; colour dark when dry; surfaces naked; veins blackish, forked, or the lower pinnate. Sori linear-oblong, slightly recurved, nearly golden-yellow, nearly costal or costular, occupying the lower half of the anterior veinlets; indusium persistent.

\section{Sumatra.}

(43a) D. olligosorum, Copel.; Athyrim aligosonum, Copel., in Philipp. Journ., IIIC, 293 :

Also in Negros.

(43b) D. polypodi̊oides, Hi.; D. asperum, Bl., var.polypodioides, Ridl., in Journ., Str. Br. R. A., 1908, so, 31; Athyrium Blumei, Copel., in Philipp., Journ., IIIO, 294.

(43c) 耳. Iatifrons, v. A. v. IR.; Athyrium platyphyllum, Copel., in Philipp. Journ., IIIC, 292. 
Rhizome $1 \mathrm{~cm}$. thick, the apex clothed like the black base of the stipes with narrow, black-brown scales $\pm 6 \mathrm{~mm}$. long. Stipes 25-50 cm. long, nearly naked, stramineous, as is the rachis. Fronds subdeltoid, nearly $60 \mathrm{~cm}$. long, 士 $40 \mathrm{~cm}$. broad, acuminate, 3-pinnatifid. Pinnae oblique, distant, acuminate, the lowest petiolate, the petioles $\pm 4 \mathrm{~cm}$. long. Pinnulae often spreading at a right angle, distant, stalked, the higher ones adnate, the highest connected, the largest $\pm 7 \mathrm{~cm}$. long; more than $2 \mathrm{~cm}$. broad, cut down in the lower part nearly to the costa; segments up to $5 \mathrm{~mm}$. broad, subfalcate, separated by open sinuses, the margin entire or provided with a few teeth at the apex. Texture coriaceous; surfaces naked. Sori rather linear, slightly recurved, distant from the margin, partly double partly simple; indusium persistent.

Luzon, Mindanao.

(43d?) D. Cumbristegium, v. A. v. T.; Athyrium fimbristegium, Copel., in Philipp. Journ., IXC, 5.

Stipes long, black-purple-brown, glabrescent, smooth. Fronds \pm 80 $\mathrm{cm}$. long by $50 \mathrm{~cm}$. broad, 3-pinnatifid, the rachis furfuraceous, glabrescent. Pinnae short-stalked, the lower $25-30 \mathrm{~cm}$. long, to $12 \mathrm{~cm}$ broad, acmuminate, the rachis often minutely furfuraceous in the groove. Pinnulae horizontal, very short-stalked, much abbreviated, to $13 \mathrm{~mm}$. broad, deeply pinnatifid. Segments subfalcate, to $\pm 2 \mathrm{~mm}$. broad, entire or obscurely crenulate, obtuse or subacute. Texture herbaceous; surfaces naked; veins simple, \pm 8 on a side. Sori occupying the lower half of the veins, the lowest double; indusium thin, bright-brown, lacerate-lobate.

Nero Guinea.

(44) D. ebenenun, I. Sm.; Athyrinm cyatheifolium, Milde, Copel., in Philipp. Journ., IIC, 293, p. p.

\section{(45a) D. asperimm, $\boldsymbol{R}$.}

Stipe and rachis muricate with short-conical warts; ultimate segments (lobes) not rarely obliquely acute. - Athyrium subscabrum Copel. (Philipp. Journ., VIII , 141, tab. IV) from Java, which is probably a young or reduced form of this, has the fronds smaller, $\pm 50 \mathrm{~cm}$. long, the stipe and rachis less prickly, rather roughish, the lobes subentire, obiquely acute, the sori $\pm 3 \mathrm{~mm}$. long, occupying the lowest veins only. 
(45a*) 沗. subpolypodioides, v. A. v. R., in Bull. Btz., 1915, XX, 11; D. asperum, Bl., var. subpolypodioides, v. A. v. R., 1914, XVI, 8.

Rachises sparingly asperulous by the hardly elevated persistent bases of scattered, weak and fragile, curved or subflexuose, subsetiform (hardly spiniform) fibrils; pinnulae of lower pinnae to $\pm 3 \frac{1}{2} \mathrm{~cm}$. broad, deeply pinnatifid; lobes to $\pm 7 \mathrm{~mm}$. broad at the base and the broadly rounded or obliquely truncate-rotundate apex, somewhat retuse near the base; edges subentire in the smaller lobes, crenate in the larger ones; veins $\pm 5-7$ on a side, simple in the smaller lobes, once to twice forked in the larger ones.

Sumatra.

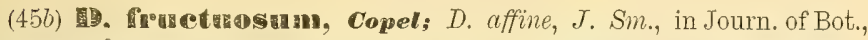
III, 407; Athyriom fructuosum, Copel., in Philipp. Journ., IIIC, 294; Leafl., II, 401.

Caudex up to $45 \mathrm{~cm}$. high, to $15 \mathrm{~cm}$. thick. Stipes to $2 \mathrm{~m}$. long, 3-4 cm. thick at the base and densely covered with soft, dull-brown trichomes above, green and smooth on the upper side, covered beneath with yellowish-brown, powdery scales which are easily rubbed off, and provided with blunt, rigid spines.

(48a) F. Essimille, Bedd., Ferns Br. I., II, tab. CCXCIV; D. umbrosum, Bedd., var. assimile, Bedd., Handb. Ind. Ferns, 190; Athyrium assimite, Pr., Tent. Pterid., 98; C. Chr., Ind. Fil.; Asplenium umbrosum, J. Sm., var. assimile, Hk. Bk., Syn. Fil., 489; Aspl. assimile, Endl. (oldest name).

Stipes 45-60 cm. long. Fronds deltoid, 3-pinnate, Pinnae alternate, lower nearly opposite, up to $30-35 \mathrm{~cm}$. long by $\pm 15 \mathrm{~cm}$. broad. Pinnulae 5-9 cm. long by $1 \frac{1 / 4}{4}-3 \frac{3}{4} \mathrm{~cm}$. broad, gradually acuminated. Tertiary segments a little more than $1 \frac{1}{4} \mathrm{~cm}$. long by $6 \mathrm{~mm}$. broad, lower subsessile, upper decurrent, almost a parallelogram in shape with a broad rounded apex, divided $1 / 2$ or $2 / 3$ of the way to the costa into \pm 5 lobes on each side. Lobes slightly falcate, entire or generally with 1 toothlet on the upper margin and rarely on the lower. Texture membranaceous, flaccid; surfaces naked; veins forked or pinnate. Sori elongated, often double.

Polynesia to New Guinea, Ceylon.

Ferns and Fern Allites. 


\section{§ 2. ANISOGONIUM.}

(49) D. Condlifolium, Bמ.; Athyrium cortifolium, Copel., in Philipp. Journ., $\mathrm{II}^{\mathrm{C}}$, 300.

Simple fronds always cordate at the base, pinnae of pinnate fronds not invariably so.

Forma minor: Simple fronds and pinnae of pinnate fronds much smaller. - Var. angustior, Rst. (in Nov. Guin, VIII, Bot., 722) is a form intermediate between this and the type.

(50) D. Forbesii, C. Chr.; Athyrium Forbesii, Copel., in Philipp. Journ., VIIC, 142.

Forma typica. - Also in Sumatra.

Forma angustissima (v. A. v. R., in Bull. Btz., 1913, XI, 9): Pinnae narrower, gradually long-acuminate. - Java, Malacca.

(51) D. alismifolium, v. A. v. R.; Athyrium Cumingii, Copel., in Philipp. Journ., IIIC, 299.

(52) D. fraxinifolium. Pr.; Athyrium fraxinifolium, Milde, Copel., in Philipp. Journ, IIIC, 299, p.p.

(52a) D. asperulam, v. A. v. R., in Bull. Bț., 1914, XVI, 8.

Stipes $\pm 20-25 \mathrm{~cm}$. long or longer, sparingly scaly in the lower part, the scales caducous. Fronds (of fully developed plants?) pinnate, $\pm 22 \frac{1}{2}-27^{1 / 2} \mathrm{~cm}$ long, $\pm 15 \mathrm{~cm}$. broad. Pinnae \pm 6 on each side below the terminal one; terminal pinna ovate-acuminate, $\pm 10 \mathrm{~cm}$. long and half as broad, the edge rather entire, recurved when dry; lateral pinnae smaller, horizontal, remote, the central ones the largest, lanceolate, $\pm 7 \% / 2 \mathrm{~cm}$. long by $2 \frac{1}{2} \mathrm{~cm}$. broad, acuminate, rotundate-cuneate at the base; lowest pinnae petiolulate, following narrowly adnate, higher more broadly so, highest smallest, often connected with the terminal one. Texture coriaceous; surfaces naked; rachis roughish with crowded, deciduous, horizontal, shortly hair- or gland-like elevations (not positively pubescent or glandular), sometimes provided with axillary buds; veins anastomosing more or less copiously. Sori numerous, long, mostly double.

Celebes. 
(54) D. pariens, C. Chr.; Athyrium pariens, Copel., in Philipp. Journ., IIIC 299.

Copeland thinks this to be probably indentical with D. Forbesii C. $C h r$.

Also in Java.

(55) D. proliferum, Thouars; Anisogonium decussatum, Pr, Tent. Pterid., tab. IV, fig. 13; - var. accedens; Athyrium accedens, Milde, Copel., in Philipp. Journ., IIIC, 298.

Veins anastomosing regularly or with additional areolae between the regular rows.

(55a) D. Swantziii, Bu., Enum., 191; D. protiferum, Thouars, var., C. Chr., Ind. Fil.; Athyrium Swartaii, Copel., in Philipp. Journ. IX , 229.

Differs from D, proliferum Thouars in having the stipes entirely smooth, the pinnae irregularly serrate, truncate-auriculate-subcordate at the base.

Java.

(55b) D. Tidleyi, v. A. v. R.; Athyrium Ridleyi, Copel., in Philipp. Journ., XIC, 39 .

Fronds large, the rachis smooth, grooved, minutely pilose in the groove. Pinnae stalked, shortly falcate, acuminate, nearly $40 \mathrm{~cm}$. long, more than $10 \mathrm{~cm}$. broad, coarsely serrate-crenate in the lower part with the teeth obtuse or rounded. Veins to $10-12$ on a side, anastomosing irregularly, i. e. with additional areolae between the regular rows. Indusium very narrow. - Near D. Swartzii $B l$.

Malacca.

(55̌c) D. Brooksii, v. A. v. R.; Athyrium Brooksii, Copel., in Philipp. Journ., IX ${ }^{\mathrm{C}}, 229$.

Rhizome erect. Stipes smooth, $\pm 20-35 \mathrm{~cm}$. long. Fronds ovate, $\pm 30 \mathrm{~cm}$. long, pinnate. Pinnae \pm 5 on a side below the terminal one; terminal pinna inciso-serrate; lateral pinnae stalked, the barren ones $\pm 15 \mathrm{~cm}$. long, $\pm 3^{\mathbf{1}} / \mathbf{2} \mathrm{cm}$. broad, acuminate, acutely coarsely serrate. Texture coriaceous; surfaces naked; veins anastomosing towards the margin. Sori copious.

Sumatra. 
(56) D. Smaithionnunn, Diels.; Athyrium dolichosorum, Copel., in Philipp. Journ., IIIC, 294, p. p.

(57) D. Spinulosum, Bt.; - var. novoguineensis, Rst., in Hedwi., LVI, 351.

Var. novoguineensis: Fronds larger, to $3 \mathrm{~m}$. long; pinnae to $50 \mathrm{~cm}$. long by about $22 \mathrm{~cm}$. broad; pinnulae stalked, acuminate, less deeply crenate; subentire in the upper part; sori more numerous, to 5 on a side. - New Guinea.

(58) D. esculentum, Sw.; Athyrizm, escutentum, Copel., in Philipp. Journ., IIIC, 295.

A form gathered in New Guinea has the fronds smaller, and the veins less copiously anastomosing.

\section{A'THYIRIUM, Roth.}

(1a) Danum, Christ; A. grammitoides, Milde, Copel, in Philipp. Journ., IIIC, 290, p. p.; Diplazium grammitoides, Pr., C. Chr., Ind. Fil., Suppl., p. p.

(1c) A. Toppinginnam, Copel.; A. grammitoides, Milde, Copel., in Philipp. Journ., IIIC, 290, p. p.; Diplazium grammitioides, Pr., C. Chr., Ind. Fil., Suppl., p. p.

Differs from Diplazium grammitoides $\operatorname{Pr}$. by the shape of the indusium only.

Also in Java.

(2) A. gedleanum, Christ.

Lower pinnae not rarely subequilateral and truncate-subcordate at the base; sori sometimes more elongated.

Also in Sumatra.

(3b) A. benguetense, Christ.

Omit this species, it being identical with Dryopteris gracilescens O. Ktze (Copel., in Philipp. Journ., IIIC, 300 ).

( $\left.3 b^{*}\right)$ A. hallconense, Christ, in Philipp. Journ., IIIC, 273; A. macrocarpum, Bedd., p. p., C. Chr., Ind. Fil., Suppl.

Rhizome thick, suberect. Stipes tufted, 6--9 cm. long, green or 
brown, rigid, clothed with subulate-lanceolate, brown, pellucid scales. Fronds oblong, $20 \mathrm{~cm}$. long by $4^{1 / 2} \mathrm{~cm}$. broad, acuminate, pinnate, hardly narrowed at the base. Pinnae spreading, close, short-stalked, \pm 30 on each side, oblong-rhomboidal, up to $2 \frac{1}{2} \mathrm{~cm}$. long, $1 / 2 \mathrm{~cm}$. broad, obtuse, unequal-sided at the base, conspicuously auricled at the upper base, cuneate at the lower base, inciso-lobate but more conspicuously on the anterior side. Lobes $7-8$ on each side, $\pm 2 \mathrm{~mm}$. broad, ovate, subacute. Texture herbaceous; surfaces smooth; colour bright-green; veins very oblique, black, forked. Sori 1 to each lobe, on the anterior veinlet, rather large; indusium distinct, thin, persistent, grey-brown, roundish-reniform, entire. - See Copeland's information in Philipp. Journ., IVC, 112.

Mindoro.

(3c) A. Copelandi, Christ.; A. japonicum, Copel., in Philipp. Journ., III , 290, p. p.; Diplazium japonicum, Bedd., p. p., C. Chr., Ind. Fil., Suppl.

(3d) See No. 4.

(3e) See No. 6.

(3f) A. Hochreutineri, Christ, in Ann. Cons. Gen., XVXVI, 197.

Rhizome thick, suberect. Stipes few, angular, about $12 \mathrm{~cm}$. long, rufo-stramineous, scaly, the lower scales ovate, acute, reddish-brown, the others subulate, somewhat crisped, brown. Fronds caudate-elongate from a subdeltoid base, about $28 \mathrm{~cm}$. long by $9 \mathrm{~cm}$. broad, not or hardly narrowed at the base, the rachis reddish-brown, furfuraceous. Pinnae about 25 on a side, horizontal, falcate, the largest petiolate, about $5 \mathrm{~cm}$. long by $1 \frac{1}{2} \mathrm{~cm}$. broad, blunt or subacute, the upper part cut about $1 / 3^{-}$ way down to the costa, the lower part deeply incised, the upper base auriculate, the lower cuneate; lower pinnae reflexed. Segments to 5 $\mathrm{mm}$. long and $3 \mathrm{~mm}$. broad, obtuse, obtusely crenate, the lowest anterior segments acute, resupinate towards the rachis. Texture herbaceous; upper surface dark-green, lower paler; costae and veins black; veins 3-4 on a side. Sori solitary on the higher segments more numerous on the lower; indusium roundish-reniform, grey, persistent,

Java. 
(4) A. macrocarpum, Bedd.

Fronds not rarely under $10 \mathrm{~cm}$. broad with less incised pinnae, and the sori in a single row on each side of the costae, partly subreniform, partly hamate, partly straight.

(5) A. acrostichoilles, Diels; Asplenium thelypteroides, Mchx, Schk., Krypt. Gew., I, tab. $76 b$.

\section{(6) A. Iyalostegium, Copel.}

A duplicate of Merrill's No 5186 occurring in the Buitenzorg Herbarium has the lower pinnae deeply pinnatifid, with a single small, oblong, free pinnula on the upper side at the base, $\pm 3-4 \mathrm{~mm}$. long, $1 \frac{1}{2}-2 \mathrm{~mm}$. broad, parallel to the main rachis, blunt at the apex, obliquely cuneate at the base, and with the indusia mostly asplenioid.

\section{(7) A. Iotheri, Christ.}

Also in Mindoro.

(14a) A. Jrovipinnulum, Copel., in Philipp. Journ., IIC, 291. Rhizome ascending, clothed with narrow, crinite, brown scales. Stipes 15-25 cm. long, stramineous like the rachis, scaly at the base. Fronds 25-30 cm. long, $\pm 15 \mathrm{~cm}$. broad, hardly broadest at the base; main rachis narrowly winged towards the apex only. Pinnae sessile, spreading, \pm 12 on each side. Pinnulae to \pm 13 on each side, trapezoidal, cuneateauriculate, $\pm 11 \mathrm{~mm}$. long, $\pm 7 \mathrm{~mm}$. broad, shortly inciso-crenate, obtuse or subacute. Texture herbaceous; surfaces naked. Sori costal, often asplenioid. - Near A. nigripes Moore but with crinite rhizome scales, sessile spreading pinnae, and short, broad, non-decurrent pinnulae.

Luzon.

(14b) A. Iriangulare, v. A. v. R., in Bull. Btz., 1915, XX, 8.

Rhizome short, the scales subulate-lanceolate, dark-fuscous, entire. Stipes aggregate, $\pm 10-25 \mathrm{~cm}$. long, stramineous, sparingly scaly at the base. Fronds deltoid, $\pm 10-18 \mathrm{~cm}$. each way, 2-pinnate. Pinnae \pm 7-10 on each side below the acuminate apex; higher pinnae ascending, simple, oblong, the apex rounded, serrate, the sides serrate-crenate, the base decurrent or obliquely truncate-cuneate, more or less auricled on the upper side, the auricle serrate; central and lower pinnae pinnatifid 
towards the acuminate apex, otherwise pinnate; central pinnae triangularlanceolate, $1^{3 / 4}-21 / 2 \mathrm{~cm}$. broad at the subtruncate base; lowest pinnae largest, horizontal or deflexed, ovate-lanceolate, $\pm 5-9 \mathrm{~cm}$. long, $2-3 \%$ $\mathrm{cm}$. broad between the midale and the base. Pinnulae to 10 on a side, similar to the simple higher pinnae, the largest to $\pm 2 \mathrm{~cm}$. long by $71 / 2$ $\mathrm{mm}$. broad. Texture coriaceous; surfaces naked; rachis deciduously ferrugineo-puberulous; secondary rachises and upper part of the main rachis provided with remote, spine-like appendages on the upper side; veins simple or forked, oblique. Sori short, oblique, subcostal.

Java.

(14c) A. appendiculiferum, v. A. v. R., in Bull. Btz., 1914, XVI, 3.

Rhizome short-ascending, sparingly scaly; scales lanceolate-subulate, pale-brown, entire. Stipes $\pm 30 \mathrm{~cm}$. iong, pale-brown, scaly, the lower scales rather approximate, similar to those of the rhizome, the higher scattered, smaller, becoming similar to those of the rachises. Fronds ovate, \pm 30 $\mathrm{cm}$. long and half as broad, acuminate, 3-pinnate in the lower part, the rachises above sparingly velutinous, glabrescent, provided with a few deciduous, scattered, subfiliform, pale-brown scales. Pinnae spreading, subhorizontal, close, stalked, acuminate, obliquely truncate at the base, often slightly upcurved, the largest $\pm 171 / 2 \mathrm{~cm}$. long, $3 \mathrm{~cm}$. broad at the base. Pinnulae approximate, short-stalked, blunt, mostly pinnate in the lower part and pinnatifid towards the apex, of the lowest pinnae the central posterior the largest, to $2 \mathrm{~cm}$. long, of the following pinnae the lowest anterior the largest, to $1^{3 / 4} \mathrm{~cm}$. long. Segments oblique, oblong, sharply toothed, the lower free, the lowest anterior often more spreading, short-stalked, oblong, to $5 \mathrm{~mm}$. Iong, blunt, deeply lobed, cuneate at the base, the lobules acute or acutely 2-3-dentate at the apex. Texture firm-herbaceous; surfaces naked; rachises provided above with erectadpressed, spine-like appendages at the base of the petioluli; costae spinulose above; veins beneath naked or sparingly and minutely fibrillose. Sori costal, short, broad; indusium entire or erose.

Sumatra.

(17) A. Mearnsianum, v.A. *. R.; A. nigripes, Moore, var. Mearnsianum, Copel., in Philipp. Journ., IIIC, 291.

Rhizome and base of stipe clothed with dark-brown or nearly black 
scales; pinnulae acutely dentate-serrate, with the midribs not spinulose above, - Otherwise like A. nigripes Moore but shorter.

(18) A. stramineam, Copel, in Philipp. Journ. III ${ }^{\circ}, 292$.

Stipes $\pm 30 \mathrm{~cm}$. long, naked except at the base which in provided with a few brown scales, very succulent, green, as is the rachis. Fronds $\pm 50 \mathrm{~cm}$. long, $\pm 20 \mathrm{~cm}$. broad. Pinnae \pm 8 on each side, petiolate, pinnate, the largest $\pm 15 \mathrm{~cm}$. long, $\pm 5 \mathrm{~cm}$. broad, acuminate, the lowest somewhat shorter, suberect. Pinnulae suboblique, $\pm 21 / 2 \mathrm{~cm}$. long, $\pm 1 \% \mathrm{~cm}$. broad, obtuse, cut down nearly to the costa, the medial ones narrowly adnate; segments oblong, denticulate. Texture thinly membranaceous; upper surface nearly black, lower deep-green. Sori linear-oblong, up to $3 \mathrm{~cm}$. long, narrow, costal, remote; indusium narrow, pale-green, often asplenioid; sporangia pale-brown.

Negros.

(19) A. costulison'um, Copel.s in Leafl., III, 815; Diplazium costutisorum, C. Chr., Ind. Fil., Suppl.

Stipes close, up to $1 \mathrm{~m}$. or more long, green, brown-spotted below, naked, black at the base, white-margined, the margin intumescent. Fronds $1 \mathrm{~m}$. or more long, 3-pinnate. Pinnae opposite, horizontally spreading, the largest $50 \mathrm{~cm}$. or more long, sessile, acuminate, the rachis soon glabrescent. Pinnulae to $\pm 11 \mathrm{~cm}$. long; subsessile, acuminate, the rachis grooved above, pubescent beneath with persistent, crinite, dirty-rufous hairs. Tertiary segments \pm 20 on a side, to $13 \mathrm{~mm}$. long, to $4 \mathrm{~mm}$. broad, obtuse, serrate or inciso-serrate, the lowest hardly adnate. Surfaces naked; veins $\pm 7-10$ on a side, forked, pubescent beneath. Sori short; indusium rudimentary, soon fugacious.

Mindanao.

(20) A. macrosorum, Copel., in Leafl., III, 815.

Stipes close, 60-150 cm. long, green, black towards the base. Fronds subdeltoid, $\pm 60-150 \mathrm{~cm}$. long, 3-pinnatifid. Pinnae long-stalked, to $50 \mathrm{~cm}$. long. Pinnulae short-stalked, to $15 \mathrm{~cm}$. long, $\pm 2 \frac{1}{2} \mathrm{~cm}$. broad, acuminate, lobed to pinnatifid, the apex acuminate, coarsely toothed, the base cuneate-truncate; lobes close, oblique, rotundate-truncate, denticulate or serrate at the apex. Texture herbaceous; surfaces naked; under surface somewhat paler than the upper, very sparingly fibrillose on the 
costae and veins; rachises very sparingly and deciduously scaly; main veins pinnate in the lobes; veins simple, $\pm 3-4$ on a side. Sori linear, 2-3 mm. long; slightly recurved; indusium narrow. - In appearance this suggests Diplazium brevisorum $\dot{J}$. Sm.

Mindanao,

(21) A. puleherroimuan, Copel., in Philipp. Journ., VIIJ', 141, tab. III.

Stipes stramineous, $\pm 30 \mathrm{~cm}$. long, clothed towards the base with scattered, pale-brown, lanceolate scales. Fronds ovate, $\pm 30-40 \mathrm{~cm}$. long, acuminate, 3-pinnate in the lower part, the rachis naked. Pinnae horizontal, short-stalked, to $15 \mathrm{~cm}$. long and $5 \mathrm{~cm}$. broad, long-acuminate, often imbricate, the lowest somewhat deflexed. Pinnulae imbricate, spreading, short-stalked, oblong, to $21 / 2 \mathrm{~cm}$. long and $\pm 1 / 2$ as broad at the base, blunt, the lowest obliquely truncate at the base. Ultimate segments small, oblong, the lowest anterior the largest, horizontal, \pm ${ }_{12}{ }^{--3} / 4 \mathrm{~cm}$. long, blunt, acutely toothed, cuneate at the base. Texture herbaceous; surfaces naked; costae sparingly hairy above. Sori short, broad; indusium brown, often lacerate.

Java.

(22) A. Aoultomi. Copel., in Journ. Str. Br. R. A. Soc., LXIII, 71. Stipes to $90 \mathrm{~cm}$. long, slender, black, glossy, smooth, the base often provided with deflexed black scales. Fronds 3 -pinnate, at least $60 \mathrm{~cm}$. long by $30 \mathrm{~cm}$. broad when fully developed, the rachises black, minutely scaly. Pinnae to $25 \mathrm{~cm}$. long, $6 \mathrm{~cm}$. broad, short-stalked, the anterior ones the longer, to $4 \mathrm{~cm}$. long by $1 \mathrm{~cm}$. broad, acuminate, with only the lowest segments free, sessile, linear-oblong, $1 \frac{1}{2} \mathrm{~mm}$. broad, obtuse, serrate. Texture papyraceous; costae and veins black, the former squamulose, the latter sometimes so; veins simple, 2-3 on a side. Sori costal, short; indusium broad, thin.

Borneo.

\section{5ร. ASPLEIVIUM, Linné.}

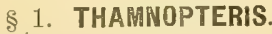

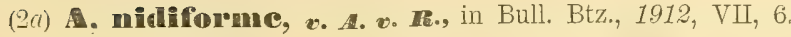


Rhizome short. Fronds cuneate-spathulate, $\pm 40-50 \mathrm{~cm}$. long, $10-12 \frac{1}{2} \mathrm{~cm}$. broad near the apex, rather suddenly rostrate-acuminate, entire or not rarely irregularly, broadly and shallowly sinuate-undulate, narrowed gradually into the acutely cuneate base or a short stipe. Texture rather coriaceous; under surface provided with scattered, very minute, deciduous, punctiform, fimbriate to filiform or capillary, brown scales; costa rather flattened above and prominent beneath, flanked by rows of long, filiform, deciduous, blackish scales; veins fine, ascending, $\pm 1-11 / 2$ $\mathrm{mm}$. apart. Sori confined to the broadest portion of the frond, occupying the lower $1 / 3-1 / 2$ of the veins, not reaching the costa. - Differs from A. nidus $L$. principally by its spathulate fronds.

New Guinea.

(3c) A. nidus, L.; - var. musifolium; A. ellipticum, Copel., in Leafl, III, 819; - var. phyllitidis; A. Phillitidis, Don., in Prod. Flor. Nepal., 7.

Forma typica: Fronds simple; often all the fork branches of the veins soriferous.

Forma monstruosa: Fronds irregularly dichotomous at the apex.

Var. musifolivum: A form reported from Negros has the fronds intermediate between this and $\mathrm{A}$. cymbifolium Christ.

Var. phyllitidis: Otten only the anterior fork branch of the veins soriferous.

(3d) A. oblanceolatum, Copel., in Philipp. Journ., IX ${ }^{\mathrm{C}}, 229$.

Fronds subsessile, narrowly oblanceolate, $\pm 40-60 \mathrm{~cm}$. long, \pm 4 cm. broad, acute, entire, narrowed gradually towards the base. Texture coriaceous; surfaces naked; costa prominent; veins erecto-patent. Sori occupying the lower $1 / 3$ of the veins.

Sumatra,

\section{§ 2. NEOTTOPTERIS.}

\section{(5) A. epiphyticum, Copel.}

Forma typica. - Also in Luzon.

Forma phyllitoides: Stipes about $1 \frac{1}{2}-6 \mathrm{~cm}$. long, naked or nearly 
so, pseudo-articulate at the base; fronds $15--30 \mathrm{~cm}$. long, $3-4 \mathrm{~cm}$. broad, the apex acuminate to abruptly caudate, the edge crenate to very irregularly sinuate and crenate, the base sometimes hastate or semihastate but more especially in the younger plants, the costa sparingly scaly beneath, the veins pellucid. - General aspect of a Phyllitis. - Sumatra.

\section{(6) A. amboinense, Willd.}

Fronds not rarely cuneate (but not decurrent) at the base.

(6o) A. Brooksii, Copel., in Philipp. Journ., VIC, 137 , tab. XX B.

Near A. amboinense Willd. but the stipes aggregate, short $(1-2 \mathrm{~cm}$. long), less scaly, the fronds to $10 \mathrm{~cm}$. broad, provided beneath with ternate hairs, i. e. the hairs placed in threes with a common base.

Borneo.

(7a) A. pa puanum, Copel., in Philipp. Journ., VIC, 79.

Rhizome creeping, green, black-striped, sparingly and minutely scaly. Stipes $\pm 1 \mathrm{~cm}$. apart, $\pm 3 \mathrm{~cm}$. long, clothed towards the base with minute, narrow scales. Fronds simple, $\pm 15 \mathrm{~cm}$. long, $\pm 22^{1 / 2} \mathrm{~cm}$. broad, crenated, acuminated, blunt at the point. Texture herbaceous; surfaces naked; under surface whitish; veins oblique, remote, Sori reaching from the costa nearly to the edge; indusium broad, pale.

New Guinea.

(7b) A. Scalare, Rst., in Fed., Rep., XIII, 214.

Stipes short, stramineous, to $2 \mathrm{~cm}$. long, approximate, scaly, the scales few, lanceolate, brown, sparingly toothed. Fronds simple, to 50 $\mathrm{cm}$. long, $\pm 4 \frac{1}{2} \mathrm{~cm}$. broad, broadest in the upper half or at the middle, narrowed from there towards the long-decurrent base, and upwards suddenly into a long-linear acumen, proliferous below the apex, the edge truncate-crenate, slightly recurved and bordered by a narrow whitish stripe. Texture papyraceous; costa flattened on both sides, scaly; veins rather horizontal, simple or forked, not reaching the margin. Sori occupying the lower $1 / 2$ of the veins; indusium narrow, firm, whitish. Plants occurring in the Buitenzorg Herbarium differ from Rosenstock's description in having the stipes somewhat longer, the costa prominent towards the base, the veins deciduously minutely rotundato-squamulose, 
the edges more or less irregularly repand with the undulations truncatecrenate, the marginal stripes and indusia pale but not whitish.

Sumatra.

(7c) A. subscalane, v. A. v. Re, in Bull. Btz., 1915, XX, 6.

Near A. scalare Rst. but the stipes fuscous, as is the costa, the fronds with the marginal pale stripe indistinct (in dried material), the indusia brown.

Malacca.

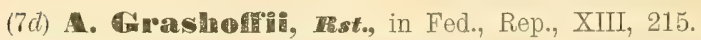

Rhizome stout, scandent, densely clothed with lanceolate, brown scales. Stipes 2-seriate, those of each row $\pm 2-3 \mathrm{~cm}$. apart, $0-3 \mathrm{~cm}$. long, scaly. Fronds lanceolate, $100 \mathrm{~cm}$. or more long; $\pm 14 \mathrm{~cm}$. broad, narrowed towards both ends, entire. Texture papyraceous; surfaces provided with scattered, ferrugineous, adpressed, simple or forked, short hairs; costa beneath prominent, quadrangular, 2-marginate, short-hairy; veins forked, sparingly astomosing towards the apex, not reaching the margin. Sori occupying the lower ${ }^{5 / 7}-{ }_{17}^{6}$ of the veins, nearly reaching the costa; indusium narrow, firm.

Sumatra.

(7e) See No. 6.

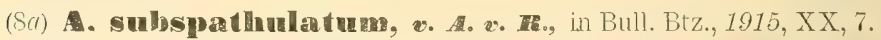

Rhizome creeping, clothed with sparingly toothed or ciliated, palefuscous, lanceolate-subulate scales. Stipes remote, to $5 \mathrm{~cm}$. long, slightly scaly, the scales few, lanceolate, pale-fuscous. Fronds simple, $\pm 20-30$ $\mathrm{cm}$. long, $\pm 6-7 \mathrm{~cm}$. broad in the upper half which is oblong-lanceolate, cuspidate, crenate or repando-crenate but more conspicuously towards the apex; near the middle the frond is rather suddenly narrowed into the wing-like lower half which is $\pm 1 / 2-1 \mathrm{~cm}$. broad and decurrent upon the stipe. Texture membranaceous or herbaceous; surfaces naked; costa rather flattened, sparingly or deciduously scaly beneath; veins parallel, ascending, simple or forked, not reaching the margin. Sori narrow, occupying the lower $1 / 2-2 / 3$ of the veins, rather distant from the costa; indusium narrow, pale, at length recurved.

Sumatra. 


\section{(14) A. scellopendrioides, J. Sm.}

Rhizome creeping or ascending, chaffy with small, brown, lanceolate scales. Stipes more or less approximate, $\pm 1 / 2-4 \mathrm{~cm}$. long, erect, somewhat scaly. Fronds lanceolate, $25-50 \mathrm{~cm}$. long; $2-4 \mathrm{~cm}$. broad, the apex acute or more or less suddenly caudate, the base narrowed very gradually, the edge entire or more or less crenate especially towards the apex which is sometimes 2-4-fid. Texture more or less firm; surfaces naked; upper surface darker than the lower; costa prominent beneath, less so above; veins oblique, rather distant, $\pm 2 \mathrm{~mm}$. apart, often simple. Sori reaching from $1-4 \mathrm{~mm}$. of the costa to within $5-7 \mathrm{~mm}$. of the edge; indusium leaving a distinct, elevated ridge on the frond when it dehisces; spores prickly.

Borneo, Plitippines.

(15a) A. Pliceps, Copel., in Philipp. Journ., VC, 285.

Rhizome woody, the scales dense, lanceolate, apiculate, dark-brown, paler at the edge. Stipes close, $\pm 10 \mathrm{~cm}$. long, slender, green, minutely squamulose, the scales pale-brown. Fronds simple, $20-24 \mathrm{~cm}$. long, $2-2 \frac{1}{2} \mathrm{~cm}$. broad, narrowed at both ends, narrowly long-caudate, obscurely serrate. Under surface minutely squamulose; veins free. Sori nearly close to the costa, not reaching the margin, to $\pm 8 \mathrm{~mm}$. long; indusium whitish, persistent.

Borneo.

\section{(18) A. glochidliatum, inac.}

Differs from A. scolopendrioides $J$. Sm. in having the stipes longer, the fronds broader, the veins less oblique, more close, $\pm 1 \mathrm{~mm}$. apart, the sori close to the costa, both surfaces equally green.

Borneo.

(18a) acrobryum, Chrest, in Nov. Guin., VIII, Bot., 150.

Rhizome succulent, thick, ascending, shortly scandent, clothed with acute, lanceolate, brown scales. Stipes thick, sulcate, scattered, more distinctly approximate towards the apex of the rhizome, clothed with scattered, acute, lanceolate-ovate or subulate-ovate or subulate, brown scales. Fronds lanceolate, $\pm 30-55 \mathrm{~cm}$. long, $\pm 4-6 \mathrm{~cm}$. broad at the middle, the base gradually decurrent upon the stipe, the margin undulate, repand towards the long, narrowly acuminate apex, the acumen 
to $\pm 6 \mathrm{~cm}$. long, $\pm 1 \mathrm{~mm}$. broad, proliferous below the point. Texture chartaceous; colour pale-green, surfaces naked; costa prominent; veins numerous, nearly horizontal, simple, or rarely forked at the base, slender. Sori occupying nearly the whole frond except the apex; not reaching the margin; indusium narrow, black-brown.

New Guinea.

(18b) A. paucidens, v. A. v. R., in Bull. Btz., 1912, VII, 6.

Rhizome ascending, shortly scandent, clothed with subulate-lanceolate, acute, grey-brown scales. Stipes erect, seriate, short, slightly scaly towards the base. Fronds linear-lanceolate, $\pm 30 \mathrm{~cm}$. long and $2 \frac{1}{2}-3 \mathrm{~cm}$. broad, caudate-acuminate, narrowed gradually towards the base, the margin narrowly recurved, provided with a few distant, horizontal, short and broad, deltoid, tooth-like outgrowths $\pm 1 \mathrm{~mm}$. long and $4 \mathrm{~mm}$. broad, the acumen proliferous below the point. Texture chartaceous; surfaces naked; costa prominent; teins numerous, nearly horizontal, fine, simple, or rarely forked at the base. Sori occupying nearly the whole frond except in the narrowest portions, mostly reaching both costa and margin; indusium narrow, dark-brown.

New Guinea.

\section{§ 3. EU-ASPLENIUM.}

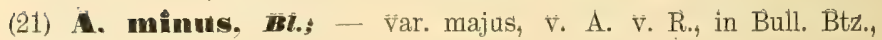
$1915, \mathrm{XX}, 6$.

Var. majus: Stipes to $10 \mathrm{~cm}$. long; fronds larger, to $30 \mathrm{~cm}$. long by $2 \frac{1}{2}-3 \frac{1}{2} \mathrm{~cm}$. broad; pinnae to $1^{3} / 4 \mathrm{~cm}$. long, more deeply incisodentate; veins simple or forked, the lowest anterior flabellato-dichotomous. - Java.

(23a) A. trichomanes, L. ; Schk., Krypt. Gew., I, tab. $74 a$.

(26) A. salignum, $B l$.

Omit this, it being a young or undeveloped form of A. vulcanicum Bl. only.

(26a) A. glaucostipes, v. A. v. R., in Bull. Btz., 1914. XVI, 2. 
Stipes tufted or approximate, glaucous-opaque or finally black-glossy, deciduously scaly especially in the lower part. Fronds pinnate. Pinnae pausijugate, stalked, lanceolate, $\pm 12 \frac{1}{2}-17 \frac{1}{2} \mathrm{~cm}$. long, $2-4 \mathrm{~cm}$. broad acuminate, entire or crenate, cuneate at the base; terminal pinna similar to the lateral ones or incised at the base. Texture flaccid-coriaceous; surfaces naked or the under surface sparingly deciduously squamulose at least on the costae; colour glaucous or pale-olivaceous when dry; veins mostly forked, spreading. Sori long, reaching the costa but not the margin; indusium pale, persistent.

Sumatra.

(26b?) A. Kingii, Copel., in Philipp. Journ., VIC, 79.

Stipes long, dark-grey, grooved, naked above. Fronds $\pm 50 \mathrm{~cm}$. or more long. Pinnae \pm 5 on each side, subsessile, $\pm 20 \mathrm{~cm}$. long, \pm 5 $\mathrm{cm}$. broad, abruptly acuminate, obscurely crenate, equal-sided at the base, the lowest stalked, not rarely forked. Texture herbaceous; surfaces naked; veins forked. Sori long, reaching neither the costa nor the edge; indusium narrow, black-brown.

New Guinea.

(26c?) A. trifoliatum, Copel., in Phillipp. Journ., VC, 284.

Rhizome suberect, woody, the scales dense, membranaceous, ovatelanceolate, entire, acuminate, brown. Stipes clustered, $15-20 \mathrm{~cm}$. long, scaly, the higher scales smaller, subdeciduous. Fronds ternate. Lateral segments $\pm 12 \mathrm{~cm}$. long, $3-5 \mathrm{~cm}$. broad, caudate, adnate, decurrent; terminal segment $40-50 \mathrm{~cm}$. long, nearly $10 \mathrm{~cm}$. broad, caudate, sharply serrate. Texture herbaceous; upper surface black-green, naked, lower paler, minutely and sparingly scaly; costae black-brown and prominent beneath. Sori unequal, not reaching the costa and margin, hardly $1 \mathrm{~mm}$. broad; indusium persistent.

Borneo.

\section{(27) A. diver'sifolium, $\boldsymbol{B}$.}

Barren fronds simple, lanceolate, acuminate at both ends; fertile fronds sometimes so, commonly pinnate; texture varying from membranaceous to coriaceous; margins entire to crenate; stipe, rachis, petioles and pinnae more or less distinctly pellucid-margined; pinnae naked or sparingly minutely scaly. 


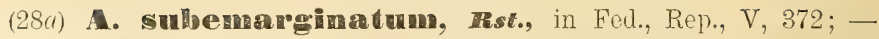
var. logavensis, Rst., X, 326.

Rhizome short-creeping, woody; scales dense, greyish, lanceolate, acuminate, ciliate. Stipes approximate, $\pm 25 \mathrm{~cm}$. long, densely scaly towards the base, upwards naked, castaneous. Fronds elongate-obovate, \pm $50 \mathrm{~cm}$. long, $20 \mathrm{~cm}$. broad, pinnate. Pinnae 7-9 on a side below the terminal one; terminal pinna unequal-sided at the base, narrowed into a petiole $1 / 2-2 \mathrm{~cm}$. long, much longer than the lateral ones, forked towards the apex, with the fork branches often forked again; lateral pinnae erectopatent, straight, linear-lanceolate or elongate-oval, entire or slightly serrulate-crenate, the apex narrowed, the base cuneate, slightly produced on the upper side; higher pinnae subsessile; central largest, to $20 \mathrm{~cm}$. long, $\pm 2 \frac{1}{2} \mathrm{~cm}$. or more broad, $\pm 3 \mathrm{~cm}$. apart; lowest to $9 \mathrm{~cm}$. long, $\pm 1^{3 / 4} \mathrm{~cm}$. broad, petiolate, opposite, more remote. Texture thinly herbaceous; surfaces naked; upper surface olive-green, lower paler; rachis firm, brownish or castaneous, naked or nearly so, as are the costae; veins oblique, parallel, simple or forked. Sori straight, $\pm 3 \mathrm{~mm}$. apart, near the costae, occupying the lower $3 / 4$ of the veins; indusium narrow.

Var. Iogavensis: Pinnae elongate-obovate, subentire; veins more close.

New Guined.

(29) A. Demotam, Hoore; - var. dareoides; A. multitineatum, Hk., var. dareoides, Rst., in Fed., Rep., X, 326.

Var. dareoildes: Pinnae $\pm 15 \mathrm{~cm}$. long; $4-6 \mathrm{~cm}$. broad, deeply pinnatifid, pinnate at the base; secondary segments to $3 \mathrm{~cm}$. long, $1-1^{1}{ }_{12}^{1}$ $\mathrm{cm}$. broad, obtuse, deeply pinnatifid; tertiary segments $\pm 6 \mathrm{~mm}$. long, $1 \frac{1}{2} \mathrm{~mm}$. broad, simple or 2 -fid, or the lower pinnate again; ultimate segments linear; sori linear, to $4 \mathrm{~mm}$. long; dareoid. - New Guinea.

\section{(31) A. sumeatramean, MHe.}

Also in Malacca.

(32) A. vulcanicum, Bl. is construed as including 3 distinct forms: A. vulcanicum Bl., A. cuspidifolium $v . A . v \cdot R$. and A. Wightianum $H$.

(32a) A. voleanicuan, Bu.; A. salignum, Bl., Enum., 175.

Fronds varying from simple to pinnate with few to numerous pinnae 
on a side. Pinnae rather broadly and often somewhat obliquely truncate. cuneate or rotundate-cuneate at the base, entire to serrate, acute or acuminate. Malaya; Ceylon.

(32b) A. cuspidifollum, v. A. v. Re, in Bull. Btz., 1915, XX, 7.

Near the preceding but in aspect very different, with the pinnae subabruptly and narrowly long-cuspidate-acuminate, the cusp $\pm 1 / 2$ as long as the blade.

Borneo.

(32c) A. Wightianum, mk., Spec. Fil., III, 105, tab. CLXVII; Bedd., Ferns S. I., tab. CXXVI.

Pinnae gradually, narrowly and equally cuneate at the base, coarsely serrate-dentate, acuminate, sometimes irregularly and narrowly pinnate (teratophylloid).

Philippines (?); Br. India, Ceylon.

(35а) A. prollfeans, v. A. v. R., in Bull. Btz., 1913, XI, 4.

Rhizome erect. Stipes close or approximate, $\pm 221 / 2-27 \frac{1}{2} \mathrm{~cm}$. long, dirty-dark-fuscous when dry and chaffy with scattered, deciduous, dark-brown and pale-brown scales different in size, as is the rachis. Fronds oblong, $\pm 35-45 \mathrm{~cm}$. long. Pinnae ascending, $\pm 5-6$ on each side below the terminal one, lanceolate-oblong, 7-20 cm. long, 2-6 cm. broad, the terminal one the largest, the lowest the smallest; terminal pinna irregularly toothed towards the abruptly caudate-acuminate apex, proliferous at the point, gradually entire or subentire towards the cuneate and decurrent base; lateral pinnae similar but not proliferous, with the lower base decurrent; lowest pinnae shortly petiolulate. Texture thinly coriaceous, rather flaccid; surfaces naked; costae more or less chaffy beneath especially at the base; veins oblique, simple or forked, thickened at the apex. Sori long, often occupying the lowest $3 / 4$ of the veins; indusium firm, persistent, brown. - Young plants with the fronds simple, similar to the terminal pinna but much larger and not proliferous.

Borneo.

\section{(37) A. bon'meense,}

Forma truncata (v. A. v. R., in Bull. Btz., 1914, XVI, 57): Pinnae truncate at the apex. - Sumatra.

Ferns and Fern Allies. 
(38) A. tenerum, Forst.; A. elongatum, Sw.; A. tenerum, Forst., var. elongatum, Rst., in Fed., Rep., V, 370.

Veins simple or the lowest anterior forked.

A collection made in Negros Island includes the common form of this with rounded pinnae. With it and connected by gradations is a form with very acute long pinnae and a prominent auricle $5 \mathrm{~mm}$. or more long, which, if by itself, would pass easily for a distinct species. In more monstruous individuals this auricle becomes almost free and more than $2 \mathrm{~cm}$. long; and finally several lower pairs of pinnae may break up into pinnules connected only by a wing, each pinnule like a small pinna of a normal frond. In such freaks, the basiscopic pinnules are the largest ones. (Copel.).

\section{(39) A. Iumulatum, Swo.}

Pinnae blunt to acute at the apex; veins mostly forked, the higher sometimes simple and the lowest anterior, not rarely pinnate.

(40a) A. Steerei, Harr.; A. contigunm, J. Sm., var. bipinnatifidum, Christ, in Bull. Herb. Boiss., VI, 152; A. laxivenium, Copel., in Philipp. Journ., IIC, 132; ? A. insiticium, Brack., Christ, in Philipp. Journ., II', 166.

(41a) A. stemochlaemoides, v. A. v. $\boldsymbol{F}$.. in Bull. Btz., 1913, XI, 4; 1914, XVI, tab. I-II.

Rhizome woody, scandent, dark-brown, clothed with numerous scattered, adpressed, minute, blackish scales. Stipes remote, 2-seriate, when dry grey-brown, naked like the rachis or sparingly appresso-squamulose, \pm $10-15 \mathrm{~cm}$. long, apparently articulated at the base. Fronds $25-35 \mathrm{~cm}$. long , 10-20 cm. broad, subdimorphous, simply pinnate. Pinnae \pm 10 pair on each side, subspreading to suberect, remote, petiolulate, linear-lanceolate, gradually long-acuminate, the upper base more or less abruptly and broadly rotundate-cuneatae to rotundate-subtruncate, the lower base narrowly cuneate and partly cut away; central or lower pinnae the largest, 5-12 cm. long, $1 / 2-1 \frac{1}{2} \mathrm{~cm}$. broad, the barren ones the largest and broadest, serrate-crenate, the fertile ones the shortest and narrowest, subentire or crenate; terminal pinna similar to the lateral ones but mostly less unequal-sided at the base. Texture herbaceous, transparent; surfaces naked; costae prominent; veins oblique, simple or forked, numerous. Sori numerous, close, more or less reaching nearly the costa and 
margin; indusium membranaceous, persistent. - The young plants have the fronds much smaller, with the pinnae short, membranaceous, resembling in aspect those of A. tenerum Forst, or A. Belangeri Kze.

Mangoli Island.

(41b) A. Teratophyllaides, v. A. v. R., in Bull. Btz., 1914, XVI, 2, tab. III.

Near A. stenochlaenoides $v . A . v . R$. - Stipes not articulated at the base, green or stramineous; fronds of young plants laxly and deeply 3pinnatifid with linear-oblong or narrow-cuneate, subacute or emarginate tertiary segments. Fertile fronds unknown. - Resembles somewhat A. Wightianum Wall. which, however, has the pinnae equal-sided at the base.

Celebes.

(41c) A. heteromorphum, v. A. v. R., in Bull. Btz., 1915 $\mathrm{XX}, 7$.

Rhizome short, the scales linear-subulate, dark-brown. Stipes approx imate, 5-20 cm. long, olivaceous when dry, rather naked, very narrowly winged. Fronds simple or 3 -foliate, or probably pinnate in the fully developed plant; simple fronds lanceolate or oblanceolate, $15-25 \mathrm{~cm}$. long, $2-3 \mathrm{~cm}$. broad, the apex more or less suddenly acuminate, the edge very shallowly but rather broadly crenulate, bounded by a pellucid strand, the base gradually decurrent; 3-foliate fronds with the terminal pinna similar to the simple fronds, the lateral pinnae sessile, rather erectopatent, shorter than the terminal one, the upper base narrowly rounded, the lower base cuneate, suddenly decurrent upon the stipe. Texture herbaceous; surfaces olivaceous when dry, under surface sparingly and very minutely scaly, the scales brown, fimbriate-stellate; veins subspreading, fine, simple or forked. Sori occupying the lower $1 / 2-2 / 3$ of the veins, not reaching the costa; indusium pale-olivaceous-brown.

Java.

\section{(42) A. griseum, Copel.}

Pinnae remote, tough-herbaceous or flaccid-coriaceous, unequally and rather abruptly rotundate-cuneate at the base, subserrate or broadly crenulate, to $31 / 3 \mathrm{~cm}$. broad. - The terminal pinna and the one next below it are very close together and almost of the same size, giving the frond a peculiar appearance of truncateness. 
(44) A. Schoggersii, v. A. v. R.

Omit this, it is a young (or reduced) form of A. caudatum Forst.

(45) A. caudatum, Forst.; v. A. v. R., in Bull. Btz., 1911, I, tab. I, fig. 2.; A. Schoggersii, v. A. v. R., 1. c., tab. I, fig. 1; - var. minus, v. A. V. R., 1. c., 3.

The typical form differs from $\mathrm{A}$. horridum $K l f$. in having the pinnae cut at best $2 / 3$-way down to the costa, the lobes close or approximate, hardly decurrent. - See Schk., Krypt. Gew., I, tab. 77 (sori not correct).

Forma Schoggersii: Fronds small, lanceolate-ovate, $8-10 \mathrm{~cm}$. long, $士 4 \mathrm{~cm}$. broad; pinnae $\pm 1 / 2 \mathrm{~cm}$. broad, bluntish or acute and toothed at the apex, for the rest lobed; lobes truncate or rounded, suberenate; sori small, oblong. - United with the type by intermediates. - Java.

Var. mimus: Fronds smaller, $\pm 25-35 \mathrm{~cm}$. long, $\pm 5-7 \mathrm{~cm}$. broad; pinnae approximate, eresto-patent, less acuminate or bluntish, the largest $\pm 3-5 \mathrm{~cm}$. long, the lower more or less reduced and spreading. - Java, Luzon

(46) A. contiguum, $K l f$. is construed as including two different forms: A. contiguum $K l f$. and A. lepturus J. Sm. - Omit the variety bipinnatifidum as being identical with A. Steerei Harr.

(46a) A. contiguum, Krf.; Hk., Spec. Fil., III, tab. CXCIV, fig. 1; - var. subadiantoides, v. A. v. R., in Bull. Btz., 1912, VII, 5.

Forma typica: Fronds $15-30 \mathrm{~cm}$. long; pinnae $\pm 4-7 \frac{1}{2} \mathrm{~cm}$. long by $1-1 \frac{1}{2} \mathrm{~cm}$. broad, acute or acuminate, obliquely and broadly serrate, the higher serratures simple or 2-dentate, the lower serrate or toothed. Philippines; Hawaii.

Var. subadiantoides: Fronds smaller, to $15 \mathrm{~cm}$. long; pinnae shorter, $\pm 2-2 \% / 2 \mathrm{~cm}$. long, to $1 \mathrm{~cm}$. broad, sublobate-serrate, the lower lobules serrate again, the apex subsubulate; only the highest sori parallel or subparallel to the costa. - Resembles in aspect a small form of $\mathrm{A}$. adiantoides C. Chr. - Timor.

(46b) A. lepturus, J. Sm.; A. contiguum, Klf., var. lepturus, Hk., Spec. Fil., III, tab. CXCIV, fig. 5; v. A. v. R., in Bull. Btz., 1911, I, tab. I, fig. 3.

Like the preceding but the pinnae longer, $\pm 9-12^{1 / 2} \mathrm{~cm}$. long, 
deeply serrate-lobate at least in the lower part, serrate towards the subulate-acuminate apex, the lobes sharply serrate.

Luzon.

(47a) A. nigrescens, $\boldsymbol{B} \boldsymbol{t}$. . V. A. V. R., in Bull. Btz., 1911, I, tab. I, fig. 4 .

(50a) A. Ejellerapii, v. A. ש. R., in Bull. Btz., 1912, VII, 7; A. Sancti Christophori, Rst., in Nov. Guin., VIII, Bot., 721.

Rhizome short, scaly, the scales lanceolate-linear, black-brown, brownmargined, rather entire. Stipes tufted, black-brown and pale-margined, chaffy like the rachis, $\pm 10-25 \mathrm{~cm}$. long, the scales crowded, irregularly radiate-fimbriate, partly persistent partly deciduous, brown or blackish. Fronds lanceolate, $15-30 \mathrm{~cm}$. long, $5-15 \mathrm{~cm}$. broad, acuminate. Pinnae approximate, subrhomboidal-oblong, blunt to acuminate, the edge broadly crenate-serrate, the teeth inconspicuously crenulate, the base cuneatetruncate, truncate or cordate, and sometimes subauriculate on the upper side, cuneate or rotundate on the lower side; central pinnae the largest, spreading, $1:-3 \mathrm{~cm}$. broad near the base; lower pinnae not rarely somewhat deflexed and subtruncate-rotundate on the lower side at the base; terminal pinna triangular, whether or not deeply incised at the base. Texture coriaceous; surfaces copiously (not densely) scaly on both sides on the costae and veins, the scales brown, capillary or palmato-fimbriate, those of the upper side rather deciduous, those of the lower side rather persistent; veins parallel, erecto-patent or the lower somewhat radiating, distinct beneath, somewhat decurved. Sori linear, not reaching the margin and costa; indusium firm, naked, persistent.

New Guinea.

(52) A. acutiosulum, $\boldsymbol{B t}$.

Forma simplicivenia (v. A. V. R., in Bull. Btz., 1914, XVI, 3): Veins mostly simple. - Sumatra.

(53a) A. Keyssenianum, Fest., in Fed., Rep., X, 328; - var. brevipes \& var. obtusifolium, Rst., I. c. XII, 528.

Stipes $\pm 15 \mathrm{~cm}$. long, dirty-purplish, terete, deciduously paleaceopilose, soon glabrescent. Fronds linear-oblong, $32-35 \mathrm{~cm}$. or more long, $\pm 2{ }_{2}-3 \mathrm{~cm}$. broad, pinnate, acuminate. Pinnae numerous, trapezoidlanceolate, nearly horizontal, subsessile, acute or short-acuminate or the 
lower obtuse, the upper base truncate, the lower base cuneate, the edge irregularly serrate-crenate; central pinnae the largest, $\pm 2 \mathrm{~cm}$. long; $7-8 \mathrm{~mm}$. broad, $\pm 1 \frac{1}{2} \mathrm{~cm}$. apart; lower pinnae $\pm 3 \mathrm{~cm}$. apart, opposite; higher pinnae alternate; terminal pinna lanceolate-triangular, whether or not lobed at the base. Texture subcoriaceous; under surface and edges scaly with black-purple, dilacerate or hair-like scales; rachis slender, provided with blackish, flaccid, narrowly lanceolate, fimbriate or hair-like scales; veins oblique, subflabellate, simple or forked. Sori linear, reaching neither the costa nor the margin; indusium broad, coriaceous.

Var. Wrevipes: Stipes short, $1 \mathrm{~cm}$. long; pinnae bluntish or acute.

Var. obtusifolium: Fronds shorter, to $20 \mathrm{~cm}$. long by $2 \mathrm{~cm}$. broad; pinnae about 12-jugate, shortly trapezoid-oblong, rounded or blunt at the apex, obtusely toothed; veins provided with lacerate-ciliate squamules.

New Guinea.

(53b) See No. 56.

(54a) A. Cronuwelliamuan, Rest., in Fed., Rep., X, 327.

Rhizome short-creeping, woody; scales dense, lanceolate, shortly acuminate. Stipes flexuose, $\pm 20 \mathrm{~cm}$. long, scaly at the base, and like the rachis grey-green or purplish, naked. Fronds broadly linear, to $\pm 20 \mathrm{~cm}$. long, $6 \mathrm{~cm}$. broad, acuminate, pinnate. Pinnae \pm 20 on each side below the serrate-lobate terminal one, alternate, suberect, petiolulate, lanceolate, subfalcate, lobed, serrate towards the shortly acuminate apex, obliquely cuneate at the base; lower pinnae $\pm 6 \mathrm{~cm}$. long, $1 \frac{1}{2} \mathrm{~cm}$. broad, nairowed gradually towards the apex. Lobes obtuse, sharply serrate with 2 or more teeth, the lowest anterior lobe auricle-like, nearly free. Texture chartaceous to coriaceous; surfaces naked; costae and veins prominent; veins once or twice forked, the lowest anterior pinnate in the auricle. Sori long, slightly curved, reaching nearly from the costa to the margin, those of the auricle sometimes apparently diplazioid; indusium firm.

New Guinea.

\section{(55) A. adimuteides, c. chr.}

A very variable species, with the pinnae not rarely much shorter than in the type, whether or not auriculate on the upper side at the base and the auricle sometimes free, cuneate-obovate.

Forma minor: Fronds shorter and narrower; pinnae to \pm 6 on a side, $\pm 1 \mathrm{~cm}$. broad, 


\section{(56) A. Sancti-Christophoni. Cherist.}

The plant gathered by Gjellerup, determined by Rosenstock as A. Sancti-Christophori, is A. Gjellerupii $v . A . v . R$.

(57) A. maceophyllum, Sw.; - var. angustipinna \& var. Treubii, v. A. v. R., in Bull. Btz., 1912, VII, 7.

Var. angustipinns: Pimle narower, plurijugate, erecto-patent, linear-lanceolate, acute, broadly and shallowly serrate-crenate, the base equally cuneate on both sides or nearly so. -- New Guinea.

Van. 'Treabi: Pinnae narrower, paucijugate, the lower horizontal, acuminate-lanceolate, broadly and shallowly serrate-crenate, the base nearly equally cuneate on both sides. - Amboina.

(57a?) A. psendofalcatum, Hillebr., Flor. Hawail., 597.

Stipes crowded, $15-45 \mathrm{~cm}$. long, sparsely paleaceous only at the base. Fronds $20-45 \mathrm{~cm}$. long, oblong-lanceolate, pinnate, the rachis often gemmiferous near the apex. Pinnae 12-20 on a side, patent, stalked, rhomboidal-ovate to obliquely ovate-lanceolate, $4-12 \frac{1}{2} \mathrm{~cm}$. long by $2-4$ cm. broad, obtuse or acute, bluntly and remotely serrate or inciso-serrate, abscisso-truncate at the base, the upper half rounded off, the auricle often detached as a broadly obovate segment. Texture chartaceous to coriaceous and brittle; veins oblique, the higher simple, the lower forked, the lowest subpinnate in the auricle. Sori elongate, straight and parallel near the apex, curved lower down and subpinnate in the auricle, $1_{1 / 2}-3$ $\mathrm{cm}$. long but not rarely shorter; indusium broad.

New Guinea; Hawaii.

(58) A. pacadoxum, $\boldsymbol{H}$.; $\quad$ - var. paucijugum, v. A. v. R., in Bull. Btz., 1912, VII, 7.

Var. pancijasum: Fronds smaller, pinnae paucijugate. Batu, Borneo.

\section{(60a) A, unilateralle, tam.}

Pinnae with 3 or more, rarely 2 veins on the lower side of the costa (in the typical form).

(60b) A. fillipes, Copel. 
Pinnae with 1 vein, rarely 2 veins on the lower side of the costa (in the typical form).

Also in Mindanao.

(62a) A. Kelelense, Brau., in Lautb., Beitr. Flor. Pap., I, 29, fig. $2 A-a$.

Rhizome short, erect. Stipes tufted, 3-11 cm. long, grey-brown, winged, and clothed with deciduous, brown, narrowly linear, acuminate scales. Fronds lanceolate, $10-17 \mathrm{~cm}$. long, $2 \frac{1}{2}-5 \mathrm{~cm}$. broad, slightly narrowed at the base, sub-2-pinnate; main rachis winged, scaly. Pinnae $\pm 12-15$ on each side; higher pinnae approximate, spreading, sessile or subpetiolulate; central pinnae largest, horizontal, deeply pinnatifid, subpinnate, to $2^{1 / 2} \mathrm{~cm}$. long and $1^{1 / 2} \mathrm{~cm}$. broad, the base unequally cuneatetruncate, broadest on the upper side; lower pinnae deflexed, to $2 \mathrm{~cm}$. apart. Segments to 3 on a side below the terminal one, connected by a narrow costal wing, roundish, obovate or cuneate, the apex rounded and crenate or toothed, the base cuneate, rotundate-cuneate or truncatecuneate. Texture chartaceous; surfaces naked; veins to 3 on a side, simple or forked. Sori scattered (occupying the terminal segments only?); indusium membranaceous.

New Guinea.

(62h) A. hapalophyllum, Rst., in Fed., Rep., XII, 167.

Rhizome creeping; woody, the scales dense, ferrugineous, lanceolate from a slightly dilated base, fibrillose-acuminate, subentire or sparingly ciliated. Stipes subapproximate, to $15 \mathrm{~cm}$. long and, like the rachis, castaneous, naked, glossy, fragile. Fronds elongate, $\pm 20 \mathrm{~cm}$. long by $1 / 1 / 2-2 \mathrm{~cm}$. broad, shortly acuminate, 2-pinnate. Pinnae \pm 15 on a side, ascending, petiolate, trapezoid-rhomboidal, the higher cuneate, the largest $\pm 2 \mathrm{~cm}$. long by $1 \mathrm{~cm}$. broad. Pinnulae $1-2$ on a side, linear-cuneate, $\pm 8 \mathrm{~mm}$. long by $1 \mathrm{~mm}$. broad, straight or incurved, entire, or incised at the apex. Texture herbaceous; surfaces naked, subopaque-green; veins forked, subimmersed. Sori linear, $1-3$ to a pinna; indusium membranaceous, whitish.

New Guinea.

(62c) A. inciso-dentatum, Fst., in Fed., Rep., X̃II, 167.

Rhizome wide-creeping, woody, the scales ferrugineous, lanceolate, acuminate, ciliate. Stipes $\pm 1 \frac{1}{2}-4 \mathrm{~cm}$. apart, slender, to $15 \mathrm{~cm}$. long, 
castaneous, naked, glossy. Fronds lanceolate, $\pm 15 \mathrm{~cm}$. long by $5 \mathrm{~cm}$. broad, acuminate, 2-pinnatifid, cuneate or truncate at the base. Pinnae to 12 on a side, petiolate, ascending, trapezoid-lanceolate, pinnatifid in the upper part, cut down nearly to the costa at the base, the lowest the largest, $\pm 3 \frac{1}{2} \mathrm{~cm}$. long by $1 \frac{1}{2} \mathrm{~cm}$. broad. Segments $2-3$-jugate, cuneate or linear, deeply toothed on the anterior side, the teeth linear, acuminate. Texture subcoriaceous; colour blackish when dry; rachis, surfaces and costae naked above, more or less scaly beneath; veins flabellate, subimmersed. Sori linear.

New Guinea.

(62d) A. varians, Woull., Hk. Bk., Syn. Fil., 216; Hk. \& Grev., Ic. Fil., tab. CLXXII; - var. squamuligera, Rst., in Fed., Rep., XII, 528.

Stipes tufted, $2 \frac{1}{2}-7 \frac{1}{2} \mathrm{~cm}$. long, slender, naked, greenish. Fronds oblong-lanceolate, $\pm 10-15 \mathrm{~cm}$. long, $2 \% \mathrm{~cm}$. broad. Pinnae 8-12 on a side, the lower remote, deltoid-oblong, blunt, toothed or incised and toothed at the apex, $\pm 11 / 4-2 \mathrm{~cm}$. long, $\pm 3 / 4-11 / 4 \mathrm{~cm}$. broad, cut down to the rachis into a fow cuneate-flabellate pinnulae, the lowest of which $\pm 5 \mathrm{~mm}$. across, toothed or sparingly lobed and toothed on the outer edge with $\pm 5-8$ teeth. Texture herbaceous; rachis slender, naked, green; veins 1 carried into each tooth. Sori copious, short, when mature covering nearly the whole under surface of the pinnulae.

Forma typica. - South Africa, Ceylon, China, Japan, Hawaii.

Var. squamuligera: Stipe and rachis provided with spreading, flexuose, linear-lanceolate, denticulate scales; pinnulaẹ entire. New Guinea.

(64a) See No. 62d.

(65) A. Hagenii, v. A. v: R.

Omit this species, it being a smaller form of A. stereophyllum $K z e$.

(65a?) A. perakense, Matt. Christ, in Linn. Soc., Bot., XXXIX, 214.

Near A. praemorsum Sw. - Stipes $\pm 21 \mathrm{~cm}$. long, with a few scattered, subulate scales; lower part ebeneous, upper part black-green; rachis either ebeneous or green. Fronds elongate, $\pm 28 \mathrm{~cm}$. long, 7 $\mathrm{cm}$. broad, not narrowed at the base. Pinnae numerous, $\pm 31 / 2 \mathrm{~cm}$. 
long, resembling those of A. caudatum Forst., approximate, nearly simply pinnatifid, with a large, deeply 3-fid auricle at the base (on the upper side); lobes $\pm 7 \mathrm{~mm}$. long, $4 \mathrm{~mm}$. broad, cuneate, obtuse, the apex erose. Texture firmly chartaceous; colour bright-green; veins flabellate. Sori numerous, flabellate; indusium grey, very narrow.

Malacca.

\section{(66) A. horridum, Klf:}

The typical form differs from A. caudatum Forst. in having the pinnae deeply pinnatifid often nearly to the costa, the lobes decurrent and separated by broad sinuses which may be as broad as or broader than the lobes.

\section{(67) A. tenuifolium, Don.}

Also in Luzon and British Burmah.

(68a) A. stereophyllum, Kze; A. Hagenii, v. A. v. R.

Rhizome short and erected in the specimens occurring in the Buitenzorg Herbarium.

Forma paucipinna: Fronds shorter; pinnae $\pm 4-5$-jugate.

(69a) A. nutaus, Rst, in Fed., Rep., XII, 168.

Rhizome short-creeping, woody, the scales dense, ferrugineous, lanceolate, acuminate, entire. Stipes approximate, $\pm 20 \mathrm{~cm}$. long, castaneous, naked, glossy, scaly at the base. Fronds to $70 \mathrm{~cm}$. or more long, to 7 $\mathrm{cm}$. broad, long-acuminate, 2-pinnate. Pinnae numerous; petiolate, linearlanceolate, straight, acuminate; central pinnae largest, to $10 \mathrm{~cm}$. long, $7 \mathrm{~mm}$. broad; lower pinnae somewhat smaller. Pinnulae \pm 10 on a side, remote, subpetiolulate, obliquely cuneate-obovate, irregularly incised on the anterior side, the largest $\pm 9 \mathrm{~mm}$. long by $4 \mathrm{~mm}$. broad. Texture firm; surfaces sparingly minutely scaly; rachises slender, sparingly fibrilloso-paleaceous; veins flabellato-pinnate. Sori short, somewhat curved; indusium subsemiorbicular.

New Guinea.

(69b) A. Fersteri, Rst., in Fed., Rep., XII, 168.

Fronds $\pm 50 \mathrm{~cm}$. long, $\pm 10 \mathrm{~cm}$. broad below the middle, sub-3. pinnate. Pinnae \pm 20 on a side below the toothed apex, somewhat remote, ascending, lanceolate, acuminate, obliquely cuneate-truncate, and 
broadest on the upper side at the base; largest pinnae $\pm 6 \mathrm{~cm}$. long by $2 \mathrm{~cm}$. broad; lowest pinnae somewhat abbreviated. Pinnulae $\pm 7-8$ on a side, obtuse, the lowest $\pm 1-1 \frac{1}{2} \mathrm{~cm}$. long by $1 \mathrm{~cm}$. broad, pinnate. Tertiary segments $1-2$ on a side, cuneate, $\pm 5 \mathrm{~mm}$. long by $2 \mathrm{~mm}$. broad, inciso-dentate on the anterior side. Texture herbaceous; rachises often proliferous in the axils, castaneous, glossy, naked above, scaly beneath, the scales scattered, fibrillose, lanceolate from a hastate-ciliate base; surfaces naked; veins flabellate, subimmersed. Sori linear; indusium firm, whitish.

New Guineà.

(69c) A. insiticium, Erack, Expl. Exp., XVI, 161, tab. XXII, fig. 2 .

Stipes rather slender, $20-45 \mathrm{~cm}$. long, generally fibrillose. Fronds oblong-lanceolate, $25-50 \mathrm{~cm}$. long, 2-pinnate in the lower part, the rachis flbrillose, compressed and often proliferous below the apex. Pinnae $\pm 10-15$ on a side, patent, the lowest $\pm 7 \frac{1}{2}-12 \frac{1}{2} \mathrm{~cm}$. long by $2 \frac{1}{2}-4$ $\mathrm{cm}$. broad, pinnate towards the base, the upper basal pinnule parallel to the main rachis. Pinnulae stalked, ovate-rhomboidal or oblong, $3-5$ below the pinnatifid upper part, $\pm 2-2^{1 / 2} \mathrm{~cm}$. long by $\pm 1-1^{3 / 4} \mathrm{~cm}$. broad, with a broadly cuneate or abscisso-truncate base, obtuse, bluntly toothed or serrate. Texture chartaceous; upper surface inpresso-striate between the veins; veins oblique. Sori $6-7$ to a pinnule, reaching costa and margin, those of the pinnatifid portion of the pinnules similar to those of A. pseudofalcatum Hillebr.

Luzon to Polynesia, Hawaii.

(70a) A. Gracilifolium, Copel, in Philipp. Journ., IV ; 113.

Rhizome short. Stipes close, up to $10 \mathrm{~cm}$. long, castaneous, glossy, clothed with narrow, thin, castaneous scales, as is the rhizome, at length glabrescent. Fronds $15-25 \mathrm{~cm}$. long, $2 \frac{1}{2}-3^{1 / 2} \mathrm{~cm}$. broad, acuminate, 2-pinnate. Pinnae stalked, ovate, obtuse. Pinnulae of the largest pinnae $1-2$ on the anterior side, 1 on the posterior side, flabellato-cuneate, up to 8 $\mathrm{mm}$. long and $6 \mathrm{~mm}$. broad, the apex rounded, slightly inciso-crenate with obtuse lobes. Texture herbaceous; surfaces naked; rachis castaneous in the lower part, greenish and winged in the upper part, sometimes proliferous in the wing; venation lax. Sori short, not near the margin; indusium broad, pale.

Luzon. 
(72) A. nitidum, Sw.; Schk., Krypt. Gew., I, tab. 81.

\section{(74) A. affine, Sm.}

Forma typica: Secondary and tertiary segments rather crowded.

Forma spathulina: Secondary and tertiary segments rather lax.

(74a) A. glavcophyllum, v. A, v. Re, in Bull. Btz., 1912, VII, 6; A. nitidum, Christ. (not Sw.), in Ann. Btz., XX, 111.

Fronds larger, 2-pinnate, the rachises blackish-grey. Pinnae spreading or horizontal, short-stalked, alternate, subfalcate, linear-lanceolate, \pm $20-35 \mathrm{~cm}$. long, $6-12 \mathrm{~cm}$. broad at or near the base, gradually acuminate towards the apex. Pinnulae numerous, close; lateral pinnulae rhomboidal, irregularly inciso-crenate, coarsely toothed towards the apex, broadly cuneate or truncate on the upper side at the base, cuneate on the lower side; largest pinnulae $\pm 6 \mathrm{~cm}$. long, $3 \mathrm{~cm}$. broad near the base, straight or falcate, very acute or acuminate at the apex, often with a short auricle-like lobe on the upper side at the base; smallest pinnulae blunt or rounded at the apex; terminal pinnulae elongate-deltoid, coarsely toothed towards the apex, pinnatifid at the base, the lobes rather imbricate, truncate or rotundate-truncate and coarsely crenate or crenate-dentate at the apex. Texture coriaceous; surfaces opaque, glaucous, naked like the rachises. Sori long, linear, the lower radiating or subradiating; indusium narrow, pale-brown.

Borneo.

\section{§ 4. DAREA.}

(77) A. Lauterbachii, Christ; C. Chr., Ind. Fil., Suppl.; $A$. obtusilobum, Hk., Hk. Bk., Syn. Fil., 221; Hk., Icon. Pl., X, tab. M; $A$. oceanicum, C. Chr., Ind. Fil.

Rachis and surfaces purveyed with some scattered, deciduous, black bristles.

Two forms which may be found on the same rhizome:

Forma typica: See the description of A. Lauterbachii C. Chr in my handbook, p. 473.

Forma obtusiloba: See the description of A, obtusilobum Hk. in my handbook, p. 474. 
(79) A. obtusilobum, Hk.

Omit this, it is a form of A. Lauterbachii Christ.

(80) A. Helangeri, Kre; - var. acuminatum, Rst., in Fed., Rep., $\mathrm{V}, 373$.

Fronds $\pm 5-15 \mathrm{~cm}$. broad; pinnae horizontal or nearly so, sometimes somewhat deflexed, blunt to acute or acuminate. - Very variable.

Var. acuminatum: Pinnae narrow, elongate, to $12 \mathrm{~cm}$. or more long, 8-10 $\mathrm{mm}$. broad above the base; segments arcuate-incurvate, very oblique, imbricate; several lower segments forked. - Rhizome, stipes and lower half of the fronds unknown. - Perhaps a distinct species. New Guinea.

(81a) A. impressivenium, v. A. v. R.. in Bull. Btz., 1915, XX, 8.

Rhizome probably scandent, obtusely angular, sparingly dark-fuscosquamulose. Stipes remote, about $15 \mathrm{~cm}$. long, provided like the rachises beneath with scattered dark-fuscous, ovate-lanceolate, acute, sparingly denticulate-fimbriate paleae. Fronds elongate-ovate, $30-40 \mathrm{~cm}$. long, 8-12 cm. broad, acuminate, 3-pinnatifid, the main rachis winged in the upper part. Pinnae many, shortly petiolulate, lanceolate, straight or falcate, bluntly. acuminate, the rachis winged; largest pinnae horizontal or nearly so, sparingly and coarsely toothed at the apex, $1_{12}^{1 /}-2 \mathrm{~cm}$. broad. at the base; higher pinnae growing gradually smaller and more ascending; lowest pinnae somewhat abbreviated, deflexed. Pinnulae elose, the higher oblique, subcuneate, $1 \frac{1}{2}-2 \mathrm{~cm}$. broad, simple or sparingly and shallowly 2-3-lobed at the obliquely rotundate-truncate apex, the lower horizontal or nearly so, rhomboidal-oblong, sparingly incised, i. e. partly shallowly lobed partly pinnatifid. Ultimate lobules close, oblique, blunt, the lowest anterior the longest, similar to the higher pinnulae but shorter. Texture subcoriaceous; costae and costulae prominent above; veins above slightly prominent or rather depressed and provided at the apex with a short, linear impression; surfaces naked. Sori linear or linear-oblong; indusium coriaceous, pale-yellow-brown. - The whole plant when dry pale-olivaceous, subglaucous.

New Guinea.

(81b) See under No. 29. 
(81a) A. dubium, Krack., Expl. Exp., 172; A. rhizophyllum, $K z e$, Hk. Bk., Syn. Fil., 220, p. p.

Rhizome creeping, black. Stipes scattered, angular, sparingly hirsutopaleaceous. Fronds small, deltoid-ovate, 2-3-pinnate. Pinnae subopposite, spreading, lanceolate-oblong; pinnulae linear-oblong, inciso-pinnatifid; laciniae linear, obtuse. Texture membranaceous; surfaces naked. - The proper place of this species is uncertain because of incomplete description. New Guinea; Polynesia.

\section{§ 5. LOXOSCAPHE.}

(82c) A. Sehultzei, Brau., in Lautb., Beitr. Flor. Pap., I, 31.

Fronds lanceolate, $\pm 75 \mathrm{~cm}$. long, $\pm 40 \mathrm{~cm}$. broad, compound. Pinnae short-stalked, lanceolate, to $20 \mathrm{~cm}$. long, to $8 \mathrm{~cm}$. broad; lower pinnae to $\pm 8 \mathrm{~cm}$. apart, abbreviated, higher less remote. Pinnulae long-triangular, very long-acuminate, unequal-sided, broadest on the upper side at the base, the largest $\pm 5 \mathrm{~cm}$. long by $13 / 4 \mathrm{~cm}$. broad, $\pm 2 \mathrm{~cm}$. apart; lowest pinnulae horizontal, following oblique. 亡ower tertiary segments 2-pinnatifid; lobes narrowly linear, hardly $2 \frac{1}{2} \mathrm{~mm}$. long, dilated and 2-fid at the apex. Texture herbaceous; rachises anb surfaces naked; veins forked in the lobes. Sori subterminal on the lobes, occupying the longest veinlet; indusium semiovate, opening towards the shortest veinlet.

New Guinea.

\section{PHYLLITIS, Ludevig.}

\section{§1. SCOLOPENDRIUM.}

a. Sori separated by a distinct, elevated ridge at the place where the free edges of the indusia meet when young.

(5) $\mathrm{Ph}$. longifolia.

a.a. Sori without an intermedial ridge, at best separated by a fine spurious veinlet.

b. Rhizome short-creeping or erect.

(4) Ph. schizocarpa.

b.b. Rhizome wide-creeping or scandent. 
c. Fronds of adult plants simple, sometimes incised.

(3a) Ph. d’Urvillei.

c.c. Fronds of adult plants pinnate.

(3b) Ph. Grashoffii.

(1) Ph. scolopendropsis, v. A. v. R.

Omit this, it being referred to $\mathrm{Ph}$. d'Urvillei 0 . Ktze.

(2) $\mathrm{Ph}$. intermedia, $v, A, v . R$.

Omit this, it being refered to $\mathrm{Ph}$. d'Urvillei 0 . Ktze.

(3) Ph. mambare, v. A. v. R.

Omit this, it being refered to $\mathrm{Ph}$. d'Urvillei 0 . Ktze.

(3a) Ph. d'Urvillei, o. Ktze, Copel., in Philipp. Journ., VIIIC, 153; Ph. scolopendropsis, v. A. v. R., in Bull. Dép. Agr. I. N., 1908, XXI, 6; Ph. mambare, v. A. v. R., l. c.; Ph. intermedia, v. A. v. R., l. c.; Bull. Btz., 1911, I, 11, tab. IV, fig. 1; Ph. linza, v. A. v. R., 1. c., 12; Stenochlaena sorbifolia, J. Sm., var., C. Chr., Ind. Fil.; Diplora integrifolia, Bk., Hk. Bk., Syn. Fil., 492; Scolopendrium Durvillaei, Bory, in Dup., Voy. bot., I, 273, tab. XXXVII, fig. 1; Hk. Bk., 1. c., 247; Kze, Farnkr., I, tab. V; Sc. mambare, Bail., in Queensl. Agr. Journ., III ${ }^{2}$, 162; Asplenium scolopendropsis, Muell., Pap. Pl., III, 49; A. Linza, Ces., Fel. Bece. Polin., 4, 7; Triphlebia Linza, Bk., in Becc., Mal., III, 42, tab. V; Tr. dimorphophylla, Bk., l. c., tab. IV; Diels, in Engl. \& Prantl, Nat. Ptl. fam., I ${ }^{4}$, fig. $122 C-D$.

Rhizome wide-creeping, often angular, naked or sparingly minutely appresso-squamulose. Stipes scattered, apparently articulate at the base, \pm 5-10 cm. long, naked or sparingly minutely appresso-squamulose. Fronds lanceolate, $\pm 15-45 \mathrm{~cm}$. long, $\pm 1 \frac{1}{2}-5 \mathrm{~cm}$. broad, narrowed gradually at both ends, the apex acuminate to finely caudate, the edge entire, or whether or not irregularly crenate, toothed, repand or sinuate. Texture membranaceous to chartaceous; surfaces naked; costa distinct; veins simple or forked, oblique to subhorizontal. Sori in pairs, long but not always reaching the costa or margin, those of each pair not rarely separated by a pellucid space often provided with a very fine intermedial spurious veinlet. - Fronds of the young plants, polymorphous, i. $\Theta$. varying from variously (often irregulariy) divided to invariably simple in age

Borneo, Obi, Papua to Polynesia. 
(3b) Ph. Crashofiii, Rst., in Fed., Rep., XIII, 216.

Rhizome scandent, woody, the extremity clothed with minute, ovatelanceolate, black-brown, pale-margined, denticulate scales. Stipes firm, \pm $20 \mathrm{~cm}$. long, scaly, as are the rachis and costae. Fronds $\pm 40 \mathrm{~cm}$. long by $20 \mathrm{~cm}$. broad, pinnate. Pinnae, 3-4 (or more?) on each side below the terminal one; lateral pinnae ascending, short-stalked, trapezoidal-subfalcate, acuminate, crenulate, the upper base truncate-rotundate, the lower base cuneate; lowest pinnae $\pm 15 \mathrm{~cm}$. long by $4 \mathrm{~cm}$. broad, the others as large or the higher somewhat smaller and the terminal one somewhat larger. Texture herbaceo-chartaceous; surfaces naked or somewhat scaly near the costae; costae slender; veins fine, immersed, the lower once to thrice forked, the higher simple. Sori long, reaching costa and margin, intermixed with a few shorter ones, those of each pair approximate, \pm $1 \mathrm{~mm}$. apart; indusium membranaceous.

Sumatra.

(4) Ph. schizocarpa, ข. A. ข. $\mathrm{R}$.

Also in New Guinea.

(5) P. Iongifolia, o. Ktae, Copel., in Philipp. Journ., VIIIC, 153; Ph. pinnata, O. Ktze; Triphlebia longifolia \& pinnata, Bk., in Becc., Mal., III, 41, 42; Tr. pinnata, Bk., Hk., Icon. Pl., XVII, tab. MDCLII; Scolopendrium longifolium, Pr., Rel. Haenk., I, 48, tab. IX, fig. 1; Sc. pinnatum, J. Sm., Hk. Bk., Syn. Fil., 247; Kze, Farnkr., I, tab. LVI.

Stipes compressed, greyish or blackish, naked or sparingly scaly. Fronds $50-120 \mathrm{~cm}$. long, with 1-6 pinnae on each side below the terminal one. Pinnae lanceolate, acuminate or caudate, $10-20 \mathrm{~cm}$. 1ong, $1 \frac{1}{2}-5$ $\mathrm{cm}$. broad, entire or more or less irregularly repando crenate; terminal pinna proliferous at the point; lateral pinnae erecto-patent, the highest decurrent, whether or not subconfluent, the lower short-stalked, obliquely cuneate at the base. Texture firm-membranous or subcoriaceous; surfaces naked; veins oblique, mostly once forked. Sori numerous, not reaching either the midrib or the edge, those of each pair approximate with the indusia reaching each other with the free edges when young, at length leaving a distinct, elevated lamelliform crest on the frond medial between the 2 sori. - The young plants have the fronds simple though not rarely fructiferous.

Celebes (?), Philippines to Papua. 
57. TRIPHLEBIA, Baker.

(1) T. linza, $B k$.

Omit this species, it being referred to Phyllitis d'Urvillei 0. Ktze.

(2) T. longifolia, $B k$.

Omit this species, it being referred to Phyllitis longifolia 0 . Ktze.

(3) T. pinnata, Bk.

Omit this species, it being referred to Phyllitis longifolia 0 . Ktze.

(4) T. dimorphophylla, $B k$.

Omit this species, it being a young form of Phyllitis d'Urvillei O. Ktze.

\section{MONACHOSORUM, Tunze.}

M. subdigitatum, Kuhn; $M$. Davallioides, Kze, Farnkr., I, tab. CT.

\section{0\%, PHEGOPTERIS, Fée.}

\section{§ 1. EUPHEGOPTERIS.}

(*1) Ph. melanolepis, v. A. ז. ז., in Bull. Btz., 1914, XVI, 25 ; Dryopteris melanolepis, v. A. v. R., MS. in Herb. Bog.

Rhizome erect, the scales long, lanceolate-subulate, entire, blackish. Stipes $\pm 45 \mathrm{~cm}$. long, scaly, the scales blaskish, scattered, the higher nearly subulate-filiform, the lower more resembling those of the rhizome. Fronds lanceolate-ovate, $\pm 45 \mathrm{~cm}$. long by $20 \mathrm{~cm}$. broad, acuminate, pinnate. Pinnae several; terminal pinna subtriangular, very deeply pinnatifid at the base, lobate-dentate towards the apex; lateral pinnae sessile, elongateoblong, sublanceolate, acuminate, coarsely toothed (lobate-dentate), truncate or subtruncate and often sub-2-auriculate at the base; central pinnae largest, $\pm 13 \mathrm{~cm}$. long, $3-3 \frac{1}{2} \mathrm{~cm}$. broad, subspreading or arcuateascending; lowest pinnae \pm horizontal, smaller. Ultimate segments (teeth) oblique, to $4 \mathrm{~mm}$. deep and $6 \mathrm{~mm}$. broad, blunt to apiculate, subentire. Texture herbaceous; rachis rather scaly, the scales scattered, blackish, 
hair-like, the lower more resembling those of the stipe; surfaces naked; costae beneath sparingly piloso-squamulose, glabrescent; main veins fine, flexuose, pinnate; veins free, $2-4$ on a side, alternate, subparallel to the main veins. Sori round, in 2-3 irregular rows on each side of the costae, inframedial on the lower veins.

Sumatra.

(1a) Ph. Moussetii, v. A. ש. R.; Dryopteris Moussetii, Rst., in Fed., Rep., VIII, 278; C. Chr., Ind. Fil., Suppl.

Rhizome erect. Stipes slender, $\pm 15 \mathrm{~cm}$. long, slightly pubescent, clothed with flaccid, ferrugineous, narrowly lanceolate, somewhat ciliate scales. Fronds up to $65 \mathrm{~cm}$. long, $12 \mathrm{~cm}$. broad, elongate-lanceolate, pinnate, the base truncate, the upper part pinnatifid or lobed, long-acuminate, the apex crenate. Pinnae subopposite, spreading, the higher and central ones adnate, the lower ones sessile or short-stalked; central pinnae largest, up to $6 \mathrm{~cm}$. long, $1-1 \frac{1}{2} \mathrm{~cm}$. broad at the base, subapproximate, lanceolate, acuminate, straight or somewhat falcate, the lower part cut $1 / 2$-way down or more to the costa into shortly linear, somewhat oblique, entire lobes which are repando-crenulate at the obtuse apex, the apex subrepand; lower pinnae somewhat shorter and broader, to $4{ }_{2}^{\prime} \mathrm{cm}$. apart; higher pinnae decurrent, confluent at the base. Texture thinly herbaceous; colour yellowish-green; upper surface nearly naked or with a few subadpressed, subulate hairs, lower provided with long, straight, hyaline hairs and short-stalked, globose, yellow glands; rachises brown, hirsute above, sparingly setulose beneath; main veins pinnate in the lobes; veins $3-5$ on each side, simple, or those of the lower lobes forked. Sori $1-3$ on each side, nearer the margin than the main veins, occupying the lower veins; capsules sometimes provided with $1-2$ hairs.

Java.

(1b) Ph. schizoloma, v. A. v. R., in Bull. Btz., 1914, XVI, 24; Dryopteris schizolomia, v. A. v. R., MS, in Herb. Bog.

Stipes purple-brown, $22 \mathrm{~cm}$, more or less long, deciduously fibrillose= tomentose, as is the rachis, at length glabrescent and rather glossy, the pubescence (hairs) rather dense, ferrugineous or fuscous, articulated. Fronds ovate-oblong, 2-pinnatifid, deeply pinnatifid towards the entire or toothed, acuminate point. Barren fronds $\pm 40 \mathrm{~cm}$. long $\pm 25 \mathrm{~cm}$. broad at or near the base; pinnae subremote, to $15 \mathrm{~cm}$. long, the higher linear, sub. 
erecto-patent, $\pm 1 \frac{1}{\mathrm{~cm}}$. broad, adnate, or sessile and truncate at the base, the edge cut $\pm 1 / 2$-way down to the costa, the apex subcaudateacuminate and entire or crenate, the lowest pinnae sublanceolate, horizontal, spreading or deflexed, short-stalked, unequal-sided, $\pm 4 \mathrm{~cm}$. broad at the middle, deeply pinnatifid, the central anterior lobes produced; lobes oblong to linear-oblong, oblique, separated by narrow, subacute sinuses, the shortest, $\pm 3 \mathrm{~mm}$. each way, blunt and entire, the longest $\pm 21 / 2 \mathrm{~cm}$. long and $1 / 2 \mathrm{~cm}$. broad, bluntish, bluntly toothed. Texture herbaceous, thin; both surfaces articulato-fibrillose; costulae pinnate in the lobes; veins simple and at least 3 on each side in the smaller lobes, often forked or twice forked and to \pm 12 on each side in the longer lobes. Fertile fronds similar but smaller and contracted, the pinnae more distant, the lobes more distant and separated by broader, more rounded sinuses. Sori submarginal, terminal on the veins or veinlets.

Borneo.

(2a) Ph. quadriaurita, v. A. $\boldsymbol{v}$. R.

Also in Negros, New Guinea.

(2c) Ph. oppositipinna, v. A. v. R., in Bull. Btz., 1914, XVI, 24 ; Dryopteris oppositipinna, v. A. v. R., MS. in Herb. Bog.

Rhizome short. Stipes aggregate, $\pm 15-25 \mathrm{~cm}$. long, brown when dry, as is the rachis, deciduously pilose, slightly asperulous and sparingly deciduously scaly towards the base. Fronds lanceolate, $\pm 35-40 \mathrm{~cm}$. long, $\pm 10-15 \mathrm{~cm}$. broad, acuminate, pinnate, deeply pinnatifid towards the apex; rachis rusty-tomentose above, deciduously pilose beneath. Pinnae several, opposite, horizontal or spreading, straight or subfalcate; higher pinnae broadly adnate; central pinnae longest, sublanceolate-subulate, sessile, $\pm 1-1^{1} \frac{1}{2} \mathrm{~cm}$. broad at the truncate base, narrowed gradually towards the entire or crenate, acuminate apex, the edge cut $1 / 2$-way down or more; lower pinnae similar but shorter, broader at the base, more deeply pinnatifid. Lobes oblong, blunt, rounded or truncate at the apex, separated by narrow, acute sinuses, entire or crenate, nar. rowly revolute at the edge, $\pm 3-4 \mathrm{~mm}$. broad at the base. Texture firm; costae, costulae and veins more or less copiously or sparingly puberulous above, setoso-pilose beneath; costulae pinnate in the lobes; veins $\pm 4-6$ on a side, forked. Sori round, rather small, medial or higher on the veins; capsules pilose.

\section{Sumatra.}


(2d) Ph. Schlechteri, v. A. v. R.; Dryopteris Schlechteri, Brau., in Lautb., Beitr. Flor. Pap., I, 16, fig. 1 E; C. Chr., Ind. Fil., Suppl.; var. djamuensis, Brau., 1 c., 18.

Stipes to $35 \mathrm{~cm}$. or more long, fuscous, grooved on the inner side, glossy, glabrescent. Fronds subtriangular, $\pm 75 \mathrm{~cm}$. long by $\pm 56 \mathrm{~cm}$. broad, abruptly acuminate. Pinnae \pm 15 on each side below the terminal one, deeply pinnatifid; lateral pinnae alternate, linear-lanceolate, the higher sessile, approximate, the others stalked, the lower distant, horizontal, the largest $\pm 28 \mathrm{~cm}$. long by $6 \mathrm{~cm}$. broad, with the apex long-acuminate, repand. Lobes to 36 on a side, linear, to $\pm 3 \mathrm{~cm}$. long, $5 \mathrm{~mm}$. broad, separated by acute sinuses, ciliate when young, acuminate, entire, the lowest abbreviated, the following often shorter than the higher, the lower anterior horizontal, the higher anterior spreading, falcate, the posterior spreading, falcate. Texture chartaceous; surfaces naked; upper surface dark-green, lower paler, verruculose; rachis glabrescent, when young provided with brown, adpressed, linear scales; costae sparingly hairy above; costulae hairy beneath, the hairs rufous; veins to 25 on a side, simple. Sori to 14 on a side, costular, not occupying the higher and lower veins.

Van. ljamuensis: Under surface smooth; segments a little narrower; apices more acute; sori subcostular.

New Guinea.

(3) Ph. Smithii, $v, A, v$. R.

Omit this, it being referred to Dryopteris Beddomei O. Ktze.

(3a) ? Ph. finisterrae, v. A. v, R.; Dryopteris Finisterrae, Brau., in Lautb., Beitr. Flor. Pap., I, 20; C. Chr., Ind. Fil., Suppl.

Rhizome ascending, naked. Stipes tufted, fuscous, $\pm 20 \mathrm{~cm}$. long, when young ferrugineo-paleaceous, the base provided with short, pale scales. Fronds subdeltoid, $\pm 45 \mathrm{~cm}$. long and $15 \mathrm{~cm}$. broad, acuminate. Pinnae \pm 18 on each side below the pinnatifid apex, subsessile, distant, the 5-6 lower suddenly reduced to mere auricles, the longest linear, spreading, $\pm 7 \frac{1}{2} \mathrm{~cm}$. long, under $1 \mathrm{~cm}$. broad, deeply pinnatifid, the apex long-acuminate, repand. Lobes to 18 on a side, oblique, linear, obtuse, crenate. Texture chartaceous; surfaces, rachis, costae and costulae minuttely hairy; upper surface dark-green, lower paler; veins simple, oblique, $4-6$ on a side. Sori numerous, to 6 on a side, medial; capsules setose.

New Guinea. 
(6a) Ph. polita, v. A. v. R.; Dryopteris potitu, Rst., in Fed., Rep, XIII, 218.

Rhizome erect, densely clothed with firm, brown, linear-lanceolate, sparingly fimbriated scales. Stipes tufted, stramineous-brown, naked, sparingly scaly towards the base. Fronds lanceolate-oblong, to $30 \mathrm{~cm}$. or more long, $\pm 15 \mathrm{~cm}$. broad below the middle, 2-pinnate, sub-3-pinnatifid, acuminate. Pinnae 7-10 on each side below the pinnatifid apex, ascending, the lower distant, stalked, the higher subapproximate, adnate with a decurrent base; largest pinnae $\pm 15 \mathrm{~cm}$. long by $31 / 2 \mathrm{~cm}$. broad, lanceolate-oblong, pinnatifid towards the acuminate, crenate-serrate apex, pinnate towards the base; lowest pinnae shorter, produced on the lower side. Segments slightly crenate, denticulate at the blunt apex, the largest deeply lobed, the lower petiolulate, the following sessile with a contracted base, the higher gradually adnate with a decurrent base and finally confluent. Texture subcoriaceo-chartaceous; surfaces naked like the rachis; veins prominent, simple, forked or pinnate. Sori medial.

Sumatra.

(8a) Ph. Engleninas, v. A. v. R.; Dryopteris Engleriana, Brau, in Lautb., Beitr. Flor. Pap., I, 19; C. Chr., Ind. Fil., Suppl.

Rhizome erect. Stipes tufted, $\pm 16 \mathrm{~cm}$. or more long, fuscous, grooved down the face, sparingly hairy and scaly, as is the rachis, the base densely scaly, the scales fuscous, glossy, elongate-deltoid, toothed. Fronds lanceolate, to $\pm 50 \mathrm{~cm}$. long, $\pm 16 \mathrm{~cm}$. broad, acuminate, 2-pinnatifid, not narrowed at the base. Pinnae remote, $\pm 14-16$ on each side below the pinnatifid apex, short-stalked, linear-lanceolate, spreading, upcurved, deeply pinnatifid, the apex acuminate, repand; largest pinnae $\pm 10^{1 / 2} \mathrm{~cm}$. long and $1^{1}{ }_{2} \mathrm{~cm}$. broad; 2-3 lower pinnae deflexed. Lobes falcate, to 20 pair, to $1 \mathrm{~cm}$. long and $3^{3 / 4} \mathrm{~mm}$. broad, bluntish, slightly crenated, the lowest often remote and separated. Texture papyraceous; surfaces naked; upper surface dark-green, lower paler; costae hairy above; veins indistinct, naked, simple, to 7 on a side. Sori numerous, to 7 on a side, the lower medial, the following gradually subcostular.

New Guinex.

(9a*) Ph. hypolepioides, v. A. v. R.; Dryopteris Inypolepioides, Rst., in Fed., Rep., XII, 175.

Stipes black-brown, punctate-asperulous, clothed with articulate and 
narrowly lanceolate, curved, reddish-brown squamules. Fronds elongateovate, to $40 \mathrm{~cm}$. or more long, $\pm 14 \mathrm{~cm}$. broad below the middle, 3 pinnatifid, the apex acuminate, toothed, the base slightly narrowed. Pinnae \pm 20 on a side, alternate; central and lower pinnae upcurved in the upper part; largest pinnae $\pm 10 \mathrm{~cm}$. long by $2 \frac{1}{2} \mathrm{~cm}$. broad; lower pinnae a little abbreviated, the lowest opposite. Pinnulae to \pm 18 on a side, subremote, nearly horizontal, linear-oblong, obtuse, deeply pinnatifid, truncate or cuneate at the base. Lobes oblong, subentire, obliquely decurrent, the lowest contracted at the base. Texture herbaceous; surfaces naked; under surface paler than the upper; rachis and costae like the stipe; veins simple. Sori numerous, $1-3$ on a lobe, remote from the margin, at length confluent.

New Guinea.

(12a) Ph. banajacensis, v. A. v. R.; Dryopteris tenerrima, Copel., in Philipp. Journ., IVC, 111; D. banajaoensis, C. Chr., Ind. Fil., Suppl.

Rhizome erect. Stipes $\pm 20 \mathrm{~cm}$. long, close, blackish, succulent, slender when dry, the base thickened in fresh material, clothed with small, bright-brown, ciliated squamules. Fronds up to $25 \mathrm{~cm}$. long and $15 \mathrm{~cm}$. broad, subdeltoid, 3-pinnatifid. Lower pinnae short-stalked, acuminate, produced on the lower side at the base. Pinnulae sessile, mostly obtuse, the lowest posterior ones the largest, cut down to a narrow wing into oblong, obtuse, inciso-crenate lobes. Texture thinly membranaceous; rachis and surfaces naked; colour black-green when dry; veins simple. Sori medial, small, subglobose.

Luzon, Mindanao.

(15a) Ph. heterolepia, v. A. v. $\boldsymbol{R}$., in Bull. Btz., 1914, XVI, 23; Dryopteris heterolepia, v. A. v. R., MS. in Herb. Bog. — var. remota, v. A. v. R., 1. c., 24.

Stipes $\pm 40-60 \mathrm{~cm}$. long, pale-brown when dry, copiously provided like the rachis with pale-brown, entire, subulate-linear scales with a dark-brown, streak-like, persistent, transversal base, the lower scales dense, long, intermixed with shorter ones, the higher scattered, growing gradually shorter and nearly filiform, intermixed with a few larger ones. Fronds triangular-lanceolate, $\pm 45-65 \mathrm{~cm}$. long, $\pm 30-45 \mathrm{~cm}$. broad at or above the base, deeply and copiously 3-pinnatifid, acuminate. Pinnae olose, short-stalked, horizontal, opposite or nearly so, straight or sub- 
falcate, triangular-lanceolate, the largest $\pm 8 \mathrm{~cm}$. broad at or above the base, acuminate, the rachis provided with short, scattered, narrowly linear scales, as are the costae. Pinnulae elose, horizontal, subsessile, the largest $\pm 1 \frac{1}{2}-3 \mathrm{~cm}$. broad at or near the base, acuminate, eut down nearly to the costa. Lobes close, spreading, subquadrangular-oblong, $\pm 4-5 \mathrm{~mm}$. broad, blunt or truncate, slightly revolute at the edge, subentire and confluent at the base, or the lower coarsely crenate to lobate-crenate and subtruncate (but not free) at the base. Texture firm; surfaces naked; veins $4-6$ on each side in the largest lobes, the higher simple, the others forked or twice forked. Sori medial.

Forma typica. - Java.

Var. remota: At least the lower pinnae, pinnulae and lobes conspicuously remote, the rachises less squamulose, often glabrous. - Sumatra.

(17) Ph. punctata, Mett.

Omit this, it being referred to Hypolepis punctata Mett.

(20) Ph. distans, Mett.; Dryopteris microstegia, Rst., in Fed., Rep., X, 334; Nephrodium microstegium, Hk., Spec. Fil., IV, tab. CCL.

Fronds sometimes more elongated, lanceolate, with the lower pinnae more reduced; pinnulae (secondary segments) close or remote, blunt or acute, at least the lowest pinnatifid, often close to the rachis and not rarely more or less elongated; lower sori often more or less oblong.

(21a) Ph. atrovinidis, v. A. v. R., in Bull. Btz., 1914, XVI, 26; Dryopteris atroviridis, v. A. v. R., MS. in Herb. Bog.

Stipes $\pm 80 \mathrm{~cm}$. long, grey-brown, deciduously shortly fibrillosotomentose, somewhat scaly towards the base, at length naked. Fronds 3-pinnatifid, $\pm 60-70 \mathrm{~cm}$. broad. Pinnae close; central pinnae spreading, short-stalked, lanceolate-oblong, $\pm 30-35 \mathrm{~cm}$. long, $\pm 8-10 \mathrm{~cm}$. broad at or near the truncate base, acuminate; lowest pinnae shorter, rather deflexed. Pinnulae numerous, the largest horizontal or nearly so, sessile or subpetiolulate, $11_{i_{2}}-2 \mathrm{~cm}$. broad at or near the truncate base, cut down to the costa into horizontal or nearly horizontal, entire or toothed, linear-oblong segments $3-4 \mathrm{~mm}$. broad and truncate or rounded at the apex, slightly dilated at the base. Texture modarately firm-herbaceous; surfaces naked, at best shortly pubescent on the costae and costulae; upper surface very dark, rather blackish, under surface somewhat paler; rachises fibrilloso-tomentose, partly glabrescent; veins simple or forked, 
$\pm 5-6$ on a side. Sori small, medial on simple veins or veinlets or in the forking of the veins.

Sumatra.

\section{§ 2. LEPTOGRAMMA.}

(*22) Ph. gymnosrammoides, v. A. v. $\boldsymbol{R} . ;$ Nephrodium gymnogrammoides, Diels, in Engl. \& Prantl, Nat. Pfl.fam., I ${ }^{\ddagger}, 170$; Dryopteris gymnogrammoides, C. Chr., Ind. Fil.; Polypodium gumnogrammoides, Bk., in Journ. of Bot., XXVI, 229; ? Currania gracilipes, Copel., in Philipp. Journ., IV', 112.

Rhizome slender, creeping. Stipes distant, stramineous-green, slender, fragile, up to $20 \mathrm{~cm}$. long. Fronds oblong- or cordate-deltoid, to $15 \mathrm{~cm}$. long to $7 \frac{1}{2} \mathrm{~cm}$. broad, deeply pinnatifid. Lobes lanceolate, connected by a narrow wing $\pm 4-5 \mathrm{~mm}$. broad, straight, the lowest deflexed, crenate. Texture membranaceous; both surfaces naked, green; veins pinnate with 2 pair of ascending veinlets Sori linear or oblong, to $3 \mathrm{~mm}$. long, in 1 row on each side of the costulae, - A specimen from Yunnan, occurring in Dr. Christ's herbarium, agrees with the description of Currania gracilipes Copel., which has the rhizome clothed at the extremity with dirtycoloured lanceolate scales, the fronds up to $9 \mathrm{~cm}$. long, to $51 / 2 \mathrm{~cm}$. broad, with the lobes broadly oblong, obtuse, serrate, the lowest lobes falcate, the texture papyraceous when dry, the veins forked, with the lowest fork branch often forked again, free, or the fork branches of the lowest acroscopical veins anastomosing, the sori placed in $1-2$ rows on each side of the costulae.

Luzon (?); China.

(*22 P) Ph. oyamencis, v. A. v. R.; Dryopteris genuflexa, Rst., in Fed., Rep., XII, 175; D. oyamensis, C. Chr., Ind. Fil.; Polypodium oyamense, Bk., in Journ. of Bot., XV, 366; Currania oyamensis, Copel., in Philipp., Journ., VIC, 147.

Rhizome creeping, branched, the scales ferrugineous, lanceolate, shortly acuminate, glanduloso-fimbriate at the edge. Stipes $10-15 \mathrm{~cm}$. long, flexuose, stramineous, provided with scattered, short, gland-like hairs. Fronds deflexed at the base, lanceolate-deltoid, $\pm 12 \mathrm{~cm}$. long by $6 \mathrm{~cm}$. 
broad, deeply pinnatifid, acuminate, the point blunt, the base cordate. Lobes \pm 12 on a side, spreading, linear, to $3 \mathrm{~cm}$. long by $1 \frac{1 / 2}{\mathrm{~cm}}$. broad, separated by narrow sinuses, obtuse, serrate, the teeth serrate again; lower lobes largest, somewhat deflexed. Texture membranaceo-herbaceous ; surfaces naked; costa grooved above, somewhat prominent below; costulae flexuose ; veins leaching the margin, once or twice forked, the lower pinnate. Sori oblong, medial.

New Guinea; Japan, China.

(22) Ph. tottn, Mett.; Gymnogramma Totta, Schl., Bl., Flor. Jav., II, tab. XXXVII.

(22a) Ph. uncidens, v. A. v. R.; Dryopteris uncidens, Rst., in Fed., Rep., X, 337; C. Chr., Ind. Fil., Suppl.

Rhizome erect; scales dense, lanceolate, ferrugineous, long-acuminate, denticulate, the teeth spreading, red-brown, often hamato-2-fid at the apex. Stipes tufted, to $30 \mathrm{~cm}$. long, stramineous-brown, densely scaly towards the base, less so in the upper part. Fronds deltoid-ovate, to \pm $40 \mathrm{~cm}$. long, nearly $30 \mathrm{~cm}$. broad, shortly acuminate, pinnate. Pinnae \pm 60 on a side below the terminal one, subopposite or alternate, nearly horizontal, subapproximate; largest pinnae petiolate, linear-lanceolate, to $15 \mathrm{~cm}$. long, $5 \mathrm{~cm}$. broad, acuminate, deeply pinnatifid, nearly pinnate at the base; lower pinnae shorter, ovate at the base, following obliquely truncate at the base; terminal pinna lobed at the base, serrate towards the apex. Lobes \pm 12 on a side in the larger pinnae, spreading, linearoblong, to $2 \frac{1}{2} \mathrm{~cm}$. long, $3 / 4 \mathrm{~cm}$. broad, obtuse, crenate, separated by subacute sinuses. Texture firm-herbaceous; colour brownish-green; rachis, costae and costulae scaly, the scales scattered, floccose; veins naked, forked, the higher simple. Sori linear, subcostular.

New Guinea.

(23) Ph. opaca, Mett.; Athyrium opacum, Copel., in Philipp. Journ., III , 292; Diplazium opacum, Christ, C. Chr., Ind. Fil., Suppl.

(23a) Ph. gymmocarpa, v. A. v. R.; Dryopteris gïmnocarpa, Copel., in Leafl., III, 807; C Chr., Ind. Fil., Suppl.

Rhizome short-creeping. Stipes approximate, rather close, $\pm 1-2$ cm. long, scaly at the base, clothed like the rachis with crowded whitish 
hairs. Fronds lanceolate, $\pm 7-15 \mathrm{~cm}$. long, acuminate, the point blunt or bluntish, the upper part coarsely crenate or entire, the medial part deeply pinnatifid, with subentire lobes, the basal part pinnate. Pinnae oblong, blunt, coarsely or bluntly toothed, $\pm 1-1^{\prime}{ }_{4} \mathrm{~cm}$. long, $\pm 6-71 / 2$ $\mathrm{mm}$. broad near the base, the higher spreading, partly adnate partly sessile with a truncate-cuneate or rounded base, the central ones spreading, the lower subpetiolate or short-stalked, truncate or nearly cordate at the base, somewhat deflexed or spreading, as long as the central ones or somewhat shorter, slightly lobed or coarsely toothed. Texture thin; surfaces more or less hairy on the costae and veins; veins once or twice forked. Sori oblong, occupying the lower part of the veinlets, rather medial between the costa and margin.

Mindancio.

(23b) Ph. Elmeri, v. A. v. R.; Athyrium Elmeri, Copel., in Philipp. Journ., IIIC, 292 ; C. Chr., Ind. Fil., Suppl.; Dryopteris Elmeri, v. A. v. R., in Herb. Bog.

Rhizome suberect, crowned with lanceolate, fuscous scales. Stipes $\pm 10-20 \mathrm{~cm}$. long, paleaceous near the base. Fronds lanceolate, \pm $25-40 \mathrm{~cm}$. long, $8-20 \mathrm{~cm}$. broad. Pinnae acuminate, deeply pinnatifid, or at least the lower pinnate at the base, the lowest sometimes a little shorter than the next following. Lowest pinnulae subpetiolulate, the following narrowly adnate or decurrent, subentire or cut more than half-way down to the costa, nearly entire towards the apex. Texture membranaceous; surfaces naked. Sori short, irregular, subcostal.

Negros.

(23c) Ph. Ieptogramma, v. A. v. R., in Bull. Btz., 1915, XX, 21; Diplazium leptogramma, v. A. v. R., MS. in Herb. Bog.

Stipes stout, pale-brown, naked in the age but probably fibrillose when young, as are the rachises. Fronds more than $80 \mathrm{~cm}$. long when fully developed, $\pm 80 \mathrm{~cm}$. broad at the base, 3-pinnatifid. Pinnae horizontal or spreading; lowest pinnae largest, distant, stalked, $\pm 40 \mathrm{~cm}$. long. Pinnulae horizontal, lanceolate, the largest $\pm 9 \mathrm{~cm}$. long, $\pm 21 / 2$ $\mathrm{cm}$. broad at the truncate base, subpetiolate, long-acuminate, deeply pinnatifid in the lower part, toothed towards the apex, the acumen entire or crenulate. Lobes horizontal, approximate, linear-oblong, the lowest the 
largest, $\pm 1 \% \mathrm{~cm}$. long by $\pm 4 \mathrm{~mm}$. broad, serrate-crenate, truncaterotundate at the apex. Texture coriaceous; surfaces naked; costae beneath more or less deciduously fibrillose, above canaliculate with 2 interrupted lateral crests; veins to 8 on a side, forked at the middle, the higher simple. Sori numerous, the lower oblong, occupying the unbranched portion of the veins, the higher roundish, subcostular.

Java.

\section{§ 3. GONIOPTERIS.}

(25a) Ph. obtusifolin, v. A. v. R.; Dryopteris obtusifolia, Rst., in Fed., Rep., X, 336; C. Chr., Ind. Fil., Suppl.

Rhizome short-creeping; seales sparse, contort. Stipes $\pm 2-5 \mathrm{~cm}$. long, dirty-brown, grooved and strigose above, densely clothed beneath with short, adpressed hairs, as is the rachis. Fronds lanceolate, pinnate, acuminate. Pinnae \pm 8 on a side below the terminal one, alternate, subhorizontal, subsessile, oblong, the largest $\pm 1^{\prime}{ }_{2} \mathrm{~cm}$. long, 8-10 mm. broad, obtuse, subentire or slightly wavy, truncate or broadly cuneate at the base; terminal pinna lanceolate, pinnatifid at the base, subentire towards the acute apex; lower pinnae gradually reduced to mere auricles. Texture herbaceo-chartaceous; colour dark-green; upper surface sparingly, lower densely short-hairy; main veins \pm 8 on a side; veins $1-2$, the single or basal ones anastomosing, the others (if present) mostly free. Sori 1-seriate, rarely incompletely 2-seriate, medial between the costa and margin, approximate or confluent in pairs; sporangia setose.

New Guinea.

(29d) Ph. acanthocarpa, v. A. v. R.; Dryopteris acanthocarpa, Copel., in Philipp. Journ., VIC, 136, tab. XVII; C. Chr. Ind., Fil., Suppl.

Rhizome creeping. Stipes aggregate, those of the fertile fronds \pm $35 \mathrm{~cm}$. long, naked. Fronds with an oblong, crenated, abruptly acuminated terminal pinna $\pm 15 \mathrm{~cm}$. long, $8 \mathrm{~cm}$. broad, rounded at the base, and below this a smaller, subsessile, similar, subentire one on each side, \pm $10 \mathrm{~cm}$. long, and $5 \mathrm{~cm}$. broad, bulbiferous in the axil. Texture coriaceous; surfaces naked; veins copious. Sori in several rows on each side of the costa, nearly close to the main veins, round or oblong; sporangia spiny.

Borneo. 
(30) Ph. rubida, v. A. v. R.,

Plants received from Luzon, determined as Nephrodium rubidum $J$. Sm. (= N. rubidum Copel.), differ from Hooker and Baker's diagnosis in having the stipe and rachis dirty-brown when dry, the frond smaller, the pinnae pauci-(1-6)-jugate, shorter, with the apex conspicuously caudate-acuminate, the edge subentire to coarsely lobate-crenate, the base cuneate and whether or not provided with a scaly bud on the anterior side, the under surface minutely hairy, the sori partly oblong partly roundish, partly distant partly confluent and meniscioid. - Cuming's original plant is unknown to me.

(30a) Ph. rubrinervis, Mett., Kuhn, in Linn., XXXVI, 116; Polypodium rubrinerve, Bk., Hk. Bk., Syn. Fil., 315; Dryopteris rubrinervis, C. Chr., Ind. Fil.; D. urophylla, C. Chr., var. rubrinervis, Rst., in Fed., Rep., XII, 162.

Stipe and rachis naked, rubro-stramineous. Fronds deltoid-oblong, 60-90 cm. long, simply pinnate. Pinnae ligulate-acuminate, to $30 \mathrm{~cm}$. or more long, $\pm 5 \mathrm{~cm}$. broad, the higher sessile, the lower stalked, crenate, deltoid at the base, more cut away on the lower side. Texture papyraceous; surfaces dark-green, naked; midribs reddish; main veins distinct, $5-71 / 2 \mathrm{~mm}$. apart; veins $16-20$ on a side. Sori remote from the main veins.

New Guinea; Polynesia.

(32) TP. granulosa, v. A. v. R.

A specimen received from Palawan (Merrill No. 9178) has the stipes to $30 \mathrm{~cm}$. long, the fronds $15-25 \mathrm{~cm}$. long, the pinnae 3-6-jugate, truncate or truncate-subcordate and whether or not slightly auricled on one side or on both sides at the base but mostly on the upper side only, crenate to irregularly toothed, verruculose on the under surface or on both surfaces, the fertile pinnae a little smaller than the barren ones.

\section{(33) Ph. diversiloba, Christ.}

Omit the variety acrostichoides, it being referred to Dryopteris Bakeri Copel.

(34) Ph. pennigera, o. A. v. R.

Also in Borneo. 
(36b) Ph. Chamaeotaria, v. A. v. R.; Mesochlaena polycarpa, Bedd., var., C. Chr., Ind. Fil., Suppl.

$\left(36 b^{*}\right)$ Ph. pentaphylla. v. A. v. R.; Dryopteris pentaphylla, Rst., in Fed., Rep., XII, 529.

Rhizome creeping, the scales rigid, red-brown, narrowly lanceolate, ciliate. Stipes $\pm 1-3 \mathrm{~cm}$. apart, to $30 \mathrm{~cm}$. long, stramineous-brown. Fronds ovate, to $\pm 17 \mathrm{~cm}$. long, $6-10 \mathrm{~cm}$. broad, acuminate, pinnate. Pinnae \pm 2 on a side below the terminal one, opposite, sessile or the lower very shortly petiolulate; lateral pinnae ascending, elongate-obovate, to $6 \mathrm{~cm}$. long by $1 \frac{1}{2} \mathrm{~cm}$. broad, shortly acuminate, lobed $1 / 4$-way down to tho costa, slightly narrowed at the base, the lower base suhauriculate; terminal pinna $\pm 12 \mathrm{~cm}$. long by $2 \frac{1}{2} \mathrm{~cm}$. broad, more deeply lobed. Lobes subacute. Texture firm; rachis stramineous, short-hairy; costae and veins appresso-strigose above, hirsute beneath; veins \pm 5 on a side, the 2-3 lowest anastomosing. Lower sori medial, higher nearer the main veins; capsules setulose.

New Guinea.

(36d) Ph. perrigida, v. A. v. K., in Bull. Btz., 1914, XVI, 27; Dryopteris perrigida, v. A. v. R., MS. in Herb. Bog.

Stipes long, at length naked like the rachis, scaly at the base, the scales linear-subulate, entire, with a persistent compresso-tuberculiform base. Fronds ovate-lanceolate, probably $60-120 \mathrm{~cm}$. long, acuminate. Pinnae linear, subsessile, spreading or horizontal, $\pm 15-30 \mathrm{~cm}$. long, \pm $1 \frac{1}{2}-2 \mathrm{~cm}$. broad at the middle, acuminate, truncate at the base, the edge cut $\pm 1 / 2$-way down to the costa; lower pinnae a little abbreviated. Lobes numerous, falcate, $3-4 \mathrm{~mm}$. broad at the base, entire, apparently acute because of the much recurved or reflexed edges; lower lobes abbreviated but the lowest not rarely more elongated. Texture rigidly coriaceous; surfaces naked or the under one hairy on the costae, costulae and veins; costae pubescent above; costulae and veins impressed above; veins simple, more or less pellucid, $\pm 8-12$ on a side, the $3-6$ lower anastomosing. Sori costular, close, at length confluent so as to form broad bands hiding the costulae.

Sumatra.

(36e) Ph. supraspinigera, v. A. v. R.; Dryopteris supraspini. gera, Rst., in Hedwi., LVI, 353. 
Stipes to more than $40 \mathrm{~cm}$. long, like the rachis livid-brown, very shortly puberulous, grooved, the groove provided with scattered, ferrugineous, lanceolate, acuminate squamules and blunt, short spines. Fronds linear-oblong, to $75 \mathrm{~cm}$. or more long by $32 \mathrm{~cm}$. broad, 2-pinnatifid, obtusely and shortly acuminate, cordate-truncate at the base. Pinnae suberecto-patent, the higher sessile, the lower subpetiolulate; largest pinnae linear, to $18 \mathrm{~cm}$. long by $1 \frac{3}{\mathrm{~s}} \mathrm{~cm}$. broad, acuminate, the base truncate, the edge cut about $1 / 3 \ldots 1 / 2$-way down to the costa. Lobes somewhat oblique, about $3 \mathrm{~mm}$. broad, slightly crenulate, the apex obliquely truncate; lower lobes of lower pinnae somewhat reduced. Texture herbaceo-chartaceous; upper surface olive-green, naked, lower paler, shortly glanduloso-pilose; veins to 8 on a side, simple, the $3-4$ lower anastomosing. Sori costular, to 8 on a side.

\section{New Guinea.}

(37a) Ph. armala, v. A. v. R.; Dryopteris armata, Rst., in Hedwi., LVI, 351.

Rhizome erect, the apex densely clothed with reddish-brown, subulate, setoso-ciliate scales. Stipes to more than $70 \mathrm{~cm}$. long, spiny and densely scaly; spines black-brown, setiferous; scales deciduous, similar to those of the rhizome. Fronds lanceolate-oblong from a truncate base, to $2 \mathrm{~m}$. long by $1 \mathrm{~m}$. broad, shortly obtusely acuminate, the rachis stramineous, spiny and scaly. Pinnae short-stalked or subsessile, linear, the apex gradually acuminate, the edge cut nearly $1 / 2$-way down to the costa; lower and central pinnae horizontal, the lower to $50 \mathrm{~cm}$. or more long, $5 \mathrm{~cm}$. broad, produced on the lower side, truncate and slightly narrowed at the base. Lobes subfalcate, $1 / 2-2 \mathrm{~cm}$. long, 4-6 mm. broad, obtuse. Texture rigid; surfaces naked; colour olive-green; costae densely shorthairy above; veins to $15-20$ on a side, sparingly shortly puberulous, the 4-5 lower anastomosing. Sori inframedial, the higher subcostular, the lower more or less divaricating.

New Guinea.

(37b) Ph. Iongissima, v. A. v. F.; Goniopteris longissima, Brack, Expl. Exp., XVI, 29, tab. V; Nephrodium longissimum, Diels, in Engl. \& Prantl, Nat. Pfl.fam., I', 179; Polypodium longissimum, Hk., Spec. Fil., V, 7; Dryopteris longissima, C. Chr., Ind. Fil.; - var. novoguineensis, Rst., in Hedwi., LVI, 351. 
Caudex erect, to about $60-90 \mathrm{~cm}$. high. Fronds large, about 120-150 cm. broad, 2-pinnatifid. Pinnae approximate, sessile, horizontal, linear, about $3{ }_{14}^{3} \mathrm{~cm}$. broad. Lobes linear-oblong, subfalcate, acute. Texture coriaceous; veins and edges setose; veins numerous, the $2-4$ lower anastomosing. Sori small, approximate; capsules naked.

Forma typica. - Tahiti.

Var. novoguineensis: Pinnae more deeply pinnatifid; lowest veins only anastomosing: capsules setose. - New Guinea.

\section{§ 4. STEGNOGRAMMA.}

\section{(38) Ph. canescens, Mett.}

\section{Var. subsimplicifolia. - Also in Mindanao.}

(38a) Ph. melanophlebia, v. A. v. R.; Dryopteris melanophlebia, Copel., in Philipp. Journ., VIC, 147; C. Chr., Ind. Fil., Suppl.

Rhizome short. Stipes approximate, $1-10 \mathrm{~cm}$. long, those of the fertile fronds the longest, setose. Simple upper portion of the frond \pm 4-5 cm. long, 1-2 cm. broad, obtuse, entire or with 1-2 minute lobes at the base; below this $1-2$ pair of sessile or adnate, roundish or oblong pinnae 2-4 mm. long. Texture coriaceo-papyraceeus; surfaces setose, the setae scattered, caducous except on the lower part of the costa beneath; veins of the terminal pinna distinct, often blackish beneath, the 2 lower often anastomosing; veins of the lateral pinnae often free, Sori costular, more or less elongated. - This differs from $\mathrm{Ph}$. canescens Mett. var. subsimplicifolia in having the pinnae still more reduced.

Negros.

(39a) Ph. stegnognamma, Mett.; - var. meniscioides, v. A. v. R., in Bull. Btz., 1914, XVI, 27.

Var. meniscioides; Pinnae narrowed rather regularly from base to apex; sori mostly produced along the anastomosing intermedial veins. - Sumatra.

$\left(39 a^{*}\right)$ See No, $29 d$. 
(39b) Ph. Spenceri, v. A. v. R.

Omit this species, it being referred to Dryopteris Spenceri Christ.

\section{§ 5. MENISCIUM.}

(40a) Ph. oblamceoluta, v. A. v. H.: Dryopteris oblanceolata, Copel., in Philipp. Journ., IX ${ }^{\mathrm{C}}$, 3.

Rhizome densely clothed with lanceolate scales. Stipes aggregate, $\pm 1-3 \mathrm{~cm}$. long, hairy and scaly. Fronds oblanceolate, $\pm 25-30 \mathrm{~cm}$. long, $\pm 3 \mathrm{~cm}$. broad, acuminate, erenate, narrowed towards the rarely minutely 2-auriculate base. Texture subcoriaceous; surfaces naked; costa setose; veins \pm 6 on each side of the main veins.

New Guinea.

(41a) See No. 30.

(41b) Ph. cordifolia, v. A. v. R.. in Bull. Btz., 1913, XI, 19, tab. V; Dryopteris cordifolia, v. A. v. R., MS. in Herb. Bog.

Near $\mathrm{Ph}$. triphylla Mett. -- Pinnae broader; terminal pinna to $8 \mathrm{~cm}$. broad, long-acuminate, cordate at the base, with the veins more numerous, forming to 20 series of areolae between the midrib and edge, the lower areolae whether or not more irregular, the margin varying from entire to coarsely crenated; lateral pinnae shortly acuminate or acute, truncate, at the base; costae shortly pubescent beneath. - Young plants with the fronds simple and similar to the terminal pinna of adult plants.

Borneo.

(42) Ph. Hosei, ข. A. ข. r.

A form, found by a native collector employed by the Philippine Bureau of Science, shows an exceedingly minute, rudimentary indusium. - See Copel., in Philipp. Journ., X⿳一, 146.

(42a) See No. $39 \alpha$.

(44) Ph. sallicifolia, Met.

Also in Borneo. 


\section{0b. IIOTYOPTERIS, Prest.}

\section{\$1. ARCYPTERIS.}

(1) D. ptenoides, Pr.; Aspidium irregulare, C. Chr., var., C. Chr., Ind. Fil., Suppl.

(1a) D. Dahiti, v. A. v. R., in Bull. Btz., 1912, XII, 11; Phegopteris Dahlii, Hier., in Notizbl. Bot. Gart. Berl., II, 84; Aspidium Dahlii, Diels, in Schum. \& Laut., Flor. deut. Sch.geb., 116; C. Chr., Ind. Fil.

Stipes $50 \mathrm{~cm}$. more or less long, glossy, stout, canaliculate, blackishbrown and scaly towards the base. Fronds elongate-ovate, 2-pinnatifid, to $\pm 40 \mathrm{~cm}$. long or longer, the rachis brownish or reddish-brown, naked or puberulous. Pinnae linear-oblong, $\pm 4-12 \mathrm{~cm}$. long, $\pm 1-2 \mathrm{~cm}$. broad, acute or acuminate, cut to $1 / 2$-way down or more to the costa into numerous obtuse, more or less crenated lobes. Texture moderately thin; surfaces naked, or the costae more or less puberulous; venation more or less as in Pleocnemia. Sori roundish, confined to the margin of the lobes. - Copland King's No. 312 is perhaps another species or a more decompound form of this; the specimen is a fragment (pinna) of a 3-pinnatifid frond mistaken for a whole frond.

New Guinea (?); New Lauenburg.

(1b) D. hemitelifformis, v. A. v. R., in Bull. Btz., 1913, XI, 7; Pleocnemia, leuzeana, Pr., var. hemiteliiformis, Rac., Flor. Btz., I, 194 ; Aspidium hemiteliiforme, $v$. A. v. R., MS. in Herb. Bog.

Fronds $100 \mathrm{~cm}$. more or less long, 2-3-pinnate, the rachises densely fibrilloso-villose above, less so beneath, the hairs reddish-brown. Pinnae pinnate, $50 \mathrm{~cm}$. more or less long. Pinnulae remote, of the lowest pinnae \pm 6-10 $\mathrm{cm}$. long, 8-15 mm. broad, cut $\pm 1 / 2$-way down to the costa, or the lower posterior ones elongated and similar to the higher pinnae. Lobes oblong, blunt, separated by rounded sinuses provided with a small tooth, the edges entire or nearly so, more or less fibrilloso-ciliate. Texture more or less firm; surfaces naked; venation as in Pleocnemia, forming 1--2 rows of areolae on each side of the costae and costulae. Sori in rows nearer the margin than the costulae, parallel to the former, often confined to the lobes only.

Java.

Ferns and Fern Alimes. 
(2a?) D. gynmocarpa, v. A. v. R.; Tectaria gymnocarpa, Copel., in Philipp. Journ., IX ${ }^{0}, 4$.

Stipes $\pm 35 \mathrm{~cm}$. long, castaneous, provided at the base with a few narrowly lanceolate scales. Fronds deltoid, $\pm 30-40 \mathrm{~cm}$. each way, sub-3-pinnate. Lower pinnae 2-pinnatifid at the base, the lowest deltoid, $\pm 15 \mathrm{~cm}$. broad. Ultimate segments subacute, serrate. Texture membranaceous; surfaces naked; veins hirsute, the lowest anastomosing as in Pleocnemia. Sori superficial, often submarginal, exindusiate (?).

Newo Guinea.

(9) D. fenruginea, v. A. v. T.; Tectaria ferruginea, Copet., in Philipp. Journ., VIC, 76.

(9a) D. ulivacea, v. A. v. K.; Tectaria olivacea, Copel., in Philipp. Journ., IXc, 228.

Stipes glossy, castaneous, clothed densely towards the base with filiform, crinite, rufo-castaneous scales. Fronds large, the rachis glossy. Pinnae short-stalked, $60 \mathrm{~cm}$. more or less long, $\pm 20 \mathrm{~cm}$. broad, acuminate. Pinnulae stalked, $\pm 11 / 2 \mathrm{~cm}$. broad, pinnatifid more than $1 / 2$-way down, cordate-truncate at the base. Segments falcate-oblong, blunt, entire. Texture papyraceous; surfaces naked; upper surface castaneousgreen, lower olivaceous; veins indistinct, the lower anastomosing as in Pleocnemia.

Sumatra.

(11) D. Inbrusea, v. A. v. R.; Tectaria labrusca, Copel., in Philipp. Journ., VIC, 137, tab. XXa.

(11a) ID. Bavoksii, v. A. r. R.; Tectaria Brooksii, Copel., in Philipp. Journ., VIC, 137, tab. XXb; Aspidium Brooksii, C. Chr., Ind. Fil., Suppl.

Like D. labrusea $v, A . v \cdot R$.forma typica but smaller, subentire, darker, and the sori more elongated.

Borneo.

(11b) D. Brooksiae, v. A. v. R.; Aspidium Brooksiae, v. A. v. $R .$, MS. in Herb. Bog. 
Rhizome woody, creeping, more or less intricate, glabrescent, the apex provided with pale-brown, subentire, lanceolate scales. Stipes approximate or remote, $\pm 4-8 \mathrm{~cm}$. long below the wing-like decurrent portion of the frond, sparingly pale-brown-scaly towards the base. Fronds spathulate, $\pm 40-50 \mathrm{~cm}$. long, 6-10 $\mathrm{cm}$. broad, the upper part lanceolate-oblong to lanceolate-ovate, acuminate, entire or slightly irregularly wavy, narrowed rather suddenly into the narrowly linear-cuneate lower part; barren fronds with the upper part about twice to thrice as long as the lower part; fertile fronds just the contrary, in all corresponding parts narrower than the barren ones, and on the longest stipes. Texture thincoriaceous; surfaces naked; costa and main veins prominent, the latter not reaching the margin, straight or somewhat curved, much spreading but not horizontal, the lower growing gradually irregular and disappearing in the wing. Sori compital, or medial to terminal on free veinlets, varying from roudish to short-linear, straight or somewhat curved, those near the costa and main veins often parallel or subparallel to these.

Sumatra.

(12) D. Iamanensis (lamoensis), v. $\boldsymbol{A}$. $\boldsymbol{R} . ;$ Aspidium lamaoense, Cupel.; A. irriguum, J. Sm., C. Chr., Ind. Fil., Suppl., p. p.

(15) D, pentaplnylla, v. A. v. R.; Aspidium quinquefoliolatum, C. Chr., Ind. Fil., Suppl.

(16) D. Whitfordi, v. A. v. $\boldsymbol{R e}$.; Aspidium irregulare, C. Chr., var., C. Chr., Ind. Fil., Suppl.

\section{§ 2. DIGRAMMARIA.}

(20) D. subnequalis, v. A. v. R.; Aspidium subaequale, Rst., in Fed., Rep., XII, 176; Tectaria subaequalis, Copel., in Philipp. Journ., IX $^{\mathrm{C}}, 5$.

Stipes to $20 \mathrm{~cm}$. or more long, minutely tomentose. Fronds ovate, 2 pinnatifid, acute, broadest below the middle. Pinnae $5-7$ on a side below the deeply lobed apex, subopposite, suberecto-patent, sessile, adnate; laryest pinnae elongate-oblong, $\pm 13 \mathrm{~cm}$. long by $3 \mathrm{~cm}$. broad, cut more than $1 / 2$-way down to the costa, narrowly adnate at the base, somewhat 
dilated on the upper side at the base; lower pinnae a little abbreviated, petiolulate. Lobes oblique, linear, falcate, blunt, entire or repando-crenate, separated by rounded sinuses. Texture membranaceo-herbaceous; surfaces naked; upper surface olive-green, lower paler; costae and costulae subflexuose, the former a little tomentose above; veins immersed. Sori oblong, in 1 row on each side of and approximate to the costulae, to 10 in a row on the longest lobes.

New Guinea.

(21) D. elliptica, v. A. v. R.; Tectaria elliptica, Copel., in Philipp. Journ., IX, 228.

Stipes $\pm 50 \mathrm{~cm}$. long, dirty-black-brown, provided towards the base with a few scattered lanceolate scales. Fronds more than $50 \mathrm{~cm}$. long, 35-40 $\mathrm{cm}$. broad, 2-pinnatifid, abruptly acuminate. Pinnae $\pm 5-8$ on each side below the pinnatifid apex, sessile or the higher adnate, the lowest the shortest and broadest; central pinnae longest, to $25 \mathrm{~cm}$. long; $\pm 6 \mathrm{~cm}$. broad, much acuminated, deeply lobed, minutely ciliated in the sinuses. Lobes falcate, $\pm 5-8 \mathrm{~mm}$. broad, entire. Texture herbaceous; surfaces naked; veins indistinct, anastomosing so as to form 1 -2 rows of areolae on each side of the costulae, otherwise free. Sori medial, more or less elongated.

Sumatra.

\section{OONIOGRAMMA, Fé.}

(2) C. subcordata, Copel., in Leafl., III, 823.

Fronds 2-pinnate. Pinnulae membranaceous, serrate, the apex shortly caudate, coarsely serrate, the base cordate or rotundate-subtruncate. Near C. fraxinea Diels var. serrulata.

Mindanao.

\section{GQu. ANOGTRAMMA, Limk.}

Sori linear or linear-oblong, simple or forked, terminal or subterminal on the veins, without paraphyses. No indusium. 
Rhizome short. Stipes not articulate to the rhizome. Fronds pinnately divided, naked; leaflets cuneate-flabellate; veins free, flabellatodichotomous. Diels, in Engl. \& Prantl., Nat. Pfl.fam., I*, fig. $136 A-B$; Hk. Bk., Syn. Fil., tab. VI, fig. 52a (as Eugymnogramme).

Tropical and extra-tropical.

(1) A. Ieptophylla, cink, Fil. Sp., 137; Diels, in Engl. \& Prantl, Nat. Pfl.fam, I*, fig. 136 A-B; Gymnogramme leptophylla, Desv., Hk. Bk., Syn. Fil., 383; Hk., Br. Ferns, tab. I; Hk. \& Grev., Ic. Fil., tab. XXV; Polypodium leptophyllum, L. (oldest name).

Stipes tufted, $1-12 \% \mathrm{~cm}$ long, slender, glossy, brown, those of the fertile fronds the longest. Fronds subdimorphous, ovate or deltoid, 2-10 $\mathrm{cm}$. long, $1^{1}{ }_{2}-4 \mathrm{~cm}$. broad, the barren ones the smallest, 1-2-pinnate, the fertile ones the largest, 2-4-pinnate. Leaflets roundish or flabelliform, spathulate or obovate, $3-10 \mathrm{~mm}$. long, as broad or somewhat narrower, cuneate at the base, the outer edge rounded, more or less deeply incised; leaflets of the barren fronds the largest. Segments cuneate or oblong, simple, emarginate or 2-3-lobate into roundish or oblong, blunt ultimate lobules. Texture delicate-membranaceous; rachises and surfaces naked; veinlets 1 to each ultimate lobule, not reaching the apex.

West and South Europe, tropical and extra-tropical Africa, Persia, Br. India across Jana to Australia, New Zealand, Central America to Argentinia.

\section{ANTHHROPIYM, Kaulfuss.}

(2a) A. vittarioides, Bk., in Journ. of Bot., XXVIII, 267; v. A. v. R., in Bull. Btz., 1913, XI, 2, tab. II; - var. majus. v. A. v. R., 1. c., 1914, XVI, 56.

Rhizome short, the scales lanceolate, blackish. Stipes tufted, very short. Fronds linear, $\pm 15 \mathrm{~cm}$. long, $6-8 \mathrm{~mm}$. broad at the middle, narrowed gradually towards both ends. Texture moderately firm; surfaces naked; veins forming long narrow areolae parallel to the midrib and margin, without free veinlets. Sori intramarginal, long-linear, sunk in distinct grooves in $1-2$ rows on each side of the midrib, parallel to the midrib and margin. - Specimens gathered in Borneo have the fronds 
$10-30 \mathrm{~cm}$. long, $2-6 \mathrm{~mm}$. broad, the sori provided with linear paraphyses not thickened at the apex.

Forma typica. --Borneo; Tonkin.

Var. umajus: Rhizome scales dark-brown; fronds $30-40 \mathrm{~cm}$. long, about $1 \mathrm{~cm}$. brood; sori mostly 1 on each side, very long, whether or not interrupted, submarginal, whether or not accompanied by a few intramarginal ones. - Sumatra.

(4) A. parvalum, $\boldsymbol{E}$.s - var. subsemicostatum, V. A. V. R., in Bull. Btz., 1914, XVI, 56.

Forma typica. - Also in Mindanao, Negros.

Var. subsemicostatum: Fronds costate in the lower half, the costa depressed, narrowed gradually towards the apex, blackish or brown when dry. - Sumatra.

(7) A. semicostarum, El.; v. A. v. R., in Bull. Btz., 1911, I, 1, tab. II, fig. 1a; - var. ceratophyllum; Grammitis Blumei, Zipp., var. ceratophylla, Zipp., MS. in Herb. Bog.; var. caudatum, v. A. v. R., I. c., 1912, VII, 3; -- var. Marthae, v. A. v. R., 1. c., 1911, I, 1, tab. II, fig. 1b; A. callifolium, Christ (not Bl.), in Nov. Guin., VIII, Bot., 157.

Forma typica: Fronds ligulate or sublanceolate, the apex acute or more or less suddenly acuminate; paraphyses clavate or narrowly pyriform, much longer than broad, smooth, rounded at the apex.

Forma parva: Like the type but the fronds smaller; paraphyses broadly pyriform, often much broader than long. - Java.

Vas:. cera iophyllum: Fronds narrow, either linear-oblanceolate with the apex suddenly long-subulate-acuminate or linear-cuneate with the apex the broadest and irregularly incised into 2-8 erected tooth-like or narrowly subulate laciniae; paraphyses as in the type. - Java.

Var. Darthae: Like the type but the paraphyses obconical, rather obpyramidal, narrowed at the base, the apex dilated, truncate, 3-6angular with rounded angles and imprissed sides, the apical plane therefore conspicuously 3-6-lobed. - New Guinea.

(8a) A. simulans, v. A. v. R., in Bull. Btz., 1913, XI, 2.

Rhizome short, the scales fine, linear-lanceolate, denticulate, blackish. Stipes approximate, $\pm 12-20 \mathrm{~cm}$. long, compressed when dry. Fronds lanceolate-ovate or lanceolate-spathulate, $15-20 \mathrm{~cm}$. more or less long, 
$\pm 4-5 \mathrm{~cm}$. broad, acuminate, entire, pellucid-margined, cuneate and slightly decurrent at the base. Texture coriaceous; no midrib; areolae longitudinal. Sori often copious, mostly free; paraphyses elongate-clavate at the apex.

Java.

(9) A. plandagineusu, Kuf:; - var. Lessonii, Rst. in Fed., Rep., V, 370; A. Lessonii, Bory, in Dup., Voy. Coq., Bot., I, 255, tab. XXVIII, fig. 2; A. angustatum, Brack., Expl. Exp., XVI, 63.

Var. Lessumii: Fronds ligulate, about $30 \mathrm{~cm}$. long by $2 \mathrm{~cm}$. broad, membranaceous. - New Guinea; Tahiti.

(14) A. callifoliuru, Bı.; -- val elongatum; $A$. reticulatum, Bedd. (not $K l f$ ), Handb. Ind. Ferns, 401, fig. 235; Ferns R. I. taib. CCXXXI.

Fronds broadly lanceolate or spathulate-lanceolate, of the fully developed plants commonly less than 7 times as long as broad; costa wanting or indistinct; sori free or slightly confluent.

Var. elonintum: Fronds linear-ligulate or linear-spathulate, of the fully developed plants generally more than 8 times as long as broad.

(15) A. Alatum, Erack.

Like A. callifolium $B l$. but the costa distinct in the lower $1 / 3-2 / 3$ of the frond.

(16) . Meticula tume, Kuf:; Hemionitis reticulata, Forst., Schk., Krypt. Gew., I, tab. 6.

Differs from A. callifolium Bl. and A. alatum Brack. in having the fronds proportionally short and broad with the sori more or less copiously reticulate.

(17) A. Cumingi:, Fée.

Also in Sumatra (Burck).

\section{LOXOGRAMMA, Prest.}

Sori oblong to linear, parallel, forming an acute angle with the 
costa, rarely parallel to it, several on each side, if parallel to the costa, then rarely a single long-one on each side of it, continuous or interrupted. No indusium.

(1) E. parallela, Copel., in Philipp. Journ., XIC, tab. II, fig. 7.

A specimen received from Luzon has the fronds $5-15 \mathrm{~cm}$. long, 5-10 mm. broad, and the costa subterete above, keeled beneath (when seen in a saturate chloral-hydrate solution); sori parallel or subparallel to the costa. - Perhaps a narrow form of L. lanceolata Pr. only.

Also in Java.

(2) L. arandis, Copel., in Philipp. Journ., XIC, tab. III, fig. 11.

(4) L. Innceolata, Pr. ; ? L. malayana, Copel., in Philipp. Journ., $\mathrm{XIC}^{\mathrm{C}}$,46, p.p.; Grammitis lanceolata, Sw., (oldest name).

Fronds linear-lanceolate or oblanceolate, often broadest above the middle, $\pm 15-30 \mathrm{~cm}$. long by $1-2 \mathrm{~cm}$. broad, narrowed gradually from there towards the long-decurrent base. - The specimens gathered in Java have the costa subterete above, flattened to keeled beneath (when examined in a saturate chloral-hydrate solution), and the sori much ascending, partly remote partly slightly imbricate, near the costa and not rarely subparallel to it, and specimens received from Ceylon, British India and another unmentioned locality have the sori sometimes even very remote and positively parallel to the costa, as in L. parallela Copel. It may be possible that Copeland was right when separating the Asiatic specimens from the typical African but L. malayana, as represented in Philipp. Journ., XIc, tab. I, fig. 1, resembles very much some of our specimens of L. Blumeana Pr. var, avenia.

(4a) T. Trooksii, Copel., in Philipp. Journ., IX ${ }^{\mathrm{C}}, 232$; XIC, tab. II, fig. 6.

Near L. lanceolata $\mathrm{Pr}$. but the fronds linear-lanceolate, $\pm 12-20 \mathrm{~cm}$. long by $1-1 \frac{1}{2} \mathrm{~cm}$. broad, broadest at or below the middle, hardly decurrent at the base; sori not imbricated, rather remote, short, sometimes nearly round, nearer the margin than the costa (conf. Copeland's figure and a duplicate of Brooks' No. 124 on which Copeland founded this species).

Sumatra. 
(5) L. Elumeana, Pr.; Antrophyum coriaceum, Bl., Flor. Jav., II, tab. XXXVII, fig. 1; - var. avenia; L. avenia, Pr.; A. avenium, Bl., 1. e., fig. 2 ; ? L. malayana, Copel., in Philipp. Journ., XIC, 46, p. p., tab. I, flg. 1; - var. Forbesii; L. Forbesii, Copel., 1. c., IX ${ }^{\mathrm{C}}, 232$; 1. c., XI $\mathrm{XI}^{\mathrm{C}}$, tab. III, fig. 12 .

Fronds oblanceolate, broadest above the middle; sori elongate, erectopatent, imbricate, not rarely reaching nearly the margin.

Forma typica: Fronds $\pm 25-60 \mathrm{~cm}$. long by $2-7 \frac{1}{2} \mathrm{~cm}$. broad, cuneate or decurrent at the base.

Var. avenia: Like the type but the fronds smaller, $\pm 10-30$ cm. long by $1-2 \mathrm{~cm}$. broad.

Var. Forbesii: Like the type but the fronds to $10 \mathrm{~cm}$. broad, abruptly narrowed at the broadly cuneate or rounded base.

(6) Comferta, Copel., in Philipp. Journ., XI ${ }^{\circ}$, tab. IV, fig. 16.

(7) L. irvidifolia, Copel., in Philipp. Journ, XIC, tab. III, fig. 13.

A specimen gathered in Borneo differs from the typical form in having the barren fronds rounded at the apex. - In old plants, however, the fronds are acute or acuminate.

(8) L. ensifrons, v. A. v. R., in Bull. Btz., 1913, XI, 16, tah. VI; Polypodium ensifrons, v. A. v. R., MS. in Herb. Bog.

Rhizome elongated, clothed with brown, lanceolate-subulate scales. Stipes $0-2 \mathrm{~mm}$. long, $1 \frac{1 / 2}{\mathrm{~cm}}$. or more apart. Fronds dimorphous; barren fronds oblanceolate-spathulate, $\pm 30-40 \mathrm{~cm}$ long, acuminate, $4-6 \mathrm{~cm}$. broad in the upper half, narrowed gradually in the lower part, $\pm 11_{2}-2 \frac{1}{2} \mathrm{~cm}$. broad above the rotundate-cuneate base, entire. Texture coriaceous, rather flaccid; surfaces naked; costa prominent above, flattened beneath; main veins slightly distinct beneath; areolae fine, with few free veinlets. Fertile fronds linear, $\pm 40-50 \mathrm{~cm}$. long, $1 \frac{1}{2}-2 \frac{1}{2} \mathrm{~cm}$. broad, the longest the narrowest, gradually acuminate. Sori erecto-patent, not subparallel to the costa, occupying the upper $1 / 3-1 / 2$ of the fronds, not quite reaching costa and margin, sometimes decurrent along the costa, Borneo,

(9) L. dimorpha, Copel., in Leafl., II, 407; Philipp. Journ., $\mathrm{XIC}$, tab. IV, fig. 14 . 
Rhizome creeping, scandent, clothed with lanceolate, apiculate, greycastaneous scales. Stipes nearly wanting, subarticulate. Barren fronds $\pm 30 \mathrm{~cm}$. long, $\pm 2 \mathrm{~cm}$. broad when dry, $\pm 3 \mathrm{~cm}$. broad in tresh material, acute, broadest above the middle, crisped or broadly undulate, rufescent in the lower part. Texture rather fleshy; costa rufescent, keeled above; main veins wanting; veins laxly anastomosing, with fow free included veinlets. Fertile fronds contracted, $30-40 \mathrm{~cm}$. long, 3-4 mm. broad, keeled, acute at the edge. Sori long, linear, 1 on each side of the costa, often continuous, occupying the upper $2 / 3$ of the fronds, with few linear, non-capitate paraphyses.

Negros, Mindanao.

(10) E. paItomidides, Copel., in Philipp. Journ., VIC 87 ; XIC, tab. IV, fig. 15; Polypodium paltonioides, C. Ch., Ind. Fil., Suppl.

Rhizome creeping, ascending (scandent?), clothed with pale-brown, subulate scales. Fronds scattered or approximate, sessile or nearly so, lanceolate, $15-20 \mathrm{~cm}$. more or less long, $\pm 1 \frac{1}{2}-2 \mathrm{~cm}$. broad, narrowed very gradually to the base, entire. Texture coriaceous; surfaces naked; costa prominent on both sides. Sori linear, 1 on each side of and parallel to the costa, rather medial between it and the margin, confined to the narrowed upper part of the frond.

New Guinea.

\section{SYNGRAMMA, J. Smith.}

\section{§ 2. TOXOPTERIS.}

(5a) \$. angusta, Copel., in Philipp. Journ., IIIC, 348.

Rhizome creeping, woody, clothed at the apex with minute, obscure, lanceolate scales. Stipes approximate or aggregate, naked except at the paleaceous base, $\pm 5-20 \mathrm{~cm}$. long, those of the fertile fronds much the longest. Barren fronds simple, not decurrent, much acuminated, $\pm 20-30$ $\mathrm{cm}$. long, $\pm 2 \mathrm{~cm}$. broad, the margin entire, cartilagineous. Texture subcoriaceous; surfaces naked; veins partly simple partly forked (united 
by the marginal cartilagineous strand?). Fertile fronds $\pm 20 \mathrm{~cm}$. long, hardly $5 \mathrm{~mm}$. broad, veins free quite to the thinly cartilagineous margin, all fertile.

Borneo.

(7) S. alismifolia, J. Sme.

Var. Wallichii: Also in Malacca, Sumatra

\section{§ 3. CALLOGRAMMA}

(9) S. quimata, Carr.; Craspedodictyum quinatum, Copel., in Philipp. Journ., VIC, 85.

Var. ternata. - Also in Borneo.

(9a?) \$. groandis, C. Chr., Ind. Fil., Suppl.; Craspedodictynum grande, Copel., in Philipp. Journ., VIC, 84.

Stipes nearly $60 \mathrm{~cm}$. long, $8 \mathrm{~mm}$. diam., stramineous-brown, naked above the black base. Fronds ternate. Central segment largest, shortstalked, $\pm 40 \mathrm{~cm}$. long; $8 \mathrm{~cm}$. broad; lateral segments adnate, $\pm 25 \mathrm{~cm}$. long, gradually acuminated; margins subtended by 2 rows of areolae.

New Guinea.

(96?) Schlechteri, Brau., in Lautb., Beitr. Flor. Pap., I, 32.

Stipes to $50 \mathrm{~cm}$. or more long, glabrescent, fuscous, grooved down the face. Fronds 3 -foliate, $\pm 34-42 \mathrm{~cm}$. long, $\pm 28 \mathrm{~cm}$. broad. Pinnae petiolulate, lanceolate, $\pm 30-40 \mathrm{~cm}$. long, $\pm 6-7 \mathrm{~cm}$. broad, entire or slightly undulate; central (terminal) ninna largest, lateral ones smallest, ascending, auricled at the base, the auricles adnate, ovate, $\pm 8 \mathrm{~mm}$. long by $6 \mathrm{~mm}$. broad. Texture coriaceous; upper surface naked, lower provided with scattered, caducous, minute, fuscous, ciliate scales; costae slightly grooved above, rounded beneath; veins distinct, spreading, simple or forked, slightly anastomosing towards the margin. Sori linear, slender, not reaching the margin.

New Guinea. 


\section{§ 4. DICTYOGRAMMA.}

\section{(11) S. Ianceola1a, Diels.}

Also in Borneo.

\section{HEMIONITIS, Linné.}

\section{(2) H. arifolia, Moore.}

Under surface chaffy with scattered hair-like scales especially on the costa. - Specimens from Luzon, occurring in the Buitenzorg Herbarium, have both barren and fertile fronds equally cordate with blunt or rounded lobes.

\section{7 $u$. HEMIGRAMMA, Christ.}

Sori lineai, running along the veins, placed in parallel rows on each side of the costa, not rarely united by transversal bars, approximate or contiguous and at length often confluent, sometimes acrostichoid. No indusium. No paraphyses.

Rhizome erect or oblique. Fronds very dimorphous, not articulate to the rhizome, simple, incised or divided. Barren fronds sessile or stalked, clustered; venation anastomosing irregularly, with the main veins distinct, and the areolae provided with included free veinlets. Fertile fronds much contracted, without distinct main veins, and the areolae without free veinlets.

Mailaya.

(1) H. Zollingeri, Christ.

Omit this name, it should be to H. latifolia Copel.

(1) H. Iatifolia, Copel., in Philipp. Journ., IIC, 406; IIC , tab. I; H. Zollingeri, Christ, in Philipp. Journ., II ${ }^{\mathrm{C}}, 170$; Acrostichum taccaefolium, Hk., Hk. Bk., Syn. Fil., 418; Hemionitis Zollingeri, Kurz., Rac., Flor. Btz., I, 64; Christ, Farnkr. d. Erde, fig. 147; H. gymnopteroidea, Copel., Polypod. Philipp., 67; Syngramma Zollingeri, Diels, in Engl. \& Prantl, 
Nat. Pfl.fam., I, 64; Gymnopteris latifolia, Pr., Tent. Pterid., 244 ; G. taccaefolia, J. Sm., Copel., Polypod. Philipp., 42; G. trilobata, J. Sm., Hk., Icon. Pl., X, tab. CMVI; G. subquinquefida, Pr., Epim., 151; Polybotrya latifolia, Meyen., (oldest name); - var. major, Christ, in Philipp. Journ., 1. c.

Rhizome short, erect or creeping, the scales brown, linear, lanceolate or subulate, often crisped, entire or variously fringed. Fronds sessile, or placed on stalks to $30 \mathrm{~cm}$. long, approximate, clustered or placed in a dense rosette, the fertile ones often placed on the longest stipes. Barren fronds $\pm 7 \frac{1}{2}-30 \mathrm{~cm}$. long, simple, entire, repand, undulate, incised, 3-fid or pinnate, sometimes rooting at the apex, the simple fronds acute, rounded, truncate or cordate at the base, the pinnate fronds to $60 \mathrm{~cm}$. long, with the pinnae acute, entire, lanceolate, with the rachis winged in the more complex forms, and the lowest pinnae forked. Texture varying from membranaceous to coriaceous; surfaces naked but the costa occasionally scaly like the stipe; main veins united by transverse veins. Fertile fronds simple, linear-lanceolate, $\pm 5-15 \mathrm{~cm}$. long, $3-12 \mathrm{~mm}$. broad, sometimes 3 -fid at the base, rarely pinnate. Sori mostly in 2 or more longitudinal rows. - Exceedingly variable.

Forma typica. - Malaya.

Var. major: Stipes scaly, the scales subulate-setiform, black. Fronds very thin, nearly diaphanous. - Philippines.

(2) H. grandifolia, Copel., in Philipp. Journ., VIC, 77.

Fronds pinnate, long-stalked, $\pm 30 \mathrm{~cm}$. long and as broad. Pinnae opposite, in 2-3 pair; terminal barren pinna 3 fid, 1-2 lower barren ones forked, lowest fertile ones simple, to $15 \mathrm{~cm}$. long, $\pm 2 \mathrm{~mm}$. broad. Sori occupying the whole under surface of the fertile pinnae.

New Guinea.

\section{CAMPYLOGIRAMMA, v. A. v. R.}

Sori free, mostly elongated, running in various directions along free or anastomosing veinlets. No indusium. No paraphyses.

Fronds uniform or the fertile ones slightly contracted; veins anastomosing irregularly; main veins and included free veinlets present in both barren and fertile fronds.

East Malaya, Papua. 
* Fronds simple, not or hardly incised.

(1) C. lancifolium.

* Fronds at least lobed.

(2) C. pteridiformis.

(1) C. Iancifolia, v. A. v. $\mathrm{R}$.

Rhizome creeping, intricate, black when dry, clothed with deciduous, brown, lanceolate, acuminate, entire, fragile scales. Stipes more or less scattered, winged, $10-45 \mathrm{~cm}$. long, those of the fertile fronds the longer ones, naked, the unwinged portion $5-30 \mathrm{~cm}$. long, the wing narrowly linear-cuneate, passing gradually into the frond. Fronds lanceolate, acuminate, the point blunt to acute, the edge subentire or irregularly subsinuate; barren fronds $\pm 25-30 \mathrm{~cm}$. long, 4-6 cm. broad; fertile fronds somewhat smaller. Texture thin-coriaceous; surfaces naked; costa and main veins prominent, the latter not reaching the margin, straight or somewhat flexuose, spreading, the lower growing gradually more irregular, wanting in the wing. Sori compital or on free veinlets; receptacles roundish to shortly linear, the longer ones straight, curved, subcircular to irregularly flexuose or branched, scattered or often placed in rows which are parallel or subparallel to the costa or the margin.

Celebes.

(2) C. pteridiformis, v. A. v. R.

Stipes $\pm 20-25 \mathrm{~cm}$. long, brown to purple, glossy, when young very minutely puberulous, the hairs deciduous, purple-brown, intermixed with scattered, deciduous, fuscous, linear-subulate scales leaving the stipes rough or roughish by their persistent bases. Fronds $\pm 10-20 \mathrm{~cm}$. long, nearly as broad, the fertile the smallest, deeply 3-fid. Segments lanceolate, mostly broadest at or near the middle; central segment $8-16 \mathrm{~cm}$. long, 2-4 cm. broad, acuminate, the edge narrowly revolute, apparently thickened, entire or irregularly and shallowly repando-undulate; lateral segments similar to the central one but smaller, suberecto-patent, shortly decurrent upon the stipe, not rarely forked on the lower side with a spreading, short and blunt or long and acuminate auricle. Texture firmherbaceous, subpapyraceous; surfaces naked; central ribs of the segments prominent beneath, minutely deciduously puberulous above; main veins distinct; areolae numerous, with free veinlets. Sori numerous, partly terminal on free veinlets, partly running along free or anastomosing 
veins; receptacles varying from short to long, the shortest round or straightoblong, the longest linear,-flexuose and not rarely very irregularly serpentine, sometimes shortly and sparingly branched, the intermediate ones curved, i. e. semicireular, subcireular, sigmoidal.

New Guinea.

\section{MONOGIRAMMA, Schiuhr.}

Sori linear, placed on or close to the costa, superficial or immersed, ofter protected by $1-2$ lateral outgrowths of leaf-tissue outside the receptacle and not belonging to the costal parenchyma, single or double, if double then ultimately confluent, covering the costa.

\section{§1. EUMONOGRAMMA.}

(1) II. Ianeicanpa, Hk.; v. A. v. R., in Bull. Btz., 1912, VII, tab. $\mathrm{V}$, fig. 8 .

Also in Singapore.

(1a?) M. capolllaris, Copel., in Philipp. Journ., VIC 147.

Rhizome creeping, slender, densely clothed with narrow, black-brown

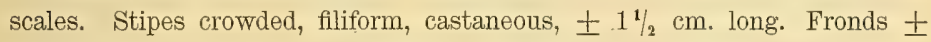
$21 / 2 \mathrm{~cm}$. long, $1 / 2 \rightarrow 1 \mathrm{~mm}$. broad, not dilated towards the apex. Sori continuous, unilateral, open towards the margin.

Negros.

(1h) N. ennarginata, Rrau., in Lautb., Beitr. Flor. Pap., I, 34.

Rhizome creeping, clothed with subulate, denticulate scales. Fronds 2-seriate, erowded, sessile, linear-ligulate, to $\pm 9 \mathrm{~cm}$. long, $\pm 13 / \mathrm{mm}$. broad, entire or slightly undulate, the apex bluntish, emarginate, the lower part narrowed gradually towards the base. Texture membranaceous; surfaces naked; costa flanked by spurious veins. Sori protected by a single lateral outgrowth of leaf-tissue.

Nero Guinea.

(2) DI. Irichoidea, . $\mathbf{S m}$. 
Sori when young with the capsules intermixed with fibril-like, articulated, pale-ochraceous paraphyses.

Also in Malacca, Sumatra, Java, New Guinea.

(3) M. paradoxa, Bedd.; v. A. v. R., in Bull. Btz., 1912, VII, tab. V, fig. 9-10; - var. novo-guineensis, Rst., in Fed., Rep., VIII, 164.

Var. novo-guineensis: Stipes capillary; fronds very small, hardly more than $2-3 \mathrm{~cm}$. long; both sterile and fertile nearly as broad; sori always unilateral, occupying the upper half of the fronds only. - A plant gathered in Java agrees with this except that the fronds are narrowed very gradually into a nearly filiform base; fronds $1 / 4-1 / 2 \mathrm{~mm}$. broad; rhizome scales narrowly linear-lanceolate, subfiliform; sori not always occupying the upper half of the fronds only.

New Guinea, Java (?).

\section{§ 2. PLEUROGRAMMA.}

(5) II. Intermedia, Copel.

Also in Sumatra.

(6) M. Loheriana, $v . A . v . R$.

Omit this species, it being referred to Scleroglossum pusillum $v$. A. v. R.

\section{VITTARIA, J. Smith.}

Sori linear, 1 on each side of the costa, continuous or rarely interrupted, never confluent, marginal, submarginal or intramarginal, mostly sunk in more or less shallow furrows with the inner lip of the furrownot consisting of thickened costal parenchyma. Paraphyses present, stalked, cuneate.

Fronds not especially thickened in the fertile region.

\section{\$ 1. EUVITTARIA. -}

$\S 2$. TAENIOPSIS. The inner lip of the furrow sometimes much broader than, or as broad as, the outer but then the latter 
distinctly differentiated from the margin of the frond, forming a more or less elevated submarginal ridge.

\section{§ 1. EUVITTARIA.}

(3) V. angustifolia, $\boldsymbol{B}$ I.; V. elongata, Sw., var. angustifolia, Rst., in Nov. Guin., VIII, Bot., 731.

A plant from New Guinea, cultivated in the Buitenzorg Gardens, agrees with this except that the rhizome scales are dark-brown or blackish.

(4a) V. nervosa, Christ, in Nov. Guin., VIII, Bot., 156.

Rhizome short. Fronds caespitoso-fasciculate, linear-lanceolate, narrowed into a short stipe, $\pm 8-12 \mathrm{~cm}$. long, $\pm 4-6 \mathrm{~mm}$. broad at the middle, clothed at the base with a few rigid, brown, glossy, subulate scales, the apex acuminate. Texture rigidly coriaceous; colour black-green; costa slender; veins very prominent above, rather hidden beneath, simple or forked, very oblique, subparallel to the costa. Sori confined to the upper half of the frond, marginal, continuous or interrupted; lower lip of the groove narrow; upper \pm twice as broad.

New Guinea.

(7) V. elongata, Sav.; - var. alpina, Christ, in Philipp. Journ., IIIC, 275.

Forma late-labiata (v. A. v. R., in Bull. Btz., 1912, VII, 28): Like the type but the fronds with the base much narrowed, stipitiform, and the upper lip of the soral grooved much broader than the lower, twice as broad. - New Guinea.

Var. alpina : Fronds $20-25 \mathrm{~cm}$. long, $\pm 11 \mathrm{~mm}$. broad, densely caespitose, soriferous towards the apex only. - Mindoro.

(9b) Wernillii, Christ.

Also in Luzon, Negros.

\section{§ 2. TAENIOPSIS.}

(11b) V. alternans, Copel.

Also in Negros.

Ferns and Fern Aluies. 
(14) V. debilis, Kuhn.

Omit this species, it being referred to Scleroglossum.

(15) V. pusilla, $B l$.

Omit this species, it being referred to Scleroglossum.

(16) V. sulcata, Kuhn.

Omit this species, it being referred to Scleroglossum.

\section{V. anboin: ensis, Fée.}

Also in Mindanao.

(18a) W. Iineata, Sm.; v. A. v. R., in Bull. Btz., 1912, VII, tab. V, fig. 6 .

Forma angustata (v. A. v. R., 1. c., 28): Fronds narrower than in the type, $\pm 2-3 \mathrm{~mm}$. broad, short-stalked, nearly sessile; sori when young protected by a narrow, elevated, interior outgrowth of leaf-tissue (reduced inner lip) and the broadly recurved or reflexed edge of the frond.

(18a*) V. scabroiconst, Copel., in Philipp. Journ., VIC, 87.

Rhizome short; scales narrow, broad at the base, black, sparingly denticulate. Fronds linear, $\pm 20-25 \mathrm{~cm}$. long, $4 \mathrm{~mm}$. broad, sessile, narrowed to both ends, acuminate. Texture coriaceous; costa distinct but not prominent. Sori intramarginal.

New Guinea

$\left(18 a^{*} a\right)$ V. sessillis, Copel., in Philipp. Journ., IX ${ }^{\mathrm{C}}, 231$.

Rhizome short, densely clothed with nearly black, ovate, long-setosoacuminate scales. Fronds sessile, aggregate, to $35 \mathrm{~cm} \cdot$ long, $\pm 7 \mathrm{~mm}$. broad, narrowed gradually towards a base $\pm 2-3 \mathrm{~mm}$. broad. Texture coriaceous; surfaces naked; costa hidden. Sori intramarginal, immersed.

Sumatra.

(19) U. secilopendroinat, Thav.; v. A. v. R., in Bull. Btz., 1914, XVI, 38.

Rhizome short-creeping, paleaceous with black or brown, filiformsubulate scales. Fronds sessile or on stalks to $\pm 15 \mathrm{~cm}$. long, linearlanceolate, narrowed gradually towards both ends, the apex acute or bluntish. Texture more or less coriaceous; surfaces naked; costa not 
rarely black in the lower part, sometimes nearly lost upwards; veins fine, oblique, parallel. Sori in broad, continuous, submarginal grooves, with the unaltered margin of the frond at first revolute over the fructification.

Forma typica: Fronds $\pm 30-45 \mathrm{~cm}$. long and $\pm 1-3 \mathrm{~cm}$. broad.Samoa to Ceylon, Br. India, South Africa.

Forma pallidior: Fronds $25-130 \mathrm{~cm}$. long and $\pm 2-6 \mathrm{~cm}$. broad in the fully developed plants. - Borneo, Sumatra.

(20a) W. Copelandii, v. A. . R., in Bull. Btz., 1912, VII, 28; V. Merrillii, Copel. (not Christ), p. p., in Leafl., II, 407.

Rhizome creeping, not caespitose, clothed with long, spreading, capillary-subulate, black-brown scales. Stipes distant, pendulous, slender, grey-brown, $\pm 12-15 \mathrm{~cm}$. long. Fronds $60 \mathrm{~cm}$. or more long, $1 / 2-11 / 2$ $\mathrm{cm}$. broad, linear, narrowed gradually into the stipe, the margin thickened. Texture firm when dry; surfaces opaque; costa visible. Sori long, submarginal, dorsal, occupying the thickened edge, with the lips of the soral groove narrow, thick.

Negros.

\section{9a. SOLEROGLOSSUM, v. A. v. I.}

Sori long, linear, deeply immersed in submarginal or intramarginal grooves, i. e. protected (separated) by the much produced (thickened and widened) costal parenchyma which is sometimes as broad as the lamina. No paraphyses.

Rhizome short or elongated, creeping or ascending. Fronds linear, narrow, simple, rarely forked, rigidly coriaceous, thick, much thickened in the fertile region, sometimes as thick as broad; veins free, ascending, simple or forked, indistinct or invisible. - v. A. v. R., in Bull. Dép. Agr. I. N., 1908, XXI, tab. II, fig. 2-3 (Vittaria, p. p.).

a. Stipes short or wanting.

b. Lateral veins simple.

(1) Sc. debile.

b.b. Lateral veins forked. 
c. The lamina beyond the sori relatively thin, rounded or acute at the edge.

(2) Sc. pusillum.

c.c. The lamina beyond the sori relatively thick, 2-angled at the edge.

(3) Sc. sulcatum.

a.e. Stipes distinct, elongated.

(4) Sc. pyxidatum

(1) Ce. Aenoile, v. A. v. IR., in Bull. Btz., 1912, VII, 39; Vittaria debilie, Kuhn, Hk. Bk., Syn. Fil., 518; C. Chr., Ind. Fil.; Pleurogramme debitis, Mett., MS., (oldest name).

Rhizome creeping, the scales linear, pale-brown. Fronds sessile, close, ligulate-linear, obtuse, $2 \frac{1}{2}-5 \mathrm{~cm}$. long, $2 \frac{1}{2}-4 \mathrm{~mm}$. broad, narrowed gradually to the base. Texture coriaceous; costa distinct beneath from the base to the apex, slightly sulcate above; veins oblique, simple, subimmersed, hardly produced beyond the receptacle in the fertile region, the lamina beyond the sori rather thin, much produced beyond the costal parenchyma which is \pm half as broad as the lamina.

Borneo.

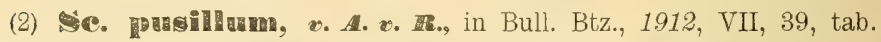
V, fig. 1-2; Vittaria pusilla, Bl., Rac., Flor. Btz., I, 60; v. A. V. R., in Bull. Dép. Agr. I. N., 1908, XXI, tab. II, fig. $2 a-c$; C. Chr., Ind. Fil.; V. falcata, Kze, Hk. Bk., Syn. Fil., 395; V. minor, Fée, Hk., Spec. Fil., V, 183; V. Loheriana, v. A. v. R., in Bull. Btz., 1911, I, 13; Taenitis pusilla, Mett., Ann. Mus. Bot. L. B., IV, tab. VII, fig. 11-14; Pleurogramme pusilla, Christ, in Philipp. Journ., IIC, 175; Pl. minor, Copel., in Philipp. Journ., VIIC, 53; Pl. Loheriana, Christ, in Bull. Herb. Boiss., 20 Sér., VI, 1006; Monogramma Loheriana, v. A. v. R., Mal. Ferns, 553:var. novoguineensis, Rst., in Nov. Guin., VIII, Bot., 729.

Rhizome ascending, the scales yellow-brown or brown, linear-subulate or lanceolate, hidden among the roots and fronds. Fronds approximate, numerous on the longest rhizomes, linear, 2-15 cm. long, 2-4 $\mathrm{mm}$. broad, sometimes slightly dilated and often nearly as thick as broad in the fertile region, simple or occasionally forked, the apex blunt or rounded, the lower part narrowed gradually to the base or a short stipe. Texture coriaceous; midrib rather distinct beneath but lost in the fertile region, somewhat grooved above; veins free, oblique, forked. Sori confined to the upper $1 / 3-1 / 2$ of the frond; the lamina beyond the sori 
moderately thin (linear or subulate in transversal section), rounded or acute at the edge, the costal parenchyma nearly as broad as the lamina or produced a little beyond the margin. - V. minor Fee (V. Loheriana v. A. v. R.) is a narrow form with the fronds $\pm 1 / 2$ as thick as broad in the fertile region, and united with the type by intermediates between which it is impossible to draw the precise limit. - A plant gathered in Borneo by Hallier, determined as $V$. debilis Kuhn (Ann. Btz., XX, 129), has the upper. surface provided with scattered, deciduous, stellate hairs.

Uar. novoguimeensis: Fronds very narrow, $\pm 1 \mathrm{~mm}$. broad in the barren region, to twice as broad and very thick in the fertile region.

Malacca, Java, Borneo, Phitippines, New Guinea; Queensland, Ceylon.

(3) Sc. Sulestuste. v. A. re., in Bull. Btz., 1912, VII, 39, tab. V, fig. 3-4; Vittaria sulcata, Kuhn, Bedd., Handb. Ind. Ferns, 408; v. A. v. R., in Bull. Dép. Agr. I. N., 1908, XXI, tab. II, fig. $3 a-c$; C. Chr., Ind. Fil.; Taeniopsis falcata, Bedd., Ferns Br. I., II, tab. CLXXV; Taenitis simplicivenia, Ces., Fel. Becc. Polin., 5 \& 8; Pleurogramme sulcata, Mett., MS., (oldest name).

Rhizome short-creeping, the scales dense, pale-brown, lanceolate. Fronds sessile, crowded, ligulate, $5-10 \mathrm{~cm}$. long, 3-4 mm. broad, obtuse, narrowed towards the base. Texture coriaceous; midrib visible in the lower part, lost in the fertile region; veins forked, or rarely subpinnate. Sori confined to the upper half of the frond, the lamina beyond the sori rather thick, the margin 2-angled (obliquely truncate in transversal section), the costal parenchyma \pm half as broad as the lamina.

Ceylon to Polynesia.

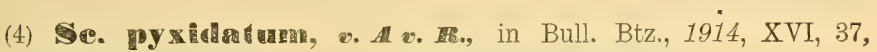
tab. IX; Vittaria pyxidata, v. A. v. R., MS. in Hèrb. Bog.

Rhizome elongate, ascending, the scales yellow-brown, subulate-lanceolate, blunt at the tip. Stipes numerous, crowded, $4-8 \mathrm{~cm}$. long, $\pm 1 / 3$ $\mathrm{mm}$. thick, terete, naked, grooved above. Fertile fronds ${ }_{2}{ }_{2}-1{ }^{1} / 2 \mathrm{~cm}$. long, decurved, subsigmoidal, $\pm 1-1 \frac{1}{2} \mathrm{~mm}$. broad and as thick in the fertile region, narrowed at both ends, the apex rostrate, the costa grooved above, the under surface deeply 2-sulcate. Texture coriaceous; surfaces naked; costa and veins invisible. Sori linear; continuous, in the groeves. Barren fronds ......

Borneo. 


\section{YO. TAENITIS, Willdenow.}

(1a) 'T'. drymoglossoides, Copel., in Philipp. Journ., III', 349, tab. VIII.

Stipes seriate, approximate, $8-12 \mathrm{~cm}$. long, reddish in the lower part, rufo-stramineous upward, naked. Fronds simple, entire, oblong or linear-oblong, $3-4 \mathrm{~cm}$. long, bluntly rounded at the apex. Texture rigidly coriaceous; surfaces naked; costa distinct in the lower half, less so in the upper. Sori in a continuous or interrupted line about midway between the costa and the margin or nearer, and parallel to, the latter, occupying the upper part of the frond, united at the apex. - Plants with the habit of a Drymoglossum.

Borneo.

(1b) 'T'. Waonksil, Copel., in Philipp. Journ., VI, 139, tab. XXIII a. Stipes rather tufted, reddish, $\pm 3-4 \mathrm{~cm}$. long, clothed at the base with minute, narrow, black scales, otherwise naked. Fronds simple, subulate-lanceolate, $\pm 8 \mathrm{~cm}$. long, $\pm 1 \% \mathrm{~cm}$. broad, narrowed gradually from the abruptly, broarly cuneate and slightly decurrent base to the apex. Texture coriaceous, rigid; surfaces naked.

Borneo.

(2) T. blechnoinles, Sw.; T. pteroides, Schik, Krypt. Gew., I, tab. $6 b$.

(3) Thenophyila, Christ.

Also in Celebes.

\section{Oa, BRAINEA, Houties.}

Sori more or less continuous along transverse veinlets near, and parallel to, the midrib and generally more or less produced along the veins in the direction of the edge of the frond. No indusium.

Caudex subarborescent. Stipes not articulate to the caudex. Fronds pinnately divided; veins simple or forked, anastomosing near the base only by transverse veinlets bearing the sori in the fertile fronds or segments. Hk. Bk., Syn. Fil., tab. VI, fig. 53. 
(1) R. insignis, Mk., Hk. Bk., Syn., Fil., 390; Hk., Fil. Exot., tab. XXXVIII; Diels, in Eng. \& Prantl, Nat. Pfl.fam., I', fig. $132 E-F$; Bedd., Ferns Br. I., I, tab. CXXXIX.

Trunk $60-120 \mathrm{~cm}$. high, $71 / 2--10 \mathrm{~cm}$. thick, clothed with shaggy, linear, brown or ferrugineous scales $2-2 \frac{1}{2} \mathrm{~cm}$. long. Stipes firm, $71 / 2-10$ $\mathrm{cm}$. long, naked, scaly only at the base. Fronds Lomaria-like, \pm 50-100 $\mathrm{cm}$. long, $15-30 \mathrm{~cm}$. broad, simply pinnate or partly z-pinnate. Pinnae close, numerous, linear-subulate, $5-10 \mathrm{~mm}$. broad at the often cordateauriculate base, serrate or serrulate, the fertile ones often the narrowest. Texture coriaceous; rachis and both surfaces naked. Sori at length filling up nearly the whole under surface of the fertile pinnae when contracted. Pulo Sembilan, Mindoro (?); South China, Tonkin, Burmah, Khasya.

\section{POLYPODIUM, tinné.}

Sori round or oblong, several to many on each side of the costa, superficical or sunk in cavities, dorsal or terminal on free veins or veinlets or uniting the apices of free veinlets, sometimes protected by the recurved or reflexed margin of the frond or immersed in saccate or indusium-like, marginal or submarginal depressions of the frond, the oblong ones parallel or generally more or less oblique to the costa or the margin. No indusium.

Rhizome creeping or erect. Stipes as a rule articulate to the rhizome, the articulation often indistinguishable in the smaller species ( ${ }^{1}$ ). Fronds simple, incised or pinnate, rarely more compound; surfaces naked, scaly or hairy, the hairs not stellately branched; veins free, if anastomosing, the arenlae regular, with the included free veinlets running in the direction of the margin.

(1) Not only of late, but also formerly, some species of Polypodium and Pleopeltis with non-articulated stipes have been found; it is, moreover, a well-known fact that in the smaller species of the said genera the articulation is often not observable. Consequently one of the main points of diffence between those two genera and Phegopteris and Dictyopteris, i. e. the articulated or non-articulated stipes, partly dissapears.

For this reason the unarticulated species of Polypodium and Pleopeltis logically ought to be classified among those of Phegopteris and Dictyopteris. There is, however, such a great difference of habit and mode of growth between the two former and the 
§ 1. EUPOLYPODIUM.

a. Integrifolia.

b. Furenta.

c. Pinnatifida.

d. Pinnata.

e. Composita.

\section{§ 2. PROSAPTIA.}

§ 3. GONIOPHLEBIUM.

a. Crypsinus.

b. Symammia.

c. Margingr ria.

d. Selnellolepis.

\section{\& 4. PHLEBODIUM.}

\$ 5. CAMPYLONEURON.

\section{$\S 1$. EUPOLYPODIUM.}

(3a) sparsipilam, Copel., in Philipp. Journ., VIC, 139, tab. XXIII $b$.

Rhizome short, the -scales dense, broadly lanceolate, brown, glossy. Stipes aggregate, filiform, $6-9 \mathrm{~mm}$. long, clothed with spreading hairs. Fronds linear-ligulate, $\pm 5 \mathrm{~cm}$. long, 3-4 mm. broad, subentire. Texture herbaceous, diaphanous; surfaces sparingly pilose; veins often forked. Sori round, superficial, subcostal.

Borneo.

two latter genera, that in this special case another arrangement is to be preferred, and habit and mode of growth are to be considered as more important characteristics than te articulation of the stipes.

This may cause some difficulties to inexperienced students of Pteridology, as in regard to babit and mode of growth a sharp line is hard to draw; but those who once have learned to recognize the species of Polypodium and Pleopeltis at the first sight, will easily distinguish them from Phegopteris and Dictyopteris.

(1) For the characters of the sections and groups, see my Handbook, pp. 567 seq. 
(6a) Sonbrepandum, Broun., in Lautb., Beitr. Flor. Pap. I, 37.

Rhizome short, erect, the scales dense, triangular-oblong, long-acuminate, entire, pale. Stipes tufted, to $51_{2} \mathrm{~cm}$. long, clothed with numerous rather horizontal, short hairs. Fronds linear-lanceolate, to $23 \mathrm{~cm}$. long by $1 \frac{1}{4} \mathrm{~cm}$. broad, bluntly acuminate, repand or slightly crenate, narrowed very gradually at the base. Texture coriaceous; surfaces naked; veins flexuose, subpinnate with 2 veinlets on the anterior and 1 veinlet on the posterior side. Sori copious, slightly immersed, in $2-3$ rows on each side of the costa.

New Guinea.

(6b) Perraeforme, Brau, in Lautb., Beitr. Flor. Pap., I, 36, 'fig. $2 \mathrm{D}$.

Rhizome short, ascending. Stipes tufted, $1 \frac{1}{2}-31 / 2 \mathrm{~cm}$. long, hairy, scaly at the base, the hairs short, fuscous, dense, the scales triangularoblong, ferrugineous, entire. Fronds linear-lanceolate; $\pm 9^{1 / 2}-14 \mathrm{~cm}$. long by $\pm 1 \% \mathrm{~cm}$. broad, narrowed gradually at both ends, irregularly crenated to toothed or sinuated, ciliated when young. Texture coriaceous; costa hairy on both sides; upper surface hairy when young; main veins numerous, sparingly pinnate. Sori $1-2$ on each side of the main veins, immersed, round.

New Guinea.

(Ta) setaceams, Copet., in Philipp. Journ., VI, 139 , tah. XXIV.

Rhizome creeping, clothed with shortly linear, ferrugineous scales. Fronds aggregate, rush- or string-like, $\pm 55 \mathrm{~cm}$. long, $1 \frac{1}{2} \mathrm{~mm}$. broad, narrowed into a short stipe, entire, naked, the costa grooved above, prominent beneath, the lamina above convex on each side of the costa, beneath concave; veins hidden. Sori nearly costal, elongated.

\section{Borneo.}

(7b) P. pyxidifonme, v. A. $\boldsymbol{T}$., in Bull. Btz., 1911, 1, 28.

Rhizome ascending, elongated in the fully developed plant, the extremity clothed with crowded, subadpressed, pale-brown, lanceolate, entire scales. Stipes numerous, crowded, erected, very slender, nearly filiform, $\pm 1 / 2 \mathrm{~mm}$. thick, slightly flexuose-tortunse, $\pm 21 / 2-5 \mathrm{~cm}$. long, subterete, slightly compressed, sulcate above, naked. Fronds dimorphous. Barren fronds linear or linear-oblong, decurved, to $10 \mathrm{~mm}$. long, hardly 
more than $1 / 2 \mathrm{~mm}$. broad, passing gradually into the stipe, nearly semiterete, the under surface rather flat, the upper surface convex, sulcate in the lower half, the apex blunt. Texture coriaceous; surfaces naked; costa slightly prominent beneath, decurrent upon the stipe; veins invisible. Fertile fronds oblong or linear-oblong, decurved, naked, semiterete, $3-10 \mathrm{~mm}$. long, $\pm 2 \mathrm{~mm}$. broad, $\pm 1 \mathrm{~mm}$. thick, the base cuneate, the sides parallel, the apex narrowed, the point bluntish, the under surface rather flat, the upper surface convex, grooved in the lower half, the costa somewhat prominent beneath, decurrent upon the stipe. Sori oblong, $1-6$ on each side of and parallel to the costa, medial, alternate, deeply immersed, at length prominent and confluent, occupying the whole under side of the frond except the narrowed base and the apex; sporangia sparingly setulose. - Very remarkable by its fertile fronds resembling the long-stalked sporocarps of a moss.

New Guinea.

(16a*) Plurum, Copet., in Leafl., III, 837.

Rhizome short-creeping, densely clodhed with ovate, acuminate, entire, ochraceous scales. Stipes approximate, $\pm 1-2 \mathrm{~cm}$. long, black, naked. Fronds $\pm 20 \mathrm{~cm}$. long, $8-9 \mathrm{~mm}$. broad, obtuse, entire, narrowed gradually towards the base. Texture rigidly coriaceous; surfaces nearly glabrous. Sori in 1 row on each side of the costa, occupying the upper half of the frond, slightly immersed, round when mature; sporangia black-bristly.

Mindanao.

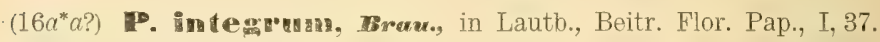

Rhizome creeping; scaly; scales squarrose, crowded, triangular-oblong; acuminate, entire, grey-brown, peltate at the base. Stipes approximate, $\pm 3 \mathrm{~cm}$. long, fuscous, very narrowly winged. Fronds linear-lanceolate, $\pm 32 \mathrm{~cm}$. or more long, to $\pm 1 \% / 4 \mathrm{~cm}$. broad, entire, sparingly ciliated when young, narrowed very gradually at the base, the edge narrowly revolute. Texture coriaceous; surfaces glabrescent; veins indistinct, pinnate. Sori large, oblique, remote, in 1 row on each side, subcostal, occupying the upper part of the frond, placed on the lowest anterior veinlets, slightly immersed.

New Guinea.

(16c) planum, v. A. v. M., in Bull. Btz., 1914, XVI, 32.

Rhizome short-ascending, clothed with pale-brown, narrow, subulate- 
lanceolate, entire scales. Stipos approximate, $\pm 1-2 \frac{1}{2} \mathrm{~cm}$. long, brown, naked. Fronds linear, $15-20 \mathrm{~cm}$. long, 5-7 mm. broad, narrowed gradually towards the base, the margin repand. Texture coriaceous; surfaces naked or the under surface provided with a few scattered minute hairs on the costa; costa somewhat prominent beneath; veins immersed distinct when seen towards the light, forked. Sori solitary at the base of the anterior veinlets, subcostal, somewhat remote, suboblong; superficial; capsules setulose.

Sumatra.

\section{(18) P. Merorillihi, Coped.}

Also in Amboina.

(21a) P. parvom, Erau., in Lautb., Beitr. Flor. Pap., I, 36, fig. $2 C-c$.

Rhizome short-ascending. Stipes tufted, filiform, to $\pm 1 \mathrm{~cm}$. long, provided with horizontally spreading, fuscous hairs. Fronds linear-lanceolate, $\pm 3 \mathrm{~cm}$. long by $2 \mathrm{~mm}$. broad, entire or slightly undulate, narrowed at both ends. Texture pellucido-membranaceous; surfaces clothed with long, fuscous hairs; veins simple or forked, ascending, not reaching the margin. Sori roundish, dorsal on simple veins or on the anterior branchlets of forked veins.

New Guinea.

\section{P. Pothesiticum, Metz.}

A plant gathered in $J \alpha v a$, which is probably a form of this species, has the largest fertile fronds $\pm 4-6 \mathrm{~cm}$. long, subsessile or short-stalked, forked at the middle, with the fork-branches $\pm 2 \mathrm{~mm}$. broad, the stipe and both surfaces clothed with copious moderately short, red-brown hairs, the sori confined to the upper part of the fork-branches, not reaching the apex.

Also in Malacca; Br. India.

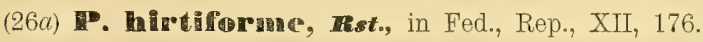

Rhizome short, the scales minute, ovate, ferrugineous. Stipes aggregate, to $2 \mathrm{~cm}$. long, capillary, densely clodhed with long, weak, spreading, rufous hairs. Fronds simple, linear, to $10 \mathrm{~cm}$. long by $2^{1} / 2-3 \mathrm{~mm}$. broad, bluntish, entire, narrowed gradually in the lower part. Texture membran- 
aceous; both surfaces rufo-pilose especially on the costa and edge; costa prominent; veins black, simple when sterile. Sori in 1 row on each side, subcostal, dorsal on the very short anterior branchlets of the arcuateascending, forked, fertile veins.

New Guinea.

\section{(27) P. subevengsum, Bh.}

Malacca to Celebes and the Phitippines.

(29a) p. pillstipes, o. A. r. ., in Bull. Btz., 1913, XI, 20 ; P. Maxwellii, Bk., p. p., v. A. v. R., 1. c.

Rhizome short, erect, the scales subulate-lanceolate, membranaceous, pale-brown. Stipes subtufted, short, distinctly but not densely clothed with short, pale-brown, deciduous hairs. Fronds simple, to $6 \% \mathrm{~cm}$. long, $\pm 4-5 \mathrm{~mm}$. broad, rather entire, blunt or bluntish, narrowed at the base. Texture rather coriaceous; surfaces naked but the edges sparingly and very minutely ciliolated; costae slightly deciduously pubescent towards the base; veins oblique, forked, not reaching the margin, with the anterior fork branch the shortest. Sori oblong, subimmersed, nearer the costa than the margin, terminal on the anterior veinlets.

Malayan?

(32a) Se日 No. 42.

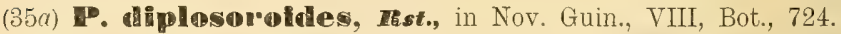

Rhizome creeping, clothed with crowded, pale-brown, lanceolate scales. Stipes somewhat remote, $1-2 \mathrm{~cm}$. long, wiry, clothed with long, spreading, pale-ferrugineous or dark-brown, deciduous hairs. Fronds linearlanceolate, $\pm 12 \mathrm{~cm}$. long, $71 / 2-10 \mathrm{~mm}$. broad, narrowed gradually towards both ends, the edge undulate-crenate, sparingly ciliated with.long, brown hairs. Texture firm-coriaceous; surfaces naked; costa pilose with long; brown hairs; veins oblique, forked, the anterior branchlet short, soriferous, the posterior branch long, mostly forked again. Sori roundish, oblong when young, in 1 row on each side, nearer the costa than the margin, superficial.

New Guinea.

\section{(37b) P. dolichosonum, Copel.}

A specimen received from Mindanao (Elmer No. 10636) has the 
fronds with the costa setose beneath, the margins (and the edges of the soral cavities) positively ciliated with dark, acute setae.

(38) P. setosum, Pr.

Fronds sometimes eroso-denticulate.

(38a) See No. $37 b$.

(38b) P. ciliaferenum, v. A. v. R., in Bull. Btz., 1914, XVI, 32.

Rhizome creeping, the upper part densely. clothed with deciduous, pale-ochraceous, lanceolato-ovate, entire scales. Stipes seriate, $1-10 \mathrm{~mm}$. apart, 1-2 cm. long, marginate, and remotely ciliate with short, erected, red-brown hairs, as are the fronds. Fronds linear, $\pm 20 \mathrm{~cm}$. long, \pm 8-10 $\mathrm{mm}$. broad, blunt, entire, narrowed very gradually at the base. Texture rigidly coriaceous; costa beneath provided with a few scattered red-brown hairs; veins forked at the base: veinlets long, the posterior mostly forked again. Sori in 1 row on each side, subcostal, somewhat remote, placed at the base of the anterior veinlets, slightly immersed.

Sumatra.

(39) pubinerve, Christ.

Also in Mindanao.

(40) E. Aliplosorean, Christ.

Also in Luzon, Mindanao, Negros, New Guinea.

(42) PD. Boseurum, Mett.; - var. angustatum; Grammitis obscura, Bl., var. angustata, Bl., Flor. Jav., II, 113, tab. L, fig. 2; P. Reinwardtii, Pr., var., C. Chr., Ind. Fil.

Var. angangtume : Fronds shorter, narrower, hardly pubescent, short-stalked; sori nearly round, confluent. - Java.

(44) Eetigerum, Bl.; P. fasciculatum, Pr., Tent. Pterid., 180.

(45) TP. Sumatrganum, $\boldsymbol{B R}$.

Also in New Guinea. 


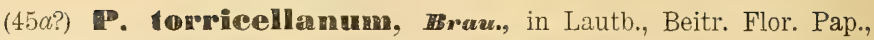
I, 45, fig. $3 \mathrm{~A}$.

Rhizome short, erect, the scales triangular-subulate, fuscous, entire, peltate-cordate at the base. Stipes tufted, $\pm 1 / 2-1 \mathrm{~cm}$. long, fuscous, densely clothed with short, fuscous, spreading hairs. Fronds linearlanceolate, to $\pm 15 \mathrm{~cm}$. long by $1-1 \frac{1}{3} \mathrm{~cm}$. broad, narrowed gradually at both ends, crenate. Texture rigidly coriaceous; surfaces dark-green; upper surface nearly naked, lower short-hairy, the hairs fuscous; costa densely hairy beneath, less so above; higher and lower veins simple or forked, free; central veins forked at the apex, for the rest united by a single row of transversal veinlets forming 1 row of pentagonal areolae on each side of the costa; areolae provided with a single included excurrent free veinlet springing from the anterior side of the veins. Sori in 2 rows on each side, the inner ones terminal on the included veinlets, the outer on the anastomosing veinlets. - The systematical place of this species is uncertain; Brause placed it in $\S$ Phlebodium.

New Guinea.

(45b) subrediculatuan, Copel., in Philipp. Journ., IXC, 6.

Rhizome short-creeping; the scales dense, ovate-lanceolate, brightbrown. Stipes approximate, $\pm 1-2 \mathrm{~cm}$. long, firm, provided with darkpurple-brown setae. Fronds to $25 \mathrm{~cm}$ long by $12 \mathrm{~mm}$ : broad, narrowed gradually at both ends, entire or nearly so. Texture coriaceous; surfaces provided with scattered, nearly black hairs, at length not rarely naked; veins forked with the veinlets free, or sparingly subpinnate with the veinlets sometimes uniting here and there. Sori in 2-3 irregular rows, round or suboblong.

New Guinea.

(46) r. subdichoterandan, Rac. (v. A. v. R., in C. Chr., Ind. Fil., Supp.).

(47) P. gancillinansan, Copel., Polypod. Philipp., 121; v. A. v. R., in Bull. Btz., 1912, VII, tab. III, fig. $1 a-b$; - var. ciliatum, v. A. v. R., 1. c., 40, tab. III, fig. 1 c.

Rhizome creeping or ascending, the scales brown, lanceolate. Fronds stalked or subsessile, linear-lanceolate, narrowed gradually towards both ends, deeply pinnatifid. Lobes decurrent, connected by a narrow costal 
wing, ascending; fertile lobes relatively shorter and broader than the barren ones, roundish-oblong. Texture relatively thin; surfaces naked or the costa provided with a few scattered, relatively long or short, simple or branched hairs; veins simple, 1 in each lobe, not reaching the apex. Sori 1 to each fertile lobe, medial, protected by the inflexed lower side of the lobe.

Forma typica: Fronds $6-12 \mathrm{~cm}$. long by $3-5 \mathrm{~mm}$. broad; lobes distant, the barren ones linear-oblong, blunt or subacute, to $4 \mathrm{~mm}$. long and $1 \mathrm{~mm}$. broad. - Java, Sumatra, Philippines, New Guinea.

Forma abbreviata: Fronds shorter; barren lobes more approximate, proportionally shorter and broader, oblong, about $1 \frac{1}{4}-1 \frac{1}{2} \mathrm{~mm}$. broad, bluntly rounded at the apex. - Java.

Var. cillata: Fronds shorter, narrower; lobes smaller, sparingly long-ciliate at the edge. - Celebes.

(47a) P. anuscerides, Copel., in Leafl., III, 839 ; v. A. v. R., in Bull. Btz., 1912, VII, tab. III, fig. $3 a-b$.

Rhizome short, erect. Stipes short, aggregate. Fronds $2-5 \mathrm{~cm}$. long, $\pm 3 \mathrm{~mm}$. broad, the edge cut down to a relatively broadly winged costa into rather approximate, more or less confluent, roundish- or triangular-oblong; subacute or blunt lobes $\pm 1 \mathrm{~mm}$. broad; fertile lobes \pm as long as or somewhat shorter than the barren ones, rather suborbicular, with the lower edge folded so as to clasp the sorus. Texture firm; surfaces and edges naked or very sparingly and inconspicuously short-hairy; veins 1 in each lobe. Sori solitary on the lobes, medial.

Mindanao.

(47b) 댈. calynamodin, Fée; P. cucullatum, Nees \& Bl., Mett., Farng., I, Polypod., 33, p. p.; v. A. v. R., in Bull. Btz., 1912, VII, tab. IV, fig. $2 a-b$; Grammitis cucullata, Bl., Flor. Jav., II, 119, tab. L. fig. 3; Calymmodon cucullatus, Pr., Tent. Pterid., 203, 204, tab. IX, fig. 1.

Rhizome short, the seales lanceolate, acuminate, yellowish to fuscous, thin. Fronds aggregate, sessile or short-stalked, linear-lanceolate, $2 \frac{1}{2}-10$ $\mathrm{cm}$. long, 3-4 mm. broad, narrowed gradually at both ends, pinnatifid. Lobes ascending, decurrent, connected by a narrow wing; lower lobes barren, tooth-like, bluntish, entire; central and higher lobes fertile, roundish-obovate or subsemiorbicular, the apex rounded, rarely bluntish. Texture thin to firm; surfaces naked; veins solitary in the lobes, simple, not 
reaching the apex of the lobe. Sori solitary and medial on the lobes, with the lower edge of the lobe recurved so as to clasp the sorus. Fée's diagnosis is not to my disposal, but I think it fits this species, which is doubtless different from $\mathrm{P}$. cucullatum Nees \& $\mathrm{Bl}$.

Java.

(47c) P. consociatum, v. A. v. Re., in Bull. Btz., 1912, VII, 41, tab. IV, fig. $1 a-a^{\prime}, b-b^{\prime}, c-c^{\prime}$; (? P. cucullatum, Bedd., Handb. Ind. Ferns, 307, fig. 161; Calymmodon cucullatus, Bedd., Ferns S. I., tab. CCXXXIII).

Rhizome erect or ascending, clothed with pale-brown, lanceolate, acute, entire scales. Fronds consociate, linear or linear-lanceolate, \pm 6-12 cm. long, 5-10 mm broad, sessile or short-stalked, narrowed towards both ends, cut down to a rather narrowly winged costa into remote or approximate, erecto-patent or spreading, oblong, or linear-oblong lobes; lobes blunt, $1 \frac{1}{2}-2 \mathrm{~mm}$. broad, the fertile ones similar to the barren but somewhat broader, with the lower edge partly reflexed so as to clasp the sorus. Texture firm; both surfaces copiously (not densely) longhairy; a simple central vein only in each lobe. Sori 1 to each lobe, oblong, medial.

Philippines; Ceylon (?).

(47d) P. knmiense, Brau., in Lautb., Beitr. Flor. Pap., I, 40, fig. $2 \mathrm{H}-\mathrm{h}$.

Rhizome short, erect. Fronds tufted, sessile, linear, to $25 \mathrm{~cm}$. long, 4-6 $\mathrm{mm}$. broad, bluntish, cut down nearly to the costa, narrowed very gradually at the base, the base provided with linear, entire, ferrugineous scales. Segments ascending; lower and central segments sterile, rather approximate, the lower deltoid, bluntish, the central subquadrangular, to $21 / 2 \mathrm{~mm}$. long, $2 \mathrm{~mm}$. broad, entire or excised at the apex; higher segments fertile, to $5 \mathrm{~mm}$. long, 2-fid, the lobules acute. Texture firm; surfaces and edges when youg provided with forked, dark-brown hairs; veins indistinct, simple or forked, not reaching the margin. Sori solitary on the anterior lobule of the fertile segments, superficial, protected by the folded posterior lobule.

New Guinea.

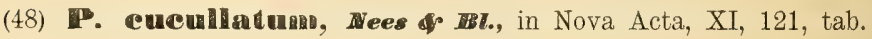


XII, fig. $3 A, a-b$; P. subgracillimum, v. A. v. R., in Bull. Btz., 1912, VII, 40, tab. III, fig. $2 a-b$; - ? var. planum, Copel., in Philipp. Journ., IIC, 137.

Rhizome elongate in the adult plant, the scales lanceolate, yellowish to fuscous. Fronds fasciculate, sessile or short-stalked, linear or linearlanceolate, $7 \frac{1}{2}-20 \mathrm{~cm}$. long, $4-5 \mathrm{~mm}$. broad, deeply pinnatifid, narrowed gradually towards both ends. Lobes remote, ascending, decurrent, connected by a narrow wing; barren lobes triangular-lanceolate, $2--4 \mathrm{~mm}$. long, straight or somewhat falcate, acuminate, the lower growing gradually shorter, obliquely deltoid, acute or bluntish; higher lobes fertile, ovate or roundish-rhomboidal, subacute or. subacuminate, sometimes bluntish. Texture moderately thin to firm; surfaces naked; veins solitary in the lobes, simple, not reaching the apex of the lobes. Sori solitary and medial on the lobes, with the lower edge of the lobe recurved so as to clasp the sorus. - The forms described and drawn as Grammitis cucullata Bl. and Calymmodon cucullatus $\mathrm{Pr}$. are not this species.

Forma typica. - Ceylon (?) across Malaya to Fiji and Newo Caledonia.

Var. planum: Lobes flattened, large, approximate, orbicularoblong; sori large, superficial. - Mindoro.

(48a) P. pergracillimmm, v. A. v. F., in Bull. Btz., 1915, XX, 23; P. gracillimum, Rst. (not Copel.), in Nov. Guin., VIII, Bot., 725.

Near P. cucullatum Nees \& Bl. but the fronds narrower, $1-2 \mathrm{~mm}$. broad, the segments shortly and obliquely deltoid, recurved at the apex. New Guinea.

(49a) Pedeense, v. A. v. R., in Bull. Btz., 1914, XVI, 33.

Rhizome elongate, ascending, the scales lanceolate, pale-brown. Stipes approximate, to $1 / 2 \mathrm{~cm}$. long, naked, filiform. Fronds linear, $\pm 5 \mathrm{~cm}$. long, $\pm 4 \mathrm{~mm}$. broad, bluntish, deeply pinnatifid, narrowed towards both ends but very gradually towards the base. Lobes distant, connected by their dilated decurrent bases, obliquely deltoid, blunt, entire, or the horizontal upper edge slightly retuse near the apex. Texture subcoriac. eous, fragile when diy; surfaces naked or very nearly so; veins forked in the lobes. Sori solitary on the lobes, at the base, on the anterior veinlets, superficial.

Java.

Ferns and Fern Alites. 
(49b) See $98 b$.

(49c) P. setuliferum, v. A. v. R., in Bull. Btz., 1914, XVI, 33.

Rhizome short, clothed with pale-brown, lanceolate scales. Stipes aggregate, $0-2 \mathrm{~cm}$. long, filiform, setulose with short, spreading, scattered, reddish hairs, as are the fronds. Fronds linear, $\pm 2 \% \frac{2}{\mathrm{~cm}}$. long, 3-5 mm. broad, deeply lobed, the apex somewhat narrowed, bluntish, the base narrowed, decurrent. Lobes approximate, oblique, the narrowest nearly triangular and bluntish or rounded, the broadest subtrapeziform or subrhomboidal and truncate-emarginate at the apex. Texture subcoriaceous; veins solitary in the lobes, simple in the narrowest lobes, forked in the broadest ones. Sori solitary on the broadest lobes, at the base of the anterior veinlets, at length confluent and hiding the costa.

Sumatra, Malacca.

(49d) P. pumilam, Erau., in Lautb., Beitr. Flor. Pap., I, 38, fig. $2 F-f$.

Rhizome short, erect, the scales entire, ferrugineous. Fronds subsessile, tufted, linear-oblanceolate, $\pm 2-4 \% \mathrm{~cm}$. long, $\pm 4 \mathrm{~mm}$. broad, bluntish, pinnatifid, narrowed gradually at the base; lobes spreading, the lower ones barren, triangular, entire, bluntish or subacute at the apex, the central and higher fertile, truncate and deeply emarginate at the apex. Texture chartaceous; costa stout, clothed with long brown hairs, as are the surfaces; veins prominent above, simple in the barren lobes, forked in the fertile ones. Sori solitary on the lobes, occupying the anterior veinlets.

New Guinea.

(50) Solpoinnatifidum, Bt.

Also in Nero Guined and the Philippines.

(50a) P. govidjoaense, Brau., in Lautb., Beitr. Flor. Pap., I, 41, fig. $2 K-k$.

Rhizome erect, clothed with linear-lanceolate, entire, ferrugineous scales. Fronds tufted, subsessile, linear, to $13 \mathrm{~cm}$. long, $2-3 \mathrm{~mm}$. broad, narrowed gradually towards both ends, the margin deeply incised. Lobes ascending, obliquely triangular, tooth-like, entire, bluntish, separated by rounded sinuses. Texture rigidly coriaceous; surfaces naked; veins 1 in each lobe, forked on the anterior side near the base. Sori subcostal, 
deeply immersed, solitary on the lobes, occupying the short anterior veinlets, provided with fungiform paraphyses.

New Guinea.

(51a) P. bolobense, Brau., in Lautb., Beitr. Flor. Pap., I, 38, fig. $2 E-e$.

Rhizome short, erect, clothed with ovate-lanceolate, ciliate, fuscous scales. Fronds subsessile, tufted, linear-oblanceolate, $4-8 \mathrm{~cm}$. long, to 8 $\mathrm{mm}$. broad, pinnatifid, the apex bluntish, the base narrowed gradually; lobes spreading, oblong, rounded at the apex, separated by narrow bluntish sinuses. Texture membranaceous; costa prominent, provided with long, brown hairs, as are the surfaces; veins indistinct, forked or pinnate in the lobes. Sori oblong, superficial, hairy.

New Guinea.

(51b) P. capitellatum, Braw., in Laut., Beitr. Flor. Pap., I, 39, fig. $2 G-g$.

Rhizome short, erect. Stipes tufted, stout, short, $\pm 2 \mathrm{~mm}$. long, clothed with long; whitish, spreading hairs. Fronds linear-oblanceolate, $\pm 4 \frac{1}{4} \mathrm{~cm}$. long by $6 \mathrm{~mm}$. broad, bluntish, pinnatifid, narrowed gradually at the base; lobes ascending; triangular-subfalcate, to $3 \mathrm{~mm}$. long and $11 / 2 \mathrm{~mm}$. broad, bluntish, entire or slightly undulate, separated by blunt sinuses. Texture membranaceous; costa, surfaces and edges provided with long, whitish hairs; veins simple, or the fertile ones forked on the upper. side at the base, the anterior veinlets short. Sori solitary on the lobes, subcostal, on the anterior veinlets, long-hairy.

Newo Grinea.

The specimens occurring in the Buitenzorg Herbarium have the fronds provided with peculiar, thick, black stripes running along (or parallel to) the veins. - See also No. 90.

Also in Celebes.

\section{P. IBurbidgei, Bk.}

The largest fronds have the typical arrangement of sori, but some distinctly more slender fronds have the segments bearing all the sori there is room for, and looking quite like those of $\mathrm{P}$. celebicum $\mathrm{Bl}$. - (Copel.). 
(53a) P. rachisorum, Christ, in Nov. Guin., VIII, Bot., 154; (? P. Burbidgei, $B k$.).

Rhizome ascending, rather elongate, clothed with minute, brown scales. Stipes approximate, $\pm 6 \mathrm{~cm}$. long, broadly winged quite to the base. Fronds $\pm 20 \mathrm{~cm}$. long, $\pm 3 \mathrm{~cm}$. broad, pinnatifid, the apex elongate, subdentate. Lobes numerous, pectinate, separated by rounded sinuses, spreading, the central ones sublinear-ligulate, $\pm 11_{4} \mathrm{~cm}$. long, $\pm 3 \mathrm{~mm}$. broad, subacute, the lower ones abbreviated. Texture herbaceous; colour pale-green, opaque; surfaces naked; costa hairy; costulae flexuose; veins simple, oblique, \pm 6 on each side of the costulae. Sori minute, $\pm 1-5$ on each side of the costulae, medial, immersed, round, the lower ones oblong, approaching the main costa.

New Guinea.

(53b) P. geluense, Rst., in Fed, Rep., V, 374.

Rhizome short-creeping, densely scaly at the apex, the scales elongatelanceolate, bluntish, livid-fuscous, cancellate, provided with black-purplish, often forked setae especially near the margin. Stipes fasciculate, erect, $2-5 \mathrm{~cm}$. long, subterete or slightly chanelled above, fuscous-green, densely clothed with rufo-fuscous, forked or stellate, spreading setae. Fronds 60 $\mathrm{cm}$. or more long, $4-6 \mathrm{~cm}$. broad, nutant, revolute when dry, linear, narrowed towards both ends, decurrent upon the stipe, deeply pinnatifid. Segments numerous, alternate, suberecto-patent, connected by a wing \pm $2 \mathrm{~mm}$. broad, nearly linear or narrowed gradually from the base to the apex, the largest ones $\pm 2 \frac{1}{2} \mathrm{~cm}$. long, $5-61 / 2 \mathrm{~mm}$. broad at the base, the base often nearly equal-sided (the upper base somewhat broader than the lower), the edge entire, flat, the apex acute or bluntish; upper pinnae gradually abbreviated but hardly narrower, lower ones much abbreviated and dilated, connected by a narrow wing. Texture papyraceoherbaceous; surfaces clothed with tufted, rufo-fuscous setae but more or less densely so with forked ones at the margin; upper surface livid-green, lower paler; costa elastic, slightly prominent beneath; costulae and veins immersed but visible when seen towards the light; veins simple, the lowest anterior ones forked, the lowest posterior ones originating from the costa. Sori 8-11 on each side, rather terminal, not occupying the lower and upper veins of the segments, elliptic, slightly immersed, surrounded by simple or forked, rufo-fuscous setae.

New Guinea. 


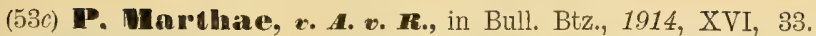

Rhizome short-creeping, the scales subulate, brown, eiliate with somewhat remote, horizontal, acute hairs. Stipes approximate, $\pm 1-2 \mathrm{~cm}$. long, clothed with copious rufous or fuscous hairs spreading in all directions. Fronds linear-lanceolate, $\pm 20-40 \mathrm{~cm}$. long, $2 \frac{1}{2}-4 \mathrm{~cm}$. broad, cut $5 / 6-7 / 8$-way down to the costa, acute, gradually repand towards the long-decurrent base. Lobes horizontal or nearly so, straight or subfalcate, separated by subacute sinuses, subsubulate from a dilated base, $\pm 1-1^{3} / 4 \mathrm{sm}$. long, $3-5 \mathrm{~mm}$. broad at the base, bluntish, entire, when dry recurved at the edge, the lower growing gradually shorter. Texture coriaceous; surfaces naked; costae, costulae and margins more or less sparingly red-brown-hairy especially when young; costulae and veins hidden; veins $\pm 7-10$ on a side in the longest lobes, simple, a single vein often proceeds from the costa in the direction of the sinus between 2 adjacent segments. Sori submarginal, deeply immersed, slightly prominent above, the cavity suboblong, parallel to the margin, without raised edges.

Celebes.

(53d) P, jovanicum, Copel., in Philipp. Journ., VIIC, 142.

Rhizome short, clothed with castaneous, lanceolate scales. Stipes aggregate, hardly $1 \mathrm{~cm}$. long, whitish-velutinous. Fronds pendulous, \pm $10 \mathrm{~cm}$. long, $1-1 \frac{3}{4} \mathrm{~cm}$. broad, obtuse, cut down to a narrow wing into oblong, abruptly subacute, entire, often imbricated lobes $\pm 4 \mathrm{~mm}$. broad. Texture thick; surfaces minutely pubescent; veins hidden. Sori slightly immersed, small, submarginal, not prominent on the upper surface.

Java.

(53e) P. monocanpum, Rst., in Fed., Rep., XII, 178.

Rhizome elongated, densely clothed with brown, lanceolate, ciliate scales. Stipes $\pm 2-3 \mathrm{~cm}$. or more long, more or less sparingly hairy. Fronds linear-lanceolate, to $35 \mathrm{~cm}$. or more long, nearly $2 \mathrm{~cm}$. broad, narrowed gradually towards both ends, deeply pinnatifid, the lower part wing-like, sinuate. Lobes numerous, horizontal, subapproximate, linear, the central ones the largest, incurved, $\pm 1 \mathrm{~cm}$. long by $1 / 4 \mathrm{~cm}$. broad, unequal-sided, broadest on the anterior side, narrowed at the apex, hardly dilated at the base, separated by rounded sinuses. Texture coriaceous; surfaces naked; costa black, prominent beneath, naked or sparingly shorthairy; costulae and veins hidden; veins simple. Sori $1-3 \mathrm{~mm}$. long, 
deeply immersed, solitary and subterminal on the anterior side of the lobes, the mouth of the cavity encircled by a much elevated, extrorse, rufo-ciliate ridge which is abbreviated on the outer side.

New Guinea.

(53f) A. Cifrevimvallatum, Rst., in Fed., Rep., XII, 178.

Rhizome short-creeping, clothed with grey, linear-lanceolate, acuminate, rufo-ciliate scales. Stipes to $7 \mathrm{~cm}$. long, hirsute with spreading, rufous hairs. Fronds linear-lanceolate, to $35 \mathrm{~cm}$. or more long, $\pm 3-4 \mathrm{~cm}$. broad, narrowed towards both ends, deeply pinnatifid. Lobes numerous, spreading, lanceolato-deltoid, subfalcate, to $2 \mathrm{~cm}$. long, $\pm 5 \mathrm{~mm}$. broad at the base, shortly bluntly acuminate, entire, rufo-ciliate. Texture rigidly coriaceous; surfaces naked; costa prominent, rufo-pilose; costulae and veins hidden. Sori oblong, oblique, 5-6 on a side, medial, immersed, the mouth of the cavities very prominent.

\section{New Guinea.}

(53g) Finkleri, Rst., in Fed., Rep., XIII, 219.

Rhizome short-creeping, the scales membranaceous, lanceolate, bluntish, entire; pale-brown. Stipes approximate, very short, scaly at the base. Fronds oblanceolate, $\pm 38 \mathrm{~cm}$. long, $\pm 7 \mathrm{~cm}$. broad in the upper part, acuminate, deeply pinnatifid, long-decurrent at the base. Lobes many, spreading; linear-lanceolate from a dilated base, subacute, the largest \pm $4 \mathrm{~cm}$. long by $1 / 4 \mathrm{~cm}$. broad. Texture subcoriaceous; surfaces naked; costa rather prominent on both sides, naked; veins very oblique, simple or rarely forked. Sori medial, subimmersed, not prominent on the upper surface.

\section{Sumatra.}

(56) Ir. Indingulare, scort.; Acrosorus triangularis, Copel., in Philipp. Journ., IIIC, 347.

(59a) pseudo-spirale, *. A. v. r., in Bull. Btz., 1911, I, 29 ; P. Roemerianum, Rst., in Nov. Guin., VIII, Bot., 725.

Rhizome short-creeping, the scales dense, brownish, lanceolate, entire. Fronds approximate or somewhat remote, sessile or short-stalked, linear, $10-20 \mathrm{~cm}$. or more long, $\pm 5-8 \mathrm{~mm}$. broad, obtuse, narrowed towards the base, simply pinnate. Pinnae numerous, horizontạl, alternate, oblong 
or semiorbicular, entire, bluntly rounded, dilated and contiguous at the base, separated by rounded sinuses \pm as broad as the pinnae, the anterior side obliquely decurved, the upper and outer edge more or less revolute. Texture very thick; surfaces naked; rachis flexuose, sulcate, and sparingly and deciduously provided above with black-brown, setiform hairs, prominent beneath; veins invisible. Sori round, superficial or hardly immersed, $1-2$ in the lower part of the pinnae, at length confluent; sporangia very sparingly spinulose. - Very peculiar by the slightly twisted pinnae, which give the whole frond the aspect of being spirally twisted when seen from the side.

New Guinea.

(59b) P. sikkimense, Her., C. Chr., Ind. Fil.; P.trichomanoides, Bedd., Hand. Ind. Ferns, 308; Ferns Br.I., I, tab. II.

Rhizome short, erect, paleaceous above. Stipes short, $1 \frac{1}{4}-2^{1 / 2} \mathrm{~cm}$. long, densely tufted, patent-villous with long, fibrous hairs. Fronds linear, $7 \frac{1}{2}-15 \mathrm{~cm}$. long, $1 / 2-1 \mathrm{~cm}$. broad, narrowed at both ends, deeply pinnatifid, pinnate at the very base. Segments rather horizontal from a broad base, ovate-oblong, entire, subconcave beneath. Texture rigidly membranaceous; surfaces subdeciduously hairy with long, fibrous or blackish, patent hairs; veins solitary in each segment, simple or forked. Sori solitary on the lobes, near the base of the veins and the costa.

Malacca; $\mathrm{Br}$. India.

(59c?) W. pulogense, Copel., in Philipp. Journ., VIC 148.

Rhizome short, provided with a few entire, pale-brown scales. Stipes close, very short. Fronds $5-8 \mathrm{~cm}$. long, $5-7 \mathrm{~mm}$. broad, narrowed at both ends, deeply pinnatifid. Segments narrowly triangular, acute, conected by a narrow wing. Texture coriaceous; surfaces deciduously hairy; veins 1 in each lobe, simple in the barren lobes, forked in the fertile ones, with a short anterior veinlet bearing a single round sorus.

Luzon.

(63a) Pufescens, Braw., in Lautb., Beitr. Flor. Pap., I, 43.

Rhizome short, erect. Stipes densely tufted, slender, $\pm 3-3 \frac{1}{2} \mathrm{~cm}$. long, copiously clothed like the rachis and both surfaces with long, spreading, rufescent hairs. Fronds linear-lanceolate (-oblanceolate?), 士 $11 \mathrm{~cm}$. long and $1 \mathrm{~cm}$. broad, bluntish, narrowed gradually towards the 
base. Pinnae numerous, confluent, sublinear from a broad, decurrent base, to $6 \mathrm{~mm}$. long, $\pm 2 \mathrm{~mm}$. broad, shortly acuminate, the lower more remote, the higher more approximate. Texture papyraceous; veins stout, to 6 pair, simple, not reaching the margin. Sori terminal on the veins, occupying the upper part of the frond.

New Guinea.

(64a) P. serrato-dentatum, v. A. v. R.

Omit this, it being a narrow form of P. solidum Mett. only:

(64b) P. Meruitti, Copel.; - var. poense, Copel., in Philipp. Journ., VII, 66 .

Var. poense: Fronds smaller, $6-12 \mathrm{~cm}$. long, $\pm 1 / 2 \mathrm{~cm}$. broad; segments subdigitate-lobate; sori $1-2$ to a segment. - Borneo.

(66) P. subminutum, v. A. v. R.

Omit this, it being referred to $\mathrm{P}$. repandulum Mett.

(66a) See No. $70 a$.

(67) P. lancifolium, v. A. v. R.

Omit this, it being referred to P. mollicomum Nees \& Bl.

(68) Pubsecundo-dissectuan, zoll., Hk. Bk., Syn. Fil., 328; P. gedeanum, Rac., Flor. Btz., I, 96; -.. var. novoguineensis, Rst., in Nov. Guin., VIII, Bot., 725.

Stipes tufted, $1 / 2-2 \mathrm{~cm}$. long, densely clothed with spreading, yellowish or brownish hairs. Fronds linear-lanceolate, $10-20 \mathrm{~cm}$. long, 2-3 em. broad, cut down nearly or quite to the costa into many close, subdimidiate pinnae. Pinnae oblong, decurrent, deeply lobed or pinnatifid on the anterior side into $4-6$ oblong or linear-oblong, entire, rounded, close lobes up to $4 \mathrm{~mm}$. long, to $1{ }^{\prime \prime} / \mathrm{mm}$. broad, the posterior side entire, toothed or lobed towards the apex with $1-3$ teeth or lobes. Texture thin or papyraceo-herbaceous; rachis, veins and edges furnished with white or yellowish hairs; veins 1 in each lobe. Sori solitary at the base of the secondary segments. - $P$. subfalcatum Bl. var. semiintegrum Copel. (in Philipp. Journ., II', 138) seems to be a reduced form of this,

Forma typica, - Java, Luzon, Mindoro; New Caledonia, 
Var. novoguineensis: Pinnae subremote, decurved, quite entire on the lower side, the central and lower decurrent, not connected at the base, the lobes more numerous, roundish-oblong, conspicuously narrowed at the base, the lower reduced; sori subcostal. - New Guinea.

(70a) P. repandulum, Mett.; P. subminutum, v. A. v. R., Mal. Ferns, 598; Bull. Btz., 1914, XVI, 35.

Forma typica: Fronds firm-herbaceous to coriaceous; surfaces naked but the costa and costulae sometimes provided with a few scattered, clustered or branched hairs.

Forma pilosa: Fronds more copiously long-hairy, at length not rarely glabrescent, the hairs yellowish; pinnae often subentire.

Also in Java and Sumatra.

(70a*) P. diaphanum, Brau., in Lautb., Beitr. Flor. Pap., I, 42.

Rhizome wide-creeping, the scales triangular-ovate, acuminate, entire, fuscous, peltate at the base. Stipes scattered, $71 / 2-14 \mathrm{~cm}$. long, naked. Fronds linear-lanceolate, to $48 \mathrm{~cm}$. long, $\pm 4^{3 / 4} \mathrm{~cm}$. broad, narrowed gradually towards the linear-acuminate, crenate apex. Pinnae numerous, horizontal, linear-lanceolate from a slightly dilated base, to $2_{12}^{1 /} \mathrm{cm}$. long, $\pm 6 \mathrm{~mm}$. broad, slightly crenated, confluent at the base, deciduous; lower pinnae slightly deflexed, hardly shorter than the following. Texture membranaceous, pellucid; rachis and surfaces naked; veins fine, conspicuous, to 10 pair, simple or forked, not reaching the margin. Sori few, 3-4 on a side, not occupying the lower veins, terminal on the abbreviated anterior branchlets of forked veins.

New Guinea.

(70b) P. erythrotrichum, Copel.

Omit this, it being referred to $\mathrm{P}$. venulosum $\mathrm{Bl}$.

(71) P. brevifrons, scort.; P. repandulum, Mett., var., C. Chr., Ind. Fil., Suppl.

(73) P. Obliquatum, $\boldsymbol{B t}$. g $P$. Schenckii, Harr., in Journ. of Linn. Soc., Bot., XVI, 31 ; - var. novoguineensis, Rst., in Fed., Rep., V, 374 ; - var. multijugum, Rst., 1. c., XII, 178. 
Var. novogulneemsis: Sori more numerous, to 12 on each side of the costae, less deeply immersed. - Nero Guinea.

Var. multijugnam : Rhizome scales deltoid, not or sparingly ciliated; fronds to $50 \mathrm{~cm}$. long, $4^{1 / 2} \mathrm{~cm}$. broad, rigidly chartaceous; pinnae to 130 on a side, $1 \frac{1}{2}-2 \mathrm{~mm}$. broad. - New Guinea.

(74) P. Schenckii, Harr.

Omit this species, it being referred to P. obliquatum $B$.

\section{(75) IP. decipiens, Mett.}

Upper surface at length glabrescent, lower copiously short-hairy; sori nearer the margin than the costulae, when young protected by a circle of moderately long hairs; hairs red-brown or pale-brown.

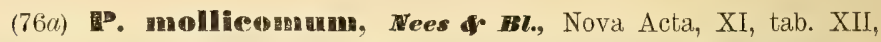
fig. 2, A, A, a-c; P. lancifolium, v. A. v. R., in Bull. Dép. Agr. I. N., 1908, XVIII, 21.

(76c) P. megrosense, Copel., in Leafl., II, 409.

Rhizome short, clothed with fuligineous, acuminate, ciliate scales. Stipes aggregate, $\pm 1 \mathrm{~cm}$. long, black, clothed with black-purple, spreading hairs. Fronds sublinear, up to $\pm 20 \mathrm{~cm}$. long, $\pm 2 \mathrm{~cm}$. broad, cut down nearly to the rachis, the largest ones nearly abruptly contracted, the smaller ones gradually narrowed. Segments ovate, entire, obtuse, \pm 4 mm. broad near the base. Texture spongy, translucent; surfaces pubescent with minute hairs; margins shortly ciliate; costulae and veins hidden; veins simple, not reaching the margin. Sori terminal on the segments, $2-5$ to each, submarginal, slightly immersed or encircled by an elevated ring, protected by long hairs.

Negros.

(81) P. celeldicum, Bt.; P. craterisorum, Harr.

(83a) P. coloratum, Copel., in Philipp. Journ. IIIC, 347, tab. VI.

Rhizome scandent, slender, bluish-pruinose, the scales dense, squarrose, reddish-brown or castaneous, setiform, sparingly and shortly ciliate, with the base dilated and peltate. Stipes distant, red, glossy, naked, \pm 10 $\mathrm{cm}$. long. Fronds $\pm 10 \mathrm{~cm}$. long, $\pm 4 \mathrm{~cm}$. broad, acuminate, the edge cut down nearly to the rachis. Segments straight, rather oblique, obtuse, 
slightly serrate, the largest ones $\pm 2 \% \mathrm{~cm}$. long, $\pm 3 \mathrm{~mm}$. broad, dilated at the very base, the lowest hardly reduced. Texture subcoriaceous; surfaces naked; rachis chanelled above; veins free towards the margin, generally united near the base by a row of anastomosing veinlets so as to form a row of costal areolae on each side. Sori small, in 1 row on each side of the costae, solitary on the anastomosing veinlets or on a rudimentary branch excurrent from them.

Borneo.

(83b) P. proavir aum, Copel., in Philipp. Journ., III', 347.

Rhizome creeping, $\pm 3 \mathrm{~mm}$. thick, bluish-pruinose, the scales squarrose, black, setiform, dilated and peltate at the base. Stipes black-brown, naked, $\pm 10-15 \mathrm{~cm}$. long. Fronds up to $\pm 50 \mathrm{~cm}$. long, $8-11 \mathrm{~cm}$. broad, very acuminate, cut down nearly to the rachis. Segments acute, straight or falcate, entire, dilated at the base, the largest ones $\pm 6 \mathrm{~cm}$. long, $\pm 4 \mathrm{~cm}$. broad, $\pm 1 \mathrm{~cm}$. apart, the lowest much reduced, the margins recurved when dry. Surfaces naked; rachis black, sulcate above. Sori and venation as in P. coloratum Copel. but the anastomosing veinlets sometimes with excurrent free veinlets.

Borneo.

(88b) P. multicaudatum, Copel.

A specimen received from Mindando (Elmer No. 11422) has the pinnae distinctly separate at the base.

(88c?) Shawil, Copel., in Philipp. Journ., IX ${ }^{\mathrm{C}}, 6$.

Fronds $\pm 25 \mathrm{~cm}$. long, $\pm 15 \mathrm{~cm}$. broad. Segments $4-4 \frac{1}{2} \mathrm{~mm}$. broad towards the dilated base, $\pm 2 \frac{1}{2} \mathrm{~mm}$. broad at the middle, abruptly narrowed at the apex. Sori occupying the upper part of the segments, numerous, small, deeply immersed, the mouth of the cavities not elevated.

New Guinea.

(90) solidum, Mett.; P. serrato-dentatum, v. A. v. R., in Bull. Dép. Agr. I. N., 1908, XVIII, 20; - var. majus, v. A. v. R., in Bull. Btz., 1914, XVI, 59; - var. bolanicum, Rst., in Fed., Rep., XII, 177.

Pinnae close or approximate, blunt or acute, serrate-dentate; veins hidden, accompanied by more or less prominent ridges parallel to them. 
Forma typica: Fronds $10-20 \mathrm{~cm}$. long and $7 \frac{1}{2}-10 \mathrm{~mm}$. broad; pinnae oblong, with 3-4 teeth on a side. - Java, Phitippines, New Guinea.

Var. majus: Fronds to $35 \mathrm{~cm}$. long and $3 \mathrm{~cm}$. broad; pinna linear-oblong, with 5-10 teeth on a side. - Sumatra.

Var. Ibaldanicam: Fronds to $40 \mathrm{~cm}$. long and $4 \mathrm{~cm}$. broad; pinnae coarsely toothed. - New Guinea.

(92) wutans, $\boldsymbol{B} \boldsymbol{\text { I. }}$; - var. trichocarpa, Rst., in Fed., Rep., X, 339. Forma typica. - Also in New Guinea and the Philippines.

Van r. Irichoearpan: Sori provided with numerous long, red-brown hairs. - New Guinea.

(92a) Pendens, Rst., in Fed., Rep., XII, 177.

Rhizome short-creeping, the scales linear-lanceolate, brown, blunt, ciliate. Stipes approximate, $\pm 15 \mathrm{~cm}$. long, striate on each side, hirsute with long, reddish-brown hairs. Fronds elongate-lanceolate, $\pm 100 \mathrm{~cm}$. long by $10 \mathrm{~cm}$. broad, pinnate, narrowed towards both ends. Pinnae numerous, ascending, linear-lanceolate, subfalcate, ciliolate with hyaline hairs, apiculate with $2-3$ long, deciduous, rufous hairs; central pinnae largest, $\pm 6 \mathrm{~cm}$. long by $3 \mathrm{~mm}$. broad, separated by rounded sinuses \pm $1 \mathrm{~cm}$. broad, much dilated and confluent at the base; lower pinnae auriclelike. Texture chartaceous or subcoriaceous; surfaces naked; costa prominent, provided with long, rufous hairs; costulae rufo-setulose; veins immersed, \pm 25 on a side, often forked, the higher simple. Sori superficial, roundish or oblique-oblong, axillary or dorsal on the veins.

\section{New Guinea.}

(92b) P. Iongiceps, Rst., in Fed., Rep., XII, 177.

Rhizome short-creeping, the scales dense, ochraceous, broadly lanceolate, bluntish, entire. Stipes tufted, to $4 \mathrm{~cm}$. long, hirsute with short, spreading hairs. Fronds lanceolate, to $20 \mathrm{~cm}$. long by $4 \mathrm{~cm}$. broad, pinnate, caudateacuminate, the acumen serrate-crenate, the base narrowed. Pinnae \pm 20 on a side, ascending, linear or lanceolate from a dilated base, to $21 / 2$ $\mathrm{cm}$. long, $4 \mathrm{~mm}$. broad, setoso-ciliate, acute, separated by rounded sinuses, the lower reduced. Texture subcoriaceous; surfaces naked; rachis setose; veins simple or rarely forked. Sori superficial, medial between the costa and margin; capsules pauci-setose.

New Guinea. 
(92c) See No. 64a.

(95) P. craterisorum, Harr.

Omit this, it being referred to $\mathrm{P}$. celebicum $\mathrm{Bl}$.

(96a) P. Moultoni, Copel., in Philipp. Journ., Xc, 149.

Nearly allied with P. decorum Brack. - Scales fuscous; fronds 12-15 cm. long, 10-12 mm. broad; pinnae coriaceous, subhorizontal, straight, hardly more than $1 \mathrm{~mm}$. broad, obtuse, entire or obscurely crenulate; sori subcostal, elongated, immersed, the cavities not setigerous.

Borneo.

(97) Tobbianum, Hk.

Hooker's plate is not at all a good one; it represents the pinnae as much too wide, and changes very essentially the appearance of the fern. The pinnae are exceedingly narrow, and lobed very nearly to the costa. (Copel.).

Also in New Guinea.

(98) P. elnvifer', Hk.; - var. calvum. v. A. v. R., in Bull. Btz., 1914, XVI, 35; - var. diversifolium, Rst., in Fed., Rep., XII, 530.

A specimen gathered in New Guinea (von Römer No. 732) differs from Hooker's diagnosis in having the fronds thinner, both barren and fertile pinnae spathulate but the former more narrowly, the rachis and the central ribs and the margins of the pinnae sparingly long-hairy.

Forma typica: Young sori often protected by the folded edges of the pinnae. - Also in Mindanao.

Var. calvum : Like the type but the rachis nearly naked, and the pinnae without terminal bristles. - Taliabo Island.

Var. diversifolium: Fertile pinnae abbreviated, without stipitiform base, naked. - New Guinea.

(98a) P. conduplieatum, Brau., in Lautb., Beitr., Flor. Pap., I, 41, fig. $2 \mathrm{~J}-i$.

Rhizome ascending, brown-hairy. Stipes tufted, $3-5 \mathrm{~mm}$. long, marginate, long-brown-hairy. Fronds linear-lanceolate, $\pm 3-6 \mathrm{~cm}$. long, to $4 \mathrm{~mm}$. broad, blunt, pinnate, narrowed gradually at the base, the rachis margined (very narrowly winged). Pinnae ascending, entire; lower pinnae 
barren, linear or lanceolate, to $3 \mathrm{~mm}$. long, $\pm 1 / 3 \mathrm{~mm}$. broad, acute; higher pinnae fertile, a little shorter, ovate, to $1 \mathrm{~mm}$. broad, acute, often hair-pointed. Texture chartaceous; rachis and surfaces long-brown-hairy; veins simple, 1 in each segment. Sori solitary on the pinnae, protected by the folded edges at least when young.

New Guinea.

(98b) P. W thewianum, v. A. v. R., in Bull. Btz., 1914, XVI, 34, tab. VI.

Rhizome short. Stipes close or approximate, deciduously glandular, to $5 \mathrm{~mm}$. long. Fronds linear, $\pm 2-3 \mathrm{~cm}$. long, $\pm 3 \mathrm{~mm}$. broad, bluntish, pinnate. Pinnae remote or the higher more close, oblique, the central ones the largest, $\pm 1 / 2 \mathrm{~mm}$. long, cuneate-obovate in the upper part, suddenly dilated and broadly adnate at the base, obliquely retuse, emarginate or 2-fid at the apex with rounded lobules, the lower ones oblong; simple. Texture subcoriaceous; surfaces and rachis more or less deciduously glandular, the glands minute, elongate-clavate; veins 1 in each pinna, of the lower pinnae simple, of the central and higher forked. Sori solitary on the pinnae, at the base of the anterior veinlets.

Java.

(98c) Dryophylimm, v. A. v. R., in Bull. Btz., 1914, XVI, 35.

Stipes tufted, to $1 \mathrm{~cm}$. long, capillary or filiform, provided like the fronds with minute, scattered, whitish or brownish, narrowly clavate glands. Fronds linear, $2-4 \mathrm{~cm}$. long, the apex bluntish. Segments oblong, $1 \frac{1}{2}-3$ $\mathrm{mm}$. long, $1-1 \frac{1}{2} \mathrm{~mm}$. broad, bluntish, rounded or more or less obliquely truncate and slightly retuse at the apex. Texture thin-coriaceous; veins simple, solitary in the lobes. Sori solitary on the lobes the receptacle consisting of a lateral increasing of the veins, at the base, on the anterior side.

Forma junior: Fronds $\pm 3 \mathrm{~mm}$. broad, deeply lobed towards the apex, deeply pinnatifid in the gradually narrowed lower part; lobes erectopatent, approximate.

Forma senior: Fronds $\pm 4 \mathrm{~mm}$. broad, deeply pinnatifid towards the apex, pinnate towards the base; pinnae remote, subspreading, connected by a very narrow wing.

Penang.

(99) P. Selhefreri, v. A. v. R.

Also in Sumatra. 
(99a) P. papillatum, v. A. v. R., in Bull. Btz., 1914, XVI, 35, tab. VII.

Rhizome short, brown-scaly. Stipes approximate, short, slender, nearly filiform, deciduously glandular (papillose). Fronds elongate-lanceolate, 士 $10-15 \mathrm{~cm}$. long, $1-1 \frac{1}{2} \mathrm{~cm}$. broad, pinnate. Pinnae oblique, approximate, lanceolate-oblong, bluntish, the base obliquely cuneate, adnate, decurrent, the lower edge entire or sparingly bluntly crenate-dentate, the upper edge sparingly bluntly lolate-dentate with the lowest lobe often elongated and auricle-like; lower pinnae gradually much reduced and entire. Texture firm; surfaces and rachis glandular, the glands minute, clavate, decoloured, deciduous or caduous; costae pinnate with $1-3$ veins on a side. Sori round, 1 to each vein, subcostal, distant.

Sumatra.

(99b) P. Irooksine, v. A. v. R.

Rhizome short, pale-brown-squamulose. Stipes tufted, to $1 \frac{1}{2} \mathrm{~cm}$. long, very narrowly winged (2-marginate) at least in the upper part, provided like the rachis, costae and veins with short or more elongated, scattered, pale-brown hairs. Fronds lanceolate, $\pm 3-6 \mathrm{~cm}$. long by $3 / 4-1$ cm. broad, narrowed more or less gradually towards both ends, pinnate. Pinnae remote, oblique, linear, to $\pm 6 \mathrm{~mm}$. long by $1 \mathrm{~mm}$. broad, blunt, entire to sparingly coarsely toothed on one side or on both sides but often on the upper side only, slightly dilated and very narrowly confluent at the base. Texture firm-herbaceous; costae straight or subflexuose; veins few or wanting, oblique, simple, mostly 1 to each tooth, not reaching the margin. Sori on abbreviated veins, not copious, the higher ones solitary at the base of the higher (abbreviated) pinnae, the others mostly 1 to each tooth.

Sumatra.

(100a) P. venulosum, Bt.; P. erythrotrichum, Copel., in Philipp. Journ., I, Suppl., 160, tab. XX.

$\left(100 a^{*}\right)$ See No. $88 b$.

(101a) P. halconense, Copel.,

Also in Mindanao. 
(102) P. gedeanum, Rac.

Omit this species, it being referred to P. subsecundo-dissectum Zoll.

(102a) See No. 68.

(102b) P. Alderwereliii, Rst., C. Chr., Ind. Fil., Suppl; $P$. Koningsbergeri, Rst., in Nov. Guin., VIII, Bot., 726.

Stipes aggregate, slender, $\pm 1-2 \mathrm{~cm}$. long, clothed like the rachis with long, scattered, spreading, weak, yellowish hairs. Fronds lanceolate, $\pm 10-12 \mathrm{~cm}$. long and $1 \frac{1}{2}-2 \mathrm{~cm}$. broad, 2-pinnatifid, narrowed at both ends, the rachis terete, narrowly winged. Pinnae numerous, approximate, erecto-patent, stalked, deeply pinnatifid, unequal-sided, broadest on the anterior side; central pinnae largest, subrhomboidal-oblong, $\pm 1 \mathrm{~cm}$. long and $31 / 2 \mathrm{~mm}$. broad, bluntish, deeply pinnatifid, obliquely cuneate at the base, the lower base cut away, the stalk marginate or narrowly winged. Lobes oblique, approximate, $3-4$ on the lower side, $4-5$ on the upper side, the lowest anterior or the next following the largest, oblong, \pm 4 $\mathrm{mm}$. long, nearly $1 \mathrm{~mm}$. broad, slightly dilated near the apex, entire, blunt, some of them somewhat more dilated and obliquely emarginate or 2-fid near the apex with rounded lobules. Texture firm-herbaceous, pellucid; surfaces naked; costae prominent; veins 1 in each ultimate lobe or lobule, not reaching the apex, simple or with a very short anterior veinlet at the base. Sori terminal on the basal veinlets.

New Guinea.

(103a) P. pulcherrinuuu, Copel., in Leafl., III, 841.

Rhizome wide-creeping, black, clothed with fulvous, ovate scales. Stipes $\pm 1 \mathrm{~cm}$. apart, $2-5 \mathrm{~cm}$. long, naked, or provided with few minute, caducous scales. Fronds elongate-lanceolate, $\pm 20-35 \mathrm{~cm}$. long, \pm 3-7 cm. broad, 2-pinnate, the main rachis dark, narrowly marginate. Pinnae and pinnulae contracted, the former spreading or horizontal, the latter subterete when barren, to $\pm 5 \mathrm{~mm}$. long, $\pm 1 / 4-1 / 3 \mathrm{~mm}$. broad, $\pm 1-1 \%$ mm. apart, acute; fertile pinnulae flattened, lanceolate, to \pm $2 \mathrm{~mm}$. long, $\pm 1 / 2-3 / 4 \mathrm{~mm}$. broad at the dilated middle. Texture coriaceous; surfaces naked or the rachises sparingly fibrillose; veins 1 in each pinnula. Sori occupying the upper $1 / 3-1 / 2$ of the frond, solitary and medial on the pinnulae.

Mindanao. 
(103b) T. Puciforme, Rst., in Nov. Guin., VIII, Bot., 726.

Rhizome short-creeping, the scales small, linear-subulate, brown. Stipes subapproximate, $\pm 10-15 \mathrm{~cm}$. long, naked, winged in the upper part. Fronds $\pm 15-18 \mathrm{~cm}$. long, irregularly 3-4-pinnate at the base, the rachises winged, the wings $3-5 \mathrm{~mm}$. broad, passing gradually into the ultimate segments. Pinnae erecto-patent, alternate, $3-5$ on a side, the higher simple, the lower to $14 \mathrm{~cm}$. long, irregularly decompound, with the various divisions erecto-patent, alternate; ultimate segments linearsubulate, $\pm 1 / 2-4 \mathrm{~cm}$. long, $1-2 \mathrm{~mm}$. broad at the base. Texture chartaceous; central ribs of the segments prominent beneath; veins oblique, simple or rarely forked; surfacos naked. Sori minute, occupying the ultimate segments, placed in single rows medial between the midrib and margin.

New Guinea.

(104) Dipinnatifidum, Bk.; - var. Foersteri, Rst., in Fed., Rep., XII, 179.

War. Foersteri: Fronds larger, to $60 \mathrm{~cm}$. long, clothed everywhere with pale-grey hairs. - New Guinea.

(105a) rerogidifrons, v. A. v. Re, in Bull. Btz., 1915, XX, 23; P. millefolium, Rst. (not Bl.), in Nov. Guin., VIII, Bot., 726; - var. angustatum, v. A. v. R., 1. c., 24.

Rhizome short, erect, hidden by the roots and stipes. Stipes tufted, $\pm 2--3 \mathrm{~cm}$. long, wiry, densely clothed with long, spreading, ferrugineous or pale-coloured hairs, at length naked like the rachis. Fronds lanceolate, $\pm 15-25 \mathrm{~cm}$. long, $21 / 2-5 \mathrm{~cm}$. broad, narrowed towards both ends, the apex coarsely and remotely toothed. Pinnae erecto-patent or spreading, stalked, straight or often decurved, sometimes linear and coarsely subremotely toothed, more commonly lanceolate and regularly pinnate, the largest to $3 \mathrm{~cm}$. long, to $1 \mathrm{~cm}$. broad near the base, subcaudate-acuminate and coarsely toothed at the apex. Pinnulae linear, $\pm 11 / 4 \mathrm{~mm}$. broad, coarsely toothed. Ultimate segments (teeth) short, oblique, blunt or rounded, 1-3 on each side of the pinnulae but more numerous in the apices of the fronds and pinnae. Texture rigidly coriaceous; surfaces naked; veins hidden. Sori roundish, solitary at the base of the teeth.

Var. divisions narrower, narrowly toothed.

Newo Guinea.

Ferns and Fern Allies. 
(107a) PP. taxodioides, Bki.s - var. ericoides, Rst., in Fed., Rep., XI, 179.

Wa r. enicoifles: Fronds relatively longer and narrower, $\pm 25-30$ $\mathrm{cm}$. long by $4-4 \frac{1}{2} \mathrm{~cm}$. broad: pinnulae narrower, contracted. - New Guinea.

(107b) T. Toferi, Copel.; - var. setulosa, Rst., in Fed., Rep., XII, 179 ,

Forma typica. - Also in New Guinea.

Var. sedrigsa: Rhizome scales ochraceous; pinnae somewhat broader; costae beneath setulose like the upper surface of the pinnulae. New Guinea.

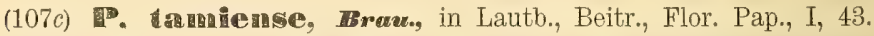

Rhizome wide-creeping, the scales squarrose, lanceolate, long-acuminate, entire, iridescent, cordate-peltate at the base. Stipes remote, to 8 cm. long, copiously hairy, the hairs horizontal, fuscous. Fronds linearlanceolate, to $25 \mathrm{~cm}$. long, $\pm 5 \frac{1}{2} \mathrm{~cm}$. broad, narrowed gradually at the base, 2-pinnatifid below the abruptly acuminate, pinnatifid apex. Pinnae numerous, remote, sessile, subhorizontal, linear-lanceolate from an adnate, decurrent base, cut down nearly to the costa. Lobes linear, $\pm 2 / 2 \mathrm{~mm}$. long, $\pm 1 / 3 \mathrm{~mm}$. broad, sparingly ciliated, the fertile ones dilated at the apex. Texture herbaceous; rachis, costae and veins hairy; veins simple, solitary, not reaching the apex of the lobules. Sori terminal on the veins, intermixed with hairs, occupying the upper part of the fronds.

New Guinea.

\section{§ 2. PROSAPTIA.}

$\left(108 a^{*}\right)$ See No. $108 b$.

\section{(108b) P. exalratuns, Copel.}

A diplicate of Copeland's No. 1478, occurring in the Buitenzorg Herbarium, has the barren lobes bluntly rounded at the apex, the fertile ones more or less acute. when seen from above, but the compressed projection blunt or obliquely retuso-truncate when seen from the side.

Also in Celebes. 
(108c) P. tortile, v. A. v. R.; Davallia Merrillii, C. Chr., Ind. Fil., Suppl.

(1106) P. polynnorplnum, v. A. v. R.; Davallia polymorpha, C. Chr., Ind. Fil., Suppl.

\section{(111) 도. contigaum, J. Sm.}

Var. monosontum. - Also in Java, Amboina.

Van'. pectisadum: Sori intramarginal. - Also in Malacct.

(111a) ․ nerosoroides, v. A. v. $\boldsymbol{R}$. in Bull. Btz., 1913, XI, 21 ; Prosaptia linearis, Copel., in Philipp. Journ., IVC, 115; Davallia linearis, C. Chr., Ind. Fil., Suppl.

Rhizome subcreeping, the extremity clothed with narrow, ciliate, cancellate, black-brown scales. Stipes short, approximate. Fronds up to $40 \mathrm{~cm}$. long, $\pm 3 / 4-1 \frac{1}{2} \mathrm{~cm}$. broad, pinnate. Pinnae spreading, approximate, triangular-oblong, blunt to acute, entire, broadly adnate, dilated in the fertile region, sometimes slightly decurrent, not confluent, the lower ones rather remote and gradually diminished to mere teeth. Texture coriaceous; rachis slender, black, naked. Sori oblong, subterminal and solitary on the pinnae, deeply immersed, the mouth of the cavity marginal or intramarginal, on the acroscopical side, elevated and surrounded by a ring of hairs.

\section{Luzon.}

(111b) Engiraman, v. A. v. R.; Davallia Engleriana, Brau., in Lautb., Beitr. Flor. Pap., I, 27, fig. 1 ; C. Chr., Ind. Fil., Suppl.

Rhizome short, erect, clothed with linear, fuscous, long-acuminate, ciliate scales. Stipes tufted, 1-2 cm. long, terete, provided with long, fuscous, horizontally spreading hairs. Fronds linear-lanceolate, $\pm 85 \mathrm{~cm}$. long and $61 / 2 \mathrm{~cm}$. broad, narrowed gradually towards both ends, deeply pinnatifid, bluntish. Lobes subulate-linear from a dilated base, bluntish, entire, ciliate, separated by rounded sinuses, the central ones the largest, $\pm 31 / 2$ $\mathrm{cm}$. long and $1 / 2 \mathrm{~cm}$. broad, the lower deltoid. Texture coriaceous, subpellucid; under surface sparingly hairy when young, glabrescent; costa long-hairy; costulae and veins prominent above; veins forked, to 12 on a side. Sori terminal on the anterior veinlets, intramarginal.

New Guinea. 
(111c) P. ancestralle, *. A. v. IR.; Prosaptia ancestralis, Copel., in Leafl., III, 835: Davallia ancestratis, C. Chr., Ind. Fil., Suppl.

Rhizome scales ciliate. Fronds $\pm 60 \mathrm{~cm}$. long by $5-6 \mathrm{~cm}$. broad, deeply incised into lanceolate, entire or crenulate segments $\pm 4 \mathrm{~mm}$. broad, dilated at the base; surfaces and costa provided with reddish pubescence. Sori \pm 10 on a side, submarginal.

Mindanao.

(111d) D. Semien'y ptuna, v. A. v. IR.; Prosaptia semicrypta, Copel, in Philipp. Journ., IX ${ }^{\mathrm{C}}, 231$.

Rhizome short-creeping. Stipes $1-2 \mathrm{~cm}$. long, black at least towards the base, minutely pilose. Fronds $\pm 20-40 \mathrm{long}$, to $8 \mathrm{~cm}$. broad, abruptly narrowed towards the base, deeply pinnatifid, subpinnate. Segments linear from an abruptly dilated base, to $\pm 4 \mathrm{~cm}$. long, $\pm 2-21 / 2 \mathrm{~mm}$. broad, acute, slightly crenated. Texture herbaceous; surfaces naked; costa provided beneath with scattered, caducous hairs. Sori small, submarginal, subremote.

Sumatra.

(112a) P. Cryptocarpum, v. A. v. Re.; Davallia cryptocarpa, C. Chr., Ind. Fil., Suppl.

(112b) P. 'Toppinariog, v. A. v. IR.; Davallia Toppingii, C. Chr., Ind. Fil., Suppl.

\section{§ 3. GONIOPHLEBIUM.}

(115b) D. Dersieifolium, Desv.; - var. Mettenii, Rst., in Fed., Rep., XIII, 220.

Paraphyses golden-yellow, resembling the stalks of fallen capsules, not rarely provided with short, irregular, branch-like increasings at the apex.

War. Mettenii: Pinnae very slightly truncate-crenate, the incisions hardly visible with the unarmed eye. - Sumatra.

(116a*) F. Cyatheoirles, Sw., C. Chr., in Ark. för Bot., IX ${ }^{\mathbf{1 1}}$, 39; Cyathea percussa, Cav., Deser., 548. 
Like $\mathrm{P}$. Koningsbergeri $v . A . v$. $R$. but the sori and paraphyses similar to those of $\mathrm{P}$. verrucosum $W$ all.

Java (Malaya?); Marianne Islands.

(1160) P. Vernucosum, Wall.; P. cyatheoides, Sio, var. verrucosa, C. Chr., in Ark. för Bot., X.I", 39.

(117b) P. pallens, Bl.

Omit this, it being a variety of $\mathrm{P}$. subauriculatum $\mathrm{Bl}$.

(121b) P. Subauriculatum, Br.; - var. pallens; P. pallens, Bl., Flor. Jav., II, 178, tab. LXXXIV.

Areolae in 1-3 rows on each side of the costae.

Forma typica: Under surface when young covered with scattered, minute, roundish, irregularly ciliate-stellate, deciduous, peltate scales.

Var. pallens: Under surface when young covered with deciduous, whitish hairs; fronds not rarely much reduced. Java

(121c) F. Memersant, Brau., in Lautb., Beitr. Flor. Pap. I, 44.

Rhizome wide-creeping, the scales triangular, acuminate, entire, palefuscous, iridescent. Stipes scattered, $\pm 33 \mathrm{~cm}$. long, at length naked, when young probably scaly. Fronds lanceolate, $\pm 55 \mathrm{~cm}$. long by half as broad, pinnate. Pinnae remote, sessile, slightly narrowed at the base, subopposite, \pm 23 on each side below the terminal one; lowest pinnae largest, arcuate-ascending, linear-lanceolate, to $19 \mathrm{~cm}$. long by $\pm 3 / 4 \mathrm{~cm}$. broad, subserrate, the apex very long-acuminate and more distinctly serrate. Texture chartaceous; surfaces naked; rachis clothed with brown, triangular-elongate, acuminate, ciliate scales. Sori in 1 row on each side of the costae, deeply immersed.

Nero Guinea.

(121d) P. tenuissimunn, Copel., in Philipp. Journ., IX ${ }^{\mathrm{C}}, 6$.

Rhizome calcareous, clothed with narrow, moderately deciduous scales. Stipes $\pm 20 \mathrm{~cm}$. long, castaneous, glossy, deciduously scaly towards the base. Fronds probably $1 \mathrm{~m}$. or more long, 士 $20 \mathrm{~cm}$. broad. Pinnae remote, separated by about five times their own breadth, sessile, to $\pm 14 \mathrm{~cm}$. long, $\pm 3-5 \mathrm{~mm}$. broad, acuminate, minutely acutely 
serrulate, truncate at the slightly dilated base. Texture papyraceous; veins forming a single row of areolae on each side. Sori small, numerous, immersed.

New Guinea.

\section{$\S 6$. PLEOPELTIS.}

Omit this section, it being referred to the genus Pleopeltis.

\section{§ 7. SELLIGUEA.}

Omit this section, it being referred to the genus Pleopeltis.

\section{Y1a, PLEOPEITIS, Tumb. S० Hompl.}

Sori round, oblong, linear-oblong or linear, several to many on each side of the costa, superficial or immersed, the round and oblong ones dorsal, or submarginal and not rarely protected by the recurved marginthe of the frond when young; the oblong ones either parallel or oblique to the costa or the margin, the linear ones always dorsal and nearly always oblique. No indusium but the capsules sometimes covered by longstalked peltate scales when young.

Rhizome mostly long and creeping, rarely short and erect or tuberous, generally scaly, very rarely naked. Stipes as a rule articulate to the rhizome, the articulation often indistinct and sometimes wanting in the smaller species. Fronds simple, pinnatifid or pinnate; surfaces naked, scaly of hairy, the hairs not stellate; veins anastomosing as a rule very irregularly, if somewhat regularly, then not as in Polypodium §§ Goniophlebium, Phlebodium or Campyloneuron; free included veinlets often present in the areolae, generally thickened at the apex, mostly spreading in various directions, rarely directed towards the costa or the margin. (')

Tropical and subtropical.

(1) See the information inder Polypodium. 
(Arrangement of the sections and groups 1).

$\S 1$. EUPLEOPELTIS (Pleopeltis).

a. Firynecophilla (excl. Lecanopteris).

b. Atactosia.

* Lepisorus.

** Pleuridium.

c. Clnrysopteris (excl. Aglaomorpha).

* Phymatodes.

** Phymatopsis.

*** Drynariopsis.

§ 2. SELLIGUEA.

\section{$\S 1$. EUPLEOPELTIS.}

(v. A. v. R., in Bull. Dép. Agr. I. N., 1909, XXVII, 2-11).

(122) P1. sintusa, Moore.

Fronds when dry not rarely thin and flaccid, pellucid, with the venation very distinct when seen towards the light.

(123) ㅍ. Ionnarioides, Moore.

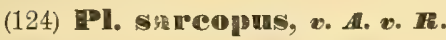

(125) Pl, imbricata, v. $\boldsymbol{A}$ v. $\mathbb{R}$.

(132) Pl. holoplinylla, v. A. v. Re.

(133) T. Subsparsa, v. A. v. Ie.

(134) Pl. tenuiloris, moore.

(1) For the characters of the sections, groups and species, see my handbook pp. 568-569 and 623-677. For the sake of convenience the species are given in this supplement with the same numbers, and, with a few exceptions, with the same specific names as in the handbook, where they are enumerated under the heading Polypodium. 
(135) Pl. sarew wakensîs, v. A. v. R.

(136) Pl. Supen'ficialls, Bedd.

(136a) Se日 No. 188.

(137) Pl. peltata, Scort.

(138) P1. antrophyolules, v. A. v. IR.

(139) 표. curtidens, v. A. v. R.

(140) Pl. IBakeri, v. A. ซ. M., 1. o., tab. I.

(141) Pl. Wrayi, Bedd.

Also in Borneo.

(142) Pl. Beccanii, v. A. v. $\mathbb{R}$.

(142a?) PI. senescens, v. A. v. Th.; Polypodium senescens, Copel., in Philipp. Journ., VIC, 88; C. Chr., Ind. Fil., Suppl.

Rhizome creeping, the scales pale-ferrugineous, soon whitish, broadly lanceolate, entire. Stipes $\pm 1 \mathrm{~cm}$. apart, $1-5 \mathrm{~cm}$. long, those of the fertile fronds the longest, naked, glossy, slender, firm. Barren fronds broadly elliptical, $\pm 1 \mathrm{~cm}$. broad, broadly cuneate at the base, the edge revolute, minutely and broadly incised. Texture rigid; surfaces naked. Fertile fronds linear, narrowed to both ends, hardly $5 \mathrm{~mm}$. broad. Sori in 1 row on each side, medial, remote, small, slightly immersed.

New Guinea.

(143a) 1PL. accedens, Moore.

(143b) 1, dannumensis, v. A. v. $\boldsymbol{R}$.

(144) Pl. nummularial, Moore, v. A. v. R., l. c., tab. II; Pl. hammatisora, v. A. v. R.; — var. sumatrana; Polypodium pyrolifolium, Goldm., var. sumatrana, Rst., in Fed., Rep., XIII, 220. 
71a. PLEOPELTIS, § 1. EUPLEOPELTIS.

Var. sumatrana: Rhizome scales whitish; fortile fronds about twice as long, long-stalked, truncate-crenate; sori superficial or slightly immersed. - Sumatro.

(145) Pl. hammatisora, v. A. v. R.

Omit this, it being referred to $\mathrm{Pl}$. nummularia Moore.

(146) Pl. stemopteris, v. A. v. I.

(147) IPI. soridens, v. A. v. IR., 1. c., tab. III.

(147a) FPl. Versteegil, v. A. v. Re.; Polypodium Verstegii, Christ, in Nov. Guin., VIII, Bot., 154; C. Chr., Ind. Fil., Suppl.

Rhizome slender, firm, wide-creeping, dark, minutely scaly and verruculose. Stipes distant, $1-6 \frac{1}{2} \mathrm{~cm}$. long, those of the fertile fronds the longest, sparingly clothed at the base with minute, blackish scales. Barren fronds oval, $\pm 5-8 \mathrm{~cm}$. long, $\pm 1 \frac{1}{2}-2 \frac{1}{2} \mathrm{~cm}$. broad, blunt or bluntish, entire, cuneate and subdecurrent at the base, the edge somewhat thickened and prominent beneath. Texture coriaceous; colour brown-green; surfaces naked or sparingly furfuraceous; costa distinct; veins oblique, flexuose, indistinct, hardly reaching the margin; areolae with free included veinlets. Fertile fronds lanceolate, $\pm 12-15 \mathrm{~cm}$. long, $\pm 1 \frac{1}{2}-2 \mathrm{~cm}$. broad, cuneate at the base. Sori in 1 row on each side, medial between the midrib and edge, large, round, shallowly immersed, forming slightly elevated, impressed papillae on the upper surface (in dried material).

New Guinea.

(147b) Pl. Soronanes, v. A. v. $\mathbb{R} . ;$ Polypodium soromanes, Christ, in Nov. Guin., VIII, Bot., 152; C. Chr., Ind. Fil., Suppl.

Rhizome long, twining, ochraceous, naked or sparingly covered with brown, ovate, scattered scales. Stipes distant, naked, yellow-brown, $4-20$ $\mathrm{cm}$. long. Barren fronds lanceolate-oblong, $7-14 \mathrm{~cm}$. long, $\pm 1 \frac{1}{2}-21 / 2$ $\mathrm{cm}$. broad, obtuse, entire, provided with a roundish auricle at the base on one side, not decurrent. Texture thin-chartaceous; surfaces naked; colour pale-green; costa distinct; veins fine, not reaching the margin; areolae irregular, with included free veinlets. Fertile fronds linear, \pm $15-40 \mathrm{~cm}$. long, blunt, cuneate or rounded and unequal-sided at the base, the margin sinuate-undulate, bounded with a somewhat thickened 
line. Sori in 1 row on each side, close to the costa or nearly so and parallel to it, shallowly immersed, hardly prominent on the upper surface, occupying the upper $1 / 3-3 / 4$ of the fronds, the lower ones more distant, elongate, to $1 \frac{1}{2} \mathrm{~cm}$. long and $4 \mathrm{~mm}$. broad, the higher ones roundish.

New Guinea.

(147c) TPl. craspedosora, $\boldsymbol{v}$ A. v. IR.; Polypodium craspedosorum, Copel., in Philipp. Journ., IX ${ }^{\mathrm{C}}, 233$.

Rhizome creeping, slender; scales setiform from a small, peltate base, the lower part reddish, the upper part paler. Stipes $\pm 4-6 \mathrm{~cm}$. long, naked. Fronds linear-lanceolate, $\pm 10-20 \mathrm{~cm}$. long, $\pm 4-8 \mathrm{~cm}$. broad, the fertile ones the longest and narrowest, narrowed gradually towards both ends, the point obtuse, the edge entire, narrowly cartilagineous. Texture coriaceous; surfaces naked; costa slender, prominent; veins fine, hidden, forming $1-3$ rows of areolae on each side of the costa. Sori submarginal, slightly immersed, somewhat prominent above, the largest oblong, parallel to the margin.

Sumatra.

(148) Ml. meglecta, Moore.

(149) $\mathrm{Pl}$. rudimenta, v. A. v. R.

Omit this, it being referred to $\mathrm{Pl}$. oodes Moore.

(150) Pl. subecostata, v. A. v, R.

(151) ศP. rostrata, Bedd.

(152) P1. Iinenuis, Moove.

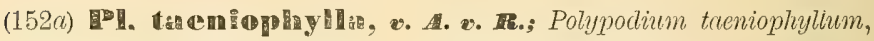
Copel., in Philipp. Journ., VIC, 65; C. Chr., Ind. Fil., Suppl.

Rhizome creeping, wiry, densely clothed with narrow, setaceous, reddish-brown scales. Stipes $\pm 3-6 \mathrm{~mm}$. apart, hardly $1 \mathrm{~cm}$. long, naked. Fronds 7-15 (mostly 10 ) $\mathrm{cm}$. long, to 3-4 mm. broad, obtuse or subacute, entire, narrowed gradually towards the base, the margin of the fertile fronds folded down against each sorus. Texture coriaceous, pellucid; surfaces naked; costa prominent beneath, slightly grooved above; veins 
indistinct. Sori few, nearer the margin than the costa, slightly immersed, hardly oblong.

Borneo.

(152b) IPl. subundilatata, v. A. v. IR.; Polypodium subundulatum, Rst., in Fed., Rep., XII, 180.

Rhizome creeping, bluish, woody, the scales dense, spreading, lanceolate, whitish, fibrilloso-acuminate, sparingly subciliate-dentate, peltate at the base. Stipes $1-4 \mathrm{~cm}$. apart, $\pm 5 \mathrm{~cm}$. long, slender, stramineous, glossy, naked. Fronds elongate-lanceolate, $\pm 15 \mathrm{~cm}$. long by $1 \mathrm{~cm}$. broad, acuminate, undulate, the edge cartilagineous, remotely and slightly crenate, the base cuneate. Texture chartaceous; surfaces naked; costa slightly prominent beneath; veins immersed; areolae irregular, in 2 rows on a side, with few free veinlets. Sori in 1 row on a side, nearly medial between the costa and margin.

New Guinea.

(153) FI. Forbesii, v. A. v. R.

Fully developed plants with the fronds to $25 \mathrm{~cm}$. long, to $5 \mathrm{~cm}$. broad, on stipes to $15 \mathrm{~cm}$. long; sori superficial or slightly immersed.

Also in Java.

(154) Pl. indurata, v. A. v. R.

(154a) See No. 153.

(155) Pl. Stenophylla, Moore.

Rhizome soales pale-brown, white or ferrugineous; edges of the soral cavities raised.

(156a) PI. revoluta, v. A. v. Be.; Polypodium productum, Christ, in Philipp. Journ., IIC, 178.

(156c) Pl. Smithil, v. A. v. IR., in Bull. Btz, 1914, XVI, 29; Polypodium Smithii, v. A. v. R., MS. in Herb. Bog.

Rhizome creeping, the scales linear-subulate, brown or rufous, subspreading, hair-pointed. Stipes scattered; 2-4 cm. long, naked. Fronds linear, $\pm 30-70 \mathrm{~cm}$. long, $\pm 5-71 / 2 \mathrm{~mm}$. broad, broadest in the lowest $1 / 4-1 / 3$ part, narrowed gradually from there to both ends, the tip 
bluntish, the base acute, the edge thickened, revolute, broadly repand in the fertile region. Texture thick; surfaces naked; no main veins; areolae hidden, with few free veinlets. Sori more or less oblong, to twice as long as broad, parallel to the edge, confined to the upper $2 / 3-3 / 4$ part of the fronds, placed in a line nearly close to the edge, deeply immersed so as to form laterally compressed, truncate-conical warts on the upper surface.

Celebes.

(157) P1. sulbgeminata, v. A. v. He; - var. ovata; Polypodium subgeminatum, Christ, var. ovata, Rst., in Fed., Rep., X, 340.

Var. ovata: Fronds shorter, broader, ovate, acuminate. - New Guinea.

(158) P1. papuava, v. A. v. R.

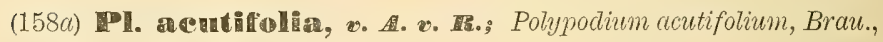
in Lautb.; Beitr. Flor. Pap., I, 49.

Rhizome wide-creeping, the scales dense, when young peltate, deltoidsubulate, afterwards oval, obtuse, adpressed, brown, pale-margined, lacerate. Stipes $\pm 2-5 \mathrm{~cm}$. apart, $2-5^{1 / 2} \mathrm{~cm}$. long, firm, naked, very narrowly winged. Fronds lanceolate, to $16 \mathrm{~cm}$. long, $\pm 2 \frac{1}{2} \mathrm{~cm}$. broad, the apex very long-caudate-acuminate, the edge narrowly revolute, the base cuneate. Texture coriaceous; upper surface dark, provided with whitish, ciliate scales, lower paler, naked; veins distinct. Sori in 1 row on each side of the costa, nearer the costa than the margin, oblique, oblong, immersed; paraphyses fungiform, the apex crateriform, ciliated.

New Guinea.

(159) Pl. Anmabellac, v. A. v. E.: Dendroconche Annabellae, Copel., in Philipp. Journ., VIC, 91.

(160) P1. Iycoporioides, $P_{p}$.

(161) PI. Raapii, v. A. v. R.

(161a) P1. imspersuta, v. A. *. R., in Bull. Btz., 1914, XVI, 28; Polypodium insperatum, v. A. v. R., MS. in Herb. Bog.

Rhizome creeping, slender, clothed with brown, lanceolate-subulate, 
deciduously ciliolate-denticulate scales. Stipes $\pm 1 / 2-1 \mathrm{~cm}$. apart, \pm $4-8 \mathrm{~cm}$. long, angular when dry, naked. Fronds linear-lanceolate, \pm $10-20 \mathrm{~cm}$. long, $1 / 2-3 / 4 \mathrm{~cm}$. broad, narrowed very gradually towards both ends, the point bluntish, the edge broadly and very shallowly crenated, bounded by a somewhat pellucid line. Texture thiniy coriaceous; surfaces naked; veins distinct towards the light, very oblique, connected by transversal veins so as to form 3 rows of subquadrangular areolae; free veinlets present except in the costal areolae, 1-2 in each areola, excurrent or those of the marginal areolae recurrent. Sori in 1 row on each side of the costa, medial, slightly immersed, roundish or obliqueoblong, occupying the abbreviated veinlets of the central areolae.

Sumatra.

Pl. zosteriformis, Bedd.

P1. normalis, Moore.

(164a) Pl. myriocarpa, Moore; - var. Schlechteriana, v. A. v. R., in Bull. Btz., 1913, XI, 19.

Var. Selhlechteriana: Stipes $\pm 5-7 \frac{1}{2} \mathrm{~cm}$. long; fronds linear-lanceolate, $15-25 \mathrm{~cm}$. long, $1 \frac{1}{4}-2 \mathrm{~cm}$. broad. - New Guinea.

(164b) Pl. sablaniana, v. A. v. R.

Also in Borneo, Mindanao.

(164c) PP1. TBamleriana, v. A. v. R.; Polypodium Bamlerianum, Rst., in Fed., Rep., VIII, 163; C. Chr., Ind. Fil., Suppl.

Rhizome wide-creeping, woody, clothed with adpressed, irregular, roundish or linear-lanceolate, entire or ciliate scales. Stipes scattered, subflexuose, stramineous, naked, glossy, 2-marginate. Fronds simple, elongate-oval, $\pm 25 \mathrm{~cm}$. long, $31 / 4-4 \mathrm{~cm}$. broad, the base cuneate, the apex narrowed, often acuminate. Texture subcoriaceo-chartaceous; surfaces naked; upper surface olive-green, lower paler; costa and veins hardly prominent above, more distinctly so beneath; primary veins flexuose, forming a series of large costal areolae on each side and beyond these a second series of smaller primary areolae, with secondary and tertiary areolae with free included veinlets. Sori round, separate, rarely confluent in pairs, scattered irregularly, occupying the whole under surface of the fronds.

New Guinea. 


\section{(165) Pl. glossipes, v. A. v. IR.}

(165a?) P1. Wolbensis, v. A. v. $\boldsymbol{R}$; Polyportium wobbense, Brau., in Lautb., Beitr. Flor. Pap., I, 51; C. Chr., Ind. Fil., Suppl.

Rhizome creeping, branched, the scales brown, peltate, elongate-deltoid, long-acuminate. Stipes $\pm 2 \frac{1}{2} \mathrm{~cm}$. apart, $3 \frac{1}{3}-7 \mathrm{~cm}$. long, narrowly winged. Fronds to $28 \mathrm{~cm}$. long, asuminate; barren fronds lanceolate, \pm $2^{3 / 4} \mathrm{~cm}$. broad; fertile fronds linear-lanceolate, $\pm 13 / 4 \mathrm{~cm}$. broad. Texture thin; veins distinct. Sori small, scattered. -. The proper place of this species is uncertain because of incomplete description.

New Guinea.

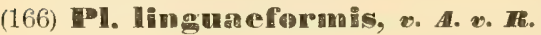

(167) PI. cost ulata, v. A. v. R., l. c., tab. IV.

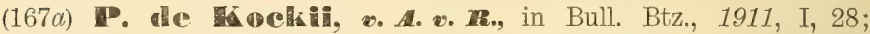
Polypodium de Kockii, v. A. v. R., MS. in Herb. Bog.; C. Chr., Ind. Fil., Suppl.; P. prolixum, Rst., in Nov. Guin., VIII, Bot., 727.

Rhizome ascending, thick, woody, black, elongated, the scales dense, lanceolate, pale-ferrugineous, peltate near the base, entire, the apex finely acuminate, the point hair-like, crisped, deciduous. Stipes scattered, erect, $\pm 1 \%-6 \mathrm{~cm}$. long, naked, slightly sulcate above, rather convex beneath, those of the fertile fronds the longest. Fronds very dimorphous. Barren fronds lanceolate, $\pm 6--9 \mathrm{~cm}$. long, $\pm 11 / 2-2 \mathrm{~cm}$. broad near the base, narrowed gradually to the acuminate apex, the base cuneate or rotundatecuneate and slightly decurrent, the edge thickened, revolute, broadly and shallowly crenated. Texture rigidly coriaceous; surfaces naked; costa slightly sulcate above, prominent beneath, as are the main veins; main veins ascending, not reaching the margin, veins hidden. Fertile fronds linear, $\pm 15-25 \mathrm{~cm}$. long, $\pm 4-5 \mathrm{~mm}$. broad, narrowed gradually towards both ends, when dry conspicuously induplicate, or rather involuto-canaliculate, the edge thickened, entire, the costa prominent angular, and 2-marginate beneath. Sori numerous, large, oblong, superficial, in 1 row on each side of the costa, medial, remote, parallel to the costa. - Very distinct by its apparently terete (conspicuously canaliculate) fertile fronds.

New Gvinea. 
(169) PI. rhy nelnophylla, Moore.

Also in New Guinea.

(170) FP. Griffithians, Moore; - var. borneensis.

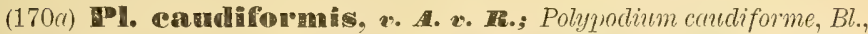
Flor. Jav., II, 146, tab. LIV, fig. 2; P. Feei, Mett., var., C. Chr., Ind. Fil.; v. A. v. R., Mal. Ferns, 675; Selliguea caudiformis, J. Sm., Bedd., Handb. Ind. Ferns, 390, p. p.

Rhizome wide-creeping, firm, brownish, deciduously scaly, the scales ovate-lanceolate, acuminate, thin, entire or obsoletely erose, peltate at the base, pale-ochraceous, at length brown or red-brown. Stipes scattered, $10-20 \mathrm{~cm}$. long or longer, those of the fertile fronds the longest, scaly at the base. Fronds dimorphous. Barren fronds oblong-lanceolate, \pm $15-25 \mathrm{~cm}$. long, 5-10 cm. broad, acuminate, the edge cartilagineous, entire to subrepand, the base cuneate and more or less decurrent. Texture coriaceous; surfaces naked; costa rather prominent beneath; main veins distinct. Fertile fronds linear-lanceolate, $\pm 20-30 \mathrm{~cm}$. long, $3 / 4-21 / 2$ $\mathrm{cm}$. broad, narrowed at the base and very gradually so to the apex. Sori large, solitary between the main veins or the lower double, round or oblong, free or confluent and then oblong or linear-oblong and parallel to the main veins. - United with Pl. Feei $v$. A. $v$. $R$. by intermediates. Malaya to Polynesia.

(170b) Pl. albieanIa, v. A. v. IR.; Polypodium albicaulum, Copel., in Philipp. Journ., VIC, 90; C. Chr., Ind. Fil., Suppl.

Rhizome white-calcareous, sparingly scaly, the scales needle-like, chestnut, squarrose, peltate and pale margined at the base. Stipes slender. Barren fronds broadly lanceolate, $10-15 \mathrm{~cm}$. long, much acuminated, coriaceous; fertile fronds narrowly lanceolate. Sori superficial. - Much resembling $\mathrm{Pl}$. caudiformis $v$. A. v. $R$.

New Guinea.

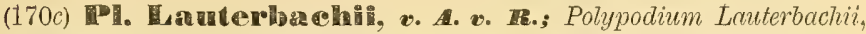
Brau., in Lautb., Beitr. Flor. Pap., I, 52; C. Chr., Ind. Fil., Suppl.

Rhizome wide-creeping, branched, sometimes whitish, the scales 
fuscous, peltate, elongate-deltoid, acuminate, fimbriate, squarrose. Stipes $\pm 1^{1 / 2}-4^{1 / 2} \mathrm{~cm}$. apart, $2-5 \mathrm{~cm}$. long, of the fertile fronds the longest, firm. Fronds lanceolate or linear-lanceolate, to $16 \mathrm{~cm}$. or more long, t $1 / 2-21 / 2 \mathrm{~cm}$. broad, the fertile ones the longest and narrowest; barren fronds crenulate, fertile ones undulate. Texture rigidly coriaceous; surfaces naked; main veins prominent, spreading, connected by $2-3$ transverse veins. Sori large, in 1 row on each side of the costa, at length close and covering the whole under surface of fertile fronds

New Guinea.

(171) Fl, WVlieforodi, v. A. v. IR.

(171a) TP. subeandiformis, v. A. v. H.; Polypodium heterocarpum, Mett., var. abbreviatum; v. A. v. R., Mal. Ferns, 676; P. caudiforme, Christ, (not Bl.), Farnkr. d. Erde, 108.

Rhizome creeping, firm, blackish, deciduously scaly, the scales paleto dark-brown, lanceolate-subulate, dilated and peltate at the base. Stipes scattered, $3-20 \mathrm{~cm}$. long, those of the fertile fronds often longer than those of the barren fronds. Fronds dimorphous; barren fronds oblong, ovate or lanceolate, $15-25 \mathrm{~cm}$. long, $3-4 \mathrm{~cm}$. broad, narrowed at both ends, the apex varying from blunt to acuminate, the base from acute to decurrent, the edge entire, slightiy cartilagineous and revolute. Texture coriaceous; surfaces naked; costa rather prominent beneath; mains veins distinct, not reaching the margin. Fertile fronds longer and narrower, linear-lanceolate, subcaudiform, $.15-30 \mathrm{~cm}$. long, 2-21/2 cm. broad, cuneate or decurrent at the base, narrowed very gradually to the apex. Sori rather large, numerous, solitary between the main veins, immersed, the higher round, the lower and central oblong, spreading, nearly horizontal. - United with Pl. heterocarpa v. A. v. R. by intermediates.

Mataya.

(172a) 푤. Treubil, v. A. v. IR.

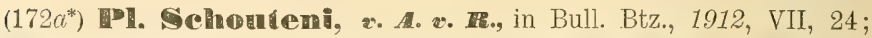
Polypodium Schouteni, v. A. v. R., MS. in Herb. Bog.; C. Chr., Ind. Fil., Suppl.

Rhizome creeping, firm, the scales brown, dense, linear-subulate, dilated and peltate at the base, finely acuminate at the apex. Stipes 
scattered, \pm 4-10 $\mathrm{cm}$. long, naked. Fronds uniform, linear-lanceolate, $\pm 12-22 \mathrm{~cm}$. long, $1-1 \% \mathrm{~cm}$. broad, the fertile ones not rarely the largest, entire, narrowed gradually towards both ends, the base more or less decurrent, the edge slightly cartilagineous and revolute. Texture firm; surfaces naked; costa prominent beneath; main veins fine, not reaching the margin, areolae numerous, with few free veinlets. Sori large, numerous, in 1 row on each side of the costa, medial, solitary between the main veins, slightly but distinctly immersed, at length contiguous, the higher round, the central and lower oblong, parallel to the main veins, horizontal or nearly so, or the lower round.

Java.

(172a*a) PI. batacorum, v. A. v. R.; Polypodium bataconum, Rst., in Fed., Rep., XயI, 220.

Rhizome wide-creeping, the scales whitish, somewhat brunnescent, lanceolate from a peltate base, long-acuminate, somewhat spreading. Stipes $\pm 2-3 \mathrm{~cm}$. apart, $3-5 \mathrm{~cm}$. long, naked. Fronds simple, lanceolateoblong, to $20 \mathrm{~cm}$. long, entire, long-decurrent. Texture subcoriaceous; surfaces naked; costa prominent; main veins distinct, reaching the margin; areolae hidden. Sori oblong, in 1 row on each side, medial, suboblique, deeply immersed, prominent above, with the mouth of the cavity encircled by an elevated ridge.

Sumatra.

(172a*b) L1. papilligera, v. A. v. R.; Polypodium papilligenum, Rst., in Fed., Rep., XIII, 220.

Rhizome creeping, the scales ochraceous, subadpressed, setiform from a dilated base, entire. Stipes approximate, $\pm 5-10 \mathrm{~cm}$. long, naked, those of the fertile fronds the longest. Fronds simple, lanceolate or linearlanceolate, to $13-16 \mathrm{~cm}$. long by $2 / 3-1 \frac{1}{2} \mathrm{~cm}$. broad, the fertile ones the longest and narrowest, entire, narrowed towards the base. Texture subcoriaceo-chartaceous; surfaces naked; costa prominent; venation subdistinct; main veins subspreading, not reaching the margin. Sori in 1 row on each side, medial, suboblong, deeply immersed, prominent above, with the mouth of the cavity hardly elevated.

Sumatra.

(172b) Fl. Valetoniama, v. A. v. R.

Ferns and Fern Allies. 
(172c) IPI. iboensis, v. A. v. R.; Polypodium iboense, Brau., in Lautb., Beitr. Flor. Pap., I, 50, fig. 3 B-a-b; C. Chr., Ind. Fil., Suppl.

Rhizome wide-creeping, branched, fuscous, the scales whitish, peltate, linear-lanceolate, acuminate, entire, squarrose. Stipes $\pm 13 / 4-31 / 2 \mathrm{~cm}$. apart, twisted, $1 \frac{11}{2}-31 / 2 \mathrm{~cm}$. long, of the fertile fronds the longest, naked. Barren fronds lanceolate-ovate, $\pm 13 \frac{1}{2} \mathrm{~cm}$. long, $1-3 \mathrm{~cm}$. broad, acuminate, the base slightly revolute, entire or subcrenulate, the base cuneate, somewhat decurrent. Texture coriaceous; surfaces naked; main veins prominent, spreading; veins anastomosing, indistinct; areolae irregular. Fertile fronds linear, $\pm 15 \frac{1}{2} \mathrm{~cm}$. long, $1 \frac{1}{2}-31 / 2 \mathrm{~mm}$. broad; costa narrowly winged beneath; veins free, distinct, in 2-3 rows on each side of and parallel to the costa. Sori linear-oblong, in 1 row on each side of parallel to the costa, immersed, at length covering the whole under surface of the fertile fronds, protected by the costal wings when young.

New Guinea.

(173) PI. platyphylla, Bedd.

(174) Pl. campyloneuroides, v. A. v. R.

(174a) Pl. selliguedides, v. A. v. R.; Polypodium selligueoides, v. A. v. R., MS. in Herb. Bog.

Rhizome wide-creeping, slender, black, the scales scattered, rather adpressed, subulate or lanceolate, brown. Stipes short, sparingly scaly at the base. Fronds elongate-lanceolate, $\pm 20-30 \mathrm{~cm}$. long, $2-2 \frac{1}{2} \mathrm{~cm}$. broad at or below the middle, narrowed gradually towards the acuminate apex and the decurrent base. Texture thin; surfaces naked; main veins present but very slender, oblique; areolae irregular, with free-veinlets. Sori in 1 row between the main veins, 4-7 in a row, roundish to shortly linear, sometimes confluent or accompanied by a few other scattered ones.

Sumatra.

(175) PI. plilebiscopa, v. A. v. R.

(176a) Pl. Inemionitidea, Moore.

(176b) PI. Wermeri, v. A. v. R. 
(177) Pl. Mippelii, Moore.

(177a) Pl. cochlearis, v. A. v. R.; Polypodium cochleare, Brau., in Laut., Beitr. Flor. Pap., I, 48; C. Chr., Ind. Fil., Suppl.

Rhizome creeping, the scales triangular-subulate, peltate, acuminate, entire, pale, squarrose. Stipes $\pm 5 \mathrm{~mm}$. apart, slender, firm, tortuous, $\pm 3-5 \mathrm{~cm}$. long, of the fertile fronds the longest. Fronds spathulate or lanceolate, $\pm 5 \frac{1}{2}-6 \frac{1}{2} \mathrm{~cm}$. long, $3 / 4-1 \frac{1}{12} \mathrm{~cm}$. broad, the fertile ones the longest and narrowest, subobtuse, narrowly revolute at the edge, cuneate at the base. Texture papyraceous; surfaces naked; main veins prominent; areolae indistinct. Sori in 2 rows between the main veins, slightly immersed.

Nero Guinea.

(178) Pl. membramncea, Moore.

Omit the variety grandifolia, which is a form of the type only.

Also in Matacca.

(179) PI. leucophora, v. A. v. R.

(180) Pl. triquetra, v. A. v. R.

(181 $\alpha$ ) IPl. rupestris, Mosre; - var. taeniopsis ; - var. subalbula; - var. leucolepis.

Rhizome scales not iridescent; fronds not invariably black-dotted above. Forma typica; Rhizome scales dull-brown. - Mataya.

Var. taeniopsis: Rhizome scales ferrugineous. - Celebes. New Guinea.

Var. subalbula: Intermediate between the type and Pl. albula $v$. A. $v$. $R$. but the rhizome scales often yellow-brown, not aristate. - Java.

Var. leucolepis: Rhizome scales white. - New Guinea.

(181a*) Pl. nigrieans, v. A. v. R., in Bull. Btz., 1915, XX, 22; Pl. mpestris, Moore, var. nigricans, v. A. v. R., 1912, VII, 24; Polypodium nigricans, v. A. v. R., MS. in Herb. Bog.; - var. parallela; Pl. rupestris, Moore, var. parallela, v. A. v. R., 1. c.,

Near Pl. rupestris Moore but the rhizome scales iridescent, the upper surface dark-brown or blackish when dry, the under surface paler, grey 
or olivaceous when dry, the main veins rather indistinct; sori relatively small.

Var. parallela: Stipes shorter with regard to the fronds, to 3 $\mathrm{cm}$. long; fronds lanceolate or broadly linear, $15-45 \mathrm{~cm}$. long, 2-6 cm. broad, the base gradually long-decurrent, the edges more or less parallel to the costa, the main veins distinct, blackish; sori relatively large.

Java.

$\left(181 a^{*}(t)\right.$ Fl. randulato-sinuata, v. A. $\boldsymbol{v}$. R.; Polyportium undulato-sinuatum, Rst., in Fed., Rep., XII, 179.

Rhizome creeping, woody, the scales dense, whitish, lanceolate, peltate at the base, fibrilloso-acuminate, ciliolate-denticulate. Stipes $1-4 \mathrm{~cm}$. apart, to $10 \mathrm{~cm}$. long, naked, glossy. Fronds lanceolate, shortly cuneate at the base, narrowed gradually towards the apex, undulate-sinuate, the margin cartilagineous, reflexed, the lobules $\pm 4 \mathrm{~mm}$. deep by $8 \mathrm{~mm}$. broad, serrulate-crenate. Texture subcoriaceous; surfaces naked; costa prominent beneath; main veins distinct; veins indistinct; areolae in 2-3 rows on each side of the costa, with free veinlets. Sori in 2 rows between the main veins.

New Guinea.

(181b) Pl. Iuzonica, v. A. v. IR.g - var. javanica, v. A. v. R., in Bull. Btz., 1911, I, 12.

Var. Javanica: Rhizome wide-creoping, the scales brown, less acuminate, sparingly denticulate-ciliate; fronds much smaller, \pm 6-10 $\mathrm{cm}$. long, 1-2 cm. broad, the fertile ones the longest and narrowest, lanceolate, with the edge entire to repando-sinuate, the base cuneate; main veins not reaching the margin. - Perhaps a distinct species. - Java.

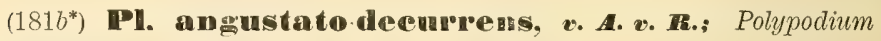
angustato-decurrens, Rst., in Fed., Rep., XIII, 221.

Rhizome short-creeping, the scales ferrugineous, lanceolate from a denticulate, cordate base, long-acuminate, entire, clavate at the point. Stipes approximate, $\pm 3 \mathrm{~cm}$. long, slender, firm, naked, stramineous-brown. Fronds simple, linear-lanceolate, to. $20 \mathrm{~cm}$. long, $\pm 6-9 \mathrm{~mm}$. broad, broadest in the upper part, narrowed towards both ends, long-decurrent, broadly truncate-crenulate. Texture subcoriaceochartaceous; surfaces naked; upper surface wrinkled when dry; costa prominent beneath; main 
veins distinct, very oblique, areolae rather hidden. Sori roundish, small, in 2 rows between the main veins, $2-4$ in a row.

Sumatra.

(182) PI. albula, v. A. v. $\boldsymbol{R}$.

(182a) H. Iimaefonmis, v. A.v. I.; Polypodium limaeforme, Brau., in Lautb., Beitr. Flor. Pap., I, 49; C. Chr., Ind. Fil., Suppl.

Rhizome creeping, the scales squarrose, pale, peltate, lanceolate, acuminate, entire, rounded at the base. Stipes $\pm 21 / 2 \mathrm{~cm}$. apart, \pm $23_{4}-5 \mathrm{~cm}$. long, those of the fertile fronds the longest, naked. Fronds linear-lanceolate, $\pm 7^{1} / 2-15^{1} / 2 \mathrm{~cm}$. long, $\pm 3 / 4 \mathrm{~cm}$. broad, the fertile ones the longest, bluntish, crenulate, acute at the base. Texture coriaceous; surfaces naked; main veins prominent; areolae indistinct. Sori in 2 rows between the main veins.

New Guinea.

(182b) P1. rhomboidea, v. A. v. R.; Polypodium thomboideum, Brau., in Laut., Beitr. Flor. Pap. I, 46; C. Chr., Ind Fil., Suppl.

Rhizome wide-creeping, branched, the scales lanceolate, peltate, pale, long-acuminate, entire. Stipes $\pm 1 / 2-21 / 2 \mathrm{~cm}$. apart, slender, firm, pale, $3 / 4-63 / 4 \mathrm{~cm}$. long, those of the fertile fronds the longest. Fronds lanceolate or subrhomboidal, $\pm 3 \frac{1}{4}-6 \mathrm{~cm}$. long, $1 \frac{1 / 2}{2}-2 \mathrm{~cm}$. broad, cuneate at the base; barren fronds bluntish, crenulated; fertile fronds acuminate, incisocrenate. Texture rigidly coriaceous; surfaces naked; main veins prominent, not reaching the narrowly revolute margin; areolae hidden. Sori in 2 rows between the main veins, immersed.

New Guinea.

(182c) PI. Iucidula, v. A. v. Re, in Bull. Btz, 1914, XVI, 58; Polypodium lucidulum, v. A. v. R., MS. in Herb. Bog.

Rhizome creeping, the scales lanceolate, when youg capillary-acuminate, minutely remotely denticulate, red-brown towards the base, pale-ochraceous towards the apex. Stipes subapproximate, $\pm 3-5 \mathrm{~cm}$. long, naked. Fronds lanceolate-elongate, $15-25 \mathrm{~cm}$. long, $2:-3 \mathrm{~cm}$. broad, bluntly acuminate, entire, the edge cartilagineous, thickened, subrevolute, the base narrowed very gradually into the stipe. Texture coriaceous; surfaces naked and glossy; costa prominent beneath, subpellucid; main veins fine, 
rather hidden; areolae immersed, very fine. Sori in 2 rows between the main veins, $\pm 4-6$ in a row.

Borneo,

(183) PI. oo sles, Moore.

$P l$. rudimenta $v . A . v . R$. is a young form of this species.

(184) T. Iulitemsis, v. A. v. FR.

(185a) P1. subopposita, v. A. v. R.

Rhizome creeping, scaly. Stipes seriate, about $3 \mathrm{~cm}$. long, naked, winged nearly to the base by the decurrent base of the fronds. Fronds lanceolate, about $35-55 \mathrm{~cm}$. long, to about $6 \mathrm{~cm}$. broad at the middle, acuminate. Texture flaccido-papyraceous; surfaces naked; colour palegreen; costa distinct, main veins more or less spreading, fllexuose, distinct nearly to the edge; areolae hidden, longitudinal, divided into numerous smaller ones with included free veinlets. Sori numerous, irregular.

Luzon.

(185b) PI. Scortechinii, Hedd.

(186a) P1. ovata, Moore.

(186b) MP. Zollingeriana, v. A. v. $\boldsymbol{R}$.

Stipes (exclud. the wing) sometimes to $45 \mathrm{~cm}$. long, and the fronds to $70 \mathrm{~cm}$. long and $15 \mathrm{~cm}$. broad, bluntish, acute or even caudate at the apex.

(186c?) Pl. neo-guineensis, v. v. . H.; Polypodium neo-guineense, Copel., in Philipp. Journ., VIC, 89; C. Chr., Ind. Fil., Suppl.

Fronds sessile, elongate-oblanceolate, $40-50 \mathrm{~cm}$. long, $5-6 \mathrm{~cm}$. broad, narrowed gradually at both ends, caudate at the apex, entire. Texture thin-membranaceous; main veins oblique, reaching te margin, secondary ones parallel to the costa. Sori minute, superficial, scattered irregularly.

New Guinea.

(187) PI. millisora, v. A. v. R.

Also in New Guinea to Polynesia. 
(187a) F1. melamocaulos, v. A. v. R., in Bull. Btz., 1913, XI, 19; Polypodium melanocaulon, v. A. v. R., MS. in Herb. Bog.

Rhizome wide-creeping, dark-coloured when dry, clothed with long, spreading, flexuose, hair-like, rufous scales. Stipes scattered, $\pm 1 \frac{1}{2}-31 / 2$ cm. long, deciduously pilose. Fronds lanceolate or linear-lanceolate, \pm 10-30 cm. long, 2-4 cm. broad, subrostrate-acuminate, entire, decurrent or cuneate at the base. Texture thin-papyraceous to coriaceous, the thinnest transparent; both surfaces copiously furnished with short and long, more or less persistent whitish hairs; upper surface provided with numerous scattered, white, deciduous, cretaceous dot-like scales; costa somewhat prominent on both sides; main veins distinct, spreading or nearly horizontal, not reashing the margin; areolae fine, with numerous free veinlets. Sori minute, scattered.

Borneo.

(188) PI. pumctata, Bedd.; - var. mindanensis, subiridea, subdrynariacea; Polypodium mindanense, subirideum, subdrynariaceum, Christ, C. Chr., Ind. Fil., Suppl.

Main veins not rarely very indistinct even in dried material, as in Lepisorus.

(189) Pl. musifolia, Moore; - var. Schumanniana, Rst., in Nov. Guin., VIII, Bot., 729.

Forma typica: Fronds linear or ligulate, cordate or rounded at the base, sessile; main veins long, rather straigt, reaching nearly the margin, connected by transversal arched veins so as to form several rows of nearly regular, subtetragonal primary areolae. - Malaya.

Var. Schumanniana: Fronds smaller, ovate-oblong or panduriform to lanceolate, sessile with a cordate base with overlapping auricles to stalked with a long-decurrent base; main veins evanishing gradually towards the margin, connected by transversal veins forming variously shaped primary areolae not arranged in subregular rows, nearly as in Pl. myriocarpa Moore. - United with the type by forms having the higher primary areolae subregular, the lower irregular. - New Guinea, Amboina.

(189a) PI. glossophylla, v. A. v. R.; Polypodium glossophyllum, Copel., in Philipp. Journ. IX, 7. 
Rhizome creoping, densely clothed with glossy, black, narrowly lanceolate scales. Stipes $\pm 1 \mathrm{~cm}$. long, firm, naked, castaneous. Fronds oblanceolate-elongate, $\pm 60-90 \mathrm{~cm}$. long, $\pm 7 \mathrm{~cm}$. broad above the middle, narrowed gradually towards both ends, acute, entire, the very base often suddenly contracted. Texture coriaceous; surfaces naked; under surface glaucous; costa prominent beneath; main veins numerous, somewhat oblique, straight, reaching nearly the margin; areolae in $4-5$ rows on each side, not conspicuous. Sori in 2 somewhat irregular rows between the main veins, round, superficial.

New Guinea.

(190a) PI. valida, v. A. v. T.

(190b) F1. monstrosa, v. A. v. R.; - var. leucophlebia; var. integrior.

(191) IP. Weinlandii, v. A. v. $\boldsymbol{R}$.

(191a) Pl. Holosenices, v. A. v. Ih.; Polypodium holosericeum, Rst., in Fed., Rep., V, 375; C. Chr., Ind. Fil., Suppl.

Rhizome short-creeping, subcarnose, densely scaly, the scales membranaceous, ferrugineous, paler at the margin, shortly toothed, narrowly lanceolate from a broadly rounded, peltate base, the apex long, hair-like, curved. Fronds subsessile or short-stalked, simple, lanceolate-oblong, to $20 \mathrm{~cm}$. or more long, $\pm 3 \frac{1}{2} \mathrm{~cm}$. broad, acute, the margin sinuato-repand, bordered by a callous line, the base narrowed very gradually. Texture herbaceo-chartaceous; colour brownish when dry; surfaces densely clothed with weak, short, subhamate hairs; costa and veins dirty-yellow, prominent on both sides; main veins erecto-patent, subflexuose, reaching nearly the margin; primary areolae in $4-5$ rows on each side of the costa, divided into numerous irregularly subquadrangular smaller ones with free included veinlets. Sori unknown.

New Guinea.

(192) Pl. paucijuga, v. A. v. F.

(192a) Pr. Cromwellii, v. A. v. R.; Polypodium Cromvellii, Rst., in Fed., Rep., X, 340; C. Chr., Ind. Fil., Suppl. 
Rhizome wide-creeping, wiry, more or less glaucous; scales roundish, peltate, scattered, black at the centre, brown and entire at the edge. Stipes slender, 10-12 cm. long, brown, naked. Fronds 3-fid. Lobe\$ linear-lanceolate, $\pm 1 \frac{1}{2} \mathrm{~cm}$. broad, acuminate, slightly repand; central lobe 15-30 cm. long, lateral ones much ascending, $\pm 15 \mathrm{~cm}$. long. Texture membranaceo-herbaceous; upper surface provided with white, calcareous, dot-like scales, lower naked; central ribs stramineous, prominent; veins distinct; areolae in 2 rows on each side, with free veinlets. Sori in 1 row on each side, medial or intramedial.

New Guined.

(193) P1. sumatrana, v. A. v. IR.; Polypodium sundense, C. Chr.

(193a) PI. papyracen, v. A. v. R.; Polypodium papyraceum, Copel., in Philipp. Journ., VIC, 90; C. Chr., Ind. Fil, Suppl.

Stipes $\pm 15 \mathrm{~cm}$. long, brown, naked, narrowly winged towards the frond. Fronds $\pm 22 \mathrm{~cm}$. long, $12 \mathrm{~cm}$. broad, deeply pinnatipartite. Segments \pm 7 on a side, ascending, the largest $\pm 11 \mathrm{~cm}$. long, $8 \mathrm{~mm}$. broad, the lower narrowed at both ends, dilated at the very base, connected by a narrow wing, entire or subsinuate. Texture papyraceous; surfaces naked; veins forming 1 row of mostly long and narrow areolae on each side close to the costulae and beyond these 2 large areolae to each costular one; included free veinlets present. Sori solitary between the larger areolae, nearly superficial, round, small.

New Guinea.

(194a) P1. alata, Moore.

(194b) PI. In accida, v. A. v. R.

(195) Pl. commutata, v. A. v. R.

A form gathered in Borneo has the stipes winged in the upper part only, and the sori placed in $1-2$ series.

(195a) Pl. sibomensis, v. A. $\boldsymbol{v}$. R.; Polypodium sibomense, Rst., in Fed., Rep., X, 340; C. Chr., Ind. Fil., Suppl.

Stipes slender, $20 \mathrm{~cm}$. or more long, red-brown, naked, 2-marginate. Fronds oblong, to $40 \mathrm{~cm}$. long, $25 \mathrm{~cm}$. broad, acuminate, deeply pinnatifid 
nearly pinnate at the base. Lobes $\pm 5-10$ on a side below the terminal one, alternate, erecto-patent, remote, linear-l anceolate, long-acuminate, entire, narrowed towards the dilated base, the largest \pm 20 $\mathrm{cm}$. long, $1 \frac{1}{2} \mathrm{~cm}$. broad, the lower somewhat shorter, much contracted at the base, apparently petiolulate. Texture herbaceo-chartaceous; surfaces naked; upper surface dark-green, lower paler; costa and costulae brown, glossy; veins fine, translucent, forming $2-3$ rows of areolae on each side of the costulae, with free veinlets. Sori in 2 rows on each side of the costulae, nearer the costulae than the margin.

New Guinea.

\section{(196) Pl. ebenipes, Bedd.}

\section{(197) PI. glauca, Moore.}

(198) P. hastata, Moore, Bedd., Handb. Ind. Ferns, 362; Pl. oxyloba, Bedd., Ferns S. I., tab. CLXXV; Polypodium hastatum, Thb., Hk. Bk., Syn. Fil., 361; Kze, Farnkr., I, tab. LXXXII; C. Chr., Ind. Fil. - var. oxyloba, MS. in Herb. Bog.; Pol. oxylobum, Wall, Mett., Farng., I, Polypod., 106, p. p.; - var. trifida, MS. in Herb. Bog.; Pol. trifidum, Don, Hk. Bk., 1. e., 363, p. p.

Edges of the fronds more or less distinctly thickened and often repando-undulate. Sori semetimes medial but more commonly nearer the costulae than the margin.

Forma typica: Fronds simple or 2-3-fid with the lateral lobes shorter than the terminal one.

Var. oxyloba: Fronds deeply pinnatifid with $1-6$ lobes on a side; lobes $\pm 10-15 \mathrm{~cm}$. long, absolutely entire.

Var. trifialu: Like the preceding but the lobes remotely crenulate or serrulate.

(198a) PI. multijugata, v. A. . R.; Polypodium multijugatum, Copel., in Philipp. Journ., VIC, 90; C. Chr., Ind. Fil., Suppl.

Stipes $\pm 40 \mathrm{~cm}$. long, thick, dark-stramineous-brown, naked. Fronds $\pm 60 \mathrm{~cm}$. long, $25 \mathrm{~cm}$. broad, deeply pinnatifid, pinnate at the very base. Segments to $15 \mathrm{~cm}$. long, $\pm 1-1 \frac{1}{2} \mathrm{~cm}$. broad, acuminate, entire or slightly sinuated, connected by a narrow costal wing, the lowest free. Surfaces naked; main veins moderately conspicuous; areolae hidden. Sori 
often in 2 rows on each side of the costulae, solitary in the larger areolae, round, large, superficial.

New Guinea.

(199) PI. quinquefida, $v$. A. $v$. K.

(199a) P1. Powellii, Carr., Seem., Fl. Vit., 367; Polypodium Powellii, Bk., Hk. Bk., Syn. Fil., 364; C. Chr., Ind. Fil.

Rhizome woody, scandent. Stipes $45-60 \mathrm{~cm}$. long, brownish, naked. Fronds $60-90 \mathrm{~cm}$. long, $30 \mathrm{~cm}$. or more broad, cut down within $7 \mathrm{~mm}$. of the rachis throughout into close, acuminate, entire lobes $121 / 2-15 \mathrm{~cm}$. long, $1 \frac{1}{2}-2 \mathrm{~cm}$. broad. Texture subcoriaceous; surfaces naked; colour dark-green; main veins not at all prominent but distinct when held up to the light; areolae rather large, with copious free veinlets. Sori in single rows about midway between the edge and the costulae. - Lobes narrower and more numerous than in $\mathrm{Pl}$. nigrescens Carr., the veins different, and the sori not at all immersed.

New Guinea; Samoa.

(199b) Pl. ceratophylla, v. A. v. R.; Polypodium ceratophyllum, Copel., in Philipp. Journ., IIIC, 348, tab. VII; C. Chr., Ind. Fil., Suppl.

Rhizome slender, creeping, the scales $2 \frac{1}{2} \mathrm{~mm}$. long, ferrugineous, setiform, peltate at the base. Stipes slender, brown, up to $\pm 8 \mathrm{~cm}$. long, winged in the upper half. Fronds up to $\pm 21 / 2 \mathrm{~cm}$. long above the wing, to $\pm 4 \mathrm{~cm}$. broad, 2-3-furcate, the segments divaricating; simple or once or twice forked again, the barren fronds the less divided. Ultimate segments $\pm 2 \mathrm{~mm}$. broad, blunt, with the margin bounded by a narrow, cartilagineous strand. Texture coriaceous; surfaces naked; costae blackish; veins hidden, laxly anastomosing. Sori superficial, in 1 row on each side of the costulae.

Borneo.

(199c) PP. Sehlechteri, v. A. v. R.; Polypodium Schlechteri, Brau, in Lautb., Beitr. Flor. Pap., I, 54, fig. $3 C-c$; C. Chr., Ind. Fil., Suppl.; Aglaomorpha Schlechteri, Copel., in Philipp. Journ., IX ${ }^{\mathrm{C}}, 9$.

Rhizome creeping, scaly; scales subulate, fuscous, fimbriate, palemargined, peltate at the base. Stipes scattered, winged, $\pm 15-30 \mathrm{~cm}$. long, those of the fertile fronds the longest; wings broadly sinuated, the 
lobes alternate, $\pm 4 \mathrm{~mm}$. deep by $3 \frac{1}{2} \mathrm{~cm}$. broad. Fronds dimorphous, deeply pinnatifid, $\pm 30-50 \mathrm{~cm}$. long, the fertile ones the longest. Barren fronds linear-oblong, to $\pm 17 \mathrm{~cm}$. broad, the lobes articulated to the costa, alternate, \pm 5 on each side below the terminal one, ascending or horizontal, lanceolato-oblong, to $10 \mathrm{~cm}$. long by $31 / 2 \mathrm{~cm}$. broad, entire, abruptly shortly acuminate, dilated at the base, separated by rounded sinuses narrower than the lobes. Texture coriaceous; surfaces glabrescent (naked?). Fertile fronds deltoid-oblong, to $30 \mathrm{~cm}$. broad at the base, the lobes opposite, \pm 8 on each side below the terminal one, ascending, linear-subulate, straight or falcate, the lowest the largest, to $\pm 16 \mathrm{~cm}$. long by $1 \mathrm{~cm}$. broad, dilated at the base, separated by rounded sinuses broader than the lobes. Sori numerous, large, round or suboblong, placed in 2-3 rows on each side of the costulae.

New Guinea.

$(199 d)$. Pl. Huchanani, v. A. v. R.; Aglaomorpha Buchanani, Copel., in Philipp. Journ., IX ${ }^{\mathrm{C}}, 8$.

Near Pl. Schlechteri $v$. A. v. R. but the segments with the edges parallel, not narrowed gradually from the base; the fertile ones suddenly much dilated at the base.

New Guinea.

(199e) See No. 219a.

(200) HI. anomala, v. A. v. $\boldsymbol{\text { IR. }}$

(200a?) Pl. Kingii, v. A. v. K.; Polypodium Kingii, Copel., in Philipp. Journ., VIC, 89; C. Chr., Ind. Fil., Suppl.

Rhizome scandent, clothed with peltate, black, brown-margined, adpressed scales. Stipes $\pm 6 \mathrm{~cm}$. long, provided with a few minute scales at the base. Fronds $\pm 15 \mathrm{~cm}$. each way, deeply 5-lobed with rounded sinuses, shortly cuneate at the base. Lobes entire, much acuminated, the terminal one broadly, the lateral ones narrowly lanceolate. Texture papyraceo-coriaceous; surfaces naked; main veins black, conspicuous, not reaching the margin, forming 1 row of costal areolae in the lateral lobes, 1-2 rows in the terminal one; veins indistinct, hidden. Sori round, moderately large, superficial. - Barren fronds simple, borne lower down on the tree than the fertile.

New Guinea. 
(202a) Pl. pteropus, Noore, Bedd., Handb. Ind. Ferns, 359, fig. 203; Pl. tridactyla, Moore, Bedd., Ferns Br. I., I, tab. XI; Polypodium pteropus, Bl., Flor. Jav., II, 168, tab. LXXVI; P. tridactylum, Wall., Hk. \& Grev., Ic. Fil., tab. CCIX; var. minor, Bedd., Handb., 361, fig. 204; Ferns S. I., tab. CLXXIX; v. A. V. R., in Bull. Dép. Agr. I. N., 1908, XVIII, tab. IV, fig. $2 a-b$; Ernst, in Ann. Btz., XXII, tab. XV.

Rhizome creeping, branched, the scales lanceolate-subulate, blackish or brownish. Stipes scattered, 2-20-30 cm. long, and as well as the back of the costa and costulae squamulose. Fronds $\pm 5-30 \mathrm{~cm}$. long by $2-5 \mathrm{~cm}$. broad, lanceolate, acuminate, entire, or pinnatifid with a large terminal lobe and 1-2 smaller ones on each side. Lobes lanceolate, acute or acuminate, entire or irregularly repando-crenate, the lateral ones below long-tapering into a decurrent wing upon the stipe. Texture herbaceous; surfaces naked or the lower somewhat squamulose on the veins; main veins rather wide apart, extending $\pm 2 / 3$ of the way to the margin, then uniting and forming a series of large costal primary areolae, a second series of smaller areolae is formed nearer the margin, both filled up with a net-work of smaller irregular areolae with included free veinlets. Sori small, not very numerous, scattered irregulary, 1.7 in the large costal areolae, compital, not rarely confluent into oblong or linear (grammitoid) sori. - Var. minor is a small, shorter stalked form with always simple fronds, and the sori in $1-3$ more or less regular rows on each side of the costa.

Tropical Asiu.

(202a*) P1. aquatica, v. A. v. R.; Polypodium aquaticum, Christ, in Nov. Guin., VIII, Bot., 153; C. Chr., Ind. Fil., Suppl.

Rhizome creeping, grey, clothed with brown, subulate-lanceolate scales. Stipes distant, $\pm 25 \mathrm{~cm}$. long, somewhat flexuose, sulcate, yellowgrey, provided with brown, lanceolate, acute, spreading scales. Fronds 3-partite, to $28 \mathrm{~cm}$. long, to $22 \mathrm{~cm}$. broad, suddenly narrowed at the base, gradually decurrent upon the stipe. Lobes lanceolate-oblong, $\pm 41 / 2 \mathrm{~cm}$. broad, entire, acuminate, the lateral ones porrect, as long as the central one or somewhat shorter. Texture thinly herbaceous, flaccid; surfaces naked; color grey-green, opaque; costulae distinct, slender; main veins fine, rather spreading, flexuose, not reaching the margin, forming large primary 
areolae enclosing very irregular secondary ones with numerous free veinlets. Sori minute, roundish, $\pm 1-7$ between the main veins, scattered irregularly.

Nero Guinea.

$\left(202 a^{*} \alpha\right)$ Pl. Huanensis, ט. A. v. R.; Polypodium tuanense, Copel., in Philipp. Journ., IX ${ }^{\mathrm{C}}, 8$.

Rhizome wide-creeping, the scales dense, at length suborbicular, black, brown-margined. Stipes curved, $\pm 10 \mathrm{~cm}$. long, naked. Fronds more than $20 \mathrm{~cm}$. each way, deeply pinnatifid into \pm 2 segments on each side below the terminal one, shortly decurrent. Segments lanceolate, much acuminated, entire; terminal segment $\pm 2 \mathrm{~cm}$. broad, lateral ones $\pm 1-1 \frac{1}{2} \mathrm{~cm}$. broad. Texture papyraceous; surfaces naked; primary areolae in 1 row on each side of the costulae; secondary ones irregular, moderately visible. Sori minute, superficial, scattered irregularly.

New Guinea.

\section{(202b) PI. dolichoptern, v. A. v. R.}

Rhizome slender but woody; stipes often with a narrow wing much more than $3 \mathrm{~cm}$. long.

(202c) See No. 204.

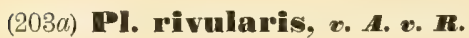

(203b) PI. pentaphylla, v. A. v. R.

(203c) See No. $202 b$.

\section{(204) Pl. insignis, Bedd.}

Forma aptera (aperta, in Bull. Btz., 1914, XVI, 29): Stipes to $45 \mathrm{~cm}$. long, shortly winged in the uppermost portion only. - Sumatra.

(204a) DP. Curramii, v. A. v. R.s Polypodium Curranii, Copel., in Philipp. Journ., IVC, 114; C Chr., Ind. Fil., Suppl.

Rhizome $\pm 3 \mathrm{~mm}$. thick, clothed with narrow, black-brown scales. Stipes naked, winged in the upper part, up to $\pm 15 \mathrm{~cm}$. long, the unwinged, lowest part at least $\pm 1 \mathrm{~cm}$. long, the wing $\pm 2-3 \mathrm{~mm}$. broad in the broadest part. Fronds furcato-pinnatifid with a few acuminate, 
divaricating segments $5-15 \mathrm{~cm}$. long, $3-7 \mathrm{~cm}$. broad. Texture herbaceous; surfaces naked; veins fine, indistinct. Sori numerous, irregularly scattered, minute, often elongate. - The true place of this species is uncertain because of incomplete description. It is allied to $\mathrm{Pl}$. tenuiloris Moore and dolichoptera $v . A . v$. R.

Luzon.

(205) HI. dilatata, Bead.

(205a) P1. Schultzei, v. A. v. R.; Polypodium Schultzei, Brau., in Lautb., Beitr. Flor. Pap., I. 53; C. Chr., Ind. Fil., Suppl.

Stipes to $30 \mathrm{~cm}$. or more long, narrowly winged, brown, glossy, hairy when young, densely scaly, the scales elongate-deltoid, toothed, peltate, cordate at the base, pale-fuscous. Fronds lanceolate, to $75 \mathrm{~cm}$. long and 30 $\mathrm{cm}$. broad, deeply pinnatifid. Lobes \pm 6 on each side below the terminal one, lanceolate; terminal lobe $\pm 33 \mathrm{~cm}$. long by $8 \mathrm{~cm}$. broad; central lobes $\pm 31 \mathrm{~cm}$ long by $6 \mathrm{~cm}$. broad, acuminate; lower lobes somewhat shorter, $\pm 10 \mathrm{~cm}$. apart; higher lobes less remote. Texture chartaceous; surfaces naked; costa, costulae and main veins prominent, more or less densely short-hairy beneath; veins distinct. Sori numerous, very small, scattered irregularly.

New Guinea.

(206) Pl. incurvata, Moore.

(207) Pl. Iaciniata, Bedd.; Polypoctium macrochasmum, Bk.

(208a) Pl. phymatodes, Moore; Polypodium phymatodes, L., Schk., Krypt. Gew., I, tab. 8d, 9, 17; - var. multisecta, Christ, in Nov. Guin.. VIII, Bot., 152; ? var. uniserialis, Rst., in Fed., Rep., X, 340.

Var. multisecta : Lobes many, connected by a wing to $1 \frac{1}{2} \mathrm{~cm}$. broad. Sori in 1 row on each side of the costulae, nearer the costulae than the margin. - New Guinea.

(208a*) Tl, tenuinervis, v. A. v. $\boldsymbol{R} . ;$ Polypodium tenuinerver Copel., in Philipp. Journ., IX, 7.

Rhizome wide-creeping, the scales adpressed, lanceolate, castaneous. Stipes to $20 \mathrm{~cm}$. long, slender, castaneous. Fronds $\pm 35 \mathrm{~cm}$. long by 
$\pm 20 \mathrm{~cm}$. broad, shortly decurrent, cut down to a very narrow wing into \pm 7 segments on each side. Segments nearly $20 \mathrm{~cm}$. long, 1-2 cm. broad, much acuminated, entire or subundulate, narrowed slightly towards the base. Texture membranaceous; surfaces naked. Sori small, in 1 row on each side of the costulae, somètimes accompanied by a few outer ones, slightly immersed.

Nero Guinea.

(208b) Pl. phanerophlebia, v. A. v. R.

(209) Pl. violaseens, v. A. v. R.

(210) PI. nigrescens, Carr.

(211) PI. Selineideri, v. A. v. R.

(211a) Pl. teme nimborensiss, v. A. v. $\boldsymbol{R}$. , in Bull. Btz., 1912, VII, 23; 1914, XX, 23; Polypodium temenimborense, v. A. v. R., MS. in Herb. Bog.; C. Chr., Ind. Fil., Suppl.

Rhizome short-creeping, the scales short-ovate, peltate, subacute, pale-brown. Stipes rather approximate, $12-20 \mathrm{~cm}$. long, subterete, naked. Fronds simple, or 3 -fid, with the lobes similar to the simple fronds but smaller; simple fronds lanceolate, $\pm 20-30 \mathrm{~cm}$. long, $3-4 \mathrm{~cm}$. broad in the lower half, narrowed gradually towards the apex, entire, cuneate and very slightly decurrent at the base. Texture papyraceous; surfaces naked; costa prominent; primary veins forming a series of large, costal primary areolae, 1--2 other series of stout veins form much smaller but still very conspicuous secondary areolae outside the primary ones, both including numerous finer ones with free included veinlets. Sori large, in 1 row on each side of the costa, solitary in the primary areolae, round or very slightly oblong, deeply immersed so as to form very prominent, truncate (cylindrycal or subconical) papillae on the upper surface, nearer the costa than the edge.

New Guinea.

(212) Ti. Iongissina, Moore.

(213) IPI. lagumensis, v. A. v. R. 
(214) PI. seulpturata, v. A. v. R.

(215) Pl. Sauvinierrei, . A. v. $\pi$.

(216) PI. subaquatilis, v. A. v. $\mathrm{R}$.

\section{(217) PI. albido-squamata, $P r$.}

Forma simplex: Both barren and fertile fronds simple, much smaller than the pinnae of the pinnate fronds, the fertile ones not rarely conspicuously contracted. - Hort. Bog.

Omit var. varians.

(217a) PI. Matthewi, v. A. v. R., in Bull. Btz., 1914, XVI, 30; Polypodium Matthewi, v. A. v. R., MS. in Herb. Bog.

Rhizome firm, creeping, clothed with linear-lanceolate, erose, brown scales. Stipes scattered, $\pm 25-50 \mathrm{~cm}$. long, glossy, naked. Fronds roundish in outline, $\pm 25--40 \mathrm{~cm}$. each way, pinnate. the rachis narrowly marginate. Pinnae distant, linear-lanceolate, $\pm 3-8$ on each side below the terminal one, $\pm 10-20 \mathrm{~cm}$. long, $1-2 \mathrm{~cm}$. broad, the fertile ones the narrowest, somewhat narrowed towards the suddenly much dilated adnate base, the edge broadly shallowly crenate, tnickened, subrevolute; higher pinnae ascending, free or connected with the terminal one; lower pinnae straight or upcurved, spreading or horizontal, rotundatecuneate or less dilated at the lower base. Texture coriaceous; surfaces naked; upper surface provided with deciduous, scattered, white, cretaceous, roundish dots; costae and main veins prominent; areolae hidden, with free veinlets. Sori moderately large, superficial, in 1 row on each side of the costae, medial or nearer the margin than the costa.

Sumatra.

(218) PI. Mloseleyi, v. A. v. R.

(219a) FI. Laeniata, v. A. v. R., in Bull. Btz., 1914, XVI, 30; Pl. palmata, Moore, Bedd., Handb. Ind. Ferns, 368; Polypodium palmatum, Bl., Flor. Jav., II, 150, tab. LXIV ; P.taeniatum, Sw. (oldest name), C. Chr., Ind. Fil., Suppl.; - var. angustata.

Rhizome not cretaceous; rhizome scales pale-brown, linear-lanceolate, obscurely eroso-denticulate; secondary veins not invisible; areolae irregular, with the free veinlets spreading in various directions; sori on the anastomosing veins, superficial or slightly immersed.

Ferns and Fern Alites. 
Forma submarginalis: Sori submarginal.

Forma connata: Pinnae long-decurrent and connected at the base.

Omit the variety obtusa, which is Pl. subtaeniata $v$. A. v. R.

(219a*) Pl. taenitidis, ø. A. v. R., in Bull. Btz., 1914, XVI, 31; Polypodium taenitidis, v. A. v. R., MS. in Herb. Bog.

Near Pl. taeniata $v$. A. v. R. but the rhizome scales pale-ochraceous, entire, the pinnae horizontal or nearly so or the lower subdeflexed, the main veins distinct, the secondary veins black at the base when seen towards the light, otherwise hidden (invisible).

Sumatra.

(219a*a) Pl. subtacniata, v. A. v. R., in Bull. Btz., 1914, XVI, 30; Polypodium subtaeniatum, v. A. v. R., MS. in Herb. Bog.; P. palmatum, Bl., var. obtusum, v. A. v. R., Mal. Ferns, 669.

Near Pl. taeniata $v$. A. v. R. but the rhizome white-cretaceous, with the scales castaneous to black, narrowly linear-subulate from an ovatepeltate base, the pinnae very coriaceous, the secondary veins invisible.

Sumatra.

$\left(219 a^{*} b\right)$ Pl. taenifroms, v. A. v. F., in Bull. Btz., 1914, XVI, 31, fig. a; Polypodium taenifrons, $v$. A. v. R., MS. in Herb. Bog.

Near Pl. taeniata $v . A . v . R$. but the rhizome scales ovate-lanceolate, entire; main veins forked at the apex with 2 spreading veinlets, commonly regularly united by $2-3$ transverse veins parallel to the costa so as to form 2-3 quadrangular areolae on each side; costal areolae largest, provided with 2 oblique free veinlets springing from the base of the main veins, one on each side; other areolae commonly without free veinlets; sori solitary in the costal areolae, mostly terminal on one of the veinlets or uniting their apices.

Celebes.

(219 $a^{*}$ c) Pl. Crenulata, v. A. v. R., in Bull. Btz., 1914, XVI, 5!, fig. c; Polypodium crenulatum, Kze., Mett., Farng., I, Polypod., 110; P. taeniatum, Sm., forma, C. Chr., Ind Fil., Suppl.

Near Pl. taenifrons $v$. A. $v$. R. but the main veins commonly subregularly united by 3 flexuose transverse veins parallel to the costa so as to form 3 subquadrangular areolae on each side; areolae (except the 
costal ones) provided with 1-2 excurrent (mostly free) simple or forked veinlets springing from the transversal veins and sometimes with $1-2$ recurrent (often free) ones; sori solitary in the medial (not the costal) areolae, mostly terminal on one of the excurrent veinlets or uniting their apices.

Celebes.

(219b) P1. proteus, v. A. v. R.

(220) PI. coromans, ซ. A. v. R.

(221) PI. heraclen, v. A. v. $\boldsymbol{R}$.

\section{§ 2. SELLIGUEA.}

(v. A. v. R., in Bull. Dép. Agr. I. N., 1909, XXViI, 11-12)

(223a) Pl. selliguea, $v$. A. $v . R$.

Omit this, it being referred to $\mathrm{Pl}$. macrophylla $v$. A. v. $R$.

(223b) PI. Bolsteri, v. A. v. K.

(224) P1. interrupta, v. A. v. K.

(225) $\mathrm{Pl}$. regularis, v. A. v. $R$.

Omit this, it being referred to Pl. macrophylla $v$. A. $v . R$.

(225a) See No. 229.

\section{(226) Pl. Illosei, v. A. v. R.}

Stipes short, or long-winged, the wing distinct.

(226a) PI. Iluvintilis, v. A. v. R.; Polypodium fluviatile, Lautb., in Engl. Bot. Jahrb., XLIV, 507; C. Chr., Ind. Fil., Suppl.

Rhizome wide-creeping, black, slender, provided with few lanceolate, acuminate, grey-brown scales. Stipes naked, slender, $\pm 2-40 \mathrm{~cm}$. long, 
those of the fertile fronds the longest. Barren fronds lanceolate, $\pm 5-25$ $\mathrm{cm}$. long, 2-5 cm. broad, acuminate, entire, decurrent at the base. Texture membranaceo-papyraceous, more or less pellucid; costa prominent below; both surfaces naked; mains veins oblique, $\pm 4-8 \mathrm{~mm}$. apart, not reaching the margin; areolae nearly regular, with free included veinlets. Fertile fronds linear-lanceolate, $\pm 71 / 2-20 \mathrm{~cm}$. long, $\pm .5-10 \mathrm{~mm}$. broad, acuminate, decurrent at the base. Sori very oblique, reaching from the costa to the margin.

Borneo.

(227) F1. macrophylla, v. A. v. R.; Pl. regularis, v. A. v. R. and $P l$. selliguea, v. A. v. R., p. p.; Polypodium macrophyllum, Reinvo, C. Chr., Ind. Fil.; P. regulare, Mett. and P. selliguea, Mett., C. Chr., Ind. Fil., p. p.; var. Backeri, v. A. v. R., in Bull. Btz., 1913, XI, 50; P. selliguea, Mett., var. Backeri, v. A. v. R., MS. in Herb. Bog.

Rhizome creeping, the scales lanceolate, acuminate, red-brown to black. Stipes seriate, $0-20 \mathrm{~cm}$. long, slender or stout, nudate or marginate to broadly winged. Fronds elongate-lanceolate, $\pm 10-65 \mathrm{~cm}$. long, 1-15 $\mathrm{cm}$. broad, blunt to acuminate, entire or nearly so, the base cuneate or gradually decurrent. Texture flaccido-coriaceous or membranaceous; surfaces naked; costa prominent; main veins fine and indistinct to stout and prominent, more or less zigzag; areolae regularly subquadrangular or subhexagonal, with free veinlets. Fertile fronds similar to the barren one or sometimes much shorter and broadly lanceolate. Sori in oblique or subhorizontal, single, parallel, continuous or even much interrupted lines between the main veins. - Several forms united by intermediates.

Forma typica: Rhizome scales acute or acuminate, dull-brown; fronds mostly middle-sized, to $50 \mathrm{~cm}$. long and $10 \mathrm{~cm}$. broad, mostly very narrowly decurrent at the base; fertile fronds as large as the barren ones or nearly so; veins commonly prominent.

Forma regularis: Like the type but the fertile fronds \pm half as large as the barren ones.

Forma selliguea: Like the type but the rhizome scales black or blackish-brown; fronds mostly small, not variegated; veins often hidden.

Forma Backeri: Like forma selliguea but the fronds variegated with silvery-white patches especially when young.

Forma magna: Rhizome scales finely long-acuminate, ferrugineous; 
fronds large, to $65 \mathrm{~cm}$. long and $15 \mathrm{~cm}$, broad, broadly decurrent towards the cuneate or rotundate-cuneate base.

Malaya.

(228) PI. spurian, o. A. . R.

Also in New Guinea.

(228a) Pl. limealifolia, v. A. v. R.; Polypopium linealifolium, Rst., in Nov. Guin., VII, Bot., 728; C. Chr., Ind. Fil., Suppl.

Rhizome creeping, firm, the scales small, yellow-brown, deciduous. Stipes somewhat remote, slender, $\pm 2-3 \mathrm{~cm}$. long, scaly when young. Fronds linear, $\pm 15-20 \mathrm{~cm}$. long, 5-10 mm. broad, obtuse, irregulary repand, subundulate or crenate, narrowed gradually towards the base. Texture thin; under surface copiously short-hairy; costa prominent; veins fine but distinct; areolae irregular, in 2--3 rows on each side, with few free veinlets. Sori linear, remote, oblique, reaching nearly from the costa to $1 / 2$-way the edge.

New Guinea.

\section{(229) Pl. pedunculata, $\boldsymbol{c}$ A. $\boldsymbol{v}, \boldsymbol{R}$.}

Specimens occurring in the Buitenzorg Herbarium have the fronds very thin.

(229a) Pl. Ioxogrammoides, ש. A. v. R.; Polypodium loxogrammoides, Copel., in Philipp. Journ., VIIC, 65; C. Chr., Ind. Fil., Suppl.

Rhizome clothed with grey-brown scales especially towards the extremity. Fronds $\pm 5-8 \mathrm{~cm}$. apart, sessile, oblanceolate, acuminate, entire. Texture coriaceous; surfaces naked; costa keeled; veins nearly hidden.

Borneo.

(230) Pl. Elmeri, v. A. v. R.; - var. separata.

Barren fronds coriaceous, exceedingly rigid.

(231 a) Pl. Feei, v. A. v. R.; - var. vulcanica; - var. Elmeri, v. A. v. R., in Bull. Btz., 1911, I, 12.

Var. caudiformis: Omit this variety, it being a distinct species (Pl. caudiformis $v, A, v . R$ ).

Var. Elmeri: Fertile fronds long-acuminate-caudate; sori interrupted, round or oblong. - Mindanao. 
(231b) PI. calophlebia, v. A. v. R.

(232) Pl. heterdearpa, v. A. v. R.; - var. interrupta.

A very variably species, with the rhizome scales not rarely hair-like, the fronds often much smaller, varying from ovate with a rounded base to lanceolate with or cuneate or even decurrent base.

Var. abbreviata: Omit this, it being a distinct species (Pl. subcaudiformis $v$. A. v. R).

Malaya.

(233) PI. elliptica, v. A. v. R.

(233a) PI. flexiloba, v. A. v. R.; Polypodium flexilobum, Christ, in Bull. Ac. Int. Bot., XI, 107; C. Chr.; Ind. Fil.; Selliguea elliptica, Bedd., var. flagellaris, Christ, in Bull. Herb. Boiss., VII, 6;- var. Loheri, Christ, in Bull. Herb. Boiss., 2 e Serie, VI, 992.

Like Pl. elliptica $v$. A. $v$. $R$. but the pinnae linear-lanceolate, longacuminate, the acumen arcuate, $2-3 \mathrm{~cm}$. long, $\pm 1 \frac{1}{2} \mathrm{~mm}$. broad; the bases of the pinnae decurrent so as to form a wing reaching quite to the base of the stipe.

Forma typica. - Luzon; China.

Var. Loheri: Fronds smaller, up to $20 \mathrm{~cm}$. long, to $18 \mathrm{~cm}$. broad; pinnae $\pm 3 \mathrm{~cm}$. broad, decurrent into a very broad wing to the rachis; sori less numerous, short. - Luzon.

(234) Pl. MIaingayi, v. A. v. R.

\section{1b. LECANOPTERIS, HIume.}

Sori round or oblong, placed on marginal, often twisted or inflexed outgrowths (teeth or lobules) of the fertile fronds, superficial or immersed. No indusium.

Rhizome tuberous, inflated, soon cavernous and inhabited by ants (as in Pleopeltis \& Myrmecophila); rhizome scales wanting. Stipes articulate to the rhizome. Fronds deeply pinnatifid or pinnatie, the fertile ones with the segments provided with marginal outgrowths bearing the sori; veins anastomosing irregularly; free included veinlets generally present, spreading in various directions.

Malaya. 
1. Sori immersed in the outgrouths (teeth or lobules).

2. Soriferous outgrowths retroflexed (turned back on the upper surface of the pinnae).

3. Outgrowths not twisted, i. e. with the mouth of the cavity facing upwards.

4. Outgrowths oblong.

5. Texture thick.

5.5. Texture thin.

4.4. Outgrowths semiorbicular.
(1) L. carnosa.

(2) L. incurvata.

3.3. Outgrowths twisted, $i$. e. with the mouth of the cavity facing towards the margin or the apex of the pinna.

(4) L. davallioides.

2.2. Soriferous outgrowths not retroflexed (produced beyond the margin the of the pinnae).

a. Soral cavities occupying the whole of the teeth or lobules, $i$. $e$. extending to the base.

(5) L. Curtisii.

a.a. Soral cavities occupying only the apical portion of the teeth or lobules, i. e. not extending to the base.

b. Outgrowths horizontal.

b.b. Ooutgrowths ascending.

1.x. Sori superficial on the outgronoths (teeth or lobules).
(6) L. philippinensis.

(7) L. deparioides.

(1) L. carnosa, Hu., Flor. Jav., II, tab. XCIV $A$; Diels, in Engl. \& Prantl, Nat Pfl. fam., I , 328, fig. 169; Polypodium Lecanopteris, Mett., in Ann. Mus. Bot. L. B., II, 224; P. carnosum, Christ, in Ann. Btz., XV, $160 ; P$. patelliferum, Burck, in Ann. Btz., IV, 96, tab. VII; - var. pumila: L. pumila, Bl., 1. c., tab. XCIV B.

Rhizome thick, naked, yellowish, forming a semiglobose mass to about $15 \mathrm{~cm}$. broad and $9 \mathrm{~cm}$. high, covered with several conical or semiglobose protuberances, whether or not accompanied by subulate, simple or branched prickles (probably reduced fronds). Stipes on the protuberances, 5-15 cm. long, brown, naked, glossy. Fronds dimorphous, cut down nearly or quite to the costa. Segments many to numerous on each side below the terminal one, $2 \frac{1}{2}-5 \mathrm{~cm}$. long by $1 \frac{1}{2}-2 \mathrm{~cm}$. broad; barren segments oblong, blunt, entire or repand; fertile segments proportionally longer and narrower, lobed, the lobules oblong, oblique, rather remote, obtuse, narrowed at or near the base, retroflexed (turned back 
on the upper surface of the segments). Texture coriaceous; surfaces naked; veins indistinct. Sori on the lobules, round or oblong, deeply immersed and occupying nearly the whole of the lobules, with the mouth of the cavity facing upwards.

Forma typica: Fertile segments lanceolate, acuminate, $\pm 1-2 \mathrm{~cm}$. broad; sori large, $3-6 \mathrm{~mm}$. long.

Var. pumila: Fertile segments linear; blunt, $\pm 1 / 2 \mathrm{~cm}$. broad; sori smaller.

Malayan.

(2?) I. incurvata, Bk., in Ann. of Bot., VIII, 123; Polypodium barisanicum, v. A. v. R., Mal. Ferns, 627.

Stipes short, erect, firm, yellow-grey to brownish. Fronds lanceolateoblong, caudate, pinnate, $25-40 \mathrm{~cm}$. long. Pinnae multijugate, $3-5 \mathrm{~cm}$. long, confluent at the base or connected by a narrow wing; barren pinnae linear-oblong, $1 \frac{1}{2}-2 \mathrm{~cm}$. broad, entire, obtuse; fertile pinnae lanceolate, to $1 \mathrm{~cm}$. broad, deeply crenate (toothed?), the teeth retroflexed (turned back on the upper surface of the pinnae.). Texture thin; under surface glaucescent. Sori on the teeth, immersed, the cavity elongated, boatshaped (with the mouth facing upwards?). - The proper place of this species is uncertain because of incomplete description.

Sumatra.

(3) I. Nieuwenhuisii, Christ, in Ann. Btz., XX, 127, tab. III, fig. 1; Polypodium Nieuwenhuisii, v. A. v. R., Mal. Ferns, 626.

Rhizome thick, naked. Stipes $\pm 4-6 \mathrm{~cm}$. long, firm, naked, stramineous like the costa. Fronds linear-lanceolate, $\pm 40 \mathrm{~cm}$. long by $5 \frac{1}{2} \mathrm{~cm}$. broad, acuminate, narrowed gradually towards the base, the edge deeply incised nearly to the costa. Lobes many on each side below the terminal one, dimorphous; lower lobes barren, oblong, entire; central and higher lobes fertile, sinuate-lobate, to $\pm 3 \mathrm{~cm}$. long by $1 \frac{1}{2}-2$ $\mathrm{cm}$. broad, the lobules semiorbicular, spreading, rather approximate, retroflexed (turned back on the upper surface of the lobes). Texture firm; surfaces naked; costulae and veins visible. Sori large, roundish, deeply immersed and occupying nearly the whole of the lobules, with the mouth of the cavity facing upwards.

Borneo. 
(4) L. davallioides, v. A. v. R., in Bull. Btz., 1916, XXIII, 14; Polypodium deparioides, Christ, p. p.; v. A. v. R., Mal. Ferns, 626; var. macrocarpa, v. A. v. R., l. c.

Stipes naked, pale-brown. Fronds acuminate, very deeply pinnatipartite or pinnate. Pinnae few to many on each side below the terminal one, more or less spreading, obtuse, dimorphous; barren pinnae entire; fertile pinnae linear, to $4-5 \mathrm{~cm}$. long by $\pm 1 / 2 \mathrm{~cm}$. broad, blunt, toothed, the teeth remote, retroflexed (turned back on the upper surface of the pinnae). Texture thin to thick; surfaces naked. Sori deeply immersed and occupying nearly the whole of the teeth, the cavity laterally compressed, twisted, with the mouth facing obliquely towards the margin or the apex of the pinna so as to form a spurious, pseudodavallioid indusium.

Forma typica: Fronds to $35-45 \mathrm{~cm}$. or more long; pinnae many, thick; soral cavities proportionally small, about $2 \mathrm{~mm}$. long by $1 \mathrm{~mm}$. deep. - Karimata Island.

Var. macrocarpa : Fronds smaller; pinnae less numerous; soral cavities proportionally large, about $2-3 \mathrm{~mm}$. long by as deep or nearly so. - Sumatra.

(5) L. Curtisii, Bk., in Journ. of Bot., XIX, 366; Hk., Ic. Pl., XVII, tab. MDCVII; v. A. v. R. in Bull. Btz., 1912, VII, tab. I, fig. 1 a-c; Polypodium naviculare, v. A. v. R., Mal. Ferns, 627.

Rhizome creeping, tortuous, thick, naked, provided with conical protuberances, yellow-brown. Stipes on the protuberances, $5 \mathrm{~cm}$. or more long, pale-brown. Fronds lanceolate, $35-45 \mathrm{~cm}$. long, $5-12 \mathrm{~cm}$. broad, cut down nearly or quite to the rachis. Pinnae about 10-30 pair below the terminal one, obtuse, dimorphous; barren pinnae entire or subsinuate-repand, somewhat narrowed near the base; fertile pinnae linear, spreading, $2 \frac{1}{2}-6 \mathrm{~cm}$. long by $\pm 1 / 2-1 \mathrm{~cm}$. broad, toothed, the teeth remote, oblique, small. Texture papyraceous; surfaces naked, the under one often glaucous; veins visible Sori small, immersed, occupying more than the whole of the teeth, the cavity elongate, boat-shaped, twisted, with the mouth facing obliquely towards the apex or the margin of the pinna.

Sumatra, Lingga, Java, Borneo, Celebes.

(6) E. philippinensis, v. A. v. R., in Bull. Btz., 1911, I, 8; 1912, VII, tab. I, fig. 2 a-c.; L. pumila, Copel. (not. Bl.), in Leafl., III, 848. 
Near L. Curtisii $B k$. but the texture firmer, the soriferous teeth (lobules) distinctly larger, horizontally spreading, subquadrangular when seen from the side, the sori occupying less than the whole of the teeth.

Mindanao, Borneo.

(7) L. deparioides, Bk., in Journ. of Bot., XIX, 366 ; Polypodium deparioides, Christ, Farnkr. d. Erde, 116; v. A. v. R., Mal. Ferns, 626, p. p.; Davallia deparioides, Ces., Fel. di Bor., 13; Cyathea deparioides, Ces., l, c., tab. IV.

Rhizome creeping, tortuous, thick, at length naked, yellowishbrown. Stipes stramineous, naked. Fronds to $65 \mathrm{~cm}$. long, very deeply pinnatipartite in the upper part, pinnate towards the base. Segments numerous, linear, obtuse, dimorphous; barren segments subsinuate-repand to toothed; fertile segments $5 \mathrm{~cm}$. more or less long, $\pm 1 / 2-3 / 4 \mathrm{~cm}$. broad, toothed, the teeth remote, oblique, small. Texture firm; surfaces naked; veins distinct. Sori small, immersed, occupying the upper half of the teeth, pseudo-deparioid (conf. Cesati's drawing), the cavity oval, twisted, with the mouth facing obliquely towards the margin or the apex of the pinna.

Borneo.

(8) L. Maclenyi, Bk., in Becc., Mal., II, 244; Polypodium Macleayi, v. A. v. R., Mal. Ferns, 626.

Near L. deparioides $B k$. but the sori not immersed.

Java.

\section{OYCLOPHORUS, Desvax.}

\section{§ 1. MIPHOBOLUS.}

(2) C. rupestris, C. Chr.

Omit this species, it being not Malayan.

(2a) C. dispar, Christ, in Nov. Guin., VIII, Bot., 155, v. A. v. R.. in Bull. Btz., 1911, I, tab. II, fig. 2-3.

Rhizome wide-creeping, slender, the scales whitish, at length ferrugineous, thin, soon obliterate and erose, subulate-ovate, with a dark-brown centre. Barren fronds short-stalked or subsessile, in 2 opposite rows, 
oblong, $1-2 \mathrm{~cm}$. long, $1 / 2-1 \mathrm{~cm}$. broad, rounded at the apex, cuneate, rounded or cordate at the base. Texture very thick; upper surface soon naked, lower clothed with dense but adpressed, more or less deciduous, moderately woolly, brownish pubescence; costa somewhat prominent beneath, rather sulcate above; veins quite hidden. Fertile fronds linear or linear-lanceolate, $7-15 \mathrm{~cm}$. long, $1 \frac{1}{2}-5 \mathrm{~mm}$. broad, above subconduplicato-canaliculate when dry, narrowed towards the base, subsessile, blunt at the apex, soon naked above, densely clothed beneath with subadpressed, ferrugineous tomentum. Sori rather large, in 1-3 irregular rows on each side of the costa, when young immersed, at length prominent, with the cavities closed by a small, roundish, lid-like, introrse, deciduous lateral outgrowth of leaf-tissue which is covered by a large, globose tuft of densely crowded, very long-stalked, ferrugineous stellate hairs, the tufts $\pm 2-5 \mathrm{~mm}$. diam.

New Guinea.

\section{(3) C. adnascens, Desv.}

Forma pernuda (Bull. Btz., 1912, VII, 10): Fronds entirely naked except among the sori; only the youngest fronds and stipes provided with a fow very remotely scattered stellate hairs. - New Guinea.

(3a) C. Bamileri, Rst., in Fed., Rep., X, 339.

Rhizome wide-creeping, branched; scales narrowly lanceolate, pale, white-cuspidate, brown, rounded and peltate at the base, at length ovate, adpressed, black-brown, brown-margined. Stipes seattered, $2 \frac{1}{2}-3 \frac{1}{2} \mathrm{~cm}$. long, deciduously tomentose, those of the fertile fronds the longest. Fronds dimorphous. Barren fronds elliptical, $\pm 10 \mathrm{~cm}$. long, $\pm 2 \frac{1}{2} \mathrm{~cm}$. broad at the middle, acute at both ends, acuminate, entire, subrevolute at the edge, cuneate at the base. Texture rigidly coriaceous; both surfaces slightly tomentose with scattered, deciduous, whitish stellate hairs, at length nearly naked; costa prominent on both sides; main veins subprominent; veins immersed. Fertile fronds contracted, to $\pm 18 \mathrm{~cm}$. long and $4 \mathrm{~mm}$. broad, with the under surface rather densely tomentose. Sori occupying the whole under surface of the fertile fronds except the very base and apex, when ripe confluent and elevated above the tomentum.

New Guinea. 
(4) C. varius, Gaud.; - var. flabelliformis, v. A. v. R., in Bull. Btz., 1914, XVI, 57.

Var. flabelliformis: Fronds very heteromorphous. Barren fronds of the young plants lanceolate, entire, on stipes to $3 \mathrm{~cm}$. long. Barren fronds of the older plants intermediate in shape between those of the young plants and the fertile fronds. Fertile fronds entire and sterile in the lower part, copiously dichotomous and fertile in the upper part, the branched portion semiorbicular in outline, $7-8 \mathrm{~cm}$. long, $12-14 \mathrm{~cm}$. broad, the segments very conspicuously flabellate-divaricating and imbricating; ultimate lacinulae numerous $(60-80)$, tooth-like or subulate. - Sumatra.

(8) C. nerostiehoides, Pr.; - var. Backeri, v. A. v. R., in Bull. Btz., 1912, VII, 10.

Forma typica: Fronds coriaceous, thick when dry; veins hidden.

Forma carnosa: Fronds fleshy, rather thin when dry; veins visible. Sumatra.

Var. Tackeri: Fronds subpendulous, thick, repeatedly irregularly dichotomous with many $(20-40)$ ultimate laciniae. - Java.

(11a) C. valleculosus, v. A. v. R., in Bull. Btz., 1912, VII, 10.

Rhizome creeping, moderately slender, woody, pale-brown, clothed with crowded, adpressed, peltate, entire or lacerate, roundish or oblong scales dark at the centre, paler at the edge. Stipes scattered, $\pm 71 / 2-15$ cm. long, at length naked, scaly at the base, the scales similar to those of the rhizome. Fronds linear, $\pm 60-120 \mathrm{~cm}$. long, $\pm 22^{1 / 2}-3^{1 / 2} \mathrm{~cm}$. broad, entire, narrowed gradually towards both ends. Texture moderately thin, flaccido-coriaceous, pellucid when seen towards the light; upper surface at length naked, lower clothed with crowded, adpressed, shortbranched, pale stellate hairs; costa prominent beneath; veins distinct when seen towards the light, somewhat prominent above, the main ones slender. Sori roundish, numerous, occupying the upper portion of the frond, rather crowded, crateriform, not imimersed in the tomentum, immersed in the substance of the frond, the cavities arranged in grooves, forming obliquely longitudinal (convergent), rather closely placed, prominent, straight ridges or rows of roundish bubbles on the upper surface of the frond.

Java, Celebes (?). 


\section{§ 2. NIPHOPSIS.}

(24a) C. angustatus, Desv.; Polypodium angustatum, Sw., Schk., Krypt. Gew., I, tab. $8 c$.

(25a) C. pseudo-lingua, v. A. v. R., in Bull. Btz., 1913, XI, 6; C. lingua, Copel. (not Desv.), in Leafl. II, 414.

Rhizome wide-creeping, wiry, the scales imbricate, subulate-lanceolate, peltate, entire or somewhat erose, adpressed, whether or not somewhat crisped towards the apex, brown, or ochraceous when young. Stipes scattered, $1-8 \mathrm{~cm}$. long, deciduously tomentose, those of the fertile fronds the longest. Fronds oblong or linear-oblong, $31 / 2-8 \mathrm{~cm}$. long, $1 / 2-13 / 4$ $\mathrm{cm}$. broad, the fertile ones the longest. the apex blunt or rounded, the base cuneate, not rarely somewhat decurrent. Texture coriaceous; upper surface copiously but not densely tomentose, soon glabrescent, at length naked; under surface densely tomentose; stellate hairs ochraceous or pale-brown, rather adpressed, short-branched; costa prominent beneath; main veins slightly so; areolae hidden, irregularly obliquely quadrangular, with few free veinlets. Sori numerous, crowded, when young hidden in the tomentum, at length prominent, confluent, apparently acrostichoid, occupying the whole under surface of the fertile fronds.

Negros.

(27) C. Sarnsinorum, Christ.

Also in Mindanao, Negros.

\section{(29) C. distochoenrpus, C. Chr.}

Stellate hairs of the under surface rather long-branched.

\section{(30) C. nsterosorus, C. Chr.}

Stellate hairs of the under surface rather long-branched.

(30a) C. Winkleri, Rst., in Fed., Rep., VII, 149.

Rhizome wide-creeping, woody, densely scaly; scales membranaceous, large ( $\pm 2 \mathrm{~cm}$. long), ovate-lanceolate, rufo-ferrugineous, or yellowish when young, fulgent, the base peltate, roundish, the margin fimbriatedentate, the teeth straight or retoflexed, the apex long-acuminate, spreading. Stipes scattered, $\pm 3-5 \mathrm{~cm}$. apart, $\pm 1 \mathrm{~cm}$. long, sulcate 
above, convex beneath, stellato-tomentose, hidden by the rhizome scales. Fronds nearly uniform, straight, linear-lanceolate, to $40 \mathrm{~cm}$. or more long, $\pm 3-5 \mathrm{~cm}$. broad, the base cordate, truncate, rounded or rarely shortly cuneate, the edge entire, subrevolute, palish, the apex rather acute or obtuse; fertile fronds somewhat contracted in the soriferous upper region. Texture chartaceous when dry; upper surface fulgent-tomentose, soon calvescent, the hairs dense, subadpressed; under surface densely tomentose, the hairs pale when young, afterwards dark-brown, looser, long-branched, the branches slender, subflexuose; costa straight, prominent on both sides, naked above; main veins distinct, erecto-patent, straight, forked near the margin; veins prominent beneath, forming. 1 row of $\pm 5-6$ primary areolae between the main veins; venulae simple or forked, free, or anastomosing and forming smaller secondary areolae with free included veinlets. Sori large, semiglobose, 2 in each primary areola, placed in 2 rows between the main veins, $4-5$ in a row; receptacle when dry somewhat elevated and corresponding with a small or dot-like depression on the upper surface; sporangia intermixed with stellate hairs. - Near C. distichocarpus C. Chr. - Living specimens have the receptacle somewhat concave, without corresponding depression on the upper side of the lamina.

Sumatra.

(31a) C. Iancifolius, v. A. v. R., in Bull. Btz., 1916, XXIII, 8.

Rhizome thick, wide-creeping, the scales ovate-lanceolate, pale-fuscous, acute or acuminate, entire, at length oblong and erose with a peltate, black-brown or castaneous centre. Stipes scattered, $\pm 20-25 \mathrm{~cm}$. long, bluntly angled, at length naked. Fronds lanceolate, $\pm 55-65 \mathrm{~cm}$. long by $4 \mathrm{~cm}$. broad below the middle, narrowed gradually to a bluntish apex and a slightly decurrent base, the edge irregularly recurved when dry. Texture flaccido-coriaceous; upper surface naked (glabrescent?); under surface coated with a dense tomentum consisting of pale-rufous wool and crowded short-branched pale-grey-brown stellate hairs intermixed with scattered black-brown or castaneous ones; costa prominent on both sides; main veins slightly visible, oblique; areolae hidden. Sori proportionally small, distant from the margin, in 5-6 oblique rows on each side of the costa, in 4-5 rows between the main veins, when young immersed in the tomentum, in the upper half of the fronds.

Sumatra. 


\section{DRYNARIA, J. Smith.}

\section{§ 1. EUDRYNARIA.}

\section{(1) D. pleuridioides, Pr.}

Also in Sumatra.

(4) D. quercifolia, J. Sm.; Polypodium quercifolium, L., Schk., Krypt. Gew., tab. 13.

\section{§ 2. PORONEMA.}

(6) D. rigidula, Bedd.; - var. Koordersii, v. A. v. R., in Bull. Btz., 1911, I, 6.

Var. Koordersii: Differs from the type in having the fronds much smaller, $\pm 15-25 \mathrm{~cm}$. long, 5-7 cm. broad, the pinnae ascending, $\pm 3-7 \mathrm{~cm}$. long, 4-5 mm. broad, acute to blunt or rounded, one stipes to $10 \mathrm{~cm}$. long; fronds sometimes very short-stalked, with the lower pinnae reduced, broadly adnate to the rachis and the lowest pinnae (or the base of the frond) resembling the cup-leaves (in shape and texture) but much smaller. - Java.

\section{§ 3. SACCOPTERIS.}

(Thayeria).

(7) D. nectarifera, Diels.

Omit this species, it being referred to the genus Thayeria.

(8) D. cornucopia, $v$. A. $v . R$.

Omit this species, it being referred to the genus Thayeria.

(9) D. imvoluta, v. A. v. R.; D. convoluta, v. A. v. R., 1911, I, 6. Also in Java. 


\section{Y3a, THA Y TERA, Copeland.}

Sori round or oblong, on much contracted higher segments of deeply pinnatifid or pinnate fronds. No indusium.

Rhizome tortuose or scandent, woody. Fronds articulate at the base, placed on specialized short branchlets of the rhizome, at least the barren ones induplicate, or convolute at the base so as to form a humus-collecting corniform sack; veins anastomosing copiously; areolae with free veinlets.

Papua, Philippines.

- Fertile fronds stipitate, not humus-collecting at the base.

(1) Th. nectarifera.

- Fertile fronds sessile, humus-collecting at the base. (2) Th. cornucopia.

(1) Th. mectarifer'a, Copel., in Philipp. Journ., IC, Suppl., 166; Polypodium nectariferum, Bk., in Becc., Mal., II, 247, tab. LXV; Drynaria nectarifera, Diels, in Fngl. \& Prantl, Nat. Pfl.fam., I 330 ; C. Chr., Ind. Fil.

Rhizome stout, woody, tortuose, scaly towards the extremity, the scales adpressed, orbicular, peltate. Fronds dimorphous. Barren fronds (cup-leaves) sessile, ovate, pinnatifid, induplicate, the lobes oblong, obtuse. Fertile fronds stipitate, oblong-lanceolate, $45-60 \mathrm{~cm}$. long, simply pinnate. Pinnae numerous, the lower ones adnate, lanceolate, provided beneath with copious dot-like glands, the higher narrowed or contracted, linear, tortuose, soriferous, with the lamina more or less cut away between the sori.

New Guinea.

(2) Th. cornucopia, Copel., in Philipp. Journ., IC, Suppl., 165, tab. XXVIII; VIIC, 41, tab. I; Drynaria cornucopia, v. A. v. R., in Bull. Dép. Agr. I. N., 1908, XXI, 8; C. Chr., Ind. Fil., Suppl.

Rhizome scandent, often descendent, clothed with small, lanceolate, subpeltate, acuminate, adpressed scales. Barren fronds (cup-leaves) sessile, to $50 \mathrm{~cm}$. long, deeply pinnatifid, convolute at the base. Fertile fronds similar to the barren ones but longer, with the higher segments narrowed or contracted, linear, moniliform, soriferous, with the lamina deeply incised between the sori.

Luzon, Mindanao. 


\section{DRYOSTACHYUM, J. Smith.}

Sori large, occupying the veins as well as the parenchyma.

(1) D. splendens, J. Sm.; Aglaomorphà splendens, Copel., in Philipp. Journ., VIC, 141; - var. pilosum; A. pilosa, Copel., 1. c.

Forma typica: Costae, costulae and fertile segments naked.

Var. pilosum: Costae, costulae and fertile segments pilose on both sides.

(2) D. Hieronyml, Braw., in Lautb., Beitr. Flor. Pap., I, 55; Aglaomorpha Hieronymi, Copel., in Philipp. Journ., IX', 9.

Rhizome wide-creeping, clothed with grey-brown, pale-margined, elongated, triangular-cordate, acuminate, peltate scales. Stipes scattered, $\pm 1 \frac{1}{2}-2 \mathrm{~cm}$. long, articulated $\pm 1 / 2 \mathrm{~cm}$. above the base, provided with long, whitish hairs. Fronds lanceolate, $\pm 70-80 \mathrm{~cm}$. long, to $26 \mathrm{~cm}$. broad, deeply pinnatifid, narrowed towards both ends. Segments remote, ascending; barren segments 8-10 on a side, lanceolate-falcate from a dilated base, the central ones the largest, to $17 \mathrm{~cm}$. long, $2 \frac{1}{2} \mathrm{~cm}$. broad, acutely long-acuminate, the edge entire, narrowly recurved; higher segments fertile, 8-9 on a side, linear," ascending, falcate, to $3 \mathrm{~mm}$. broad, connected by a very narrow wing. Texture coriaceous; upper surface naked, lower long-hairy, the hairs whitish; costa more or less hairy, sulcate above. Sori oblong, at length confluent.

New Guinea.

(3) Dovoguineense, Brau., in Lautb., Beitr. Flor. Pap., I, 56, fig. $3 \mathrm{D}$.

Fronds sessile, $\pm 75 \mathrm{~cm}$. long, the sterile lower portion triangularcordate $\pm 50 \mathrm{~cm}$. long, $14 \frac{1}{2} \mathrm{~cm}$. broad at the base, suddenly dilated into a deltoid fertile upper portion $22 \mathrm{~cm}$. long by $23 \mathrm{~cm}$. broad; barren portion incised, i. e. dentate-lobate at the base, deeply pinnatifid upward, the lowest lobes (teeth) deflexed, close, the following horizontal, triangularoblong, 3-4 $4 \frac{1}{2} \mathrm{~cm}$ broad, acute, close or inbricate, the higher linearlanceolate, subspreading, $21 / 2-5 \mathrm{~cm}$. broad, undulate at the edge; fertile portion deeply pinnatifid into \pm 8 linear segments on each side below the terminal one, the lowest the largest, to $\pm 15 \mathrm{~cm}$. long and $1 \mathrm{~cm}$. broad. Texture chartaceous, pellucid; surfaces naked; costa deeply grooved

Ferns and Fern Alijes. 
above, subterete and glabrescent beneath; costulae and main veins conspicuous, prominent, clothed beneath with linear, fimbriate, brown, pale-margined scales. Sori large, round or oval, immersed, not confluent.

New Guinea.

\section{4a. AGIAAMORPHA, schot.}

Like Dryostachyum but the sori rather small, occupying the veins only. Borneo to the Philippines.

- Sori in 1 row on each side of the costa.

(1) A. Meyeniana.

*. Sori in 2 or more rows on each side of the costa.

(2) A. Brooksii.

(1) A. Neyeniama, schott., Bau. \& Hk., Gen. Fil., tab. XCI; Kze, Farnkr., I, tab. LXXXI; Polypodium Meyenianum, Hk. (not. Schott.), Hk. Bk., Syn. Fil., 366; Diels, in Engl. \& Prantl., Nat. Pfl.fam., I ${ }^{4}$, fig. 166 A-C; C. Chr., Ind. Fil.

Rhizome very stout, the scales dense, linear, crisped, bright-ferrugineous, $1-1 \frac{1}{2} \mathrm{~cm}$. long. Fronds $60-100 \mathrm{~cm}$. long, the basal part barren, \pm 15 cm. long, shallowly lobed, the central part $20-30 \mathrm{~cm}$. broad, sterile, cut down nearly to the costa into erecto-patent, linear-oblong, blunt, entire lobes $7-15 \mathrm{~cm}$. long, $1-3 \mathrm{~cm}$. broad, the upper part fertile, pinnate, the pinnae $10-20 \mathrm{~cm}$. long, narrowly linear, with the lamina cut away between the sori, i. $\theta$. consisting only of a firm midrib with a row of smal, nearly semiorbicular lobes on each side, each with a single sorus. Texture coriaceous; surfaces naked; main veins reaching the margin; areolae copious, with free veinlets.

Philippines.

(2) A. Brooksili, Copel., in Philipp. Journ., VIC, 141, tab. XXV; Polypodium Brooksii, C. Chr., Ind. Fil., Suppl.

Near A. Meyeniana Schott but the fronds somewhat longer, with the basal part broader and more deeply lobed, the fertile pinnae broader, the lamina not cut away between the sori, and the sori placed in 2 rows 
between the main veins, each row consisting of $2-4$ free or laterally confluent sori.

Borneo.

\section{DRYMOGLOSSUM, PresI.}

(1a) D. fallax, v. A. v. R., in Philipp. Journ., XId , 111, tab. VI.

Rhizome wide-creeping, slender, wiry, branched, blackish or darkbrown when dry, the scales ovate or lanceolate-subulate, reddish-brown, acuminate, minutely and irregularly denticulate, peltate at the base. .Stipes remote, 2-seriate, articulated above the base, of the barren fronds 2-3 mm., of the fertile fronds to $12 \mathrm{~mm}$. long. Barren fronds broadly oblong or ovate, $1-1 \frac{1 / 2}{\mathrm{~cm}}$. long, $3 / 4-11 / 4 \mathrm{~cm}$. broad, blunt or rounded at the tip, entire, the base broadly cuneate, rotundate-truncate or subcordate and suddenly decurrent so as to form a narrow wing reaching nearly or quite to the base of the stipe. Texture coriaceous; surfaces purveyed with a few scattered, adpressed, deciduous peltate hairs; costa evanishing in the upper part; areolae subhexagonal, oblique, with few excurrent free veinlets. Fertile fronds linear, semiterete, $1 \frac{1 / 2}{2}-4^{1 / 2} \mathrm{em}$. long, $2 \frac{1}{2}-$ $3 \mathrm{~mm}$. broad, deeply and broadly 2-sulcate beneath, the apex bluntish, the sides parallel, entire, the base narrowly cuneate, long-decurrent. Sori in the grooves, continuous, nearer the costa than the margin, filling up the whole under surface except the cuneate base, flanked by rows of long-stalked, pale peitate hairs, the capsules of each sorus separated by a longitudinal row of densely crowded, simple or variously branched, pale paraphyses so as to form 2 parallel series of capsules to a sorus.

Amboina.

(2) D. heterophyllum, C. Chr.; Pteris piloselloides, L., Schk., Krypt. Gew., I, tab. 87.

(5) D. Crassifolium, Brau., in Lautb., Beitr. Flor. Pap., I, 35.

Rhizome wide-creeping, scaly when young; scales elongate-triangular, entire, hair-pointed, at length whitish, deciduous. Stipes $\pm 1 / 2-1 / 2 \mathrm{~cm}$. apart, $\pm 3 \mathrm{~mm}$. long, articulated in the lower half, the upper part when young clothed like the upper surface of the fronds with greyish stellate hairs. Barren fronds ovate, $\pm 3-3^{1 / 2} \mathrm{~cm}$. long and $1^{1 / 1}-2 \mathrm{~cm}$. broad, 
bluntish, entire or slightly wavy. Texture coriaceous; costa distinct except in the upper $1 / 4$; veins hidden. Fertile fronds linear, $\pm 13 / 4-21 / 2$ $\mathrm{cm}$. long and $1 / 3 \mathrm{~cm}$. broad, obtuse, entire, cuneate at the base. Sori broad, occupying the whole under surface of the fertile fronds.

New Guinea.

\section{5a. PALTONIUM, Prest.}

Sori long, linear, 1 on each side of the costa, parallel to the margin, marginal or intramarginal. Receptacle thickened. No indusium.

Stipes articulate to the rhizome. Fronds simple, uniform, at best somewhat contracted in the fertile region; veins anastomosing. Pr., Tent. Pterid., tab. X, fig. 3 (Pteropsis); Diels, in Engl. \& Prantl, Nat. Pfl.fam., $I^{4}$, fig. $161 E$ (Heteropteris).

America, Papua, China.

- Areolae without free veinlets.

(1) P. vittariiforme.

* Areolae with included free veinlets.

(2) P. novoguineensis.

(1) P. vittariiforme, Rst., in Fed., Rep., X, 341.

Stipes 7-8 cm. long, flattened, narrowly marginate, naked. Fronds linear-lanceolate, $\pm 45 \mathrm{~cm}$. long, nearly $1 \mathrm{~cm}$. broad, narrowed gradually at both ends, the apex narrowly linear, the edge entire, involute in the upper part, the base decurrent. Texture coriaceous; surfaces naked; midrib flattened but prominent on both sides; veins subconspicuous, forming 1-3 rows of hexagonal areoles on each side of the costa, without veinlets. Sori long, linear, submarginal, continuous, occupying the upper part of the frond except the linear apex; paraphyses present, piliform, hardly thickened at the apex.

New Guinea.

(2) P. novoguineense, Rst., in Nov. Guin., VIII, Bot., 729.

Rhizome wide-creeping, slender, sparingly provided with lanceolate, 
obtuse, entire, hyaline scales. Stipes scattered, $\pm 2-9 \mathrm{~cm}$. long, naked or sparingly scaly, stramineous. Fronds linear-lanceolate, $\pm 15 \mathrm{~cm}$. long and $1 \mathrm{~cm}$. broad, entire, narrowed gradually towards the acuminate base and apex. Texture subcoriaceous; surfaces naked, costa somewhat prominent on both sides; areolae longitudinally oblong, in 2-3 rows on each side of the costa, with included free veinlets. Sori long, continuous, submarginal, occupying the upper part of the frond, not reaching the apex; paraphyses linear, not thickened at the apex.

New Guinea.

\section{CHIRISTOPTERIS, Copeland.}

C. sagitta, Copel. is construed as including 2 forms: C. sagitta Copel. and C. Copelandi Christ.

\section{(1) C. sngitta, Copel.}

Barren fronds to $20 \mathrm{~cm}$. each way, rigidly coriaceous.

(2) C. Cupelandi, Cherist, in Bull. Herb. Boiss., $2 \theta$ Sér., VI, 990. Near C. sagitta Copel. - Barren fronds smaller, less firm. Philippines.

\section{PI,ATYCERIUM, Desvax.}

\section{$\S 1$. EUPLATYCERIUM.}

(3)' P. Wilhelminae Teginae, v. A. v. R.; Wigm. Jr., in Teysm., 1910, 161, with figure.

In fructiferous young plants only the spreading outer halfs of the fertile fronds are soriferous, with the horns (which are normally simple in the adult plants) not rarely elongated and slightly dichotomously compound; the pendulous inner halfs then are sterile, with the sinus between the primary fork-branches whether or not provided with a more or less produced central lobe which may grow out to a branch resembling the lateral primary branches, so that the pendulous inner halfs become apparently trichotomous.

Aru Islands, New Guinea (? t. Copland King). 
(5) P. sumbawense, Cherist; Ann. Btz., 2e Sér., Suppl. III, 8, tab. I.

This is, I think, only a more copiously divided form of P. Willinckii Moore, not a distinct species.

(6) W. Wilclinkii, Moore.; Wigm. Jr., in Teysm., 1910, 156, fig. $1-2$.

Basal fronds 2 or more, convex, entire, sinuate or the upper part irregularly incised, afterwards brown. Fertile fronds mostly 4-7, clustered, irregularly dichotomous with about 9-15 ultimate segments; smallest fronds the least divided, cuneate at the base, rather nutant, resembling those of $\mathrm{P}$. bifurcatum C. Chr.; largest fronds the most divided, to about $60-90 \mathrm{~cm}$. long, very narrowly cuneate (sublinear) below the branching, pendulous or nearly so, agreeing nearly with the diagnosis of, and resembling the table mentioned under, P. sumbawense Christ; under surface tomentose with persistent, whitish, densely crowded, adpressed pubescence of stellate hairs. - The description is taken from specimens cultivated in the Buitenzorg Gardens, which do not agree exactly with Wigman's figures.

Java.

\section{§ 2. SCUTIGERA.}

(8) P. Coronarium, Desv.

Omit the variety cucullatum, it being a distinct species. - See No. 9.

(9) P. Rilleyi, Christ, in Ann. Btz., 20 Sér., Suppl. III, 8, tab. II; P. biforme, Bl., var. erecta, Ridl., in Journ. Str. Br. R. A. Soc., L, 56; P. coronarium, Desv., var. cucullatum, v. A. v. R., in Bull. Dép. Agr. I. N., 1908, XVHI, 25.

Near P. coronarium Desv., but much smaller. Fertile fronds distinctly stalked, stiffly erect, up to $30 \mathrm{~cm}$. each way; ultimate segments cuneate, dilated towards the obliquely rotundate-truncate and more or less emarginate apex; fertile segment longitudinally oblong, obovate or oval, $5-12^{1 / 2} \mathrm{~cm}$. long, to $8 \mathrm{~cm}$. broad, subcucullate, the edge broadly recurved.

Singapore, Lingga Islands, Borneo. 


\section{ELAPHOGLOSSUM, schot.}

\section{$\S 1$. ACONIOPTERIS.}

\section{(1) E. gorgomeun, Brack.}

Stipes tufted, those of the barren fronds $21 / 2-10 \mathrm{~cm}$. long, those of the fertile fronds longer, to $15 \mathrm{~cm}$. or more long; barren fronds $15-40$ $\mathrm{cm}$. long, $3-8 \mathrm{~cm}$. broad, the vein tips not rarely more or less distinctly united at the inner side of the cartilagineous edge.

North India, Malaya to Polynesia.

(2a) E. Hellwigianum, Rst., in Nov. Guin., VIII, Bot, 731.

Rhizome short-creeping, woody, sparingly provided with blackish or brownish scales. Stipes $1-4 \mathrm{~cm}$. long, slightly deciduously scaly, those of the fertile fronds the longest. Fronds broadly oblong, $1 \frac{1}{2}-3 \mathrm{~cm}$. long, $1-1 \frac{1}{2} \mathrm{~cm}$. broad, blunt, entire, pellucid-margined, cuneate at the base, the fertile ones the smallest. Texture rigidly coriaceons; surfaces provided with scattered, brown or blackish, fimbriate scales, at length naked; veins hidden.

\section{New Guinea.}

\section{(3) E. amgulatum, Moore.}

Rhizome scales ovate to lanceolate, when young pale-yellow-brown, when adult pale-brown; stipes naked or provided with scattered, small, pale-yellow-brown squamules; fronds naked or provided with very minute, scattered, brown, stellate-lacerate squamules.

Also in Luzon.

(3a) G. H๑vogutheense, Rest, in Fed., Rep., X, 341.

Rhizome suberect; scales membranaceous, yellow-brown, broadly lanceolate, shortly acuminate, sparingly fimbriate. Stipes $6-10 \mathrm{~cm}$. long, stramineous, brown at the base, sparingly scaly, soon naked. Fronds elongate-lanceolate, $\pm 25 \mathrm{~cm}$. or more long, $3 \mathrm{~cm}$. broad, narrowed gradually at both ends, the edge entire or subrepand, recurved, pellucid, the base decurrent. Texture chartaceo-coriaceous; both surfaces sparingly scaly, the scales small, brown, lacerate; costa prominent, sulcate above, flattened beneath; veins hardly visible, simple or forked.

New Guinea. 
(3b) See No. $8 a$.

(3c) See No. $4 a$.

(4a) E. decurrens, Moore.

Rhizome scales varying from pale-ferrugineous to castaneous, entire or sparingly fimbriate; fronds not invariably ciliated.

(4a*) F. Elmeri, Copel., in Leafl., III, 849.

Stipes approximate, $\pm 8 \cdots-20 \mathrm{~cm}$. long; those of the fertile fronds the longest, clothed with rather deciduous, membranaceous scales. Barren fronds oblanceolate, $\pm 20 \mathrm{~cm}$. long, $\pm 3 / / 2 \mathrm{~cm}$. broad near the rounded apex, narrowed gradually into the stipe. Texture coriaceous; the edge cartilagineous. Fertile fronds linear-elliptical, $\pm 16 \mathrm{~cm}$. long, $\pm 21 / 2 \mathrm{~cm}$. broad, abruptly shortly decurrent. - Intermediate between E. decurrens Moore and E. luzonicum Copel.

Mindanao.

$\left(4 \alpha^{*} a\right)$ E. Werrillii, Christ, in Philipp. Journ., IIIC, 275,

Rhizome clothed with long, brown, subulate, ciliate scales. Stipes winged, flattened, $\pm 8 \mathrm{~cm}$. long, the wing $\pm 1 / 2 \mathrm{~cm}$. bread, reaching quite to the base. Barren fronds up to $\pm 20 \mathrm{~cm}$. long, $\pm 5 \frac{1}{2} \mathrm{~cm}$. broad, obovate, obtuse, the margin bounded by a pale, thin, membranaceous line. Texture corky-coriaceous; colour ochraceous; upper surface smooth, lower covered with numerous scattered, hairy dots; costa flattened; veins hidden, spreading, reaching the margin. Fertile fronds similar to the barren ones but smaller, and the marginal membrane conspicuously reflexed. Sori pale-brown, not reaching the margin.

Mindoro.

(4b) E. Iuzonicum, Copel.

Also in Negros.

(5a) E. Macgregori, Copel., in Philipp. Journ., XI', 40.

Rhizome thick, creeping, densely clothed with rigid, entire, castaneous, glossy scales. Stipes compact, $1-10 \mathrm{~cm}$. long, those of the barren fronds the shortest, winged, those of the fertile fronds the longest, winged in the upper part only. Barren fronds oblanceolate, $\pm 20-25 \mathrm{~cm}$. long, 
2-3 cm. broad, subacuminate, narrowed gradually at the base, narrowly cartilagineous at the edge. Texture coriaceous; under surface sparingly provided with stellate hairs; costa flattened on both sides; veins oblique, immersed, indistinct. Fertile fronds $\pm 10 \mathrm{~cm}$. long by $2 \frac{1}{2} \mathrm{~cm}$. broad, abruptly cuneate at the base.

\section{Luzon.}

(5b) E. basilanicum, Copel., in Philipp. Journ., XIC, 41.

Near E. decurrens Moore but the scales both on the rhizome and scattered over the nether surface of the same peculiar types, the barren fronds subsessile, oblanceolate, narrower, less coriaceous, rather lightreddish-brown when dry, acute, the under surface moderately densely provided with lacerate scales near the margin and the keeled costa.

Basilan.

\section{(6) E. callifolioan, $\boldsymbol{B r}$.}

All the specimens of this, occurring in the Buitenzorg Herbarium, have the fronds provided with scattered, deciduous, microscopical, stellatefimbriate squamules. Blume's orbicular scales may have been very minute Fungi living on the leaves of various plants.

(6a) W. sorditurum, Christ, in Nov. Guin., VIII, Bot., 156.

Rhizome ascending, clothed with brown, lanceolate, hardly erosefimbriate scales. Stipes approximate, $\pm 10-16 \mathrm{~cm}$. long, those of the fertile fronds the longest, rufo-stramineous, sulcate, clothed witl lanceolatesubulate, fimbriate, brown scales. Fronds elongate, $\pm 15-20 \mathrm{~cm}$. long, $\pm 2-3 \frac{1}{2} \mathrm{~cm}$. broad, long-decurrent upon the stipe, the fertile ones the narrowest but hardly exceeding the barren ones, the apex acute, the margin diaphanous, subrevolute. Texture coriaceous; upper surface naked, lower clothed with scattered, fine, minute, adpressed, fimbriated scales, as is the costa; costa distinct, prominent on both sides; veins spreading, rather hidden, simple, reaching nearly the margin, dilated at the apex.

New Guinea.

(6b) E. permutatum, v. A. v, R., in Bull. Btz., 1914, XVI, 13; - var. mutatum, v. A. v. R., l. c.

Rhizome creeping, the scales brown, lanceolate-subulate, entire, when young pale-brown with a long, crisped, hair-like apex. Stipes scattered, 
$\pm 15-25 \mathrm{em}$. long, those of the fertile fronds the longest, plurisulcate above, sparingly scaly, the scales minute, adpressed, deciduous. Barren fronds lanceolate or oblanceolate, $\pm 15-30 \mathrm{~cm}$. long, $4-8 \mathrm{~cm}$. broad, narrowed gradually towards the acuminate base and apex, the point bluntish, the base decurrent, the edge entire, pale-cartilagineous. Texture coriaceous or subcoriaceous; surfaces provided with numerous scattered, deciduous, minute, irregularly stellate, brown scales; veins fine, numerous, distinct, subhorizontal to spreading, simple or forked. Fertile fronds much smaller than the barren ones.

Forma typica. - Sumatra.

Var. mutatum: Stipes somewhat shorter; barren fronds elongatelanceolate, $3 \frac{1}{2}-4 \frac{1}{2} \mathrm{~cm}$. broad, acuminate, the point acute, the base more or less abruptly decurrent; fertile fronds not much smaller than the barren ones. - Celebes.

(6c) I. Heterolepiam, v. A. v. R., in Bull. Btz., 1914, XVI, 13.

Rhizome short-creeping, the scales castaneous, subfiliform-subulate, deciduously ciliolate. Stipes subapproximate, $\pm 12^{1 / 2}-25 \mathrm{~cm}$. long, deciduously scaly, subglabrescent, the scales peltate, irregularly stellatofimbriate or stellato-ciliate, partly pale-brown partly black-brown. Fronds linear-lanceolate, $\pm 30-45 \mathrm{~cm}$. long, $\pm 1 \frac{1}{2^{3}-2 / 4} \mathrm{~cm}$. broad, acuminate, entire, pale-margined, recurved at the edge when dry, the base cuneate or rotundate-cuneate, not decurrent. Texture more or less coriaceous; surfaces deciduously scaly, finally glabrescent, the scales various, rather long-fimbriate or ciliate, those of the margin ovate, pale-brown, of the upper surface subrotund, decoloured, of the under surface irregularly stellate, brown, of the costa roundish or oblong, the ventral decoloured, the dorsal black-brown; veins fine, moderately distinct, numerous, subhorizontal to spreading, simple or forked. Fertile fronds .......

Celebes.

(7) E. laurifolium Moore, as construed in various handbooks, includes 2 different forms: E. laurifolium Moore and E. commutatum v. A. v. R.

(7a) E. Inurifolium, Moore, Bedd., Ferns S. I., tab. CC; E. latifolium, Bedd., Handb. Ind. Ferns, 416; Acrostichum laurifolium, Thouars, Flor. Trist. d'Ac., 31. 
Differs from E. callifolium $B l$. in having the vein tips thickened so as to form a more or less distinctly elevated ridge at the inner side of the cartilagineous edge.

Also in New Guinea.

(7b) C. Conmantatum, v. A. v. F.; E. laurifolium, Moore, var., C. Chr., Ind. Fil.; Acrostichum contorme, Bl. (not Sw.), Flor. Jav., II, 23, tab. V; A. commutatum, Mett., in Ann. Mus. Bot. L. B., IV, 292.

Differs from E. callifolium $B l$. principally in having the fronds smaller, shorter stalked.

Malayan.

\section{§ 2. EU-ELAPHOGLOSSUM.}

(8a?) E. boltunicum, Rst., in Fed., Rep., XII, 180.

Rhizome wide-creeping, the scales dense, pale-ferrugineous, spreading, lancenlate, shortly acuminate, subciliate. Stipes remote, to $7 \mathrm{~cm}$. long, of the barren fronds very short, of the fertile fronds margined in the upper half, stramineous, sparingly scaly. Barren fronds $\pm 4 \frac{1}{2} \mathrm{~cm}$. long by $3 / 4$ $\mathrm{cm}$. broad, shortly acuminate, revolute, whitish (!) and undulate at the edge, narrowed gradually at the base. Texture subcoriaceous; surfaces provided with minute, lacerate, brown scales; costa subprominent above, hidden beneath; veins immersed. Fertile fronds spathulate, $\pm 3 \mathrm{~cm}$. long by $1 \% \mathrm{~cm}$. broad, dilated in the upper half, long-decurrent at the base.

Newo Guinea.

(9) E. melanostictieum, Moore.

Also in Malacca.

(14) C. Copelandi, Christ.

Also in Negros, New Guinea.

\section{STEENOOHLAENA, J. Smith.}

\section{§ 1. LOMARIOPSIS.}

(3) S. Smithii, v. A. v. R.

Omit this name, it should be S. Raciborskii $C$. Chr. 
(3) S. Tanciborskii, C. Chr., Ind. Fil.; S. Smithii, v. A. v. R. Pinnae plurijugate in the adult plants; veins about $1 \mathrm{~mm}$. apart.

(4) S. palustri̊s, Hedd.; Onoclea scandens, Sw., Schk., Krypt. Gew., I, tab. 106-107.

\section{(4a) S. nreolaris, Copel.}

A plant gathered in New Guinea by Versteeg, determined by Christ as S. palustris Bedd., is probably a form of this; it has the pinnae provided with 2 marginal glands at the base, one on each side.

(5) S. sorbifolia, J. Sm.

Omit this, as being no Malayan species.

(5a) S. Ieptocarpa, Und., in Bull. Tor. Cl., XXXIII, 47; S. sorbifolia, J. Sm., var. spectabilis, v. A. v. R., Mal. Ferns, 720-721; Acrostichum spectabile, Rac., Flor. Btz., I, 54; Lomaria spectabilis, Kze, in Bot. Zeit., 1848, 14; Lomariopsis leptocarpa, Fée, Mém., II, 69, tab. XXIX.

Rhizome high-climbing, stout, angled by the decurrent bases of the stipes, provided with lanceolate, more or less eroso-fimbriate, dark-dirtybrown scales especially at the extremity. Stipes scattered, firm, about $10-30 \mathrm{~cm}$. long, slightly scaly. Barren fronds $30-100 \mathrm{~cm}$. long, $30-60$ cm. broad, pinnate, the rachis often narrowly winged towards the apex. Pinnae distant, shortly petiolate, articulate to the rachis, about $6-30$ on a side, linear-lanceolate, $20-30 \mathrm{~cm}$. long, $1{ }^{1 / 4}-2 \mathrm{~cm}$. broad, the apex gradually acuminate or subcaudate, the edge entire, often irrugularly and narrowly recurved and then apparently repando-crenate, the base cuneateangustate. Texture rather coriaceous; surfaces naked; colour when dry dark-olive-green, when fresh often purplish; veins spreading, $11 / 2-2 \mathrm{~mm}$. apart, simple or forked, connected by a marginal strand. Fertile fronds with the pinnae narrowly linear, as long as in the barren fronds, about 2-3 $\mathrm{mm}$. broad.

Malaya.

(5b) \$. Smithii, Und., in Bull. Torr. Cl., XXXIII, 50; Lomariop. sis Smithii, Fée, Mém., II, 71, tab XXXIII, fig. $2 g$.

Near the preceding but the scales rather rufous, the barren pinnae 
lanceolate, $15--17 \frac{1}{2} \mathrm{~cm}$. long, $3-3 \frac{1}{2} \mathrm{~cm}$. broad, the apex acuminate, repando-crenate, the veins about $1 \frac{1}{2} \mathrm{~mm}$. apart,

Philippines, Borneo.

(5c) Ф. Kingit, Copel., in Philipp. Journ., VIC, 80.

Rhizome thick, unarmed, paleaceous. Stipes not articulated, \pm 20 cm. long, paleaceous, at length glabrescent. Fronds simply pinnate. Barren pinnae multijugate, short-stalked, articulated, $\pm 16 \mathrm{~cm}$. long, 2$21 / 4 \mathrm{~cm}$. broad, acuminate, crenulate, cuneate at the base. Texture coriaceous; surfaces naked; upper surface black-green when dry, lower olivaceous. Fertile pinnae $\pm 20 \mathrm{~cm}$. long, $2 \mathrm{~mm}$. broad, on stalks to $5 \mathrm{~mm}$. Iong.

New Guinea.

(5d) S. alorupta, v. A. v. R., in Bull. Btz., 1915, XX, 24.

Near the preceding but the pinnae to \pm 10 -jugate, proportionally shorter and broader, $\pm 10-15 \mathrm{~cm}$. long by $2 \frac{1}{2}-4^{1 / 2} \mathrm{~cm}$. broad, olivaceous-brown when dry, entire, or repando-crenulate towards the apex, the apex rounded or rotundate-truncate and suddenly shortly subcaudateacuminate, the base cuneate; veins about $1-1 / 4 \mathrm{~mm}$. apart; fertile pinnae to $10 \mathrm{~mm}$. long by $3 \mathrm{~mm}$. broad.

\section{Borneo, Sumatra.}

(5e) See No. 3.

(5f) S. intermedia, Copel., in Philipp. Journ., VIIC, 67.

Rhizome stout, at length spiny by the persistent bases of the moderately dense, black-brown scales. Stipes $\pm 40 \mathrm{~cm}$. long, scaly, the lower scales similar to those of the rhizome. Fronds $60-70 \mathrm{~cm}$. long, pinnate, the rachis scaly. Pinnae \pm 8 on a side, articulate, sessile, $\pm 20-22 \mathrm{~cm}$. long, $4 \frac{1}{2}-5 \frac{1}{2} \mathrm{~cm}$. broad, abruptly shortly caudate, entire, rather obliquely rotundate-truncate at the base. Texture papyraceo-coriaceous; surfaces naked. Fertile fronds with the pinnae $15-20 \mathrm{~cm}$. long, \pm 2 $\mathrm{mm}$. broad, narrowed gradually towards the apex, on stalks $\pm 4-8 \mathrm{~mm}$. long.

\section{New Guinea.}




\section{§ 2. TERATOPHYLLUM.}

(8) S. aculeata, Kze.

According to Christ, the abnormal barren leaves, i. e. the waterleaves of the young plant, vary from simple to copiously divided, and they may even be provided with asplenioid or scolopendrioid pseudo-sori and indusia. - On this subject, however, see Copeland's article on the genus Phyllitis, in Philipp. Journ., VIIIC, 149 etc.

The specimens occurring in the Buitenzorg Herbarium belong to several forms of which the following are readily distinguishable because of the presence of both normal and abnormal barren leaves: S. aculeata Kze and $\mathrm{S}$. gracilis Kze.

(8a) S. Aculleata, Kre; Davallia achilleifolia, Wall., Hk., Spec. Fil., I, tab. LVI D; - var. crassior, v. A. v. R., in Bull. Btz., 1916, XXIII, 20-21; - var. inermis, Karst., in Ann. Btz., XII, tab. XIV-XV, fig. 25-28; Davallia spec., Bedd., Ferns Br. I., II, tab. CCIX.

Fully developed water-leaves with the ultimate segments oblong, cuneate-oblong or obovate, at least not subcapillary; pinnae of normal barren fronds green.

Forma typica: Rhizome aculeate; water-leaves 3-pinnatifid or 3-pinnate, the ultimate segments firm, narrowly cuneate-oblong, mostly rounded at the apex; pinnae of normal barren fronds sessile or short-stalked, naked, rotundate-cuneate at the base. - Trop. Asia.

Var. Crssion: Rhizome aculeate; water-leaves 2-pinnatifid or 2-pinnate, the ultimate segments thick, broadly cuneate-obovate, mostly emarginate at the apex; pinnae of normal barren fronds conspicuously stalked, deciduously minutely fimbriato-squamulose on both sides, at least the lower rotundate or rotundate-subcordate at the base. - Sumatra.

Vax. imermis: Rhizome rather smooth; water-leaves 2-pinnatifid or 2-pinnate, the ultimate segments rather thin, cuneate-oblong, rounded or sub-2-fid at the apex; pinnae of normal barren fronds short-stalked, cuneate or rounded at the base? - Borneo, Batu.

(8b) S. grncillis, Kae, in Bot. Zeit., 1848, 142; Acrostichum gracile, Rac., Flor. Btz., I, 53; Olfersia gracilis, Bl., Flor. Jav., Suppl., tab. XCVI; Lomaria gracitis, Bl., Enum., 205; - var. Williamsi; S. Williamsi, Und., in Bull. Torr. Cl., XXXIII, 41.

Like the preceding but the fully developed water-leaves copiously 
finely dissected, the ultimate segments relatively long and narrow, linear, nearly capillary; pinnae of normal barren fronds red or pink. Rhizome more or less aculeate.

Forma typica: Segments of water-leaves moderately crowded; pinnae of normal barren fronds short-stalked, to $\pm 10 \mathrm{~cm}$. long and $1-1^{1 / 2} \mathrm{~cm}$. broad, subabruptly and rather broadly cuneate or rounded to rotundatetruncate at the base. - Java.

Var. Williamms: Segments of water-leaves lax; pinnae of normal barren leaves $\pm 12-15 \mathrm{~cm}$. long, 11/2-2 cm. broad, distinctly stalked, rather gradually rotundate-cuneate at the base. - Luzon.

\section{POLTBOTRYA, Humb. A Bompl.}

\section{$\S 1$. EGENOLFIA.}

(1) P. nppendiculanta, J. Sm.; - var. subintegra, Bedd., Handb. Ind. Ferns, 427; Ferns Br. I., I, tab. CXI, left-hand top-fig.

Var. subindegra: Pinnae almost entire, of a very dull colour and more coriaceous than in the type, not at all or very slightly auricled at the superior base, and the inferior base rounded and not at all unequal. - Indo-Malaya, China.

Var. Iamiltoniana. - Also in Java (Poelo Panaitan).

\section{§ 2. PSOMIOCARPA.}

(2) P. Nieuwemhuisii, Rac.; v. A. v. R., in Bull. Dép. Agr. I. N., 1909, XXVII, tab. VI; - var. Brooksii, v. A. v. R., in Bull. Btz., 1916, XXIII, 19.

Pinnae when young naked or provided beneath with copious scattered, deciduous, fibril-like scales, not rarely very minutely and deciduously fibrilloso-ciliate at the edge; lobes of barren pinnae separated by acute sinuses in the smailer forms, by broadly rounded sinuses in the larger forms.

Forma typica. - Borneo.

War. Hroksil: Fronds broader; pinnae broader, the lower not abbreviated, with the largest lobes to $1 \mathrm{~cm}$. broad, coarsely toothed or shallowly lobed; costae and costulae beneath long-fibrillose-setose, the fibrils articulated; veins simple or forked in the smaller lobes, once to 
twice forked or sparingly pinnate in the larger lobes; veinlets very oblique, rather parallel to the veins. - Sumatra.

\section{§ 3. ARTHROBOTRYA.}

(5) P. articulata, J. Sm.

Omit this, it being referred to Lomagramma.

\section{S'TENOSEMTA, Presl.}

(1) S. aurita, Pr.

Var. minor. - Also in Sumatra.

(2) S. pinnaia, Copel.; - var. edentula, v. A. v. R., in Bull. Btz., 1916, XXIII, 21.

Var. edientula: Barren fronds smaller, to $20 \mathrm{~cm}$. each way, herbaceous, with the lobes entire. -- Sumatra.

\section{HYMENOLEPIS, Kaulfuss.}

(1) HI. rigidissima, Christ.

Also in New Guinea.

(2) I. spicata, Pr.; H. ophioglossoides, Klf., Kze, Farnkr., I, tab. XLVII, fig. 1 ; H. revoluta, Bl., Kze., l. c., fig. 2; Gymnopteris spicata, Pr., Ridl., in Journ. Str. Br. R. A. Soc., 1908, so, 54 ; - var. squamulifera, v. A. v. R., in Bull. Btz.; 1912, VII, 19; - var. graminifolia, Rst., in Fed., Rep., XII, 530; - var. novoguineensis, Rst., in Hedwi., LVI, 353 ; - var. costulata, v. A. v. R., 1. c.

Forma Schneideri (Acrostichum spicatum, L., var. Schneideri, Mans. Bail., in Comp. Cat., 649, 849, fig. 613): Fronds sometimes once or twice forked in the upper part and then bearing 2-4 fertile spikes, 1 on each lacinia.

Forma minima: Fronds very small, to about $7 \mathrm{~cm}$. long, $3-4 \mathrm{~mm}$. broad; spikes relatively large, as broad as the lamina.

Forma longipaleacea: Rhizome scales elongate-subulate, finely longacuminate, ciliate-denticulate. 
Var. squamulifern: Like forma longipaleacea but the surfaces dotted with many scattered, very minute, more or less deciduous, roundish or oblong, denticulate, black squamules; fronds $3-10 \mathrm{~mm}$. broad. New Guinea.

Var. graminifolia: Rhizome scales ovate-lanceolate, ciliate; fronds about $20 \mathrm{~cm}$. long, $4 \mathrm{~mm}$. broad. - New Guinea.

Var. novoguineensis: Rhizome scales ovate-lanceolate, toothed ; fronds coriaceous, $10-50 \mathrm{~cm}$. long, $1-2 \mathrm{~cm}$. broad; spikes $1-20 \mathrm{~cm}$. long, with the lower part of the edge not covering the sori; capsules when young protected by rounded, toothed, membranaceous squamules, of which the lower are rather persistent. - Nero Guinea.

Var. costulata: Main veins present, prominent when dry, erecto. patent, once or twice forked, not reaching the margin. - Sumatra.

(5) H. platyrhynchos, Kre ; -- var. glauca, Copel., in Leafl., III, 847 .

Var. glamea: Fronds bluish-glaucous everywhere. - Mindanao.

\section{ACIROS'TIOHUM, tinné.}

A. a ureum, L.; Schk., Krypt. Gew., I, tah. 1b; -- var. corallina, Rst., in Fed., Rep., X, 342.

War. Corallima: Fronds smaller, to $25 \mathrm{~cm}$. long; pinnae paucijugate, the highest connected with the terminal one. - New Guinea.

\section{PHOTINOPTERIS, J. Smith.}

(1) Ph. drynarioides, Bedd.; Merinthosorus drynarioides, Copel., in Philipp. Journ., VIC, 92.

\section{CHEIROPLEURIA, Prest.}

Ch. bicuspis, Pr.; Chrysodium bicuspe, Ridl., in Journ. Str. Br. R. A. Soc., $1908, \mathbf{5 0}, 55$.

Also in Malacca.

Ferns and Fern Aluies. 


\section{6a. LEPTOOHILUS, Kantfuss.}

\section{\& 1. POECILOPTERIS.}

\section{(3) L. decurrems, $\boldsymbol{B t}$.}

Omit the variety rasamalae, which is only an undivided form of $\mathrm{L}$. diversifolius $C$. $C h r$.

(3a) L. ovatus, Copel., in Philipp. Journ., IX', 229.

Like L. decurrens $B l$. but the rhizome scandent, the fertile fronds ovate, hardly $6 \mathrm{~cm}$. long by $2 \frac{1}{2} \mathrm{~cm}$. broad.

Sumatra.

(5) L. latifolius, C. Chr.

Omit this, it being referred to Hemigramma.

(7) L. zeylanicas, C. Chr.; Acrostichum quercifolium, Retz, Schk., Krypt. Gew., I, tab. 3.

(8) L. inconstans, C. Chr.

Omit this, it being a form of L. heteroclitus C. Chr .

(10a) 直. herermeliutus, C. Cher.s - var. inconstans, Christ, in Philipp. Journ., IIC, 160; L. inconstans, C. Chr., Ind. Fil.; Gymnopteris inconstans, Copel., 'Polypod. Philipp., 43.

Var. Axwortlayi. - Also in Negros.

War. inconstams: Fronds reduced; lateral pinnae 2-6-jugate, obovate, rarely orbicular or lanceolate, obtuse, entire or serrate, \pm decurrent; areolae few; lowest fertile pinnulae orbicular or oblong, 1-4 mm. long. - Luzon.

(10c?) L. ร1ำfollus, Rest., in Med. R. H. L., 1912, 14, 32.

Stipes to $\pm 35 \mathrm{~cm}$. long, those of the fertile fronds the longest, yellowish, the base brownish, provided with scattered, brown, lanceolate scales, the upper part shortly tomentose like the rachis. Fronds pinnate, roundish-deltoid, cordate-truncate at the base, the barren ones $\pm 32 \mathrm{~cm}$. long including the stipe, $\pm 27 \mathrm{~cm}$. broad. Pinnae \pm 3 on each side below the terminal one, the lateral ones opposite; barren pinnae obovate- 
oblong, shortly acuminate, the terminal one $\pm 16 \mathrm{~cm}$. long and $31 / 2 \mathrm{~cm}$. broad, the following much ascending, simple, entire, subsessile, the lowest horizontal, deeply forked, short-stalked. Texture membranaceo-herbaceous; colour yellow-green when dry; surfaces naked except on the costae above; costae distinctly prominent beneath, less so above; main veins oblique, straight, reaching nearly the margin; areolao numerous, irregular, with free veinlets. Fertile pinnae narrowly contracted, circinato-flexuose.

Lombok Island.

(11) L. Hiversifolius, C. Chr.; Acrostichum variable, Hk., var. Rasamalae, Rac., Flor. Btz., I, 50.

\section{(12) C. Dreslianus, C. Chr.}

Also in Singapore.

\section{(15) C. vine日s, C. Chr.}

Rhizome thick, short-creeping. Stipes $\pm 10-20 \mathrm{~cm}$. long, furnished with a few deciduous scales, as is the rachis. Fronds $\pm 30-60 \mathrm{~cm}$. long, pinnate; rachis not rarely winged. Pinnae 10-30 on a side, sessile or short-stalked, elongate-lanceolate, to $21 / 2 \mathrm{~cm}$. broad, acute or acuminate, entire, crenate, repand, serrated or lobed to $1 / 3$-way down, with the segments entire, crenated or serrated, the base often more or less unequal-sided; terminal pinna often much elongated and proliferous. Texture rather herbaceous; surfaces naked; costae prominent; main veins distinct to $\pm 2 / 3$ of the way to the margin; areolae broad, in $3-4$ rows, the costal ones without veinlets, the others generally with 1 to several irregularly disposed, free or connected excurrent veinlets. Fertile pinnae much contracted, entire to lobed according to the form of the sterile ones. - Very variable.

Malacca, Java, Celebes, Philippines; Burmah, Br. India, Ceylon.

(16a) D. cuspiotatus, C. Cher.; - var. marginalis, Rst., in Fed, Rep., IX, 426.

Var. margimalis: Fertile pinnae numerous, repand to lobed to $1 / 2$-way down to the costa, with the sori confined to a broad marginal line. - New Guinea. 
(17) I. Zollingeri, Fée.

Perhaps a firmer and more copiously pinnate form of L. diversifolius C. Chr. only.

(18) L. sealpturatus, C. Chr.

Also in Malacca.

\section{§2. CHRYSODIUM.}

(19b) H. rivalianus, Christ; L. normalis, Copel., C. Chr., Ind. Fil., Suppl., p. p.

(21c) H. sumatranus, v. A. v. R., in Bull. Btz., 1916, XXIII, 15, tab. II, fig. $1 a-b$.

Rhizome creeping, the scales fuscous, crisped, subdenticulate. Stipes more or less distant, erect, slender, $3-15 \mathrm{~cm}$. long, provided with scattered, deciduous squamules. Barren fronds subulate-lanceolate, \pm $14-15 \mathrm{~cm}$. long by $3 / 4-1 \mathrm{~cm}$. broad, subentire to obliquely subsinuatedenticulate, narrowed very gradually towards the long acute apex, sometimes proliferous near the tip, the base equally or obliquely cuneate. Texture papyraceous; surfaces naked; main veins oblique, indistinct, often hardly detectable; areolae irregular; no free veinlets. Fertile fronds much smaller, 6-7 cm. long, $4-5 \mathrm{~mm}$. broad, less acute, on the longer stipes.

Sumatra.

(22) L. In neeolatus, Fee; - var. normalis; L. normalis, Copel., C. Chr., Ind. Fil., Suppl., p. p.

\section{§. LOMAGRAMMA.}

Omit this section, it being referred to the genus Lomagramma.

\section{6̈c. LOMAGRAMMA, J. Smith.}

Sporangia more or less densely crowded over the under surface of 
the contracted segments of fertile fronds. Paraphyses wanting. Spores oblong or bean-shaped (2-lateral).

Rhizome wide-scandent over trees. Stipes not articulate to the rhizome. Fronds dimorphous, pinnate or 2-pinnate; pinnae articulate to the rachis; no main veins; veins free, or anastomosing copiously and forming hexagonal areolae without free veinlets.

Assam, Malaya, Polynesia.

1. Veins free.

(1) L. articulata.

(2) L. bipinnata.

1.1. Veins anastomosing.

2. Leaflets serrate or toothed.

(3) L. lomarioides.

2.2. Leaflets entire or crenate, at best somewhat toothed towards the apex.

3. Main rachis winged towards the apex.

1. Leaflets thin, if firmer, then reddish when dry.

(4) L. pteroides.

4.4. Leaflets subcoriaceous, not reddish when dry.

5. Veins beneath reddish when dry. (5) L. Brooksii. 5.5. Veins beneath not reddish when dry.

(6) L. abscondita.

3.2. Main rachis not winged.

(7) L. perakensis.

(1) L. artieulata, Copel., in Philipp. Journ., IIIC, 32; C. Chr., Ind. Fil., Suppl.; Acrostichum articulatum, Hk., Hk. Bk., Syn. Fil., 413; Polybotrya articulata, J. Sm., Copel., Polypod. Philipp., 40; Christ, Farnkr. d. Erde, fig. 101; C. Chr., Ind. Fil.

Rhizome woody, wide-creeping, naked. Stipes scattered, $\pm 30 \mathrm{~cm}$. long, firm, slichtly scaly. Barren fronds ovate-oblong, 30-80 cm. long, 20-30 cm. broad, 2-pinnate. Pinnae lanceolate, stalked, spreading, rather remote, articulate to the rachis. Pinnulae rhomboidal, articulate, unequalsided, $\pm 1-1 \frac{1}{2} \mathrm{em}$. long, $\pm 1 / 2-1 \mathrm{~cm}$. broad, blunt, erenate or toothed, the upper base truncate, often auricled, the lower base cuneate. Texture herbaceeus; costae and veins distinct, more or less scaly. Fertile pinnulae contracted, shortly linear, $\pm 3 / 4 \mathrm{~cm}$. long, with the sporangia acrostichoid.

Celebes, Philippines; Society Islands. 
(2) 耳. Dipinnata, Copel., in Philipp. Journ., XIC 41.

Barren fronds ovate, $\pm 40 \mathrm{~cm}$. long, 2-pinnate, the rachis castaneostramineous, very minutely and sparingly paleaceous, glabrescent. Pinnae lanceolate. Pinnulae conspicuously auriculate, the lower base cut away, the portion above the auricle lanceolate, acuminate, serrate. Texture herbaceous; surfaces naked; veins free, simple. Fertile pinnulae moderately contracted, with the higher sporangia acrostichoid, the lower often forming sori on the apices of the veins. - Aside from the incomplete dimorphism, this is distinguished from L. articulata Copel., most evidently by the much narrower pinnulae.

Samar (Philippines).

(3) I. Iomerniuides, „. Sm., Bedd., Handb. Ind. Ferns, Suppl., 106; C. Chr., Ind. Fil., Suppl.; Leptochitus lomarioides, Bl., Enum., 206; C. Chr., Ind. Fil.; Gymnopteris lomarioides, Christ, in Bull. Herb. Boiss., 20 Sér., I, 456; Acrostichum lomarioides, Christ, in Ann. Btz., XV, 179; A. Blumeanum, Hk., Rac., Flor. Btz., I, 55, p.p.

Stipes 15-30 cm. long, deciduously scaly. Barren fronds 30-100 cm. long. Pinnae numerous, sessile, simple, rather falcate, $\pm 6-20$ $\mathrm{cm}$. long, $1 \frac{1}{2}-2 \frac{1}{2} \mathrm{~cm}$. broad, the base generally truncate-rotundate or rounded, the edge serrate or toothed but more prominently towards the apex, the apex acuminate. Texture thin, transparent; colour not reddish; rachis and costae more or less scaly beneath, the former narrowly winged particularly towards the apex; veins distinct and more or less prominent, costal areolae rather large. Fertile fronds with the pinnae to $\pm 6 \mathrm{~mm}$. broad, soriferous over the whole under surface, but sometimes only partly contracted and soriferous.

Assam across Malaya to Polynesia.

(4) L. pteroides, J. Sm., in Journ., of Bot., III, 402; Bau. \& Hk., Gen. Fil., tab. XCVIII; L. lomarioides, J. Sm., var., C. Chr., Ind. Fil.; Acrostichum Blumeanum, Hk., Rac., Flor. Btz., I, 55, p. p.; - var. negrosensis, Copel., in Leafl., II, 393; - var. subcoriacea, Copel., in Philipp. Journ., $\mathrm{II}^{\mathrm{C}}, 32$.

Like L. lomarioides J.Sm. but the pinnae entire or crenate, or more or less strongly crenate-dentate towards the apex. Sori sometimes marginal on more dilated fertile pinnae.

Var. megnosensis: Barren pinnae shorter, less falcate; costa $\theta$ rather naked beneath. 
Var. subcoriacea: Toxture firmer than in the type; colour reddish when dry.

Philippines.

(5) E. Brooksii, Copel., in Philipp. Journ., II', 345.

Rhizome wide-scandent, scaly. Stipes $\pm 4 \mathrm{~cm}$. long, scaly: Barren fronds $1 \mathrm{~m}$. or more long, $\pm 15-30 \mathrm{~cm}$. broad. Pinnae simple, $\pm 7^{1 / 2}-15$ $\mathrm{cm}$. long, $\pm 1_{12}^{\prime} \mathrm{cm}$. broad, the base truncate, the edge subentire, the apex falcate, short-acuminate. Texture subcoriaceous; rachis scaly in the lower part, naked and winged in the upper part; surfaces naked, green; veins immersed, reddish beneath; costal areolae small. Fertile fronds to more than $30 \mathrm{~cm}$. broad; pinnae straight or falcate, $\pm 2-3 \mathrm{~mm}$. broad, the base dilated but not auricled.

Borneo.

(6) L. absconditu, v. A. v. F., in Bull. Btz., 1913, XI, 16; Leptochitus absconditus, v. A. v. R., 1. c.; Acrostichum Blumeanum, Hk., Rac., Flor. Btz., I, 55, p. p.

Near L. Brooksii Copel. but the barren pinnae 5-12\% $\mathrm{cm}$. long, obliquely cuneate-truncate and often subauriculate to 2-auriculate at the base, the veins pale, not reddish beneath; fertile pinnae shorter, sometimes barren and much dilated at the base.

Java.

(7) I. perakensi̊s, Fedd., Handb. Ind. Ferns, Suppl., 107; C. Chr., Ind. Fil., Suppl.; Leptochitus perakensis, C. Chr., Ind. Fil.; Acrostichum Blumeanum, Hk., Rac., Flor. Btz., I, 55, p. p.

Stipes $\pm 30 \mathrm{~cm}$. long, slightly scaly, the scales caducous. Fronds $\pm 90-120 \mathrm{~cm}$. long, very similar to those of L. lomarioides J. Sm. but subcoriaceous in texture, the rachis not winged, the pinnae entire or obscurely crenated, the surfaces quite naked or the costae very slightly scaly, the veins sunk and scarcely visible, the venation closer and the costal areolae smaller; fertile pinnae $1-4 \mathrm{~mm}$. broad.

Malacca, Java. 


\section{OSMUNDACEAE.}

\section{OSMIUNDA, Linné.}

\section{§ 1. PLENASIUM.}

(1) O. javanica, $B l$. is construed as including 3 distinct forms: O. javanica, Bl.; O. banksiifolia, Kuhn; O. bromeliifolia, Copel.

(1a) D. Javamica, $\boldsymbol{B}$.;.; Bedd., Ferns S.I., tab. LXXVII; Kze; Farnkr., II, tab. CXI; C. Chr. Ind. Fil.

Barren pinnae $2-3 \mathrm{~cm}$. broad, acuminate, cuneate at the base, entire, repand or sinuate, on stalks $1 \mathrm{~cm}$. long or longer; veins repeatedly forked.

Malaya.

(1b) b. banksiffolia, Fuhn, in Ann. Mus. Bot. L. B., IV, 299; C. Chr., Ind. Fil.; Nephrodium banksiaefolium, Pr., Rel. Haønk., I, 34.

Near O. javanica $B l$. - Barren pinnae short-stalked, $\pm 2 \mathrm{~cm}$. broad, acuminate, acute at the base, coarsely lobate-serrate, the teeth $\pm 2-6$ mm. deep; veins pinnate, the veinlets often forked.

Moluccas, Celebes, Philippines; South China, Japan, Kamtchatka.

(1c) D. bromeliffolia, Copel., in Philipp. Journ., IIC, 147; C. Chr., Ind. Fil., Suppl.; O. banksiitolia, Kuhn, var., C. Chr., Ind. Fil.; O. Prestiana, J. Sm., Diels, in Engl. \& Prantl, Nat. Pfl.fam., I" fig. 205 A; 0. Zeylanica, Kze, Farnkr., II, tab. CXXII; Nephrodium bromeliaefolium, Pr., Rel. Haenk., I, 33.

Near O. javanica $B l$. - Barren pinnae $\pm 7-9 \mathrm{~mm}$. broad, on stalks $1 \mathrm{~cm}$. long or longer, long-acuminate, decurrent at the base, serrate, the teoth $\pm 1 / 2-1 \mathrm{~mm}$. deep; veins pinnate, the veinlets often simple.

Luzon, Mindoro.

89. LEPTOPTERIS, Presl.

(2) L. alpina, C. Chr.; - var. major, Rst., in Fed., Rep., X, 342.

Var. major: Fronds larger; pinnae broader; lowest ultimate segments forked. - New Guinea. 


\section{MARATTIACEAE.}

\section{O. ANGIOPTERIS, Hoffmann.}

(1) A. Smithii, Rac.

Omit this, as being referred to Macroglossum.

\section{(3a) A. evecta, Hoffm.}

Secondary rachises naked. Pinnulae subrepando-crenate, serrulate towards the apex, the base broadest and shortest on the upper side, longest and narowest on the lower side; recurrent veinlets long.

(3a*) A. ferex, Copel., in Philipp. Journ., VIC, 134, tab. XII $b$.

Stipe and main rachis clothed with strong, black-brown setae $1-1 \frac{1}{2}$ $\mathrm{cm}$. long. Pinnae $\pm 70 \mathrm{~cm}$. long, the rachis provided with smaller setae towards the base. Pinnulae \pm 30 on a side, the lower diminished, the central $\pm 16 \mathrm{~cm}$. long, $\pm 2 \mathrm{~cm}$. broad, minutely denticulate, rather gradually long-acuminate, the acumen slightly serrate, the base as in A. evecta Hoffm. Texture coriaceous; costae prominent on both sides, scaly towards the base beneath; veins conspicuous, pellucid; recurrent veinlets opaque, very long. Sori often contiguous, rather intramarginal, consisting of $\pm 7-9$ capsules.

Borneo.

( $\left.3 a^{*} a\right)$ A. subfurfuracea, v. A. v. H., in Bull. Btz., 1913, XI, 1.

Rachises deciduously furfuraceous with scattered, adpressed, ferrugineous, small, ragged scales and long, fuscous, crisped hairs. Pinnulae numerous, the central ones the largest, linear, $\pm 17 \frac{1}{2}-20 \mathrm{~cm}$. long, $2-21 / 2 \mathrm{~cm}$. broad, acuminate, crenate, serrate towards the apex, the base unequally truncate-rotundate or truncate-cuneate, shortest and broadest on the upper side. Texture thinly coriaceous, rather flaccid; upper surface bright-green (when dry bronce-green or fuscous), lower paler; costae and veins naked or beneath somewhat fimbriato-squamulose; veins nearly horizontal, upcurved, simple or forked, rather dark beneath; more or less pellucid; recurrent veinlets moderately long, impellucid. Sori often contiguous, intramarginal, consisting of $\pm 6-9$ capsules; indusium minute, fimbriate.

Hort. Bog. 


\section{(3b) M. Wiqueliang, de $\mathbf{W}$.}

Edges crenulate or dentate-crenulate, serrulate towards the apex. - Perhaps a form of A. javanica Pr. only.

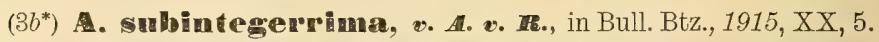

Pinnae $60 \mathrm{~cm}$. more or less long, the rachis terete, naked. Largest pinnulae $12^{1 / 2}-17^{1 / 2} \mathrm{~cm}$. long, $1^{3 / 4}-2 \mathrm{~cm}$. broad, subsessile, subentire, the apex caudate, serrate, the base obliquely rotundate-truncate, or more or less broadly and abruptly cuneate on the upper side and more or less rounded on the lower side. Texture chartaceo-coriaceous, fragile when dry; costa pale, prominent above, less so beneath, naked, or sparingly chaffy at the base; veins distinct, horizontal or nearly so, fuscous, opaque; recurrent veinlets fine, fuscous, opaque. Sori submarginal, contiguous, consisting of $12-15$ capsules.

Borneo.

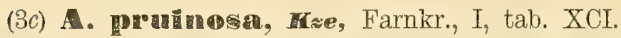

Pinnulae crenate or obtusely serrate, acutely serrate or serrate-dentate towards the apex.

(3c*) A. crinitat, Christ, in Nov. Guin., VIII, Bot., 162.

Pinnulae nearly sessile, broadly linear, \pm 8-12 $\mathrm{cm}$. long, $\pm 1_{1 / 2}^{1 / 2}$ $\mathrm{cm}$. broad, the base equally subcordate; upper surface black-green, lower white-pruinose; veins distinct; sori submarginal, consisting of \pm 8-12 capsules. - Main rachis minutely black-verrucose, setose and scaly; secondary rachises scaly; costae subfurfuraceous beneath.

New Guinea.

(3d) A. crassifolin, de $V x$.

Pinnulae obtusely and broadly serrate-crenate, serrate towards the apex, the base shorter and broader on the upper side, longer and narrower on the lower side.

\section{(3e) A. javamica, Pr.}

Edges copiously and - closely serrulate-crenulate or crenulate, or obtusely denticulate, serrate towards the apex. - Secondary rachises naked.

Also in the Philippines (?). 
(3e*) A. sumatrana, v. A. v. F., in Bull. Btz., 1916, XXIII, 6.

Near A. javanica $\mathrm{Pr}$. but the largest pinnulae to $15 \mathrm{~cm}$. long, $1 \frac{1}{2}-1 \frac{3}{4} \mathrm{~cm}$. broad, entire or very obsoletely remotely crenulate, bluntly serrate at the apex, the veins and veinlets.opaque, sometimes slightly pellucid. - Secondary rachises deciduously squamuloso-furfuraceous.

Sumatra.

$\left(3 e^{*} a\right)$ See No. $3 i$.

$\left(3 e^{*} b\right)$ A. Elnperviana, Copel., in Leafl., V, 1679.

Fronds to $\pm 3 \mathrm{~m}$. long. Pinnae to $80 \mathrm{~cm}$. or more long. Pinnulae $\pm 15 \mathrm{~cm}$. long, $1-13 / 4 \mathrm{~cm}$. broad, subsessile or short-stalked, entire, the base more or less obliquely truncate, subcordate, the apex narrowed gradually into an indistinctly, though sharply, serrulated acumen. Texture subcoriaceous when dry; upper surface black-green, lower paler, provided with scattered, brown, lacerated, caudate squamules especially on the costa; veins opaque; recurrent veinlets opaque. Sori intramarginal, consisting mostly of $9-11$ capsules; indusium wanting (?).

Mindanao.

(3f) A. Hantingians, de $\boldsymbol{V} \mathbf{r}$.

Pinnulae crenate, serrate towards the shortly acuminate apex.

(3g) A. angustifolín, $\mathbb{E} x$.

A variable species. - Pinnulae more or less thinly coriaceous, the largest $10-15 \mathrm{~cm}$. long, $1-1_{14}^{3 / 4} \mathrm{~cm}$. broad, with the edges crenulate, serrate towards the apex, the veins subhorizontal or spreading, blackish or fuscous, impellucid or subpellucid, the recurrent veinlets pellucid.

Malaya to Formosa and Annam.

(3h) A. angustata, Miq.

Pinnulae repando-crenulate, crenate at the apex.

(3i) A. caudata, de $V \mathbf{r}$.

Pinnulae to $1 \frac{1}{4} \mathrm{~cm}$. broad, repando-crenulate to crenulato-denticulate, the caudiform acumen serrate. Secondary rachises sparingly chaffy.

(3j) A. Inypoleucan, de $\boldsymbol{V}$.

Pinnulae serrate. 
(3k) A. approximata, de $\boldsymbol{V} \mathbf{r}$.

Pinnulae crenate in the lower part, serrate in the upper part.

(37) A. aphamosorus, de $\mathbf{V}$.

Pinnulae serrulate-crenulate, narrowly long-acuminate.

(3m) A. cuspialata, de $\boldsymbol{V}$.

Pinnulae obtusely serrate or crenate-serrate.

(3n) A. Teysmannimu, de $\boldsymbol{E} \boldsymbol{r}$.

Pinnulae obtusely crenate in the lower part, serrate towards the acute or subacuminate apex.

\section{(30) A. Willinckii, Miq.}

Pinnulae crenate.

( $3 p$ ) A. Presliana, de $\boldsymbol{T r}$.

Pinnulae toothed.

\section{(3q) A. pallescens, de $\boldsymbol{V} \boldsymbol{r}$.}

Pinnulae broadly and shallowly crenulate, very shortly serrulate towards the apex.

(3r) A. similis, Pr.

Pinnulae serrate-crenate in the lower part, acutely serrate or crenulate-serrulate towards the narrowly long-acuminate apex.

\section{(3s) A. d'Urvilleana, de $\mathrm{Vr}$.}

Pinnulae crenulate, serrate at the apex.

\section{(3t) A. microsporangia (microsporangion), de $\mathbf{V r}$.}

Pinnulae acutely serrate at the apex, beneath very minutely pilose with scattered, caducous hairs; costa beneath deciduously woolly or at length minutely albido-punctulate.

(3u) A. ankolama, de $\boldsymbol{w}$.

Pinnulae nearly equally cuneate-truncate to subcordate at the base, crenulate, the apex serrate. 


\section{(3v) A. nuboinensis, de $\boldsymbol{V}$.}

Pinnulae obtusely toothed, the apex obtusely serrate; no recurrent veinlets.

\section{(3w) A. muricata, Pr.}

Pinnulae crenate, serrate at the apex; recurrent veinlets very short.

\section{(3x) A. crassipes, Waut}

Pinnulae serrulate, shortly acuminate, the apex serrate; no recurrent veinlets.

Also in New Guinea.

\section{(3z) A. Uncimata, de $\mathbf{V r}$.}

Pinnulae crenulate or serrulate-crenulate, the apex serrate or acutely short-toothed; no recurrent veinlets.

(3z*) A. IBrooksii, Copel., in Philipp. Journ., VIC, 133, tab. XII a; $\mathrm{X}^{\mathrm{C}}, 145$, tab. I.

Rachises terete, naked. Pinnae about $50 \mathrm{~cm}$. long. Largest pinnulae about $20 \mathrm{~cm}$. long and $2 \mathrm{~cm}$. broad, petiolate, the higher unequally rotundate-truncate at the base, subentire, serrate at the caudate apex, the acumen $1-1 \frac{1}{2} \mathrm{~cm}$. long; costa depressed above, prominent beneath; veins moderately conspicuous, opaque; no recurrent veinlets. Sori marginal, consisting of 9-10 capsules; indusium conspicuous. - Young plants with the fronds simply pinnate, yet fructiferous; the first fronds formed, always simple.

Borneo.

(3z*a) A. Lorentzii, Rst., in Nov. Guin., VIII, Bot., 732.

Pinnulae subsessile, linear-lanceolate-oblong, pellucido-punctulate, entire, the apex acuminate, serrulate, the upper base rotundate-truncate or broadly rotundate-cuneate, the lower base somewhat longer, rounded; largest pinnulae about $12 \mathrm{~cm}$. long, $1^{3} / 4 \mathrm{~cm}$. broad; veins fuscous, subpellucid, provided with a few fibril-like scales, as are the rachises and costae; no recurrent veinlets. Sori near the margin, consisting of $5-7$ capsules.

Newo Guinea. 


\section{Oa, MAOROGILOSSUM, Copeland.}

Like Angiopteris but the sporangia more numerous, even to 60 to a sorus, and the fronds simply pinnate.

Malayan.

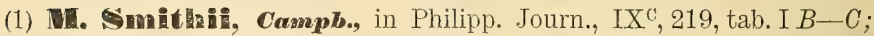
Angiopteris Smithii, Rac., in Bull. Ae. Crac., 1902, 54; C. Chr., Ind. Fil.

Caudex short, $\pm 10 \mathrm{~cm}$. thick. Fronds large, $\pm 1 \frac{1}{2}-3 \mathrm{~m}$. long (incl. the stipe). Pinnae 5 to numerous on a side, short-stalked, articulate, elongate-oblong, $20-40 \mathrm{~cm}$. long, $5-10 \mathrm{~cm}$. broad, the upper part narrowed gradually towards the acuminate apex, the edge entire, the base obliquely or unequally rounded or subcordate. Texture coriaceous, flaccid; upper surface dark-green, naked, lower pale-green, minutely and sparingly scaly, nearly naked; costae prominent on both sides; veins numerous, often forked, uncurved, rather subhorizontal at the base, oblique towards the apex; recurrent veinlets wanting. Sori close, submarginal, the largest consisting of $\pm 20-30$ capsules. - A specimen received from C. J. Brooks differs from that cultivated in the Buitenzorg Gardens, on which Raciborski's diagnosis has been based, in having the veins nearly horizontal and nearly all straight or somewhat decurved, and the capsules less numerous.

Sumatra.

(2) IIIAc, Copel., in Philipp. Journ., IIIC, 343, tab. I; IVC, 9, tab. V; Campb., in Philipp. Journ., IX ${ }^{\mathrm{C}}$, tab. I $A$.

Caudex globose. Fronds suberect, $\pm 3-4 \mathrm{~m}$. long. Pinnae attached to the rachis by a pulvinus, up to $50 \mathrm{~cm}$. long, $\pm 6 \mathrm{~cm}$. broad, abruptly narrowed into a caudate apex, the edge entire, the base rounded. Texture coriaceous; surfaces naked; veins nearly horizontal; spurious veinlets indistinct. Sori borne on the specialized convex margin of the pinnae, the largest consisting of $30-60$ capsules.

Borneo. 


\section{MAREATITIA, swart:}

\section{$\S 1$. EUMARATTIA.}

1. Main rachis rather densely scaly.

- Scales not blackish.

(1) M. vestita.

* Scales blackish.

(1a) M. squamosa.

1.1. Main rachis not densely scaly.

2. Largest lateral leaflets at least about $2 \mathrm{~cm}$. broad when fertile.

a. Largest synangia at least 12-celled.

$\nabla \quad$ Under surface naked. (6) M. ternatea.

$\nabla \nabla$ Under surface more or less squamulose. (6a) M. papuana.

a.a. Largest synangia at best 12-celled.
b. Synangia 6-8.celled.
(6b) M. obesa.

b.๘. Synangia 8-12-celled.

c. Leaflets $2-21 / 2 \mathrm{~cm}$. broad.
d. Under surface not naked.
(7) M. Smithii.

(7a) M. Teysmanniana.

d.d. Under surface naked.

(7b) M. rugulosa.

c.c. Leaflets $3-3^{1} / 2 \mathrm{~cm}$. broad.

(7c) M. grandifolia.

2.2. Largest lateral leaflets at best about $2 \mathrm{~cm}$. broad when fertile.

3. Veins parlly simple partly forked, the stipes neither twberculate nor rugutose.

- Texture herbaceous or membranaceous.

+ Leaflets suddenly acuminate. (4) M. pellucida.

++ Leaflets not suddenly acuminate. (5) M. fraxinea.

$\odot \odot$ Texture coriaceous or chartaceous.

+ Leaflets not caudate. $\quad(5 a)$ M. paleolata.

++ Leaflets caudate. $\quad(5 b)$ M. caudata.

3.3. Veins simple, or the stipes tuberculate or rugulose.

4. Largest synangia at least 12-celled

Leaflets moderately small. $\quad$ (3) M. silvatica.

Leaflets rather large or middle-sized. (6) M. ternatea.

4.1. Largest synangia at best 12-celled.

5. Leaflets beneath not albo-punctulate or verruculose.

○ Rachis tuberculate; leaflets mostly multijugate.

(2) M. sambucina.

O Rachis rugulose, or the leaflets to 5-jugate.

(2a) M. Brooksii. 
5.5. Leaflets beneath albo-punctulate or verruculose.

c. Sori marginal or submarginal.

*. Synangia 4 8-celled.

(2b) M. novoguineensis.

\%. Synangia, at least the largest, 9-12-celled.

(2c) M. andaiensis.

6.6. Sori more remote from the margin.

(2d) M. Kingii.

(1a) DI. squamosn, Christ, in Nov. Guin., VШI, Bot., 163.

Stipes thick, sulcate, castaneous, clothed like the main rachis with copious black setae and ovate, blunt or subulate, crisped, black scales. Fronds large, narrowed towards the base. Pinnae distant, more or less petiolate, up to $\pm 40 \mathrm{~cm}$. long, to $\pm 12 \mathrm{~cm}$. broad, narrowed at the base, the rachis brownish, provided with few scattered, black scales, not winged though somewhat dilated. Pinnulae opposite or alternate, nearly sessile, subremote, $\pm 15-20$ pair below the terminal one, ligulate-oblong; the largest $5-7 \mathrm{~cm}$. long, $\pm 1 \mathrm{~cm}$. broad, the apex acute, the edge serrate, revolute, the upper base somewhat broader than the lower; lowest pinnulae very small. Texture coriaceous; colour black-green above, paler beneath; surfaces naked or nearly so; veins simple, prominent above, immersed beneath. Sori submarginal, numerous, close; synangia $\pm 6-12$ celled, yellow-brown. - See v. A. v. R. in Bull. Btz., 1911, I, 10.

New Guinea.

\section{(2) M. รanbucina, $\boldsymbol{R t}$.}

Leaflets multijugate, rarely to $11 \mathrm{~cm}$. long and $1 \frac{1 / 2}{\mathrm{~cm}}$. broad; veins very rarely forked.

(2a) D. HBrooksili, Copel., in Philipp. Journ., VIIC, 59.

Stipes clothed towards the base with small, castaneous scales, provided in the upper part with rugiform, transverse thickenings, as is the main rachis. Fronds 3-pinnate. Pinnae long-stalked. Pinnulae short-stalked, \pm 3 on a side. Leaflets \pm 5 on a side, sharply serrate, acute or acuminate, broadly cuneate at the base, the lower stalked, the higher the largest, $\pm 5 \mathrm{~cm}$. long, $13 / 4 \mathrm{~cm}$. broad. Texture subcoriaceous; veins 
simple, hyaline. Sori distant from the margin; synangia 3-7-celled; indusium distinct. - See Bull. Btz., 1913, XI, 17.

Borneo, Java (?).

(2b) M. novoguineensis, Rst., in Fed., Rep., X, 342; Hedwi., LVI, 354.

Stipes grey-green or brownish, aculeate with short spines and provided with ferrugineous, fibrillose scales. Fronds large, 2-pinnate. Pinnae nearly horizontal, short-stalked, elongate-oblong, to $\pm 50 \mathrm{~cm}$. long, 17 $\mathrm{cm}$. broad, the rachis narrowly marginate above. Pinnulae numerous, \pm 30 on each side below the terminal one, spreading or the higher suberect, short-stalked, lanceolate, the central ones the largest, nearly 9 $\mathrm{cm}$. long, $1 \frac{1}{2} \mathrm{~cm}$. broad, the base cuneate, the margin broadly and sharply toothed but more conspicuously towards the acuminate apex; lower pinnae conspicuously shorter, higher less so. Texture coriaceous; both surfaces white-punctulate, the lower more distinctly; main and secondary rachises fuscous, naked above, scaly beneath with scattered, linear, fimbriate scales; costae and veins naked above, sparingly scaly beneath; veins simple, oblique. Sori oblong, submarginal; synangia 4-5-celled; indusium fimbriate.

New Guinea.

(2c) M. andaiensis, v. A. v. R., in Bull. Btz., 1916, XXIII, 16.

Pinnae $43 \mathrm{~cm}$. or more long, the rachis fuscous, naked, upward narrowly winged between the pinnulae. Pinnulae sessile, spreading or the higher more ascending, the central ones the largest, lanceolate, $\pm 10 \mathrm{~cm}$. long, to $1 \frac{1}{2} \mathrm{~cm}$. broad, the base abruptly cuneate, the margin repando-subdentate, here and there sparingly serrate-dentate, serrate at the acuminate apex; lower pinnae conspicuously shorter, higher less so. Texture coriaceous; surfaces naked; upper surface dark-olivaceous when dry; under surface paler, albo-punctulate; veins simple, spreading. Sori oblong, submarginal; synangia to 9-12-celled; indusium fimbriate.

New Guinea.

(2d) M. Kingit, Copel., in Philipp. Journ., VIC, 66.

Fronds probably $\pm 1 \mathrm{~m}$. long. Pinnae $20-25 \mathrm{~cm}$. long, the rachis sparingly scaly towards the base, winged towards the apex. Pinnulae sessile or subsessile, lanceolate, the largest $\pm 3 \frac{1}{2}-5 \mathrm{~cm}$. long, \pm

Ferns and Fern Alties. 
9-12 $1 / 2 \mathrm{~mm}$. broad, acuminate, sharply serrate especially towards the apex, the base broadly and obliquely rotundate-cuneate. Texture rigidly coriaceous; under surface albo-punctulate; costae prominent on both sides; veins spreading, simple, deciduously scaly beneath like the costae. Sori nearer the margin than the costa, hardly medial; synangia 4-5-celled; indusium present, fimbriate.

New Guinea.

(3) M. silvatica, $\boldsymbol{H I}$.

Fronds not invariably 3-pinnate. - Too near M. sambucina Bl.

(4) M. pellucida, $\boldsymbol{P r}$.

This is probably only a form of M. fraxinea $\mathrm{Sm}$. with conspicuously falcate-serrate, caudate leaflets (pinnules).

(5) D. fraximea, Sm.; ? M. macrophylla, de $V r$., Mon. Maratt., 3, tab. III, fig. 17.

Various writers have included under this name several related forms. The original plant from Bourbon has 2-pinnate fronds, naked axes, almost sessile pinnules 5-8 cm. long, lanceolate, serrate, acuminate. (Copel. in Philipp. Journ., IV , 10).

(5a) U. paleolara, v. A. . F., in Bull. Btz., 1916, XXIII, 16.

Fronds probably 2-pinnate, the rachises dark-dirty-brown, slightly scaly, the scales deciduous, lanceolate, long-acuminate, erisped, often longitudinally fimbriate, ferrugineous. Pinnae $50 \mathrm{~cm}$. more or less long. Pinnulae sessile, spreading or the lower horizontal or somewhat deflexed, lanceolate, the largest about $12^{1 / 2} \mathrm{~cm}$. long, to about $2 \mathrm{~cm}$. broad near the obliquely rotundate-cuneate base, narrowed gradually towards the acuminate apex, serrate; lower pinnulae conspicuously smaller. Texture coriaceous; upper surface when dry nearly black-olivaceous, under surface paler, minutely albo-verruculose, sparingly squamulose on the costae and veins, the squamules deciduous, fimbriate, crisped, ferrugineous; veins subpellucid, rather spreading, simple, partly forked. Sori remote from the margin, submedial on the veins; largest synangia about 12-celled; indusium fimbriate.

Sumatra. 
(5b) N. Caudata, Copel., in Philipp. Journ., IX ${ }^{\mathrm{C}}, 227$.

Fronds large, the rachis castaneous or black-brown, naked, nearly smooth. Pinnae to $50 \mathrm{~cm}$. long, stalked, the rachis black-brown, smooth. Pinnulae stalked; the higher the largest, to $\pm 15 \mathrm{~cm}$. long, $\pm 1 \frac{1}{4}-1 \frac{1}{\mathrm{~s}}$ cm. broad, caudate, serrate, or entire towards the cuneate base. Texture papyraceous; surfaces naked; veins opaque, mostly simple. Sori distant from the margin; synangia 6-8-celled; indusium black-brown.

Sumatra.

\section{(6) M. ternatea, de $\boldsymbol{r} \mathbf{r}$.}

Pinnulae $1 \frac{1}{2}-2 \frac{1}{2} \mathrm{~cm}$. broad; largest synangia $12-15$-celled.

Omit the information regarding Teysmann's plant.

Also in Java (?).

(6a) N. Dapuana, v. A. v. R., in Bull. Btz., 1916, XXIII, 17.

Fronds probably 2-pinnate, the rashises smooth, apparently naked. Pinnulae to 10 or more on a side, shortly petiolulate, ascending; higher pinnulae largest, linear, $15-20 \mathrm{~cm}$. long, 2-2//4 $\mathrm{cm}$. broad, serrulate, serrate at the gradually and slightly acuminate apex, the base moderately broadly unequally cuneate or rotundate-cuneate; lower pinnulae much shorter, unequally rotundate-truncate or rotundate-cuneate at the base. Texture coriaceous; upper surface when dry fuscous; under surface paler, brown; costae and veins provided beneath with some scattered, deciduous, lanseolate, lacerate-fimbriate, ferrugineous squamules; veins subhorizontal, simple or sometimes apparently forked by their much approximated (confluent?) bases, fuscous, impellucid. Sori more or less remote from the margin, approximate; synangia elongated 12-15-celled; indusium fimbriate.

\section{New Guinea.}

(6b) U. obesa, Christ, in Nov. Guin., VIII, Bot., 163.

Stipes up to $50 \mathrm{~cm}$. or more long, black, provided with a few lanceolate-subulate, black-brown, scattered scales. Fronds large, up to \pm $150 \mathrm{~cm}$. long, the rachis black or dark-castaneous, naked or subfurfuraceosquamulose. Pinnae to $\pm 40 \mathrm{~cm}$. long or longer. Pinnulae in 5 pair below the terminal one, erecto-patent, ovate-oblong, $\pm 10-18 \mathrm{~cm}$. long and $2 \%_{2}=3 \%$ crn. broad, shortly calloso-petiolate, the apex acute, shortacuminate, the margin minutely repando-crenulate, the base unequally 
rotundate-cuneate. Texture firm, flaccid; colour pale-yellow-green, somewhat glossy; costae distinct, deciduously squamulose beneath; veins distinct, subspreading, mostly simple. Sori marginal, close; synangia $\pm 6-8$ celled, yellowish or pale-brown.

New Guinea.

(7a) M. Teysmanniama, v. A. v. R., in Bull. Btz., 1916, XXUI, 18; M. ternatea, de Vr., v. A. v. R., Mal. Ferns, 766, p. p.

Rachises pale-yellow-brown. substramineous, apparently naked. UItimate pinnulae ascending, petiolulate, lanceolate, acuminate, serrulate, serrate at the apx, obliquely rotundate-cuneate at the base, broadest at the upper base; higher (largest?) pinnulae $12-15 \mathrm{~cm}$. long, 2-2\% $\mathrm{cm}$. broad. Texture coriaceous, when dry very fragile and pale-olivaceous on both sides but somewhat darker on the upper side; under surface minutely albo-punctulate, sparingly and deciduously squamulose on the costae and veins; veins subhorizontal, pale, impellueid. Sori somewhat remote from the margin; largest synangia 10-12-celled; indusium fimbriate.

Ternate Island.

(7b) DI. rugulosa, v. A. v. K., in Bull. Btz., 1916, XXIII, 17.

Fronds probably 2-pinnate, the rachises dirty-pale-brown, provided with scattered elevated points or transversely oblong, low thickenings when dry connected by numerous longitudinal, fine, irregular rumples. Pinnulae $5-6$ on a side, stalked, the higher the largest, lanceolate, ascending, $10-15 \mathrm{~cm}$. long, $2-2 \% \mathrm{~cm}$. broad at the middle, acuminate, serrate, obliquely cuneate or rotundate-cuneate at the base. Texture coriaceous, fragile when dry; surfaces naked; upper surface when dry brown or fuscous; under surface pale-brown; veins subhorizontal, simple, partly forked, not pellucid. Sori more or less remote from the margin; largest synangia 8-10-celled; indusium fimbriate.

Borneo.

(7c) DI. grandifolia, Copet., in Philipp. Journ., VIC, 66.

Near M. fraxinea Sm. but the pinnulae larger, the largest more than $20 \mathrm{~cm}$. long and $3 \mathrm{~cm}$. broad, acuminate, slightly acutely serrated, the base unequally rotundate-cuneate, on stalks to $2 \mathrm{~mm}$. long, the stalks subvelutinous, glabrescent. Texture firm-herbaceous; surfaces naked; under 
surface pale; secondary rachises narrowly winged; veins simple, not pellucid. Sori submarginal; synangia 9-12-celled.

New Guinea.

\section{CHRISTENSENIA, Maxon.}

(1) C. Cumingiana, Christ; Copel., in Philipp. Journ., IVC, tab. VIII; C. Cumingii, Copel, in Leafl., III, 797.

Synangia often, though not invariably, in 2 rows between the main veins.

Also in Luzon, Negros.

(2) C. nesculifolia, Max.

Synangia mostly, though not always, scattered irregularly.

\section{OPHIOGLOSSACEAE.}

\section{OPHIOGLOSSUM, tinné.}

\section{§ 1. EU-OPHIOGLOSSUM.}

(1a) D. limeare, schlt. Hrau., in Lautb., Beitr. Flor. Pap., I, 59, fig. $3 \mathrm{~F}$.

Rhizome cylindrical. Whole plant to $5 \mathrm{~cm}$. high, consisting of a single fertile segment without barren blade, the spike dilated, $\pm 1 \mathrm{~cm}$. long, blunt, on a peduncle $\pm 1-1 \frac{1}{2} \mathrm{~mm}$. broad.

New Guinea (Bismarck Islands).

(3) D. inconspieuum, o. A. v. R.; - var. majus; O.gregarium, Christ, in Nov. Guin., VII, Bot., 164; C. Chr., Ind. Fil., Suppl.

(4) D. pumilum, v. A. v. R.

Rhizome short, erect. Whole plant $1-8 \mathrm{~cm}$. high. Fronds $1-3$, sometimes more, the barren segment roundish or oblong, sessile with a cuneate, acuminate, adnate base, placed near the base of the plant, 3-12 (mostly under 10) mm. long, $\pm 3 / 5-4 / 5$ as broad, blunt or minutely 
apiculate. Texture flaccid; costa very slender, disappearing towards the apex; veins fine; marginal cells straight. Fertile spikes $2-15 \mathrm{~mm}$. long, with the peduncle to $\pm 5 \frac{1}{2} \mathrm{~cm}$. long.

Java.

(4a) D. Selhlechteri, Brau., in Lautb., Beitr. Flor. Pap., I, 58, fig. $3 E$.

Rhizome cylindrical. Whole plant $2-5 \frac{1}{2} \mathrm{~cm}$. high. Fronds $1-2$. Barren segment often placed a little above the middle, ovate or cordate from a short, broadly cuneate base, $3-4 \mathrm{~mm}$. long, $2-31 / 2 \mathrm{~mm}$. broad, entire or slightly crenate. Texture fleshy; veins hidden; costa indistinct towards the apex. Fertile spike with the penduncle dilated gradually from the base to the sporangiferous region which is $\pm \mathrm{L}^{3} / \mathrm{m} \mathrm{mm}$. broad.

Newo Guinea.

\section{§ 2. OPHIODERMA.}

(12a) D. Boultomi, Copel., in Journ. Str. Br. R. A. Soc., LXIII, 72. Fronds lanceolate, $25-30 \mathrm{~cm}$. long, $5 \mathrm{~cm}$. broad, narrowed gradually towards both ends, the stipe about as long as the frond, winged. Fertile spike to $10 \mathrm{~cm}$. long, shortly pedunculate.

Borneo.

(12b) See also No. 13.

(13) D. pendulum, $\boldsymbol{L}$.

Stipes commonly flattened when dry, with thin fronds.

A form gathered in Newo Guinea (forma nutans) has the fronds rather short, spreading, falcate (nutant), and a form cultivated in the Buitenzorg Gardens (forma angustata) differs from the type in having the fronds or the fork-branches very narrow, at best $1 \mathrm{~cm}$. broad.

\section{BOTRYCHIUM, Swarts.}

\section{§. PHYLLOTRICHUM.}

(1) IB. daucifolium, Wall.; - var. parvum, v. A. v. R., in Bull. Btz., 1911, I, 3. 
Forma typica. - Br. India across Ceylon to Java and the Philippines. Forma subbasalis (Bull. Btz., 1913, XI, 2, tab. II): Fronds smaller; both barren and fertile segments $\pm 4-5 \mathrm{~cm}$. each way, relatively longstalked, springing nearly from the base of the whole plant, the stipe therefore very short. - Java.

Var. parvaum: Fronds smaller; barren segment $\pm 5 \mathrm{~cm}$. long, $8 \mathrm{~cm}$. broad, 2-pinnate; pinnulae subentire, toothed or slightly incised; fertile segment $4-5 \mathrm{~cm}$. long. - Java.

\section{(2) B. Ianuginosum, Walt.}

Also in Java. 

HYDROPTERIDES. 



\section{SALVINIACEAE.}

\section{7, SALVINIA, Adansos.}

(1) \$. natans, Alt. (not Hoffm.), Flor. pedem., II, 289. 


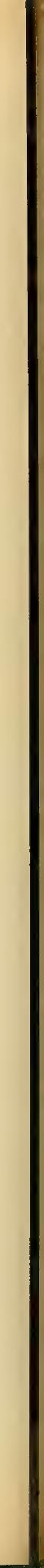




\section{EQUISETINEAE.}





\section{EQUISETACEAE.}

\section{EQUISFT UM, Linné.}

\section{$\S 1$. HIPPOCHAETE.}

(2) E. debile, Rb.; E. virgatum, Bl., Hassk., Plant. Jav. Rar., 1.

(3) E. tenggeremse, Hockr., in Ann. Cons. Gen., XV-XVI, 223.

Stems numerous, erected, rigid, simple (i. e. branched in the subterraneous lower part only), to $60 \mathrm{~cm}$. long, $3 / 4-2 \mathrm{~mm}$. thick, glaucous, smooth, with a very large central hollow; vascular bundles encircled by an own endodermis*); ribs 8-10, convex, narrower than the grooves; grooves provided with series of stomata consisting of 1 line of pores and series of very minute rosulae. Sheaths short, cylindrical, sometimes encircled by a brown ring at the base, the teeth persistent, black, much acuminated, sparingly piloso-denticulate towards the apex, separated from the tube by a black ring; ribs as in E. debile $R b$. Spikes . . . . .

Java.

(*) See Hochreutiner's information, 1. c., 224. 



\section{LYCOPODIINEAE.}





\section{LYOOPODIACEAE.}

\section{0ఖ. LYCOPODIUM, Linné.}

\section{§1. UROSTACHYS.}

(1) L. serratum, Thb., Flor Jap., 341, tab. XXXVIII.

My description is construed as including var. javanicum Hert. in Ann. Cons. Gen., XV-XVI, 227.

(16) L. Iaxum, Pr. (not Spring), Rel. Haenk., 83; Spring, Mon., I, 60 .

Perhaps a form of L. carinatum Desv. only with shorter, rigid leaves probably due to habitat.

(29) H. pinifolium, $\boldsymbol{B}$.; - var. Hochreutineri, Hert., in Ann. Cons. Gen., XV-XVI, 227.

Var. Hochrentineri: Fertile branchlets thicker, to $6 \mathrm{~mm}$. diam. - Java.

(36) I. phlegmaria, $\boldsymbol{L}$.

Vur. Iaxum: $L$. myrtifolium Nees \& Bl. (in Nova Acta, XI, 120, tab. XII, fig. 1. A, a-f) is very probably a young or reduced form of this variety.

\section{§ 2. RHOPALOSTACHYS.}

(42a) L. pumgens, *. *. R., in Bull. Btz., 1915, XX, 26.

Shoots erect, moderately copiously branched, the rachises more or less deciduously pubescent; ultimate branchlets subterete, $\pm 1-5 \mathrm{~cm}$. long, $\pm 2-2 \% 2 \mathrm{~mm}$. diam. including the leaves. Leaves coriaceous, naked, costate; of the principal rachises remote, erect, adpressed, straight, flattened, acutely subulate, sparingly and minutely denticulate, thickened 
at the base; of the ultimate branchlets subdimorphous, crowded, decurrent, to $2 \mathrm{~mm}$. long, acutely acuminate, the ventral ones sublanceolate, suberect, slightly incurved, minutely spinuloso-serrulate, the dorsal and lateral ones subulate, subspreading, strongly incurved, entire or sparingly denticulate, thickened towards the base, somewhat longer than the ventral ones. Spikes solitary and terminal on the branchlets, sessile, often cernuous, cylindrical, $\pm 3-10 \mathrm{~mm}$. long, $\pm 2-3 \mathrm{~mm}$. diam.; sporophylla acuminate from an ovate base, coriaceous, ecostate, eroso-ciliolate.

Borneo, Sumbawa (?).

(44) L. casuarinoides, spring; $L$. leucolepis, Jungh. \& de Vr., in Ned. Kruidk. Arch., 1848, I, 13.

(46) L. Jacobsoniif, v. A. v. R., in Bull. Btz., 1916, XXIII, 22, tab. III-IV.

Main stem erect or more probably scandent, terete, pinnately branched, sparsely leafed. Barren branches copiously dichotomous with leafy, mostly more or less erected rachises and erected ultimate branchlets $\pm 10-20$ $\mathrm{cm}$. long, flattened, $1 \frac{1}{2}-1^{3 / 4} \mathrm{~mm}$. broad at the base. Leaves heteromorphous; leaves of the main stem scattered irregularly, $\pm 1 / 2-3 / 4 \mathrm{~cm}$. long, with a-small, coriaceous, peltate-oblong, keeled portion pale-brown to castaneous when dry, and a flat, white-scariose, more or less deciduous portion at the base and the apex, the basal portion short, more or less deeply longitudinally fimbriate, the apical portion long-subulate, ciliolate-denticulate; lower leaves of the branches similar to those of the main stem, following ones passing gradually into those of the ultimate branchlets; leaves of the branchlets platystichous; lateral leaves opposite, in 2 close planes (apparently 1 plane), isomorphous, imbricate, $\pm 1 / 3-3 / 4 \mathrm{~cm}$. long including the long-decurrent-adnate portion brown when dry, the free portion with a short, thick, convex basal part and a long, erect, subadpressed, subulate, flat, deciduous or persistent, sparingly serrulate-ciliolate, white-scariose apex, the decurrent portions contiguous, separated by a narrow ventral groove, and a broad dorsal groove in which the intermedial leaves are placed, the leaves of both (ventral and dorsal) planes similar but alternate; intermedial leaves remote, in 2 close rows (apparently 1 row), the decurrent portion narrowly cuneate, keel-shaped, the base of the free portion flattened, the apex similar to that of the lateral leaves. Fertile branches copiously divergent-dichotomous, roundish 
in outline, with the leaves similar or subsimilar to those of the barren branches but not quite similarly arranged on the ultimate branchlets (= the stalks of the spikes) which are $\pm 1 \frac{1}{2}-6 \mathrm{~cm}$. long. Spikes terminal and solitary on the branchlets, deflexed, cylindrycal, $\pm 1-2 \frac{1}{2}$ em. long, $\pm 5 \mathrm{~mm}$. diam.; sporophylla spreading, with a short, roundishoblong, coriaceous base with a fimbriate-ciliate, scariose margin and a long, white-scariose, fimbriate-ciliate-serrulate, subulate apex.

It seems that the stalks of the spikes and perhaps also other parts of the plant are capable to curl and catch as tendrils of a vine when meeting with other objects. - Te ventral and dorsal leaves of the lateral rows are only distinguishable from each other by the position (ventral or dorsal) of their apices.

Sumatra.

(48) L. complanatum, L.g Bau. \& Hk., Gen. Fil., tab. CXVII A; - var. angustiramosum, v. A. v. R., in Bull. Btz., 1917, XXIV, 6.

Var. angustimanosum: Primary branches dichotomous with the branching crowded, erect, not flabellate; ultimate branchlets $\pm 1 \mathrm{~mm}$. broad. - New Guinea.

(48a) L. alpinum, $\boldsymbol{L}$. , Spring, Mon., I, tab. 104; Bk., Fern All., 27: Sehk., Krypt. Grew., I, tab. 161; Hk., Br. Ferns, tab. LIII.

Main stem (rhizome) wide-trailing, usually hypogeous, distichously branched; with leaves only rudimentary; branches erect, the lower copiously subflabellately branched; branchlets subquadrangular, about $2 \mathrm{~mm}$. diam. including the leaves. Leaves 4-farious, erect, adpressed, imbricate, subisomorphous, the dorsal ones a little smaller than the ventral, subulate-oblong, to $3 \mathrm{~mm}$. long, thick, acute, entire, rounded or keeled on the back, broarly adnate to and decurrent upon the stem or rachis. Spikes solitary and terminal on the branchlets, sessile, cylindrical, $1^{1}{ }_{4}-21 / 2$ cm. long; sporophylla ascending, broadly ovate, acute or acuminate, denticulate.

Java (t. Hert.); Arctic zones and mountains of the north temperate zone.

(49a) See No. $48 \alpha$. 

SELAGINELLINEAE. 



\section{SELAGINELLACEAE.}

\section{SEI,AGINEI,LA, spring.}

\section{A ${ }^{1}$. MONOSTELIGAE.}

(7a) See No. $41 a$.

(11a) \$. subalpina, v. A. v. R., in Bull. Btz., 1915, XX, 26.

Shoots decumbent or ascending, pinnate down nearly or quite to the base, whether or not dichotomous in the lower part, the primary rachis flexuose, obtusely angular, $\pm 21 / 2-3 \mathrm{~mm}$. thick, pale-stramineous-brown, 土 10-12 $\mathrm{mm}$. broad including the laterel leaves; pinnae erecto-patent, $\pm 10-15 \mathrm{~cm}$. long, or longer and growing out to new shoots; pinnulae simple, forked or pinnately compound; ultimate branchlets short, $\pm 5-6$ $\mathrm{mm}$. broad. Leaves heteromorphous; lateral leaves subhorizontal; of the main rachis rather remote, unequal-sided, oblong, b] unt, the upper side entire or subentire at the middle, obsoletely denticulate towards the apex, minutely serrulate towards the broadly rounded base, the lower side entire except at the obsoletely denticulate apex and the minutely serrulate and narrowly rotundate-subcordate base, the largest leaves $\pm 5 \frac{1}{2} \mathrm{~mm}$. long, $\pm 2^{3 / 4} \mathrm{~mm}$. broad; of the branchlets subsimilar, close or imbricate, subfalcate, less unequal-sided, provided with narrow, interrupted spurious veinlets, the upper side narrowly pellucid-margined, more copiously denticulate throughout, rotundate-cuneate at the base, the largest leaves $\pm 3 \mathrm{~mm}$. long; intermedial leaves erect, adpressed; of the main rachis rather remote, obliquely cordate-oblong, acuminate, hardly aristate, minutely serrulate, 2-auriculate at the base, the inner auricle narrowly rounded, the outer auricle produced, broadly incurved, the largest leaves $\pm 3-31 / 4$ mm. long; of the branchlets subsimilar, smaller, imbricate, shortly aristateacuminate, narrowly pellucid-margined, the inner base hardly cordate, the outer base hardly incurved. Spikes nearly spuare, single or double, \pm $11 / 2 \mathrm{~mm}$. diam. when young, stouter when adult; sporophylla erect, subisomorphous, deltoid-ovate, acuminate, minutely serrulate, narrowly pellucid-margined, keeled, the ventral ones somewhat larger than the 
dorsal, to $2 \mathrm{~mm}$. long, at length spreading; macrospores probably reticulate or rugulose, when young pale-yellow-brown, at length ..... ; microspores.......

Java.

(20a) S. Lebongtandalana, v. . v. I., in Bull. Btz., 1916, XXIII, 23.

Shoots trailing, more or less flexuose, the main stem $6-9 \mathrm{~mm}$. broad including the lateral leaves; pinnae ascending, the higher short, sparingly pinnate, the lower elongated, with the lower pinnulae forked or sparingly pinnate; ultimate branchlets to $\pm 1 \frac{1}{2} \mathrm{~cm}$. long by $3-5$ mm: bread at the base, narrowed towards the apex. Leaves heteromorphous; leaves of the lower plane horizontal on the main stem, spreading on the branchlets; of the main stem somewhat remote, obliquely subovate, unequal-sided, broadest on the upper side, bluntish, moderately pale beneath, the upper side more or less obsoletely denticulate towards the apex, entire or sparingly serrulate at the middle, minutely serrulate towards the rounded base, narrowly pellucid-margined at least in the lower half, the lower side entire, or obsoletely denticulate towards the apex, rotundate cuneate at the base, the largest leaves $3-4 \frac{1}{2} \mathrm{~mm}$ long, to $2 \mathrm{~mm}$. broad; of the branchlets smaller, to $8 \mathrm{~mm}$. long, contiguous or approximate, less unequal-sided, blunt, obliquely rotundate-cuneate at the base, more distinctly pellucid-margined on the upper side; leaves of the upper plane erect, broadiy falcate-oblong or subobovate, unequal-sided, abruptly cuspidate, minutely serrulate on both sides but less copiously on the outer side, the outer base much produced with a straight, rounded auricle, the inner base rotundate-cuneate, the cusp $\pm 1 / 3-2 / 3$ as long as the blade; of the main stem the largest, $\pm 3 \mathrm{~mm}$. long, contiguous; of the branchlets imbricated. Spikes terminal and mostly solitary on the branchlets, $1 \frac{1}{2}-3 \mathrm{~mm}$. diam.; sporophylla erect, at length spreading, ovate, acuminate, minutely serrulate, keeled, to $1 \frac{3}{4} \mathrm{~mm}$. long; macrospores whitish or yellowish-white, reticulate, the areolae large, the apical ribs encircled by a ring-shaped crest; microspores yellowish, provided with long-stalked, capitate or subclavate projections on the basal side.

Sumatra.

(23) S. sumntrann, Hieman. of v. A. ש. R.

Leaves of the upper plane ciliolate. 
(41a) S. barbata, Spring; Mon., II, 204, p. p.; Bk., Fern All., 74; Lycopodium barbatum, Klf., Enum., 18.

Shoots erect, or ascending from an ascending or creeping base, 5-15 $\mathrm{cm}$. long, pinnate, the stem stramineous, $1 / 2-1 \mathrm{~mm}$. thick at the base, the main rachis about $3-4 \mathrm{~mm}$. broad including the lateral leaves; pinnae simple or forked in the smaller specimens, more compound in the fully developed plants; ultimate branchlets $5-10 \mathrm{~mm}$. long, $2-3 \mathrm{~mm}$. broad. Leaves heteromorphous; lateral leaves somewhat spaced on the stem, close or somewhat imbricated on the branchlets; of the main rachis spreading, the largest $2 \frac{1}{2} \mathrm{~mm}$. long, $1 \frac{1}{2} \mathrm{~mm}$. broad, nearly straight, subequilateral, acute, pellucid-margined and minutely serrulate on both sides, ciliate at the obliquely rounded base but more suddenly and less copiously on the lower side; of the branchlets similar, more ascending, smaller, to $2 \mathrm{~mm}$. long; intermedial leaves erect; of the main rachis close, the largest about $1 \frac{11}{2} \mathrm{~mm}$. long, ovate, acuminate, pellucid-margined and minutely serrulate on both sides, the outer base produced, auriculatecordate, ciliate, the inner base slightly cordate, sparingly ciliolate; of the branchlets similar, smaller, relatively narrower, the outer base slightly cordate or rounded, sparingly ciliate, the inner base rotundate-cuneate, not or hardly ciliolate. Spikes solitary, terminal, $5 \mathrm{~mm}$. more or less long, about $2 \mathrm{~mm}$. diam.; sporophylla ovate, acuminate, pellucid-margined, minutely serrulate, keeled; macrospores whitish, yellowish or paleochraceous, snooth or pulverulent; mierospores .....-The description is taken from Merrill's No. 7112 and Ramos' No. 21670 (Bur. Sci.).

\section{Philippines.}

\section{(59) . ascendens, v. A. v. R.}

Stems to $2 \frac{1}{2} \mathrm{~mm}$. thick, whether or not grooved; leaves of the lower plane more or less approximate on the stem, contiguous or subcontiguous on the ultimate branchlets, rotundate to rotundate-cuneate on the upper side at the base; of the branchlets to $6 \mathrm{~mm}$. long; leaves of the upper plane more or less distinctly hamate-auriculate; of the stem entire on the outer side or obsoletely denticulate te serrulate towards the apex, with the basal auricle provided with $\pm 0-2$ minute teeth; of the branchlets less copiously serrulate on the inner side; spikes not invariably terminal on the branchlets, not rarely also in higher forks or on reduced axillary branchlets.

Also in Sumatra. 


\section{(94) \$. cupressina, spring.}

Largest intermedial leaves (of the principal rachises) minutely serrulate in all the specimens occurring in the Buitenzorg Herbarium.

\section{(95) S. leytensis, Hieron.}

Near S. cupressina Spring but the branching less compound, loose, and the rachises distinctly narrower.

(124a) S. Robinsonii, ט. A. ש. R., in Philipp. Journ., XIC, 118.

Shoots decumbent, trailing, repeatedly forked or subpinnate, probably caespitose, the secondary shoots pinnate, the stem slender, stramineous, to $1 / 2 \mathrm{~mm}$. thick, irregularly grooved when dry, $3_{12}^{1 / 1}-4 \mathrm{~mm}$. broad including the lateral leaves; pinnae distant, oblique, simple or forked, or subpinnate; ultimate - branchlets short, to about $6 \mathrm{~mm}$. long, $1 \frac{1}{2}-21 / 4$ $\mathrm{mm}$. broad. Leaves heteromorphous; leaves of the lower plane spreading and spaced on both stem and branches; of the stem broadly ovate, $13 / 4-2 \% \mathrm{~mm}$. long, to $1 \% \mathrm{~mm}$. broad, very unequal-sided, blunt or bluntish, minutely but rather copiously papillose-puberulous above, the upper edge obsoletely serrulate towards the apex, serrulate at the middle, gradually ciliate towards the base, the lower edge subentire or obsoletely serrulate, and often sparingly ciliate-serrulate at the base, the upper base much dilated, broadly rotundate-cordate, the lower base narrowly rotundate-cordate, the costa wanting in the upper $1 / 8$; of the ultimate branchlets to $1 \frac{1}{2} \mathrm{~mm}$. long, less unequal-sided, more remotely serrulate and ciliate, the upper base rotundate-cuneate, the lower base rounded; leaves of the upper plane erect, spaced on the stem, close on the ultimate branchlets; of the stem ovate, long-acuminate to cuspidate, nearly keeled, to about $1 \mathrm{~mm}$. long, the outer side minutely serrulate, produced and rotundate-subcordate at the base, the inner side ciliate, rounded or rotundate-cuneate at the base; of the ultimate branchlets smaller. Spikes solitary or double, about $4-6 \mathrm{~mm}$. long, 2-21/2 $\mathrm{mm}$. broad; sporophylla of the upper plane spreading, subremote, lanceolate, shortly subapiculate-acuminate, naked or shortly puberulous above, keeled, the upper edge and the keel remotely ciliate; of the lower plane erected, imbricated, ovate, long-acuminate, proportionally long-ciliate; spores..... (young microspores yellow or pale-orange, minutely verruculose).

Amboina. 
(132a) \$. Incerta, v. A. *. K., in Bull. Btz., 1916, XXIII, 24.

Shoots $15-20 \mathrm{~cm}$. long, rather copiously pinnate, the stem terete, to $2 / 3 \mathrm{~mm}$. thick, stramineous, to $4 \mathrm{~mm}$. broad including the lateral leaves; pinnae erecto-patent, not rarely subparallel to the main stem; higher pinnae short, simple, lower to $15 \mathrm{~cm}$. long, pinnately decompound; ultimate branchlets short, $1 \frac{1}{2}-2 \mathrm{~mm}$. broad. Leaves heteromorphous; lateral leaves remote on both stem and branches; of the stem horizontal or much spreading, broadly ovate, unequal-sided, bluntish, the upper side entire towards the apex, gradually ciliolate to ciliate towards the broadly rounded base, the lower side entire, provided with $0-3$ minute teeth at the narrowly rounded base, the largest leaves $\pm 2 \%_{2}-23 / 4 \mathrm{~mm}$. long, to $2 \mathrm{~mm}$. broad, the upper surface provided with very short toothlike projections near the lower edge; of the ultimate branchlets smaller, to $\pm 1 \frac{1}{2} \mathrm{~mm}$. long, nearly equal-sided at the rotundate-cuneate base, the upper side more distinctly ciliate in the lower $1 / 2-2 / 3$; intermedial leaves erect; of the stem elongate-ovate, acuminate, more or less keeled, rounded at the base, the inner side more or less deciduously serrulateciliolate, the outer side minutely serrulate at least in the upper part, the largest leaves $\pm 1 \% \mathrm{~mm}$. long; of the branchlets similar, smaller. Spikes numerous in the fully developed plant, terminal, single or double, $2-2 \mathbf{1} / \mathbf{2}$ $\mathrm{mm}$. broad; sporophylla of the upper plane imbricate, much spreading, lanceolate-oblong, to $1 \frac{1}{2} \mathrm{~mm}$. long, keeled, the upper side very minutely serrulate in the upper part, serrulate-ciliolate in the lower part, the keel ciliate; of the lower plane erect, elongate-ovate, acuminate, keeled, spinuloso-ciliate; macrospores white, smooth or very minutely punctulate; microspores.. .. - By its habit and rooting stem intermediate between the Intertextae and the Suberosae.

Sumatra.

(135a) \$. pyemocarpa, v. A. v. R., in Bull. Btz., 1916, XXIII, 25. Shoots trailing, $10-15 \mathrm{~cm}$. long, pinnate, or forked with pinnate secondary shoots, the stem slender; pinnae spreading to suberect, to $2 \frac{1}{2}$ $\mathrm{cm}$. long (excluding the spikes), the higher simple or forked, the lower sparingly pinnate to repeatedly dichotomous; ultimate branchlets short, the shortest not rarely stalk-shaped and without leaves. Leaves heteromorphous; lateral leaves spaced even on the branchlets, horizontal or spreading; of the stem broadly ovate, unequal-sided, broadest on the upper side, subacute or bluntish, the upper side obsoletely denticulate towards 
the apex, sparingly minutely serrulate at the middle, gradually ciliolate to ciliate towards the broadly rounded base; the lower side obsoletely denticulate towards the apex, for the rest entire or sometimes provided with 1-2 minute teeth at the rotundate-subcordate base, the largest leaves $\pm 2{ }^{3} / 4 \mathrm{~cm}$. long by nearly $2 \mathrm{~mm}$, broad; of the branchlets smaller, to $\pm 1 / 4 \mathrm{~mm}$. long, less unequal-sided, obliquely rotundate-cuneate at the base, with the upper surface provided with minute tooth-like projections near the lower edge; intermedial leaves erect, subfalcate-ovate, longacuminate to subcuspidate-acuminate, the base obliquely rotundate to rotundate-cuneate, slightly produced on the outer side, the outer side remotely and minutely serrulate in the upper half, the inner side remotely and minutely serrulate throughout or ciliolate in the lower half. Spikes copious, to $\pm 21 / 2 \mathrm{~cm}$. long, $3 \mathrm{~mm}$. broad or when young somewhat narrower, the longer ones straight, curved or somewhat flexuose; sporophylla of the upper plane crowded, spreading, subhorizontal, lanceolate, acute or shortly acuminate, the upper side sparingly and minutely serrulate with the lower teeth growing gradually longer and ciliiform, keeled, the keel spinuloso-ciliolate; of the lower plane erect, imbrieate, much smaller, ovate, long-acuminate, spinuloso-ciliate; spores .... . .

Sumatra.

(150b) See No. $132 a$.

(164) S. d'Armandvillei, v. A. v. R.

At least the lower axillary leaves of the stem proportionally short and broad, deltoid-cordate or deltoid-ovate, as broad as long or nearly so.

(165) S. brachystachya, Spring.

Omit this species, as being not Malayan.

(166) \$. fimbriata, spring; S. brachystachya, Spring, var. ornata, Bk., 113, p. p.

Axillary leaves proportionally long and narrow, lanceolate-ovate, distinctly longer than broad. Intermedial leaves not always very dis. tinctly cordate-auriculate on the outer side at the base.

(167) S. subfimbriata, v. A. v. R.; - var. polyura, S. fimbriata, Spring, var. polyura, Warb.; - var. Backeri, v. A. V. R. 
United with S. fimbriata Spring by intermediates with long-acuminate or short-cuspidate intermedial leaves.

Var. polyura : Differs from the type in having the lateral leaves remote (even on the branchlets) and proportionally shorter and broader.

Var. Hackeri: Differs from the type in having the branches narrowier, the lateral leaves approximate on the main rachis, rather close on the branches and not rarely subimbricate on the branchlets, the spikes narrower, $1-1 \frac{1}{2} \mathrm{~mm}$. broad.

(167a?) \$. ornata, Spring, Mon., II, 259; S. brachystachya, Spring, var. ornata, Bk., Fern All., 113, p. p.; Lycopodium ornatum, Hk. \& Grev., Hk., Bot. Misc., III, 108.

Shoots probably suberect, 3-pinnate; pinnae plumose; lateral leaves horizontally pectinate, oblong, slightly falcate, blunt, denticulate on the upper edge; intermedial leaves ovate, mucronate, denticulate; spikes nearly $2 \frac{1}{2} \mathrm{~cm}$. long. - The systematical place of this species is uncertain because of incomplete description.

A plant gathered by C. J. Brooks (Bengkoelen, Lebong Tandai, No. 31:S) agrees very well with Spring's brief diagnosis of this except that the intermedial leaves are cuspidate, and the spikes shorter. It is distinguished by its regularly feathery aspect, and has the intermedial leaves ovate, more or less broadly and obliquely adnate at the nonauriculate-cordate base, the spikes $1 \frac{1}{2}-2 \mathrm{~mm}$. broad, the lateral sporophylla blunt, minutely denticulate, the intermedial sporophylla ovate, long-acuminate, minutely serrulate, the macrospores whitish, smooth or very indistinctly punctulato-verruculose, the microspores whitish or very pale-orange, densely minutely punctulato-verruculose.

Sumatra.

\section{$\mathrm{A}^{2}$. Pleiostelicae.}

(176a) See No. 192.

(176b) S. nemorosa, v. A. v. R., in Bull. Btz., 1916, XXПI, 26.

Shoots erect, to $60 \mathrm{~cm}$. high, the lower part thick, stipitiform, 3-stelical, with a few reduced pinnae, sparingly foliate with small, scattered, subjsomorphous, ovate, blunt or acute, erected leaves, the upper part 
2-pinnate, with the lower axillary leaves ovate-oblong or ovate-subcordate, broadest below the middle; pinnae erecto-patent, close, lanceolate-ovate, not articulate at the base, the largest to $25-30 \mathrm{~cm}$. long, $8-9 \mathrm{~cm}$. broad; pinnulae crowded, subhorizontal or more ascending, rarely simple, mostly once or twice forked above the middle, to $5-6 \mathrm{~cm}$. long, to 10-12 $\mathrm{mm}$. broad including the lateral leaves and below the forking. Leaves of the pinnae heteromorphous, entire; lateral leaves lanceolatesubfalcate, acute or shortly acuminate, very narrowly pellucid-margined, with the upper base rotundate-cuneate, the lower base rather narrowly rounded or subcordate; of the secondary rachises rather remote; of the pinnulae close, subhorizontal, the higher more ascending, the largest $6-61 / 2 \mathrm{~mm}$. long, to $23 \mathrm{~mm}$. broad; intermedial leaves erect, unequalsided, falcate-ovate; of the secondary rachises whether or not sessile on a subpetioluliform tumefaction, obliquely rotundate-cuneate to narrowly 2-auriculate-cordate at the base, the lower acutely acuminate, the higher gradually cuspidate; of the pinnulae obliquely adnate at the base, rather abruptly cuspidate, to $\pm 3 \mathrm{~mm}$. long, the cusp $1 / 3^{--1 / 2}$ as long as the blade, the outer base produced, cordate or rotundate. Spikes terminal, solitary or 2-3-nate, normally $1-1 \frac{1}{2} \mathrm{~mm}$. diam., sessile or pedunculate, the stalk provided with erected, ovate, acute or acuminate, entire sterile bracts; sporophylla broadly ovate, to $1 \mathrm{~mm}$. long, acuminate, entire, keeled, erect or finally spreading; macrospores whitish, densely and finely verruculose; microspores whitish or yellowish, copiously provided with shortly stipitate-capitate or more commonly clavate projections.

Sumatra.

(176c) \$. nemorosoides, v. A. v. R., in Bull. Btz., 1916, XXIII, 26.

Shoots 2-pinnate, the main rachis 3-stelical, sparingly foliate with small, subisomorphous, ovate, blunt or acute, erected leaves, with the lower axillary leaves deltoid-ovate or deltoid-subcordate, broadest at or near the base; pinnae close, erecto-patent, elongate-lanceolate, narrowed gradually in the upper part, not articulate at the base, the largest to 35-40 cm. long, 6-8 cm. broad; pinnulae crowded, arcuate-ascending, lanceólate, generally simple, sometimes forked or rarely twice forked above the middle, the simple ones lanceolate, to $5-6 \mathrm{~cm}$. long, to $10-12$ $\mathrm{mm}$. broad including the lateral leaves. Leaves of the pinnae heteromorphous, entire; lateral leaves lanceolate-subfalcate, acute or shortly 
acuminate, very narrowly pellucid-margined; of the secundary rachises rather remote, horizontal, with the upper base rounded, the lower base rotundate-truncate; of the pinnulae approximate, subhorizontal, the higher more ascending, the largest $6-6 \frac{1}{2} \mathrm{~mm}$. long, to $2^{3 / 4} \mathrm{~mm}$. broad, with the upper base hardly plicate, rotundate-cuneate, the lower base rotundate or rotundate-truncate; intermedial leaves erect, unequal-sided, falcateovate, very narrowly pellucid-margined; of the secondary rachises obliquely adnate and narrowed on both sides at the base (the outer base produced, rather decurrent-cuneate), the lower acutely acuminate, the higher gradually cuspidate; of the pinnulae subabruptly cuspidate, to $4 \mathrm{~mm}$. long, with the cusp $1 / 3-1 / 2$ as long as the blade, the outer base cordate or rounded, produced. Spikes terminal, solitary or $2-3$-nate, normally $1-1 \frac{1}{2} \mathrm{~mm}$. diam., sessile or pedunculate, the stalk to $\pm 1 \mathrm{~cm}$. long, provided with lax, erected, ovate, acute or acuminate, entire, sterile bracts; sporophylla broadly ovate, to $1 \mathrm{~mm}$. long, acuminate, entire, very narrowly pellucidmargined, keeled, erect or finally spreading; macrospores whitish, densely and finely verruculose; microspores whitish, provided with densely crowded, sessile or short-stalked capitate projections. - The true systematical place of this species is uncertain, the description being founded on an incomplete specimen.

\section{Sumatra.}

(177a) See No. 192.

(177b) S. simulans, v. A. v. R., in Bull. Btz., 1915, XX, 27; ? S. Pouzolziana, Spring, var. brevifolia, Hieron.

Shoots erect, or ascending from a creeping base, 25-45 cm. long, pinnate throughout, or the lower part simple, or forked with pinnated secondary shoots, the stem $2 \mathrm{~mm}$. thick, 3-stelical, stramineous and irregularly grooved when dry, with the lower axillary leaves short-oblong, or broad-ovate, acuminate, broadest at or below the middle; pinnae remote, subovate in outline; lower pinnulae pinnate, higher simple; ultimate branchlets few, remote, to $1_{1}^{1} / 2 \mathrm{~cm}$. long, the lower part $3 \mathrm{~mm}$. broad including the lateral leaves. Leaves heteromorphous; leaves of the stem very remote, subsimilar to those of the secondary rachises but less oblique; leaves of the branches pellucid-margined; lateral leaves spreading or more ascending, subfalcate-oblong, entire or subentire towards the base, shortly and remotely denticulate towards the mucronulate-

Ferns and Fern Aluies. 
acuminate apex, the upper side subrotundate, cuneate at the base, the lower side nearly straight, rotundate- or abruptly cuneate-truncate at the base; of the secondary rachises somewhat remote, $2-21 / 2 \mathrm{~mm}$. long by $1 \mathrm{~mm}$. broad; of the branchlets close, to $2 \mathrm{~mm}$. long and $3 / 4 \mathrm{~mm}$. broad; intermedial leaves erect, obliquely lanceolate-oblong, entire towards the base, obsoletely denticulate towards the acuminate apex, the outer side subrotundate, the inner side slightly arcuate or nearly straight; of the secondary rachises $2 \mathrm{~mm}$. long, the base narrowly rounded, somewhat produced on the outer side; of the branchlets smaller, obliquely rotundatecuneate at the base. Spikes solitary, 2-3 mm. diam.; sporophylla elongate-ovate, acute, keeled, pellucid-margined, obsoletely denticulate towards the apex, at length spreading; macrospores yellowish or nearly white, rugulose or verruculose; microspores whitish or yellowish, provided with crowded, conical, bacilliform or tuberculiform projections often thickened at the apex.

Borneo.

(182) \$. Wallichii, spring.

Also in New Guinea (t. Ridl.).

\section{(187) S. Eittyne, v. A. ש. R.}

A specimen received from C. J. Brooks (Bengkoelen, Lebong Tandai, No. 30, S) has the spikes partly single partly 2 -3-nate.

\section{(192) \$. Pounolziand, spring.}

According to Spring's diagnosis this species is said to have the axillary leaves obovate, narrowed at the base, and the lateral leaves entire. The specimens occurring in the Buitenzorg Herbarium have the lower axillary leaves broadly cordate to ovate, broadest at or near the base, and the lateral leaves often, if not invariable, very minutely denticulate-serrulate towards the apex.

Forma typica: Lower pinnae broadly ovate or triangular-ovate; lower pinnulae broad, conspicuously pinnate to 2-pinnate, the higher simple or forked; macrospores verruculose, whitish or pale-brown when young, grey-brown or black-brown when adult; micropsores whitish or yellowish, provided with more or less crowded, bacilliform or stipitate-capitate projections. 
Forma punctata: Like the type but the pinnae lanceolate or elongateoblong; pinnulae narrow, simple, the lower rarely forked or sparingly pinnate. (=Var. punctata Hieron, in Leafl., VI, 2050).

(203a) See No. 176c.

\section{INDEFINITAE.}

S. barbata, Spring.

Omit this species here. See No. $41 a$. 

APPENDIX. 



\section{APPENDIX.}

This appendix principally treats with the ferns and fern allies discovered after Januari 1st 1916, besides the additions wich could not be inserted in the first part of the work when in the press.
Buitenzorg, Januari 1917.
v. A. v. R.

\section{OYATHEA, Smith.}

(2a) C. Klossii, rtidt., in Trans. Lin. Soc., Bot., 2nd. Ser., IX, 251. Trunk very slender. Stipes $\pm 10 \mathrm{~cm}$. long, purple-brown, rough, the base provided with acuminate scales. Fronds 2-pinnatifid, $\pm 60 \mathrm{~cm}$. long by $13 \mathrm{~cm}$. broad, the rachis above grooved and hirsute with black hairs, beneath copiously scaly. Central pinnae largest, $\pm 5 \mathrm{~cm}$. long by $11 / 2 \mathrm{~cm}$. broad, the edge cut to $\pm 3 / 4$-way down to the costa. Lobes to \pm 11 on a side, oblong, obtuse. Texture papyraceous; surfaces naked, the under one subglaucous; veins to 12 on a side, often forked. Sori at the base of the veins; indusium globose, bursting irregularly at the apex.

New Guinea.

(3a) C. papuana, v. A. v. It.; Alsophila papuana, Ridl., in Trans. Lin. Soc., Bot., 2nd Ser., IX, 252.

Stipes long, naked, sparingly spinulose. Fronds $\pm 115 \mathrm{~cm}$. long, 2.pinnatifid. Pinnae subremote, $\pm 30 \mathrm{~cm}$. long. Pinnulae $\pm 8 \mathrm{~cm}$. long by $2 \mathrm{~cm}$. broad, lanceolate, long-acuminate, short-stalked, the edge cut more than $1 / 2$-way down to the costa. Lobes 20 , oblong, obtuse, crenulate. Texture subcoriaceous; surfaces naked; veins to 12, forked. Sori to 12, medial; indusium small, at first globose but soon breaking up into very minute fragments.

Nero Guinea. 


\section{(18) C. crenulata, $\boldsymbol{B t}$.}

Forma squamulosa (incl. forma asperula): Like forma subspinulosa but the segments more distinctly crenulate, the covering intermixed with proportionally long, lanceolate-subulate, brown scales. - Java.

\section{HEMITELIA, R. Brown.}

\section{§ 2. AMPHICOSHIA.}

(3c) เ. Demichlamidea, v. A. v. T.

Stipes provided above with 2 rows of glands (linear aërophores).

(3c) H. leptolepia, v. A. v. F., in Bull. Btz., 1916, XXIII, 12.

Stipes $\pm 90-100 \mathrm{~cm}$. long, slender, blackish, scaly, deciduously ferrugineo-furfuraceous and acutely muricate near the base, otherwise red-brown, naked (glabrescent?), minutely verruculoso-asperulous and provided above with two rows of pale-yellow-brown longitudinal streaks (long-linear aërophores); scales erected, red-brown, linear-subulate, entire. Fronds 3-pinnatifid, the rachis similar to the upper part of the stipe at least in the lower part. Pinnae sessile or nearly so, horizontal or spreading, lanceolate-ovate or elongate-oblong, $\pm 27 \%-30 \mathrm{~cm}$. long, $10-12$ $\mathrm{cm}$. broad at the middle, more or less abruptly acuminate, the rachis rather loosely tomentose above, deciduously chaffy beneath, narrowly winged in the upper part, the hairs long, rufous, the squamules brown, flattish, sublanceolate. Pinnulae to \pm 20 on a side below the terminal one; terminal pinnulae long-triangular, deeply pinnatifid at the base with entire to toothed lobes, the apex bluntly serrate-dentate; lateral pinnulae spreading; largest pinnulae sessile or subsessile, linear-sublanceolate, to 6 $\mathrm{cm}$. long, $\pm 1 \frac{1}{2} \mathrm{~cm}$. broad at the truncate base, deeply pinnatifid (pinnatipartite), narrowed gradually towards the subabruptly acuminate apex, the acumen blunt, entire or subentire, sparingly bluntly serrate-dentate at the base; lower pinnulae more or less reduced. Segments subcontiguous, spreading, linear-oblong, straight or subfalcate, the largest to $73 / \mathrm{mm}$. long by $3 \mathrm{~mm}$. broad, blunt or rounded at the apex, entire or indistinctly subrepando-crenulate. Texture rather coriaceous; surfaces naked; costae brown-hairy above, deciduously squamulose below, the lower squamules flattish, sublanceolate, the higher more or less bullate; costulae naked 
above, sparingly squamulose towards the base beneath, the squamules bullate, pale-yellow-brown; veins oblique, to $7-10$ on a side, forked, the higher simple. Sori subcostular or inframedial on the lowest (1 or more lower?) veins; indusium small, thin, pale-yellow-brown.

Sumatra.

(6) H. Intebrosa, Mett.; - var. paraphysata, v. A. v. R., in Bull. Btz., 1916, XXIII, 13.

Var. paraphysata : Capsules intermixed with proportionally long, fibril-like, articulated paraphyses. - Borneo.

\section{A LSOPIILA, T. Brovn.}

\section{(1) A. dubia, Bedd.}

Main and secondary rachises when young with the tomentum not rarely intermixed with a few scattered, subfiliform squamules; pinnula sometimes incised to $1 / 2$-way down to the costa, with the costa beneath naked or glabrescent (when young sparingly deciduously subulate-squamulose); main veins with $2-4$ veins on a side.

Also in Sumatra.

(5a) A. xanduolepia, v. A. v. R., in Bull. Btz., 1916, XXIII. 1. Stipes to $50 \mathrm{~cm}$. or more long, fuscous when dry, densely scaly, the scales long, palish-yellow-brown, very minutely brown-ciliolate-serrulate, the lower subfiliform, the others subulate-lanceolate, long-acuminate, leaving the stipe rough when they fall. Fronds 2-pinnatifid, the rachis above deciduously puberulous with short, curved, red-brown hairs, beneath when young probably furfuraceous with red-brown, irregularly fimbriatestellate squamules, the covering leaving the rachis punctulato-asperulous when it falls. Pinnae lanceolate-ovate, shortly acuminate, to $50 \mathrm{~cm}$. or more long, the rachis pale-brown, rather hispid above and deciduously squamulose beneath, as are the costae, the hairs acute, erected, articulated, pale-yellow-brown, the squamules red-brown, partly lanceolate and ciliolate, partiy roundish and irregularly fimbriate (substellate-peltate). Pinnulae subremote, horizontal, articulated to the rachis, the higher sessile, the central the largest, the lower somewhat deflexed, short-stalked; largest 
pinnulae linear, $\pm 8 \mathrm{~cm}$. long by $\pm 1 \frac{1}{2} \mathrm{~cm}$. broad, the sides subparallel, cut $\pm 2 / 3$-way down to the costa, the apex bluntish or shortly acuminate, bluntly serrate-dentate, the base truncate, deeply pinnatifid. Segments subhorizontal, not close, $\pm 4-5 \mathrm{~mm}$. broad, slightly obliquely truncate or truncate-subrotundate at the apex, entire or indistinctly repando-crenate; costulae above naked but not rarely provided with 1-2 acute, setiform, articulated, pale hairs, beneath squamulose, the squamules lanceolate-ovate, red-brown, acuminate, more or less bullate, ciliolate; veins to $5-7$ on a side, oblique, simple or forked, distinct, at least the under side provided with adpressed, minute, gland-like hairs. Texture firm-herbaceous; surfaces naked. Sori medial on the $1-5$ lower veins, the lower somewhat divaricating.

Sumatra.

(7c) A. Annae, v. A. v. R., in Bull. Btz., 1916, XXIII, 3.

Trunk slender, to $1-1^{1 / 2} \mathrm{~m}$. high. Stipes slender, castaneous, 15-25 cm. long, provided with 3-4 reduced pinnae on each side at the base, and 2 rows of long-elliptical, pale-rufous, depressed glands (aërophores) on the upper side, the base scaly, the rest furfuraceo-squamulose, the upper side 3-sulcate and scaly; lower scales crowded, linear-subulate, brown, pale-margined; higher scales copious but not crowded, rufo-fuscous, subfiliform, intermixed with rufous hairs; lower reduced pinnae finely dissected, with filiform, tooth-like or narrowly cuneate tertiary segments. Fronds ovate-lanceolate, $70-75 \mathrm{~cm}$. long excluding the reduced pinnae, 45-50 cm. broad, acuminate, 2-pinnate to 3-pinnatifid; rachises like the upper part of the stipe but not or less distinctiy grooved. Pinnae rather remote, about 14 on a side; lower normal pinnae stalked, horizontal, higher ones sessile or nearly so, subhorizontal; largest pinnae lanceolate-ovate, to $25 \mathrm{~cm}$. long, about $7-8 \mathrm{~cm}$. broad, acuminate, the rachis narrowly winged towards the apex. Pinnulae dimorphous, to about 14 on a side below the terminal one, remote, horizontal or nearly so; terminal pinnulae elongate-deltoid, serrate towards the apex, deeply pinnatifid towards the base; higher pinnulae sessile with an obliquely rotundate-truncate base; lower pinnulae short-stalked, cordate-truncate at the base, the stalk rufotomentose; largest pinnulae linear-oblong, to $4 \mathrm{~cm}$. long and $1 \mathrm{~cm}$. broad at the dilated base, acute; barren pinnulae serrate at the apex, bluntly sub-2-auriculate at the base, otherwise coarsely serrate-lobate to $1 / 3$-way down to the costa, the lobules entire, oblique; fertile pinnulae smaller, 
somewhat contracted, pinnatifid to $3 / 4$-way down to the costa, the lobes blunt, sparingly repand, horizontal or nearly so. Texture firm; upper surface dark-olivaceous when dry, naked; under surface paler, squamulose on the costae, costulae and veins, the scales minute, scattered, bullate, ovate, acuminate, brown or pale-brown; main veins pinnate in the teeth or lobes; veins to 4 on a side, simple, the lowest sometimes forked. Sori medial, to 3 (rarely 4) on a side.

\section{Amboina.}

(10a) See No. $5 a$.

(11c) A. Tumphiana, v. A. v. R., in Philipp. Journ., XIc, 104.

Stipes to $1 \mathrm{~m}$. long. Fronds to $\pm 3 \mathrm{~m}$. Jong, 3-pinnatifid; main rachis subfuscous when dry, scabrous with numerous, minute, black-browntipped, longitudinally oblong projections which are probably the persistent bases of fallen hairs and scales, beneath deciduously furfuraceo-tomentose, above hairy and scaly, the tomentum pale-ochraceous, the hairs moderately long, dense, pale-ochraceous, longitudinally subadpressed, intermixed with spreading, fragile, articulated bristles which are mostly red-brown towards the base (and whether or not flattened, non-articulate, pale-yellow and shortly ciliolate in the upper part), the scales long, narrowly subulatelanceolate, pale-yellow, ciliolate with short, suberect, acute, red-brown hairs. Pinnae \pm 15 on a side, short-stalked, to $50 \mathrm{~cm}$. or more long, acuminate, the rachis and costae smooth or nearly so, beneath deciduously pale-furfuraceous, above copiously clothed with moderately long, subadpressed, pale-ochraceous hairs. Pinnulae close or approximate, sessile, horizontal or nearly so, deeply pinnatipartite, acuminate, the acumen bluntish, serrate or crenate towards the apex, coarsely toothed in the lower part; central pinnulae largest, about $11 \mathrm{~cm}$. long, $2 \frac{1}{2} \mathrm{~cm}$. broad at the truncate base. Segments approximate, subhorizontal, linear-oblong, straight or subfalcate, to $1 \frac{1}{4} \mathrm{~cm}$. long and $3 \mathrm{~mm}$. broad, dilated at the base, blunt or bluntish, crenate, the crenations simple or 2-3-crenate again, at least the lower deciduously ciliated, the ciliae spreading, articulated, solitary on the apice of the veins; lowest segments not rarely free, horizontal and not dilated at the base. Texture herbaceous; surfaces naked; upper surfaces provided with shallow impressions corresponding: with the receptacles; costulae and veins provided above with a few scattered, acute, pale-yellow setae; costulae scaly beneath, the scales 
minute, ovate, bullate, acuminate and finely fimbriate at the apex; veins to $12-15$ on a side, somewhat prominent beneath, once or twice forked, the higher simple. Sori occupying the lower veins, to 8 on a side, subcostular; capsules intermixed with red-brown articulated hairs not or hardly longer than the capsules, - Stipes unknown but probably rough, not aculeate. Amboina.

(20) A. saparuensis, v. A. v. H.

Also in New Guinea (t. Ridl.).

(26e) A. amboimensis, v. A. v. Re, in Philipp. Journ., XIC, 103. Stipes more than $50 \mathrm{~cm}$. long, more or less fuscous when dry, aculeate with short, conical warts, deciduously ferrugineo-furfuraceous. Fronds 3-pinnatifid, narrowly elliptic in outline, $\pm 21 / 2 \mathrm{~m}$. long, the rachises beneath when young probably furfuraceous and more or less scaly, above pubescent, the main rachis aculeolate in the lower part; furfur ochraceous; scales narrowly subulate or filiform, brown; pubescence consisting of short, spreading, incurved, red-brown or castaneous hairs. Pinnae to \pm 35 on a side, spreading, short-stalked, acuminate, the largest ovate-lanceolate, to $50 \mathrm{~cm}$. or more long and $17 \frac{1}{2} \mathrm{~cm}$. broad, the rachis narrowly winged towards the apex; lower pinnae very remote, reducer. Pinnulae to about $20-25$ on a side, shortly petiolulate, oblique or the lower horizontal or spreading, rather coarsely serrate-crenate at the long-acuminate, subcaudate apex, otherwise deeply pinnatifid, the base cuneate-truncate; largest pinnulae about $9 \mathrm{~cm}$. long by $1^{3 / 4} \mathrm{~cm}$. broad. Segments close or approximate, linear-oblong, straight or subfalcate, to $1 \mathrm{~cm}$. long by $3 \mathrm{~mm}$. broad, crenate or crenulate in the lower part, serrate-dentate towards the bluntish or subacute apex. Texture firm-herbaceous or subcoriaceous; surfaces naked; costae fusco-puberulous above; costae and costulae more or less deciduously squamulose beneath, the squamules ovate, bullate, acuminate, pale, intermixed with flatter ones; veins to about $8-10$ on a side, forked, the higher simple. Sori subcostular, occupying the lower veins, to 6 on a side, at length confluent; capsules intermixed with hyaline, articulated hairs not or not much longer than the capsules.

Amboina.

(27) A. glauca, J. Sm.; Cyathea contaminans, Copel., in Philipp. Journ., IVC, 60; - var. squamulosa, v. A. v. R., in Bull. Btz., 1916, XXIII, 2. 
(276) A. beneulensis, v. A. v. R., in Bull. Btz., 1916, XXIII, 2.

Stipes to $\pm 30 \mathrm{~cm}$. or more long, like the main rachis black-purplebrown, aculeate with short, acute warts, above scaly, otherwise furfuraceous, the scales gradually long-filiform or piliform from a subulate base, dark-purple-brown, sparingly ciliated, the lower copious, the higher more scattered (deciduous?), the furfur ferrugineous. Fronds $\pm 130 \mathrm{~cm}$. broad, 3-pinnatifid, sub-3-pinnate. Pinnae spreading, the largest ovatelanceolate, $\pm 25 \mathrm{~cm}$. broad at the middle, acuminate, somewhat narrowed at the base, the lower remote and gradually much reduced; rachis deciduously scaly above, tomentose beneath, the scales scattered, filiform or piliform, dark, the tomentum ferrugineous. Pinnulae horizontal, lanceolate, the higher sessile, the central the largest, the lower shortstalked and somewhat abbreviated, the largest $\pm 2-2^{1} / 2 \mathrm{~cm}$. broad, deeply pinnatifid, bluntly serrate-dentate at the acuminate apex, slightly narrowed at the base; costa naked above, beneath tomentose with interlaced but not crowded, crisped, brown hairs, the tomentum intermixed in the lower part with copious erected, dark, lanceolate squamules. Segments spreading, falcate, the largest $\pm 21 / 2-3 \mathrm{~mm}$. broad, separated by a blunt sinus at the dilated base, crenulate, or bluntly crenate-dentate at the blunt or bluntish apex, the lowest free and more or less abbreviated. Texture coriaceous; surfaces, costulae and veins naked; upper surface when dry dark-olivaceous, lower paler; veins to $\pm 11-12$ on a side, forked, the higher simple. Sori subcostular, to \pm 6 on a side, occupying the lower veins; spurious indusium moderately large, shallowly saucer-shaped.

Sumatra.

(32) A. tomentosa, Mr.

Scales not rarely deciduous in age, partly linear-subulate, flat, and ciliolate with short, ascending, acute, red-brown hairs, partly ovate, subbullate, conspicuously ragged.

(43) A. palembanica, $\boldsymbol{v}$. A. v. R., in Bull. Btz., 1916, XXIII, 4.

Fronds 3-pinnatifid, the rachises above naked, beneath when young ferrugineo-lanuginoso-tomentose, at length not rarely naked; main rachis muriculato-asperulous, when dry castaneous in the lower part, otherwise fuscous, as are the sparingly asperulous secondary ones. Pinnulae remote, the largest horizontal or spreading, shortly petiolulate, 
about $10-12 \mathrm{~cm}$. long by $2 \frac{1}{2}-3 \mathrm{~cm}$. broad at the truncate base, deeply pinnatifid, crenate at the acuminate apex, the costa naked above, beneath tomentose like the rachises, the tomentum intermixed with a few minute, subulate, castaneous, deciduous squamules. Segments spreading or the largest horizontal, not close, nearly straight, to $1^{1}{ }_{2} \mathrm{~cm}$. long by $3 \frac{1}{2}-4$ mm. broad, blunt or bluntish, crenate or the largest bluntly toothed to deeply lobed, the costula naked above, beneath sparingly provided with bullate, acuminate, castaneous squamules; veins to 10-12 on a side, the higher simple, the others forked or 3-furcate, sometimes sparingly pinnate in the lobed segments. Texture coriaceous; surfaces naked. Sori to \pm 7 on a side, not on the higher veins, costular or the lower somewhat divaricating; spurious indusium consisting of a moderately large, flat or shallowly saucer-shaped, dark-or pale-brown scale encircling the receptacle, when young cup-shaped with a truncate open mouth. Stipes unknown.

\section{Sitmatra.}

(44) A. okiana, v. A. v. R., in Bull. Btz., 1916, XXIII, 4.

Pinnae about $60-65 \mathrm{~cm}$. long, acuminate, the rachis above 3-sulcate and provided like the costae above with deciduous or persistent, acute, yellowish or pale-ochraceous hairs, beneath very sparingly and minutely pustulate, when young probably pale-furfuraceous and perhaps more or less squamulose. Pinnulae sessile, approximate, spreading, linear, the largest about $12 \mathrm{~cm}$. long, $21 \% \mathrm{~cm}$. broad at the truncate base, deeply pinnatipartite, narrowed gradually towards the subabruptly acuminate, serrate or crenate-serrate apex, the costa deciduously pale-furfuraceous beneath, the covering intermixed with (few?) scattered, deciduous, subulate, piloso-acuminate, ciliolate-serrulate, minute, whitish squamules. Segments numerous, approximate, spreading, linear-oblong, falcate or nearly straight, blunt or bluntish, the largest $3-31 / 2 \mathrm{~mm}$. broad, dilated at the base, serrate-crenate, the higher crenations simple, the others 2 crenate, the costula provided above with scattered, needle-like, often curved, pale setae, scaly beneath with lanceolate, bullate, acuminate, pale-ochraceous, minute squamules. Texture papyraceous, fragile when dry; surfaces naked; under surface pale-green, apparently glaucous; veins to \pm 12 on a side, the higher often simple, the others forked. Sori inframedial, in the forks or the veins, corresponding with an impression on the upper side, to 9 on a side, not occupying the higher veins; capsules 
intermixed with brown, fine, articulated hairs not surpassing the capsules; spurious indusium consisting of a whorl of pale fibres. - Stipe and main rachis unknown. Probably near A. glauca J. Sm.

Buru.

(45) A. Iastreoides, v. A. v. R., in Bull. Btz., 1916, XXIII, 5. Pinnae to $40 \mathrm{~cm}$. or more long, acuminate, to rachis narrowly winged in the upper part, above brown-hairy like the costa, beneath roughish with scattered, minute pustules, when young provided with scattered, ferrugineous, entire, subulate squamules dilated at the cordate base. Pinnulae close, the higher ascending, adnate, the following sessile, growing gradually larger, horizontal, the largest to $8 \mathrm{~cm}$. long, to $13 / 4 \mathrm{~cm}$. broad at or near the truncate base, deeply pinnatipartite, narrowed gradually towards the serrate, acuminate apex, the lower shortly petiolulate, somewhat deflexed and abbreviated, the costa squamulose beneath, the scales acuminate, the lower subulate or lanceolate, ferrugineous, the following growing gradually smaller, ovate and paler. Segments spreading, rather straight, close or nearly so, to $21 / 2-3 \mathrm{~mm}$. broad, slightly narrowed near the base, serrate towards the blunt apex, otherwise twice serrulate, the costula naked above, minutely pale-bullate-squamulose towards the base beneath, the veins to 9 on a side, the higher simple, the others forked, rarely 3-furcate. Texture papyraceous; surfaces naked; under surface when dry more or less olivaceous or apparently glaucous. Sori to \pm 4 on a side, subcostular or nearly medial, occupying the lower veins; capsules intermixed with pale, articulated hairs not longer than the capsules. - Stipe and main rachis unknown.

Batu.

\section{DICKSONIA, VHéritier.}

(1) D. Inumei, Moore.

Also in New Guinea (t. Ridl.).

(3) D. sorbifolia, Sm.

Pinnulae subcoriaceous to firm-coriaceous, the lowest anterior often the largest, the lowest posterior often abbreviated; edges crenulate towards the base; veins mostly forked; sori exserted, terminal on the teeth; 
indusium 2-valved, the outer valve cucullate, formed by the apex of a tooth, the inner valve flat, transversely oblong or suborbicular, distinctly developed. - Omit the synonym D. papuana Muell.

Forma typica: Sterile portion of the fertile teeth proportionally short and broad, shorter than the fertile portion.

Var. Ientara: Sterile portion of the fertile teeth proportionally long and narrow, longer than the fertile portion.

(3a) D. papunana, Muell., Pap. Pl., IV, 76.

Near D. sorbifolia Sm. but the pinnae shorter, to $\pm 4{ }^{1} /_{2} \mathrm{~cm}$. broad, the pinnulae to $2 \frac{1}{2} \mathrm{~cm}$. long by at best $6 \mathrm{~mm}$. broad, serrulate throughout, the lower not rarely shorter than the central ones; the inner valve of the indusium less distictly developed, much broader than deep or even obliterate. - We possess three specimens (Sclechter Nos. 14207, 14460, Copland King No. 103) with abbreviated and non-abbreviated lower pinnulae, with contracted and non-contracted fertile pinnulae; Mueller's original plant is unknown to me but Schlechter's No. 14460 (with somewhat abbreviated lower and non-contracted fertile pinnulae) seems to be the typical form.

New Guinea.

\section{GLEICHENIA, Smith.}

\section{§ 3. MERTENSIA.}

(3d) See No. $5 a$.

(3e) G. excelsa, J. Sm., Hk., Spec. Fil., I, 5, tab. IV $B ; G$. glauca, Hk. var., C. Chr., Ind. Fil.

Near G. glauca J. Sim. but the pinnulae remote, with the lowest segments often semihastate with a short or more elongated, horizontal lacinia on the lower side.

Philippines.

\section{(5a) A. gigantea, Wall.}

Ultimate segments more or less remote, not positively contiguous. 
(7b) C. monticola, Fidl., in Trans. Lin. Soc., Bot., 2nd Ser., IX, 252.

Stipes fragile, $\pm 11 \mathrm{~cm}$. long, scaly, the scales lanceolate, acuminate, bright-brown at the base. Fronds forked. Branches dichotomous, twice branched, the rachises scaly, the scales white-woolly at the apex. Pinnulae $\pm 9 \mathrm{~cm}$. long by $5 \mathrm{~cm}$. broad. Ultimate segments ovate, \pm $2 \mathrm{~cm}$. long, obtuse, much recurved at the edge. Texture very coriaceous; surfaces naked; under surface glaucous; colour black-brown when dry; veins 5, prominent, branched. - Habit of G. microphylla $R$. $B r$.

New Guinea.

\section{(9) C. deaniea, Kuhn.}

A plant received from Savaii, gathered by Reinecke (No. 82i), has the rachises minutely squamulose, and the lobes varying from $1 / 2-21 / 2$ $\mathrm{cm}$. long, sparingly and minutely fibrillose beneath.

(96) A. amoena, v. A. v. R., in Bull. Btz., 1916, XXIII, 12.

Stipes $30 \mathrm{~cm}$. or more long, at length naked. Fronds pinnate in the adult plants, probably dichotomous at the apex, the branches repeatedly dichotomous at an acute angle or the lowest branches pinnate and dichotomous, the axils provided with tufted, castaneous or ferrugineous, subulate, ciliate squamules. Primary and secondary branches $\pm 4-6$ $\mathrm{cm}$. long, nudate, provided with deciduous, spreading squamules similar to those of the axils; following branches foliaceous; tertiary branches \pm $3 \mathrm{~cm}$. long, lobed, the lobes reduced, passing gradually into those of the higher branches; ultimate branches suberect, linear-lanceolate, $10-35 \mathrm{~cm}$. long, $1 \frac{1}{2}-2 \mathrm{~cm}$. broad, deeply pinnatifid, narrowed gradually into an acuminate apex, the lobes spreading, $\pm 3 \mathrm{~mm}$. broad, toothed at the blunt apex. Texture firm-membranaceous or papyraceous; costae and surfaces naked; under surface glaucous. Sori medial, consisting of 3-4 capsules.

Lingga Islands.

(14a) See No. 9.

\section{HYMENOPHYLLUM, Smith.}

\section{§ 1. EUHYMENOPHYLLUM.}

(9) H. bnalium, Hk. Grev.

Also in Nero Guinea (t. Ridl.).

Ferns and Fern Alites. 
(13) H. salakense, rac.

Also in Sumatra.

\section{TIRIOHOMANES, Linné.}

\section{§ 2. EUTRICHOMANES.}

\section{(2) T. Mntleyi, ש. D. $\boldsymbol{B}$.}

Fronds bounded by a strand of darker or thickened cells.

Omit the synonym T. Henzaiense Bedd., which is a Burmese species near T. minutissimum $v . A . v . R$.

( $5 b)$ T. mimutissimum, v. A. . R., in Philipp. Journ., XI", 102, tab. V, fig. 1 .

Rhizome filiform, deciduously dark-tomentose. Stipes seriate, $0-2$ $\mathrm{mm}$. long, deciduously dark-tomentose, as is the lower part of the costa. Fronds different in shape, costate, $4-5 \mathrm{~mm}$. long, $1-4 \mathrm{~mm}$. broad, the apex rounded or rotundate-truncate; barren fronds mostly roundish-oblong, broadly ovate or cuneate-obovate, entire or nearly so, whether or not emarginate, retuse or 2-lobate at the apex, the costa evanishing in the upper $1 / 4-1 / 2$ of the frond; fertile fronds mostly linearcuneate or cuneate-obovate, emarginate to 2-fid at the apex, the costa terminating in the sinus. Texture thin; veins pinnately arranged, erectopatent in the narrowest fronds, apparently flabellate in the broadest fronds; spurious venules few, parallel to the real veins. Sori solitary and terminal on the costa, exserted, sessile or short-stalked; indusium infundibuliform, the mouth dilated, spreading, 2-valved, the valves semiorbicular; receptacle exserted, fragile.

Amboina.

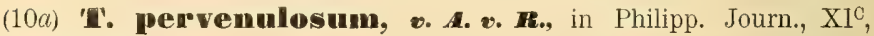
103, tab. V, fig. 2.

Rhizome creeping, filiform, copiously branched, probably caespitose, ferrugineo-tomentose, at length not rarely naked. Stipes scattered, filiform, $1 / 2-5 \mathrm{~mm}$. long. Fronds simple or more commonly $2-3$-fid with simple, forked or rarely irregularly furcate-flabellate segments, the base cuneate to narrowly long-decurrent; simple fronds linear, 5-15 $\mathrm{mm}$. long, $1 \frac{1}{2}-2 \mathrm{~mm}$. broad, entire, the apex rounded, sometimes emarginate; 
divided fronds $5-20 \mathrm{~mm}$. long, 3-20 $\mathrm{mm}$. broad, with the primary segments erect, erecto-patent or spreading; ultimate segments varying from very short to $15 \mathrm{~mm}$. long, similar to the higher part of the simple fronds. Texture very thin; surfaces naked; a single central rib carried into each segment; spurious venules copious, scattered irregularly, short, straight or slightly curved or flexuose, erecto-patent or parallel to the costa, costula or margin. Sori 1 or more; solitary and terminal on the simple fronds or the segments of the divided fronds; indusium infundibuliform, quite sunk, the mouth dilated, spreading, scarcely 2-valved; receptacle not or shortly exserted.

Amboina.

10. LYGODIUM, Swartz.

\section{§ 2. HYDROGLOSSUM.}

(14) L. Versteegit, Christ.

Also in Luzon.

15. OLFANDIRA, Cuvanilles.

(4) (1. neriiformis, Cax.; Aspidinm neriiforme, Sio., Kze, Farnkr., I, tab. XVIII.

(6) D. Wallichii, Pr.; Aspidium Wallichii, Hh., Kze, Farnkr., I, tab. XIX.

\section{NEPHTROLFPIS, schott.}

\section{§ 2. EUNEPRHOLEPIS.}

(11b) N. Thomsoni, v. A. v. R., in Bull. Btz., 1917, XXIV, 2.

Near N. radicans $K u / h n$ but the fronds to $150 \mathrm{~cm}$. or more long and 
to $7 \mu_{2} \mathrm{~cm}$. broad, the lower pinnae small, roundish or oblong, rounded at the apex, the following growing gradually longer, falcate and acuminate, the central the longest, to $33_{4}^{3 /} \mathrm{cm}$. long, the higher growing gradually shorter, the costae provided with scattered pale-brown hairs, as is the rachis, the sori more or less immersed, prominent above, the projections subconical, the indusia round (subreniform with a closed sinus).

New Guinea.

\section{POLYSTIOHUM, Roth.}

(6a) P. truncatulum, $v, A, v, R$.

Omit this, it being referred to Dryopteris adnata $v . A . v . R$.

\section{DIDYMUCHI,AENA, Desvaux.}

D. Iumulata, Desw.; D. dimidiato, Kze, Farnkr., I, tab. LXXXIV.

\section{PLEOCNEMIA, Prest.}

(8) P. Ievexa, v. A. v. R.; - var, permutata, v. A. V. R., in Bull. Btz., 1916, XXIII, 18.

Var. permutata: Like var. minor, but the upper surface copiously, though very minutely, glanduloso-puberulous, and the under surface naked or nearly so. - Java.

\section{DREYOFTERIS, Adanson.}

\section{\$ 1. LASTREA}

(4) ID. Koor'dersii, Christ.

Ultimate segments narrowly linear-lanceolate to subclavate; veins not invariably black. 
(6b?) D. Klossii, v. A. v. R.; Lastrea Klossii, Ridl., in Trans. Linn. Soc., Bot., 2nd Ser., IX, 257.

Stipes slender, black-purple, hairy, provided beneath with few scattered, broadly ovate, thin scales. Fronds $\pm 30 \mathrm{~cm}$. long, $5-51 / 2 \mathrm{~cm}$. broad, the rachis hairy and scaly, the scales red-brown. Pinnae cut down nearly to the costa, the largest $\pm 21 / 2 \mathrm{~cm}$. long by ${ }_{1 / 4} \mathrm{~cm}$. broad, the lower hardly abbreviated. Lobes oblong, obtuse, entire. Texture coriaceous; costulae sparingly scaly, the scales red-brown; veins \pm 8 . Sori medial on the veins; indusium reniform. - The proper place of this species is uncertain because of incomplete description.

New Guinea.

(14) U. Heccariana, C. Chr.; Lastrea Beccariana, Ridl., in Trans. Linn. Soc., Bot., 2nd Ser., IX, 257.

Also in New Guinea (t. Ridl.).

(27) D. conteronimoides, C. Chr.; Lastrea Macgregorii, Ridl., in Trans. Linn. Soc., Bot., 2nd Ser., IX, 257.

(30) D. admata, v. A. $\boldsymbol{\text { R.; }}$ D. filix mas, Schott, var., C. Chr., Ind. Fil.; Aspidium adnatum, Bl., Enum., 162; [not A. paleaceum, Don (not Bl.), Rac. Flor. Btz., I, 171]; A. filix mas, Sw., var. paleaceum, Moore, Mett., Farng., IV, Phegop. \& Aspid., 55, p. p.; Polystichum truncatulum, v. A. v. R., in Bull. Btz., 1914, XVI, 60, tab. VII.

Rhizome short, erect, the scales brown, narrowly subulate, subentire. Stipes to $20 \mathrm{~cm}$. or more long, densely scaly like the rachis; lower scales of the stipe partly long, narrowly subulate, reddish-brown, partly hairlike, partly minute, irregularly fimbriate; higher scales of the stipe similar to the lower ones of the rachis; higher scales of the rachis gradually similar to those of the costae beneath. Fronds lanceolate-oblong, to 45 $\mathrm{cm}$. or more long, $15-20 \mathrm{~cm}$. broad at or about the middle, acuminate. Pinnae sessile, somewhat remote, linear; higher pinnae spreading, adnate, blunt, simple or slightly incised; central pinnae largest, horizontal, to $1 \frac{1}{2} \mathrm{~cm}$. or more broad, bluntly or sometimes subacutely acuminate, the apex crenate, the edge cut down to the costa, the base truncate; lower pinnae gradually abbreviated, more remote, deflexed, blunt. Segments subhorizontal, close, oblong, to $3-4 \mathrm{~mm}$. broad, subentire, or crenulate to sparingly crenulate-subserrulate at the rounded or rotundate-truncate 
apex, the higher confluent or connected by a narrow wing; the lowest sometimes free. Texture subcoriaceous or coriaceous; costae copiously fibrillose-setose above, squamulose beneath, the squamules lanceolate, long-acuminate, pale-ferrugineous, intermixed with much smaller ones of the same shape; costulae and veins sparingly fibrilloso-setulose above, naked or sparingly appresso-pilose beneath; veins to \pm 4 on a side, forked, the higher or highest simple. Sori medial, on the anterior veinlets; indusium pale-ferrugineous. - See Copeland's information in Philipp. Journ., VIII ${ }^{\mathrm{C}}$, 140.

Java.

(31a) D. subsagenioides, v. A. v. R. (not Christ).

Omit this name, it should be D. Vangenderenstortii $v$. A. $v . R$.

(31a) D. Vangenderenstortii, v. A. v. R., in Bull. Btz., 1916, XXIII, 11; D. subsagenioides, (not Christ), v. A. v. R., in Bull. Btz., 1913, XI, 9.

(34) D. filix mas, Schott.

This species is construed as including two distinct forms: D. filix mas Schott and D. cochleata C. Chr .

(34*) D. filix mas, Schott; - var. patentissima; var. parallelogramma, v. A. v. R., Mal. Ferns, 192-193; A. patentissimum, Wall., List, No. 340; A. paleaceum, Don (not Bl.), Rac., Flor. Btz., I, 171 (not A. adnatum, Bl., Enum., 162); A. filix mas, Sw., var. paleaceum, Moore, Mett., Farng., IV, Phegop. \& Aspid., 55, p. p.; Nephrodium filix mas, Rich., var. fibrillosa, Clarke, in Trans. Linn. Soc., Bot., 2nd Ser., I, 520, tab. 70; var. marginata, Clarke, 1. c., 521.

Stipe and rachis paleaceous, the scales lanceolate or subulate, palebrown to blackish; fronds uniform, ovate-lanceolate or oblong, costae more or less squamulose or at length naked; surfaces naked or the under surface more or less piloso-paleacous; sori not covering the whole under surface of the fertile segments; indusium entire.

Forma typica: Stipe and rachis more or less scaly, the scales palebrown to brown; pinnae with the segments oblong, bluntly rounded at the apex, naked beneath or slightly piloso-paleaceous. - Inhabiting nearly the whole northern hemisphere and the cool alpine regions of the tropics.

Vax. patentissima : Stipe and rachis densely scaly, the scales 
varying from dark-brown to blackish; pinnae with the segments parallelogram, truncate or rotundate-truncate at the apex, more distinctly piloso-paleaceous beneath. - I cannot distinguish from this a specimen from Trinidad (America) received as A. filix mas var. parallelogrammum (=A. paleaceum Sw.). - Scattered in the cool alpine regions of tropical Asice and America.

Var. margimata: Rachises nearly naked; lowest pinnae often 2-3-pinnate; segments oblong, obtuse, serrate to deeply pinnatifid sometimes nearly to the costa. - Luzon; Central China, North India.

(34**) D. cochleata, C. Chr., Ind. Fil.; D. filix mas, Schott, nar. cochleata, v. A. v. R., Mal. Ferns, 193; Lastrea cochleata, Moore, Bedd., Ferns S. I., tab. CXV; L. filhx mas, Pr., var. cochlenta, Bedd., Handb. Ind. Ferns, 250, fig. 130; Aspidium filix mas, Sw., var. cochleatum, Christ, Farnkr. d. Erde, 257; Nephrodium coehleatum; Don, (oldest name).

Stipe and rachis paleaceous or often quite glabrous; fronds dimorphous in the typical form; barren fronds subdeltoid, pinnate, with the pinnae deeply pinnatifid, and the segments provided with a sharp tooth on the upper side near the apex; fertile fronds 1-2-pinnate, the leaflets contracted, bead-like, serrulate; sori very large, completely covering the under surface of the leaflets.

Malacca; Brit. India.

(5yd) D. Escriturii, v. A. v. R., in Bull. Btz., 1916, XXIII, 10.

\section{§ 2. NEPHRODIUM.}

(83) D. urophylla, C. Chy.

Indusium fugacious or undeveloped, not rarely metamorphosed into a bunch of short, setiform hairs.

(84a) D. tandikatensis, v. A. v. I.

Fronds to $45 \mathrm{~cm}$. long except the auricles; pinnae to 4 on a side, ovate-oblong to obovate-oblong, varying from entire to very coarsely and irregularly toothed. - The systematical place of this species should be under No. $87 c$.

(87c) See No, $84 a$. 
(109e) D. pseudo-arbuscula, v. A. v. R., in Philipp. Journ., $\mathrm{XI}, 106$.

Rhizome erect, forming a short trunk, the extremity clothed with long, subulate, entire, pale-brown scales. Stipes tufted, $2 \frac{1}{2}-31 / 2 \mathrm{~cm}$. long below the reduced pinnae, shortly hispid. Fronds lanceolate, 20-25 cm. long, 5-6 cm. broad at the middle, acuminate, the rachis densely hispid with long, pale, acute hairs. Pinnae about 18 on each side below the terminal one; terminal pinna triangular, the apex subcaudate, subentire, the base deeply pinnatifid; lateral pinnae remote, linear, blunt, the higher adnate, the others subpetiolulate; largest pinnae $3 \mathrm{~cm}$. long, to $7 \mathrm{~mm}$. broad at the truncate or subtruncate, slightly dilated (sub1-2-auriculate) base, lobed to $1 / 3$-way down to the costa, the others less incised or subentire; lower pinnae more distant, suddenly or gradually reduced to minute auricles. Lobes blunt, entire or sparingly repandocrenate. Texture herbaceous; both surfaces minutely puberulous; costae and veins hispid beneath; main veins oblique, the higher simple, the others pinnate; veins simple, $1-3$ on a side, the single or the lowest anastomosing. Sori medial on the veins, proportionally large; indusium persistent, copiously hispido-ciliate.

Amboina.

\section{MESOCHLAENA, R. Brown.}

(1) DI. polyearpa, Bedd.; Sphaerostephanos asplenioides, J. Sin., Kze, Farnkr., I, tab. XI-XII.

\section{ASPIDIUM, Swartz.}

\section{\& 1. TECTARIA.}

(1) singaporianum, Wall.; Kze, Farnkl., I, tab. IX, fig. 1. Indusium round and entire or subreniform with conspicuously overlapping basal lobes. 


\section{$\S 2$. SAGENIA.}

(11*) See No. 1.

(24) A. nebulosum, C.Chr.; - var. gigas, v. A. V. R., in Bull. Btz., 1916, XXIII, 6.

Forma typica: Stipes deciduously finely fibrillose or puberulous; lowest pinnae sessile or shortly petiolulate.

Var. gigas: Stipes to $\pm 80 \mathrm{~cm}$. long, the seales more numerous, long, subulate; fronds to $\pm 55 \mathrm{~cm}$. long, the terminal pinna with the lower lobes shorter, the lowest pinnae more conspicuously petiolate; indusia rudimentary, soon hidden among the capsules.

(27a) A. Fidleysumm, v. A. v. Re; Asplenium alaium, Ridl., in Trans. Linn. Soc., Bot., 2nd Ser., IX, 256.

Stipes $60 \mathrm{~cm}$. more or less long, winged at the base. Fronds about $60 \mathrm{~cm}$. long by $25 \mathrm{~cm}$. more or less broad, lobed, the costa clothed beneath with large, lanceolate, acuminate, brown scales; fertile fronds somewhat narrower than the barren ones. Lobes lanceolate, to $15 \mathrm{~cm}$. long by 3 cm. broad, cuspidate-acuminate; terminal lobe 3-fid, lowest ones unequally 2-fid. Texture herbaceous; surfaces naked; costulae scaly beneath; veins distinct; areolae large; included free veinlets present. Sori numerous, in 1 row on each side near the costulae; indusium reniform, persistent.

New Guinea.

\section{LINDSAYA, Dryander.}

\section{§ 1. ODONTOLOMA.}

(8b) L. Wollastonil, v. A. v. R.g Odontosoria tenera, Ridl., in Trans. Linn. Soc., Bot., 2nd Ser., IX, 254.

Rhizome slender, elongated. Stipes scattered, pale, purplish in the lower part. Fronds pinnate, $\pm 16-20 \mathrm{~cm}$. long by $2 \mathrm{~cm}$. broad. Leaflets shortly petiolulate, cuneate, $\pm 1 \mathrm{~cm}$. long, dimidiate, the lower edge entire, the upper edge cut down into \pm 5 lobes. Lobes linear, 
rounded and emarginate at the apex. Texture herbaceous; surfaces naked; colour pale-green; a single central vein in each lobe. Sori solitary and subterminal on the lobes; indusium ovate.

New Guinea.

\section{§ 2. EULINDSAYA.}

(19a) L oblancedata, v. A. v. R., in Bull. Btz., 1916, XXIII, 15.

Rhizome wide-creeping or scandent, the scales brown, small, lanceolate, deciduous. Stipes remote, $\pm 1 \frac{1}{2}-5^{1 / 2} \mathrm{~cm}$. long, semiterete, brown, naked, or sparingly scaly at the base. Fronds oblanceolate, simply pinnate, $\pm 10-20 \mathrm{~cm}$. long, $\pm 13 / 4-21 / 2 \mathrm{~cm}$. broad between the middle and the bluntly rounded apex, narrowed gradually towards the base. Leaflets $12-20$ on a-side below the terminal one; terminal leaflet broadly flabellate, not rarely as large as the largest lateral leaves, often broader than long; lateral leaflets semilunulate, horizontal, subsessile; largest lateral leaflets close, $\pm 1_{14}^{11} \mathrm{~cm}$. iong by $6 \mathrm{~mm}$. broad, the upper and outer edge rounded, broadly crenate at least in the upper part, the lower edge decurved, the inner edge parallel to the rachis; lower lateral leaflets gradually reduced and rather remote, more decurved and more distinctly crenate. Texture thin; rachis naked, stramineous, quadrangular; surfaces naked. Sori along the upper and outer edge, interrupted.

\section{Sumatra.}

\section{(29) H. Iancea, Bedd.}

Variable, with the rhizome varying from short-ereeping to widescandent, the stipes stramineous to black-purple-brown, the fronds to 50 cm. long, the branches abruptly shortly acuminate to subcaudate, the leaflets $1 \frac{1}{4}-31 / 2 \mathrm{~cm}$. long, pale to dark when dry.

Forma typica: Fronds simply pinnate or more commonly 2-pinnate with $\pm 1-4$ branches on a side, the leaflets entire on the upper and outer edge.

Var. caudeta: A large form with more branches the usually, and the leaflets crenulate on the upper and outer edge. 


\section{\&2. SYNAPHLEBIUM.}

(32) H. davallioides, Bu.; Kzo, Falnkr., I, tah. VII.

(33b) I. subalpinn, v. A. v. IR., in Bull. Btz., 1916, XXIII, 15.

Rhizome creeping, naked (sparingly deciduously fibrillose?). Stipes approximate, sometimes more remote, $\pm 15-25 \mathrm{~cm}$. long, more or less obtusely quadrangular and grooved especially on the back and face, stramineous or pale-dirty-fuscous, naked. Fronds lanceolate, $\pm 22-30$ $\mathrm{cm}$. long by $4-5 \mathrm{~cm}$. broad, simply pinnate, the apex acuminate, the base slightly narrowed. Leaflets $\pm 30-35$ on each side below the terminal one; terminal leaflet lanceolate, acuminate, sparingly coarsely serrate, deeply lobed at the cuneate base; lateral leaflets subhorizontal or the higher more ascending; central leaflets largest, close or approximate, subsessile, linear-oblong, to $2 \frac{1}{2} \mathrm{~cm}$. long by $7 \frac{1}{2} \mathrm{~mm}$. broad, the apex bluntly rounded or obliquely truncate, the sides parallel or nearly so, the upper and outer edge incised 1/4-1/2-way down, the Jobes oblique, truncate or rotundate-subtruncate, the terminal and basal ones often much the broadest, the inner side parallel to the rachis, the lower side straight or very slightly up- or decurved. Texture firm-herbaceous; rachis acutely quadrangular, canaliculate on the face and back, stramineous or pale-dirtybrown, naked; surfaces naked. Sori subterminal on the lobes; indusium narrow. - Barren fronds not seen, but the fertile leaflets with the occasionally barren lower lobes and barren portions of fertile lower lobes acutely dentiform or acutely serrate or toothed. - Resembles at first sight a branch of $\mathrm{L}$. davallioides $B l$. but much larger.

Sumatra.

\section{HUMATA, Cavanilles.}

\section{§ 2. LEUCOSTEGIA.}

(21) H. Kingii, Diels.

Omit this, it being referred to Davallodes.

(22) H. viscidula, v. A. v. R.

Omit this, it being referred to Davallodes. 


\section{DAVALLIA, Smith.}

\section{§ 1. SCYPHULARIA.}

(2) D. penta phylla, BI.; Kze, Farnkr., II, tab. CVIII.

\section{§ 2. COLPOSORIA.}

(22a) See No. 24*.

(24*) D. subdissecta, v. A. v. R., in Bull. Btz., 1916, XXПI, 11.

Like D. dissecta J. Sm. but the soriferous lobules proportionally broader at the base, retuse at the apex with mostly 2 teeth unequal in length, of which the outer one sometimes may be elongated to a short horn, the indusia semicylindrical, \pm twice to thrice as long as broad, proportinally broadly winged by the edges of the lobules, and the truncate apex nearly reaching the apex of the lobule.

Java.

\section{MICROULEPIA, Prest.}

(10) N1. strigosa, Pr.

Forma bidentata: Lower pinnulae sometimes much elongated, not rarely pinnate again.

(15) จน. proxinama, Pr.

Veins beneath sparingly short-hairy, at length often naked; indusia sparingly short-hairy at the base, at length not rarely naked.

(15 $\alpha)$ Sue No. 10.

\section{TAPEINIDIUM, Christensen.}

(3) T. gracile, $v, A . v, R$.

Omit this name, it should be T. biserratum v. A. v. R. - Forma decomposita is a small form of T. amboinense C. Chr. 
(3) T. biserratum, v. A. v. Re.; T. gracile, v. A. v. R., Mal. Ferns, 315; T. pinnatum, C. Chr., var., C. Chr., Ind. Fil.; Microlepia pinnata, J. Sm., var. gracilis, Copel., Polypod. Philipp., 55; M. pinnata, J. Sm., var. Luzonica, Bedd., Handb. Ind. Ferns, Suppl., 15; Wibelia gracilis, Christ (not Bl.), in Ann. Btz., XV, 154; Davallia biserrata \& gracilis, Bl., Enum., 232-233; D. Luzonica, Hk., Spec. Fil., I, tab. LX, fig. 235.

Forma typica (T. gracile, v. A. v. R., forma grandidentata): Fronds simply pinnate; pinnae linear, $\pm 5-15 \mathrm{~mm}$. broad, at least the lower coarsely serrate to toothed or subpinnatifid, the teeth broadly and obliquely deltoid, acute and entire or blunt and 2-serrulate, the lobules short, oblique, obtuse or truncate, subentire, emarginato-2-denticulate or crenulate.

Forma gracilis (T. gracile. v. A. v. R., forma dissecta): Fronds pinnate; pinnae $\pm 2-5 \mathrm{~cm}$. broad, at least the lower deeply pinnatifid nearly to the costa or pinnate again; secondary segments (lobes or leaflets) oblong to linear-lanceolate, entire to obliquely toothed, adnate, decurrent or cuneate at the base.

Malaya.

(4) T. amboinense, C. Chr.; T. gracile, ", A. v. R., formu decomposita, V. A. v. R., Mal. Ferns, Suppl., 234; Wibelia pinnata, Fée (not Bernh.) var. gracilis, Christ, in Schum. \& Laut., Flor. deut. Sch.geb., Suppl., 40.

Tertiary segments (lobes or leaflets) narrowly linear or linear-lanceolate, entire to serrate or toothed.

\section{A DIANTUUM, himé.}

\section{§ 1. EU-ADIANTUM.}

(5c) A. Hebonisonil, v. A. v. R., in Philipp. Journ., XIC, 110.

Rhizome short, densely clothed with narrowly linear-subulate, palerufo-fuscous scales. Stipes approximate, black-brown, naked, glossy, as are the rachises, scaly and finally roughish towards the base. Fronds about $10-15 \mathrm{~cm}$. long, to $12 \mathrm{~cm}$. bread, pinnate with $1-2$ branches on a side below the terminal one. Leaflets approximate, shortly and finely petiolulate, dimidiate-oblong, $1-1 \frac{1}{2} \mathrm{~cm}$. long, to $3 / \mathrm{cm}$. broad, rounded at the apex, the upper and outer edge serrulate or slightly 2-lobate and 
serrulate, pellucid-striated; terminal leaflets rhomboidal-lanceolate, lower sometimes subrotundate. Texture coriaceous; upper surface somewhat glossy, lower opaque; veins rather flabellate, terminating in the sinuses between the serratures. Sori $1-2$ to a leaflet, on the upper edge, transversely oblong or linear-oblong, rather straight; sporangia springing from the veins only; indusium narrow, coriaceous, dark-brown.

Amboina.

(10a*) A. Edgeworthif, Mk.; Bedd., Ferns Br. I., I, tab. XVII.

Fronds linear-lanceolate, about $2 \frac{1}{2} \mathrm{~cm}$. broad, acuminate, the lower leaflets somewhat ablureviated and deflexed, the higher growing gradually smaller and obliquely triangular.

40. PLAGIOGYRIA, Metenius.

(4) P. sInuca, Mett.; Lomaria glanca, Bl., Kze, Farnkr., II, tab. CXXXVIII.

(6) P. euphlebia, Mett.; Lomaria euphlebia, Kze, Farnkr., II, tab. CXXV.

\section{4:3. HISTIOPTERIS, Smith.}

(*1) r. alte-alpina, v. A. v. I., in Bull. Btz., 1916, XXIII, 13.

Rhizome creeping, paleaceous, the scales brown, fibril-like. Stipes to $6 \mathrm{~cm}$. long, naked, subcastaneous when dry. Fronds deltoid, 5-10 cm. long by about as broad, 2-pinnatifid, sub-2-pinnate. Lowest pinnae largest, to $2 \frac{1}{2} \mathrm{~cm}$. broad, deeply pinnatifid, at best pinnate at the base, with the segments (lobes or pinnulae) triangular, blunt or bluntish, revolute at the edge, the lowest (stipule-like) ones more or less abbreviated, narrowly subcordate at the base. Texture rigid; veins once or twice forked, somewhat prominent above.

Sumatra. 


\section{5a. PTERIS, Linné.}

\section{$\$ 1$. EUPTERIS}

(9a) Pt. Brooksiana, v. A. v. R., in Bull. Btz., 1916, XXIII, 19.

Rhizome short, the scales minute, subulate-triangular, blackish. Stipes stramineous to purple-brown-black, naked, $10-50 \mathrm{~cm}$. long, those of the fertile fronds much the longest, 2-marginate-canaliculate on the upper side except towards the base. Fronds ternate; barren fronds $\pm 15-20$ cm. long. Central (terminal) pinna short-stalked, with a long-linear terminal segment $1 \frac{1}{2}-2 \mathrm{~cm}$. broad and coarsely serrate-dentate towards the bluntly acuminate apex besides $1-4$ remote or contiguous segments near the acutely subdecurrent base, which are oblong or linear-oblong, to $2 \mathrm{~cm}$. long by $3 / 4-1 \mathrm{~cm}$. broad and more or less coarsely serrate-dentate at the blunt apex; lateral (basal) pinnae similar to the central one but much shorter, narrower, with $1-2$ basal segments on the lower side only. Texture coriaceous; surfaces naked; costae prominent beneath, 2-marginatecanaliculate above; veins numerous, spreading, simple or once to twice forked. Fertile fronds contracted, with the central pinna longer stalked, and the lateral segments suddenly dilated on the lower side at the base. Sori not reaching the repando-crenate apex of the fertile segments.

\section{Sumatra.}

(44) Pt. Iripartita, Sw.; - var. dissoluta, v. A. v. R., in Bull. Btz., 1916, XXII, 20.

Forma typica: Ultimate segments approximate or moderately close, separated by sinuses with a blunt angle. - Paleotropical.

Var. dissoluta : Ultimate segments (at least those in the lower half of the larger pinnulae) more remote, separated by sinuses with an obliquely truncate angle. - Sumatra.

\section{PAESLA, st. Hilaire.}

(2) P. rugosula (not rugulosa), Kuhn; P. rugulosa, Diels (not Kuhn), in Eng. \& Prantl, Nat. Pfl.fam., I, 297.

Omit this species, as being not Malayan. 


\section{LOM ARIA, Willdenow.}

(1) L. Patersoni, spr.; Kze, Farnkr., I, tab. XXXIV; 一 var. elongata; L. punctata, Bl., Kze, II, tab. CXXXVII.

\section{HI, EOHNUJM, Limné.}

\section{(8) FB. egregium, Copel.}

Specimens received from the Phitippines differ from Copeland's original description in having the fronds smaller at least when barren, pinnate at best at the very base only, otherwise deeply pinnatifid often nearly to the costa, the segments very dimorphous, the barren segments approximate, hardly dilated at the base, the lower barren segments either abbreviated or gradually much reduced, the fertile segments remote, narrowly linear and lomarioid or sublomarioid from a rather suddenly much dilated base.

\section{DIII,AZIUUM, Swartz.}

\section{§ 1. EUDIPLAZIUM.}

(7) D. silvaricum, Sav.g - var. latipinnatum, v. A. v. R., in Bull. Btz., 1916, XXIII, 10

\section{(28a) E. Pelensenii, Christ.}

Stipes piloso-fibrillose and squamulose but more distinctly towards the base; rachis and at least the costae and veins piloso-fibrillose or fibrilloso-paleaceous beneath or on both sides.

(39d) D. albido-squanmatum, v. A. v. $\boldsymbol{R}$. , in Bull. Btz, 1916, XXIII, 9.

Rhizome erect. Stipes $\pm 35 \mathrm{~cm}$. long, subquadrangular, grooved above, like the rachises dark-fuscous and squamulose, at length rough by the persistent bases of fallen scales; scales squarrose, small, lanceolate or subulate, fuscous, dark-margined, deciduously denticulate, the teeth hori- 
zontal, minute, divided at the apex into 2 divaricating, decurved toothlets. Fronds ovate-lanceolate, $\pm 70 \mathrm{~cm}$. long, 2-pinnate, acuminate. Pinnae \pm 10 on a side; higher pinnae lobed to deeply pinnatifid; central pinnae largest, stalked, arcuate-ascending, ovate, to $25 \mathrm{~cm}$. long, pinnate, acuminate; lower pinnae deflexed. Pinnulae to \pm 8 on each side below the terminal one; terminal pinnulae deltoid, serrate at the apex, gradually deeply pinnatifid at the base; lateral pinnulae remote, more or less horizontal, the higher adnate, the others sessile or subsessile, subobovateoblong; central or inframedial pinnulae of the largest pinnae largest, $5-6^{1 / 2} \mathrm{~cm}$. long, $2-2^{1 / 3} \mathrm{~cm}$. broad at or above the middle, lobed $1 / 5-1 / 2$. way down or somewhat more to the costa, serrate at the blunt or rounded apex, not rarely more or less auriculate on one side or on both sides at the truncate base; lower pinnulae more or less abbreviated and deflexed. Lobes spreading or subhorizontal, to $5 \mathrm{~mm}$. each way, crenated or toothed at the truncate or rounded apex, separated by narrow, acute sinuses. Texture herbaceous; surfaces naked but the upper surface prov. ided with deciduous, white-cretaceous, dot-like squamules on the vein tips; main veins pinnate in the lobes; veins to \pm 5 on a side, simple, suberect, upcurved, the lowest not reaching the margin. Sori to 4 on a a side, the lowest the longest, often double; indusium persistent, brown. - Young plants simply pinnate, with the fronds rather similar to the largest pinnae of the adult plants but less copiously soriferous.

Sumatra.

\section{ASELFIVIM, Linné.}

\section{§3. EU-ASPLENIUM.}

(356) A. squanuliferum, v. A. v. R. in Bull. Btz., 1916, XXIII, 6 .

Stipes aggregate, short, like the rachis black-brown or castaneous and copiously, deciduously chaffy, the squamules black or castaneous, rather suddenly long-filiform-subulate from a broad, sparingly piloso-ciliate base. Fronds pinnate, lanceolate or oblanceolate, $75-85 \mathrm{~cm}$. long by $12 \frac{1}{2}-17 \frac{1}{2} \mathrm{~cm}$. broad, narrowed towards both ends but more gradually Ferns and Fern Alutes. 
towards the base, the apex abruptly short-acuminate, the base narrowly cuneate. Pinnae sessile, numerous; terminal pinna shortly deltoid, deeply pinnatifid at the base; lateral pinnae subhorizontal; central pinnae largest, approximate, linear-lanceolate, to $9 \mathrm{~cm}$. long, to $1 \mathrm{~cm}$. broad above the basal auricle, acuminate, the point bluntish or acute, the edge coarsely obliquely serrate towards the apex, serrulate-crenulate towards the base, the base obliquely cuneate, auricled on the upper side, the auricle bluntly deltoid; lower pinnae very gradually reduced, nearly close, the lowest obliquely roundish, auricle-like. Texture coriaceous; upper surface naked, or slightly minutely squamulose on the costae; under surface squamulose on the costae and veins, the squamules minute, deciduous, scattered, black or castaneous, irregularly stellately branched; veins very oblique, once or twice forked. Sori numerous, occupying the lower $1 / 2-2 / 3$ of the veins; indusium firm, persistent.

Sumatra.

\section{§ 4. DAREA.}

(80a) A. aclnille follioun, C. Chr., Ind. Fil.; A. rutalofium, Kze, Hk. Bk., Syn. Fil., 222; A. protongatum, Hk., 2nd Cent. of Ferns, tab. XLII; Adiantum achilledefolium, Lam., (oldest name).

Rhizome short, ascending, hardly scaly. Stipes aggregate, $\pm 15-25$ cm. long, subcompressed, naked, stramineous or greenish. Fronds elongatelanceolate, $\pm 15-30 \mathrm{~cm}$. long, truncate at the base. Pinnae 10-20 on a side, somewhat remote, the lower and central horizontal or spreading; the higher more ascending; lower or central pinnae largest, subdeltoid to subrhomboidal, $2{ }^{11}-5 \mathrm{~cm}$. long or longer, eut down to the rachis or nearly so. Segments linear-oblong, oblique, blunt, the upper side somewhat narrowed at the base, the lower side decurrent; lowest anterior segments largest, rather spreading, sparingly pinnate or pinnatipartite on the anterior side; lowest posterior segments suppressed. Texture coriaceous or subchartaceous; rachis often prolonged and proliferous; colour palegreen; a single vein in each ultimate segment. Sori oblong; indusium firm-membranaceous.

South Africa, Brit. India across Malaya to Japan and China, Polynesia and New Caledonia. 


\section{0a. PIHEGOTTERIS, Fée.}

\section{§ 2. LEPTOGRAMMA.}

(22) Pl. Lotta, Mett.; - var. subcalcarata; Aspidinm calcaratum, Bl., var., Christ, MS. in Herb. Bog.

Pinnae, at least the largest, pinnatifid to $1 / 2$-way down to the costa below the entire or repando-crenulate, blunt or acute, triangular apex. Sori with the capsules somewhat setulose.

Forma typica: Pinnae relatively broad, with a short-triangular apex. Fronds resembling those of Dryopteris mollis Hieron.

Var. subcalcarata: Pinnae relatirely narrow, with a longtriangular apex. - Fronds resembling those of Dryopteris calcarata 0 . Ktze. - Sumatra (Mt. Singgalang, Beccari No. 4:30).

\section{§ 3. GONIOPTERIS.}

(31a) Ph. Fidleyana, v. A. v. R.; Goniopteris rutis, Ridl., in Trans. Linn. Soc., Bot., 2nd Ser., IX, 259.

Stipes scaly at the base, otherwise hairy like the rachis; scales lanceolate, acuminate; hairs rigid, red-brown. Fronds $\pm 60 \mathrm{~cm}$. long. Pinnae about 9, sessile, oblong, $\pm 16 \mathrm{~cm}$. long by $4 \mathrm{~cm}$. broad, entire, subabruptly cuspidate, shortly and broadly cuneate at the base. Texture herbaceous; main veins copious; veins $\pm 5-6$, slender. Sori round, terminal on the veins.

New Guinea.

(33) Ph. diversiloba, v. A. v. R.; Dryopteris div rsiloba, Christ, in Philipp. Journ., IIC, 199; C. Chr., Ind. Fil., Suppl.

Stipes 10-30 cm. long, those of the fertile fronds often the longest. Barren fronds $10-20 \mathrm{~cm}$. long, with $\pm 2-7$ pinnae on a side, the lobes to $5 \mathrm{~mm}$. broad. Fertile pinnae whether or not contracted.

(35a*?) Ph. Wollastonii, v. A. v. R.; Goniopteris vigida, Ridl., in Trans. Linn. Soc., Bot., 2nd Ser., IX, 258.

Fronds $\pm 45 \mathrm{~cm}$. long by $8 \mathrm{~cm}$. broad, the rachis densely hirsute, 
as is the stipe, the hairs rufous. Pinnae approximate, sessile, $\pm 5 \mathrm{~cm}$. long by $1 \mathrm{~cm}$. broad, the edge cut about 1/2-way down to the costa. Lobes rounded, recurved at the edge; veins 10, depressed above, prominent and hirsute below, the hairs black. Sori small, medial on the veins. - The proper place of this species is uncertain because of incomplete description.

New Guinea.

$\left(36 c^{*}\right)$ Pl. mamberamensis, v. A. v. R., in Bull. Btz., 191\%, XXIV, 3; Dryopteris memberamensis, v. A. v. R., MS. in Herb. Bog.

Stipe and rachis pale-fuscous, very minutely puberulous, soon glabrescent. Fronds lanceolate-ovate, $\pm 85--125 \mathrm{~cm}$. long, broadest at or above the base, 2-pinnatifid, suddenly acuminate. Pinnae numerous, rather remote, spreading or more ascending, linear-lanceolate, long-acuminate or caudate, the acumen entire, the edge cut $\pm 4 / 5$-way down to the costa; central pinnae sessile, truncate at the base; lower pinnae shortly petiolulate, narrowed gradually at the base; largest pinnae \pm $25-35 \mathrm{~cm}$. long, $2-2 \frac{1}{2} \mathrm{~cm}$. broad at the middle. Lobes numerous, separated by narrow, bluntish sinuses, entire or subentire, the lower and central subhorizontal, the central the largest, the following growing gradually shorter and more ascending, the higher tooth-like; largest lobes linear-oblorig, $3 / 4-1 \mathrm{~cm}$. long, 3-4 $\mathrm{mm}$. broad at the base, rounded at the apex. Texture herbaceous; surfaces naked; veins oblique, simple, to 12 on a side, the lowest meeting $\pm 1 / 3$ below the sinus and then either united or running abreast. Sori numerous, nearer the costula than the margin, slightly immersed.

Nero Guinea.

\section{§ 5. MENISCIUM.}

(45) Ph. cuspidata, Met.

Pinnae not rarely reddish when dry, acuminate to cuspidate, entire to crenate. Sori not invariably setose. 
606. DIOTYOPTERIS, Prest.

\section{$\S 1$. ARCYPTERIS.}

(11) D. Iabrusea, v. A. v. $\boldsymbol{R}$.

Omit the variety ternata. See No. $11 c$.

(11b) D. Brooksiae, v. A. v. R., in Bull. Btz., 1916, XXIII, 9.

Omit this, it being a form of Pleopeltis Zollingeriana $v$. A. v. R.

(11c) D. nusakembang ma, v. A. v. R.; $D . l a b v u s c a, v, A . v, R$, var. ternata, V. A. v. R., in Bull. Dép. Agr. I. N., 1908, 16, tab. I; Polypodium Labrusca, Rac. (not Hk.), Flor. Btz., I, 90; Nephrodium Labrusca, Rac., in Bull. Ac. Crac., 1902, 61, p. p.; Aspidium nusakembangana, v. A. v. R., MS. in Herb. Bog.

Rhizome short-creeping, the scales crowded at the apex, linearsubulate, fuscous. Stipes aggregate, $15-25 \mathrm{~cm}$. long, blackish and slightly scaly at the base. Fronds 3-partite or 3 -foliolate, $15-20 \mathrm{~cm}$. long, $121 / 2-15 \mathrm{~cm}$. broad, cordate at the base. Central segment 3-fid at the base with the central lobe 3-angular, acuminate, sinuate, the lateral lobes suberecto-patent, subsubulate, bluntish or acute, entire or subentire; lateral segments spreading or suberecto-patent, free or connected with the central one, obliquely lanceolate-ovate, acuminate, entire or subentire, the upper base rotundate-cuneate, the lower base broadly rounded. Texture subcoriaceous; upper surface naked, lower minutely hairy; main veins oblique, subflexuose, not reaching the margin; areolae numerous, irregular, with free veinlets. Sori copious, small, scattered irregularly.

Noesa Kembangan (Java).

6?. CONIOGIRAMMA, Fée.

Segments (pinnae, pinnulae) bounded at the edge by a strand consisting of 1 or more rows of sclerotic cells; vein tips (hydathodes) thickened, clavate. - See Hieron., in Hedwi., LVII, 278. 
1. Hydathodes neither reaching the marginal strand of sclerotic cells nor terminating in a bundle of sclerotic cells.

2. Segments cuneate to rotundate at the base.

(1) C. fraxinea.

2.2. Segments cordate to rotundate-truncate at the base.

3. Segments naked beneath.

(2) C. subcordata.

3.3. Segments more or less sparingly pilose beneath.

(3) C. squamulosa.

1.1. Hydathodes either reaching the marginal strand of sclerotic cells or terminating in a more or less elongated bundle of sclerotic cells, which may reach the marginal strand.

* Segments entire or subrepand.

(4) C. macrophylla.

* Segments crenulate, serrulate or toothed.

(5) C. intermedia.

(1) C. fraxinera, Diels; Hieron., in Hedwi., LVII, 286; - var. serrulata; Gymnogramma sermilata, Bl., Flor. Jav., II, tab. XLII; var. cremulata, v. A. v. R., in Bull. Btz., 1916, XXIII, 8.

Stipes at best somewhat squamulose at the base, for the rest naked, as are the rachises; fronds of young soriferous plants simply pinnate, of adult plants 2-pinnate to sub-3-pinnate at the base; segments (leaflets) herbaceous, gradually acuminate to abruptly cuspidate at the apex, cuneate to rotundate at the base, bounded by a narrow marginal strand consisting of $1-3$ rows of pale-coloured sclerotic cells.

Forma typlca: Edges entire or subrepand throughout; vein tips not reaching the marginal strand. - Brit. India acros Ceylon and Malaya to Formosa.

War. serrulata: Edges crenulate to serrulate below the entire or repand acumen; vein tips not reaching the bases of the crenulations or serratures. - Java.

(2) C. subcortatsa, Copel., in Philipp. Journ., IIIC, 823.

Stipes and rachises more or less sparingly provided with mostly caducous or rarely persistent squamules; fronds 2-pinnate; pinnulae membranaceous, the apex proportionally shortly acuminate or cuspidate, the base cordate to rotundate-truncate; edges serrulate or serrate except at the very base, the acumen often more coarsely serrate; surfaces naked; vein tips not reaching the marginal strand consisting of $2-3$ rows of sclerotic cells though often produced into the serratures,

Luzon. 
(3) C. squamuloss, Eieron., in Hedwi., LVII, 318; (? C. subcordata, Copel., forma or var.).

Very near C. subcordata Copel. but the under surface pilose with scattered, articulated hairs.

Luzon.

(4) C. macrophylla, Hievon., in Hedwi., LVII, 291; C. fraxinea, Diels, var. Copelandi, Christ, in Philipp. Journ., IIC, 171; Gymnogramma javanica, Bl., var. macrophylla, Bl., Flor. Jav., II, 95; Fée, Gen. Fil., 167; - var. sumatrana, v. A. v. R., in Bull. Btz., 1917, XXIV, 2.

Fronds simply pinnate; pinnae entire or subrepand, cuneate to rotundate-cuneate at the base, the largest $20-30 \mathrm{~cm}$. long, $4-8 \mathrm{~cm}$. broad; vein tips straight or falcate, terminating in a more or less elongated bundle of sclerotic cells reaching or nearly reaching the cartilagineous edge consisting of 4 or more rows of sclerotic cells; surfaces naked.

Forma typica: Pinnae elongate-lanceolate, the cartilagineous edge rather thick, more or less reflexed or recurved, the apex subabruptly acuminate, the acumen $1-3 \mathrm{~cm}$. long. - I cannot distinguish from this var. Copelandi (Hieron., 1. c., 292). - Java, Luzon.

Var. sumatrama: Pinnae elliptical, the cartilagineous edge rather thin, flat or hardly reflexed, the apex abrubtly cuspidate, the cusp 2-4 cm. long. - Sumatra.

(5) C. intermedian, Hieros., in Hodwi., LVII, 301.

Fronds pinnate; lower pinnae forked, or pinnate with $1-3$ pinnulae on each side below the terminal one; pinnulae linear-lanceolate or linear-oblong, cuneate or rotundate-cuneate at the base, serrulate, often more coarsely serrate at the gradually acuminate to abruptly cuspidate apex; serratures deltoid or falcato-deltoid, spreading or arcuate-ascending; surfaces naked or the under surface provided with scattered, articulated hairs; vein tips terminating in an elongated, rather narrow, straight or

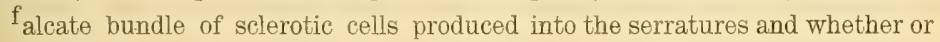
not reaching the marginal strand consisting of 2-3 rows of sclerotic cells. - Very variable, with the forms passing gradually into each other. Backer's No. 9742, from Java, probably a form of this species, agrees very well with Hieronymus' diagnosis; the hairs of the under surface, however, are not bulbous at the base. 
Forma typica: Under surface naked.

Forma pilosa: Under surface pilose.

Java (?); Brit. India, China, Korea, Japan.

61. ANTRROPHYUM, Kaulfuss.

(12) A. Coriaceum, Wall.

Omit the synonym $A$. reticulatum Bedd.

67b. CAMPYLOGRAMMA, v. A. v. R.

(1) C. Inncifolia, v. *. ש. in Bull. Btz., 1916, XXIII, 7, tab. I.

(2) C. pteridiformis, *. A. R., in Bull. Btz, 191\%, XXIV, 1.

69. VITTARIA, J. Smith.

\section{\& 1. EUVITTARIA.}

(7) V. elongata, Suv.

Forma typica: Rhizome scales black or castaneous-black. -- Trop. Asia, Polynesia, New South Wales.

Forma lurida: Rhizome scales dirty-red-brown. - Java.

69a. SCILROGLOSSUM, v. A. v. R.

(2) Se. pusillum, v. A. v. $\boldsymbol{\text { R. }}$

Also in Amboina. 


\section{POLYIUDIUM, Linné.}

\section{$\S 1$. EUPOLYPODIUM.}

(6b) P. serraeforme, Brau.

Omit this name, it should be P. Brauseanum v.A. $v$. $R$.

(6b) F. Brauseanum, v. A. v. H.; $P$. serraeforme, Brau., in Lautb., Beitr. Flor. Pap., I, 36, fig. 2 D.

(19a) IP. papuense, v. A. v. R.; P. papucunum, Rill., in Trans. Linn. Soc., Bot., 2nd Ser., IX, 260.

Fronds sessile, caespitose, narrowly linear, to $5 \mathrm{~cm}$. long, $1 \mathrm{~mm}$. broad, slightly and bluntly acuminate, the base somewhat narrowed. Texture subcoriaceous; surfaces sparingly black-hairy; costa prominent; veins hidden. Sori copious, elliptical, soon confluent and hiding the lamina, occupying the upper part of the fronds.

New Guinea.

\section{(25) P. parasiticum, Mett.}

Surfaces of the fronds more or less (not invariably densely) clothed with long hairs, and the sori often mixed with long hairs.

(28a?) P. friggidum, radm., in Trans. Linn. Soc., Bot., 2nd Ser., IX, 259.

Rhizome stout, the scales lanceolate, acuminate, pale-brown. Stipes slender, $\pm 4 \mathrm{~cm}$. loug, furfuraceo-pubescent, glabrescent. Fronds narrowly linear, $\pm 17 \mathrm{~cm}$. long, entire, acuminate at both ends, the top blunt. Texture coriaceous; surfaces naked; costa proportionally stout; veins hidden. Sori subelliptical, in 1 row on each side of the costa, not occupying the narrowed base and apex of the fronds. - The proper place of this species is uncertain because of incomplete description.

New Guinea.

(38) P. setosum, Pr.

Veins forked, the anterior veinlet short, simple, very oblique, or subparallel to the costa, the posterior veinlet long, subspreading, simple, or slightly compound (with $2-3$ branchlets). 
(45c) P. canaliculatum, v. A. v. R.g P. petiolatum, Ridl., in Trans. Linn. Soc., Bot., 2nd Ser., IX, 260.

Rhizome slender, provided with silvery-white. lanceolate, acuminate scales. Stipes slender, $4-8 \mathrm{~cm}$. long, canaliculate, naked. Fronds oblanceolate, $\pm 12 \mathrm{~cm}$. long by $1 \frac{1}{2}-13 / 4 \mathrm{~cm}$. broad, narrowed at the base, the edge recurved, indistinctly undulated. Texture coriaceous; veins copious, straight, fine; veinlets 6 , indistinct. Sori round, proportionally large, terminal on the veinlets, elevated on the upper surface. The proper place of this species is uncertain because of incomplete description.

New Grinea.

(45cl) W. biseriale, Ridl., in Trans. Linn. Soc., Bot., 2nd Ser., IX, 260 .

Rhizome clothed with ovate, obtuse, brown scales. Stipes slender, terete, pubescent. Fronds caespitose, lanceolate, $\pm 14 \mathrm{~cm}$. long by $4-5$ $\mathrm{cm}$. broad, acuminate, undulate, narrowed towards the base. Surfaces shortly black-hairy; veins indistinct, simple, flexuose. Sori in 2-4 rows on each side of the costa.

New 'Guinea.

(46a) P. alcicone, Ridl, in Trans. Linn. Soc., Bot., 2nd Ser., IX, 261.

Rhizome moderately stout, provided with pale-brown, lanceolate, acuminate scales. Stipes $+10 \mathrm{~cm}$. long, naked, winged. Fronds $20-35$ $\mathrm{cm}$. long, 3-4 times forked. Primary segments $4-5 \mathrm{~mm}$. broad, ultimate ones linear, $2-2 \frac{1}{2} \mathrm{~cm}$. long, $\pm 2 \mathrm{~mm}$. broad, narrowed towards the obtuse point. Texture coriaceous; surfaces naked. Sori subcostal, round or elliptical, subremote, occupying the ultimate segments.

New Guinea.

(54a) P. Cn r'stenszense, Ridl., in Trans. Linn. Soc., Bot., 2nd Ser., IX, 260.

Rhizome provided with thin, lanceolate, acuminate, pale-brown scales. Stipes slender, terete, $\pm 7-8 \mathrm{~cm}$. long, pubescent. Fronds linear, \pm $20 \mathrm{~cm}$. long by $1 \frac{1}{2} \mathrm{~cm}$. broad, undulated towards the acuminate apex, shallowly, bluntly and broadly lobed towards the cuneate base. Texture subcoriaceous; veins numerous, flexuous; veinlets \pm 6 , short. Sori small, elliptical, slightly immersed, terminal on the veinlets.

New Guinea. 
(55)

P. streptopliyllum, Bk.

Also in New Guinea.

(70a) P. repandulum, Mett.

Also in New Guinea.

(73) P. obliquatum, $\boldsymbol{B l}$.

Forma typica: Fronds $2 \frac{1}{2}-8 \mathrm{~cm}$. broad, herbaceous to firm-coriaceous; pinnae horizontal to oblique, sparingly ciliated when young; sori $\pm 4-10$ on a side. - Malaya ; Ceylon, South China.

(76a*) See No. $81 b$.

(81 ?) P. pensile, Ridl., in Trans. Linn. Soc., Bot., 2nd Ser., IX, 262.

Stipes 5-6 cm. long, (red-brown-hairy?). Fronds pendulous, \pm 70 $\mathrm{cm}$. long, pinnate. Pinnae numerous, linear, $\pm 21 / 2 \mathrm{~cm}$. long by ${ }^{31}{ }_{4} \mathrm{~mm}$. broad, shortly and obtusely acuminate, decurrent at the base. Texture subcoriaceous; surfaces and especially the rachis red-brown-hairy; veins hidden. Sori marginal, \pm 6 on each side of the costae. The proper place of this species is uncertain because of incomplete description

Nero Guinea.

(81b) P. melanorhachis, v. w. R., in Bull. Btz., 1917, XXIV, 3.

Rhizome short, densely clothed with narrowly linear, shining, redbrown or subcastaneous, ciliated scales. Stipes aggregate, $3-5 \mathrm{~cm}$. long, dark-brown; clothed with long, fine, spreading, black-brown hairs. Fronds elongate-lanceolate, pinnate, $\pm 30-35 \mathrm{~cm}$. long by $3 \frac{1}{2}-5 \mathrm{~cm}$. broad, narrowed towards both ends; rachis black, depressed above, terete beneath, elothed with long or short, black-brown hairs. Pinnae numerous, rather remote, subhorizontal, straight or falcate, linear, $2-3 \mathrm{~mm}$. broad, blunt, suddenly dilated and confluent at the base, the edges parallel, revolute when dry, entire; lower pinnae free, more remote and more dilated at the base. Texture rigidly coriaceous; under surface pilose with short, black-brown, scattered hairs; costae flexuose, obscure; veins simple, hidden, oblique. Sori numerous, superficial, in 1 row on a side, at length often filling up nearly the whole under surface of the pinnae, the higher rather round, the lower when young oblong and parallel to the margin. 
- Young fructiferous plants with the fronds smaller and resembling those of P. mollicomum Nees \& Bl. var. fuscatum.

Sumatra.

(99b) H. IBrogksine, v. A. v. R., in Bull. Btz., 1916, XXIII, 19, tab. II, fig. $2 a-c$.

$\left(100 a^{*} a\right)$ See No. $81 b$.

(106a) See No. 68.

(106b) P. secundeum, Ridl., in Trans. Linn. Soc., Bot., 2nd Ser., IX, 262 ; (? subsecundo-dissectum, Zoll., var. novoguineensis).

Stipes $\pm 3 \mathrm{~cm}$ long, densely barbate. Fronds $15-18 \mathrm{~cm}$. long, $\pm 2 \frac{1}{2} \mathrm{~cm}$. broad, pinnate, the rachis and costae barbate. Pinnae $\pm 1 \frac{1}{2}$ cm. long, recurved, dimidiate, entire on the lower side, pinnatifid on the upper side. Lobes oblong to obovate or nearly spathulate, $\pm 1 \mathrm{~mm}$. long, rounded at the apex, narrowed at the base. Sori small, solitary at the base of the lobes, hirsute.

New Guinea.

(106c) P. Gollastomili, Ride, in Trans. Linn. Soc., Bot., 2nd Ser., IX, 262.

Rhizome long, slender, the scales scattered, ovate, acuminate, brown, deciduous. Stipes remote, $\pm 12 \mathrm{~cm}$. long, slender, purple, minutely pubescent. Fronds 2-pinnatifid, $\pm 45 \mathrm{~cm}$. long by $10 \mathrm{~cm}$. broad. Pinnae 5-6 cm. long. Lobes linear-lanceolate, falcate, decurrent at the base, $\pm 7 \mathrm{~mm}$. long by $2 \mathrm{~mm}$. broad, the higher shorter; one of the basal ones longer, serrate at the apex. Texture subcoriaceous; rachis and costae minutely pubescent; surfaces sparingly hirsute. Sori $2-4$ in the lower part of the lobes.

New Guinea.

\section{1a. PLEOPELTIS, Hamb. Hompl.}

\section{§ 1. EUPLEOPELTIS.}

(140a) ? P1. argyropus, v. A. v. R.; Polypodium argyropus, Ridl., in Trans. Linn. Soc., Bot., 2nd Ser., IX, 262. 
Rhizome stout, clothed with crowded, lanceolate, acuminate, silverywhite scales. Stipes $2-7 \mathrm{~cm}$. long, terete, naked. Fronds dimorphous; barren fronds lanceolate, $\pm 10 \mathrm{~cm}$. long by $2-21 / 2 \mathrm{~cm}$. broad, acuminate, recurved at the edge, cuneate at the base. Texture coriaceous; veins to 40 or more on a side. Fertile tronds linear, $\pm 13 \mathrm{~cm}$. long by $2 \mathrm{~mm}$. broad. Sori large, elliptical. - The proper place of this species is uncertain because of incomplete description.

New Guinea.

(143a) P. accedens, Moore; Polypodium rhynchophyilum, Christ (not Hk.), in Schum. \& Laut., Flor. deut. Sch.geb., Suppl., 46, (p. p.?).

Forma typica: Soriferous region of fertile fronds proportionally broad, the sori therefore not or hardly protruded beyond the margin. Malaya; Polynesia.

Forma excedens: A duplicate of Schlechter's No. 14398, received as P. rhynchophyllum $H k$., has the soriferous region of the fertile fronds more contracted, and the sori therefore conspicuousty protruded beyond the margin. - New Guinea.

(144a?) H. reniferan, Hidl., in Trans. Linn. Soc., Bot., 2nd Ser., IX, 263.

Rhizome slender, clothed with narrow, pale, acuminate scales. Stipes slender. Fronds dimorphous. Barren fronds linear-spathulate, $\pm 5 \mathrm{~cm}$. long by $3 \mathrm{~mm}$. broad, rounded at the apex. Texture coriaceous; surfaces naked; costa prominent; veins hidden. Fertile fronds linear, $\pm 15 \mathrm{~cm}$. long by $2 \mathrm{~mm}$. broad, obtuse, undulated at the edge, narrowed gradually into the stipe. Sori \pm 16 , round, remote. - The proper place of this species is uncertain because of incomplete description.

\section{New Guinea.}

(157) Pl. subgeminata, v. A. v. R.; Polypodium subgeminatum, Christ, in Schum. \& Laut., Flor. deut. Sch.geb., Suppl., 47 ; P. phymatodes, L., Copel., in Philipp. Journ., VIC, 89, p. p.; - var. ovata, Rst., in Fed., Rep., X, 340.

Rhizome elongated, firm, provided with few scattered, deciduous, dark, orbicular scales. Stipes 1-3 (mostly 2) on short, lateral branchlets of the rhizome, $1 \mathrm{~mm}$. to $3 \mathrm{~cm}$. long, naked, 2-marginate. Fronds entire, acute or acuminate, rotundate or rotundate-cuneate at the base. Texture coriaceous; upper surface provided with scattered, white-cretaceous, dot-like 
scales; under surface naked; costa more or less prominent; areolae numerous, irregular, hidden, with copious free veinlets. Sori moderately large, in 1 row on each side, medial, immersed.

Forma typica: Fronds lanceolate, $\pm 71 / 2-15 \mathrm{~cm}$. long, $1-2^{1 / 2}$ cm. broad.

Var. vata: Fronds ovate, proportionally short and broad.

New Guinea.

(174a) Pl. selliguedides, v. A. v. R., in Bull. Btz., 1916, XXIII, 18.

(174b) See No. 176a.

\section{(176a) Pl. hemionitidea, Moore.}

Fronds often wing-like in the lower part. Texture membranaceous to thinly coriaceous: costa slightly, deciduously scaly, glabrescent, as is the stipe; main veins whether or not blackish; primary areolae irregular or subquarrangular, in several rows on a side, divided into irregular smaller ones with included free veinlets.

\section{(185a) Pl. suboppositu, v. A. $\boldsymbol{v}$. R.}

A duplicate of Merrill's No. 8536, occurring in the Buitenzorg Herbarium, differs from Christ's diagnosis in having the fronds oblanceolate, broadest above the middle, and a duplicate of Mearns' No. 3429 (?), Bur. of Sci., has the fronds sinuated, narrowly long-decurrent.

(186b) PI. Zollingeriana, v. A. v. R.; Dictyopteris Brooksiae, v. A. v. R., in Bull. Btz., 1916, XXIII, 9; Aspidium Brooksiae, v. A. v. R., l. c.

Sori roundish, scattered irregularly between the main veins, not rarely confluent so as to form about 3-4 interrupted lines which are mostly parallel to the main veins but the lower elongated sori often parallel to the costa.

\section{(219a) PI. Iaeniata, v. A. v. K.; - var. angustata.}

Forma typica: Pinnae linear-lanceolate, broadest at or near the middle, free, the higher narrowly to broadly adnate to the rachis; sori medial or nearer the costa than the margin.

Forma submarginalis: Like the type but the sori submarginal. 
Forma connata: Like the type but the pinnae suddenly long-decurrent and connected at the base.

Var. angustata: Like the type but the pinnae subulate, broadest a little above the rotundate-cuneate base.

$\left(219 a^{*} b\right)$ Pl. taenifrons, $v$. A. v. R.

Omit this, it being a form of $\mathrm{Pl}$. crenulata $v, A, v, R$.

$\left(219 a^{*} b\right)$ Pl. cremulata, v. A. v. I., in Bull. Btz., 1914, XVI, 59, fig. c; Pl. taenifrons, v. A. v. R., l. c., 31, fig. a; Polypodium crenulatum, Kze, Mett., Farng, I, Polypod., 110; P. taenifrons, v. A. v. R., l. c., 31; P. taeniatum, Sm., forma, C. Chr., Ind. Fil., Suppl.

Near Pl. taeniata $v . A . v$. $R$. but the rhizome scales ovate-lanceolate, entire; main veins forked at the apex with 2 spreading, free or uniting veinlets, for the rest commonly united regularly by transverse veins forming 2-3 quadrangular areolae on each side of the costa; areolae with or without few free veinlets; costal or medial areolae commonly provided with 1-2 excurrent free veinlets, those of the costal areolae springing from the main veins, one on each side, those of the medial areolae from the transversal veins; sori solitary in the costal or medial areolae terminal on one of the free veinlets or uniting their apices.

Celebes.

\section{DRYMOGILOSSUM, Prest.}

\section{(1) D. Carnosum, J. $\mathbf{S m}$.}

Free veinlets of the areolae recurrent.

\section{FILAPHOGILOSSUM, sehott.}

(4c?) E. minahasae, v. A. v. $\boldsymbol{R} . ;$ Acrostichum conforme, Christ (not Sw.), in Ann. Btz., XV, 174.

Stipes $15-20 \mathrm{~cm}$. long, thickened $\pm 11 / 2 \mathrm{~cm}$. above the base, naked or sparingly scaly, the scales ovate, pale-brown, acuminate, entire or 
sparingly fimbriate. Fronds dimorphous; barren fronds $\pm 17 \frac{1}{2} \mathrm{~cm}$.long, $3 \mathrm{~cm}$. broad, narrowed gradually from the middle towards the decurrent base, rounded at the apex, the edge somewhat pellucid and slightly reflexed. Texture rigidly coriaceous; surfaces naked; under surface provided with an intramarginal elevated ridge uniting the vein tips; costa prominent and slightly channelled on both sides; veins somewhat prominent. Fertile fronds contracted, narrowed gradually towards the base and the bluntish apex. - Rhizome..... . .

\section{ANGIOFTERIS, Hofimann.}

$\left(3 e^{*}\right)$ A. sumatuana, v. A. $\boldsymbol{v}$. R.

Koorders' No. 169833 from Celeties differs from this only in having the pinnulae somewhat longer, less oblique at the base, and the rachises apparently naked (glabrescent?).

Sumatra, Celebes.

\section{MARATTIA, Swartz.}

(6) DI. ternatea, de $\boldsymbol{V} \boldsymbol{r} .$, Mon. Maratt., 4, tah. III, fig. 16; Christ, in Philipp. Journ., $I^{\mathrm{C}}$, 185; Copel, in Philipp. Journ., IV, 11 , tab. VII.

Fronds 3-pinnate. Leaflets 3-10 (or more?) on a side, linear-lanceolate, $10-20 \mathrm{~cm}$. long, $1 \frac{1}{2}-21 / 2 \mathrm{~cm}$. broad, petiolulate, acute or gradually acuminate, the edge crenate-serrulate and often deflexed, more sharply serrate towards the apex, the base obliquely ovate-cuneate or rotundatecuneate, broadest on the upper side. Texture herbaceous to coriaceous; surfaces naked but the under one not rarely albo-punctulate, paler than the upper one; costae sparingly squamulose beneath; veins invariably simple, pellucid, nearly horizontal. Sori not close, somewhat remote from the margin; largest synangia 12-15-celled; indusium narrow, fimbriate. The description is taken from Philippine specimens determined by Christ, l. .c.

Moluccas, Luzon. 
(6*) M. Koordersii, v. A. v. R.; M. frarined, Christ (not Sin.), in Ann. Btz., XV, 184.

Near M. ternatea de $V r$, but the leaflets proportionally shorter, ovate-lanceolate to lanceolate, subabruptly acuminate, the veins partly simple partly forked.

Celebes.

\section{LYCOPODIUM, tinné.}

\section{§ 1. UROSTACHYS.}

(9a) L. campestre, v. A. v. K., in Bull. Btz., 191\%, XXIV, 3.

Shoots erect, simple, $\pm 10-12 \mathrm{~cm}$. long, $\pm 5-7 \mathrm{~mm}$. diam. including the leaves. Leaves erowded, \pm 10 -farious (arranged in alternate spurious whorls of 5), coriaceous, rigid, erecto-patent or subspreading, intermixed with prolific buds, entire or sparingly and very minutely serrulate, flattened, the lower sublanceolate-subulate, acute or subacute, narrowly costate, $\pm 3-4 \mathrm{~mm}$. long; $\pm 1 \mathrm{~mm}$. broad at the base, the higher and central and occasionally also the lower ones elliptical-oblong, \pm $1 \mathrm{~mm}$. broad at or below the middle, acute or acuminate, indistinctly costate. Sporangia in the axils of unaltered central and higher leaves.

New Guinea.

(12a) L. rubricaule, v. A. v. H., in Bull. Btz., 191\%, XXIV, 3.

Shoots erect, simple or sparingly dichotomous, $\pm 5-10 \mathrm{~cm}$. long, the stem and branches red in age, $\pm 4-8 \mathrm{~mm}$. diam. including the leaves. Leaves horizontal or deflexed, coriaceous, \pm 8-farious (arranged in alternate spurious whorls of 4), rather remote, intermixed with prolific buds, lanceolate, $\pm 1 \frac{1}{2}-31 / 2 \mathrm{~mm}$. long, $\pm 1 / 2-1 \mathrm{~mm}$. broad, flattened, acute, entire, not or hardly narrowed at the base, indistinctly costate. Sporangia in the axils of unaltered leaves.

New Guinea.

(15) L. tetrastichum, Kze.

Leaves ascending, suberect, complicate-conduplicate.

\section{(16) L. Iaxum, Pr.}

United with L. carinatum Desv. by intermediates.

Ferns and Fern Allies. 
(16a) E. crelore, v. A. v. R., in Bull. Btz., 1917, XXIV, 4.

Shoots to $30 \mathrm{~cm}$. or more long, dichotomously branched, the stem and lower branches $\pm 5 \mathrm{~mm}$. diam. including the leaves. Leaves much ascending, \pm 8-12-farious (arranged in alternate spurious whorls of $4-6$ ), crowded, rigid, acerose, linear-subulate, subcanaliculate by the slightly involute edges, the lower $\pm 4-6 \mathrm{~mm}$. long, $\pm 3 / 4 \mathrm{~mm}$. broad, not or hardly narrowed at the base, indistinctly costate, entire or sparingly and minutely denticulate, the central shorter, more distinctly costate and serrulate, the higher more copiously serrulate, passing gradually into the sporophylla. Spikes dichotomous, the branches cylindrical, $\pm 3 \mathrm{~mm}$. diam.; sporophylla 8 farious, imbricate, rigid, ovate, long-acuminate, subcomplicato-canaliculate, keeled, serrulate, the higher $\pm 2 \% / 2 \mathrm{~mm}$. long.

New Guinea.

(16b) D. Versteegii, v. A. v. R., in Bull. Btz., 191\%, XXIV, 4. Shoots pendulous, $\pm 30-.45 \mathrm{~cm}$. long, the stem and branches \pm ${ }^{31}{ }_{4} \mathrm{~cm}$. diam. including the leaves. Leaves remote, 8-farious (arranged in alternate spurious whorls of 4), rigidly coriaceous, green, entire, when dry often involute at the point; lower leaves erecto-patent or subspreading, lanceolate, $\pm 5 \mathrm{~mm}$. long by $\pm 13 / 4 \mathrm{~mm}$. broad, subacuminate, the edges parallel, mostly involute in the lower part, the base decurrent, the decurrent portion narrowed; higher leaves passing gradually into the sporophylla. Spikes elongated, dichotomous; ultimate branchlets $3-5$ mm. diam.; sporophylla crowded, coriaceous, the lower ovate-oblong, the higher broadly ovate, yellow, $\pm 2-3 \mathrm{~mm}$. long, acute to shortly acuminate, entire, indistinctly costate.

New Guinea.

(18) H. Carinatum, Desv.

Leaves canaliculate or complicate to conduplicate. - See No. 16.

(31) L. horizontale, v. A. v. R.; - var. submoniliforme, v. A. จ. R., in Bull. Btz., 191\%, XXIV, 4.

Var, sulbmoniliforme: Leaves smaller, $\pm 5-7 \mathrm{~mm}$. long, \pm $1-1 \frac{1}{2} \mathrm{~mm}$. broad; spikes shorter, to $3 \mathrm{~cm}$. long, the branchlets submoniliform, $\pm 1 \mathrm{~mm}$. diam., the sporophylla very short, smaller than the sporangia, broadly deltoid-ovate, bluntish. - New Guinea. 


\section{(33) L. phlegmarioides, Gaud.}

A plant gathered in Pulo Bisc (Obi Islands, Lieut. Hulstijn's Explor. Exped., Coll. Sa-anam No. 62) differs from the type in having the leaves thin, with the costa prominent on both sides, and the spikes $2 \mathrm{~mm}$. diam.

Also in the Obi Islands

(37a) L. patentissimum, v. A. v. R., in Bull. Btz., 1917, XXIV, 4 .

Shoots simple or dichotomous, $\pm 12 \frac{1}{2}-20 \mathrm{~cm}$. long including the spikes, the stem subfiliform. Leaves loose, horizontal, 6-farious, oblanceolate-oblong, firm-herbaceous, $\pm 4-5 \mathrm{~mm}$. long, $\pm 1 \frac{1}{2}-2 \mathrm{~mm}$. broad at or above the middle, narrowed gradually towards both ends, minutely apiculate, entire, costate, decurrent. Spikes $\pm 1 / 8$ as long as the whole plant, irregularly dichotomous, the branchlets $\pm 3-4 \mathrm{~mm}$. diam.; sporophylla suberect, moderately loose, subulate-ovate, rather involuto. canaliculate, entire, keeled, $\pm 2 \frac{1}{2}-3 \mathrm{~mm}$. long.

New Guinea.

\section{§ 2. RHOPALOSTACHYS.}

(41a) L. hygrophilum, v. A. v. R., in Bull. Btz., 1917, XXIV, 5.

Main stem (rhizome) wide-creeping, remotely branched; primary branches dichotomous; secondary and following branches erect; ultimate branchlets terete, the fertile ones $\pm 5-10 \mathrm{~cm}$. long, $\pm 3-4 \mathrm{~mm}$. diam. including the leaves. Leaves coriaceous, naked, subulate-lanceolate, \pm $3 \mathrm{~mm}$. long, costate, the apex acuminate, scariose, deciduous; leaves of the main stem subsecund or falcate, erected or somewhat spreading, minutely fimbriate-serrulate; leaves of the ultimate branchlets crowded, much incurved, decurrent, entire, flat or somewhat canaliculate. Spikes solitary and terminal on the branchlets, on a short peduncle provided with more or less remote whorls of bracts similar to the leaves, cylindrical, $\pm 2-3 \mathrm{~cm}$. long, $\pm 3-6 \mathrm{~mm}$. diam.; sporophylla subulate-lanceolate, eroso-fimbriate-denticulate, at length spreading or deflexed, with a deciduous, scariose point.

New Guinea.

(41b) L. hydrophilum, v. A. *. R., in Bull. Btz., 1917, XXIV, 4. Main stem (rhizome) stout, creeping, deciduously pubescent, copiously 
branched; primary branches copiously branched, decumbent in the lower part; secondary and following branches subdichotomous, erected, crowded; ultimate branchlets terete, $21 / 2-5 \mathrm{~cm}$. long, $1-3 \mathrm{~mm}$. diam. including the leaves. Leaves subulate, $\pm 2-3 \mathrm{~mm}$. long, coriaceous, naked; leaves of the rhizome the largest, straight or somewhat curved, erect or somewhat spreading, ciliolate, thickened; leaves of the ultimate branchlets crowded, much ineurved, quadrangularly thickened towards the base by the very prominent, keel-shaped costa, the edge sparingly and minutely ciliolate. Spikes solitary and terminal on the ultimate branchlets, sessile, cylindrical, to $\pm 1 \mathrm{~cm}$. long, as thick to twice as thick as the branchlets; sporophylla suberect, acutely subulate from a broadly ovate base, involutocanaliculate, ciliolate in the lower part, ecostate, at length squarrose.

New Guinea.

(42) E. cernuum, L.; - var. suffruticosum, V. A. v. R., in Bull. Btz., 1917, XXIV, 5.

Varp. sufruticosum: Leaves of the ultimate branchlets much incurved, thick, naked, entire; spikes rather thick, subcernuous; ultimate branchlets crowded, erect, slender, to $2 \mathrm{~mm}$. diam. - Ncw Guinea.

(42h) L. brevibracteatum,, v. v. R., in Bull. Btz., 1917, XXIV, 5 .

Shoots erect, several $\mathrm{m}$. long, the lower part simple, foliate, at length aculeate-tuberculate by the persistent bases of fallen leaves, the upper part copiously branched, the branching moderately lax, the rachises woolly on 1 side with long, crisped hairs; primary branches 2-farious, horizontal or spreading; secondary branches between pinnate and dichotomous; ultimate branchlets $\pm 4 \mathrm{~mm}$. diam. including the leaves. Leaves rather loose and terete, linear-subulate, entire, naked, decurrent, upcurved; of the primary branches horizontal; of the ultimate branchlets arcuateascending, fine, to $\pm 3 \mathrm{~mm}$. long. Spikes erect, sessile at the end of the branchlets, cylindrical, $\pm 5-20 \mathrm{~mm}$. long by $\pm 1 \frac{1}{2}-2 \mathrm{~mm}$. diam.; sporophylla short, triangular, ascending or at length subhorizontal, coriaceous, upcurved, acute or shortly acuminate, ecostate, eroso-crenate.

New Guinea.

(42c) L. Tomentosum, v. A. v. F., in Bull. Blz., 191\%, XXIV, 6 ; - var. laxius, v. A. v. R., 1. c, 
Shoots erect, rather copiously and elosely branched, the rachises more or less tomentose with ochraceous hairs; ultimate branchlets rather crowded, terete, $\pm 1-5 \mathrm{~cm}$. long, $\pm 2-2 \frac{1}{2} \mathrm{~mm}$. diam. including the leaves. Leaves coriaceous, subulate, costate, those of the ventral side (except the higher) more or less deciduously tomentose, those of the dorsal side naked; of the principal rachises remote, straight, erect, adpressed, flattened, thickened at the base, sparingly and very minutely ciliolate-denticulate; of the ultimate branchlets crowded, decurrent, subspreading, much incurved, to $2 \mathrm{~mm}$. long, entire, thickened towards the base. Spikes solitary and terminal on the branchlets. sessile, erected, cylindrical, 3-15 mm. long, 2-3 mm. diam.; sporophylla acuminate from an ovate base, coriaceous, ecostate, fimbriate-ciliate.

Var. Iaxius: Branches laxer; ultimate branchlets finer, to 2 $\mathrm{mm}$. diam.; leaves of the ventral side less copiously tomentose, those of principal rachises whether or not entire; spikes more slender, cernuous.

New Guinea.

(44a) E. Pullei, v. A. v. R., in Bull. Btz., 1917, XXIV, 6.

Shoots wide-scandent, naked, pinnately branched, the branches copiously compound, 2-farious; primary branches with the branching divaricating, partly pinnate partly dichotomous; ultimate branchlets straight or more commonly flexuose and intricate, to $\pm 5 \mathrm{~cm}$. long, \pm 4-6 mm. diam. including the leaves. Leaves squarrose, subulate, \pm 3--7 mm. long, coriaceous, naked, the upper part scariose, more or less evanishing; of the stem the largest, upcurved towards the apex; of the stem and principal rachises remote, more or less copiously eroso-denticulate; of the branchlets less remote, incurved at the apex, entire, decurrent. Spikes several on a long, branched peduncle terminal on the primary branches, with distant, adpressed, lanceolate-subulate eroso-denticulate bracts, cylindrical, $\pm 21 / 2-5 \mathrm{~cm}$. long by $\pm 4-5 \mathrm{~mm}$. diam.; sporophylla broadly ovate, eroso-denticulate, with an acuminate, scariose point, at length squarrose.

New Guinea.

\section{SELAGINELIA, Spring.}

\section{$A^{1}$. MONOSTELICAE.}

(51a) \$. Vomroemeri, v. A. v. H., in Bull. Btz, 1917, XXIV, 7. 
Shoots erect from a decumbent or ascending base, to $40 \mathrm{~cm}$. or more long, the lower part simple, when dry pale-dirty-fuscous, obtusely angled or 2-sulcate on the face, convex on the back, the upper part branched, suboblong in outline, the main rachis $\pm 10-12 \mathrm{~mm}$. broad including the lateral leaves; pinnae ascending, the lower 2-3-pinnate; pinnulae simple or forked; ultimate branchlets varying from very short to $6 \mathrm{~cm}$. long, $\pm 5-9 \mathrm{~mm}$. broad. Leaves heteromorphous; lateral leaves blunt or bluntish; of the stipe much ascending, remote, unequal-sided, obliquely ovate, bluntish, the upper (inner) side rounded, minutely serrulate, ciliate at the subcordate base, the lower (outer) side less rounded, entire, ciliate at the narrowly rounded base; of the main rachis approximate, much spreading, elongateoblong, subfalcate, blunt, provided with a submarginal spurious veinlet on each side, the upper side very minutely serrulate, or entire at the middle, gradually ciliolate at the cordate base, the lower side entire, obsoletely denticulate towards the apex, provided with $\pm 2-6$ proportionally long ciliae at the subabruptly cuneate base, the largest leaves \pm $6 \mathrm{~mm}$. long and $\pm 2 \% \mathrm{~mm}$. broad; of the ultimate branchlets similar but smaller, $\pm 4-5 \mathrm{~mm}$. long; intermedial leaves erect, unequal-sided, acuminate; of the stipe remote, subfalcate, rhomboidal-ovate, very minutely serrulate, narrowly pellucid-margined, gradually and deciduously ciliate towards the obliquely cordate base, the outer base the broadest, produced, the largest leaves $\pm 3^{1} / 2-4 \mathrm{~mm}$. long; of the branched portion similar but growing gradually smaller, with the basal ciliae more persistent; of the ultimate branchlets imbricate, obliquely rotundate-subcordate at the base. Spikes square, $\pm 1 \frac{1}{2}-2 \mathrm{~mm}$. diam.; sporophylla suberect, ovate, acuminate, keeled, minutely serrulate, to $2 \mathrm{~mm}$. long, at length spreading; macrospores reticulate-rugulose, the apical ribs encircled by a ringshaped crest; microspores provided with verruciform, bacilliform or stipitate-capitate projections on the basal side.

New Guinea.

(139a) \$. carnea, v. A. v. R., in Bull. Btz., 1917, XXIV, 7.

Shoots creeping, $\pm 40 \mathrm{~cm}$. long, pinnate, forked at the base, the stem when fresh pale-red, when dry pale-brown and irregularly grooved, $\pm 11 / 2-2 \mathrm{~mm}$. thick, the main rachis $\pm 6-8 \mathrm{~mm}$. broad including the lateral leaves; pinnae pinnate; pinnulae of the largest pinnae compound, the branching between pinnate and dichotomous; ultimate branchlets \pm $1-2 \mathrm{~cm}$. long, $\pm 3-5 \mathrm{~mm}$. broad. Leaves heteromorphous; lateral 
leaves remote and horizontal or deflexed on the main rachis, approximate and subhorizontal on the branchlets, mucronulate, the muero divided into $\pm 3-5$ crowded, tooth-like fibres, the apper side sparingly ciliolateserrulate, the lower side entire, or sparingly serrulate towards the apex; of the main rachis unequal-sided, obliquely ovate, the upper side rounded, broadly rotundate-cuneate at the base, the lower side nearly straight, narrowly truncate-cuneate at the base, the largest leaves $\pm 5 \mathrm{~mm}$. long and $21 / 2 \mathrm{~mm}$. broad; of the branchlets less unequal-sided, oblong, rotundate-cuneate at the base but more gradually on the upper side, the largest leaves $\pm 3 \mathrm{~mm}$. long, $\pm 1 \mathrm{~mm}$. broad; intermedial leaves erect, abruptly cuspidate-acuminate, the cusp nearly $1 / 2$ as long as the blade; of the main rachis remote, slichtly unequal-sided, obovate-oblong, narrowly rounded at the base, ciliolate but more sparingly on the inner side, the largest leaves $\pm 4 \frac{1}{2} \mathrm{~mm}$. long; of the branchlets much smaller, imbricate, entire or sparingly ciliolate-serrulate, more narrowly rotundate cuneate at the base. Spikes solitary and terminal on the branchlets, $\pm 3 \mathrm{~mm}$. broad; sporophylla not very dimorphous, unequal-sided, ovate-oblong, acuminate, keeled, to $\pm 3 \mathrm{~mm}$. long; of the upper plane erecto-patent, keeled, the lower spreading or recurved, the upper side irregularly ciliolate, entire at the rotundate-cuneate base, the lower side entire, ciliolateserrulate at the base, the keel minutely serrulate; of the lower plane nearly similar, the upper side ciliolate-serrulate throughout, broadly rounded at the base, the lower side sparingly ciliolate-serrulate; spores. . .

Newo Guinea.

(192) \$. Poumolmiana, spring; - var. punctata, Hieron., in Leafl., VI, 2050 ; var. angustiramosa, Hieron., MS.; S. punctata, A. Br., MS. According to Spring's diagnosis this species is said to have the axillary leaves obovate, narrowed at the base, and the lateral leaves entire. The specimens occurring in the Buitenzorg Herbarium have the lower axillary leaves roundish, cordate or ovate at the base, bluntish or subacute, broadest at or near the base, the intermedial leaves of the stem rounded or somewhat cordate at the base, the ultimate branchlets 3-5 $\mathrm{mm}$. broad with the lateral leaves whether or not somewhat dilated on the lower side at the base and often, if not invariably, minutely serrulate towards the apex like those of the stem, the spikes at length $21 / 2-3 \mathrm{~mm}$. diam.

Forma typica: Lower pinnae broadly ovate or triangular-ovate; lower 
pinnulae conspicuously 1-2-pinnate; macrospores whitish, pale-yellow, or grey-brown to castaneous, verruculose, the projections round or sometimes shortly rugiform; mierospores whitish or yellowish, provided with more or less crowded, bacilliform, tuberculiform, clavate or stipitate-capitate projections which are free or sometimes laterally connected. - Nicobares to the Moluccas, Formosa and China.

Var. pumctara: Like the type but the pinnae elongate-oblong or lanceolate, the pinnulae simple or the lower sometimes forked or pinnate. - Philippines; Formosa, South China.

\section{(204) S. d'Urvillei, A. Br.}

The typical form has the stems $4-5$-stelical with the steles arranged in 3 planes, i. e. the central stele is lying between 2 ventral ones (which are placed abreast) and 1 dorsal one which may be double (2 steles placed also abreast). - The related forms (which probably belong to distinct species) have the stems 4-5-stelical. (or 3-stelical with a tendency to become 4-5-stelical) with the steles arranged in 4-5 planes, i. e. placed in 1 line from the ventral stele to the dorsal one. 
INDEX. 



\section{INDEX.}

\section{A.}

Acrophorus ............ 221

nodosus, Pr........... 200

stipellatus, Moore ....... 200

Acrosorus

triangularis, Copel....... 358

Acrostichum . . ........ 433

articulatum, Hk. . ..... 437

aureum, L. . ......... 433

Blumeanum, Hk..... 438, 439

commutatum, Mett. ...... 427

conforme, Bl......... 427

conforme, Christ........ 527

gracile, Rac.......... 430

laurifolium, Thouars .... 426

lomarioides, Christ ...... 438

quercifolium, Retz .... .. 434

spectabile, Rac... ...... 428

spicatum, $L$.

var. Schneideri . ..... 432

taccaefolium, Hk. ..... . 332

Thelypteris, L. ...... . 160

variabile, $H k$.

var. Rasamalae ...... 435

Adiantum ........... 235

achilleaefolium, Lam. . ... 514

aethiopicum, L......... 238

caudatum, L.......... 236

Christii, Rst. ......... 237

cuneatum, L. \& F... ... 239

cupreum, Copel. ...... . 238

\section{Adiantum}

decorum, Moore ........ 239

diaphanum, Bl......... 235

Doctersii, v. A. v. R..... 236

Edgeworthii, Hk. .... 236, 510

Farleyense, Moore ...... 238

Fergusonii, Moore ...... 239

hispidulum, Sw. ....... 240

hollandiae, v. A. v. R. ... 237

Kingii, Copel........... 235

opacum, Copel. ........ 238

prbescens, Schk......... 240

pulcherrimum, Copel..... 236

rhizophorum, Sw....... 236

rhomboideum, Schk. ..... 236

Robinsonii, v. A. v. R. ... 509

scabripes, Copel........ 235

serratifolium, v. A. v. R. . 235

stenochlamys, Bk...... . 240

suborbiculare, v. A. v. R. 238

tenerum, Sw.......... 238

tinctum, Moore ......... 239

trapeziforme, L..... . . . 236

Wagneri, Hk. Bk....... 239

Wagneri, Mett. ........ 239

Aglaomorpha ........... 418

Brooksii, Copel........ 418

Buchanani, Copel. ....... 396

Hieronymi, Copel. . . . . . 417

Meyeniana, Schott (See the corrections) ........ 418

pilosa, Copel... . ...... 417 
Aglaomorpha

Schlechteri, Copel. ...... 395

splendens, Copel. ....... 417

Alsophila ............. 54

alpina, v. A. v. R..... . 62

amboinensis, v. A. v. R.. 492

Annae, v. A. v. R. .... 490

apiculata, Rst........ 73

atropurpurea, C. Chr..... 62

batjanensis, Christ ...... 65

benculensis, v. A. V. R. .. 493

biformis, Rst.......... 71

brevifoliolata, v. A. v. R. . 64

Burbidgei, Bk......... 55

calocoma, Christ ....... 59

caudata, J. Sm. ...... . 52, 61

Christii, v. A. v. R. .... 69, 70

Clementis, Copel......... 69

commutata, Mett....... 59

comosa, Christ......... 70

contaminans, Wall.

var. robusta......... 68

crenulata, Mett......... 42

crinita, Hk. . . . . ... . . 66

Curranii, C. Chr........ 70

dimorpha, Christ ...... 60

dimorphotricha, v. A. v. R. 61

dubia, Bedd.. . . . ...... 489

Elmeri, Copel. .......... 66

extensa, J. Sm. ........ 37

extensa, Spr.......... 70

Fenicis, C. Chr.......... 66

fuliginosa, Christ ...... 65

glabra, Hk. . . . . . . 55, 56

glauca, J. Sm. . . . . . 6 68, 492

heteromorpha, v. A. v. R.. 56

heterophylla, v. A. V. R. . 60

Hewittii, v. A. v. R. . . 55
Alsophila

Hieronymi, Brau. ....... 67

inciso-serrata, C. Chr. ... 72

indrapurae, v. A. v. R... 63

Junghuhniana, Kze .... 45

Kingii, Clark $\theta . . . \ldots \ldots .60$

latebrosa, Wall. ......51, 62

lastreoides, v. A. v. R... 495

lepidoclada, Christ ...... 62

lepifera, J. Sm. ........ 65

leucocarpa, C. Chr....... 66

longipinna, C. Chr....... 67

lurida, Bk. .......... 70

Margarethae, Schroet. . . 56

Matthewii, Christ....... 71

melanopus, Hassk. ...... 65

melanorachis, Copel..... . 71

mindanaensis, Christ ... . 71

modesta, Bk. ........ 61

Naumanni, Kuhn . . .... 59

obliqua, C. Chr.......... 54

obscura, Scort. ....... 57

okiana, v. A. v. R. ..... 494

ornata, Scott........ . 66

palembanica, v. A. v. R... 493

papuana, Ridl. ........ 487

paraphysata, v. A. v. R... 58

poiensis, v. A. v. R. ... . 56

punctulata, v. A. v. R... 64

ramispina, Hk........ 56

Ridleyi, Bk. . ........ 55

Rumphiana, v. A. v. R. . 491

sangirensis, Christ ...... 62

saparuensis, v. A. V. R. . 492

sarawakensis, C. Chr. .... 58

scabriseta, v. A. v. R.... 73

Schlechteri, Brau...... 61

squamulata, Hk. ....... 56 


\section{Alsophila}

subcomosa, C. Chr. .... 69, 70

subdimorpha, v. A v R. . 60

subdubia, V. A. V. R. .... 54

subobscura, V. A. v. R.... 57

tomentosa, Hk. . . . 65, 70, 493

trichodesma, Scort. ..... 59

trichophora, v. A. v. R. . 72

tristis, Bl........... . 201

truncata, Brack. . ..... 70

Wallacei, Mett. ........ 61

wengiensis, Brau....... 68

woodlarkensis, v. A. v. R. 54

xantholepia, v. A. v. R. . 489

Amphicosmia

riparia, Gardn......... 44

Angiopteris ............. 441

amboinensis, de $\mathrm{Vr}$..... 445

angustata, Miq. ....... . 443

angustifolia, $\mathrm{Pr}$. . . . . 443

ankolana, de Vr... . . ... 444

aphanosorus, de Vr...... 444

approximata, de Vr...... 444

Brooksii, Copel. . ..... 445

caudata, de Vr. . ..... 448

crassifolia, de Vr... .... 442

crassipes, Wall......... 445

crinita, Christ. . . . . . . . 442

cuspidata, de Vr. ..... . 444

d'Urvilleana, de Vr..... . 444

Elmeriana, Copel........ 443

evecta, Hoffm........... 441

ferox, Copel. ........... 441

glauca, v. A. V. R. (See the

corrections)

Hartingiana, de Vr. . . . . 443

hypolemea, de Vr....... 443

javanica, Pr. (See the
Angiopteris

corrections) . .... 442, 443

Lorentzii, Rst.......... 445

microsporangia, de $\mathrm{Vr}$. . . 444

microsporangion, de $V r$. . 444

Miqueliana, de Vr.... . 442

muricata, Pr..... .... 445

mutata, v. A. v. R. (See

the corrections)

olivacea, v. A. v. R. (See

the corrections)

pallescens, de Vr....... 444

Presliana, de Vr........ 444

pruinosa, Kze (See the cor-

rections) ........... 442

similis, Pr. . . . ... . . 444

Smithii, Rac. . . ... 441, 446

subfurfuracea, v. A. v. R. 441

subintegerrima, v. A. v. R. 442

sumatrana, v. A. v. R. 443, 528

Teysmanniana, de Vr. .. 444

uncinata, de Vr. ...... 445

Willinckii, Miq..... ... . 444

Anisogonium

decussatum, Pr........ 275

Anogramma .......... 324

leptophylla, Link .... . . 325

Antrophyum .......... 325

alatum, Brack. ....... 327

angustatum, Brack...... 327

avenium, Bl. ......... 329

callifolium, Bl........ . 327

callifolium, Christ....... 326

coriaceum, Bl.......... 329

coriaceum, Wall........ 520

Cumingii, Fée ......... 327

immersum, Mett.

var. spathutinum (See 


\section{Antrophyum}

the corrections)

Lessonii, Bory .......... 327

parvulum, Bl. ....... . 326

plantagineum, Klf. ...... 327

reticulatum, Bedd. .... 327, 520

reticulatum, Klf...... . 327

var. parvulum (See the

corrections)

semicostatum, Bl....... 326

simulans, v. A. v. R. ... 326

vittarioides, Bk. ...... . 325

Arthropteris ........... 133

caudata, Rst........ 133

Kingii, Copel. ......... 133

oblanceolata, v. A. v. R... 134

obliterata, J. Sm. ....... 133

Aspidium ............. 191

aculeatum, Sw. ......... 140

adenophorum, v. A. v. R. 196

adnatum, Bl....... 501, 502

amplifolium, v. A. v. R. . 197

aristatum, Sw.. ....... 145

Bamlerianum, Rst. ...... 192

Beccarianum, Bk. .... . . 192

Brooksiae, v. A. v. R..... 526

Brooksii, C. Chr......... 322

calcaratum, Bl.,var...... 515

canescens, Christ

forma acrostichoides (See

the corrections) ....... 173

Christii, C. Chr... . .... 198

coadunatum, Christ...... 198

confluens, Mett..... . . . . 199

Copelandii, C Chr.... .. 195

Dahlii, Diels ... ..... . 321

de Castroi, v. A. v. R. ... 197

decurrens, Pr......... 195

\section{Aspidium}

edentulum, Kze ........ 164 edulentum, $v . A . v, R$... 164 fibrilliferum, $v, A, v, R . \ldots 146$ filix mas, Sw.

var. cochleatum ..... 503

var. paleaceum ..... 501, 502

var. parallelogrammum . 503 grande, J. Sm..... . ... 198 hemiteliiforme, v. A. v. R. 321 heterodon, Copel......... 195 hirsutulum, Sw......... 135 intermedium, Christ ...... 172 irregulare, C. Chr.

var. pteroides........ 321

var. Whitfordi ....... 323

irriguum, J. Sm......... 323

Kawakamii, v. A. v. R. .. 196 lamaoense, Copel....... . 323

Lobbii, Hk........... . 194 latifolium, J. Sm.

var. coriacea......... 199 malayense, Christ ...... . 146 microphyllum, Bl....... 140 Mülleri, C. Chr........... 199 nebulosum, C. Chr....... 505 neriiforme, Sw. ........ 499 nodosum, Bl.......... 200 nusakembangana, v. A. v. R. 517 nymphale, Schk......... 183 pachyphyllum, Kze ... 192, 200 paleaceum, Don....... 501, 502 paleaceum, Sw. .. . .... 503 papuanum, v. A. v. R. . . 191 parasiticum, Sw........ 183 patentissimum, Wall. ..... 502 persoriferum, Copel... . 193, 199

forma latipinna ...... . 199 
Aspidium

forma paucipinna..... pilosum, $L . \& F$. (See the corrections)

platyphyllum, Pr. ...... 193

polymorphum, Wall...... 194

prominens, v. A. v. R. .. 198

quinquefoliolatum, C. Chr.. 323 repandum, Willd. 192, 199, 200

Ridleyanum, v. A. v. R.. 505 sagenioides, Rac........ 165 semibipinnatum, Wall.... 195 siifolium, Mett.

var. pachyphyllum .... 192 singaporianum, Wall. . 191, 504 subaequale, Rst......... 323 subconfluens, Bedd. ..... 195 ternatense, v. A. v. R. .. 191 ternatum, Diels ... .... 193 ternifolium, v. A. v. R. .. 194 thelypteris, Sw. ....... 160 tricuspe, Bedd. ........ 191 trifolium, v. A. v. R. . 193, 194 Trimeni, Diels........ 146 triste, $B l \ldots \ldots \ldots \ldots \ldots .201$ Wallichii, Hk......... 499 Weberi, C. Chr. ........ 195 Asplenium ............ 281 achilleifolium, C. Chr. .... 514 acrobryum, Christ ...... 285 acutiusculum, Bl. ...... 293 adiantoides, C. Chr.... 292, 294 affine, Sm........... 300 alatum, Ridl......... 505 amboinense, Willd....... 283 assimile, Endl.. ..... : 273 Belangeri, Kze ...... 291, 301 borneense, Hk. ....... 289
Asplenium

Brackenridgei, Bk. ...... 258

Brooksii, Copel. ......... 283

caudatum, Forst. ..... 292, 298

chlorophyllum, Bk. ..... 258

contiguum, J. Sm. ....... 292

var. bipinnatifidum ..... 290

var. lepturus ........ 292

Cromwellianum, Rst. ..... 294

cuspidifolium, v. A. v. R. 288, 289

cymbifolium, Christ ..... 282

diversifolium, Bl........ 287

dubium, Brack........ 302

elatum, Mett. ......... 259

ellipticum, Copel........ 282

elongatum, Sw......... 290

epiphyticum, Copel. ..... 282

filiceps, Copel.......... 285

filipes, Copel.......... 295

Foersteri, Rst.......... 298

Gjellerupii, v. A. v. R. 293, 295 glaucophyllum, v. A. v. R. 300 glaucostipes, v. A. v. R... 286 glochidiatum, Rac...... 285 gracilifolium, Copel. ..... 299 Grashoffii, Rst. ........ 284 griseum, Copel......... 291 Hagenii, v. A. v. R. . 297, 298 hapalophyllum, Brau... .. 296 heteromorphum, v. A. v. R. 291 horridum, Klf. . . . . 292, 298 impressivenium, v. A. v. R. 301 inciso-dentatum, Rst. .... 296 insiticium, Brack. . . . 290, 299 kelelense, Brau. ........ 296 Keysserianum, Rst. ..... 293 Kingii, Copel.......... 287 lanceum, Thb. ......... 257 
Asplenium

Lauterbachii, Christ... 300, 301 laxivenium, Copel........ 290 lepturus, J. Sm. ........ 292 Linza, Ces. . ........ 303 lunulatum, Sw. ........ 290 macrophyllnm, Sw... . 295 minus, Bl. ......... . 286 multilineatum, $\mathrm{H} k$.

var. dareoides. .... ... 288 nidiforme, v. A. v. R. . . 281 nidus, L........... . 282 nigrescens, Bl.......... 293 nitidum, Christ ........ 300 nitidum, Sw........ . . 300 nutans, Rst........... . 298 oblanceolatum, Copel...... 282 obtusitobum, Hk. .... 300, 301 oceanicum, C. Chr....... 300 papuanum, Copel........ 283 paradoxum, Bl......... 295 paucidens, v. A. v. R.... 286 perakense, Matt. \& Christ 297 Phyllitidis, Don ........ 282 praemorsum, Sw. ....... 297 prolificans, v. A. v. R. .. 289 prolongatum, Hk....... 514 pseudofalcatum, Hillebr. 295, 299 Pullingeri, Bk........ 258 remotum, Moore....... 288 rhizophyllum, Kze ...... 302 rutaefolium, Kze...... 514 salignum, Bl.......... 286 Sancti Christophori, Christ 295 Sancti Christophori, Rst. 293, 295 scalare, Rst. ....... 283, 284 Schoggersii, v. A. v. R. .. 292 Schultzei, Brau......... 302

\section{Asplenium}

scolopendrioides, J. Sm.... 285

scolopendropsis, Muell.... 303 sorzogonense, $\operatorname{Pr}$. (See the corrections)

speciosum, Mett. (See the corrections)

squamuliferum, v. A. v. R. 513 Steerei, Harr. . . . . . . . 290 stenochlaenoides, v. A. v. R. 290,291 stereophyllum, Kze... 297, 298 subemarginatum, Rst. ... 288 subscalare, v. A. v. R. ... 284 subspathulatum, v. A. v. R. 284 sumatranum, Hk..... . 288 tenerum, Forst. ..... 290, 291 tenuifolium, Don........ 298 teratophylloides, v. A.v. R. 291 thelypteroides, Mchx ..... 278 trichomanes, L. . . . . . . 286 trifoliatum, Copel....... 287 umbrosum, J. Sm.

var. assimile........ 273 unilaterale, Lam. ........ 295 varians, Wall. . . . . . . . 297 vulcanicum, Bl. ..... 286, 288 Wightianum, Hk. . 288, 289, 291 Athyrium ............. 276 accedens, Milde ......... 275 acrostichoides, Diels ..... 278 appendiculiferum, . A. v.R. 279 assimile, Pr........... 273 atratum, Copel.......... 269 benguetense, Christ.... 153, 276 Blumei, Copel. (See the corrections) ........... 271 Bolsteri, Copel........ . 263 
Athyrium

brachysoroides, Copel..... 263

brevipinnulum, Copel.... 278

Bruoksii, Copel.......... 275

carnosum, Copel......... 264

chlorophyllum, Copel....... 258

Christii, Copel.......... 262

confertum, Copel......... 260

Copelandi, Christ ....... 277

cordifolium, Copel. ...... 274

costulisorum, Copel... ... 280

crenato-serratum, Milde ... 261

cultratum, Milde....... 261

Cumingii, Copel. ........ 274

cyatheifolium, Milde... 265, 272

davaoense, Copel......... 265

deltoideum, Milde ....... 268

dolichosorum, Copel... . 265, 276

elatum, Copel............ 259

Elmeri, Copel. . . ...... 314

esculentum, Copel. . ...... 276

fimbristegium, Copel. ..... 272

Forbesii, Copel. . . ...... 274

fraxinifolium, Milde .. 261, 274

fructuosum, Copel...... . 273

gedeanum, Christ ....... 276

geophilum, Copel. ....... 263

grammitoides, Milde 262, 263, 276

halconense, Christ....... 276

Hewittii, Copel. ........ 265

Hochreutineri, Christ .... 277

horizontale, Rst........ 151

hyalostegium, Copel. .... 278

japonicum, Copel..... 262, 277

lanceum, Milde ......... 257

Loheri, Christ ......... 278

macrocarpum, Bedd. . 276, 278

macrosorum, Copel. ... .. 280

Ferns and Fern Aluies,
Athyrium

Mearnsianum, v. A. v. R., 279

Merrilli, Copel.......... 257

Meyenianum, Milde ..... 269

Moultoni, Copel. ........ 281

muricatum, Copel....... 265

nanum, Christ........ 276

nigripes, Monre. . . 278, 280

var. Mearnsianum ..... 279

oligosorum, Copel. ....... 271

opacum, Copel.. ....... 313

palauanense, Copel....... 261

pallidum, Mitde ......... 261

pariens, Copel.......... 275

paripinnatum, Copel. ..... 266

Petersenii, Copet....... 263

pinnatum, Copel......... 258

platyphyllum, Copel...... 271

polycarpum, Copel....... 264

porphyrorachis, Copel. .... 257

propinquum, Copel....... 259

pulcherrimum, Copel..... 281

Ridleyi, Copel......... 275

sarawakense, Copel....... 266

sibuyanense, Copel. ...... 270

sorsogonense, Copel. (See the

corrections) ....... 262, 263

var. major (See the cor-

rections)

var. pounse (See the cor-

rections)

straminium, Copel...... 280

subscabruin, Copel. ...... 272

subserratum, Milde...... 257

Swartzii, Copel........ 275

tabacinum, Copel. ....... 260

Toppingianum, Copel..... 276

triangulare, v. A. v. R... 278 


\section{Athyrium}

vestitum, Milde ....... 267

Whitfordi, Copel........ 264

Williamsi, Copel........ 262

zeylanicum, Milde....... 257

\section{B.}

Balantium ............ 75

Copelandi, Christ ....... 76

javanicum, Copel....... 75

pilosum, Copel. ......... 76

Blechnum.............. 255

Bamlerianum, Rst....... 254

Blumei, Moore........ 2b5

egenolfroides, Copel........ 244

egregium, Copel........ 512

Finlaysonianum, Wall.... 255

Keysseri, Rst.......... 254

orientale, L........... 255

serrulatum, Rich........ 255

Treubii, v. A. v. R..... 255

Brainea................ 342

insignis, Hk. ........ 343

Botrychium ............. 454

daucifolium, Wall. ...... 454

lanuginosum, Wall. ..... 455

\section{C.}

Calymmodon

cucullatus, Bedd......... 352 cucullatus, Pr........ 351, 353

Campylogramma ......... 333

lancifolia, $\vee$. A. v. R. . 334, 520 pteridiformis, v. A. v. R. 334, 520

Cephalomanes

singaporianum, V. D. B. . 108
Cheilanthes ............. 248

hirta, Sw........... 243

tenuifolia, Sw........ . 243

Cheiropleuria ........... 433

bicuspis, Pr. ........ 433

Christensenia ............ 453

aesculifolia, Max. ..... . 453

Cumingiana, Christ ..... 453

Cumingii, Copel. ........ 453

Christopteris............ 421

sagitta, Copel. .... ..... 421

Copelandi, Christ........ 421

Chrysodium

bicuspe, Ridl.......... 433

Cibotium ............. 77

baranetz, J. Sm........ 77

barometz, J. Sm........ 77

Cumingii, $K z e \ldots \ldots \ldots \ldots \quad 77$

var. semihastatum. ... 77

sumatranum, Christ..... 77

Coniogramma (-me) ....... 517

fraxinea, Diels ....... 518

var. Copelandi ....... 519

intermedia, Hieron.... ... 519

macrophylla, Hieron. . . . . 519

squamulosa, Hieron...... 519

subcordata, Copel. ... 5 518, 519

Craspedodictyum

grande, Copet. .......... 331

quinatum, Copel......... 331

Currania

gracitipes, Copel........ 312

oyamensis, Copel......... 312

Cyathea .............. 22

albidosquamata, Rst. . . . 31

Alderwereltii, Copel....... 48

alternans, $\operatorname{Pr} . \ldots \ldots \ldots \ldots 23$

ampla, Copel........... 26 


\section{Cyathea}

apoensis, Copel......... 26

arachnoidea, Hk. ..... 38, 39

arthropoda, Copel........ 22

atropurpurea, Copel....... 62

auriculifera, Copel....... 39

batjanensis, Copel........ 65

bicolor, Copel........... 44

biformis, Copel.......... 71

borneensis, Copel....... 33

botryocarpa, Copel....... 71

Brooksii, Copel......... 58

Burbidgei, Copel......... 55

callosa, Christ ..... . 37

calocoma, Copel. ........ 59

capensis, Sm.......... 44

caudata, Copel......... 29, 52

celebica, v. A. v. R. .... 39

Christii, Copel.......... 29

cinerea, Copel. . ....... 36

Clementis, Copel........ 69

contaminans, Copel..... 34, 492

crenulata, Bl. (See the cor-

rections) $\ldots \ldots \ldots 27,488$

crinita, Copel............ 66

Curranii, Copel......... 70

deparioides, Ces........ 410

dimorpha, Copel........ 60

dimorphotricha, Cope!.... 61

Elmeri, Copel. ......... 66

Fenicis, Copel......... 66

Foersteri, Rst.......... 28

Foxworthyi, Copel...... 35

fructuosa, Copel........ 37

fugax, v. A. v. R. ..... 34

fuliginosa, Copel. ..... 42, 65

fusca, Bk........... 25

geluensis, Rst......... 30
Cyathea

glabra, Copel.......... 55

halconensis, Christ....... 24

hemichlamydea, Copel. .... 47

heterochlamydea, Copel..... 53

Hewittii, Copel ....... 55

hypocrateriformis, v. A. v.R. 39

inciso-serratc, Copel...... 72

integra, J. Sm........ 25, 39

javanica, Bl. ....... . 32

Junghuhniana, Copel..... 45

Keysseri, Rst. ... . . 23

Kingii, Copel. ........ 60

Kingii, Rst. . . . . . 25

Klossii, Ridl. ......... 487

Korthalsii, Mett. ....... 27

lanaensis, Christ ....... 23

latebrosa, Copel......... 51

latipinnula, Copel........ 52

lepifera, Copel.......... 65

leucocarpa, Copel. ..... 66

Loheri, Christ ........ 37

var. tonglonensis .... 37, 42

longipinna, Copel. ...... 67

lurida, Copel. ......... 70

Margarethae, Copel....... 56

Mearnsii, Copel. ........ 24

melanopus, Copel........ 65

melanorachis, Copel...... 71

microphylloides, Rst. ... . 38

mindanaensis, Copel. .... 71

mitrata, Copel. ......... 37

modesta, Copel. ......... 61

novo-guineensis, Brau..... 35

obliqua, Copel. ... ...... 54

obscura, Copel......... 57

oinops, Hassk. (See the corrections) ........... 
Cyathea

orientalis, Moore (See the corrections) ........ 29

ornata, Copel...... . . . 66

papuana, v. A. v. R..... 487

paraphysata, Copel...... 58

patellifera, v. A. v. R. ... 31

percussa, Cav......... 372

philippinensis, Bk. . ... 23, 30

poiensis, Copel. ........ 56

pruinosa, Rst. ......... 29

Raciborskii, Copel........ 42

ramispina, Copel. ...... 56

recommutata, Copel. ...... 59

Ridleyi, Copel. . ....... 55

rigens, Rst. . . ........ 33

Robinsonii, Copel........ 30

sangirensis, Copel........ 62

scabriseta, Copel. . ... ... 73

senex, v. A. v. R. ...... 34

sibuyanensis, Copel...... 38

sinops, Rac. (See the corrections)

spinulosa, Wall........ 36

squamulata, Copel. ..... 56

stipulata, Copel. ........ 29

subdimorpha, Copel. ...... 60

subuliformis, v. A. v. R. . 32

suluensis, Bk. :........ 24

sumatrana, Bk. . .... . 32

Teysmannii, Copel....... 39

tomentosa, Zoll. \& Morr... 70

trichodesma, Copel. ...... 59

trichophora, Copel........ 72

tripinnata, Copel. ....... 39

truncata, Copel......... 70

Versteegii, Christ....... 25

Wallacei, Copel.......... 61
Cyathea

warihon, Copel. ........ 43

woodlarkensis, Copel...... 54

Zollingeriana, Mett. (See the

corrections). ....... . $\quad 26$

Cyclopeltis ............ 138

latupana, v. A. v. R. ... 138

mirabilis, Copel. ... ..... 140

novoguineensis, Rst...... 139

Presliana, Berk. ........ 139

var. biauriculata ..... 139

semicordata, J. Sm. ..... 138

Cyclophorus .......... 410

acrostichoides, Pr. . ..... 412

adnascens, Desv........ 411

angustatus, Desv..... ... 413

asterosorus, C. Chr..... . 413

Bamleri, Rist.......... 411

dispar, Christ. ......... 410

distichocarpus, C. Chr. 413, 414

lancifolius, v. A. v. R. ... 414

lingua, Copel........... 413

pseudo-lingua, v. A. v R. . 413

rupestris, C. Chr. ....... 410

Sarasinorum, Christ...... 413

valleculosus, v. A. v. R... 412

varius, Gaud............ 412

Winkleri, Rst... . .... 413

Cystodium

sorbifolium, J. Sm........ 74

Cystopteris............ 200

nodosa, Mett. ........ 200

stipellata, v. A. v. R. ... 200

tristis, Mett......... 200, 201

\section{D.}

Davallia ............... 222

achillaeifolia, Wall...... 430 


\section{Davallia}

ancestralis, C. Chr....... . 372

barbata, v. A. ₹. R. ... . 226

bidentata, Schk. ........ 222

biserrata, Bl. ........ 509

borneensis, J. Sm....... 167

bullata, Wall....... 223, 226

calvescens, Hk......... 229

ciliato, Hk........... 227

cryptocarpa, C. Chr..... . 372

decipiens, Ces. ......... 202

decurrens, Bk......... 222

decurrens, Hk......... 223

denticulata, Mett. ...... 222

deparioides, Ces. . . ... 410

dissecta, J. Sm. 224, 225, 226, 508

divaricata, Bl. ........ 223

elata, Spr. .......... 223

embolostegia, Copel,.... . 224

Engleriana, Bran....... 371

fermginea, Cav......... 202

fructuosa, Christ. . . . . 224

gracitis, Bl. .. . . .... 509

hirsuta, v. A. v, $R$. . 222, 227

Hookeriana, Wall....... 229

Kingii, Bk.......... 228

Koordersii, v. A. v. R. ... 225

linearis, C. Chr. ....... 371

Luzonica, Hk. . . ..... 509

Merrillii, C. Chr......... 371

nodosa, Hk.......... 200

papuana, Copel.. ....... 223

pedata, Sm.

var. minor. .. ...... 217

pentaphylla, B1. . . . 222, 508

polymorpha, C. Chr.... .. 371

polypodioides, Bth...... 230

pro:xima, Bl. ........ 232
Davallia

proxima, Rac.......... 232

Pullei, Rst. .......... 226

simplicifolia, C. Chr...... 222

solida, Sm............ 224

stipellata, Wall......... 200

subdissecta, V. A. v. R. .. 508

sumatrana, Copel. .... 222, 223

Toppingii, C. Chr........ 372

trichomanoides, Bl....... 224

tristis, Rac. . ........ 201

urophylla, Bedd........ 229

venusta, Schk. ........ 202

villosa, Don. . ...... 233, 234

viscidula, Mett. ....... 229

Wagneriana, Copel. ..... 224

Davallodes ............ 226

grammatosorum, Copel.... 228

gymnocarpum, Copel...... 228

hirsutum, Copel. ..... 227, 228

Kingii, Copel. ... . . . 228, 229

viscidulum, v. A. v. R... 229

Dendroconche

Annabellae, Copel........ 380

Dennstaedtia ........... 126

acuminata, Rst......... 130

ampla, Bedd. ........ 126

articulata, Copel........ 126

articulata, Rst. ........ 127

canaliculata, v. A. v. R... 126

concinna, Rst.......... 131

cuneata, Moore......... 130

dennstaedtioides, Copel. 127, 230

Elmeri, Christ ........ 76

Elmeri, Copel. ......... 131

erythrorachis, Diels (See the

corrections) ........ 126

flaccida, Bernh......... 130 


\section{Dennstaedtia}

Hooveri, Christ. . . . . . . 129 javanica, Christ ...... 75, 130 multifida, v. A. v. R. .... 129 paraphysata, v. A. v. R. . 128 Rosenstockii, v. A. v. R. . 127 samoensis, Moore...... 128 Smithii, Moore......... 127 terminalis, v. A. v. R. . . 129 villosa, Copel.......... 233

Dicksonia ............. 74

Blumei, Moore ....... 74, 495 Copelandi, Christ ...... 74, 76 flaccida, Sw........... 130 javanica, Bl.......... 75 papuana, Muell......... 495 Schlechteri, Brau....... 74 sorbifolia, Sm. ...... 74, 495

Dicranopteris dolosa, Copel. .......... 85

Dictyopteris ........... 321 Brooksice, v. A. v. R. . 517, 526 Brooksii, v. A. v. R. .... 322 Dahlii, v. A. v. R. ...... 321 elliptica, v. A. v. R. .... 324 ferruginea, v. A. v. R. .. 322 gymnocarpa, v. A. v. R... 322 hemiteliiformis, v. A. v. R.

labrusca, v. A. v. R. . 322, 517 var. ternata ......... 517 lamaoensis, v. A. v. R... 323 lamoensis, $v$. A. v. R.... 323 musakembangana, v. A. v. R. 517 olivacea, v. A. v. R. .... 322. pentaphylla, v. A. v. R. .. 323 pteroides, Pr.......... 321 subaequalis, v. A. v. R. . 323
Dictyopteris

Whitfordi, v. A. v. R.... 323

Didymochlaena .......... 145

dimidiata, Kze ....... 500

lunulata, Desv. ..... 145, 500 truncatula, J. Sm.

var. ozeanica....... . 145

Didymoglossum

affine, $V, D, B, \ldots \ldots \ldots .94$

Diplazium ........... 257

acrocarpum, Rst....... 258

acuminatum, Bl........ 262

affine, J. Sm. ......... 273

albido-squamatum, v.A. v. R. 512 alismifolium, v. A. v. R . 274 amplifrons, v. A. v. R. ... 270 assimile, Bedd. ......... 273 asperulum, v. A. v. R. ... 274 aspervm, Bl. ......... 272

var. polypodioides (See

the corrections)........ 271

var. subpolypodioides... 273 atratum, Christ......... 269 atropurpureum, Rst. ..... 268 Bamlerianum, Rst. ...... 260 bantamense, B1. ....... 261 Bolsteri, Copel......... 263 brachypodum, Copel. ..... 263 brachysoroides, Copel.... 263 Brackenridgei, Diels ..... 258 brevisorum, J. Sm....... 281 Brooksii, v. A. v. R..... 275 bulbiferum, Brack.. . . 258, 264 chlorophyllum, Bedd. .... 258 chrysocarpum, v. A. v. R. 271 confertum, C. Chr. ...... 260 cordifolium, Bl. . ....... 274 costulisorum, C. Chr. .... 288 


\section{Diplazium}

crenato-serratum, Moore

(See the corrections) .. 261

cultratum, Pr.... ..... 261

cyatheifolium, Pr....... 265

davaoense, Copel. ...... 265

deltoideum, Pr......... 268

dolichosorum, Copel...... 265

ebeneum, J. Sm......... 272

elatum, Fée, ......... 259

esculentum, Sw........ 276

fimbristegium, v. A. v. R. 272

Forbesii, C. Chr. .... 274, 275

fraxinifolium, Pr. ...... 274

fructuosum, Copel. ...... 273

geophilum, v. A. v. R. ... 263

grammitoides, Pr. ... 262, 276

Grashoffii, Rst. ........ 260

Hewittii, C. Chr... ...... 265

japonicum, Bedd..... 262, 277

lanceum, Pr. . . ..... 257

latifrons, v. A. v. R..... 271

leptogramma, v. A. $v$. R.

(See the corrections) ... 314

Lobbianum, Moore ...... 261

mamberamense, v. A. v. R

(See the corrections)

matangense, C. Chr....... 264

melanolepis, v. A. v. R... 266

Merrilli, Copel. ........ 257

Meyenianum, Pr........ 269

microphyllum, Desv.... .. 267

muricatum, C. Chr...... . 265

nitens, Rst. . ....... 269

oligosorum, Cepel........ 271

opacum, C. Chr........ 313

palauanense, Copel. ..... 261

pallidum, Moore.... . . 261
Diplazium

pariens, C. Chr.......... 275

paripinnatum, v. A. V. R. 266

Petersenii, Christ .... 263, 512 petiolare, Pr........ 258, 262

polycarpum, C. Chr....... 264

polypodioides, Bl. (See the

corrections) ........ 271

porphyrolepium, v. A. v. R. 257

porphyrorachis, Diels ..... 257

proliferum, Thouars...... 275

var. Swartzii......... 275

propinquum, v. A. v. R. . 259

protensum, Rst. ....... 262

Pullingeri, J. Sm........ 258

Ridleyi, v. A. v. R. ..... 275

sarawakense, C. Chr..... 266

scotinum, Rst.......... 269

serratum, Moore....... 257

sibuyanense, v. A. v. R... 270

silvaticum, Sw... 258, 259, 262,

264,512

var. elatum ........ 259

Smithianum, Diels .... .. 276

sorzogonense, Pr. (See the

corrections) ...... 262, 263

var. mamberamense (See

the corrections) ...... 263

var. poense (See the cor-

rections) ............ 263

speciosum, Bl. (See the cor-

rections)

spiniferum, v. A. v. R. ... 265

spinulosum, Bl. ....... 276

subpolypodioides, v. A. v. R. 273

Swartzii, Bl. ........ 275

tabacinum, Copel........ 260

umbrosum, Bedd. 


\section{Diplazium}

var. assimile ........ 273

Vanvuureni, v. A. v. R. . 267

vestitum, Pr.......... 267

Whitfordi, Copel. ....... 264

Williamsi, Copel. ....... 262

Woodii, Copel. (See the cor-

rections) ............ 262

zeylanicum, Moore ...... 257

Diplora

integrifolia, Bk........ 303

Doodia............... 256

dives, $\mathrm{Kze} \ldots \ldots \ldots \ldots \ldots 256$

media, R. Br. ........ 256

Doryopteris ............. 245

ludens, J. Sm.. ........ 245

var. pluritoba......... 245

papuana, Copel......... 245

Drymoglosum.......... 419

carnosum, J. Sm. ....... 527

crassifolium, Brau. ...... 419

fallax, v. A. v. R. ..... 419

heterophyllum, C. Chr. ... 419

Drynaria............. 415

convoluta, v. A. v. R..... 415

cornucopia, v. A. v. R. 415, 416

involuta, v. A. v. R. .... 415

nectarifera, Diels.... 415, 416

pleuridioides, Pr....... 415

quercifolia, J. Sm. ...... 415

rigidula, Bedd.. ....... 415

Dryopteris ............ 147

acanthocarpa, Copel...... 315

acrostichoides, v, A. v. R.

(See the corrections)

adenophora, C. Chr...... 175 adnata, V. A. v. R... 500, 501 alpina, Rist. ...
Dryopteris

amboinensis, o. Ktze .... 180

angusta, Copel. .. . ..... 186

angustipes, Copel. ...... 184

arbuscula, O. Ktze ..... 180

armata, Rst. ......... 318

aquatilis, Copel. ....... 187

aquatiloides, Copel... .... 177

arida, o Ktze......... 175

athyriocarpa, Copel. ...... 164

atroviridis, v. A. v. R. ... 311

aureo-viridis, Rst........ 161

Backeri, v. A. v. R. . 169, 171

badia, v. A. v. R. ...... 149

Bakeri, Copel. (See the corrections) ........... 173

var. acrostichoides (See

the corrections) ...... 173

balabacensis, Christ ..... 168

Bamleriana, Rst......... 163

banajaoensis, C. Chr..... 310

basilaris, C. Chr......... 182

basisora, Copel. ......... 150

batacorum, Rst. ....... 185

Beccariana, C. Chr. ...... 501

Beddomei, O. Ktze .. 159, 308

besukiensis, v. A. v. R. . 156

bipinnata, Copel....... 156

Blumei, v. A. v. R. (See the

corrections) ......... 189

borneensis, O. Ktze ... .. 167

Boryana, C. Chr. (See the corrections)

Brooksii, Copel.......... 185

calcarata, O. Ktze . . . 152, 515

calva, Copel........... 153

canescens, C. Chr.

var. acrostichoides (See 
Dryopteris

the corrections. ..... 173

var. incana .......... 173

caudiculata, Rst........ 187

chrysotricha, C. Chr. .... 145

cochleata, C. Chr........ 503

compacta, Copel. ....... 176

conferta, Brau. ........ 175,

confusa, Copel. ........ 157

conterminoides, C. Chr.... 501

conversa, v. A. v. R. .... 148

cordifolia, v. A. v. R. ... 320

crassifolia, O. Ktze ...... 149

crenata, O. Ktze. ....... 168

decomposita, O. Ktze.... 168

decursive-pinnata, O. Ktze

(See the corrections)

dichrotricha, Copel....... 189

dichrotricha, Copel. (See the

corrections ......... 158

dichrotrichoides, v. A. v. R.

(See the corrections)

didymosora, C. Chr...... 183

discophora, Rst. ....... 190

dissecta, O. Ktze 165, 166, 169

distans, O. Ktze ........ 174

divergens, Rst. ........ 154

diversiloba, Christ....... 515

var. acrostichoides (See the

corrections) ........ 173

dubia, Copel........... 168

dura, Copel........... 148

edentula, O. Ktze .... 163, 164

edulenta, v. A. v. R...... 163

Elmeri, v. A. v. R....... 314

Engleriana, Brau....... 309

erythrosora, O. Ktze ..... 162

Escritorii, v. A. V. R. 170, 503
Dryopteris

exigua, 0. Ktze . . . . . . 157

extensa, O. Ktze ......... 175

falcatipinnula, Copel. ..... 151

ferox, O. Ktze :........ 181

filix mas, Schott ...... 502

var. adnata ......... 501

rar. cochleata ........ 503

var. parallelogramma .. 502

Finisterrae, Brau........ 308

flavovirens, Rst. ........ 165

genuflexa, Rst......... 312

glabrior, Copel. ......... 168

glandulosa, o. Ktze..... 176

gracilescens, O. Ktze . 153, 276

gymnocarpa, Copel. . ..... 313

gymnogrammoides, C. Chr. 312

Hallieri, C. Chr. ........ 152

hamifera, v. A. V. R.... 181

herbacea, v. A. v. R. .... 166

heterolepia, v. A. v. R.... 310

heterophylla, O. Ktze..... 145

Hewittii, Copel... . . . . . . 189

hirsuta, O. Ktze ........ 175

hispidifolia, v. A. v. R... 186

horizontalis, v. A. v. R. . 151

hypolepioides, Rst.. ..... 309

immersa, O. Ktze....... 155

intermedia, O. Ktze .... · 167

iridescens, v. A. v. R.... 176

Keysseriana, Rst. . . . . . 157

Kingii, Copel. ........ 161

Klossii, v. A. v. R. ..... 501

Koordersii, Christ........ 500

Lauterbachii, Brau..... . 150

lineata, C. Chr. (See the

corrections) ...... 174, 177

logavensis, Rst........ 154 
Dryopteris

longgissina, C. Chr...... 318

Luerssenii, C. Chr....... 159

malayensis, C. Chr. ..... 176

mamberamensis, v. A. v. R. 516

Marthore, v. A. v. R..... 152

media, v. A. v. R...... 162

megaphylla, C. Chr...... 179

megaphylloides, Rst. . . 188

megaphylloides, v. A. v. R. 180

melanolepis, v. A. v. R... 305

melanophlebia, Copel. . . . 319

mesodon, Copel. . ...... 169

microstegia, Rst. ........ 311

mirabilis, Copel. ....... 174

mixta, Rst. ......... 159

mollis, Hieron. .... . 183, 515

Monssetii, Rst. ........ 306

multilineata, O. Ktze.. . 180

multiseta, Bk. ...... 169, 171

novoguineensis, Brau... , 159

oblanceolata, Copel. . .... 320

obtusifolia, Rst........ 315

olivacea, Rst.......... 163

oppositipinna, v. A. v. R. . 307

orientalis, C. Chr.

var. fejeensis ...... 152

oyamensis, C. Chr. . .... 312

paleata, Copel.......... 152

paraphysata, Copel.... . 189

parasitica, C. Chr. . . ... 183

parasitica, O. Ktze...... 183

paucijuga, v. A. v. R. . 178

paucisora, Copel........ 153

pectinata, V. A. V. R. . 152

peltata, v. A. v. R. ..... 190

penangiana, C. Chr.

var. calvescens ........ 181

\section{Dryopteris}

pentaphylla, Rst.... ... 317

parakensis, C. Chr. ..... 183

perpilifera, v. A. v. R. . 183

perrigida, v. A. v. R. ... 317

persquamifera, $\nabla$. A. v. R. 149

piloso-squamata, v. A. v. R. 181 polita, Rst. .......... 309

porphyricola, Copel. ..... 186

propria, v. A. v. R. ... . 152 pseudo-arbuscula, v. A. v. R. 504 pseudomegaphylla, v. A. v. R.

179,180

pulvinulifera, O. Ktze .... 167

purpurascens, Christ ..... 168

Raciborskii, v. A. v. R. 165, 166

recedens, O. Ktze....... . 166

rhodolepis, C. Chr... . 168, 172

Roemeriana, Rst. ...... 179

rubrinervis, C. Chr.... . 316

sagenioides, O. Ktze .... 160

sagittifolia, O. Ktze ..... 182

sarawakensis, v. A. v. R. 167

schizoloma, v. A. v. R. ... 306

Schlechteri, Brau. ....... 308

Schultzei, Brau. ........ 156

sessilipinna, Copel. . .... 173

setigera, O. Ktze. ... 169, 171

Smithii, v. A. v. R. .... 159

Spenceri, Christ..... 188, 320

squamulifera, v. A. v. R. 167

subarborea, C. Chr. ...... 171

var. glabrior......... 172

subattenuata, Rst. ...... 158

subsagenioides, v. A. v. R. 160, 502

subsparsa, v. A. v. R.... 170

subviscosa, v. A. v. R. . 153

superficialis, v. A. v. R. 155 


\section{Dryopteris}

supraspinigera, Rst. .... 317

suprastrigosa, Rist. . . . . 182

syrmatica, O. Ktze .... . 161

tabacicoma, v. A. v. R. . 172

tamatana, C. Chr......... 161

tandikatensis, v. A. v. R. 178, 503

tenerrima, Copel. ........ 310

thelypteris, A. Gray . . 160

todayensis, Christ ...... 184

truncata, O. Ktze .... 185, 189

uncidens, Rst. ......... 313

uniauriculata, Copel. ..... 174

urdanetensis, Copel. . ... 147

urophylla, C. Chr. (See the

corrections) ... . . 177, 503

var. rubrinervis. . .... 316

Vangenderenstortii, v. A.

v. R. . . ........... 502

verrueulosa, v. A. v. R. . . 177

viscosa, O. Ktze ........ 153

vitis, O. Ktze . . . . 167

wariensis, Copel......... 150

Dryostachyum ......... 417

Hieronymi, Brau. .. . .. 416

novoguineensis, Brau. .... 417

splendens, J. Sm....... 417

\section{E.}

Elaphoglossum .. ........

angulatum, Moore (See the corrections). . . . . . . . . 423

basilanicum, Copel.... . 425

bolanicum, Rst. . . .... 427

callifolium, Bl. ...... 425, 427

commutatum, v A.v. R 426, 427

Copelandi, Christ ...... 427
Elaphoglossum

decurrens, Moore .. 424, 425

Elmeri, , Copel. ... . . . . 424

gorgoneum, Brack. .. . . 423

Hellwigianum, Rst. . . . 423

heterolepium, v. A. v. R. , 426

laurifolium, Moore... .. 426

var. commutatum ... . 427

luzonicum, Copel. ... ... 424

Macgregorii, Copel.. . .... 424

melanosticticum, Moore . 427

Merrillii, Christ .......... 424

minahasae, v. A. v. R. . . 527

novoguineense, Rist. ...... 423

permutatum, v. A. v. R. . 425

petiolatum, Urb. (See the

corrections)

sordidum, Christ........ 425

Equisetum ........... 463

debile, Rb. ........ 463

tenggerense, Hochr... . . 463

virgatum, Bl. ......... 463

\section{G.}

Gleichenia . .......... 80

amboinensis, $v . A . v . R . .85,86$ amoena, v. A. v. R. .... 497

arachnoidea, Mett. .... 82, 83

bolanica, Rst.......... 86

bracteata, $B l . \ldots \ldots \ldots \ldots . \quad 85$

bullata, Moore.......... 83

circinata, auctt. plur..... 80

conversa, v. A. v. R. ... 81

crassifolia, Copel. ....... 83

dicarpa, R. Br. ........ 80

dichotoma, Hk. ........ 83

dolosa, Copel. ........ 85, 86 


\section{Gleichenia}

Elmeri, Copel......... 81

excelsa, J. Sm,. ........ 496

ferruginea; Bl........ . 83

gigantea, Wall.... 82, 83, 496 glauca, Hk. ... 81, 82, 83, 496

var. excelsa .......... 496

var, gigantea ....... 83

Hermanni, R. Br...... 83

hirta, B1. . . . . ..... 85, 86

hispida, Mett. ....... . 86

japonica, Spr......... 81

laevigata, Hk. ........ 85

laevissima, Christ...... 82, 85

linearis, Clarke......... 83

longissima, Bl.. ....... 81

microphylla, R. Br.... 80, 497

monticola, Ridl........ 497

oceanica, Kuhn....... 85, 497

opposita, V. A. v. R. .... 80

ornamentalis, Rst. ...... 85

rigida, J. Sm.......... 83

semivestita, Lab. ........ 80

sordida, Copel......... 82

vestita, Bl.......... 86

volubilis, Jungh. . . . . 8. 82, 83

Goniopteris

longissima, Brack........ 318

rigida, Ridl........... 515

rudis, Ridl........... 515

Grammitis

Blumei, Zipp.

var. ceratophylla ...... 326

cucullate, Bl........ 358, 353

lanceolata, Sw.......... 321

obscura, Bl.

var. angustata ........

349

Gymnogramma (-me)
Gymnogramma (-me)

javanica, Bl.

var. macrophylla ...... 519

leptophylla, Desv. . ..... 325

serrulata, Bl. .......... 518

Totta, Schl.......... 313

Gymnopteris

inconstans, Copel....... 434

latifolia, $\operatorname{Pr} . \quad \ldots \ldots \ldots \ldots .333$

lomarioides, Christ....... 438

spicata, Pr. ......... 432

subquinquefida, $\operatorname{Pr} . . . .$. : 333

taccaefolia, J. Sm. .... . . 333

trilobata, J, Sm........ 333

\section{I.}

Hemigramma........... 332

grandifolia, Copel....... 333

latifolia, Copel. ........ 332

Zollingeri, Christ....... 382

Hemionitis . . . . . . . . . . . 332

arifolia, Moore......... 332

gymnopteroidea, Copel. .... 332

reticulata, Forst........ 327

Zollingeri, Kurz ...... 332

Hemitelia ........... 40

alsophiliformis, v. A. v. R. 46

barisanica, v. A. V. R. ... 49

bicolor, v. A. v. R. ..... 44

capensis, R. Br. ....... 44

caudata, Mett......... 52

caudipinnula, v. A. v. R. . 48

confluens, v. A. v. R. ... 49

crenulata, Mett. ....... 42

glaucophylla, v. A. v. R. . 50

hemichlamidea, v. A. v. R. 47, 488

heterochlamidea, v. A. v. R. 53 
Hemitelia

horridipes, v. A. v. R. ... 47

Junghuhniana, Mett. .... 45

latebrosa, Mett. ......51, 489

latipinnula, v. A. v. R.... 52

leptolepia, v. A. v. R.... 488

manilensis, Pr. ........ 58

merapiensis, v. A. v. R... 45

salticola, v. A. v. R. . . 50

singalanensis, v. A. v. R.. 43

sumatrana, v. A. v. R... 48

tonglonensis, v. A. v. R. 37, 42

warihon, v. A. v. R.... 43

Heteropteris .......... 420

Histiopteris ........... 246

alte-alpina, v. A. v. R. .. 510

incisa, J. Sm. ......... 246

var. integrifolia ...... 246

integrifolia, Copel. ...... 246

stipulacea, Copel. ....... 246

Humata ............. 216

alpina, Moore ....... . 219

Brooksii, Copel.......... 216

crassifrons, v. A. v. R... 217

Cromwelliana, Rst. ... . 217

dimorpha, Copel........ 219

falcinellia, Copel......... 221

hymenophylloides, Copel.. 221

immersa, Mett. ......... 221

introrsa, Christ ......... 220

Kingii, Diels .......228, 507

microsora, Copel......... 216

minuscula, v. A. v. R. ... 216

obtusata, v. A. v. R. ... 220

parvula, Mett......... 216

perpusilla, v. A. v. R. ... 218

pinnatifida, Bedd. ........ 216

puberula, Copel. ........ 219
Humata

pusilla, Christ .......... 217

pusilla, J. Sm. ........ 218

repens, Diels ......... 217

var. minuscula ....... 216

Schlechteri, Brau......... 219

sessilifolia, Mett....... 216

subtilis, v. A. v. R. .... 218

tenuis, Copel. .......... 221

vestita, Moore.......... 220

viscidula, v. A. v. R.. 229, 507

Hydroglossum

auriculatum, Willd....... 115

Hymenolepis ............ 432

ophioglossoides, Klf...... 432

platyrhynchos, Kze....... 433

revoluta, Bl............ 432

rigidissima, Christ. ...... 432

spicata, Pr. (See the cor-

rections) . . . . . . . . . . 432

Hymenophyllum ......... 87

acanthoides, Rst........ 100

aculeatum, Rac. ....... 100

var. acanthoides ....... 100

alatum, Schk.......... 103

angulosum, Christ ...... 87

australe, Copel. ......... 99

australe, Willd........... 88

badium, Hk. \& Grev...... 497

Bamlerianum, Rst....... 90

batuense, Rst......... 92

bismarckianum, Christ . 99, 100

blandum, Rac.......... 97

Blumenaum, Spr....... 90, 91

Boschii, Rst........... 94

brevidens, v. A. v. R..... 96

Copelandianum, v. A. v. R. . 99

crispum; Nees \& Bl. . . . . 88 
Hymenophyllum

demissum, Sw........ 88

var. productum ....... 88

denticulatum, Sw. ...... 100

var. Neesii ........... 100

dilatatum, $S w . \ldots \ldots \ldots .90$

discosum, Christ. ..... 87, 88

edentulum, C. Chr........ 93

edulentum, v. A. v. R.... 93

Elberti, Rst........... 94

eximium, Kze ......... . 87

Foersteri, Rst......... 93

formosum, Brack........ 90

fuscum, V. D. B. . . . . . 97

geluense, Rst. ......... 96

Hallieri, Rst. . . . . . . . . 89

holochilum, C. Chr...... 94

javanicum, Spr.

var. complanata ...... 88

Junghuhnii, V. D. B..... 91

klabatense, Christ (See the

corrections)

laminatum, Copel.........

Lobbii, Moore ......... . 94

longifolium, v. A. v. R. . 91

macrosorum, v. A. v. R... 101

multifidum, Christ (See the corrections)

multifidum, Sw. (See the corrections) ........ 98

Neesii, Hk. . . . . . . . . . 100

ovatum, Copel. ......... 98

paniculiflorum, Pr..... 87, 88

pantotactum, v. A. v. R. . 91

penangianum, Matt. \& Christ 87

perparvulum, v. A. v. R. . 98

pilosum, v. A. v. R. .... 89

polyanthos, Christ....... 95
Hymenophyllum

producutum, Kze . ..... 88

var. integriloba....... 88

pyenocarpum, V. D. B.... 90

Reinwardtii, V. D. B. ... 99

rubellum, Rst.......... 95

salakense, Rac....... 89, 498

semifissum, Copel. ...... 88

serrulatum, C. Chr..... 9 98, 99

subdemissum, Christ ..... 90

subflabellatum, Ces...... 93

subrotundum, v. A. v. R.. 97

taliabense, v. A. v. R. ... 93

Treubii, Rac.......... 90

thuidium, Harr... . ...... 99

torricellianum, v. A v. R. 95

tunbridgense, Bedd....... 100

Zollingerianum, Kze ... 92, 97

Hypolepis . ........... 240

Bamleriana, Rst......... 241

bivalvis, จ. A. v. R. .... 242

papuana, Bail......... 242

punctata, Bedd.... . 241, 311

rugulosa, J. Sm.......... 241

tenerifrons, Christ ...... 240

\section{L.}

Lastr(a)ea

Beccariana, Ridl........ 501

Blumei, Moore......... 172 calcarata, Moore

var, citiata .......... 152

cochleata, Moore ....... 503

exigua, J. Sm......... 157

filix mas, $P r$.

var. cochleata. ....... 503

falciloba, Hk. ........ 152 


\section{Lastr(a)ea}

Klossii, Ridl.......... 501

Macgregorii, Ridl. ... ... 501

Thelypteris, Bory........ 160

Lecanopteris (See the correc-

tions) ........... 406

carnosa, Bl. ......... 407

Curtisii, Bk.......4409, 410

davallioides, v. A. v. R. . 409

deparioides, Bk........ 410

incurvata, Bk......... 408

Macleayi, Bk. . . . . . . 410

Nieuwenhuisii, Christ .... 408

philippinensis, v. A. v. R. 409

pumila, Bl.......... 407

pumila, Copel.......... 409

Leptochilus ............. 434

absconditus, v. A. v. R.. . 439

cuspidatus, C. Chr........ 425

decurrens, Bl. ......... 434

diversifolius, C. Chr. 434, 435, 436

heteroclitus, C. Chr....... 434

inconstans, C. Chr........ 434

lanceolatus, Fée ........ 436

latifolius, C. Chr. ....... 484

Linnaeanus, Fée (See the corrections)

lomarioides, Bl. ......... 438

normalis, Copel......... 436

ovatus, Copel. .......... 434

perakensis, C. Chr....... 439

Preslianus, C. Chr....... 435

rizalianus, Christ ....... 436

scalpturatus, C. Chr. ..... 436

siifolius, Rst. ......... 434

sumatranus, $v . A . v . R$.

(See the corrections) ... 436

virens, C. Chr.......... 435
Leptochilus

zeylanicus, C. Chr....... 434

Zollingeri, Fée......... 436

Leptocionium

edentulum, V. D. B...... 98

edulentum, v. A. v. R.... 93

Leptopteris ............ 440

alpina, C. Chr........... 440

Leucostegia

affinis, J. Sm.......... 221

hirsute, J. Sm......... 227

nodosa, Bedd......... 200

parvula, J. Sm........ 216

Lindsaya.............. 202

adiantoides, Kuhn . .... 204

azurea, Christ ......... 212

brevipes, Copel......... 207

bullata, v. A. v. R. ... .. 206

capillacea, Christ . . 202, 205

concinna, J. Sm......... 207

cultrata, Sw......... 207

davallioides, B1........ . 507

decomposita, Willd...... 213

delicatula, Christ .... 202, 203

diplosora, v. A. v. R. . 210, 211

Foersteri, Rst......... 203

glandulifera, v. A. v. R. . 204

Hewittii, Copel. ........ 212

hymenophylloides, Bl. 202, 204

Kingii, Copel......... .. 210

lancea, Bedd........... 506

Lobbiana, Hk.

var. sessilifolia ....... 207

Iunulata, v. A. v. R. .... 203

Merrilli, Copel. ...... . 204

microstegia, Copel........ 212

monocarpa, Rst. ........ 208

monosora, Copel........ 210 


\section{Lindsaya}

monosora, Rst......... 208 montana, Copel......207, 215 multisora, v. A. v. R. ... 211 napaea, v. A. v. R. ..... 209 natunae, Bk. ........ 212 nitida, Copel.......... . 213 oblanceolata, v. A. V. R. . 506 obtusa, Hk. ......... 213 orhiculata, Mett........ 208 papuana, Copel.......... 213 pectinata, Bl. ...... 203, 208 var. capillacea ....... 205 propria, v. A. v. R. . ... 207 regularis, Rst. . . . . . . . . 209 repens, Bedd.... 202, 204, 208 rigida, J. Sm. ......... 210 Roemeriana, Rst. ....... 205 Sarasinorum, Christ..... 214 Schlechteri, Brau. ..... 205 Schultzei, Brau. ........ 213 sessilis, Copel. ......... 203 subalpina, v. A. v. R.... 507 trichophylla, Copel....... 204 triplosora, v. A. v. R.... 211 Versteegii, v. A. v. R. ... 206 Wollastonii, v. A. V. R. . 505 Lomagramma $(-\mathrm{me}) \ldots . . . .4 \quad 436$ abscondita, v. A. v. R. ... 439 articulata, Copel. .... 4 437, 438 bipinnata, Copel......... 438 Brooksii, Copel......... 439 lomarioides, J. Sm........ 438 var. pteroides ........ 438 perakensis, Bedd. . ..... 439 pteroides, J. Sm. ....... 438

Lomaria . . . . . . . . . . . . . . 254

Bamleriana, v. A. v. R. .. 254

\section{Lomaria}

egenolfioides, $B k$. .... 244, 254 euphlebia, Kze ...... 510 Fraseri, A. Cunn. . ...... 255 glanca, $B l . \ldots \ldots \ldots, \ldots .510$ gracitis, Bl. .......... 430 Keysseri, v. A. v. R. ... 254 Patersoni, Spr. ........ 512 punctata, Bl. ........ 512 spectabilis, Kze....... 428 vestita, Bl. (See the corrections)

Lomariopsis

leptocarpa, Fée ........ 428

Smithii, Fée.......... 428

Loxogramma (-me) . . . . ... 327

avenia, Pr............ 329

Blumeana, Pr. .......... 329

Brooksii, Copel......... 328

conferta, Copel.......... 329

dimorpha, Copel........ 329

ensifrons, V. A. v. R. ... 329

Forbesi, Copel. .......... 329

grandis, Copel.......... 328

iridifolia, Copel...... .... 329

lanceolata, Pr.......... 328

malayana, Copel. .... 328, 329

paltonioides, Copel..... . 330 parallela, Copel. ... .... 328

Lycopodium ... . . . . . . 467 alpinum, L. . ... ..... 469 barbatum, $K l f \ldots \ldots \ldots \ldots .475$ brevibracteatum, v. A. v. R. 532 campestre, v. A. v. R. . . 529 carinatum, Desv. .... 529, 530 casuarinoides, Spring..... 468 cernuum, L. (See the corrections) ........... 532 


\section{Lycopodium}

complanatum, L........ 469

crebre, v. A. v. R...... 530

cupressinum, Willd. (See the corrections)

Everettii, Hert. (See the corrections)

gedeanum, v. A. v. R. (See the corrections)

horizontale, v. A. v. R.... 530

hydrophilum, v. A. v. R. . 531

hygrophilum, v. A. v. R. . 531

Jacobsonii, v. A. v. R. ... 468

laxum, Pr. .......... . 529

leucolepis, Jungh. \& de Vr: 468

monticolum, v. A. V. R.

(See the corrections)

myrtifolium, Nees \& Bl. . 467

ornatum, Hk. \& Grev.... 479

patentissimum, v. A. v. R. 531

pennula, Desv. (See the cor-

rections)

phlegmaria, L........ . 467

phlegmarioides, Gaud. .... 531

pinifolium, Bl......... 467

Pullei, v. A. v. R....... 533

pungens, v. A. v. R..... 467

refelexum, Lam. (See the corrections)

rubricaule, v. A. v. R. ... 529

serratum, Thb. ........ 467

tetrastichum, Kze ...... 529

tomentosum, v. A. v. R. . 532

Versteegii, v. A. v. R. .. 530

Lygodium ............. 114

borneense, v. A. v. R. .. 115

circinatum, Sw........ 115

dimorphum, Copel. ... 115, 116

Ferns and Fern ALLies.

\section{Lygodium}

japonicum, Sw......... 117

Kingii, Copel........... 117

Merrillii, Copel......... 118

Moszkowskii, Brau. ..... 116

novo-guineense, Rst....... 116

scandens, Sw. ......... 117

semihastatum, Desv... 115, 116

Teysmannii, v. A. v. R. . 115

trifurcatum, Bk..... 115, 116

Versteegii, Christ .... 118, 499

M.

Macroglossum ........... 446

Alidae, Copel. ........ 446

Smithii, Campb. ....... 446

Marattia ............ 447

andaiensis, v. A. v. R. ... 449

Brooksii, Copel. ......... 448

caudata, Copel......... 451

fraxinea, Christ ....... 529

fraxinea, $\mathrm{Sm} . . . . \ldots \ldots .450$

grandifolia, Copel........ 452

Kingii, Copel. .......... 449

Koordersii, v. A. v. R. ... 529

macrophylla, de Vr..... 450 .

novoguineensis, Rst. .... 449

obesa, Christ ......... 451

paleolata, v. A. v. R. ... 450

papuana, v. A. v. R. ... 451

pellucida, Pr.......... 450

rugulosa, v. A. v. R..... 452

sambucina, Bl......... 448

silvatica, Bl. ......... 450

squamosa, Christ ...... 448

ternatea, de Vr. ..451, 452, 528

Teysmanniana, v. A. v. R. 452 
Matonia ............. 78

Foxworthyi, Copel....... 79

pectinata, R. Br........ 78

sarmentosa, Bk......... 79

Merinthosorus

drynarioides, Copel. .....

433

Mertensia

crassifolia, Pr............

dichotoma, Willd........ 83

Mesochlaena

polycarpa, Bedd........ 504

var. chamaeotaria..... . 317

Microlepia .............. 229

Brooksii, Copel.......... 231

ciliata, Copel........... 227

dennstaedtioides, Copel.... 230

grammatosora, C. Chr..... 228

gymnocarpa, C. Chr...... 228

Hancei, Prantl ......... 230

hirta, Pr......... . 231, 234

var. villosa .......... 233

hirsuta, Pr.......... 227

hispidula, v. A. v. R. ... 233

Hookeriana, Pr......... 229

Kurzii, Bedd........... 231

manilensis, Pr. (See the corrections)

marginalis, Bedd. ........

melanorachis, Rst. ......

229

234

pinnata, J. Sm.

var. gracilis .......... 509

var. Luzonica ......... 509

proxima, Pr..... .231, 232, 508

proxima, v. A. v. R... 231, 232

pseudo-hirta, Rst. ....... 232

puberula, v. A. v. R. .... 231

Ridleyi, Copel... . ...... 231

strigosa, Pr. . . . . 231, 508
Microlepia

todayensis, Christ ...... 233

trichosticha, J. Sm. . ... 231

villosa, Pr........... 233

Monachosorum............ 305

Davallioides, Kze ...... 305

subdigitatum, Kuhn...... 305

Monogramma(-me)......... 335

capillaris, Copel ........ 335

dareicarpa, Hk......... 335

emarginata, Brau....... 335

Loheriana, v. A. v. R. 336,340

intermedia, Copel........ 336

paradoxa, Bedd........ 336

trichoidea, J. Sm........ 335

Nephrodium

acrostichoides, J. Sm. (See

the corrections) .... . 173

banksiaefolium, Pr....... 440

Blumei, Hk. . . . . . . . . 172

bromelicefolium, Pr...... 440

cochleatum, Don ... .... 503

confluens, Muell......... 199

conjugatum, T. \& B.... 165

chrysotrichum, Bk. ...... 145

decompositum, R. Br.... 168

decursivo-pinnatum, Bk. (See

the corrections)

didymosorum, Pav....... 183

distans, Hk.......... 174

edentulum, Bk......... 164

edulentum, v. A. v. R.... 164

erythrosorum, Hk....... 162

filix mas, Rich.

var. fibrillosa ........ 502

var. marginata ....... 502

gymnogrammoides, Diels .. 312

hispidulum, Christ ....... 186 
Nephrodium

intermedium, Bk....... 172

Labrusca, Rac.......... 517

lineatum, Pr. (See the cor-

rections) .......... 173

longissimum, Diels ...... 318

microstegium, Hk....... 311

molle, R. Br.......... 183

pachyphyllum, Bk...... 193

parasiticum, Bk........ 183

rhodolepis, Clarke....... 172

rubidum, Copel.......... 316

rubidum, J. Sm......... 316

Spenceri, Copel. ........ 188

tectum, Bedd.......... 183

Thelypteris, Stremp...... 160

viscosum, Bk. ......... 153

Nephrolepis ........... 134

barbata, Copel......... 137

biserrata, Schott....... 138

Clementis, Christ ....... 137

cordifolia, Pr. . ..... 136, 137

dicksonioides, Christ .. 134, 135

exaltata, Schott (See the corrections) ........ 137

hirsutula, Pr. (See the corrections) $\ldots \ldots \ldots 135,136$

iridescens, v. A. v. R.... 137 laurifolia, Christ ....... 138 niphoboloides, v. A. v. R. 136 persicifolia, Christ ...... 138 pilosa, Pr. (See the corrections)

pilosula, v. A. V. R. (See the corrections) ...... 136 radicans, Kuhn...... 137, 499 Rosenstockii, Brau ...... 134 schizolomae, v. A. v. R.... 214
Nephrolepis

Schlechteri, Brau........ 135

Thomsoni, v. A. v. R.... 499

tomentosa, v. A. v. R. ... 135

Odontosoria .... ........ . 202

chinensis, J. Sm. ...... 202

decipiens, Christ ....... 202

lindsayae, v. A. v. R. . . 202

tenera, Ridl........... 505

Versteegii, Christ ....... 206

Oleandra ............. 132

colubrina, Copel. ... ... . 132

coriacea, Copel. ........ 132

Cumingii, J. Sm........ 133

geniculata, v. A. v. R. . . 132

neriiformis, Cav........ 499

oblanceolata, Copel. ..... 132

Wallichii, Pr.......... 499

Whitmeei, Bk. ........ 133

Olfersia

gracilis, Bl. ......... 430

Onoclea

scandens, Sw........ . 428

Ophioglossum .......... 453

gregarium, Christ....... 453

inconspicuum, v. A. v. R. 453

lineare, Schlecht. \& Brau. 453

Moultoni, Copel. ... ..... 454

pendulum, L......... . 454

pumilum, v. A. v. R. .... 453

Schlechteri, Brau....... 454

Osmunda ............. 440

banksiifolia, Kuhn ....... 440

var. brometiifolia...... 440

bromeliitolia, Copel. ..... 440 


\section{Osmunda}

javanica, Bl. ......... 440

Prestiana, J. Sm....... 440

Zeylanica, Kze ........ 440

\section{P.}

Paesia................. 252

Elmeri, Copel. . . . . . . . 253

luzonica, Christ........ 252

rugosula, (not rugulosa), Kuhn

252,511

rugulosa, Diels......... 511

scaberula, Kuhn ....... 253

\section{Paltonium}

novoguineense, Rst. ..... 420

vittariiforme, Rst. . . . . . . 420

Peranema.............. 125

luzonica, Copel........ . 125

Phanerosorus........... 79

sarmentosus, Copel. ..... 79

Phegopteris ............ 305

acanthocarpa, v. A. v. R. . 315

armata, v. A. v. R. ..... 318

atroviridis, v. A. v. R. .. 311

banajaoensis, v. A. v. R. . 310

canescens, Mett. ....... 319

chamaeotaria, v. A. v. R., 317

cordifolia, v. A. v. R. ... 320

cuspidata, Mett....... 516

Dahlii, Hieron. ........ 321

decursive-pinnata, Fée (See

the corrections)

distans, Mett...........

diversiloba, V. A. V. R. (See

the esrrections)... . 316, 515

Elmeri, v. A. v. R. ..... 314

Eng leriana, v. A. v. R.... 309
Phegopteris

finisterrae, v. A. v. R. .. 308 granulosa, v. A. v. R. .. 316 gymnocarpa, v. A. v. R... 313 gymnogrammoides, V. $\Lambda$.

v. R. ............. 312

heterolepia, v. A. v. R. 310

Hosei, v. A. v. R. ..... 320

hypolepioides, v. A. v. R.. 309

leptogramma, $v, A . \quad v, R$.

(See the corrections).... 314

longissima, v. A. v. R. . 318

mamberamensis, v. A. v. R. 516

melanolepis, v. A. v. R. . 305

melanophlebia, v. A. V. R. 319

Moussetii, v. A. v. R. .... 306

oblanceolata, V. A. v. R. 320

obtusifolia, v. A. v. R. ... 315

opaca, Mett......... . 313

oppositipinna, v. A. v. R.. 307

oyamensis, v. A. v. R. ... 312

paucijuga, v. A. v. R. ... 178

pennigera, v. A. v. R.... 316

pentaphylla, v. A. V. R. .. 317

perrigida, v. A. v. R. ... 317

polita, v. A. v. R. ..... 309

punctata, Mett. ...... 241, 311

quadriaurita, v. A. v. R... 307

Ridleyana, v. A. v. R.... 515

rubida, v. A. v. R....... 316

rubrinervis, Mett. ...... 316

rugulosa, Mett......... 241

salicifolia, Mett......... 320

schizoloma, v. A. v. R. ... 306

Schlechteri, v. A. v. R... 308

stegnogramma, Mett. .... 319

Smithii, v. A. v. R. . . 159, 308

Spenceri, v. A. $\tau$. R. . 188, 320 
Phegopteris

supraspinigera, v. A. v. R. 317 totta, Mett........ 313, 515 triphylla, Mett...... 177, 320 uncidens, v. A. v. R..... 313 Wollastonii, v. A. v. R. .. 515 Photinopteris ........... 433 drynarioides, Bedd....... 433 Phyllitis ............. 302 d'Urvillei, O. Ktze ... 303, 305 Grashoffii, Rst. ....... 304 intermedia, v. A. v. R.... 303 $\operatorname{lin} z a, v . A . v . R . \ldots \ldots . .303$ longifolia, O. Ktze.... 304, 305 mambare, v. A. v. R.... 303 pinnata, 0. Ktze........ 304 schizocarpa, v. A. v. R. .. 304 scolopendropsis, v. A. v.R. 303

Plagiogyria. . ......... 243 egenolfioides, Copel. ...... 244 euphlebia, Mett. ........ 510 glauca, Mett. ......... 510 minuta, Copel......... 243 nana, Copel........... 244 pyenophylla, Mett...... 244 sumatrana, Rst. ....... 244 tuberculata, Copel. ...... 244

Platycerium ........... 421

biforme, $B l$.

var. erecta ......... 422

bifurcatum, C. Chr. ..... 422 coronarium, Desv........ 422 var. cucullatum ....... 422 Ridleyi, Christ.. . . .... 422 sumbawense, Christ..... 422 Wilhelminae Reginae, v. A. v. R. . . . . . . . 421 Willinckii, Moore ....... 422
Pleocnemia............. 145

Cumingiana, Pr........ 145 devexa, v. A. v. R... 147, 500 fibrillifera, v. A. v. R.... 146 gigantea, Pr. ......... 146 heterophylla, v. A. v. R. . 145 Kingii, v. A. v. R. ...... 147 Leuzeana, Pr. ........ 145 var. hemiteliiformis..... 321 malayensis, v. A. v. R.... 146 membranacea, Bedd.

var. novoguineensis..... 147 membranifolia, Bedd... 146, 166 Trimeni, Bedd. ... ..... 146 Pleopeltis ........ ....... 374 accedens, Moore..... 376, 525 acutifolia, v. A. v. R. .... 380 alata, Moore ......... 393 albicaula, v. A. v. R. ... 383 albido-squamata, v. A. v. R. 401 albula, v. A. v. R. ... . . 389 angustato-decurrens, v. A.

v. R............ 388

Annabellae, v. A. v. R. , 380 anomala, v. A. v. R..... 396 antrophyoides, v. A. v. R. 376 aquatica, v. A. v. R. .... 397 argyropus, v. A. v. R.... 524 Bakeri, v. A. v. R. ..... 376 Bamleriana, v. A. v. R. . 381 barisanica, v. A. v. R. (See the corrections)

batacorum, v. A. v. R. ... 385 Beccarii, v. A. v. R. .... 376 Bolsteri, v. A. v. R...... 403 Buchanani, v. A. v. R ... 396 calophlebia, v. A. v. R.... 406 campyloneuroides, v. A. v. R. 386 
Pleopeltis

carnosa, v. A. v. R. (See

the corrections)

caudiformis, v. A. v. R. 383, 405

ceratophylla, v. A. v. R. . 395

cochlearis, v. A. v. R.... 387

commutata, v. A. v. R. . 393

coronans, v. A. v. R..... 403

costulata, v. A. v. R. ... 382

craspedosora, v. A. v. R. . 378

crenulata, v. A. v. R. (See

the corrections) ...... 527

Cromwellii, v. A. v. R.... 392

Curranii, v. A. v. R. . . . 398

curtidens, v. A. v. R. ....

Curtisii, v. A. v. R. (See

the corrections)

damunensis, v. A. v. R...

de Kockii, v. A. v. R. ...

376

deparoides, v. A. v. R. (See

the corrections)

dilatata, Bedd. . . . . . . . 399

dolichoptera, v. A. v. R. 398, 399

dulitensis, v. A. v. R.... 390

ebenipes, Bedd.......... 394

elliptica, v. A. v. R. .... 406

Elmeri, v. A. v. R. ..... 405

Feei, v. A. v. R. .... 383, 405

flaccida, v. A. v. R... ... 393

flexiloba, v. A. ง. R. .... 406

fluviatilis, v. A. v. R. ... 403

Forbesii, v. A. v. R. .... 379

glauca, Moore .......... 394

glossipes, v. A. v. R..... 382

glossophylla, v. A. v. R... 391

grandidentata, v. A. v. R. 397

Griffithiana, Moore...... 383

hammatisora, v. A. v. R. 376, 377
Pleopeltis

hastata, Moore.... ..... 394

Hellwigii, v. A. v. R. . . 383

hemionitidea, Moore .. 386, 526

heraclea, v. A. v. R. .... 403

heterocarpa, Bedd. (See the corrections)

heterocarpa, Moore (See the corrections)

heterocarpa, v. A. v. R. 384, 406 holophylla, v. A. v. R. ... 375 holosericea, v. A. v. R... 392 Hosei, v. A. v. R. ...... 403 iboensis, v. A. v. R. . . . 386 imbricata, v. A. v. R..... 375 incurvata, Moore (See the corrections).......... 399 indurata, v. A. v. R. .... 379 insignis, Bedd. ......... 398 insperata, v. A. v. R. .... 380 interrupta, v. A. v. R. ... 403 Kingii, v. A. v. R........ 396 laciniata, Bedd. ......... 399 lagunensis, v. A. v. R. ... 400 Lauterbachii, v. A. v. R. . 383 leucophora, v, A. v. R... 387 limaeformis, v. A. v. R. . 389 linealifolia, v. A. v. R. .. 405 linearis, Moore......... 378 linguaeformis, v. A. v. R.. 382 lomarioides, Moore ....... 375 longissima, Moore....... 400 loxogrammoides, v. A: v. R. 405 lucidula, v. A. v. R. .... 389 luzonica, v. A. v. R. ... $\quad 388$ lycopodioides, Pr. .... . . 380 Macleayi, v. A. v. R. (See. the corrections) 
Pleopeltis

macrophylla, v. A. v. R. 403,404

Maingayi, v. A. จ. R. ... 406 Matthewi, v. A. v. R. .... 401 melanocaulos, v. A. v. R.. 391 membranacea, Moore..... 387

Meyeniana, v. A. $v$. R. (Se日

the corrections) ... ... 418

millisora, v. A. v. R..... 390

monstrosa, v. A. v. R. ... 392

Moseleyi, v. A. v. R..... 401

multijugata, v. A. v. R. . 594

musifolia, Moore....... 391

myriocarpa, Moore ...... 381

neglecta, Moore........ 378

neo-guineensis, v. A. v. R. 390

Nieuwenhuisii, $v$. A. $v$. R.

(See the corrections)

nigrescens, Carr. ..... 395, 400

nigricans, v.A. v. R. (See

the corrections)....... 387

var. parallela (See the cor-

rections) ........... 387

normalis, Moore.... . ... 381

mummularia, Moore .. 376, 377

oodes, Moore....... 378, 390

ovata, Moore ......... 390

oxyloba, Bedd.......... 394

palmata, Moore....... 401

papilligera, v. A. v. R. ... 385

papuana, v. A. v. R..... 380

papyracea, v. A. v. R.... 393

paucijuga, v. A. v. R.... 392

pedunculata, v. A. v. R. . 405

peltata, Scort. ........ 376

pentaphylla, v. A. v. R. .. 396

phanerophlebia, v. A. v. R، 400

\section{Pleopeltis}

phlebiscopa, v. A. v. R. .. 386

phymatodes, Moore...... 399

platyphylla, Bedd........ 386

Powellii, Carr. ......... 395

proteus, v. A. v. R...... 403

pteropus, Moore ........ 397

punctata, Bedd.. ....... 391

quinquefida, v. A. v. R. . 395

Raapii, v. A. v. R...... 380

regularis, v. A. v. $R$... 403, 404 renifera, Ridl. . ...... 525

revoluta, v. A. v. R..... 379

rhomboidea, v. A. v. R. .. 389

rhynchophylla, Moore.... 383

rivularis, v. A. v. R..... 398

rostrata, Bedd.......... 378

rudimenta, v. A. v. R. 378, 390 rupestris, Moore ....... 387

var. nigricans (See the

corrections).......... 387

var. parallela (See the

corrections).......... 387

sablaniana, v. A. v. R. ... 381

sarawakensis, v. A. v. R.. 376

sarcopus, v. A. v. R.... 375

Sauvinierei, v. A. v. R. . 401

Schlechteri, v. A. v. R. 395, 396

Schneideri, v. A. v. R. ... 400

Schouteni, v. A. V. R.... 384

Schultzei, v. A. v. R. .... 399

Scortechinii, Bedd. ...... 390

sculpturata, v. A. V. R. . 401

selliguea, v. A. v. R. . 403, 404

selligueoides, v. A. v. R. 386, 526

senescens, v. A. v. R.... 376

sibomensis, v. A. V. R.... 393

sinuosa, Moore......... 375 


\section{Pleopeltis}

Smithii, v. A. v. R...... 379 soridens, v. A. v. R. .... 377 soromanes, v. A. v. R. .. 377 spuria, v. A. v. R...... 405 stenophylla, Moore ...... 379 stenopteris, v. A. v. R... 377 subaquatilis, v. A. v. R... 401 subcaudiformis, v. A. v. R.

384,406

subecostata, v. A. v. R. . 378 subgeminata, v. A. v. (See

the corrections) ... 380, 525 subopposita, v. A. v. R. 390, 526 subsparsa, v. A. v. R.... 375 subtaeniata, v. A. v. R. . 402 subundulata, v. A. v. R... 379 sumatrana, v. A. v. R. ... 393 superficialis, Bedd. (See the

corrections)......... 376 taeniata, v. A. v. R. 401, 402, 526,527

taenifrons, $v . A . v . R$. (See

the corrections) ... 402, 527 taeniophylla, v. A. v. R.. 378 taenitidis, v. A. v. R. ... 402 temenimborensis, v. A. v. R. 400 tenuiloris, Moore .... 375, 399 tenuinervis, v. A. v. R. . 399 Treubii, v. A. v. R...... 384 tridactyla, Moore ........ 397 triquetra, v. A. v. R. ... 387 tuanensis, v. A. v. R. . . 398 undulato-sinuata, v. $\Lambda$. v. R. 388 Valetoniana,v. A. v. R. (See the corrections) ....... 385 valida, v. A. v. R. ..... 392 Versteegii, v. A. v. R. .. 377

\section{Pleopeltis}

violascens, v. A. v. R. ... 400

Weinlandii, v. A. v. R.... 392

Werneri, v. A. v. R. .... 386

Whitfordi, v. A. v. R... 384

wobbensis, v. A. v. R. ... 382

Wrayi, Bedd..... . ... 376

Zippelii, Moore (See the corrections) ........... 387

Zollingeriana, v. A. v. R. (See the corrections $390,517,526$ zosteriformis, Bedd. ..... 381 Pleurogramma(-me)

sulcata, Mett. ......... 341

Polybotrya ........... 431

appendiculata, J. Sm..... 431

articulata, J. Sm..... 432, 437

latifolia, Meyen......... 333

Nieuwenhuissi, Rac.... . 431

Polypodium ........... 343

acrosoroides, v. A. v. R... 371

debilis, Mett.......... 340

Loheriana, Christ........ 340

minor, Copel.......... 340

pusilla, Christ ......... 340

acutifolium, Brau........ 380

albicaulum, Copel........ 383

alcicorne, Ridl......... 522

Alderwereltii, Rst. ...... 368

ancestrale, v. A. v. R. ... 372 angustato-decurrens, Rst. . 388

angustatum, Sw. ....... 413

aquaticum, Christ ....... 397

argyropus, Ridl. ........ 524

Bamlerianum, Rst....... 381

barisanicum, v. A. v. R. . 408

batacorum, Rst........ 385

bipinnatifidum, Bk. ..... 369 


\section{Polypodium}

biseriale, Ridl.......... 522

bolobense, Brau. ....... 355

Brauseanum, v. A. v. R. . 521

brevifrons, Scort........ 361

Brooksiae, v. A. v. R. 367,524

Brooksii, C. Chr........ 418

bryophyllum, v. A. v. R. . 366

Burbidgei, Bk. ...... 355, 356

calymmodon, Fée ....... 351

canaliculatum, v. A. v. R. 522

capense, L. f.......... 44

capitellatum, Brau. ..... 355

carnosum, Christ........ 407

Carstenszense, Ridl. ..... 522

caudiforme, $B l . \ldots \ldots \ldots . \quad 383$

caudiforme, Christ....... 384

celobicum, Bl....... 362, 365

ceratophyllum, Copel...... 395

ciliiferum, v. A. v. R. .... 349

circumvallatum, Rst. . ... 358

clavifer, Hk. ......... 365

cochleare, Brau......... 386

coloratum, Copel..... 362, 363

conduplicatum, Brau.... . 365

consociatum, v. A. v. R... 352

contiguum, J. Sm. ...... 371

craspedosorum, Copel...... 378

craterisorum, Harr.... 362, 365

crenulatum, Kze ....... 527

Cromwellii, Rst........ 392

cryptocarpum, v. A. v. R. 372

cucullatum, Bedd....... 352

cucullatum, Nees\&Bl. 351, 352, 353

Curranii, Copel......... 398

cyatheoides, Sw. ...... 372

var. verrucosa ........ 373

decipiens, Mett........ 362
Polypodium

decorum, Brack. ...... 365

de Kockii, v. A. v. R. ... 382

decursive-pinnatum, v. Hall.

(See the corrections)

demersum, Brau........ 373

denticulatum, Pr. ...... 355

deparioides, Christ .... 409, 410

diaphanum, Brau........ 361

diplosoroides, Rst. . . . . . 348

diplosorum, Christ. ..... 349

dolichosorum, Copel. .... 348

durum, Copel. ........ 346

Englerianum, v. A. v. R. . 371

ensifrons, $v$. A. $v$. R.... 329

erythrotrichum, Copel. . 361, 367

exaltatum, Copel. ....... 370

fasciculatum, $\operatorname{Pr} . . . \ldots \ldots . .349$

Feei, Mett.

var. caudiforme....... 383

flexilobum, Christ........ 406

fluviatile, Lautb........... 403

frigidum, Ridl.......... 521

fuciforme, Rst........... 369

gedeanum, Rac...... 360, 368

gedeense, v. A. v. R..... 353

geluense, Rst. ......... 356

glossophyllum, Copel....... 391

govidjoaense, Brau....... 354

gracillimum, Copel....... 350

gracillimum, Rst........ 353

gymnogrammoides, Bk.... 312

halconense, Copel....... 367

hastatum, Thb........ 394

heterocarpum, Bl. (See the

corrections)

heterocarpum, Mett.

var. abbreviatum...... 


\section{Polypodium}

hirtiforme, Rst...... . 347

holosericeum, Rst. ...... 392

iboense, Brau. ......... 386

incurvatum, Bl. (See the

corrections)

insperatum, v. A. v. R. .. 380

integrum, Brau........ 346

javanicum, Copel. ....... 357

kaniense, Brau. ........ 352

Kingii, Copel.......... 396

Koningsbergeri, Rst. . ... 368

Koningsbergeri, v. A. v. R. 373

Labrusca, Rac........ 517

lancifolium, v. A. v. R. 360, 362

Lauterbachii, Brru....... 383

Lecanopteris, Mett....... 407

leptophyllum, L........ 325

limaeforme, Brau....... 389

linealifolium, Rst....... 405

lineare, Burm.......... 83

Lobbianum, Hk. . ...... 365

longiceps, Rst.......... 364

longissimum, Hk....... 318

loxogrammoides, Copel..... 405

lucidulum, v. A. v. R. . . 389

lunulatum, Forst........ 70

Macleayi, v. A. v. R. .... 410

macrochasmum, Bk. ..... 399

macrophyllum, Reinw. .... 404

Marthae, v. A. v. R. .... 357

Matthewi, v. A. v. R. ... 401

Matthewianum, v. A. v. R. 366

Maxwellii, Bk. ........ 348

melanocaulon, v. A. v. R. . 391

melanorhachis, v. A. v. R. 523

Merrillii, Copel. ......... 347

Merritti, Copel. ........ 360

\section{Polypodium}

Meyenianum, Hk...... 418

millefolium, Rst. ....... 369

mindanaense, Christ...... 391

molle, Jacq. .......... 183

mollicomum, Nees \& Bl. 360, 362

var. fuscatum ....... 524

monocarpum, Rst....... 357

Moultoni, Copel. ........ 365

multicaudatum, Copel..... 363

multijugatum, Copel....... 394

muscoides, Copel. ....... 351

naviculare, $v$. A. v. R.... 409

nectariferum, $B k$. ..... 416

negrosense, Copel........ 362

neo-guineense, Copel. .... 390

Nieuwenhuisii, v. A. v. R. 408

nigricans, v. A. v. R. (Se日

the corrections)...... . 387

normale, Don

var. sumatrana (See the corrections)

nutans, B1. .......... 364

obliquatum, Bl. .. 361, 362, 523

obscurum, Mett. ....... 349

oxylobum, Wall. ........ 394

oxyphyllum, Kze.(See the

corrections)

oyamense, Bk......... 312

pallens, Bl........... 373

palmatum, Bl. ........ 401

var. obtusum ........ . 402

paltonioides, C. Chr...... 330

papillatum, v. A. v. R. .. 367

papilligerum, Rst....... 385

papuanum. Ridl.. ...... 521

papuense, v. A. v. R. .... 521

papyraceum, Copel....... 393 


\section{Polypodium}

parasiticum, L. ....... 183

parasticum, Mett..... 347, 521

parvum, Brau.......... 347

patelliferum, Burck . . . 407

pendens, Rst........... 364

pensile, Ridl. . ....... 523

pergracillimum, v. A. v. R. 353

persicifolium, Desv. .... . 372

petiolatum, Ridl........ 522

pilistipes, v. A. v. R, . . 348

phymatodes, L...... 399, 525

planum, v. A. v. R...... 346

polymorphum, v. A. v. R. 371

Powellii, Bk. ........ 395

proavitum, Copel........ 363

productum, Christ.... ... 379

prolixum, Rst......... 382

pseudo-spirale, v. A. v. R. 358

pteropus, Bl......... . 397

pubinerve, Christ . .... 349

pulcherrimum, Copel. . ... 368

pulogense, Copel. ....... 359

pumilum, Brau......... 354

pyrolifolium, Goldm.

var. sumatrana . ..... 376

pyxidiforme, v. A. v. R. .. 345

quercifolium, L....... . 415

rachisorum, Christ ...... 356

regulare, Mett........... 404

Reinwardtii, . Pr.

var. angustata ........

repandulum, Mett. 360, 361, 523

var. brevifrons........ 361

rhomboideum, Brau...... 389

rhynchophyllum, Christ.... 525

rhynchophyllum, Hk. .... 525

rigidifrons, v. A. v. R. ... 369

\section{Polypodium}

Roemerianum, Rst. ..... 358

rubrinerve, $B k \ldots \ldots \ldots \ldots .316$

rufescens, Brau. ...... 359

Schefferi, v. A. v. R..... 366

Schenckii, Harr. ..... 361, 362

Schlechteri, Brau. ....... 395

Schouteni, v. A. v. R. ... 384

Schultzei, Brau........ 399

secundum, Ridl. ....... 524

selliguea, Mett. .......... 404

var. Backeri. ........ 404

selligueoides, v. A. v. R. . 386

semicryptum, v. A. v. R. 372

senescens, Copel......... 376

ssrraeforme, Brau.... 345, 521

serrato-dentatum. v. A. v. R.

$360 ; 363$

setaceum, Copel......... 345

setigerum, Bl. ........ 349

setosum, .Pr. ....... 349, 521

setuliferum, v. A. v. R. $\quad 354$

Shawii, Copel. ......... 363

sibomense, Rst. ........ 393

sikkimense, Hieron. . . . . 359

Smithii,v. A. v. R. ..... 379

solidum, Mett.... . 360, 363, soromanes, Christ....... 377

sparsipilum, Copel. ...... 344

streptophyllum, Bk. . ... 523

subauriculatum, Bl. ..... 373

subdichotomum, Rac..... 350

subdichotomum, v. A. v. R. 350

subdrynariaceum, Christ... 391

subevenosum, Bk....... 348

subgeminatum, Christ..... 525

var. ovata ............ 380

subgracillimum, v. A. v. R. 353 


\section{Polypodium}

subirideum, Christ....... 291

subminutum, v. A. v. R. 360, 361

subpinnatifidum, Bl...... 354

subrepandum, Brau...... 345

subreticulatum, Copel..... 350

subsecundo-dissectum, Zoll.

\& Morr. . . . . . . . 360, 368

var. novoguineense..... 524

subtaeniatum, v. A. v. R. . 402

subundulatum, Rst...... 379

sumatranum, Bk. ...... 349

sundense, C. Chr......... 393

superficiale, $B l$. (See the

corrections)

taenitidis, v. A. v. R. .... 402

taeniatum, Sw.... 401, 402, 527

taenifrons, v. A. v. R. ... 527

taeniophyllum, Copel. ..... 378

tamiense, Brau......... 370

taxodioides, Bk......... 370

temenimborense, v. A. v. R. 400

tenuinerve, Copel......... 899

tenuissimum, Copel...... 373

Toppingii, v. A. v. R. ... 372

torricellanum, Brau....... 350

tortile, v. A. v. R....... 371

trapezioides, Burm. (See the corrections)

triangulare, scort....... 358

trichomanoides, Bedd...... 359

tridactylum, Wall....... 397

trifidum, Don .......... 394

tuanense, Copel.......... 398

undulato-sinuatum, Rst.... 388

Valetonianum, $v$. A. $v, R$.

(See the corrections)

venulosum, Bl....... 361, 367

\section{Polypodium}

verrucosum, Wall. ...... 373

Versteegii, Christ........ 377

Winkleri, Rst. . . . . . . . 358

wobbense, Brau......... 382

Wollastonii, Ridl. ....... 524

Yoderi, Copel. ......... 370

Zippelii, Bl.

var: sparsisorum (See the corrections)

Zollingerianum, Kze (Se日 the corrections)

Polystichum ............ 140

aculeatum, Schott. ..... 140

var. eurylobum ....... 141

alpinum, Rst.......... 143

aristatum, Pr........ 145

Bamlerianum, Rst. ...... 143

bolanicum, Rst......... 142

diaphanum, Moore....... 140

Keysserianum, Rst...... 142

lastreoides, Rst......... 144

mucronifolium, Rst. ..... 141

obtusum, J. Sm......... 141

tenggerense, Rst......... 141

truncalulum, v. A. v. R. 500, 501 Prosaptia

ancestralis, Copel. ....... 372

linearis, Copel.......... 371

semicrypta, Copel. ....... 372

Protolindsaya........... 215

Brooksii, Copel......... 215

Pteridium .............. 253

aquilinum, Kuhn........ 253

Pteris................ 246

aquilina, $L . \ldots \ldots \ldots \ldots .253$

Beccariana, C. Chr....... 248

Brausii, Rst............ 247 
Pteris

Brooksiana, v. A. v. R... 511

Brooksii, Copel........ 250

cretica, L............ 248

Dalhausiae, Hk......... 248

decussata, J. Sm. ....... 250

deltoidea, Copel. ........ 248

esculenta, Forst......... 253

finisterrae, Rst. ....... 252

flabellata, Schk. ........ 248

furcans, Bk.......... 250

glabella, Rst.......... 248

gracillima, Rst...... 248, 249

heterogenea, $v: A . v . R . \ldots 249$

Keysseri, Rst. ........ 250

longifolia, L. . ........ 247

longipinnula, Wall.

var. sumatrana (See the corrections)

mixta, Christ ...... 249, 251

opaca, J. Sm.......... 247

orientalis, v. A. v. R. . . 247

pellucida, Pr.......... 247

piloselloides, L.......... 419

pluricaudata, Copel. ...... 249

quadriaurita, Retz....... 250

var. Lauterbachii..... 249

radicans, Christ........ 250

rangiferina, $\operatorname{Pr} . \ldots \ldots \ldots .246$

reducta, Bk.......... 246

salakensis, v. A. v. R. 246, 249

scaberula, Rich........ 253

Schlechteri, Brau........ 251

semipinnata, L. . .... . 248

serrulata, L. f.......... 248

silvatica, v. A. v. R. (See

the corrections)

stenophylla, Wall. ......

\section{Pteris}

stipulacea, Hk........ 246

taenitis, Copel. ......... 247

tremula, R. Br. ........ 251

tripartita, Sw......... 511

venulosa, Bl........... 247

vittata, $L$. (See the corrections)

Wallichiana, Agardh. .... 252

Warburgii, Christ ....... 252

Wimsettii, hort. ........ 248

Pteropsis ............ 420

\section{S.}

Saccoloma............. 215

sorbifolium, Christ .... 74, 215

Sadleria............. 256

cyatheoides, Klf. ....... 256

Sagenia

pachyphylla, Moore...... 193

repanda, Moore ........ 193

Salvinia. . .......... 459

natans, All. ......... 459

Schizoloma............ 214

fuligineum, Copel....... 214

heterophyllum, J. Sm.. 207, 215

induratum, Bk....... . 214

schizolomae, v. A. v. R... 214

Stortii, v. A. v. R...... 214

Scleroglossum ........... 339

debile, v. A. v. R. . ... 340

pusillum, v. A. v. R. 336, 340, 520

pyxidatum, v. A. v. R... 341

sulcatum, v. A. v. R. ... 341

Scolopendrium

Durvillaei, Bory....... 303

longifolium, Pr......... 304 
Scolopendrium

mambare, Bail. ........ 303

pinnatum, J. Sm........ 304

Scyphularia

simplicifolia, Copel... .. . 222

Selaginella ........... 473

anceps, $\operatorname{Pr}$. (See the cor-

rections)

ascendens, v. A. v. R.....

asperulipes, v. A. v. R. (See

the corrections)

barbata, Spring..... 475, 483

bidiensis, Hieron. (See the corrections)

biformis, A. Br. (See the corrections)

brachystachya, Spring ... 478

var. ornata .....4 478, 479

carnea, v. A. v. R.

534

celebica, v. A. v. R. (See the corrections)

cupressina, Spring (See the corrections) ........

d'Armandvillei, v. A. v. R.

deliana, v, A. v. R. (See the the corrections)

d'Urvillei, A. Br. .......

Engleri, Hieron. (See the corrections)

flabellata, Spring (See the corrections)

fimbriata, spring .... 478, 479 var. polyura. ....... 478

herpocaulos, v. A. v. R. (See the corrections)

incerta, v. A. v. R. ...... Kittyae, v. A. v. R. (See the corrections)
Selaginella

lebongtandaiana, v. A. v. R. 474

leytensis, Hieron. ....... 476

minahasae, v. A. v. R. iSee

the corrections)

nemorosa, v. A. v. R. ... 479

nemorosoides, v. F. v. R. . 480

ornata, Spring. ........ 479

padangensis, Hieron. (See

the corrections)

pennula, Spring (See the corrections !

plumosa, Bk. (See the corrections)

polystachya, Warb. (See the corrections)

Pouzolziana, Spring ..... 535

punctata, A. Br........ 535

pycnocarpa, v. A. v. R.. . 477

Robinsonii, v. A. v. R. . 476

robustipes, V. A. V. R. (See the corrections)

Rothertii, v. A. v. R. (See the corrections)

Schildei, Hieron. (See the corrections)

simulans, v. A. v. R. . ..

481

subalpina, .. A. v. R. ...

473

subfimbriata, v. A. v. R.

(See the corrections) ...

478

sumatrana, Hieron. \& v. A.

v. R. . .......... 474

Vonroemeri, v. A. v. R. .. 533

Wallichii, Spring ....... 482

Willdenowii, Bk. (See the corrections)

Selliguea

caudiformis, J. Sm. ....... 383 
Selliguea

elliptica, Bedd.

var. flagellaris ........ 406

Sphaeropteris ........... 125

Sphaerostephanos

asplenioides, 7. Sm. ..... 504

Stenochlaena ........... 427

abrupta, .v. A. v. R. .... 429

aculeata, Kze......... 430

areolaris, Copel.......... 428

gracilis, Kze............ 430

intermedia, Copel. ...... 429

Kingii, Copel.......... 429

leptocarpa, .Und. . . . . . . 428

palustris, Bedd. . . . . . . . 428

Raciborskii, C. Chr.... 427, 428

Smithii, v. A. v. R.... 427, 428

Smithii, Und.... ....... 428

sorbifolia, J. Sm... . . ... 428

var. d'Urvillei ......... 303

var. spectabilis........ 428

Williamsi, Und. ....... 430

Stenolepia.............. 201

tristis, v. A. จ. R. ...... 201

Stenosemia ............... 432

aurita, $\operatorname{Pr}, \ldots \ldots \ldots . . . .432$

pinnata, Copel. ........ 432

Syngramma(-me) . ....... 330

alismifolia, J. Sm. . . ... 331

angusta, Copel. ........ 330

grandis, C. Chr. ... ..... 331

quinata, Carr. ......... 331

lanceolata, Diels ...... . 332

Schlechteri, Brau. ....... 331

Zollingeri, Diels......... 332

\section{T.}

Taeniopsis

falcata, Bedd...........
Taenitis. ............... 342

blechnoides, Sw. . ...... 342

Brausei, Rst. ......... 247

Brooksii, Copel. ........ 342

drymoglossoides, Copel.... 342

pteroides, Schk. ......... 342

pusilla, Mett. ......... 340

simplicivenia, Ces....... 341

stenophylla, Christ ...... 342

validinervis, Mett. (See the

corrections)

Tapeinidum ............ 234

amboinense, C. Chr. 235, 508, 509 biserratum, v. A. v. R. 508, 509 gracile, v. A. v. R. 234, 508, 509

forma decomposita

234, 235, 508, 509

forma dissecta...... . 509

forma grandidentata ... 509

marginale, Copel. ..... . 234

pinnatum, C. Chr.

var. gracile. ........ 509

Tectaria

adenophora, Copel........ 196

Brooksi, Copel.......... 322

crenata, Cav. .......... 193

Cesatiana, Copel....... 192, 199

elliptica, Copél.......... 324

ferruginea, Copel. ....... 322

gigantea, Copel......... 146

gymnocarpa, Copel..... ... 322

Kingii, Copel.......... 147

labrusca, Copel. ......... 322

Lobbii, Copel. ........... 194

malayensis, Copel........ 146

olivacea, Copel. ....... 322

papuana, Copel............. 191

singaporiana, Copel. .........191 


\section{Tectaria}

subaequalis, Copel...... 323

Weberi, Copel. ......... 195

Thayeria.............. 416

cornucopia, Copel....... 416

nectarifera, Copel........ 416

Trichomanes............ 101

acrosorum, Copel........ 109

alagense, Christ......... 102

album, Bl. .......... 103

anceps, $H k . \ldots \ldots \ldots \ldots . . . .107$

aphlebioides, Christ.... .. 111

bilabiatum, Nees \& Bl. ... 103

bilobatum, v. A. v. R.... 106

bipunctatum, Poir. ...... 103

var. laxa .......... 103

borneense, v. A. v. R. ... 108

capillatum, Tasch....... 103

Christii, Copel.......... 112

Christii, Rst........... 109

eraspedoneurum, Copel.... 101

cupressoides, Desv. ....... 113

desinervium, Copel. . . . . 108

diffusum, Bl. ......... 102

digitatum, Sw. ........ 102

Foersteri, Rst. ....... . 110

grande, Copel. .......... 104

Henzaiense, Bedd. . . . . . 498

Hieronymi Brau.......... 104

humile, Forst. ... 103, 105, 111 javanicum, Bl. .... . 107, 108

var. rhomboideum ...... 108

var. singaporianum .... 108

var. Zollingeri ........ 107

javanicum, Hir. \& Grev. . 108

Kingii, Copel.......... . 110

latipinnum, Copel........ 112

maximum, Bl. ....... 107
Trichomanes

var. grandiflora....... 107

var. millefolium ...... 107

melanotrichum, Schl. ... . 105

microlirion, Copel....... 111

millefolium, Pr......... 107

mindorense, Christ ...... 101

minutissimum, v. A. v. R. 498

minutum, Bl.......... 102

Motleyi, V. D. B. ....... 498

novo-guineense, Brau. .... 106

pallidum, Bl. .......... 102

palmatifidum, K. Müll..... 102

paniculatum, v. A. v. R... 111

papillatum, K. Müll...... 110

perpusillum, v. A. v. R... 103

pervenulosum, v. A. v. R. 498

pulcherrimum, Copel. ..... 105

pyxidiferum, L......... 105

recedens, Rst. ......... 112

rhomboideum, J. Sm..... 108 rigidum, Sw.

var. papillatum ....... 110

Roemerianum, Rst....... 110

Rosenstockii, v. A. v. R. . 109

Rothertii, v. A. v. R..... 105

saxifragoides, V. D. R. . . 102

Schlechteri, Brau........ 113

Schultzei, Brau. .. ..... 104

setaceum, V. D. B....... 113

singaporianum, v. A. v. R. 108 subtrifidum, Matt. \& Christ 106 sumatranum, v. A v. R. 109 Zollingeri, V. D. B..... 107 Triphlebia ............. 305 dimorphophylla, Bk... 303, 305 linza, $B k . \ldots \ldots \ldots$..... 303, 305 longifolia, Bk...... 304, 305 
Triphlebia

pinnata, Bk. 304,305

\section{U.}

\section{Ugena}

dichotoma, Cav. ....... 115

macrostachya, Cav....... 115

semihastata, Cav........ 115

\section{V.}

Vittaria .............. 336

alternans, Copel........ 337

amboinensis, Fée....... 338

angustata, v. A. v. R. (See

the corrections)

angustifotia, $B l$. (See the corrections)

Copelandi, v. A. v. R. ... 339

debilis, Kuhn ... 338, 340, 341

elongata, Sw. ..... . 337, 520

forma angustifolia (See

the corrections)

forma lurida (See the corrections)

var. angustifolia ...... 337

falcata, $K z e \ldots \ldots \ldots \ldots .340$

\section{Vittaria}

flaccida, Hieron. (See the corrections)

lineata, $\mathrm{Sm} . . . \ldots \ldots \ldots . .338$

Loheriana, v. A. v. R. 340, 341

Merrillii, Christ ........ 337

Merrillii, Copel. ....... 339

minor, Fée... . . . . 340, 341

nervosa, Christ ...... 337

pusilla, Bl. ... . ... 338, 340

pyxidata, v. A. v, R. . . 341

scabricoma, Copel....... 338

scolopendrina, Thw. ..... 338

sessilis, Copel. . . . . . . 338

sulcata, Kuhn ...... 338, 341

zosterifolia, Willd.

var. flaccida (See the

corrections)

W.

Wibelia

gracilis, Christ........ 509 pinnata, Fée

var. gracilis....... 234, 509

Woodwardia .......... 256

radicans, $\mathrm{Sm} . . . \ldots \ldots .256$ 



\section{CORTEETIONS}

\section{MODIFIOATIONS AND ADDITIONS.}

List $A$ principally contains modifications in and additions and references to my Handbook on Malayan Ferns to which the discoveries made after January 1st 1909 and newer conceptions have given cause. List $B$ has relation to my Handbook on Malayan Fern Allies. List $C$ regards the Supplement to both works quoted.

Corrections etc. may be cut out and pasted over the places indicated.

Users of my books are requested to correct themselves with the pen the less grave clerical and typographical errors where these may be met with.

(P. = Page; l. = line; fr. b. = from bottom).

Buitenzorg, August 1917. $\quad$ v. A. v. R. 

A.

\section{MAIA Y A N FERNS.}

P. XIX - XX; COMPENDIUM. - Insert: See Malayan Fern Allies, p. XI - XII.

P. XX - XL; COMPENDIUM. - Insert: See Supplement 1, p. 9-13.

P. XXII, 1. 3; For: uniform - read: \pm equal

P. $3-5$; FILICES. - Omit this. Insert: See Supplement 1, p. $17-21$.

P. $9-10 ;$ Key to the tribes and genera. - Omit this. Insert: Se日 Supplement 1, p. 22.

P. 13, l. 11 fr. b.; For: to 3-pinnate. - Read: to 4-pinnate.

l. 6 fr. b.; After: naked.

Insert: (See also C. orientalis).

P. 14, 1. 10; After: side,

Insert: often rough or roughish. (See also C. hymenodes and C. spinulosa).

1. 13 \& 15; Omit the words: obscurely crenate, and serrate,

1. 19-31 should be modified as follows:

$\beta^{\prime}$. Main and secondary rachises provided with prom inent tuberculiform glands (aërophores) on the lower side, near the bases of the pinnae and pinnulae.

(16) C. Zollingeriana.

$\beta^{\prime} . \beta^{\prime}$. Rochises without glands (aërophores), or the glands flat, depressed.

$\gamma^{\prime}$. Main rachis hairy or tomentose, not scaly. $\delta^{\prime}$. Sori costular. (See also C. hymenodes and C. spinulosa).

є'. Indusium evanishing or breaking down more or less irregularly into 2 or more fragments.

- Costae beneath naked or bullatosquamulose. (17) C. Korthalsii.

* Costae beneath hairy, furfuraceous or plano-squamulose (chaffy).

(18) C. crenulata. 

$\varepsilon^{\prime}, \varepsilon^{\prime}$. Indusium at length regularly cup. shaped with an entire, truncate mouth. (19) C. orientalis.

P. 15, 1. 3-7 should be modified as follows:

- Indusium at length shallowly saucer-shaped, often entire.

(22) C. javanica.

* Indusium evanishing or breaking down irregularly.

1. 11; After: prickly, - Insert: at least towards the base.

1. 15; After: costular. - Insert: (See also C. orientalis).

1. 16 \& 18; Omit the words: Rxchises tomentose above. Rachises not tomentose.

1. 21; After: naked - Insert: or nearly so.

1. $9 \& 7$ fr. b.; Omit the words: Tertiary segments adnate to the rachis. and Tertiary segments slightly stalked.

P. 16, 1. 2; For: undulate, - Read: sinuate,

P. 20 ; C. integra. - Insert: Se日 Supplement 1.

C. Zollingeriana. - Insert: See Supplement 1.

P. 21; C. Konthalsii. - Omit the description of this species. See Supplement 1.

C. Crenulara. - Omit the description of this species. See Supplement 1.

C. orientalis. - Insert: See Supplement 1.

P. 22, 1. 11 fr. b.; For: Putu Run, (Teysmann).

Read: Pulo Run (Rhun or Rhoon, New Guinea).

P. 23 ; C. javanica. - Insert: See Supplement 1.

C. sumatrana. - Insert: See Supplement 1.

P. 25; C. spinulosa. - Insert: See Supplement 1.

C. oinops. - Insert: See Supplement 1, Corrections.

P. 26; C. arachnoidea. - Insert: See Supplement 1. - Omit the words: The javan plant (Leg. Scheffer) ect.

C. celebica. - Insert: Seo Supplement.

P. 27; 2. HEMITELIA. - Insert: See Supplement 1. 

P. 28, 1. 2 fr. b.; After: brown, - Insert: very small.

P. 29, 1. 4-5; Omit the words: a semiorbicular, inferior, lateral scale placed at the inner side of

.1. 17; After: tomentose. - Insert: (See also A. glabra).

1. 10-8 fr. b. should be modified as follows:

d. Stipes bearing about 3-9 relatively long, simple or branched, spine-like outgrowths or reduced pinnae at the base.

(7) A. ramispina.

d.d. Stipes without spines or reduced pinnae at the base.

1. 1 fr. b.; For: scabrous - read: rough

P. 30, 1. $1 \&$ 5; For: scabrous. - read: rough.

1. 15 fr. b.; After: muricate - Insert: at least at the base.

P. 31, 1. 6; After: muricate, -- Insert: aculeate or tuberculate.

1. 12 fr. b.; For: prickly. - Read: prickly or tuberculate.

1. 8 fr. b.; For: not prickly. - Read: smooth or roughish.

A. Iubia. - Insert: See Supplement 1, Appendix.

P. 32, 1. 14 fr. b.; For: firm, but not coriaceous;

Read: membranaceo-subcoriaceous;

A. glabra. - Insert: Se日 Supplement 1.

P. 33; A. squamulata. - Insert: See Supplement 1.

1. 17 fr. b.; For: the rest naked or - Read: and whether or not

P. 37 ; A. Iepidoclada. -- Insert: See Supplement 1.

P. 38; A. Iatebrosa. - Omit this species. Insert: See Supplement 1.

P. 39; A. Iepifera. - Omit: (? A. tomentosa, Hk., C. Chr. Ind. Fil.).

P. 41 ; A. glauea. - Insert: See Supplement 1.

P. 42 ; A. Christii. - Insert: See Supplement 1.

P. $43,1.8$ fr. b.; After: scales.

Insert: Secondary rachises densely woolly-tomentose above.

A. tomentosa. - Insert: See Supplement 1, Appendix.

A. extensa. - Insert: See Supplement 1.

P. 44; A. Iurida. - Insert: See Supplement 1.

1. 6 fr. b.; For: indefinite - read: uncertain

P. $47,1.7$ should be modified as follows: 
Caudex arborescent. Fronds decompound, with the ultimate segments equal-sided at the base;

P. 48; C. barometz. - Insert: See Supplement 1.

P. 51, 1. 2; For: $(4-10)-$ Read: $(4-14)$

1. 5-8 should be modified as follows:

Rhizome creoping, hairy. Fronds pedato-flabellate or sympodially branched; veins free or those around the sori reticulate or forming costal areolae. - Diels, in Engl. \& Prantl, Nat. Pfl.fam., I ${ }^{4}$, fig. 182-183.

Malayan.

6. MATONIA. - Omit this genus and its species here. Insert: See Supplement 1.

P. 56; C. circimata. - Insert: See Supplement 1.

P. 57 ; l. 16 fr. b.; For: erecto-patent. - Read: oblique.

1. 9 fr. b.; For: ribs. - Read: ribs when young.

1. $12 \& 14$ fr. b.; Omit the words Texture coriaceous; and Texture membranaceous;

1. $1 \mathrm{fr}$. b.; Omit the word densely

P. 58, 1. 17; For: acute or rounded, - Read: obtuse,

C. arachnoidea. - Insert: Seo Supplement 1 .

P. 59; C. linearis. - Insert: See Supplement 1.

P. 60 ; C. Deeaniea. - Omit the description of this species here. Insert: See Supplement 1.

1. 9 fr. b.; For: ciliato-dentate, - Read: ciliated,

P. 61, 1. 3; For: erecto-patent, - Read: subspreading,

l. 15; For: \pm erecto-patent, - Read: rather oblique.

1. 17; For: fimbriate - Read: lanceolate

C. vestita. - Insert: See Supplement 1.

P. 62 ; C. dolosa. - Omit this species. Insert: See Supplement 1.

G. amboimensis. - Omit this species. Insert: See Supplement 1 .

P. $65,1.10$; For: subcoriaceous; veins free.

Read: subcoriaceous, without stomata; veins free.

1. 17 fr. b.; For: uniform — Read; \pm equal

l. 7 fr. b. ; For: uniform Read: \pm equal 

P. 66, 1. 7; After: under $5 \mathrm{~cm}$. long - Insert: at least when barren.

l. $14 \& 12$ fr. b. should be modified as follows:

* Indusium longer than broad. (7) H. demissum.

* Inclusium not longer than broad. (9) H. badium.

P. 67, 1. 11; For: capitate. - Read: capitate or clavate.

1. 12-13; For: malleiform.

Read: malleiform or broadly flabellate-cuneate.

II. discosun. - Omit this species. Insert: See Supplement 1.

P. $69 ; 1.4$ fr. b.; For: slightly winged. - Read: winged.

P. 71 ; W. sulakense. - Insert: See Supplement 1.

P. 75, 1. 22; For: pinnae. - Read: pinnae or pinnulae.

1. 23; For: base. Read: base, roundish.

1. 26; For: base. - Read: base, or elongated.

P. 76, 1. 3; After: crisped, - Insert: rarely flattened in No. 41.

H. caluentum. - Insert: See Supplement 1.

P. 78, 1. 8; Omit: Bedd., Ferns S. I., tab. CCLXV.

1. 15 fr. b.; For: $\pm 2-$ Read: $1-2$

1. 10 fr. b.; For: Java. - Read: Malaya.

II. Holochilum. - Insert: See Supplement 1.

P. 79; H. serrulatum. - Insert: See Supplement 1.

P. 81, 1. 15; For: Java, Sumatra. - Read: Malaya.

P. 82 ; H. bismarekianum. - Omit this species.

Insert: See Supplement 1.

II. nculeatum. - Insert: See Supplement 1.

P. 85, 1. 2 \& 9 should be modified as follows:

a. Tenation flabellate or radiate.

a.a. Venation pinnate.

P. $85,1.10$; For: $\pm 1-1 \frac{1}{2}$ and $\pm 21 / 2-5$

Read: to $\pm 11 / 2$ and to $\pm 71 / 2$

T. motleyi. - Insert: See Supplement 1, Appendix.

P. 86, 1. 1-2 \& 7-8; Omit the synonym: T. Motleyi, V. D. B.

1. 16 ; For: $21 / 2-5 \mathrm{cM}$. - Read: $2 \frac{1}{2}-5 \mathrm{~mm}$.

P. 87, 1. 7-10 should be modified as follows: 

5. Fronds small, to about $10 \mathrm{~mm}$. long.

(7) T. saxifragoides.

5.5. Fronds somewhat larger, at least $10 \mathrm{~mm}$. long.

1. 14-15; For: Fronds roundish in general outline.

Read: Fronds commonly rounlish in outline.

l. 14-13 fr. b.; Omit the words: tooth-like, and capillary,

P. 88, 1. 2; For: 5-71/2 - Read: 5-10

1. 5; For: scarcely $1 / 2$-way - Read: at best ${ }_{1 / 5}$-way

P. 92, 1. 10 \& 12 should be modified as follows:

* Fronds small.

* Fronds large or middle-sized.

1. 15; For: or ciliate. - Read: ciliate or fibrillose.

l. 11 fr. b.; For: scattered. - Read: scattered to closely seriate.

P. 93, 1. 2; For: 25-45 — Read: 15-45

T. pallidum. - Insert: See Supplement 1.

P. 99; 'T'. maximum. - Insert: See Supplement 1.

P. 100, 1. 14; Omit the words: Receptacle much exserted.

1. 16; Omit the words: Receptacle not exserted.

P. 101, 1. 14 fr. b.; Omit the words: Fronds $\pm 71 / 2$ cM. long.

1. 12-11 fr. b.; For: extremity. Fronds $\pm 40 \mathrm{cM}$. long. Indusium

Read: extremity, or the indusium

P. 102; T. aphlebioides. - Insert: See Supplement 1.

P. 103, 1. 1; For: \pm 40 and \pm 20 - Read: to 40 and to 20

T. cupressoides. - Insert: See Supplement 1.

P. 109; 10. IXGODIUM. - Insert: See Supplement 1.

P. 110, 1. 7-6 fr. b. should be modified as follows:

d.d. Pinnulae 2-7-jugate, or the lower ones mostly hastate, subpalmate, once or twice forked or pinnate.

P. 111; L. semihastatum. - Omit the description of this species here. Insert: See Supplement 1.

L. Teysmannii. - Insert: See Supplement 1.

P. 112, 1. 7-6 fr. b.; Omit the words varying from and to 5-pinnate. 

P. 114, 1. 16; For: subpalmatifid - Read: hastatifid

L. japonicum. - Insert: See Supplement 1.

P. 121; VI. PUI,YPODIACEAE.

Insert: See Supplement 1.

P. 123, 1. 15 fr. b.; For: sometimes much recurved or

Read: single or double, straight to

P. 140, 1. 6-5 fr. b.; Read:

Rhizome creeping, hairy or fibrillose. Stipes not articulate to the rhizome. Fronds . . . . etc.

P. 141, 1. 11 \& 14 should be modified as follows:

d. Rhizome creeping.

d.d. Rhizome not creeping.

P. 142 ; D. erythrorachis. - Insert: See Supplement 1.

D. ampla. - Insert: See Supplement 1.

P. 143; D. Smithii. - Insert: See Supplement 1.

l. 10 fr. b.; For: thinly pilose. - Read: rather hairy.

1. 5 fr. b.; Omit the words valves of the and equal,

P. 145 ; D. Inceida. - Insert: See Supplement 1.

P. 153, 1. 11; After: hairs; - Insert: texture thinner.

P. 155 , 1. 10 ; For: $1-2-$ Read: $1 / 2-2$

A. obliterata. - Insert: See Supplement 1.

P. $156,1.6-8$ should be modified as follows:

Rhizome erect, ereeping or scandent. Stipes not articulate to the rhizome. Fronds pinnate; pinnae articulate to the rachis, at least the barren ones provided with deciduous, mostly white-cretaceous, dot-like, submarginal scales on the upper side, terminal on the veins.

Tropical and subtropical.

P. 158, 1. 9; For: Surfaces and - Read: Surfaces or

P. 159, l. 13 fr. b.; For: davalloides, - read: davallioides,

P. 161, 1. 2 fr. b.; Omit: Bedd., Ferns S. I., tab. XCIII;

P. $163,1.3$; After: peltate,

Insert: rarely wanting (rudimentary or caducous?)

C. semicordata. - Insert: See Supplement 1.

P. 164; C. Presliana. - Insert: See Supplement 1.

Ferns and Fern Aluies. 


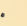


1. 4 -3 fr. b. should be modified:

f. Auricles of pinnulae aculeate-apiculate (mucronate or aristate).

(3) P. aculeatum.

f.f. Auricles of pinnulat obtuse (rounded or truncate).

(4) P. obtusum.

P. 165; P. diaphanum. - Insert: See Supplement 1.

P. 166; P. ohdusum. - Insert: See Supplement 1.

P. 168, 1. 1; For: confluent - read: connected

P. 171, 1. 13-12 fr. b.; Omit the synonym Dryopteris canascens var.

P. 172; P. Ueuzenma. - Omit the variety hemiteliiformis.

Insert: See Supplement 1.

P. 173; P. membramifolia. - Insert: See Supplement 1.

P. 175 ; § 3. CYCLOSORUS. - For: Like \& 2, - Read: Like § 1-2,

1. $18 \mathrm{fr}$. b. should be modified as follows:

a. Fronds simple, or pinnae cut less than ${ }^{11}{ }_{3}$-way down to the costa.

1. $16 \mathrm{fr}$. b. should be modified as follows:

** Fronds moderately long-stalked, or pinnae lobed 1/4-1/3-way down.

P. $176,1.18-19 \& 21-22$ should be modified as follows:

* Stipes hairy or scaly.

** Stipes naked above the base.

P. 177, 1. 3; For: Stipes more - Read: Stipes scaly or more

P. 178, 1. 19 should be modified as follows:

1.1.1. At least the lowest posterior veins of the lowest posterior segments \pm pinnate.

(34) D. filix mas.

1. 16, fr. b.; After: toothed,

Insert: sometimes lobate-dentate in No. 36 .

1. $13 \mathrm{fr}$. b.; Omit the words: Indusia red when young. 

1. $9 \& 3-2$ fr. b. should be modified as follows:

d. Under surface quite naked, and not glandular.

d.d. Under surface not naked, at least not on the main veins. Sori costal.

(39) D. edentula.

P. 179, 1. 1 should be modified as follows:

d.d.d. Under surface as in d.d. Sori not costal.

1. 10 \& 7 fr. b. should be modified as follows:

$\therefore \quad$ Fully developed fronds at best $20 \mathrm{~cm}$. broad.

:.. Fully developed fronds at least $20 \mathrm{~cm}$. broad.

1. 1 fr. b.; For: \& Raclborski,, $v$. A. $v . R$.

Read: D. recedens 0 . Ktze, D. dissecta 0 . Ktze.

P. 180, 1. 15; After: scaly - Insert: al least on the costae.

P. 181; D. Koordersii. - Insert: See Supplement 1, Appendix.

P. 188; D. immersa. - Insert: See Supplement 1.

P. 190, 1. 3-4; Omit the words: General aspect of etc.

D. Luerssenii. - Insert: See Supplement 1.

P. 191 ; D. Beddomei. - Insert: See Supplement 1.

D. adnaia. - Insert: See Supplement 1.

P. 192; D. filix mas. - Insert: See Supplement 1, Appendix.

P. 193; D. erythrosora. - Insert: See Supplement 1.

P. 194; D. edulentu. - Insert: See Supplement 1.

P. 196; D. dissecta. - Omit the description of this species and the synonym Nephrodium conjugatum $T . \& B$. Insert: See Supplement 1.

P. 197; D. Bneiborskii. - Omit this species. - See Supplement 1.

P. 199; D. vilis. - Insert: See Supplement 1.

D. intermedia. - Insert: See Supplement 1.

1. 6 fr. b.; For: 3 cM. - Read: $6 \mathrm{~cm}$.

P. 200; D. sarawakensis. - Omit the synonym D. rhodolepis var.

D. pulvinulifera. - Insert: See Supplement 1 . 

P. 201; D. boryana. - Insert:

Rachises and surfaces naked or somewhat fibrillose and slightly scaly.

D. purpurascens. - Insert: Se日 Supplement 1.

P. 202; D. rhodolepis. - Omit this species here. Insert: See Supplement 1.

D. setigera. - Insert: See Supplement 1.

P. 203; D. multiceta. - Insert: See Supplement 1.

P. $206 ; 1.4$; For: and - Read: to

1. 6; After: long, - Insert: if shorter, then naked.

1. 8; Omit the words: Under surface short-hairy and glandular.

1. 14; For: 8-14 Read: to 14

1. 19 fr. b.; For: naked. - Read: naked or glabrescent.

1. 18 fr. b.; For: $3-5-$ Read: $2-5$

1. 13 fr. b.; For: $2-3-$ Read: $1-3$

1. 12-11 fr. b. should be modified as follows:

* Pinnae blunt or bluntish.

** Pinnce acute or acuminate.
(88) D. arbuscula.

(89) D. amboinensis.

P. 207, 1 6; For: or bristly - Read: bristly or scaly.

1. 14; For: distant. Surfaces rather naked.

Read: distant, or surfaces not conspicuously hairy.

P. $208,1.13$; For: $40-$ Read: 75

1. 14 ; For: 100 - Read: 75

1. 17 fr. b. should be modified as follows:

$0^{\prime} . \delta^{\prime}$. The 2-6 lower veins anastomosing, or pinnae without a gland at the base.

(112) D. truncata.

P. 209; D. linenta. - Insert: See Supplement 1.

P. 210; D. extensa. - Insert: See Supplement 1.

P. 214 ; D. hirsuta. - Insert: See Supplement 1.

P. 216 ; D. urophylla. - Iusert: See Supplement 1.

P. 217, 1. 15, fr. b.; For: Celebes, - Read: Malaya,

P. 218, 1. 12 fr. b.; For: broadly cuneate; - Read: truncate-cuneate; 

1. 10-9 fr. b.; For: under surface villose, or the

Read: margins villose, the

D arbuscula. - Insert: See Supplement 1.

P. $219,1.9$; After: persistent.

Insert: - Often confounded with D, amboinensis O. Ktze.

D. amboinensis. - Insert: See Supplement 1.

1. 19; Omit the words: into mere auricles,

D. multilineata. - Insert: See Supplement 1.

P. 221 ; D. ferax. - Insert: See Supplement 1 .

1. 10; For: reddish or blackish, — Read: dark, spreading,

1. 11; For: spreading - read: scales or

P. 224 ; D. parasitica. - Insert: See Supplement 1.

l. 10; For: $\pm 1 / 2$-way - Read: 1/3-4/5-way

1. 17-18; Omit the information regarding forma repens.

P. 225; D. didymosora. - Insert: See Supplement 1.

l. 1 fr. b.; For: terminal, - Read: subterminal

P. 226; 1. 5-6; Omit the synonym Mesochlaena polycarpa var.

P. 227 ; D. Irumeata. -- Insert: See Supplement 1.

P. 229, 1. 15 fr. b.; For: indefinite - read: uncertcin

P. $231,1.2-3$ should be modified as follows:

* Fronds to $60 \mathrm{~cm}$. long, or the rachis not naked. (120) D. Blumei. ** Fronds $60 \mathrm{~cm}$. or more long, the rachis naked. (121) D. nephrodioides.

P. 235 ; A. singraporiamum. - Insert: See Supplement 1 , Appendix.

P. 238; . ternatense. - Insert: See Supplement 1.

P. $239 ; 1.11$ et passin; For: foliate. - Read: foliolate.

1. 17 fr. b. should be modified:

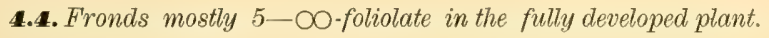

P. 242 ; A. ternatum. - Insert: See Supplement 1.

1. 18 fr. b.; For: $20-25$ and 5-8 - Read: $20-30$ and 5-10

P. 243 ; A. polly aorphuan. - Insert: See Supplement 1.

P. 244, 1. 10; For: $2-4$ - Read: $0-4$

1. 12; Omit the word small,

A. Lobbii. - Insert: See Supplement 1.

A. semibipinnatum. - Insert: See Supplement 1. 

P. 246; A. neloulosum. - Insert: See Supplement 1, Appendix.

A. Leterodon. - Omit this species. See Supplement 1.

P. 247 ; 1. 7 ; For: $20-30$ - Read: $20-60$

P. 248, l. 1 fr. b.; Omit: (Sw., C. Chr., Ind. Fil., p. p.);

P. 249, 1. 2; Insert: See Supplement 1.

1. 8-9; For: upper surface clothed with short, white pubescence, Read: at least the upper surface provided with scattered, fibril-like hairs,

P. 251; A. persoriferum. - Insert: See Supplement 1.

P. 252; A. pachyphyllum. - Insert: See Supplement 1.

P. 253, 1. 12; Omit: C. Chr., Ind. Fil.;

P. 257; 27. CYSTOPTERIS. - Insert: See Supplement 1.

P. 259; 1. Ielusa. - Insert: See Supplement 1.

1. 14-13 fr. b.; Omit the synonym D. decipiens.

P. 261; L. repens. - Insert: See Supplement 1.

P. 262 , 1. 1; For: \pm mM. - Read: to $5 \mathrm{~mm}$.

I. Nelicatulse. - Insert: See Supplement 1.

P. 263 , 1. $16-15$ fr. b.; For: \pm 6 c.M. \pm 4 c.M. \pm 7 m.M. Read: $3-6 \mathrm{~cm}$. to $4 \mathrm{~cm}$. to $7 \mathrm{~mm}$.

P. 264; L. hymenoploylloides. - Insert: See Supplement 1.

L. capillacea. - Insert: See Supplement 1.

P. $266,1.4 \& 6$ should be modified as follows:

* Fronds to about $1^{3 / 4} \mathrm{~cm}$. broad.

** Fronds about $2 \mathrm{~cm}$. or more broad.

1. $15 \mathrm{fr}$. b. should be modified as follows:

+ Sori not in a continuous submarginal line.

P. 267 ; L. concinna. - Insert: See Supplement 1.

d. montana. - Omit this species. See Supplement 1.

P. 268, 1. 8; For: $\pm 21 / 2$ c.M. - Read: $1 \frac{1}{2}-21 / 2 \mathrm{~cm}$.

P. 269: I. culdrata. - Insert: See Supplement 1.

L. pectinata. -- Insert: See Supplement 1.

1. 3 fr. b.; For: 7-10 c.M. - Read: 7-10 mm.

P. 270, 1. 4 fr. b.; After: point; - Insert: terminal leaflets often so.

P. 271, 1. 17-20; For: $7-10$ and $20-35$

Read: $5-10$ and $20-60$ 

L. rigida. - Insert: See Supplement 1.

1. 8-7 fr. b.; For: $1-4$ and flexuose, Read: $1-9$ and remote,

P. 272; L. matamac. - Not in Lingga. Insert: Soe Supplement 1.

P. 273, 1. 16; After: continuous,

Insert: or solitary and terminal on the leaflets.

L. Iancea. - Insert: See Supplement 1, Appendix.

P. 276, 1. 6 \& 12; Omit: Pinnae 4-6 m.M. broad. and: Pinnae 7-10 m.M. broad.

1. 14 fr. b.; After: long - Insert: or longer.

P. 277; §. fuligineum. - Insert: See Supplement 1.

1. 2 fr. b.; For: $2^{1 / 2}-3$ - Read: $1 \frac{1}{2}-3$

P. 279, 1. 13-12 fr. b. should be modified as follows:

d. Sterile edges not entire. (10) S. ensifolium.

d.d. Sterile edges entire. (11) S. coriaceum.

P. 280, 1. 7 fr. b.; For: thin, herbaceous. - Read: thin to thick.

P. 282: CYSTODIUM. - Omit this. Insert: See Supplement 1.

S. sorbifulium. - Omit this. Insert: See Supplement 1.

P. 285, 1. $4-3$ fr. b. should be modified as follows:

3. Lowest pinnae of barren fronds pinnatifid or pinnate, at best 2-pinnatifid at the very base.

P. 286, 1. 3-4 should be modified as follows:

3.3. At least the lowest pinnae of barren fronds more copiously 2-pinnatifid.

(14) H. vestita.

P. 287, 1. 4 \& 5; For: 5-10 and 3-5 - Read: 5-15 and 3-71/2

P. 288; W. repens. - Insert: See Supplement 1 .

P. 291; H. Vestita. - Insert: See Supplement 1.

P. 292 ; F. falcimella. - Insert: See Supplement 1. Omit the information at the base of the diagnosis.

H. immersa. - Insert: See Supplement 1.

P. 294 ; II. Kingii. - Omit this. See Supplement 1.

II. viscidula. - Omit this. See Supplement 1. 

P. 295 ; 33. ACROPHORUS. - Omit this genus. See Supplement 1.

A. nodesus. - Omit this species. See Supplement 1.

P. 299 ; ID. Iirsuta. - Omit this species. See Supplement 1.

P. 302; D. decurrens. - Not in Sumatra. - Insert: See Supplement 1.

D. elaia. - Insert: See Supplement 1.

P. 304; D. Wagneriana. - Insert: See Supplement 1.

P. 308, 1. 14; For: pinnatific. The hairs - read: pinnatifid, or the hairs

P. 312 ; 7. stroigosa. - Insert: See Supplement 1.

11. Kurzii. - Insert: See Supplement 1.

P. 313, 1. 2; For: covered with pale hairs.

Read: copiously puberulous.

1. 12 ; For: lanceolate-deltoid, - Read: rhomboidal-oblong,

II. hirta. - Insert: See Supplement 1.

1. 9-8 fr. b.; $F \circ r^{2}$ : under surface densely pubescent.

Read: veins beneath hirsute or hairy.

P. 315, heading; For: 56. — Read: 36 .

T. gracile. - Insert: Se日 Supplement 1.

T. amboimense. Insert: See Supplement 1.

P. $322,1.9$ fr. b.; For: $1-2$ and $3-5-$ Read: ${ }_{1 / 2}^{1 / 2}$ and $3-6$

P. $328,1.1$; For: placed - read: large,

P. 329, 1. 3-2 fr. b. should be modified as follows:

+ Lowest piunae more or less abbreviated. (23) A. concinnum.

+ Lowest pinnae not abbreviated.

P. 330, 1. 10; For: 3-4-pinnate. - Read: 3-6-pinnate.

1. 11 ; For: $1 \frac{1}{2}-21 / 2$ and $1-2-\operatorname{Read}: 3 / 4-21 / 2$ and $1 / 2-2$

1. 17; After: only.

Insert: - A species with several garden varieties.

A. Фpacum. - Insert: See Supplement 1.

P. 331: A. saborbieulare. - Insert: See Supplement 1.

P. 332, l. 7 fr. b.

For: Sori round, obreniform, etc. ... ; - Read: Sori round;

P. 334 ; 38. HYPOLFPIS. - Insert: See Supplement 1.

P. 335, 1. 8-9 should be modified as follows:

\$ 1. ASPIDOTIS. Rhizome not or hardly ereeping; fronds aggregate. 

§ 2. EUHYPOLEPIS. Rhizome distinctly creeping; fronds not aggregate.

l. 6 fr. b.; After: segment.

Insert: - Perhaps a reduced form of $H$. tenuifolia Bernh. only.

P. 336 , 1. 13 ; For: $50-300-$ Read: to 300

1. 17 ; For: glandular-pubescent, - Read: articulato-pilose,

P 337, 1. 15-10 fr. b. should be modified as follows:

a. Primary segments not free, connected at the base.

(2) Ch. argentea.

a.a. At least the lowest primary segments free from the next higher ones.

b. Fronds tomentose, hairy or scaly.

(3) Ch. rufa.

b.b. Fronds naked.

(4) Ch. farinosa.

P. 338, 1. 8-9; For: somewhat tomentose,

Read: more or less hairy,

1, 18; For: 3-pinnatifid. - Read: 2-3-pinnatifid.

1. 19; For: reaching to the rachis, - Read: free,

1. 1 fr. b. should be modified as follows:

1.1. Rachis not naked. (See also Ch. tenuifolia).

P. 339; Ch. tenuifolia. - Omit the description of this species here. Insert: See Supplement 1.

P. 344, 1. 11; For: modifid - Read: modified

P. 353; P1. reducta. - Insert: See Supplement 1.

P. 357 ; t. pellucida. - Insert: See Supplement 1.

P. 359, 1. 19; For: troughout. - Read: throughout.

P. 369, 1. 12-13 should be modified as follows:

* At least the barren ultimate segments inciso-crenate to dentate or serrate throughout or towards the apex. ** Both barren and fertile ultimate segments entire or somewhat crenulate.

(32) Pt. radicans,

P. 369; Pt. Iongipes. - Insert: See Supplement 1.

P1. radicuns. - Insert: See Supplement 1.

1. 4 fr, b.; For: \pm Read: to

Ferns and Fern Allies. 

P. 370, 1. 7; For: indefinite - read: uncertain

1. mixia. - Insert: See Supplement 1.

P. 372 ; Pt. Wallichiama. -- Insert: See Supplement 1.

1. 13 ; For: $25-60$ and $15-30$

Read: $15-60$ and 5-30

P. 373, 1. 8-11 should be modified as follows:

3. Veins anastomosing sparingly; costular areolae few or wanting.

(42) Pt. Junghuhnii.

3.3. Veins anastomosing copiously; costular areolae many.

(43) Pt. Milneana.

P. 373; Pt. finistermae. - Omit this species. See Supplement 1.

P. 374, 1. 11 fr. b.; For: simple (i. e. not forked at the base),

Read: whether or not forked at the base,

P. 375, 1. 11 fr. b.; For: indefinite - Read: uncertain

P. 376, 1. 2; Omit: (ex sched.)

1. 3; For: (of the primary branches?)

Read: of the primary branches

1. $3 \& 4$; For: 50 c.M. long or longer,

Read: about $50-100 \mathrm{~cm}$. long,

P. 377; Pugulosa. - Omit this. See Supplement 1, Appendix.

P. 378, 1. 17; For: linear, consisting

Read: linear, submarginal or consisting

P. 380 ; L. egenolfioides. - Omit this species. See Supplement 1.

P. 381 ; 耳. Fraser. - Insert: See Supplement 1.

P. 382, 1. 10; For: size and cutting.

Read: cutting but more or less reduced in size.

P. 387, 1. 5 fr. b.: For: in a long - Read: in long

P. 388; H. egreginan。 - Insert: See Supplement 1, Appendix.

P. 389 ; D. alives. - Insert: See Supplement 1.

P. 390 ; D. media. - Insert: See Supplement 1.

P. 398, 1. 14; For: Surfaces villose or short-hairy.

Read: Surfaces villose, pilose or fibrillose.

P. 399, 1. 13; For: lobed; main rachis tomentose.

Read: lobed, or the main rachis not scaly.

P. 401; D. porphyrorachis. - Insert: See Supplement 1.

D. Chlorophyllum. - Insert: See Supplement 1. 

P. 402; D. silvaticum. - Insert: See Supplement 1.

P. 403, 1. 6; For: shallowly - read: obliquely

P. 405; D. bantamense. - Insert: See Supplement 1.

P. 407, 1. 5 fr. b.; After: edge. - Insert: - Very variable.

P. 408; D. Cobbianum. - Insert: See Supplement 1.

D. japonicum. - Insert: See Supplement 1.

P. 409; D. petiolare. - Omit this. See Supplement 1.

P. 411 ; D. Petersenii. - Insert: See Supplement 1, Appendix

P. 412; D. sormogonense. - Insert: See Supplement 1.

P. 415 ; D. bulbiferum. - Omit this. See Supplement 1.

P. 418; D. deltoideum. - Insert: See Supplement 1.

D. Meyenianum. - Insert: See Supplement 1.

P. 420 ; D. fructuosum. - Insert: See Supplement 1.

P. 422, 1. 11; For: wavy or slightly lobed.

Read: lobed or pinnatifid.

D. cordifolium. - Insert: See Supplement 1.

D. Forlbesii. - Insert: See Supplement 1.

P. 425; D. esculentum. - Insert: See Supplement 1.

P. 426, 1. 16; For: diflerent - Read: different

P. $427,1.15-7$ fr. b. should be modified as follows:

f. Costcue or costulae beset with distant, subulate, firm or flaccid appendages on the upper side.

* Fronds to $12 \mathrm{~cm}$. broad, with the central pinnae the largest.

(13) A. gymnogrammoides.

** Fronds more than $12 \mathrm{~cm}$. broad, or the central pinnae not the largest.

(14) A. nigripes.

f.f. Costae and costulae without subulate appendages.

P. 428 ; A. nanum. - Insert: See Supplement 1 .

A. Toppingianum. - Insert: See Supplement 1.

P. 429: A. gedeanum. - Insert: See Supplement 1.

P. 430 ; A. benguetense. - Omit this species. See Supplement 1 .

P. 431 ; A. macrocarpum. -- Insert: See Supplement 1.

P. 432, 1. 15 fr. b.; After: 254; - Insert: C. Chr., Ind. Fil., Suppl, 

P. $434,1.4$ fr. b.; For: midribs of the pinnulae

Read: costae and (or) costulae

P. 435, 1. 6; For: numerous erecto-patent

Read: many often oblique

1. 9; For: ovate,

Read: ovate, adnate to subpetiolulate,

1. 10; For: thin, membranaeous or herbaceous;

Read: membranaceous to subcoriaceous;

P. 437, 1. 12 ; After: free,

Insert: or united as in $\boldsymbol{a} \cdot \boldsymbol{x}$. but then the fronds not simple.

P. 441, 1. 14-11 fr. b. should be modified:

+ Costa prominent on one side or on both sides.

(18) A. glochidiatum.

++ Costa depressed on both sides.

(19) A. comosum.

A. epiphyticum. - Insert: See Supplement 1.

A. amboinense. - Insert: See Supplement 1.

P. 444 ; A. scolopendrioides. - Omit the description of this species here. - Insert: See Supplement 1.

P. 445 ; A. glochidiatum. - Insert: See Supplement 1.

P. 446; 1. 6-7: Omit the words: Both speeies are probably identical.

P. 447, l. 11-8 fr. b. should be modified as follows:

+ Pinnae cordate at the base. (34) A. horizontale.

+ Pinnae not corclate at the base.

(35) A. longissimum.

I. 2 fr. b. After: ones, - Insert: or smaller.

P. 448 , l. 3 fr. b.; For: $4-71 / 2-\operatorname{Read}: 2-71 / 2$

P. $449,1.15$ fr. b.; For: serrate or toothed.

Read: serrate, toothed or lobed.

P. 451, 1. 1-5 should be modified as follows:

+ Pinnae blunt or bluntish. (68a) A. stereophyllum.

++ Pinnae acute or acuminate.

$\times \quad$ Texture herbaceous.

(68b) A. Elmeri.

$\times \times$ Texture coriaceous.

(69) A. praemorsum. 

P. 454; A. salianum. - Omit this species. See Supplement 1 .

A. diversifolium. - Insert: See Supplement 1.

P. 456 ; A. vuleanicum. - Insert: See Supplement 1.

P. 458; A. tenerum. - Insert: See Supplement 1.

A. Iunulatum. - Insert: See Supplement 1.

P. 459; A. griseum. - Insert: See Supplement 1.

P. 460 ; A. Sehoggersii. - Omit this species. See Supplement 1 .

A. caudatum. - Insert: See Supplement 1.

P. 461; A. contiguam. - Insert: See Supplement 1.

P. 464; A. malinntoides. - Insert: See Supplement 1.

P. 465; A. Sancti-Christophori. - Insert: See Supplement 1.

1. $15 \mathrm{fr}$. b.; After: forms. - Insert: Young plants simple or paucijugate but sterile.

1. 14 fr. b.; For: 1-2- - Read: pauci-

l. 13 fr. b.; After: jugate. - Insert: Perhaps a young form of the type only.

1. 11 fr. b.; For: Timor (Forbes, No. 3124a)

Read: Java, Sumatra.

P. 466 ; A. unilaterale. - Insert: See Supplement 1.

1. 3 fr. b.; For: less cut away - Read: rather cuneate

P. 467; A. filipes. - Insert: See Supplement 1.

P. 468; A. horridum. - Insert: See Supplement 1.

P. 469, heading; For: ASAlENIUM. -- Read: ASPLENIUM.

A. stereophyllum. - Insert: See Supplement 1.

P. 472 ; A. affine. - Insert: See Supplement 1.

1. 9 fr. b.; For: 15-30 - Read: 15-90

P. 473, 1. 8-11 should be modified as follows:

c. Fronds about $2-5 \mathrm{~cm}$. long, or the pinnae laxly divided.

(76) A. Beccarianum.

c.c. Fronds about $5-10 \mathrm{~cm}$. long, the pinnae simple or closely divided. (77) A. Lauterbachii.

P. $473,1.10$ fr. b.; For: side, the segments cuneate,

Read: side; lobes lax, cuneate,

A. Lauterbachii. - Insert: See Supplement 1.

P: 474, 1. 3; For: 2-5 lobes. - Read: $2-5$ close lobes.

A. obtusilobum. - Omit this species. See Supplement 1 . 

A. Belangeri. - Insert: See Supplement 1.

P. 475, 1. 16; For: cut down to the rachis

Read: laxly pinnatipartite

P. 476 ; 56. PHYLIITIS. - Insert: See Supplement 1.

P. 479 ; 5\%. TRIPHLEBIA. - Omit this genus. See Supplement 1.

P. $483,1.2$ fr. b.; For: $4-8$ and 3-pinnatifid

Read: $3-8$ and 2-pinnate

P. $484,1.11$; After: maturity.

Insert:- Under surface rather densely fibrillose-lanuginose.

P. 485, 1. 2 fr. b.; After: oblong - Insert: or roundish.

l. 14 fr. b.; For: davalloides, - read: davallioides,

P. 487, 1. 14-16 should be modified as follows:

e. Texture herbaceous or membranaceous.

(1) Ph. appendiculata.

e.e. Texture coriaceous or chartaceous.

1. 14 fr. b; For: gradually reduced. - Read: reduced.

1. 13 fr. b.; For: veins. Pinnae - Read: veins, or pinnae

1. 6 fr. b.; For: secondary segments sharply toothed.

Read: or secondary segments at best toothed.

P. 488, 1. 6; For: side. Ultimate - Read: side, or ultimate

1. $14 \& 16$; Omit the words: Stipes rather short, castaneous.

Stipes rather long, green or stramineous.

P. 490; Ph. Smithii. - Omit this species. See Supplement 1.

P. 495; Ph. punciata. - Omit this species. Seo Supplement 1.

P. 496; Ph. distans. - Insert: See Supplement 1.

P. 497, 1. 9; For: \pm 1 c.M. - Read: to $1 \mathrm{~cm}$.

Ph. totta. - Insert: See Supplement 1, Appendix.

P. 498, heading; For: $\$ 2$. EUPHEGOPTERIS.

Read: § 2. LEPTOGRAMMA.

Ph. opacan. - Insert: See Supplement 1.

1. 6 fr. b.; For: pinnate $\left({ }^{1}\right)$.

Read: pinnate, at least 3-foliolate ( ${ }^{1}$.

P. 499, l. 16 fr. b.; For: 100 c.M. - Raed: $150 \mathrm{~cm}$.

P. 500, 1. 1-2; Omit the words: Sori medial. 

P. 502 ; Ph. rubiala. - Insert: See Supplement 1.

1. 8 fr. b.; After: veins.

Insert: - Pinnae when dry brown or blackish, with a reddish tint.

P. 503; Ph. gramulosa. - Insert: See Supplement 1.

Ph. diversilobu. - Insert: See Supplemeut 1.

P. 504, 1. 4; For: grey-pubescent. - Read: often naked.

P. 508, 1. 4; For: Luzon. - Read: the Philippines.

Ph. Spenceri. - Omit this species. See Supplement 1.

P. 509, 1. 4-5 should be modified as follows:

b. Fornds 10-25 cm. long, or the pinnae truncate at the base.

c. Pinnae $\pm 5-20$-jugate, the barren ones to $4 \mathrm{~cm}$. or more long.

P. 511; heading; Before: PHEgopteris. - Insert: $60 a$.

Ph. cuspidanta. - Insert: See Supplement 1, Appendix.

P. 512, 1. 15; For: arches. Venation as in Campteria.

Read: arches, or venation as in Campteria or Pleocnemia.

P. 513, 1. 6 \& 11 should be modified as follows:

2. Fronds under $30 \mathrm{~cm}$. long, or longer but then entire.

2.2. Fronds more than $30 \mathrm{~cm}$. long, not entire.

P. 515, 1. 2; For: CCCXXIII; - Read: CCCXXII;

1. 11; After: veins, - Insert: or scattered irregularly.

P. 517; D. Iubrasea. - Insert: See Supplement 1, Appendix.

1. 13; Omit the words: Rac., Flor. Btz., I, 109; Hk.,

1. 14-13 fr. b.; Omit the words: entire to

P. 527; G?. CONIOGHAMMF. - Insert: See Supplement 1, Appendix.

P. 529, 1. 10; Omit: C. Chr. Ind. Fil.

1. 5 fr. b.; For: $\pm 3-$ Read: $1-3$

P. 532 ; A. semicostatun. - Insert: See Supplement 1.

A. parouluma. - Insert: A. reticulatum, Klf., var. parvulum, Bedd., Handb. Ind. Ferns, 403.

P. 534 ; A. Coriacenun. - Omit the synonym A. reticulatum Bedd.

P. $535 ;$ A. callifoliuan. - Insert: See Supplement 1.

A. alaium. - Insert: See Supplement 1. 

A. reticulatum. - Insert: See Supplement 1 .

1. 3 fr. b.; For: $21 / 2-4$-. Read: $21 / 2-8$

P. 536, 1. 8 fr. b.; For: subparallel to the costa.

Read; parallel or subparallel to the costa.

P. 537; C. parallela. - Insert: See Supplement 1.

P. 538: L. Iancealata. - Insert: See Supplement 1.

P. 540, 1. 16-13 fr. b. should be modified as follows:

e. Barren fronds at best a little broader than the fertile ones. (4) S. Lobbiana.

e.e. Barren fronds distinctly broader than the fertile ones. (5) S. borneensis.

P. 547; H. arifolia. - Insert: See Supplement 1.

P. 551; 66. MONOGIR MMA. -- Incert: See Supplement 1. l. 11-10 fr. b. should be modified as follows:
+ Fronds very fine, subcappillary.
(2) M. trichoidea.
++ Fronds less fine, not subcapillary.
(3) M. paradoxa.

P. 552, heading; For: $\$ 2 .-$ Reck: $\$ 1$.

1. 2 ; For: $7-10$ - Read: $3-10$

1. 3; For: $2-3$ and $5-6-$ Read: $1-3$ and $3-6$

P. 553; M. Loheriana. - Omit this species. See Supplement 1. 69. VITTA RIA. - Insert: See Supplement 1.

P. 554, 1. 14; For: blackish. - Read: not grey.

P. 555;. angasifialias. - Insert: See Supplement 1, Corrections.

P. 558, 1. 19; For: $1-3-\operatorname{Read}: 1-6$

P. $559,1.10$; For: $10-15$ - Read: $10-35$

V. deloilis. - Omit this species. See Supplement 1.

P. 560 ; V. pusilla. - Omit this species. See Supplement 1.

V. sulcata. - Omit this species. See Supplement 1.

P. 561 ; У. limeata. - Insert: See Supplement 1.

V. scolopendninas. - Insert: See Supplement 1.

P. $562,1.6-5$ fr. b. should be modified as follows:

* Fronds simple.

(1) T. obtusa.

$+\leftarrow$ Fronds divided. 

P. $563,1.5$ fr. b.; For: \pm 8 and \pm 12 - Read: to 8 and to 12

P. 572, 1. 15, 6 and 4 fr. b. should be modified:

4. Fronds not densely hairy.

*.*. Fronds stalked.

4.4. Fronds densely hairy.

P. 573, 1. 9; Omit the word: stellate

P. 577, 1. 2 fr. b.; Omit: P. subevenosum, Bk., var., C. Chr., Ind. Fil.

P. 578, 1. 1; For: $7-25$ and 5-7-Read: 5-25 and 3-7

P. 579, 1. 2 fr. b.; For: under 2 m.M. - Read: to $\pm 3 \mathrm{~mm}$.

P. 581, 1. 16 fr. b.; Omit the word: stellate

P. paragiticum. - Insert: See Supplement 1.

P. 582, 1. 8; For: firm-membranaceous; - Read: rather firm;

l. 10 fr. b.; For: $7 \frac{1}{2}-12^{1 / 2}$ and $21 / 2-5$

Read: $5-12 \frac{1}{2}$ and $21 / 2-6$

P. 585; P. dolichosorum. - Insert: See Supplement 1.

P. setosum. - Insert: See Supplement 1.

P. 586, 1. 3; For: Java, Celebes, Philippines; -- Read: Malaya;

P. 588, 1. 11-10 fr. b. should be modified as follows:

+ Laciniae blunt or bluntish.

++ Laciniae acute or acuminate.
(47) P. gracillimum.

(48) P. cueullatum.

l. 3 fr. b.; For: 5-10 m.M. - Read: 5-121/2 mm.

P. 589, 1. 3; For: 15 m.M. - Read: $12 \% / 2 \mathrm{~mm}$.

1. 4-6 should be modified as follows:

$\times$ Fronds pinnatifid at least $1 / 2$-way down to the costa.

(53) P. Burbidgei.

$\times \times$ Fronds lobed at best $1 / 2$-way down to the costa. (54) P. ludens.

P. gracillimum. - Omit the description of this species here. Insert: See Supplement 1.

P. cucullatam. - Omit the description of this species here. Insert: See Supplement 1.

P. 590; P. Murbidgei. - Insert: See Supplement 1.

P. 591, 1. 4 fr. b.; For: $10-13$ and $\pm 7 \frac{1}{2}$

$$
\text { Read: } 7 \frac{1}{2}-15 \text { and } 5-10
$$

P. 592, 1. 16 \& 18 should be modified as follows:

FERNS AND FERN AlLIEs, 

+ Sori not contiguous, rather distant.

++ Sori contiguous.

P. 594, 1. 17; For: $20-40$ c.M. long. Sori

Read: $20 \mathrm{~cm}$. or more long, or sori

P. 595, 1. 11; After: pinnae,

Insert: protected by the reflexed edges.

P. 596, 1. 12-11 fr. b.; Omit: (rarely to 30)

1. 7 fr. b.; For: deciduously hairy; - Read: nearly so;

P. 597 ; P. sermato-dlentatum.- Omit this species. See Supplement 1.

P. 598; P. subminutum. - Omit this species. See Supplement 1.

P. Iancifolium. - Omit this species. See Supplement 1.

P. subscundo-dissectum. - Omit the description of this species here. See Supplement 1.

P. 599; P. repandulum. -- Insert: See Supplement 1.

1. 19 fr. b. F For: $2 \frac{1}{2}-4$ - Read: $1 \frac{1}{4}-4$

1. 17 fr. b.; For: firm-herbaceous; - Read: firm;

P. erythrotriehum. - Omit this species. See Supplement 1.

P. 600 , 1. 7 fr. b.; After: young.

Insert: - Young plants sparingly ciliated.

P. obliquatum. - Insert: See Supplement 1.

W. Sehenekii. - Omit this. See Supplement 1.

P. 601; P. decipiens. - Insert: See Supplement 1.

1. 17; Omit the word: deeply

P. 605; P. Laratheophyllum. - Insert: See Supplement 1.

P. multicaudatum. - Insert: See Supplement 1.

P. 607, 1. 1; For: creeping, - Read: short,

P. craterisorum. - Omit this spicies. See Supplement 1.

P. $608,1.9$; For: $15-30$ and $1 \frac{1 / 4}{15}-2 \frac{1}{2}-$ Read: $10-30$ and $3 / 4-21 / 2$

P. Lobbianum. - Insert: See Supplement 1.

P. Clavifer. - Insert: See Supplement 1.

P. 611 ; P. gedeanum. - Omit this species. See Supplement 1.

1. $7 \mathrm{fr}$. b.; For: both surfaces naked;

Read: surfaces glandular;

P. 614 ; P. exallatum. - Insert: See Supplement 1.

P. 618; P. persicifolium. - Insert: See Supplement 1.

P. 620 ; pallens. - Omit this species. See Supplement 1.

P. 623, 1. 9-11 should be modified as follows: 

3. Soral cavities without a raised border. (123) P. lomarioides.

3.3. Soral cavities with a raised border. ( (124) P. sarcopus.

P. $624,1.2$; For: $6-20-$ Read: $3 \frac{1}{4}-7 \frac{1}{2}$

1. 4 ; For: near the central ribs of the lobes.

Réad: nearer the costula than the edge.

1. 13 ; For: $\pm 2 \frac{1}{2}-$ Read: to $2 \frac{1}{2}$

1. 7-6 fr. b. ; Omit the words: which are scattered on the upper, but densely crowded on the under side.

1. $3 \mathrm{fr}$. b.; Omit the word: erecto-patent.

P. $630,1.14$; For: $30-60$ - Read: $20-60$

l. 13 fr. b.; Omit: (? P. flabellivenium, ete. . . . )

P. $637,1.11$; For: $1-5$ - read: $1-2$

P. 638, 1. 9; For: 5-13 c.M. - Read: 5-13 mm.

P. productum. - Omit this. See Supplement 1, under Pleopeltis revoluta.

P. 641, 1. 11: For: scandent, - Read: elongate,

1. 12; For: approximate, - Read: seriate,

P. 643, 1. 3-4; - For: more than 10 c.M. long. read: or more than $10 \mathrm{~cm}$. long in the adult plant.

1. 10-8 fr. b. should be modified as follows:

$\boldsymbol{d}^{\prime}$. Rhizome scales proportionally short and broad, blunt.

(180) P. triquetum.

$\boldsymbol{d}^{\prime} \cdot \boldsymbol{d}$. Rhizome scales proportionally long and narrow, acute to acuminate or aristate.

P. 644,; 1. 7; For: or herbaceous. - Read: to papyraceous.

1. 19-16 fr. b should be modified as follows:

4'. Stipes narrowly winged; fronds rigid.

(197) P. millisorum.

4'. Stipes not winged, or the fronds not rigid.

(198) P. punctatum.

P. $650,1.2 ;$ After: row, - Insert: regular or irregular.

Omit the variety grandifolium. See Supplement 1.

P. $655,1.18$; Omit the word: black,

1. 10 fr. b.; For: indefinite - read: uncertain 

P. $656,1.12-11$ fr. b. should be modified as follows:

$$
+* \text { Sori medial, or higher on the veins. }
$$

(199) P. quinquefidum.

1. 5 fr. b.; For: \pm short-winged. Fronds

Read: short-winged, or fronds

P. 657, 1. 9 fr. b.; For: $20-50-\operatorname{Read:~} 20-90$

P. 663, 1. 1 fr. b.; For: $\pm 5-7$ - read: $1-7$

P. 668; D. albidosdanmatum. - Omit the variety varians.

P. 669 , 1. 6; For: 1 2 c.M. - read: $1 / 2-3 \mathrm{~cm}$.

P. paImatum. - Omit the synonym crenulatum. Omit the variety obtusum.

P. $672,1.5-6 \& 9-10$ should be modified as follows:

5 Sori occupying the whole frond.

Ss Sori confined to the upper $1 / 3-1 / 2$ of the frond.

(224) P. interruptum.

1. 16-19 should be modified as, follows:

4. Fronds mostly 5-25 cm. long. (226) P. Hosei. 1.4. Fronds mostly $25-45 \mathrm{~cm}$. long.

(227) P. macrophyllum.

1. 10-7 fr. b. should be modified as follows:

e. Barren fronds deltoid-oblong, truncate at the base; rhizome scales scariose-edged. (230) P. Elmeri.

e.e. Barren fronds ovate-oblong to lanceolate, rounded to cuneate at the base, or the rhizome scales not scariose-edged. (231) P. Feii.

P. 673 ; Pelliguea. - Omit this. See Supplement 1.

P. regulare. - Omit this. See Supplement 1.

P. 674, 1. 10; For: $20-25$ and 6-9-Read: $20-50$ and $6-12$

P. 675 ; Peei. - Omit the variety caudiforme. Se日 Supplement 1.

P. 676 ; . heterdearpum. - Omit the variety abbreviatum. See Supplement 1.

P. 677, 1 12; For: Malacca, etc. — Read: Malaya. 

P. 679 , 1. 10 fr. b.; For: lanceolata, - read: oblanceolata,

P. 680 ; C. rupestris. - Omit this species. See Supplement 1.

P. 681 ; C. admascens. - Insert: Se日 Supplement 1.

P. $682,1.6$; For: $1-2-$ Read: $1-6$

P. $686,1.12$; For: oblong-lanceolate, - read: oblanceolate,

P. $688,1.7$ fr. b.; For: pale-brown or ferrugineous,

Read: pale-ochraceous,

P. 697, 1. 7 should be modified as follows:

§ 3. SACCOPTERIS. Cup-leaves induplicate or saccate-convolute.

P. 698 ; D. propinqua. - Omit the variety sumatrana. See Supplement 1.

P. $700, ; 1.4$; For: $\S 3$. THAYERIA. - Read: § 3. SACCOPTERIS.

D. neetarifera \& D. cornucopia. - Omit these species. See Supplement 1.

P. 701 ; Y 4. DRYYOSTA CHYUM. - Insert: See Supplement 1.

D. splendens. - Insert: See Supplement 1.

P. 702 ; D. carmosum. - Insert: See Supplement 1, Appendix.

1. 12 fr. b.; For: long; fertile - Read: long, or fertile

P. $708,1.5-10$ should be modified as follows:

c. Fertile fronds pendulous, with about 9-20 ultimate laciniae, the least divided fronds rather nutant.

d. Laciniae about 16-20. $\quad$ (5) P. sumbawense. d.d. Laciniae about 9-15. $\quad$ (6) P. Willinckii.

c.c. Fertile fronds erect, with about 4-8 ultimate laciniae, the most divided fronds rather nutant. $\quad$ (7) P. bifurcatum.

P. 709; P. sumbnwense. - Insert: Sөe Supplement 1.

P. 710 ; P. Willinekii. - Insert: See Supplement 1.

P. 712 , I. 2-19 should be modified as follows:

a. Stipes tufted.

(1) E. gorgoneum.

a.a. Stipes not tufted.
b. Rhizome scales blackish.
(2) E. conforme.

b.b. Rhizome scales not blackish.

c. Rhizome scales yellowish.

+ Rhizome scales proportionally broad, ovate.

(3) E. angulatum. 

++ Rhizome scales proportionally narrow, lanceolate to linear.

(7) E. laurifolium.

c.c. Rhizome scales brownish.

d. Fronds bluntly rounded at the apex.

* Veins rather hidden.

(4a) E. decurrens.

** Veins |rather visible.

(4b) E. luzonicum.

d.d. Fronds not bluntly rounded at the apex.

e. Fronds large or middle-sized, vein tips often dilated but not thickened.

f. Barren fronds short-stalked. (5) E Beccarium.

f.f. Barren fronds long-stalked. (6, E. callifolium.

e.e. Fronds rather small, or the vein tips thickened, so as to form an elevated intramarginal ridge on the under side.

* Rhizome scales proportionally broad, ovate.

(3) E. angulatum.

* Rhizome scales proportionally narrow, lanceolate to linear.

(7) E. laurifolium.

P. $712,1.13$ fr. b.; For: short-creeping, and approximate, Read: short, and fasciculate,

E. gorromeum. - Insert: See Supplement 1.

P. $713,1.1$; Omit the words: jagged or fimbriate,

E. Jecurrens. - Insert: See Supplement 1.

E. amgulatum. - Insert: See Supplement 1.

P. 714; E. Callifolium. -- Insert: See Supplement 1.

E. Iaurifolium. - Insert: See Supplement 1.

1. 3 fr. b.; For: $31 / 2-71 / 2-$ Read: $31 / 2-10$

'1. 14 fr. b.; For: $10-80$ - Read: $15-80$

P. 717; E. petiolatum. - Insert:

Rhizome scales linear-lanceolate or subullate, bright-brown to blackbrown, entire to spinuloso-ciliate. Fronds above glabrescent, when young more or less copiously provided with ferrugineous or pale.grey, stellatefimbriate squamules, beneath hairy, the hairs copious, ferrugineous or rufous, simple or cut to the base into $2-12$ tufted or stellately spreading branches; edges often recurved. 

P. 720 ; S. sorbifolia. - Omit this. See Supplement 1.

P. 721, 1. 12 fr. b.; For: Indefinite - read: Dubious

P. 722 ; \$. meuleata. - Insert: See Supplement 1.

1. 9-8 fr. b.; Omit the words: and adpressed to the substratum

P. 724; P. Nieuwemhuisii. -- Insert: See Supplement 1.

P. 725; F. articulata. - Omit this. See Supplement 1.

P. 728; II. spicata. - Insert: See Supplement 1.

1. 7 fr. b.; For: $1-3-$ Read: $1 / 2-3$

P. 733, 1. 13; After: veinlets.

Insert: - Pinnae not articulate to the rachis.

P. 734, heading; For: POECILOPTERIS. LEPTOCHILUS.

Read: LEPTOCHILUS. $\S 1$. POECILOPTERIS.

1. 16-14 fr. b. should be modified as follows:

e. Pinnae rather short.

(10a) L. heteroclitus.

e.e. Pinnaerather long.

(10b) L. stolonifer. (*)

(11) L. diversifolius.

1. 3-2 fr. b. should be modified as follows:

3. Pinnae at best incised to about $1 / 3$-way down to the costa; areolae with few to several free veinlets.

(15) L. virens.

P. $735,1.1-2$ should be modified as follows:

3.3. Pinnae incised at least $1 / 3$-way down to the costa, or the areolae without free veinlets.

1. Linnaeanus. - Insert as a synonym: L. sumatranus, v. A. v. R., Bull. Btz., 1916, XXIII, 15, tab. II, fig. $1 a-b$.

1. 2 fr. b.; Insert: - L. sumatranus $v . A . v, R$. is a form with indistinct or wanting main veins only.

1. 10 fr. b.; For: $1-1 \frac{1}{2}$ c.M. - Read: $3 / 4-1 \frac{1}{2} \mathrm{~cm}$.

P. 736 ; L. decurrems. - Omit the variety rasamalae.

See Supplement 1.

P. 737; L. Intifolius. - Omit this. See Supplement 1. 

P. 738; I. imeonstans. -- Omit this. See Supplement 1.

P. 741 ; L. virens. - Omit the description of this species here. Insert: See Supplement 1.

P. 742; I. Zollingeri. - Insert: Se日 Supplement 1.

l. 9 ; For: $5-7$ m.M. - Read: $1 / 2-1 \frac{1}{2} \mathrm{~cm}$.

P. $744,1.17$ fr. b.; For: $\pm 4 \frac{1}{2}$ and \pm 1 - Read: to 6 and to 1 .

1. 14 fr. b.; For: $1 \frac{1}{2}$ c.M. - Read: $1 \frac{1}{2} \mathrm{~mm}$.

P. $746 ; \S 3$. LOMAGRAMMA. Omit this section. See Supplement 1.

P. 761, 1. 5 fr. b.; For: 1-3-pinnate; - Read: 2-3.pinnate;

P. 763; 91. MARAT'TLA. - Insert: See Supplement 1.

P. 765, 1. 2 fr. b.; For: 6-12-celled. - Read: 6-10-celled.

P. 767, 1. 4-1 fr. b. should be modified as follows:

* Fronds simple, if digitate, then the central segment under $171 / 2 \mathrm{~cm}$. long. $\quad$ (1) C. Cumingiana.

** Fronds digitate, the central segment more than $171 / 2 \mathrm{~cm}$. long in the $\begin{array}{ll}\text { adult plant. } & \text { (2) C. aesculifolia. }\end{array}$

P. 768, 1. 5; For: 8-13 and 3-5-Read: 8-16 and 3-10

1. 6; For: 3-partite - read: digitate

1. 6-7; For: \pm 11 - Read: to 15

1. 8; Omit the word: adnate,

1. $11-12$; For: horizontal. - Read: oblique.

1. 6 fr. b.; For: $15-40-$ Read: $20-40$

P. 772, 1. 8; For: epiphytical. Read: epiphytical or terrestrial.

1. $12-9^{*}$ fr. b. should be modified as follows:

\$ Barren segment roundish or oblong, more than $1 / 2$ as broad as long. (4) O. pumilum.

ss Barren segment elongate, less than $1 / 2$ as broad as long. (5) 0 . macrorrhizum.

P. $773,1.16$ fr. b.; For: $3-31 / 2$ m.M. read: to $3 \frac{1}{2} \mathrm{~mm}$.

1. $15 \mathrm{fr} . \mathrm{b} . ;$ Omit the word: short

l. 13 fr. b.; For: $\pm 2^{3 / 2}$ m.M. long.

Read: to $2 \frac{1}{2} \mathrm{~mm}$. long, flat.

1. 12 fr. b.; After: Sumatra, - Insert: Borneo.

P. 774 ; 1. pumilum. - Omit the description. See Supplement 1. 

P. $776,1.4-3$ fr. $\mathrm{b}$. should be modified as follows:

+ Fronds to about $30 \mathrm{~cm}$. long.

++ Fronds $30 \mathrm{~cm}$. or more long.

(12) O. intermedium.

(13) O. pendulum.

P. 777; A. pendulum. - Insert: Se日 Supplement 1.

P. 784, 1. 6 fr. b.; For: Pinnae - Read: Pinnulae

P. 785 ; C. caudata. - Omit this. Se日 Supplement 1.

C. Christil. - Insert: Seo Supplement 1.

P. 787; C. Lolieri. - Omit the variety tonglonensis. See Supplement 1.

P. 788; C. tripinnata. - Insert: See Supplement 1.

P. 789 ; A. latebrosa. - Omit this. See Supplement 1.

P. 791; Copelandi. - Omit this. See Supplement 1.

P. 792 ; C. Daromatz. - Insert: See Supplement 1.

P. 793, heading; For: сівотUм. - Read: сівотіим.

1. 15 fr. b.; For: neaked - Read: naked

P. 794, 1. 9; For: tementum - Read: tomentum

A. dilcarpar. - Omit this. See Supplement 1.

G. glauca. - Omit the description. See Supplement 1.

P. 795; G. gignntea. - Omit the description and the synonym $G$. excelsa. See Supplement 1.

A. limearis, var. normalis. Omit this form as described here. See Supplement 1. (var. alternans).

A. Iaevissima. - Omit the description.

See Supplement 1. (No. 4c)

P. 797, 1. 4 fr. b.; For: labeled - Read: labelled

P. 799; 'T. Mhaxionam. - Insert: See Supplement 1.

T. millefolium. - Insert: See Supplement 1.

P. 800; T. Christil. - Insert: See Supplement 1.

P. 803; M. Merrilli:. - Omit the description. See Supplement 1.

P. 804; D. dennstaedioides. - Omit this. See Supplement 1.

P. $805,1.15 \& 17$; For: $\pm 18 \pm 9 \pm 3$

Read: to 30 to 15 to 4

1. 12 fr. b.; For: thinly herbaceous; - Read: often firm;

吕. Inoveri. Insert: Seo Supplement 1.

D. Elmeri. - Insert: See Supplement 1.

P. 813: I. viscosa. - Insert: See Supplement 1.

FERNS AND FERN ALLIES. 

P. 814; D. exignat. - Omit the synonym Lastraea exigua. See Supplement 1.

P. 815, 1. 10 fr. b.; Read: Philippines, Celebes.

P. 816 ; D. balabacensîs. - Insert: Seo Supplement 1.

P. 817 ; D. Facken'i. - Omit this species. See Supplement 1.

P. 820 ; D. Wasilan rils. - Insert: Seө Supplement 1.

P. 821; D. Uda yensis. - Insert: Se日 Supplement 1.

1. 13 fr. b.; For: \pm 40 - Read: to 100

P. 823 ; D. Inndisayne. - Insert: See Supplement 1.

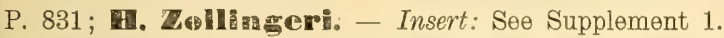

P. 833; 90. ANGIOETEFES. - Insert: See Supplement 1.

P. 847. Insert: Antrophyum alatum, Brack. . . . . 535.

P. 854. Athyrium drepanopterum. For: R. Br. - Read: A. Br.

P. 861. Diplazium. For: accedens, - Read: accedens,

P. 863. Insert: Dryopteris brunnea, C. Chr. . . . . 497

P. 871. Hymenophyllum. For: integrum, - Read: integrum, productum. For: 79 - Read: 69 serrulatum. For: 97 - Read: 79

P. 873. Leucostegia hymenophylloides. For: Bl. - Read: Bedd.

P. 876. Microlepia. For: platyphylla, - Read: platyphylla,

P. 882. Ophioglossum inconspicuum. - For: 773 - Read: 774

P. 887. Insert: Polypodium flaccidum, Christ . . . . 658

P. 889. Polypodium. For: obtusifolium, - Read: obtusissimum,

P. 895. Schizoloma Guerinianum. For: 288, - Read: 280,

P. 897. Tectaria devexa. For: 810 - Read: 811

P. 899. Vittaria. For: 533 - Read: 553

Insert: Vittaria crispomarginata, Christ . . . 556

P. 13, 1. 11 fr. b.: For: to 3-pinnate. - Read: to 4-pinnate.

P. 14, 1. 7 fr. b.; For: serrate. Indusium

Read: serrate, or the indusium.

P. 15, 1. 2 fr. b. et passim; For: M. - d.M. - c.M. - m.M. Read: m. - dm. - $\mathrm{cm}$. - mm.

P. 40; melanopus. - Insert: Seo Supplement 1.

P. 43; A. domentosa. - Insert: Soe Supplement 1, Appendix.

P. 172, 1. 10 fr. b.; For: linear-lanceolate, - Read: linear-filiform 

1. 1 fr. b.; After: wanting?),

Insert: sometimes persistent. - A variable species.

P. 177, 1. 20 fr. b.; For: scaly. Secondary segments

Read: scaly, or the secondary segments

P. 179, 1. 7; For: nearly so. - Read: glabrescent.

P. 218; D. arbuseula. - Insert: See Supplement 1.

P. 222 ; D. piloso-squamata. - Insert: See supplement 1.

P. 243, 1. 10 fr. b. F For: $2-6$ - Read: $1-6$

P. 249, 1. 7; For: deeply pinnatifid, - Read: to 2-pinnatifid,

P. 282, 1. 5 \& 8; For: § 2. and § 3. - Read: § 1. and § 2.

1. 4 fr. b.; For: § 2. - Read: \$ 1 .

P. 305, 1. 12 fr. b.; For: deeply toothed, - Read: toothed,

P. 606, 1. 16: For: seales. - Read: scales.

P. $643,1.7 \& 4$ fr. b. should be modified as follows:

e. Rhizome scales acuminate or acute.

$\boldsymbol{e}^{\prime} \cdot \boldsymbol{e}$. Rhizome scales aristate or cuspidate.

P. 652 ; P. suboppositum. - Omit the description. See Supplement 1.

P. $669,1.5$ fr. b.; For: linear-oblong; - Read: lanceolate,

P. 708; P. Wilhelmimae-Teeramed - Insert: Ser Supploment 1.

P. $755,1.5$; For: only. Stomium vertical.

Read: only, opening by a slit across the apex.

P. 756 ; D. Javanica. - Insert: See Supplement 1.

1. 9 ; For: $2-21 / 2-$ Read: $3 / 4-3$

1. 11-12; For: pinnate, subspreading . . etc.

Read: pinnate to subdichotomous, spreading to erectopatent.

P. 828 , 1. 7 fr. b.; For: elliptico-rhombeidal

Read: elongate-oblong 

B.

\section{MAILA YAN FEIRIV AIMIESS.}

P. XV, 1. 6; For: foliaceous - Read: foliate

P. 10 ; S. natans. - Insert: See Supplement 1.

P. 16, 1. 2; For: sub - Read: sub-

P. $32,1.3$ should be modified:

Forma typica. - Java.

Forma minor: Shoots shorter, $15-30 \mathrm{~cm}$. long, 4-9 $\mathrm{mm}$. diam. including the leaves. Leaves shorter, $3-6 \mathrm{~mm}$. long, $1-1 \frac{1}{2} \mathrm{~mm}$. broad, sparingly to copiously, minutely serrulate towards the apex. - Celebes.

P. 33, 1. 1 et passim; For: sporophylla similar,

Read: sporophylla similar to the barren leaves

4. Everettii. - Omit the information given at the base of the diagnosis as well as the habitats Java and Sumatra. See Supplement 1, Corrections.

P. $35,1.2-8$ should be modified as follows:

3. Leaves canaliculate, complicate or conduplicate.

- Leaves 6-8 mm. long.

(16) L. laxum.

* Leaves 10-15 mm. long.

(18) L. carinatum.

3.3. Leaves flattened.

4. Leaves ascending.

5. Leaves thick or rigid. (17) L. gunturense.

5.5. Leaves weak or thin. (19) L. proliferum.

4.1. Leaves horizontal or much spreading. (20) L. ulicifolium.

E. Iaxum. - Insert: See Supplement 1, Appendix.

1. tetrasticloum. - Insert: See Supplement 1, Appendix.

P. 36, 1. 3; For: L. carinatum Desv.

Read: united with

1. 4 ; For: but positively distinct.

Read: L. carinatum Desv. by intermediates.

C. Carinatum. - Insert: Soe Supplement 1, Appendix.

P. 43; L. phlegmarioides. - Insert: See Supplement 1, Appendix. 

P. 52, 1. 7 fr. b.; For: planes: - Read: rows;

P. 58, 1. 12 fr. b.; For: ot - Read: or

1. 8 fr. b.; For: beeing - Read: being

1. 4 fr. b.; For: of - Read: of

P. 59, 1. 16; For: then Read: than

1. 17 fr. b.; For: then - Read: than

l. 9 fr. b.; For: then - Read: than

P. $60,1.5$; For: then - Read: than

P. 61, 1. 18 fr. b. F For: then - Read: than

P. 77, 1. 17; For: 0-6 ciliate - Read: 0-6 ciliae

P. 79; S. Sumatrasa. - Insert: Seo Supplement 1.

P. $82,1.1$ fr. b.; For: rachiscs - Read: rachises

P. 91, 1. 5; For: oblipuely - Read!: obliquely

P. 125, 1. 13; For: $1 \mathrm{~mm}$. - Read: $11 / 4 \mathrm{~mm}$.

1. 15 ; For; $1 . \mathrm{mm}$. - Read: $11 \% \mathrm{~mm}$.

P. 126, 1. 15 \& 17 should be modified as follows:

Largest lateral leaves $2 \frac{1}{2} \mathrm{~mm}$. or more long.

Largest lateral leaves at best $21 / 2 \mathrm{~mm}$. long.

P. 128, 1. 13 fr. b.; For: more or less - Read: or more

P. 139, 1. 11; For: obsolately — Read: obsoletely

1. 17 fr: b.; For: subsquarose — Read: subsquarrose

P. 140 ; S. cupreasina. - Insert: See Supplement 1.

P. $141,1.14$; For: to $2 \frac{1}{2} \mathrm{~mm}$. - Read: $2^{1 / 2}-4 \mathrm{~mm}$.

S. leylensils. -- Insert: See Supplement 1.

P. 142, 1. 8; For: the largest $2 \% \mathrm{~mm}$. - Read: at best to $2 \% \mathrm{~mm}$.

P. $147,1.3$ fr. b.; For: $6-12$ - read: $6-26$

P. 155, 1. 6; For: ths base, - Read: the base,

P. 160 ; S. Rethertil. - Insert:

Stems 4-5 mm. broad in the fully developed plants; ultimate branchlets to $3 \frac{1}{2} \mathrm{~mm}$. broad. - A sterile plant gathered in the same locality (J. A. Lörzing No. 1943a) differs only in having the shoots shorter, and the leaves very compact, imbricated. (Forma compacta).

P. 170 , 1. 7 fr. b.; Omit the word: to 

P. 174, 1. 13; For: subbullate, at - Read: subbullate at

1. 16; For: $2-31 / 2-$ Read: $2-4$

l. 1 fr. b.; For: eaves - Read: leaves

P. 178, 1. 12; For: acute, - Read: acute,

P. 192, 1. 14-23 should be modified as follows:

1. Sporophylla not very heteromorphous.

(163) S. megaphylla.

1.1. Sporophylla distinctly heteromorphous.

2. Lateral leaves and sporophylla entire or subentire.

165) S. brachystachya.

2.2. Lateral leaves or sporophylla at least more or less copiously serrulate.

3. At least the lower axillary leaves of the stem proportionally short and broad.

(164) S. d'Armandvillei.

3.3. Axillary leaves proportionally long and narrow.

4. Intermedial leaves long-cuspidate. (166) S. fimbriata.

1.4. Intermedial leaves not long-cuspidate. , 167) S. subfimbriata.

P. 193; \$. d'Armandvillei. - Insert: See Supplement 1.

1. 3 fr. b.; For: sided - read: sides

P. 194 ; \$. Drmehystachya. - Omit this species. See Supplement 1.

S. fimbriata. - Insert: See Supplement 1.

P. 195 ; S. subfindoriata. - Insert: See Supplement 1.

P. 198, 1. 16-19 should be modified:

(.) Microspores reticulate-cristate.

(185) S. Schildei.

$\odot \odot$ Microspores not reticulate-cristate. (192) S. Pouzolziana.

P. 199, 1. 8; For: plicate. - read: flat or plicate.

1. 16; For: auriculate. - read: plicate.

P. 200, 1. 4 fr. b.; After: base

Insert: or, if so, the auricle plicate.

P. 207, 1. 4 et passim; For: margine - read: margin

P. $211,1.8$ fr. b.; For: keeled. - read:

keeled. - Leaves more or less distinctly or narrowly pellucid-margined on one side or on both sides.

P. 212, - Insert: 



\section{(184) \$. polystachya, Warb.}

Plants gathered on Mount Talaman (Bünnemeyer No. 370) and in Lebong Simpang (Brooks No. 359/S), which are probably forms of this, are distinguished by the following characters: Shoots erect, about 50-100 $\mathrm{cm}$. high, 2-pinnate, the stem 3-stelical, when dry to $5-8 \mathrm{~mm}$. thick in the lower part and irregularly compressed, straight or subtortuous, pale-fuscous in the lower part, fuscous in the middle, black in the upper part; pinnae short-stalked, ascending, lanceolate-elliptical, deciduous (articulated?), the higher to $\pm 20 \mathrm{~cm}$. long and $5 \mathrm{~cm}$. broad, acuminate, the rachis stramineous when dry; pinnulae crowded, ascending, to $4 \mathrm{~cm}$. long, $8-10 \mathrm{~mm}$. broad including the lateral leaves, simple or often forked or twice to thrice forked at or towards the apex. Leaves entire; leaves of the stem subisomorphous, remote, erect or suberect, oblong, narrowly rounded or subcordate at the base, the lateral ones $\pm 21 / 2 \mathrm{~mm}$. long, the intermedial ones $\pm 1 / 2 \mathrm{~mm}$. long, bluntish or shortly acumiuate; leaves of the pinnae heteromorphous, more or less distinctly and narrowly pellucid-margined; latera. leaves spreading; of the secondary rachises subfalcate-oblong, acute, the largest $4-5 \mathrm{~mm}$. long, $2-2 \frac{1}{2} \mathrm{~mm}$. broad, the upper side rotundate-cuneate at the base, the lower side narrowly rotundate-truncate or subcordate at the base; of the pinnulae nearly similar, approximate or slightly imbricate, the largest 4-6 $\mathrm{mm}$. long by $2 \mathrm{~mm}$. broad; intermedial leaves erect; of the secondary rachises oblong, 3-4 mm. long, shortly acuminate, the base narrowly rounded or subcordate on the inner side, somewhat produced and narrowly cordateauriculate on the outer side, the auricle rounded; of the pinnulae imbricate, smaller, suddenly and conspicuously acuminate, the inner side nearly straight, narrowed at the base, the outer side broadly rounded, rounded or somewhat cordate at the produced base. Spikes solitary on the ultimate short branchlets, $2-8$ (mostly $4-6$ ) to a pinnula, to $2 \mathrm{~cm}$. long, $1-2$ mm. diam.; sporophylla deltoid-ovate, acute or acuminate, more or less distinctly or narrowly pellucid-margined, often intermixed with similar but smaller sterile bracts; macrospores greyish, yellowish or pale-ochraceous, copiously verruculose, the equatorial projections whether or not the largest; microspores whitish or yellowish, provided with crowded, verruciform, clavate or capitate projections on the basal side.

\section{Sumatra.}

(185) S. Selhilldel, Hieron., MS. in Herb. Bog.

Stems 3-stelical, when dry stramineous and irrigularly groovod, pinnate; 

pinnae oblong, sparingly pinnate, to $\pm 5 \mathrm{~cm}$. long; pinnulae few, forked or very sparingly pinnate; ultimate branchlets to $1 \frac{1}{2} \mathrm{~cm}$. long, 3-4 $\mathrm{mm}$. broad including the lateral leaves. Leaves heteromorphous on both stem and branches, entire, pellucid-margined on both sides; lateral leaves ascending or spreading on the stem, spreading on the branchlets; of the stem rather remote, short-oblong, $\pm 3 \mathrm{~mm}$. long by $2 \frac{1}{2} \mathrm{~mm}$. broad, the apex blunt or rounded, the upper base broadly rounded, the lower base auriculate-cordate; of the branchlets crowded or imbricate, to $2 \frac{1}{2} \mathrm{~mm}$. long and $1 \frac{1}{2} \mathrm{~mm}$. broad, the upper base rotundate-cuneate, the lower base truncate-cuneate or rotundate-truncate; intermedial leaves erect; of the stem oblong, $\pm 3 \mathrm{~mm}$. long, the apex blunt or rounded, the base obliquely 2-auriculate-cordate, the inner auricle relatively narrow, rounded, the outer auricle proportionally large, much produced, conspicuously hamate-incurvate; of the branchlets smaller, imbricate, the apex acute or shortly acuminate, the inner side nearly straight, narrowed at the base, the outer side rounded, slightly rounded or subauriculate at the base. Spikes square, terminal on the branchlets, solitary or $2 \cdot n a t e$, to $2 \frac{1}{2} \mathrm{~cm}$. long, $1 \frac{1}{2}-2 \mathrm{~mm}$. diam.; sporophylla ascending, deltoid-ovate, acute, entire, pellucid-margined, keeled, $\pm 1 \frac{1}{2} \mathrm{~mm}$. long; mierospores provided with reticulated wing-shaped erests; macrospores . . . . . - The description is taken from a fragment sent by Hieronymus.

\section{Sumatra.}

\section{(185a) S. herpocaulos, v. A. v. R.}

Shoots decumbent, about $30-40 \mathrm{~cm}$. long, pinnate, the stem 3 stelical, when dry stramineous and angular; pinnae oblong, sparingly pinnate, to $\pm 5 \mathrm{~cm}$. long, or longer and growing out to new shoots; pinnulae few, simple, forked or very sparingly pinnate; ultimate branchlets to $\pm 3 \mathrm{~cm}$. long, $4-5 \mathrm{~mm}$. broad including the lateral leaves. Leaves heteromorphous on both stem and branches, entire, pellucid=margined on both sides; lateral leaves ascending on the stem, erecto-patent or subspreading on the branchlets; of the stem remote, broadly oblong, $\pm 3 \frac{1}{2} \mathrm{~mm}$. long and $3 \mathrm{~mm}$. broad, very minutely mucronulate at the subrotundate apex, the upper base rotundate or rotundate-cuneate, the lower base subcordate-rotundate; of the branchlets crowded or imbricate, to $31 / 2 \mathrm{~mm}$. long and $1 \frac{3}{4} \mathrm{~mm}$. broad, shortly acuminate, the upper base rotundate-cuneate, the lower base rather narrowly rounded; intermedial

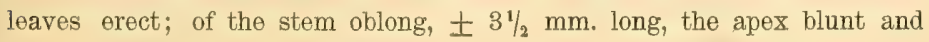



shortly mucronulate, the inner base minutely auriculate, the auricle subacute, tooth-like, the outer base auriculate-cordate, much produced, the auricle proportionally large, conspicuously hamate-incurvate; of the branchlets smaller, imbricate, the apex shortly acuminate, the inner side nearly straight, narrowed at the base, the outer side rounded, rounded or subauriculate-cordate at the base. Spikes square, terminal on the branchlets, solitary, to $2 \frac{1}{2} \mathrm{~cm}$. long, 2-3 mm. diam.; sporophylla ascending, triangular-ovate, subacuminate, entire or obsoletely denticulate, pellucidmargined, keeled, $\pm 2 \mathrm{~mm}$. long; macrospores black-brown, more or less white-pruinose, partly verruculose, partly rugulose with flexuose or branched rumples; microspores whitish or pale-orange, provided with reticulated wing-shaped crests.

\section{Sumatra.}

P. $214,1.10$ fr. b.; For: bluntish, Read: blunt or bluntish,

P. 214-215; S. Willdenowii. - Insert: - var. punctulata.

Leaves more or less narrowly pellucid-margined on both sides.

Forma typica: Stems and branches smooth. - Malaya; Cochin-China.

Var. punctulata: Stems and primary branches asperulous (often on the lower side only) with numerous very minute elevated points Sumatra.

P. 215; \$. Englen?. - Insert:

At best the lateral leaves narrowly pellucid-margined on the upper side only.

1. 12-14; Omit the information regarding Teysmann's plant and the locality Sumatra.

P. 216, 1. 19; For: central pinnae - read: central pinnulae

\$. Fouzolaiama. - Insert: Seo Supplement 1, Appendix.

P. 218, - Insert:

(192a) See No. 184.

P. 221, 1. 13; For: jcctions. - read: jections.

P. 222, 1. 13: For: branchlets, oblong, - read: branchlets oblong,

S. bidiengi̊. - Insert:

Ferns and Fern Aluies. 

Leaves of the stipe entire, pellucid-margined; of the lower plane subfalcate-ovate, the largest $31 / 4 \mathrm{~mm}$. long by $1^{1 / 2} \mathrm{~mm}$. broad, subacute, obliquely cordate at the base, the upper auricle revolute, the lower produced; of the upper plane obliquely falcate-ovate, the largest $2 \frac{2}{3} \mathrm{~mm}$. long, subacute, rotundate-cordate at the base, the auricles incurved, subacute.

\section{P. 224 ; S. padangensis. - Insert:}

Lateral leaves of the ultimate branchlets not or hardly auricled at the base.

P. 225 ; S. d'Urvillei. - Insert: See Supplement 1, Appendix.

P. 226, l. 6 fr. b.; For: indefinite - Read: uncertain

P. 227 ; S. barbata. -- Omit this species. See Supplement 1.

P. 229, 1. 6; For: rotundate - Read: rotundate

P. 236, 1. 20; For: blade: - Read: blade;

P. 255. - Azolla. - For: japonica, Fr. \& Sav. Read: japonica, Fr. \& Sav.

P. 260, S. polystachya. - For: 22 - Read: 212 

G.

\section{SUPPLEMENT.}

For: Fertile fronds (pinnae, segments, etc.) similar etc.

Read: Fetile fronds (pinnae, segments, ete.) similar to the barren ones etc. P. 7; Insert

All.

Flor. pedem.

P. $8 ;$ Insert:

Sod.
$=$ C. Allione

= Flora pedemontàna, etc. (All., 1875).

$=$ Sodiro.

P. 9, 1. 8-9; For: of small - Read: of a small

P. 18, 1. 13; For: not -- Read: (not

1. 7 fr. b.; For: material; - Read: material);

P. 22, 1. 15; For: DICKSONIAE. - Read: DICKSONIEAE.

P. 24, 1. 15 fr. b.; For: large persistent, Read: large, persistent

P. 26; C. Zollingeriana. - Insert:

Main and secondary rachises provided beneath with prominent, tuberculiform glands (aërophores) near the bases of the pinnae and pinnulae.

P. 28, 1. 1; For: $3 \mathrm{~cm}$. - Read: $3 \mathrm{~mm}$.

1. 11; For: tomentum - Read: indumentum

1. 18; Forma squamulosa. - Omit this. See the Appendix.

1. 21; Forma asperula. - Omit this, it being referred to forma squamulosa. See the Appendix.

After: No. (18b) Insert:

(18c) See No. 30 (in the corrections).

(18d) See No. 30a (in the corrections).

P. 29; C. orlentalis. - Insert: 


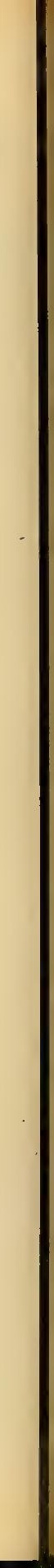


Laciniae obscurely serrulate-crenate to serrate.

1. 8; For: beneath. - Read: beneath, at length naked.

P. 32, l. 5 fr. b. et passim. - ${ }_{n}(23 a)$ Sie No. $22 "$ means that No. 22 shows characteristics urging a place for it as No, $23 a$ as well.

P. 37. 1. 15-19 should be modified as follows:

(30) C. oinops, Hassis., Obs. Fil. Jav., 23; (not C. sinops, Rac.).

Trunk slender, to about $12^{1}{ }_{2} \mathrm{~m}$. high. Stipes short, provided towards the base with caducous, fuscous, subulate-acuminate, membranaceous, minutely lacerate-ciliolate scales, otherwise furfuraceo-tomentose, castaneous and copiously punctulato-asperulous, as is the rachis, the tomentum ferrugineous. Fronds elliptical-oblong, to $150 \mathrm{~cm}$. long by $75 \mathrm{~cm}$. broad, acute at both ends, 3-pinnatifid or sub-3-pinnate, the rachis strigulosotomentose above at least in the upper part, the tomentum ferrugineous. Pinnae close, the higher sessile, the lower petiolate, the largest horizontal, elongate-lanceolate, to $40 \mathrm{~cm}$. long by $14 \mathrm{~cm}$. broad, shortly acuminate, the rachis castaneous, sparingly punctulate, ferrugineo-furfuraceous beneath, striguloso-tomentose above. Pinnulae numerous, sessile, linear, shortly acuminate, the costa above pale-ferrugineo-strigulose, beneath ferrugineofurfuraceous in the lower part, squamulose in the upper part, as are the costulae in the lower part, the scales small, subulate or lanceolate, rufous, ciliolate-lacerate; central pinnulae largest, horizontal, approximate, $7-8$ $\mathrm{cm}$. long, $1^{3} / 4_{4}-2^{1}{ }_{4} \mathrm{~cm}$. broad at the base, deeply pinnatipartite, or pinnate at the base, the acumen blunt, crenate-dentate; lower pinnulae abbreviated, often deflexed. Ultimate segments (lobes or leaflets) approximate, horizontal or nearly so, linear-oblong, straight or somewhat falcate, the largest about $1 \mathrm{~cm}$. long, about $3 \mathrm{~mm}$. broad when flattened, subacute, the edge recurved, crenate in the upper part, deeply dentate-crenate in the fertile region with subcucullate crenatures which often are crenate again; costulae above naked and lying in a conspicuous, longitudinal, complicate-canaliculate impression of the upper surface except in the barren region; veins to $10-12$ on a side, grooved above, forked, the higher simple, the lower sometimes twice forked. Texture coriaceous; surfaces naked. Sori to 8 on a side, not occupying the higher veins, close, costular; indusium firm, ferrugineous or castaneous, breaking down by a slit, at length irregularly 2-partite or lacerate. - The plant determined by Raciborski as C. oinops is quite another species. See No. $30 a$.

Java. 


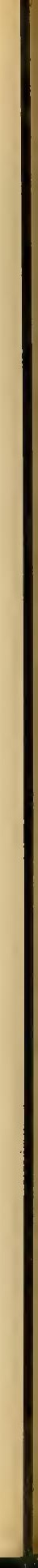


(30a) C. simops, Rac., Flor. Btz., I, 36; (not C. oinops, Hassk.).

Trunk to about $12 \mathrm{~m}$. high. Stipes to $50 \mathrm{~cm}$. long, prodived with caducous scales. Fronds elliptical-oblong, 3-pinnatifid or sub-3-pinnate, the rachises pale-fuscous, beneath sparingly punctulate and when young probably ferrugineo-furfuraceous, above striguloso-tomentose, the tomentum castaneous. Largest pinnae rather horizontal, elongate-lanceolate, about $60 \mathrm{~cm}$. long by $25 \mathrm{~cm}$. broad, on stalks to $3 \mathrm{~cm}$. long, rather abruptly acuminate. Pinnulae approximate, horizontal, sessile, linear, deeply pinnatipartite, or pinnate at the base, subabruptly acuminate, the largest $10-12^{1 / 2} \mathrm{~cm}$. long, $2-2^{1 / 2} \mathrm{~cm}$. broad, the acumen coarsely rotundatecrenate, blunt at the tip; costae above castaneo-striguloso-tomentose, beneath ferrugineo-furfuraceous in the lower part, sparingly squamulose in the upper part, as are the costulae in the lower part, the scales thin, ochraceous, ovate, flexuose-acuminate. Ultimate segments (lobes or leaflets) approximate, the lower rather horizontal and straight, the others rather spreading and more or less falcate, the largest to $1 \frac{1}{2} \mathrm{~cm}$. long by $3 \mathrm{~mm}$. broad, somewhat canaliculate above, blunt, broadly and shallowly crenate, the crenatures hardly recurved in the fertile region, the upper surface provided with rows of transversal impressions alternate with the crenatures, so as to form 1 row of minute vaults on each side of the costula except in the sterile region, 1 to each crenature, convex above, concave beneath; costulae naked above; veins on the vaults, to $10-12$ on a side, somewhat prominent above, the lower and central once or twice forked, the higher simple. Texture coriaceous; surfaces naked. Sori to 8 on a side, not occupying the higher veins, close, costular; indusium thin, ochraceous, gradually evanishing. - The name C. sinops, though a typographical error, can be maintained, since Raciborski's plant is absolutely different from that of Hasskarl.

Java.

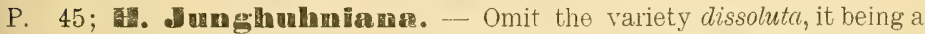
form of the species only, not a constant variety.

P. 46, 1. 4; Omit the word approximate,

1. 11; For: higher - Read: the higher

1. 13-14 should be modified:

Lobes approximate or remote, to $5 \mathrm{~mm}$. apart, not rarely narrowed in the fertile region. 

P. 47; II. Iemichlamydea. - Insert: See the Appendix.

P. 59, 1. 2 fr. b.; For: 2-furcate. - Read: twice forked.

P. 60, 1. 5 fr. b.; For: as far - Read: (as far

1. 4 fr. b.: For: Perak - Read: Perak)

P. 63, l. 13 fr. b.; For: apparently - Read: (apparently

P. $64,1.16$; For: $2^{1 / 2}-2^{1 / 2}-$ read: $21 / 4-21 / 2$

P. 68, 1. 6 fr. b.; For: contminans, - read: contaminans,

P. 74 ; D. sorbifolia. - Omit the synonym D. papuana, Muell. Insert: See the Appendix.

P. 77, 1. 1 fr. b.; For: not - Read: (not

P. 79, 1. 1; For: mostly — Read: (mostly

1. 11 fr. b.; For: Bk., - Read: Bk.,

P. 83; C. gignntea. - Insert: See the Appendix.

P. $85,1.10$; For: often less - Read: not always

Cr. oceanica. - Insert: See the Appendix.

P. $88,1.9$ fr. b.; For: Kz., - Read: Kze,

P. 92 ; For: II. Zollingeri, Kze.

read: Hi. Rollingevianum, Kae.

P. 94, 1. 2 fr. b.; For: - Malaya.

Read: Toothlets short. - Malaya.

P. 95, 1. 2; For: - Java. - Read: Toothlets short. - Java.

1. 4; For: - Java. - Read: Toothlets long. - Java.

P. 98; H. anuldifidum, Sw. - Insert: Omit the synonym H. klabatense, Christ. - See No. 35a.

(35a) H. klabatense, Christ, Fil. Saras., I, 4; H. multifidum, Christ (not Sw.), in Ann. Btz., XV, 98.

Rhizome creeping, wiry, copiously hairy, the hairs long, pale-ferrugineous. Stipes wiry, $7 \frac{1}{2}-10 \mathrm{~cm}$. long, hairy like the rachis, the hairs similar to those of the rhizome, less copious, deciduous. Fronds ovate, 3-4-pinnate at the base, $10-12 \frac{1}{2} \mathrm{~cm}$. long, acuminate, the main rachis narrowly marginate in the lower part, winged in the upper part, the rachises of the pinnae and pinnulae winged throughout or nearly so, the wings entire. Lower pinnae ovate or lanceolate, to $\pm 3 \mathrm{~cm}$. long. Lower tertiary segments forked or pinnate. Ultimate segments linear, to $5 \mathrm{~mm}$. long by about $1 / 2 \mathrm{~mm}$. broad, blunt, serrulate. Texture thin; surfaces naked; colour dark-brown when dry; a single central rib carried into each ultimate segment. Sori decurved, subaxillary on the pinnae or pinnulae, 

on abbreviated segments; indusium rather large, oblong, cleft $1 / 2$-way down, narrowly 2-marginate below the valves, the valves wille-opened at full maturity, rounded at the apex, the base obconical, provided with scattered, longitudinal crests often with a free short-dentiform or longsubulate appendix; receptacle included. - The description is taken from Koorders' No. $17136 \beta$.

Celebes.

P. 102, 1. 7 fr. b.; For: not Pr.), - Read: (not Pr.),

P. 107, 1. 12 fr. b.; For: subsetiform but not

Read: subsetiform, rarely

1. 4 fr. b.; For: lumina (');

Read: lumina or their margins $\left({ }^{1}\right)$;

P. 112, 1. 4 fr. b.; For: (provided like - read: provided (like

P. 115, 1. 1; After: 437; - Insert: C. Chr., Ind. Fil., Suppl.;

1. 6 ; For: geminate. - Read: 2 -foliolate.

1. 7 ; For: geminate - Read: 2-foliolate

1. 16; For: geminate - Read: 2-foliolate

1. 3 fr. b.; For: geminate. - Read: 2-foliolate.

P. 123, 1. 5; For: very thick; paraphyses wanting.

Read: thick, or paraphyses wanting.

P. 124, 1. 17-9 fr. b. should be modified as follows:

- Sori oblique to the costa and the margin, as a rule several to many on each side.

* Sori in parallel lines.

+ Veins, at least the main ones, commonly distinct though not rarely fine. No. 71a. Pleopellis.

++ Veins hidden, the main ones apparently wanting.

(No. 65. Loxogrammax).

** Sori spreading in various directions.

(No. 67b. Campylogramma).

$\odot \odot$ Sori parallel to the costa or the margin, as a rule 1 on each side. * Veins free.

+ Sori deeply immersed, the soral grooves reaching nearly to the costa.

No. $69 a$. Scleroglossum).

++ Sori superficial or proportionally shallowly immersed.

(No. 69. Vittaria). 

** Veins anastomosing.

+ Fronds dimorphous, the fertile ones or their segments often much contracted.

$\times$ At least the fertile fronds incised.

\section{No. 76. Christopteriø.}

$\times x$ Both barren and fertile fronds not incised.

$\triangle$ Barren fronds much shorter than the fertile ones, roundish, oblong or ovate, at best \pm 3 times as long as broad.

No. 75. Drymoglossum.

$\triangle \triangle$ Barren fronds not much shorter than the fertile ones, linear, lanceolate or oblanceolate, at least \pm 4 times as long as broad.

(No. 65. Loxogramma).

++ Fronds uniform, at best slightly contracted in the fertile region.

No. $75 a$. Praltonium.

P. 126; For: (3) ID. erytronmelnis, Diels. - Read:

(3) D. erythrorachis, Diels.

Omit this species here, see No. "4.

\section{(*4) D. erythrorachis, Diels.}

Stipes erect, polished like the rachises, grooved above, slightly aculeate or muricate towards the base. Fronds large, 3-pinnate; rachises partly pale-brown, partly red-brown, grooved above, shortly pubescent in the grooves and provided with patches of hairs at the places of insertion of the pinnae and pinnulae. Pinnae ovate-lanceolate, petiolate, articulated to the rachis, spreading or more ascending, to $30 \mathrm{~cm}$. long, broadest below the middle. Pinnulae sessile, articulated to the rachis, close or approximate, linear-lanceolate, the largest to $10 \mathrm{~cm}$. long, $\pm 21 / 2 \mathrm{~cm}$. broad at the truncate base, pinnated in the lower part, pinnatifid towards the acuminate, inciso-serrate apex. Leaflets close, spreading or more ascending, ovate-rhomboidal, connected by a very narrow wing, the apex blunt or rounded and crenated, the sides lobed at best to $1 / 2$-way down to the costa, the lowest anterior lobe often auricle-like, the largest leaflets to $1 \frac{1}{2}$ long by about half as broad, obliquely cuneate at the base. Texture firm; surfaces naked; costae beneath sparingly fibrilloso-setulose 

and provided at the base with a bunch of hairs; veins once or twice forked, rarely simple, the lower anterior often sparingly pinnate. Sori $1-3$ to a leaflet, in the lower sinuses; indusium semiglobose.

Celebes, New Guinea (?).

P. $127,1.5$ fr. b.; For: larg, - Read: large,

P. 129, l. 17 fr. b.; For: winged - Read: winged;

P. 136, 1. 10 should be modified as follows:

(8c) N. pilosula, v. A. v. R., Bull. Btz., 1913, XI, 18; ? (N. hirsutula, Pr., C. Chr., Ind. Fil., p. p.; N. exaltata, Schott, Bedd., Handb. Ind. Ferns, 282, p. p.; Ferns S. I., tab. XCIII; N. pilosa, Pr., Tent. Pterid., 79; Aspidium pilosum, L. \& F., Ic. Fil., 14, tab. XVI).

P. 141, 1. 5 fr. b.; For: $(4 a)-\operatorname{Read:~}\left(4 a^{*}\right)$

P. 144; trun rotulana. - Omit this species. See the Appendix.

P. 154, 1. 2; For: segmets - Read: segments

l. 12 ; For: $3 / 2-\operatorname{read}: 3 \frac{1}{2}$

P. 158, 1. 7 should be modified as follows:

(26b) D. dichrotroiehoides, v. A. v. R.; D. dichrotricha, Copel., in Philipp. Journ., VII, 54 (not VIC, 74 )

After No. $26 b$ insert:

(26c) D. decurgive-pinnatra, o. Ktze, Rev. Gen. Pl., II, 812; Nephrodium decursivo-pinnatum, Bk., Hk. Bk., Syn. Fil., 259; Phegopteris decursive-pinnata, Fée, Christ, Farnkr. d. Erde, 275; Polypodium decursivopinnatum, v. Hall, Hk., 2nd Cent. of Ferns, tab. IL.

Rhizome short, oblique. Stipes tufted, about 5-10 $\mathrm{cm}$. long, hairy and scaly, the scales linear or subulate-lanceolate, acuminate, ciliate. Fronds elliptical-lanceolate, 25-40 cm. long, 5-10 cm. broad, acuminate. Pinnae alternate, horizontal or spreading, 5-7 $\mathrm{mm}$. broad above the abruptly dilated base, rather entire towards the bluntish or acute point, otherwise cut about $1 / 2$-way down to the costa; lower pinnae gradually reduced, free. Lobes blunt or rounded, the basal ones large, adnate to

Ferns and Fern Alties. 

the rachis, those of contiguous pinnae connected or contiguous, so as to form a deeply incised wing to the rachis. Texture more or less firm-herbaceous; rachis hairy above, scaly beneath, the scales linear, ciliate; surfaces more or less hairy especially on the costae and veins; costae and veins more or less sparingly scaly beneath; veins about 3 on a side, simple. Sori 1-2 to a lobe, often solitary and supramedial on the lowest anterior veins; indusium metamorphosed into a central tuft of hairs (minute and fugacious after Bk.).

Celebes; Formosa, Japan, Korea, China.

P. 160; D. admata. - Insert: See the Appendix.

D. subsagenioides. - Omit this species. See the Appendix.

P. 161 ; D. flix mas. - Insert: See the Appendix.

P. $163 ;(37 \alpha)$ D. Mamlerolama, etc.

P. 169, l. 18 fr. b.; For: Bk.) - Read: (Bk.)

l. 17 fr. b.; For: aspera: - Read: aspera):

1. 6 fr. b.; For: division - Read: divisions

P. 173; Makeri. - Omit the variety acrostichoides. See No. 63e.

(63e) D. aciostichoides, v. A. v. R.; D. Bakeri, Copel., var. acrostichoides, v. A. v. R., 173; Aspidium canescens, Christ, forma acrostichoides, Christ, in Ann. Btz., XV, 132; Dryopteris diversiloba, Christ, var. acrostichoides, Christ, in Philipp. Journ., II', 200; D. canescens, C. Chr., var., C. Chr., Ind. Fil; Nephrodium acrostichoides, J. Sm., in Journ. of Bot., III, 411; N. lineatum, Pr., Hk., Spec. Fil., IV, 75, p. p.; -- var. rhombea; subvar. rhombea, Christ, 1. c.; - var. lanceola; subvar. lanceola, Christ, 1. c.

Rhizome short or somewhat elongated. Stipes more or less approximate, 5-25 cm. long, villose, as is the rachis. Fronds dimorphous; barren fronds on the shorter stipes, pinnate, $\pm 10-25 \mathrm{~cm}$. long by 3-12 cm. broad. Pinnae 5-10 on a side below the terminal one; terminal pinna elongate-triangular, 6-10 cm. long, long-acuminate, grad. ually deeply pinnatifid towards the base; lateral pinnae horizontal or arcuate-ascending, the lower not rarely deflexed; largest pinnae varying from short-oblong to long-lanceolate or obovate-oblanceolate, $1_{2}{ }_{2}-6 \mathrm{~cm}$. long by generally about $1 \frac{1}{2} \mathrm{~cm}$. broad, blunt to acuminate, broadly and shallowly crenate to regularly or irregularly lobed and then the lobes below the 

bluntish or acute and subentire or crenate, triangular apex often the longest (as in Phegopteris diversiloba $v, A . v$. R.); higher pinnae rather close, adnate at the base and passing gradually into the terminal one; following pinnae sessile, the base subcordate or truncate, often 1-2auriculate but commonly on the upper side only; lower pinnae rather remote, petiolulate, with the lower base cuneate, rounded or truncate. Texture firm-herbaceous; surfaces naked, or sparingly pilose on the costae and veins; under surface often verruculose; veins $3-4$ on each side of the main ones, the $1-2$ lowest anastomosing. Fertile fronds with the pinnae much contracted, kinear, to $3 \mathrm{~cm}$. long by $\pm 2 \mathrm{~mm}$. broad, repando-crenate. Sori marginal, solitary on the crenatures, at length laterally confluent or connected and apparently acrostichoid, i. e. filling up the whole under surface of the pinnae; indusium distinct though fugacious, dark, lacerate. - Very variable in the shape of the barren pinnae. Largest barren fronds more or less resembling the smaller ones of D. lineata $C$. Chr. occurring in the Buitenzorg Herbarium. - The description is taken from Koorders' plants from Celebes, determined by Christ, Cuming's undescribed original plant being unavailable to me.

Var. rhombea. - Stipes shorter, to $18 \mathrm{~cm}$. long; barren fronds similar to those of the type but smaller, to $12 \mathrm{~cm}$. long includ. the stipe; fertile fronds $\pm 7 \mathrm{~cm}$. long, with the pinnae rhomboidal-lanceolate to linear, 4-8 mm. broad, obtuse, crenulate; sori in 1-2 rows between the costa and margin.

Var. Inuceda: Like var. rhombea but the barren pinnae lanceolate or linear-oblong, obtuse or subacute, subentire. - Largest fertile pinnae more or less resembling the most contracted ones of D. lineata C. Chr. occurring in the Buitenzorg Herbarium.

Celebes, Philippines.

P. 177; D. Lîneata. - Insert: - var. subacrostichoides, v. A. v. R. Forma typica, - Malaya.

War. sulbacostichoides: Fronds smaller, pinnae oblong, $2 \frac{1}{2}-3 \frac{1}{2} \mathrm{~cm}$. long, $1-2 \mathrm{~cm}$. broad, gradually lobed towards the blunt or subacute apex; fertile pinnae much contracted, $\pm 11 / 2 \mathrm{~cm}$. long, entire; sori in 3-4 rows on each side of the costa, confluent; indusia very minute, ciliolate, recognizable as black-red points scattered among the sporangia. - Sumatra. 

D. urophylla. - Insert: See the appendix.

P. 178 , 1. 4 fr. b.; For: $84 a)$ - Read: $(84 a)$

Insert: See the Appendix.

P. $180,1.1$; For: $1 / 4-1 / 3$ - Read: $1 / 6-1 / 3$

P. 183, 1. 4 fr. b.; For: $(109 a-$ Read: $(109 a)$

P, 189, 1. 1; For: VIC 74 . - Read: VIC 74 (not VIC 54 ).

D. HIumei. - Insert:

Koorders' No. 17134:, from Celebes, has the barren fronds with the largest lateral pinnae broadest in the upper half, pinnatifid below the long-acuminate, rather caudate, serrate-crenate apex, deeply lobed towards the base, the terminal pinna long-triangular-lanceolate, deeply pinnatifid towards the base.

P. 192, 1. 12; For: close. - Read: closed.

P. $193,1.5$ fr. b.; For: (15) - Read: $(15 a)$

P. 204, 1. 4; For: andiantoides, - Read: adinntoides,

P. 206, 1. 16 tr. b.; For: deciduous - Read: deciduously

P. 217, 1. 3-4 should be modified as follows:

Fertile segments not rarely somewhat contracted and more conspicuously toothed but less copiously divided than in H. alpina Moore, the teeth varying from blunt to acutely upcurved. - Var. minor is a form passing gradually into the type, with the fronds often much smaller with entire and truncate-rotundate barren segments resembling those of the smaller fronds of H. pusilla Carr.

\section{5; For: Coomwelliana, - Read: Cromwelliana,} P. 219. - Insert:

(9d) See No. 8

P. 223, 1. 7 fr. b.; For: Rhizomes - Read: Rhizome

1. $6-5$ fr. b. ; For: at length; decidous

Read: at length deciduous;

P. 230. - Insert: 



\section{(4) M. manilemsis, Pr.}

Koorders' No. $17037 \beta$ from Celebes, determined by Christ, has the lobes or auricles coarsely crenated, rather lobed, the hairs grey, the indusia hairy.

P. 231; Insert:

(6c) See No. 4.

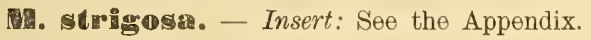

P. 232; FH. proxima. - Insert: Se日 the Appendix.

P. 234; 'T.

P. 235; T. The

P. 236; A. Ifdgew

P. 241, 1. 1; For: rather - Read: mostly

P. 244, 1. 7 fr. b.; For: gracklles: - Read: gracllis:

P. $245,1.3$; For: base' -- Read: base,

P. 246, 1. 11 fr. b.; For: Herwitt - Read: Hewitt

P. $247,1.5$ should be modified:

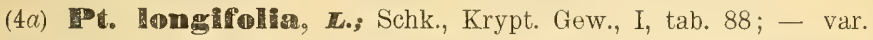
vittata, C. Chr., Ind. Fil.; Pt. vittata, L., Spec., II, 1074; Polypodium trapezioides, Burm., Flor. Ind., 233, tab. 66, fig. 2.

Terminal pinna commonly much elongated.

Ya:. vituta: Fronds proportionally narrow, with the lateral pinnae abbreviated, the higher oblong, the following growing gradually smaller and roundish.

P. 249 , 1. 19 fr. b.; For: Sch.geb.' - Read: Sch.geb.,

P. 250. - Insert:

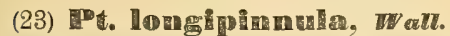

The specimens occurring in the Buitenzorg Herbarium have the fronds herbaceous to subcoriaceous, with the ultimate segments entire or nearly entire, varying from $1-4 \mathrm{~cm}$. long by $3-6 \mathrm{~mm}$. broad at the base. A specimen from Luzon (Merrill No. 234), with the smallest segments, has the sori relatively short.

Omit the variety sumatrana. See No. $23 b$. 

(23b) Pt. silvatica, v. A. v. R.

Rhizome creeping, thick, the scales subulate, fuscous, deciduous, Stipes pluriseriate, approximate, to $75 \mathrm{~cm}$. long, rufo-fuscous and sparingly, minutely punctulato-asperulous, as are the rachis and the costae beneath, sparingly and deciduously scaly towards tho dark-castaneous base. Fronds $\pm 35-45 \mathrm{~cm}$. long. Pinnae about 5- 6 on a side below the terminal one; terminal pinna lanceolate, $\pm 15 \mathrm{~cm}$. long by $4-5 \mathrm{~cm}$. broad, the edge cut down to a proportionally broad wing to the costa, the apex subulate-caudate and serrulate; lateral pinnae similar but the lower growing gradually larger, to $30 \mathrm{~cm}$. long, to $6 \frac{1}{2} \mathrm{~cm}$. broad at the middle, subspreading to suberect, the lower petiolate, the lowest forked on the lower side at the base. Lobes oblique, straight or subfaleate, close or somewhat remote by the slightly dilated bases, those on the posterior side sometimes larger than the anterior ones, to $3 \frac{1}{2} \mathrm{~cm}$. long, $3 / 4-1 \mathrm{~cm}$. broad at the base; barren lobes serrulate-crenate in the lower part, serrulate at the blunt or rounded apex; fertile lobes serrate-dentate at the barren apex. Texture herbaceous; surfaces naked; costae stramineous and shortly remotely spinulose above; veins forked, the higher simple, the lower sometimes twice forked. Sori not occupying the upper $1 / 4-1 / 2$ of the lobes. - Pt. longipinnula Wall. var. sumatrana is an irregularly lobed form of this only.

Sumatra, Java.

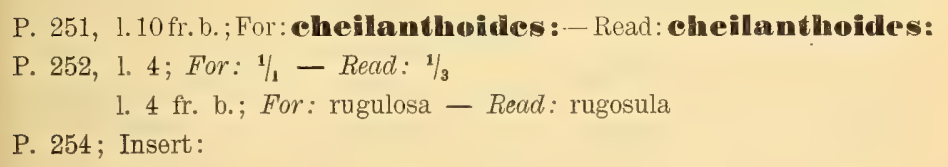

(7) L. vestita, $\boldsymbol{B t}$.

Scales of stipe and rachis at length deciduous; pinnae not rarely very rigidly coriaceous, with the edge often much and irregularly recurved or reflexed, the base rounded, truncate or cordate; veins distinct, prominent beneath. - A form gathered in Luzon (Robinson, Bur. of Sci. No. 6499) has the pinnae very blunt, and crenulate. Perhaps a distinct species.

\section{P. 255, 1. 1; For: Frascril, - Read: Fraser.iి, \\ 1. 13; For: probably specimen - Read: apparently a form}

P. 256; W. egregium. - Omit this. See the appendix. 

P. $259,1.5$; For: 1/3-way - Read: $\pm 1 / 2$-way

P. 261; D. crenato-serpratum. - Insert:

Pinnae auricled on the upper side or on both sides at the base.

P. 262, 1. 17-14 fr. b. should be modified as follows:

(27b) D. Woodii, Copel.

Omit this, it being referred to D. sorzogonense Pr.

P. 263; Petergenil. - Insert: See the Appendix.

1. 9-23 should be modified as follows:

(29a) RD. Somogonense, Tent. Pterid., 114; Copel., Polypod. Philipp. 74; Bedd., Ferns Br. I., II, tab. CCXLVI; D. Woodii, Copel., in Philipp. Journ., IIC, 129; D. speciosum, Bl., Enum., 183; Copel., Polypod. Philipp., 74; Asplenium sorzogonense, Pr., Rel. Haenk., I, 45 ; Mett., Farng., V, Asplen., 185; A. speciusum, Mett., 1. c.; Athyrium sorsogonense, Copel., in Philipp. Journ., IIIC, 296; var. poense, Copel., VII ${ }^{\mathrm{C}}$, 61; var. major, Bedd., Handb. Ind. Ferns, Suppl., 40.

Rhizome short, erect, the scales brown to black-brown, lanceolatesubulate. Stipes to $50 \mathrm{~cm}$. long, squamose at least towards the base. Fronds ovate, $25-180 \mathrm{~cm}$. long, $15-60 \mathrm{~cm}$. broad, acuminate, 2-pinnatifid, the rachis naked or sparingly provided with small, subulate, somewhat crisped, subfribilliform squamules. Pinnae several to numerous below the pinnatifid apex, approximate to spaced, linear-lanceolate, acuminate, the higher adnate and more or less ascending, the following horizontal or nearly so, sessile or somewhat petiolulate, the lower whether or not deflexed and more distinctly petiolulate, the stalks $1-4 \mathrm{~mm}$. long; largest pinnae pinnatifid at least ${ }^{2} / 3$-way down to the costa, broadest at or near the base. Lobes more or less spaeed, horizontal or nearly so, oblong to linear, $\pm 4-5 \mathrm{~mm}$. broad, rounded or rotundate-truncate at the apex, the lower whether or not abbreviated. Texture herbaceous to subcoriaceous; surfaces naked; veins 5-15 on a side. Sori in regular rows, reaching mostly the costula and edge, the lowest commonly double. - Very variable. 

Forma typica: Small or middle-sized; medial or inframedial pinnae largest, to $12 \frac{1}{12} \mathrm{~cm}$. long, $13 / 4-2 \frac{1}{2} \mathrm{~cm}$. broad; lobes entire, crenate, serrulate or denticulate; veins $\pm 5-6$ on a side, simple. - Trop. Asia.

Forma speciosa: Large or middle-sized; pinnae to $17 \frac{1}{2} \mathrm{~cm}$. long, $2 \frac{1}{2}-4 \mathrm{~cm}$. broad; veins $\pm 7-10$ on a side. - Malaya.

Forma javanica: Large; pirnae to $25 \mathrm{~cm}$. long, $4-5 \mathrm{~cm}$. broad; lobes serrate; veins $\pm 11-15$ on a side. - Java.

Forma poensis: Large; lowest pinnae to $25 \mathrm{~cm}$. long, $2 \frac{1}{2}-3 \frac{1}{2} \mathrm{~cm}$. broad. - Borneo.

Forma major: Large; pinnae to $30 \mathrm{~cm}$. long; veins mostly forked. Malacca.

(29a*) D. mamberamense, v. M. v. R.; D. sorzogonense, Pr., var. mamberamense, v. A. v. R., in Bull. Btz., 1915, XX, 11.

Near D. sorzogonense $\mathrm{Pr}$. - Fronds middle-sized; pinnae to $\pm 15 \mathrm{~cm}$. long and $2 \frac{1}{2} \mathrm{~cm}$. broad, the upper base truncate and more or less auriculate, the lower base cuneate, rounded or subtruncate, the edge cut not more than $1 / 2$-way down to the costa; lobes close, the largest $6-8$ $\mathrm{mm}$. broad; veins $4-5$ on a side, the lowest relatively long, arcuateascending.

New Guinea.

After No. $29 b$ insert:

(29c) See No. 7.

P. 264 - Insert:

(35b) D. speciosum, Bl.

Omit this, it being referred to D. sorzogonense Pr.

P. 265̄, 1. 2 fr. b.; For: dolichosorium, - Read: dolichosorum, P. 267, 1. 12 fr. b.; For: Tertiary - Read: Secondary P. 271, 1. $5-3$ fr. b. should be modified as follows:

(43b) D. polypodioides, $\boldsymbol{\text { II.; }} D$. asperum, Bl., var. polypodioides, Ridl., in Journ. Str. Br. R. A., 1908, so, 31; D. leptogramma, v. A.v. R., 

in Bull. Btz., 1915, XX, 21; Phegopteris leptogramma, v. A. थ. R., 1. c.; Athyrium Blumei. Copel., in Philipp. Journ., IIIC, 294.

Texture herbaceous to coriaceous; indusia partly distinct and persistent, partly rudimentary or caducous.

P. 281, 1.1 fr. b.; For: nidiforme, - Read: nidiforme,

P. 284, 1. 16; For: astomosing - Read: anastomosing

P. 293, 1. 7; For: Rst., - Read: Rst. (not Christ),

P. 295, l. 3 fr. b.; For: more, rarely 2

Read: more (rarely 2)

P. 296, 1. 1; For: vein, rarely 2 "veins - Read: vein (rarely 2 veins)

P. 300 , 1. 7 ; For: larger, - Read: large,

P. 302, 1. 1; For: (81a) - Read: $(81 c)$

P. 314; Ph. leptogramma. - Omit this, it being referred to Diplazium polypodioides $B l$.

P. $316,1.5-3$ fr. b. should be modified as follows:

(33) Ph. diversilobs, Christ. - See the Appendix.

Omit the variety acrostichoides, it being a distinct species (Dryopteris acrostichoides $v$ A. $v$. R.).

P. $321,1.2$ fr. b.; After: only. - Insert:

- Rachises naked in the adult fronds.

1. 1 fr. b.; After: Java, - Insert: Sumatra.

P. 322 ; D. Brooksine. - Omit this. See the Appendix.

P. 323 , 1. 19; For: A. irriguum, - Read: A. irriguum,

P. 324 ; C. subcordata. - Omit this here. See the Appendix.

P. $325,1.9-8$ fr. b. F For: - var. majus.

Read: incl. var. majus,

P. $326,1.2-7$ should be modified:

not thickened at the apex, and specimens gathered in Sumatra have the rhizome scales dark-brown, the fronds to $40 \mathrm{~cm}$. long and to $\pm 1 \mathrm{~cm}$. broad, with the sori mostly submarginal, whether or not interrupted and (or) accompanied by $2-3$ often shorter intramarginal ones.

Sumatra, Borneo; Tonkin.

Ferns and Fern Allies. 

(3) A. immersum, Mett. incl. var. spathulinum, Mett., in Ann. Mus. Bot. L. B., IV, tab. VII, fig. $4-6$.

P. $327,1.12$; For: R. I. - Read: S. I.

1. 16; For: of - Read: of

1. 7-6 fr. b.; Omit the words: the fronds proportionally short and broad with

P. 330, 1. 13; For: C. Ch., - Read: C. Chr.,

P. 334, l: 1 ; For: lancifolium. - Read: lancifolia.

P. 337, 1. 4-7 should be modified as follows:

(3) V. angustifolia, Bl.

Omit this name, it should be $\mathrm{V}$. angustata $v$. A. v. R.

(3) V. angustata, v. A. v. R.; $V$. angustifolia, Bl. (not Bk.), Enum., 199; Rac., Flor. Btz., I, 60; V. elongata, Sw., var. angustifolia, Rst., in Nov. Guin., VIII, Bot., 731.

Forma typica: Rhizome scales brown, rather dark, lanceolate-subulate.

- Malacca, Sumatra, Java, Borneo.

Forma nigricans: Rhizome scales nearly black, filiform-subulate. New Guinea.

1. 9 fr. b.; For: grooved - Read: groove

P. 345 ; serraeforme. - Omit this name. See the Appendix.

P. 347, 1. 7 fr. b.; After: apex. - Insert: (? Forma furcata).

P. 349 ; P. Setosman.-- Insert: See the Appendix.

P. 361; Pbliquatum. - Insert: See the Appendix.

P. 366, 1. 11 fr. b.; For: lobes the - Read: lobes;

P. 375 ; PI. sinu@sa, Bedd. (not Moore)

P. $376,1.2$ should be modified:

(136) Pl. superficialis, Bedd., Handb. Ind. Ferns, 350; Ferns Br. I., I, tab. LXXV; Pl. nigricans, v. A. v. R., Bull. Btz., 1915, XX, 22 ; Pl. rupestris, Moore, var. nigricans, v. A. v. R., 1912, VII, 24 ; Polypodium nigricans, v. A. v. R., l. c.; P. normale, Don, var. sumatranum, Bk., Journ. of Bot., XVIII, 215; P. superficiale, Bl., Flor Jav., II, 136, tab. LVI; Rac. Flor. Btz., I, 108; C. Chr., Ind. Fil.

Rhizome scales red-brown to fuscous, glossy or iridescent; fronds entire to irregularly and coarsely sinuate; sometimes forked; main veins mostly indistinguishable but sometimes distinct, though very fine. 

P. 380 ; Pl. Subgeminata. - Omit this here. See the Appendix.

P. 385, l. 1 fr. b. should be modified as follows:

(172b) Pl. Valetoniana, v. A. v. R.

Omit this, it being a form of $\mathrm{Pl}$. incurvata Moore.

P. 386, 1. 13; For: parallel to the costa, Read: the costa, parallel to it,

P. 387, 1. 1 should be modified:

(177) Pl. Zlppelii, Moore, Bedd., Handb. Ind. Ferns, 357; Pl. heterocarpa, Bedd., Ferns Br. I., II, tab. CCCXIX; Pl.nigricans, v. A. v. R., var. parallela, v. A. v. R., Bull. Btz., 1915, XX, 22; Pl. rupestris, Moore, var. parallela, v. A. v. R., 1912, VII, 24; Polypodium oxyphyllum, Kze, in Bot. Zeit., 1848, 116; P. Zippelii, Bl., Flor. Jav., II, 172, tab. LXXX; Rac., Flor. Btz., I, 105; C. Chr., Ind. Fil.

Rhizome scales acuminate, glossy or irridescent.

Omit var. sparsisora, which is $\mathrm{Pl}$. Zollingeriana $v . A . v . R$.

1. 16 fr. b.; For: Mosre; - Read: Moore;

Pl. nigrieans. - Omit this and its variety. See Nos. 136 and 177.

P. 390, 1. 13-11 fr. b. should be modified:

(186b) PI. Zollingeriana, v. A. v. R., Bull. Dép. Agr. I. N., 1909, XXVII, 8; Pl. heterocarpa, Moore, Ind., LXXVIII; Polypodium Zippelii, Bl., var. sparsisorum, v. A. v. R., Mal. Ferns, 649; P. heterocarpum, Bl., Flor. Jav., II, 167, tab. LXXV; Rac., Flor. Btz., I, 107; $P$. Zollingerianum, $K z$, in Bot. Zeit, 1846,422 ; C. Chr., Ind. Fil.

Stipes $2-45 \mathrm{~cm}$. long exclud. the wing, and the fronds up to $70 \mathrm{~cm}$. long by $3-15 \mathrm{~cm}$. broad, bluntish to caudate, entire or subsinuate.

P. $399,1.12$ fr. b.

(206) P1. incurvata, Moore, Bedd., Handb. Ind. Ferns, 364, fig. 206; Ferns Br. I., I, tab. CXXIV; Pl. Valetoniana, v. A. v. R., Bull. Dép. Agr. I. N., 1909, XXVII, 6 ; Polypodium incurvatum, Bl., Flor. Jav., II, 151, tab. LXV; Rac., Flor. Btz., I, 110; C. Chr., Ind. Fil.; $P$. Valetonianum, v. A. v. R., 1. c., 1908, XVIII, 23, tab. V. 

Forma typica: Barron fronds hastato-trifid or pinnatifid, sometimes simple; fertile fronds at least deeply 3-partite, mostly pinnatipartite.

Forma Valetoniana: Both barren and fertile fronds simple, the barren ones sometimes subhastate.

Malaya.

P. 399, 1. 4 fr. b.; For: tenuinerve' - Read: tenuinerve,

P. 400, l. 2 fr. b.; For: Pi. - read: FPl.

P. 401, 1. 2; For: Sauvinierrei, - read: Sauvinalerel,

P. 402 ; Pl. taenifroms. - Omit this, it being reterred to Pl. cren ${ }^{-}$ ulata $v . A . v$. R. See the Appendix.

Pl. eremulata. - Omit this here. Se日 the Appendix.

P. 404, 1. 14 fr. b.; For: one - Rexd: ones

P. 406, 1. 11 fr. b.; For: Hlume. - Read: Ieneodt.

P. 411, 1. 7; For: conduplicato- - Read: complicato-

P. 418; A. Deyemiama. - Insert: Pleopeltis Meyeniana, v. A. v. R., in Bull. Dép. Agr. I. N., 1909, XXVII, 11.

P. 420, 1. 14 fr. b.; For: novoguineensis. - Read: novoguineense.

P. 422, 1. 5 ; For: Willelinkiot, - read: Willinckil,

P. 423, 1. 16-11 fr. b. should be modified as follows:

\section{(3) E. angulatum, Moore.}

Rhizome scales proportionally broad, ovate, when young pale-yellowbrown, at length not rarely pale-brown or darker; stipes provided with pale-yellow-brown squamules at least when young; fronds naked or sparingly and minutely lacerato-squamulose; vein tips not rarely thickened, so as to form a more or less elevated intramarginal ridge on the under side.

P. 432 ; Insert:

(2) II. spoicata, Pr.; - var, validinervis, C. Chr., Ind. Fil.; $H$. validinervis, Kze, Bot. Zeit., 1818, 122; Taenitis validinervis, Mett., Ann. Mus. Bot. L. B., IV, 173, tab. VII, fig. $7-10$; - var. Bakhuizenii.

Ear. validinervis: Fronds to $60 \mathrm{~cm}$. long, $\pm 21 / 2 \mathrm{~cm}$. broad, hard-coriaceous, the spike 5-121/2 mm. broad. - Java.

Var. Fakmoizenit: Like forma longipaleacea but the fronds 4-6 cm. broad, flaccido-coriaceous, the spike $3-5 \mathrm{~mm}$. broad, now and then sterile in the lower part. - Java. 

P. 434 ; Insert:

(2) L. Limnaeanus, Fée; $L$. sumatranus, v. A. v. R., Bull. Btz., 1916, XXIII, 15, tab. II, fig. $1 a-b$.

$L$. sumatranus $v, A . v, R$. is but a form with indistinct or wanting main veins.

P. 436 ; . sumatranus. - Omit this, it being but a form of L. Linnaeanus Fée.

P. 437 , 1. 14 fr. b.; For: 3.2. - read: $\mathbf{3 . 3 .}$

P. 441, Insert:

(3a*b) A. mutata, v. A. v. R.

Rachis sparingly squamulose, the squamules partly small and fimbriate, partly long and filiform. Pinnulae numerous, shortly petiolulate, linear, the higher the largest, $171 / 2-20 \mathrm{~cm}$. long, $21 / 2-3 \mathrm{~cm}$. broad, crenulate, crenulate-serrulate towards the acuminate apex, the base unequally truncate-subcordate or truncate-rotundate, sometimes rotundatecuneate on the upper side, the upper base the broadest and shortest. Texture chartaceous; costae and veins naked, or sparingly squamulose beneath; veins subhorizontal, at length dark or fuscous; recurrent veinlets indistinct, not rarely invisible. Sori contiguous, intramarginal, consisting of 6-12 (mostly 8-10) capsules; indusium fimbriate.

- Hort. Bog.

P. 442; Insert or modify:

\section{$\left(3 b^{*} a\right)$ A. olivacea, v. A. v. R.}

Pinnulae sessile or shortly petiolulate, chartaceous, crenulate or serrulate-crenulate, the base obliquely cordate-subtruncate, the apex suddenly acuminate, serrate; largest pinnulae to $12 \mathrm{~cm}$. long, $1 / 4-2 \mathrm{~cm}$. broad; both surfaces olivaceous-green when dry but the upper darker than the lower; costa and veins black-fuscous and sparingly, deciduously, minutely chaffy beneath, the latter opaque; recurrent veinlets very fine, opaque; sori close, remote from the margin, consisting of $6-10$ capsules.

Java.

(3c) A. pruinosa, Kse, Farnkr., I, tab. XCI.

Pinnulae linear, $1 \frac{1}{4}-1 \frac{1}{4} \mathrm{~cm}$. broad, crenate or obtusely serrate, 

serrate or serrulate towards the apex, unequally rotundate-truncate to cordate at the base, beneath white-(greyish- or purplish-)pruinose, and the costa sparingly squamulose; sori submarginal.

\section{(3c*a) A. glauca, v. A. v. $\boldsymbol{R}$.}

Pinnulae short-stalked, chartaceous, linear, crenate or crenulate, serrate towards the apex, the base obliquely and unequally cuneate to subtruncate-cuneate; largest pinnulae $12-14 \mathrm{~cm}$. long, $1 / 4-1 / 4 \mathrm{~cm}$. broad; upper surface olivaceous to black-green when dry, under surface greenish-glaucous or at length pale-olivaceous-green; veins spreading, darkgrey or glaucous beneath, opaque; recurrent veinlets very fine, opaque; sori remote from the margin, consisting of 6-8 capsules. - Rachises naked, costae sparingly and minutely chaffy beneath; veins naked or nearly so.

\section{Java.}

\section{(3e) A. javanica, Pr.}

Pinnulae to $20 \mathrm{~cm}$. long, to $1 \% / \mathrm{cm}$. broad, rather gradually longacuminate, closely serrulate-crenulate or crenulate to obtusely denticulate, serrate towards the apex; veins often pale when young, pellucid or opaque, as are the recurrent veinlets. - Secondary rachises naked or glabrescent. - Very variable.

\section{P. 443; A. sumatrama. - Insert: See the Appendix. \\ P. 451 ; W. termatea. - Insert: See the Appendix. \\ P. $455,1.1$. should be modified as follows;}

Forma typica: Fertile segment arising from the base of the barren segment or from the upper half of the stipe. - Br. India across Ceylon to Java and the Phitippines.

P. 467; L. Iaxum. - Omit the information. See the Appendix.

P. $468,1.12$; For: $(46)-$ Read: $(46 a)$

P. $474,1.5$; For: $(20 a)-$ Read: $(20 b)$

P. $476,1.1-3$ should be modified:

(94) S. cupressina, Spring.

Omit this name, it should be S. pennula Spring. 

(94) S. pennula, Spring, Mon., II, 160; Bk., Fern All., y5, p. p.; S. cupressina, Spring, in Bot. Zoit., 1838, I, 211 (not Mon., II, 113) ; Hieron., in Leafl., VI, 1993; S. Aabellata, Spring, Bk., l. c.. 98, p. p.; Lycopodium cupressinum, Willd., Spec., V, 42; L. pennula, Desv., Prod., VI, 187; - var. anceps; S. anceps, Pr., Abh. Boehm. Ges., IlI, 581.

Largest intermedial leaves (of the principal rachises) minutely serrulate in all the specimens oceurring in the Buitenzorg Herbarium.

In order to avoid confusion the name S. pennula Spring should be maintained though the name $S$. cupressina Spring has a legitimate claim on priority.

(101) \$. biformis, A. $\boldsymbol{B r}$., MS. ; Hieron., in Leafl., VI, 2001; $S$. cupressina, Spring, Mon., II, 113 (not Bot. Zeit., 1838, I, 211); S. plumosa, Bk., Fern. All., 50, p. p.; S. hirticaulis, Warb., Mons., I, 114; - var. cataphracta; (? Lycopodium cataphractum, Bl., [not Willd.] Enum., II, 267).

Intermedial leaves of the stem or main rachis with the inner base rotundate-cuneate to rotundate, the outer base rotundate to subcordate; sporophylla acute to acuminate.

Var. cataphracta: Sporophylla sublanceolate-ovate, to nearly $2 \mathrm{~mm}$. long; microspores closely rugulose, the rumples very irregularly flexuose, simple or branched; macrospores . . . . . - Java.

P. $478,1.2-1$ fr. b. and P. $479,1.1-8$ should be modified:

(167) S. subfimbriata, v. A. v. R., Bull. Btz., 1911, I, 26; ? S. javanica, Klotz, var. gracilior, A. Br., MS.; - var. polyura; S. fimbriata, Spring, var. polyura, Warb., Mons., I, 127; S. brachystachya, Spring, var. polyura, Warb., MS.; - var. Backeri, v. A. v. R., l. c.; - var. Koordersii, v. A. v. R., l. c.; S. fimbriata, Spring, var. brevifolia, A. Br., MS. in Herb. Berol.

Shoots erect, or ascending from a decumbent or ascending base. Lateral leaves rotundate-cuneate, broadly rounded or subcordate at the upper base, cordate-truncate and whether or not subauriculate at the lower base, those of the main stem horizontal or spreading, of the ultimate branchlets more ascending; leaves of the upper plane acute to acuminate. Spikes single or double, simple or sometimes once or twice forked, distinctly platystichous in the broadest forms, nearly square in the narrowest forms. - Otherwise like S. fimbriata Spring and united with it by intermediates with short-cuspidate intermedial leaves. 

Forma typica: Main stem $\pm 8-10 \mathrm{~mm}$. broad including the lateral leaves; lateral leaves rather remote on the main stem, contiguous or imbricate on the branchlets; spikes $11 / 2-5 \mathrm{~cm}$. long when fully developed, $1 \frac{1}{2}-2 \mathrm{~mm}$. broad.

Var. polyuara: Differs from the type in having the lateral leaves proportionally shorter and broader, remote even on the branchlets.

War Backeri: Differs from the type in having the main stem 土 6-7 mm. broad including the lateral leaves, the lateral leaves smaller and less remote on the main stem, the spikes $1 \frac{1}{2}-2 \frac{1}{2} \mathrm{~cm}$. long when fully developed, $1-1 \frac{1}{2} \mathrm{~mm}$. broad.

Var. Koorflersili: Differs form var. Backeri in having the shoots shorter, to about $20 \mathrm{~cm}$. long, the main stem $\pm 4-5$ broad including the lateral leaves, the lateral leaves shorter, approximate on the main stem, the spikes $1 / 2-11 / 2 \mathrm{~cm}$. long, $1-1 \frac{1}{2} \mathrm{~mm}$. broad.

Java.

P. $479,1.7$ fr. b.; After: Sumatra, - Insert: Java (?)

P. 482, 1. 16-14 fr. b. should be modified:

\section{(187) S. Kittyae, v. A. v. E.}

Specimens received from C. J. Brooks (Bengkoelen, Lebong Tandai, No. 30/S) and J. A. Lörzing (Deli, Sibolangit, No. 4197) are distinguished in having the shoots $35-75 \mathrm{~cm}$. high, with the stem stramineous to palereddish-brown when dry, the pinnulae simple or the largest forked or pinnate with $1-2$ simple or forked secondary pinnulae on each side, the spikes solitary or 2-3-nate.

P. 482; S. Poumolniana. - Omit this here. See the Appendix.

P. 483. - Insert:

(192a) See No. 187.

P. 488 , 1. $1-4$ should be modified as follows:

\section{(18) C. Crenulata, $\boldsymbol{B t}$.}

Forma squamulosa (includ. forma asperula): Like forma subspinnulosa but the segments more distinctly crenulate or crenate, the indumentum of the costae and costulae beneath intermixed with proportionally large, lanceolate-subulate, brown scales; tertiary segments close or the lower somewhat remote. - Java. 

Forma latissima: Like the preceding but the largest pinnulae $2-31 / 2$ $\mathrm{cm}$. broad at the base; at least the lower tertiary segments conspicuously remote. - Java.

P. $489,1.12-16$ should be modified:

Main and secondary rachises hirsute above at least when young and whether or not provided with a few scattered subfiliform squamules; pinnulae at best incised to $\pm{ }^{1 / 4}$-way down to the costa, rarely somewhat deeper especially in the lower part; the lobules entire or somewhat crenulate or serrulate; costae beneath naked or somewhat chaffy; veins \pm $2-4$ on a side.

P. $491,1.5$ fr, b.; For: on the apice of

Read: and terminal on

1. 3 fr. b.; For: surfaces - Read: surface

P. 502, 1. 14; For: (not Christ), v. A. v. R.,

Read: $v$. A. v. R. (not Christ),

D. filix mas. - Insert:

Texture herbaceous or often more or less coriaceous; at least the lowest posterior vein of the lowest posterior segments more or less distinctly pinnate.

P. 503, 1. 9--7 fr. b. should be modified as follows:

\section{(83) D. uroplnylla, C. Chr.}

Indusium. semetimes distinct and persistent, often fugacious or undeveloped, not rarely metamorphosed into a bunch of short-setiform hairs.

P. 509. 1.8 fr. b.; For: Robmisomit. - Read: veobinsonit,

P. 512, 1. 1; For: 16. LOMARLA,-Read: 18.LOMARIA,

P. 515 , l. 8 fr. b.; For: div rsiloba, - Read: diversiloba,

P. 516, 1. 9; For: memberamensis, - Read: mamberamensis,

1. $1 \mathrm{fr}$. b. should be modified:

to crenate, the upper base longer (more decurrent) than the lower which is often partly cut away. Sori whether or not setose.

FERNS ANd FERN ALLIEs. 

P. 520; under Vittaria: insert:

(ia) V. Anceida, Mieron, in Hedwi., LVII. 200; IT. zosterifoliu. Willd., ras. flaccida, Mett., MS. in Herb. Berol., p. p.; T. elongata, Su., forma angustifolia, Rst., MS.

Rhizome creeping, the scales elongate, rery acute, often shortly hair-pointed, serrulate, fulvo-castaneous. Fronds long-linear, $40-50 \mathrm{~cm}$. long, 4-5 mm. broad, narrowed gradually towards the apex into a subobtusely mucronate, acute cusp and towards the base into a blackish or ochraceous, short, compressed stipe $1 \mathrm{~mm}$. broad. Texture chartaceous, somewhat pellucid; surfaces naked; costa hardly prominent. Sori marginal; lips of the grooves equal.

$V$. elongata $S x$. forma lurida differs from this in having the fronds sessile, 5-10 $\mathrm{mm}$. broad at the middle, $2 \mathrm{~mm}$. broad at the base, bluntish at the apex.

Jara.

P. 522, 1. 1; For: $(45 c)$ - Read: $(45 c ?)$

P. 525, 1. 8 fr. b.; For: P. phymatodes, - Read: P. phymatodes,

P. 527, 1. 12; For: entire, - Read: rather entire,

P. 529; under Lycopodium; insert:

\section{(4a) L. gedennum, v. A. v. $\boldsymbol{\text { R. }}$}

Shoots to $30 \mathrm{~cm}$. or more long, erect, or nutant at the apex, simple or dichotomous, the stem and branches slender, $11 / 4-2 \mathrm{~cm}$. diam. including the leaves. Leaves lax, 8-farious (arranged in alternate spurious whorls of 4), herbaceous, horizontal or more or less refracto-deflexed, subulatelanceolate, flat, or somewhat canaliculate above, $\pm 8-10 \mathrm{~mm}$. long, ${ }^{3} / 4-1 \mathrm{~mm}$. broad and decurrent at the base, entire, or sparingly and indistinctly serrulate towards the acute or acuminate apex, the midrib rather hidden. Sporangia in the axils of unaltered higher leaves.

Java.

(12b) L. monticelum, v. A. v. F.; L. reflexum, Lam., Rac., Flor. Btz., I, 238, p. p.

Fructiferous shoots $10-20 \mathrm{~cm}$. long, simple or to 4 times forked, the shorter erect, the longer nutant or subnutant, the stem and branches slender, $5-8 \mathrm{~mm}$. diam. including the leaves; prolific buds often present. 
Leaves crowded, 8-farious (arranged in alternate spurious whorls of 4), firm-herbaceous, horizontal or more or less refracto-deflexud, the higher ascending, subulate, $3--6 \mathrm{~mm}$. long, 1/2 $-1 \mathrm{~mm}$. broad and decurrent at the base, entire, the point acute and here and there apparently reddish. Sporangia in the axils of unaltered leaves all down the stem or branches.

Java, Sumatra.

P. 531, 1. $1 \ldots 5$ should be moditied:

\section{(33) . Ghilegmanioides, Gaud.}

Shoots nutant or pendulous; leaves mostly 4 -farions, ovate, subacute, those of each row having the blades placed in 1 plane, which gives the plant an aspect of conspicuous regularity even in dried material; spikes $\pm 1_{2}^{1}-2 \mathrm{~mm}$. diam.; sporophylla wrinkled when dry.

Specimens from Nero Guinea (Constantinhafen, Schlechter No. 14265) and Obi (Pulo Bisa, Lt. Hulstijn's Explor. Exped., Coll. Sa-anam No. 62) differ from the type in having the leaves thinly herbaceous.

Borneo, Amboina, Obi Islands, Aroe Islands, New Guinea; Polynesia (?).

\section{(34) E. pseudo-phlegunaria, Fuhn.}

Leaves mostly 4-farious, oblong-ovate, blunt. - Probably a form of L. phlegmarioides Gaud.

\section{(35) C. Coralianus, Spring.}

Leares sessile, elongate-lanceolate, $8-12 \mathrm{~mm}$. long by $21_{2}-3 \mathrm{~mm}$. broad, narrowed at the base, the costa and margins decurrent upon the stem with 3 rather prominent lines.

Omit vor. minutifolium.

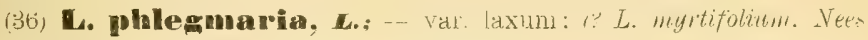
\& Bl., in Nova Acta, XI, 129, tab. XII, fig. $1 A-\alpha-f)$; - var. longifolium; L. ericaefolium, Pr., Rel. Haenk., 77; Spring 1. c., II, 29; -. var. parvifolium, Spring; 1. c.; var. ovatum \& latifolium, v. A. v. R., Mal. Fern All., 44 -45; var. pellucidum \& gracilescens, Bl., 1. c.

Shoots nutant or pendulous; leaves horizontal to erecto-patent, mostly 6 -8-farious, triangular to elongate-lanceolate, those of each row having the blades not placed in 1 plane, which gives the plant an appearance of irregularity especially in dried materia]; sporophylla wrinkled when dry.

Forma typica: As described.

Var. brachystachyum: As described.

Var. Iaxum: Leaves very lax, elongate-lanceolate. y mur, ur morte 

long, proportionally narrow, rounded or rotundate-cuneate at the base: spikes rather slender.

Var. Iongifolinan: Leaves not very lax, clongate-lanceulate, 9 mm. or mole long, proportionally narrow, rounded or rotundate-cuneate at the base; spikes rather stout.

Var. fillorome: As described.

Var. parvifolium: Leaves orate of ohlong, to is mm. long, \pm $1 / 3 \ldots 2 / 3$ as broad, rounded or rotundate-cuneate at the base.

P. 532; L, cermuum. - Insert: - val. sumatranum.

Var. sumatranum: Leaves uncurven, erect trowarls the apex, ciliolate, thick at the base; spikes straight or curved, $\pm 21 / 2 \mathrm{~mm}$. diam.; ultimate branchlets erect to pendulous, $\pm 2 \mathrm{~mm}$. diam. - Sumatra.

P. 533; under Selaginella; insert:

(41b) See also No. 45.

(41c) See also No, $45 a$.

\section{(45) ه. plumeat.}

Plants small or middle-sized; macrospores 4 in a macrosporangium, with 3 radiating apical ribs.

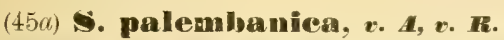

Shoots erect, or ascending from a decumbent base, when adult probably more than $10 \mathrm{~cm}$. long, the main rachis about $1-1_{1 / 2}^{1 / m m}$. thick, pinnately decompound, when dry pale-fuscous, angular or grooved, $6-7 \mathrm{~mm}$. broad including the lateral leaves; pinnae ascending; to $\pm 5 \mathrm{~cm}$. long; pinnulae oblique, the higher simple, the central forked, the lower sparingly pinnate; ultimate branchlets short, to about $3-31 / 2 \mathrm{~mm}$. broad. Leaves heteromorphous; lateral leaves somewhat spaced on the main rachis, more crowded on the branchlets; of the main rachis horizontal, $3-31 / 2 \mathrm{~mm}$. long, bluntish or subacute, bounded by a submarginal spurious vein. the upper side entire or obsoletely denticulate in the upper part, rather long-ciliate in the lower part, the higher ciliae subabruptly abbreviated and tooth-like, the base much produced and auriculate-cordate, the lower side entire 
or obsoletely denticulate, the base rotundate-cuneate; of the branchlets spreading, smaller, to about $2 \mathrm{~mm}$. long, often more acute, the submarginal spurious vein accompanied by 2 abbreviated or interrupted intermedial ones, the upper surface provided with a few scattered, short, spine-like hairs near the lower edge, the base obliquely rotundate-cuneate; intermedial leaves erect, roundish* or oblong-ovate, pellucid-margined, long-cuspidate, the cusp as long as the blade; of the main rachis abruptly cuspidate, the inner edge ciliate, the outer edge ciliolate, the base semicordate or obliquely 2-auriculate-cordate, produced on the outer side; of the branchlets acuminate-cuspidate or less abruptly cuspidate, sparingly ciliolate or serrulate, obliquely rotundate or rotundate-cuneate at the base. Spikes solitary or apparently 2-nate (i. e. solitary on very short branchlets), square, $1-1 \frac{1}{2} \mathrm{~mm}$. diam. ; sporophylla lanceolate-ovate, acuminate, ciliolateserrulate, pellucid-margined, keeled, to $1 \frac{1}{2} \mathrm{~mm}$. long; macrospores 2 in a macrosporangium, whitish, closely and irregularly reticulate or rugulose, the apex more or less flattened, without radiating ribs, encircled by a ring-shaped crest; microspores yellowish or pale-orange, provided with bacilliform or needle-like projections on the basal side.

Sumatra.

\section{P. 534; Insert:}

\section{(95a) S. minahasae, v. A. v. $\boldsymbol{R}$.}

Shoots erect from a short-creeping base, about $35-40 \mathrm{~cm}$. high, the lower part simple, stipitiform, obtusely 4 -angular, dirty-pale-fuscous, $2-2 \frac{1}{2}$ $\mathrm{mm}$. thick towards the base, the upper part closely pinnately decompound, deltoid or ovate in outline; main rachis to $4-5 \mathrm{~mm}$. broad including the lateral leaves; pinnae more or less ascending, the lower ovate-lanceolate, to about $17^{1 /}{ }_{2} \mathrm{~cm}$. Iong, 3-pinnate in the lower part; pinnulae to about $21 / 2 \mathrm{~cm}$. long, suberecto-patent; tertiary branches erecto-patent, simple or more generally forked or sparingly pinnate; ultimate branchlets suberect, $1 / 2-1 \frac{1}{2} \mathrm{~cm}$. long, $13 / 4-2$ (sometimes to $2 / 2$ ) $\mathrm{mm}$. broad. Leaves of the stipe and those of the lower part of the main rachis isomorphous, rather remote, erect, adpresised, subsubulate-cordate, 3-4 mm. long, acute, keeled, copiously, minutely serrulate, ciliolate towards the base; leaves of the branches and those of the upper part of the main rachis heteromorphous; lateral leaves subfalcate-ovate, more or less ascending; of the main rachis the largest, $3-3{ }^{1 / 2} \mathrm{~mm}$. long, $1-1^{1}{ }_{4} \mathrm{~mm}$. broad, approximate, acute, the 
upper side minutely serrulate, gradually ciliate towards the rotundate base, the lower side entire, provided with 2-4 ciliae at the auriculatecordate base; of the branches growing gradually smaller; if the ultimate branchlets contiguous or somewhat imbricate, the largest $1-1 \frac{1}{2} \mathrm{~mm}$. long, rather blunt, the upper side sparingly serrulate and ciliolate in the lower half only, rotundate-cuneate at the base, the lower side mostly without ciliae at the rotundate-truncate base; intermedial leaves erect; of the main rachis rather contiguous, subovate, the largest about $2^{1 / 2}$ cm. long, acute or acuminate, keeled, minutely (not copiously) serrulate, the inner base narrowed, the outer base produced, auriculate-cordate, the auricle rounded, provided with $2-4$ ciliae; of the branches growing gradually smaller; of the branchlets imbricate, bluntish or acute, sparingly serrulate or even nearly entire, the outer base subcordate or rounded, non-ciliate. Spikes solitary and terminal on the branchlets, square, to about $1 \frac{1}{2} \mathrm{~cm}$ long, $1-1 \frac{1}{2} \mathrm{~mm}$. (when adult to $2 \mathrm{~mm}$.) diam.; sporophylla isomorphous, ovate, acute, keeled, minutely serrulate, to $1 \mathrm{~mm}$. long, when young erect, at length spreading; macrospores when young paleyellow-brown or yellowish-white, indistinctly rugulose, the rumples crowded; microspores

Celebes.

(95b) ธ. celebica, v. A. v. $\boldsymbol{\text { S. }}$

Shoots ascending or erect from a short creeping base, $\pm 35-40 \mathrm{~cm}$. high, the lower part simple, stipitiform, pale-fuscous, obtusely quadrangular, $\pm 2 \mathrm{~mm}$. thick at the base, the upper part rather closely pinnately compound; main rachis to $3--4 \mathrm{~mm}$. broad including the lateral leaves; pinnae ascending, to $\pm 10 \mathrm{~cm}$. long, the lower 3-pinnate; ultimate branchlets much ascending, to $\pm 1 \mathrm{~cm}$. long by $1-2 \mathrm{~mm}$. broad. Leaves of the stipe isomorphous, elongate-triangular, $\pm 2{ }^{1} / 2 \mathrm{~mm}$. long, acute, keeled, minutely serrulate, the base 2-auriculate-cordate, the auricles hamato-incurvate, ciliate; leaves of the upper part of the main rachis and those of the branches heteromorphous; lateral leaves ascending; of the main rachis rather remote, subfalcate-ovate, the largest $2-21 / 2 \mathrm{~mm}$. long, $\pm 1 \mathrm{~mm}$. broad, acute, subacuminate, rotundate-cordate (sub-2-auriculate) at the base, the upper side entire in the upper half, minutely serrulate in the lower half; gradually ciliate towards the base, the lower side entire, ciliate at the base; of the branches subsimilar but growing gradually smaller; of the ultimate branchlets imbricate, to $1-1^{1{ }^{\prime}} \mathrm{mm}$. long, bluntish, 


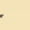


more sparingly ciliate or ciliolate and serrulate, the upper base rather rounded, the lower base hardly cordate; intermedial leaves erect; of the main rachis somewhat remote, subfalcate-ovate, the largest $\pm 1^{\prime}{ }_{2} \mathrm{~mm}$. long, acuminate, keeled, serrulate in the upper half, ciliate at the base, the inner base rouded, the outer base produced, auriculate-cordate, the the auricle hamato-incurvate: of the branches growing gradually smaller: of the branchlets imbricate, oblong, bluntish or subacute, more sparingly serrulate, not ciliated at the base, the inner base rotundate-cuneate, the outer base rotundate-subcordate. Spikes solitary and terminal on the branchlets, square, to $\pm 1 \mathrm{~cm}$. long, $-1 \mathrm{~mm}$. diam; sporophylla ascending, at length spreading, broadly ovate, to ${ }^{3}$ is $\mathrm{mm}$. long, bluntish or acute, keeled, minutely serrulate; macrospores yellowish-white, rugulose. the rumples more or less reticulate, the apical ribs encircled by a ring. shaped crest; microspores yellowish or pale orange, provided with hacilliform or stipitate-capitate projections on the basal side.

Celebes.

P. 536; Insert:

\section{(200a) S. asperulipes, v. A. v. Th.}

Shoots erect from a creeping base, $75-100 \mathrm{~cm}$. high, the lower part simple, stipitiform, 6-9-stelical, finely punctulato-asperulous, when dry stramineous, irregularly grooved, $3-4 \mathrm{~mm}$. thick towards the base, the upper part pinnately compound, the axillary leaves of the main rachis subpetiolulate, broadly ovate, to $6 \mathrm{~mm}$. long, to $4 \frac{1}{2} \mathrm{~mm}$. broad at or below the middle, blunt to subacute, narrowly plicate at the base; pinnae lanceolate or linear-lanceolate, ascending, to $20 \mathrm{~cm}$. long, not rarely provided with axillary accessory pinnae which are articulated at the base, the rachis $\pm 7 \mathrm{~mm}$. broad including the lateral leaves; pinnulae crowded, much ascending, the largest to $4 \mathrm{~cm}$. long, simple or forked, the axillary leaves elongate-obovate, conspicuously 2-auriculate at the base, the auricles revolute or plicate; ultimate branchlets $4-6 \mathrm{~mm}$. broad, narrowed gradually towards the apex, the terminal ones often much elongated and caudiform. Leaves heteromorphous, entire; lateral leaves remote on the stipe. contiguous or slightly imbricate on the branchlets; of the stem lanceolateoblong, the lower rather erect, the higher erecto-patent, the largest $33 / 4-4 \frac{1}{4} \mathrm{~mm}$. long, $\pm 1 \frac{1}{2} \mathrm{~mm}$. broad, acute or acuminate, the upper side plicate-auriculate at the narrowed base, the lower side cordate at 

the base, the auricle rounded; of the branches spreading or subhorizontal, subfalcate-oblong, with the auricle more distinct, revoluto-plicate, decurrent, the lower base subtruncate-rotundate; of the secondary rachises \pm 4 $\mathrm{mm}$. long by $1 \frac{1}{2} \mathrm{~mm}$. broad; of the ultimate branchlets to $3-31 / 2 \mathrm{~mm}$. long, the higher hardly plicate and auriculate; intermedial leaves erect; of the stem remote, subpetiolulate, subfalcate-oblong, the largest \pm 3 mm. long, acute, straight on the inner side, rounded on the outer side, the base somewhat obliquely and apparently narrowly subcordate, the auricles minute, rounded, whether or not plicate; of the branches growing gradually smaller; of the branchlets imbricate, broadly and very obliquely adnate at the base, shortly acuminate, the outer base produced, rounder or slightly cordate. Spikes solitary and terminal on the branchlets, square, to $2 \mathrm{~cm}$. long, $1 \frac{1}{2}-21_{2} \mathrm{~mm}$. diam.; sporophylla ovate, acuminate, keeled, entire, to nearly $2 \mathrm{~mm}$. long; macrospores when young paleyellow-brown, provided with crowded, minute, tuberculiform or shortly rugiform, calcareous, apparently deciduous corpusculi; microspores whitish, provided with reticulated wing-like membranes.

Obi Islands.

\section{("204) S. deliana, v. A. v. $\boldsymbol{R}$.}

Shoots (ex sched.) erect and $70-.150 \mathrm{~cm}$. high, the lower part probably simple, the upper part 4-pinnate, ovate in outline, the main rachis 7-9-stelical, sparingly foliate, when dry fuscous and irregularly grooved, the lower axillary leaves deltoid, somewhat broader than long, with the corners bluntly rounded; pinnae ascending; to $20 \mathrm{~cm}$. or more long, the largest lanceolate-ovate or eiongate-subtriangular, the rachis \pm $7 \mathrm{~mm}$. broad including the lateral leaves; pinnulae close, the lower spreading, with the secondary pinnulae forked or sparingly pinnate; ultimate branchlets $1-2 \% \mathrm{~cm}$. long, $4-7 \mathrm{~mm}$. broad, narrowed towards the apex. Leaves entire; of the main rachis subisomorphous, remote, erect or suberect, ovate-oblong, subfalcate, blunt, rounded at the base; of the branches heteromorphous; lateral leaves spreading; of the secondary rachises somewhat remote, subfalcate-oblong-ovate, blunt, the upper side narrowly pellucid-margined, rounded at the base, the lower side subcordatetruncate at the base, the largest leaves $\pm 4 \frac{1}{2} \mathrm{~mm}$. long, $2 \mathrm{~mm}$. broad; of the tertiary rachises subsimilar, somewhat smaller, the upper side subauriculate-plicate at the base; of the ultimate branchlets to $31 / 2 \mathrm{~mm}$. long and $1 \% \mathrm{~mm}$. broad, pellucid-margined on both sides, the upper side 
not or hardly plicate at the hase; intermerial leaves erect, pellucidmargined; of the secondary rachises somewhat remote, obliquely subfalcate-ovate-oblong, blunt, the inner base narrowed, the outer base produced, rotundate-cuneate or somewhat rounded, the largest leaves $\pm 3 \mathrm{~mm}$. long; of the ultimate branchlets imbrieate, smaller, bluntly and shortly acuminate, broadly and obliquely adnate at the base, the outer base cuneate or rotundate-cuneate. Spikes solitary and terminal on the branchlets, to $1 \frac{1}{2}$ cm. long, $\pm 1 \frac{1}{2} \mathrm{~mm}$. diam.; sporophylla broadly deltoid-ovate,

shortly and bluntly acuminate, entire, keeled, those of the macrosporangia $\pm 1^{1} / 2 \mathrm{~mm}$. long, the others smaller; macrospores pale-ochraceous. roughish on the rounded side, the equatorial projections tubereuliform, the others rugiform, short or long; straight or flexuose, branched or connected; microspores whitish or yellowish, provided with free or connected, irregularly and more or less coarsely bacilliform or tuberculiform projections on the rounded side.

\section{Sumatra.}

\section{(204a) \$. robustipes. c. A. v. K.}

Shoots erect, rather large, perhaps to $60-75 \mathrm{~cm}$. high, the lower part simple, when dry dirty-stramineous, irregularly grooved, 3-4 $\mathrm{mm}$. thick at the base, 4-5-stelical, or 3-stelical with a tendency to become 4-5-stelical, the steles placed in 4-5 planes, i. e. arranged in 1 line from the ventral one to the dorsal one, the upper part pinnately compound, the axillary leaves of the main rachis large, ovate, to $6 \mathrm{~mm}$. long by 4 $\mathrm{mm}$. broad, broadest at or below the middle, acute or shortly acuminate; pinnae ovate to lanceolate, ascending or spreading; the central the longest, to $15-25 \mathrm{~cm}$. long, 2-pinnate or sub-3-pinnate, not rarely provided with axiliary accssory pinnae which are articulated at the base; tertiary branches suberect, simple or forked or the lower sometimes subpinnate; ultimate branchlets $1-3 \mathrm{~cm}$. long or the terminal ones much elongated and caudiform, $2-3 \frac{1}{2} \mathrm{~mm}$. broad including the lateral leaves, narrowed gradually from the base to the apex. Leaves heteromorphous, entire, narrowly pellucid-margined; lateral leaves horizontal on the stipe, ascending on the branchlets; of the stipe and the lower part of the main rachis remote, subpetiolulate, subfalcate-oblong; acute or subacute, the largest $5-5 \frac{1}{2} \mathrm{~mm}$. long, $2-2 \frac{1}{4} \mathrm{~mm}$. broad, the upper base rounded, plicate, the lower base rotundate-cordate; of the upper part of the main rachis and those of the branches growing gradually smaller and less remote:

FERNS AND FERN ALLIES. 

of the secondary rachises with the upper base rotundate-cuneate and "onspicuously plicat' (revoluto-auriculate), the lower hase rotmdate-truncate: of the ultimate branchlets close, the largest $2--21 / 2 \mathrm{~mm}$. long; the lower distinctly plicate, the higher hardly so; intermedial leaves erect; of the stipe remote, subpetiolulate, lancolate, to $\pm 5 \mathrm{~mm}$. long, acute, the inner base rounded, the outer base very slightly produced, subcordate, the auricle plicate; of the branched portion growing gradually smaller and less remote; of the branchlets imbricate, semiovate, subfalcate, shortly acuminate, more distinctly pellucid-margined, the inner side straight, the outer side rounded, the base obliquely adnate, produced and narrowly cuneate on the outer side. Spikes solitary and terminal on the branchlets, square, to $\pm 2 \mathrm{~cm}$. long, $1 \frac{1}{2}-2$ (when ripe to 3 ) $\mathrm{mm}$. diam.; sporophylla suberect, at lingth spreading, ovate, acuminate, entire, pellucid-margined, keeled, the ventral ones somewhat larger than the dorsal ones, to $2 \mathrm{~mm}$. long; macrospores yellowish-white, densely and finely verruculose; mi. erospores yellowish-white, the projections tuberculiform, bacilliform or capitate-clarate, free or sometimes laterally connected.

Celebes.

P. 560 , under Lycopodium. - Insert: cataphractum, Bi. (See the corrections) 
$\$ 264$ 





SMITHSONIAN INSTITUTION LIBRARIES 